\title{
PAULINA MATERA
}

\section{Uwarunkowania ekonomiczne polityki Stanów Zjednoczonych wobec Europy Zachodniej za prezydentury Richarda M. Nixona (1969-1974)}


RECENZENT

Edward Haliżak

\section{REDAKTOR WYDAWNICTWA \\ Joanna Balcerak}

SKŁAD I ŁAMANIE

ESUS - Agnieszka Buszewska

PROJEKT OKŁADKI

Barbara Grzejszczak

(C) Copyright by Uniwersytet Łódzki - Wydawnictwo Uniwersytetu Łódzkiego 2012

Wydawnictwo Uniwersytetu Łódzkiego

90-131 Łódź, ul. Lindleya 8

Wydanie I. Nakład $100+41$ egz. Ark. druk. 22,25

Zam. 4924/2012. Cena $z \nmid 46,-+$ VAT

ISBN 978-83-7525-668-0 


\section{SPIS TREŚCI}

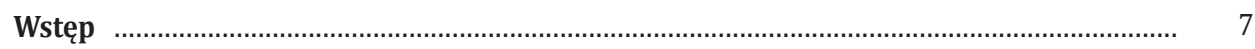

Rozdział I. Wzajemne oddziaływanie czynników politycznych i ekonomicznych w świetle teorii międzynarodowej ekonomii politycznej

1.1. Wyodrębnienie się międzynarodowej ekonomii politycznej. Definicje i zakres badań ........... 19

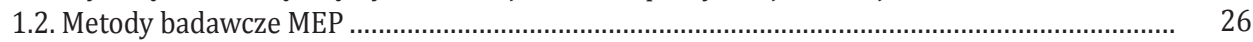

1.3. Główne nurty teoretyczne MEP .......................................................................................... 29

1.4. Czynnik gospodarczy w polityce zagranicznej państwa ...................................................... 42

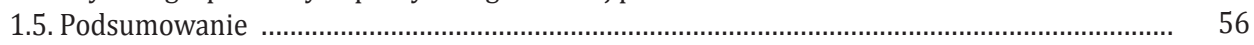

Rozdział II. Zarys polityczno-ekonomicznych relacji transatlantyckich po II wojnie światowej (1945-1969)

2.1. Kształtowanie się powojennego systemu gospodarczego

2.2. Stany Zjednoczone jako promotor integracji europejskiej. Znaczenie planu Marshalla .......... 63

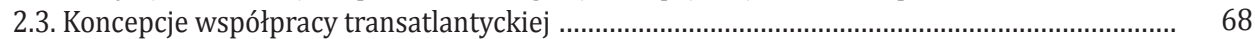

2.4. Postępy integracji europejskiej - wpływ na relacje transatlantyckie ...................................... 72

2.5. Stany Zjednoczone wobec perspektywy przystąpienia Wielkiej Brytanii do EWG ................ 73

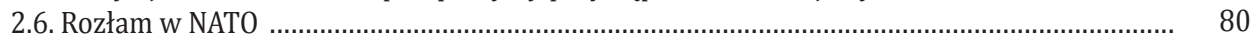

2.7. Problem dzielenia kosztów obrony .................................................................................... 82

2.8. Intensyfikacja relacji gospodarczych między Stanami Zjednoczonymi a EWG w latach

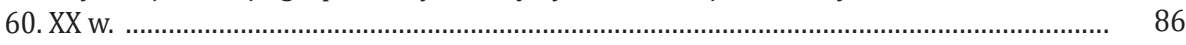

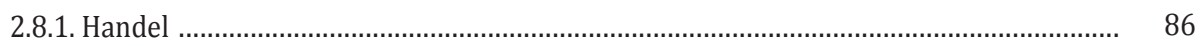

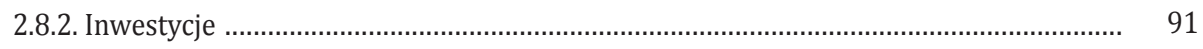

2.8.3. Kryzys światowego systemu monetarnego ............................................................ 94

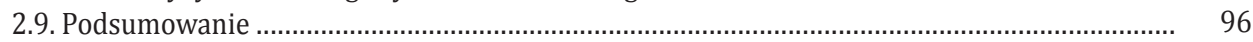

Rozdział III. Europa Zachodnia w polityce Stanów Zjednoczonych na początku kadencji Richarda M. Nixona (styczeń-grudzień 1969)

3.1. Sojusz atlantycki w koncepcjach Nixona i Kissingera ............................................................. 99

3.2. Podejmowanie decyzji w polityce zagranicznej ................................................................ 104

3.3. Pierwsza wizyta Nixona w Europie ................................................................................... 106

3.4. Sytuacja gospodarcza w Stanach Zjednoczonych i jej wpływ na relacje transatlantyckie ....... 109

3.5. Nieporozumienia dotyczące handlu i przepływu inwestycji ................................................... 118

3.6. Integracja europejska - perspektywy rozszerzenia ............................................................ 125

3.7. Wpływ nieporozumień gospodarczych na współpracę militarną ......................................... 126

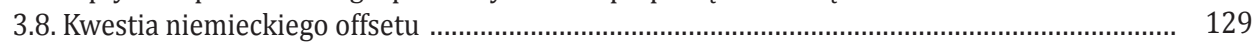

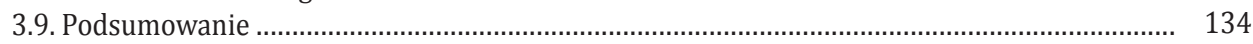


Rozdział IV. Relacje transatlantyckie w dobie kryzysu monetarnego (styczeń 1970 - sierpień 1971)

4.1. Ewolucja stanowiska Stanów Zjednoczonych wobec rozszerzenia EWG ................................. 137

4.2. Rozbieżności gospodarcze między USA a EWG .................................................................... 147

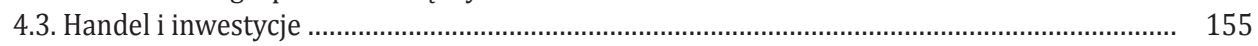

4.4. Trudności gospodarcze Stanów Zjednoczonych ............................................................... 160

4.5. Wpływ sytuacji gospodarczej w USA na kwestie obronne ................................................. 164

4.6. Znaczenie relacji gospodarczych z Europą Wschodnią w stosunkach transatlantyckich ......... 170

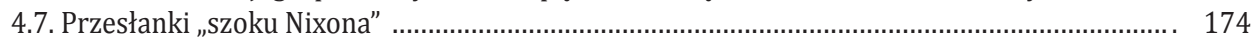

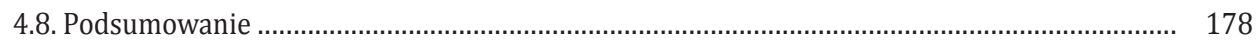

Rozdział V. Współpraca transatlantycka w dobie tworzenia nowego światowego ładu ekonomicznego (sierpień 1971 - styczeń 1973)

5.1. Droga do porozumienia smithsoniańskiego .................................................................... 183

5.2. Problemy monetarne i plany ustalenia nowych zasad handlu światowego ............................. 192

5.3. Inwestycje i przedsiębiorstwa wielonarodowe ................................................................... 206

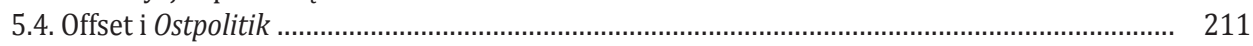

5.5. Stany Zjednoczone wobec postępu integracji europejskiej .................................................... 214

5.6. Aspekty polityczno-gospodarcze zbliżenia ze Wschodem ................................................... 220

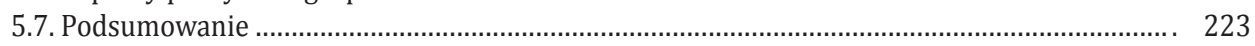

Rozdział VI. Próby instytucjonalizacji współpracy transatlantyckiej w „roku Europy” (styczeń-październik 1973)

6.1. Relacje Stanów Zjednoczonych z rozszerzoną EWG …........................................................... 225

6.2. Negocjacje monetarne i handlowe .................................................................................... 230

6.3. Koncepcja instytucjonalizacji współpracy transatlantyckiej ................................................. 238

6.4. Spotkanie Nixon - Pompidou w Rejkiawiku ....................................................................... 247

6.5. Kwestia redukcji sił amerykańskich w Europie ............................................................... 250

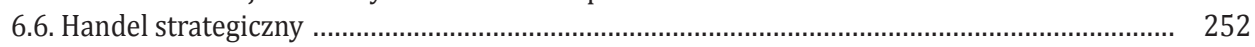

6.7. Spór o kształt Deklaracji Atlantyckiej ............................................................................. 254

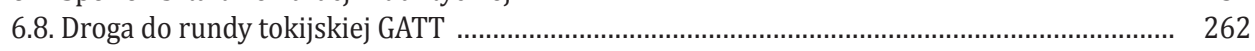

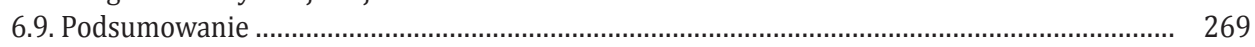

Rozdział VII. Kryzys energetyczny i destabilizacja jedności sojuszu (październik 1973 sierpień 1974)

7.1. Ocena stanu sojuszu atlantyckiego przez Komitet Dziewięciu ............................................. 271

7.2. Problem surowców energetycznych ................................................................................ 274

7.3. Konsekwencje polityczne wojny Jom Kippur i embarga OPEC ............................................... 276

7.4. Konferencja waszyngtońska .............................................................................................. 288

7.5. Wpływ kryzysu energetycznego na Deklarację Atlantycką ................................................ 296

7.6. Kwestia stacjonowania wojsk amerykańskich w Europie ....................................................... 303

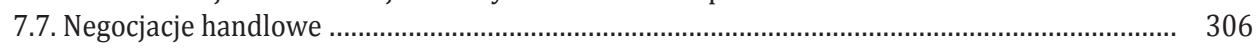

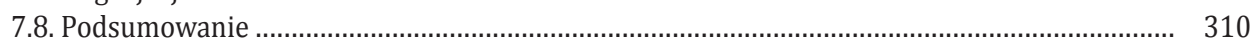

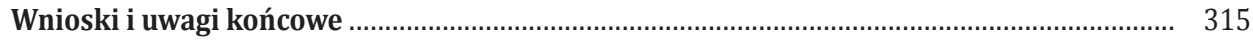

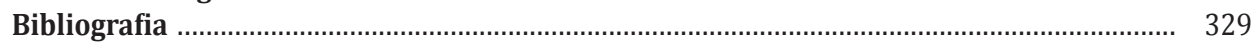


Wykaz skrótów 345

Wykaz tabel i wykresów

347

The Impact of Economic Issues on the United States Policy toward Western Europe during the Presidency of Richard M. Nixon (1969-1974) 349 Od Redakcji 
Rafałowi 


\section{WSTĘP}

\section{Uzasadnienie podjęcia tematu}

Wybór tematu rozprawy habilitacyjnej jest związany z głównym obszarem moich zainteresowań naukowych - stosunkami transatlantyckimi. Od początku relacji między Ameryką Północną a Europą, kwestie gospodarcze odgrywały bardzo istotną rolę. Wszak to nieporozumienia na tym tle między Wielką Brytanią i jej trzynastoma koloniami stały się jednym z głównych impulsów wojny o niepodległość Stanów Zjednoczonych. Wraz ze wzrostem potęgi gospodarczej tego państwa i postępującymi współzależnościami, stosunki ekonomiczne coraz bardziej spajały Stary i Nowy Świat. Chęć zapewnienia ich harmonijnego rozwoju łagodziła spory polityczne lub była przyczyną ich zaognienia. Należy pamiętać, że Amerykanie starali się zachować politykę izolacjonizmu, odcinając się od ambicji i sporów europejskich mocarstw ${ }^{1}$. Wielkim przełomem w polityce USA był początek rywalizacji zimnowojennej z ZSRR, co pociągało za sobą zwrot w stosunkach ze Starym Kontynentem: zakończyła się epoka nieufności i izolacjonizmu, a rozpoczął czas sojuszu i zaangażowania. Także w tym przypadku ważną rolę w kształtowaniu polityki Waszyngtonu odgrywał czynnik gospodarczy - chęć przywrócenia stabilności państw europejskich i normalizacja relacji handlowych.

Śledząc najważniejsze wydarzenia lat 50. i 60. XX w. można zauważyć, że w stosunkach transatlantyckich dominowały kwestie stricte polityczne i związane z kształtowaniem wspólnego systemu obrony. Punkt zwrotny nastąpił na początku lat 70., podczas prezydentury Richarda M. Nixona, kiedy Stany Zjednoczone przeżywały trudności gospodarcze, a Europa Zachodnia zaczęła aktywnie z nimi konkurować na rynkach światowych. Doprowadziło to do istotnych zmian w polityce Waszyngtonu wobec sojuszników.

W polskiej literaturze naukowej prace podejmujące tematykę wpływu kwestii gospodarczych na relacje polityczne są wciąż nieliczne². Także zagadnienia relacji między Stanami Zjednoczonymi i Europą (szczególnie Zachodnią) w okresie zim-

${ }^{1}$ P. M a te r a, R. M a te ra, Stany Zjednoczone i Europa. Stosunki polityczne i gospodarcze. 1776-2004, Warszawa 2007, passim.

${ }^{2}$ Zwraca na to uwagę Edward Haliżak: E. Haliżak, Współzależność polityki i ekonomii $w$ stosunkach międzynarodowych, [w:] Stosunki międzynarodowe w XXI wieku. Księga jubileuszowa z okazji 30-lecia Instytutu Stosunków Międzynarodowych Uniwersytetu Warszawskiego, red. E. Haliżak i in., Warszawa 2006, s. 23-24. 
nej wojny nie doczekały się wielu monografii ${ }^{3}$. Więcej prac powstało po roku 1989, kiedy rozpadał się blok komunistyczny, a Polska, aspirując do integracji ze strukturami europejskimi i NATO, nawiązała bardziej ożywione kontakty z potencjalnymi sojusznikami ${ }^{4}$. Natomiast w USA i Europie Zachodniej relacje transatlantyckie były przedmiotem wnikliwej debaty. Wiele cennych prac analizujących różne ich aspekty powstało właśnie w latach 70 . XX w. ${ }^{5}$ Ich autorzy byli świadkami wydarzeń, lecz siłą rzeczy nie mieli dostępu do dokumentów rządowych i wielu innych cennych źródeł. Po zakończeniu zimnej wojny powstały również prace na temat relacji transatlantyckich w tym czasie, lecz żadna ze znanych mi publikacji nie porusza całościowo kwestii wpływu sytuacji ekonomicznej na zmianę polityki amerykańskiej wobec Europy ${ }^{6}$.

Dokładna analiza relacji gospodarczych i politycznych w czasie trwającej pięć i pół roku prezydentury Nixona pozwala przyjrzeć się powodom i mechanizmom podejmowania decyzji przez jedną administrację, w konkretnej sytuacji wewnętrznej i międzynarodowej. Umożliwia obserwację ścierania się koncepcji poszczególnych departamentów, Kongresu i różnych grup interesów.

Dodatkowym bodźcem do podjęcia tematu było wyodrębnienie się, właśnie w latach 70. XXw., międzynarodowej ekonomii politycznej - MEP (International

\footnotetext{
${ }^{3}$ Istnieją nieliczne prace podejmujące tę tematykę, np. M. S a r, Polityka Stanów Zjednoczonych wobec procesów integracyjnych Europy Zachodniej w latach 1947-1963, Warszawa 1981. Zagadnienie to pojawia się też w pracy Agnieszki Bógdał-Brzezińskiej: A. B ó g d a ł - B r z e z i ń s k a, Globalizacja polityki Stanów Zjednoczonych 1945-1949, Warszawa 2001. Natomiast wątek relacji między Stanami Zjednoczonymi a Europą Wschodnią został przedstawiony w pracach Andrzeja Manii (m.in. A. M a n i a, Détente i polityka Stanów Zjednoczonych wobec Europy Wschodniej styczeń 1969-styczeń 1981, Kraków 2003).

${ }^{4}$ J. G ry z, Procesinstytucjonalizacjistosunków transatlantyckich, Warszawa 2004; J. K i w e r s k a, Gra o Europę. Bezpieczeństwo europejskie w polityce Stanów Zjednoczonych pod koniec XX wieku, Poznań 2000; D. E. S t a s z c z a k, USA-UE. Wzajemne stosunki na tle zmian globalnych, Toruń 1998; B. W. W i n i d, Rozszerzenie NATO w Kongresie Stanów Zjednoczonych 1993-1998, Warszawa 1999.

${ }^{5}$ Wśród tych opracowań można wyróżnić całościowe monografie (The United States and Western Europe, ed. W. Hanrieder, Cambridge 1974); prace dotyczące kwestii obronnych (D. P. C a ll e o, The Atlantic Fantasy: The U.S., NATO, and Europe, Baltimore 1970); relacji gospodarczych (International Economic Relations of the Western World, 1959-1971, ed. A. Shonfield, vol. 1: Politics and Trade, London 1976); oraz oceniające stan sojuszu atlantyckiego i zawierające prognozy na przyszłość (W. R. B u r g e s s, J. R. H u n t l e y, Europe and America. The Next Ten Years, New York 1970).

${ }^{6}$ Istnieją prace analizujące wpływ sytuacji gospodarczej na politykę, lecz dotyczą jednego z wątków poruszanych w niniejszej pracy (np. H. Z i m m e r m a n n, Money and Security: Troops, Monetary Policy and West Germany's Relations with the United States and Britain, 1950-1971, Cambridge 2002). Najczęściej jednak czasy Nixona są przedstawione pobieżnie, jako tło historyczne dla sytuacji współczesnej (L. S. K a p l a n, NATO Divided, NATO United. The Evolution of an Alliance, Westport 2004; S. R.S l o a n, NATO, the European Union, and the Atlantic Community: the Transatlantic Bargain Challenged, Lanham 2005). Motyw relacji z Europą jest także potraktowany marginalnie w najnowszej pracy Roberta Dalleka (R. D a l l e k, Nixon and Kissinger. Partners in Power, New York 2007).
} 
Political Economy), stanowiącej subdyscyplinę nauki o stosunkach międzynarodowych. Badacze - początkowo głównie ze Stanów Zjednoczonych i Wielkiej Brytanii - formułowali postulaty uwzględniania w większym stopniu powiązań między polityką a gospodarką, inspirowane współczesnymi im wydarzeniami. Pierwsze teorie wykorzystywały realia współpracy i rywalizacji Stanów Zjednoczonych z partnerami gospodarczymi, głównie z Europą Zachodnią. Naukowcy nie tylko ogłaszali konieczność zmian metodologicznych, lecz także stosowali je we własnej pracy badawczej. Wśród prekursorów MEP można wymienić Richarda Coopera, Susan Strange, Roberta Gilpina, Roberta Koehane’a czy Josepha Nye'a ${ }^{7}$. Wart podkreślenia jest również wzrost powszechnej świadomości na temat wpływu gospodarki na politykę, co można zaobserwować, czytając artykuły z ukazującej się w tym okresie prasy codziennej.

\section{Tezy i zagadnienia badawcze}

Celem pracy jest potwierdzenie tezy, że na początku lat 70. XX w. kwestie gospodarcze stały się dominujące w polityce Stanów Zjednoczonych wobec Europy Zachodniej. Stało się tak ze względu na zmierzch hegemonii USA w gospodarce światowej. Po II wojnie światowej Stany Zjednoczone, rozpinając „parasol atomowy" nad Japonią i krajami Europy Zachodniej, stworzyły warunki do powstania triady kapitalistycznych potęg gospodarczych, które miały ze sobą współpracować. Po wielkiej prosperity, na przełomie lat 60. i 70. XX w., wzrost gospodarczy nie był już tak spektakularny. Stany Zjednoczone doświadczyły trudności gospodarczych: rosnącej inflacji, bezrobocia i deficytu bilansu płatniczego ${ }^{8}$. Podobne

${ }^{7}$ R. C o o p e r, The Economics of Interdependence: Economic Policy in the Atlantic Community, New York 1968; S. S tr a n g e, International Economics and International Relations. A Case of Mutual Neglect, „International Affairs”, April 1970; R. G i l p i n, U. S. Power and the Multinational Corporation. The Political Economy of Foreign Direct Investment, Basic Books, New York 1975. Zagadnieniem powstania MEP zajmuję się szczegółowo w rozdziale I.

${ }^{8}$ Bilans płatniczy to „sumaryczne i uporządkowane zestawienie wszystkich transakcji między rezydentami danego kraju a nierezydentami w określonym czasie, z reguły w ciągu roku". Bilans płatniczy dzielony jest na trzy części: 1) rachunek bieżący, na który składają się transakcje towarami i usługami i płatności transferów; 2) rachunek kapitałowy - zmiany w krajowych i zagranicznych aktywach oraz płatnościach; 3) oficjalny międzynarodowy rachunek rezerw - transakcje w złocie i innych aktywach rezerwowych (waluty wymienialne, wkład w MFW, SDR-y). Wzrost rezerw walutowych w banku centralnym oznacza, że bilans płatniczy jest dodatni. W momencie, gdy popyt rynkowy przewyższy podaż walut, rezerwy zmniejszają się i bilans płatniczy jest ujemny. Władze monetarne interweniują w celu zbilansowania rynku walutowego, więc bilans płatniczy zawsze powinien być zerowy (J. Ś w i e r k o c k i, Zarys międzynarodowych stosunków gospodarczych, Warszawa 2004, s. 196-199). W niniejszej pracy stosuję termin dodatniego bądź ujemnego bilansu płatniczego, biorąc pod uwagę bilans obrotów bieżących (eksport oraz import towarów i usług, dochody z zagranicznych inwestycji bezpośrednich itp.) oraz obrotów kapitałowych i finansowych (np. spłaty zadłużenia, zakup patentów, handel akcjami przedsiębiorstw itp.). 
zjawiska można było odnotować również w krajach Europy Zachodniej. By przezwyciężać te trudności, każdy kraj stosował środki korzystne w swojej partykularnej sytuacji, często nie oglądając się na interes partnerów gospodarczych i zaniedbując współpracę międzynarodową. Nieporozumienia dotyczące handlu i kwestii monetarnych negatywnie wpływały na stosunki polityczne między sojusznikami.

System gospodarczy, za który po II wojnie światowej wzięły odpowiedzialność Stany Zjednoczone, wymagał gruntownej reformy. Ład monetarny z Bretton Woods $\mathrm{w}$ latach 60. stawał się nieadekwatny do dynamicznego rozwoju międzynarodowych relacji handlowych. Konkurencyjność gospodarki amerykańskiej zaczęła maleć w momencie pojawienia się silnych rywali. W latach 70. XX w. państwa Europy Zachodniej nie dążyły do zwiększenia potencjału militarnego, podjęły za to rywalizację z Amerykanami na polu gospodarczym zamiast zakładanej przez Waszyngton współpracy. Dlatego naturalnym działaniem administracji stało się ograniczanie konkurencji, hamowane jednak przez sojusz polityczny i współzależności ekonomiczne. Miało to poważne konsekwencje dla wzajemnych relacji, gdyż Stany Zjednoczone często używały nacisków politycznych w celu osiągnięcia porozumień gospodarczych.

Rozbieżności między sojusznikami, powstające głównie na tle ekonomicznym, negatywnie wpływały na pozycję mocarstwową USA, integrację europejską, a także na spoistość Zachodu. Szczególnie interesująca okazała się wyraźna zmiana stosunku do integracji europejskiej. Prezydent Richard Nixon pierwszy publicznie wyrażał przekonanie, że jej charakter i dalsze pogłębianie może być niekorzystne dla interesu narodowego Stanów Zjednoczonych. Postęp integracji europejskiej, szczególnie sukcesy związane z tworzeniem zewnętrznej unii celnej, generowały spory handlowe. Silna gospodarczo Europa Zachodnia zaczęła też dążyć do zwiększenia swej aktywności na arenie międzynarodowej. W kilku przypadkach Stany Zjednoczone blokowały inicjatywy sojuszników. Staram się zbadać, w jakim stopniu te działania miały podłoże ekonomiczne.

Relacje gospodarcze w stosunkach międzynarodowych były bardzo istotne dla Amerykanów od początku istnienia państwa. Konstytucja kładzie nacisk na wagę polityki handlowej, przyznając Kongresowi uprawnienia do ustalania ceł i regulacji handlu zagranicznego, jednak ciężar odpowiedzialności za prowadzenie polityki zagranicznej spoczywa na prezydencie. Dlatego w Stanach Zjednoczonych często burzliwie debatowano na ten temat w Kongresie, pojawiały się także napięcia między legislatywą a władzą wykonawczą. Interesy strategiczne powstrzymywały USA od podejmowania radykalnych działań, jak w przypadku zmian w międzynarodowym systemie monetarnym czy redukcji wojsk amerykańskich na Starym Kontynencie.

Założyłam również, że wpływ na zmianę polityki amerykańskiej miało poczucie mniejszego zagrożenia (szczególnie w Europie Zachodniej) wybuchem konfliktu militarnego z ZSRR w dobie zainicjowanej przez Nixona polityki odprężenia. Istniała obawa, że w tej sytuacji państwa europejskie będą prowadziły niezależną politykę zagraniczną, która mogłaby pozostawać w sprzeczności z linią Waszyngtonu. 
Oprócz wymienionych zmian można było zaobserwować również kryzys autorytetu politycznego Stanów Zjednoczonych - wiodącej demokracji i przywódcy wolnego świata $\mathrm{w}$ walce $\mathrm{z}$ komunistycznym totalitaryzmem. Było to ściśle związane z zaangażowaniem się tego państwa w Wietnamie czy aferą Watergate. Dużą rolę odgrywała niewątpliwie europejska zależność od amerykańskiej obrony. Kraje Europy Zachodniej, mimo niechęci do rozbudowy własnego potencjału, miały pod tym względem poczucie niższości w stosunku do Stanów Zjednoczonych, co również generowało konflikty.

Chcąc potwierdzić zasadność głównej tezy, zajęłam się analizą poszczególnych wydarzeń w relacjach transatlantyckich, by określić powody decyzji podejmowanych w Waszyngtonie ${ }^{9}$. Służą temu dodatkowe zagadnienia badawcze. Analizuję rolę grup interesów i ich wpływ na Kongres, który w owym czasie wykazywał nastawienie protekcjonistyczne. Forsowano w nim używanie argumentów politycznych w celu wymuszenia na Europejczykach koncesji gospodarczych. Przy tej okazji można było zbadać rolę państwa i jego struktur w funkcjonowaniu gospodarki światowej i kształtowaniu międzynarodowych relacji. Lata 70. XX w. to czas, w którym dynamicznie rozwijały się przedsiębiorstwa wielonarodowe, co skłaniało badaczy do budowania teorii o przesunięciu wpływów rządów państw narodowych na rzecz korporacji.

Przedstawiony w pracy przypadek zmian w hierarchii czynników oddziałujących na politykę zagraniczną może służyć zrozumieniu mechanizmów zachowania rządów państw narodowych w dobie kryzysu. Tradycyjne podejście zakłada, że potencjał ekonomiczny determinuje siłę strategiczną, dyplomatyczną i militarną danego państwa. Przykładem może być Wielka Brytania w XIX w. Takie samo założenie można przyjąć w przypadku Stanów Zjednoczonych po II wojnie światowej. Badanie wpływu czynnika ekonomicznego na politykę pozwala wyróżnić wiele aspektów takiego oddziaływania i założyć, że: 1) system polityczny kształtuje system gospodarczy; 2) międzynarodowe stosunki ekonomiczne zawierają w sobie, $\mathrm{z}$ definicji, także stosunki polityczne, gdyż biorą w nich udział zarówno państwa narodowe, jak i inni aktorzy - organizacje międzynarodowe i wielkie przedsiębiorstwa, przy czym państwa mogą z nimi kooperować lub je ograniczać; 3) siła gospodarcza jest jednym z kluczowych narzędzi w polityce zagranicznej; 4) stan gospodarki światowej wpływa na polityczne stosunki międzynarodowe i na politykę wewnętrzną państw; 5) wewnętrzna polityka gospodarcza państwa wpływa na relacje międzynarodowe; 6) istnieje współzależność międzynarodowej polityki gospodarczej państwa i wewnętrznej sytuacji politycznej. Weryfikacji postawionych tez i analizie zagadnień badawczych jest podporządkowana struktura rozprawy.

\footnotetext{
${ }^{9}$ Warto tutaj zauważyć, że Nixon bardzo angażował się w prowadzenie polityki zagranicznej, uważając się za eksperta w tej dziedzinie. Poza prezydentem, największy wpływ na jej kształtowanie miał Henry Kissinger - doradca prezydenta ds. bezpieczeństwa narodowego, a od września 1973 r. sekretarz stanu. Więcej informacji na ten temat znajduje się w rozdziale III.
} 


\section{Struktura dysertacji}

Ramy chronologiczne głównej części pracy stanowią daty sprawowania urzędu prezydenta przez Richarda M. Nixona (20 stycznia 1969 r. - 9 sierpnia 1974 r.). Początek lat 70. przyniósł poważne zmiany w gospodarce światowej, a także politykę odprężenia w stosunkach międzyblokowych. Nowa sytuacja powodowała konflikty w relacjach transatlantyckich. Dopiero po dokładnej diagnozie przyczyn problemów i podjęciu wspólnych działań zaczęło się łagodzenie sporów, co nastąpiło już podczas kadencji kolejnego prezydenta - Geralda Forda.

W pracy skupiłam się głównie na analizie polityki Stanów Zjednoczonych wobec Europy Zachodniej, traktowanej całościowo. Jednak ze względu na postępujące procesy integracyjne i wzrastającą rolę relacji gospodarczych, często podmiotem tych stosunków była Europejska Wspólnota Gospodarcza. Politycy amerykańscy koncentrowali się na współpracy z przedstawicielami Francji, Wielkiej Brytanii i RFN, dlatego interakcje z nimi dominują także w niniejszej pracy.

Rozprawa ma układ chronologiczno-problemowy. Stosowanie chronologii było niezbędne ze względu na to, że wydarzenia i zjawiska z różnych obszarów były ze sobą ściśle powiązane. Nie sposób było zająć się w jednym z rozdziałów np. wyłącznie problemem stosunku USA do integracji europejskiej, bez odniesienia do kwestii reformy monetarnej czy stosunków handlowych. Zastosowanie układu chronologicznego pozwoliło uniknąć chaosu dygresji i powtórzeń, uwypukliło współzależność czynników politycznych i ekonomicznych. Natomiast w ramach rozdziałów przyjęłam strukturę problemową. Nie było moim zamiarem nakreślenie zbyt szerokiego tła opisywanych wydarzeń. W pracy znajdują się jednak odniesienia do istotnych aspektów polityki zagranicznej USA (np. podpisanie układów rozbrojeniowych z ZSRR), wydarzeń w Stanach Zjednoczonych (np. afera Watergate), a także sytuacji na arenie międzynarodowej (np. konflikt bliskowschodni), jeśli miały one wpływ na tok narracji. Ponieważ są to kwestie szeroko opisane, w tych przypadkach odsyłam czytelnika do właściwej literatury.

Praca składa się z siedmiu rozdziałów. Każdy z nich kończy zwięzłe podsumowanie. Rozdział pierwszy ma charakter teoretyczny. Przedstawiam w nim powstanie i rozwój międzynarodowej ekonomii politycznej (MEP) - subdyscypliny stosunków międzynarodowych. Zamieściłam w nim opinie wybitnych naukowców, postulujących uwzględnienie czynników ekonomicznych w polityce zagranicznej państw narodowych, zaprezentowałam również definicje, teorie i zakres badań MEP. Wśród nich uwzględniam klasyczne teorie stosunków międzynarodowych: realizm (merkantylizm), liberalizm i marksizm (strukturalizm), teorię hegemonicznej stabilności i współzależności (szczególnie przydatne w niniejszej dysertacji), a także nowsze perspektywy (np. podejście ekologiczne czy krytykę feministyczną). Odniesienie do teorii, które można było zastosować w kontekście niniejszej pracy, znalazło się we wnioskach i uwagach końcowych. 
Druga część pracy stanowi wprowadzenie do okresu rządów Nixona. Przedstawiam w niej najważniejsze aspekty relacji transatlantyckich od zakończenia II wojny światowej do 1969 r. Skupiam się głównie na kwestiach polityczno-gospodarczych, do których odnoszę się w kolejnych rozdziałach, takich jak: integracja europejska; powojenne koncepcje współpracy transatlantyckiej; problem dzielenia kosztów obrony oraz charakterystyka najważniejszych zagadnień wzajemnych relacji gospodarczych.

Rozdział trzeci dotyczy działań amerykańskiej dyplomacji wobec Europy Zachodniej na początku kadencji Nixona. Są one przedstawione w kontekście zasadniczych zmian w koncepcji polityki zagranicznej Stanów Zjednoczonych - odprężenia w relacjach z ZSRR, nawiązania stosunków dyplomatycznych z ChRL oraz planów zakończenia zaangażowania w Wietnamie. Bardzo istotna okazała się także sytuacja gospodarcza na świecie i w samych Stanach Zjednoczonych. Zajmuję się ponadto kwestią podejmowania decyzji w polityce zagranicznej. Następne podrozdziały dotyczą zagadnień, które pojawiają się w kolejnych częściach pracy: relacji handlowych, stosunku USA do rozszerzenia EWG, dzielenia kosztów obrony i stacjonowania wojsk amerykańskich w Europie.

Głównym wątkiem rozdziału czwartego jest załamywanie się światowego systemu monetarnego z Bretton Woods i reakcja Stanów Zjednoczonych - tzw. „szok Nixona". Amerykański prezydent zdecydował wtedy o zawieszeniu wymienialności dolara na złoto. Ta decyzja rzutowała negatywnie na relacje transatlantyckie, gdyż została podjęta bez konsultacji z sojusznikami, a zasadniczo wpłynęła na ich wewnętrzną sytuację polityczną i gospodarczą. Nowym elementem jest kwestia relacji gospodarczych z blokiem komunistycznym.

Rozdział piąty rozpoczyna kwestia porozumienia w sprawach monetarnych po „szoku Nixona”, które zaowocowało tzw. „umową smithsoniańską”. Był to początek działań Komitetu Rady Gubernatorów MFW w celu ustalenia kształtu reformy światowego systemu walutowego. Przedstawiono rozbieżności na tym tle między Europejczykami, uważającymi za konieczne powiązanie tych prac z negocjacjami na temat liberalizacji handlu, a Amerykanami, postulującymi oddzielne rozpatrywanie tych problemów. Uwypuklona została sprawa umowy offsetowej, zgodnie z którą RFN miała rekompensować koszty stacjonowania wojsk amerykańskich na swoim terenie. Zagadnienie to łączy się z aktywnością państwa zachodnioniemieckiego w kontaktach z blokiem wschodnim. Duża samodzielność RFN w prowadzeniu Ostpolitik niepokoiła Amerykanów, podobnie - niechęć niemieckich negocjatorów do przyjęcia proponowanego przez nich kształtu umowy offsetowej.

Kolejny rozdział jest poświęcony amerykańskiej inicjatywie podpisania Deklaracji Atlantyckiej - umowy o ścisłej współpracy w różnych dziedzinach między Stanami Zjednoczonymi a Europą Zachodnią. Staram się ukazać motywy ogłoszenia przez Amerykanów roku 1973 „rokiem Europy” i zbadać hipotezę, że w dużym stopniu było to spowodowane dążeniem do zawarcia porozumienia w kwestiach gospodarczych. 
Ostatnia część pracy skupia się na konsekwencjach politycznych i gospodarczych pierwszego kryzysu energetycznego wskutek ograniczenia wydobycia ropy przez kraje OPEC w czasie wojny Jom Kippur. Różnice interesów gospodarczych Europy i Stanów Zjednoczonych spowodowały przyjęcie odmiennej polityki wobec stron konfliktu i doprowadziły do poważnych napięć między sojusznikami. Próbą ich zniwelowania była konferencja waszyngtońska, zakończona powstaniem Grupy Koordynacyjnej ds. Energii. Nie udało się natomiast podpisać Deklaracji Atlantyckiej, określającej szczegółowe zasady współpracy i konsultacji. Przyjęto jedynie deklarację na forum NATO, która była bardzo ogólna i nie spełniała pierwotnych oczekiwań Waszyngtonu. Pod koniec rządów Nixona, mimo założeń o umocnieniu sojuszu, relacje transatlantyckie uległy pogorszeniu. W dobie recesji gospodarki światowej, kryzysu monetarnego i energetycznego oraz trwającej rywalizacji zimnowojennej, perspektywa rozluźnienia sojuszu była w najwyższym stopniu niepokojąca. Pewne nadzieje wiązano ze zmianą w 1974 r. ekip rządzących, zarówno w Stanach Zjednoczonych, jak i w największych państwach Europy Zachodniej.

\section{Metodologia}

Rozprawa ma charakter interdyscyplinarny, lecz najlepiej wpisuje się w zakres badań MEP. Nauka ta czerpie metodologię z nauk politycznych, historii i ekonomii. Jej cel stanowi analiza sytuacji z uwzględnieniem czynników politycznych i gospodarczych. Zgodnie z tematem pracy, wybrałam metody przydatne w badaniu wpływu czynnika ekonomicznego na politykę zagraniczną państw narodowych.

John Odell zwraca uwagę, że na MEP wpływa wiele złożonych zjawisk: sytuacja geopolityczna, stan gospodarki światowej, rozwój technologiczny, relacje biznesowe, stosunki polityczne między państwami, sytuacja wewnętrzna w poszczególnych krajach, czynniki kulturowe itp. Niezbędne są metody jakościowe, pozwalające uchwycić szeroki kontekst oraz metody ilościowe - bardziej obiektywne i pozwalające na weryfikację niektórych tez. Połączenie w badaniach obu metod niweluje ich słabe strony ${ }^{10}$.

Zgodnie z tym postulatem, w pracy zastosowałam różnorakie metody, które uznałam za przydatne do przedstawienia mechanizmów kształtujących amerykańską politykę zagraniczną. Dominują metody jakościowe: deskryptywna - wydarzenia są opisywane chronologicznie w celu ilustracji przyjętych założeń oraz studia przypadków, ukazujące odzwierciedlenie teorii w praktyce (bądź odstępstwa od nich). Przydatna okazała się również metoda porównawcza, pokazująca, że administracja amerykańska nie zawsze kierowała się tymi samymi założeniami w relacjach

\footnotetext{
${ }^{10}$ J. S. 0 d e l l, Case Study Methods in International Political Economy, [w:] Cases, Numbers, Models: International Relations Research Methods, eds. D. F. Sprinz, Y. Wolinsky, Ann Arbor 2004, s. 65-84.
} 
z Europą. Cała praca jest studium przypadku osłabienia hegemonii gospodarczej USA i wpływu tego procesu na kształtowanie polityki zagranicznej. Jest to ukazane na podstawie wybranych zagadnień ze stosunków transatlantyckich.

Posłużyłam się również metodą ilościową, posiłkując się analizą statystyczną. Dzięki zebranym wskaźnikom wzajemnego handlu i inwestycji mogłam ukazać współzależności gospodarcze łączące Stany Zjednoczone z Europą Zachodnią, a za pomocą danych o amerykańskich wydatkach na wspólną obronę zweryfikować ich realny wpływ na deficyt bilansu płatniczego USA.

\section{Baza materiałowa}

Podczas pobytu w Waszyngtonie, dzięki stypendium przyznanemu przez Fundację Kościuszkowską, miałam możliwość skorzystania z zasobów dwóch instytucji - Archiwów Narodowych Stanów Zjednoczonych i Biblioteki Kongresu.

Podstawowym źródłem rozprawy są materiały z Archiwów Narodowych (National Archives and Record Administration). Dokumenty dotyczące polityki zagranicznej Nixona znajdują się w oddziale w College Park w stanie Maryland. Korzystałam głównie z dwóch zespołów: Nixon Presidential Materials Staff (NPMS) oraz Nixon Presidential Materials Project (NPMP). W ramach NPMS najwięcej informacji zawierają materiały Rady Bezpieczeństwa Narodowego (National Security Council), a wśród nich raporty ze spotkań Rady i jej komitetów roboczych, memoranda, korespondencja między jej członkami, korespondencja prezydenta, dokumenty przekazywane przez departamenty. W zespole znajdują się też materiały dotyczące poszczególnych zagadnień, np. handlu, integracji europejskiej, relacji z zagranicznych wizyt Nixona i Kissingera, spotkań z przedstawicielami państw europejskich w Waszyngtonie oraz analizy sytuacji w krajach europejskich i propozycje rozwiązań konkretnych problemów.

Z NPMP najcenniejsze okazały się dokumenty Białego Domu (White House Central Files), głównie materiały analizujące relacje z organizacjami międzynarodowymi, EWG i NATO, oraz dotyczące spraw gospodarczych. Z dokumentów biura Kissingera wykorzystałam relacje z jego wizyt zagranicznych i materiały dotyczące krajów europejskich.

Podstawę źródłową stanowią również zbiory drukowane, przede wszystkim Foreign Relations of the United States (FRUS), dostępne również na stronie internetowej Departamentu Stanu. Do momentu zakończenia pracy mogłam skorzystać z tomów ilustrujących założenia polityki zagranicznej oraz różne aspekty polityki gospodarczej w relacjach międzynarodowych ${ }^{11}$. Uzupełnienie stanowią przemówienia

\footnotetext{
${ }^{11}$ Foreign Relations of the United States (FRUS) 1969-1976, vol. 1: Foundations of Foreign Policy, Washington D.C. 2003; vol. 2: Organization and Management of U.S. Foreign Policy, 1969-1972, Washington D.C. Washington D.C. 2007; vol. 3: Foreign Economic Policy, 1969-1972;
} 
i oświadczenia Nixona ze zbioru The Public Papers of the Presidents of the United States, dostępne również $\mathrm{w}$ internecie oraz zapisy debat Kongresu (Congressional Record $)^{12}$.

W rozprawie została wykorzystana literatura o charakterze ogólnym i monograficznym, dotycząca różnych aspektów dyplomacji amerykańskiej wobec Europy Zachodniej. Większość stanowią prace obcojęzyczne - amerykańskie, brytyjskie i francuskie. W Bibliotece Kongresu korzystałam z niedostępnych w Polsce opracowań związanych z okresem prezydentury Nixona, sytuacją gospodarczą w Stanach Zjednoczonych i państwach europejskich, a także najważniejszymi problemami gospodarki światowej. Odnalazłam prace dotyczące różnych aspektów stosunków transatlantyckich ${ }^{13}$. Cenne okazały się wspomnienia polityków - uczestników opisywanych wydarzeń, np. Henry'ego Kissingera czy ministra spraw zagranicznych Francji Michela Joberta ${ }^{14}$.

Dzięki literaturze z dziedziny MEP zapoznałam się z rozwojem tej subdyscypliny, pionierskimi i najnowszymi teoriami oraz metodologią ${ }^{15}$. Wiedzę tę uzupełniłam, studiując artykuły z czasopism zajmujących się zagadnieniem związków polityki i gospodarki („International Organization” oraz „Review of International Political Economy”), polityki zagranicznej USA („Foreign Affairs”) oraz stosunków trnasatlantyckich („Journal of Transatlantic Studies”). Miałam możliwość dokonania kwerendy prasy amerykańskiej z okresu prezydentury Nixona: „New York Times”, „Washington Post”, „Chicago Tribune” i „The Wall Street Journal”. Zebrałam ponadto materiały statystyczne, zawarte m.in. w zbiorach: Monthly Bulletin of Statistics, US Direct Investment Abroad, Foreign Investments in the United States, Yearbook of International Trade Statistics, Historical Statistics of the United States $^{16}$. Bogate księgozbiory posiadają biblioteki amerykanistyczne: Instytutu

International Monetary Policy, 1969-1972, Washington D.C. 2002; vol. 4: Foreign Assistance, International Development, Trade Policies, 1969-1972, Washington D.C. 2003, vol. 31: Foreign Economic Policy 1973-1976, Washington D.C. 2010, dostępne także przez: www.state. gov/r/pa/ho/frus/nixon.org.

${ }_{12}$ The Public Papers of the Presidents of the United States: Richard Nixon, vol. 1-6: 19691974, Washington D.C. 1969-1978, dostępne także przez: http://www.nixonfoundation.org/.

${ }^{13}$ Na przykład prace: The United States and Western Europe. Political, Economic and Strategic Perspectives, ed. W. F. Hanrieder, Cambridge, Mass. 1974; Europe, America and the World Economy, ed. L. Tsoukalis, New York 1986.

${ }^{14}$ H. K i s s in g e r, White House Years, Boston 1979; i d e m, The Years of Upheaval, Boston 1982; M. J o b e r t, Mémoires d'avenir, Paris 1974.

${ }^{15}$ The Theoretical Evolution of International Political Economy: A Reader, eds. G. T. Crane, A. Amawi, Oxford 1997; D. N. B a l a a m, M. V e s e t h, Introduction to International Political Economy, New Jersey 2005.

${ }^{16}$ Monthly Bulletin of Statistics, October 1969-1974, United Nations, New York 1969-1974; US Direct Investment Abroad, 1966. Final Data, U.S. Department of Commerce, Washington 1967; Foreign Investments in the United States. Department of Commerce and Department of Treasury Estimates, eds M. Wilkins, New York 1977; Yearbook of International Trade Statistics, 1969-1974, United Nations, 
im. J. F. Kennedy'ego przy Freie Universität w Berlinie, a w Polsce - Ośrodka Badań Amerykańskich Uniwersytetu Warszawskiego czy Instytutu Amerykanistyki i Studiów Polonijnych Uniwersytetu Jagiellońskiego. Poza tym korzystałam ze zbiorów Biblioteki Ministerstwa Spraw Zagranicznych w Warszawie, Biblioteki Uniwersytetu Warszawskiego oraz Biblioteki Uniwersytetu Łódzkiego.

Chciałabym podziękować mojej Rodzinie, szczególnie Mężowi, za inspirację owocującą zainteresowaniem się gospodarką światową, za twórcze dyskusje i wszechstronne wsparcie, także pozanaukowe.

New York 1971-1975; Historical Statistics of the United States, vol. 1: Governance and International Relations, New York 2006. 



\section{ROZDZIAŁ I}

\section{WZAJEMNE ODDZIAŁYWANIE CZYNNIKÓW POLITYCZNYCH I EKONOMICZNYCH W ŚWIETLE TEORII MIĘDZYNARODOWEJ EKONOMII POLITYCZNEJ}

\subsection{Wyodrębnienie się międzynarodowej ekonomii politycznej. Definicje i zakres badań}

Związki między gospodarką i polityką są trwałym elementem stosunków międzynarodowych. Jednak w badaniach naukowych istniał podział między politologią i ekonomią, który doprowadził do specjalizacji na uniwersytetach. Osobno badano i nauczano międzynarodowych stosunków politycznych i międzynarodowych stosunków gospodarczych. Takie podejście dominowało w latach 50. i 60. XX w. Mniej uwagi poświęcano politycznej analizie kwestii gospodarczych. Skupiano się raczej na strategicznych, politycznych i militarnych aspektach zimnej wojny ${ }^{1}$.

Na początku lat 70. XX w. wyraźnie zarysowała się interakcja między polityką a gospodarką. Spadło wtedy napięcie związane z zagrożeniem wybuchem światowego konfliktu militarnego ze względu na politykę odprężenia w relacjach między Wschodem a Zachodem. Ważnym wydarzeniem na początku tego okresu było odejście od systemu monetarnego ustalonego w 1944 r. w Bretton Woods, wymuszone przez światowy kryzys walutowy. Do uwypuklenia współzależności między polityką a gospodarką przyczynił się również kryzys naftowy 1973 r., spowodowany decyzją państw OPEC o ograniczeniu produkcji ropy naftowej i nałożeniu embarga na dostawy tego surowca do Stanów Zjednoczonych i Holandii².

Bardzo istotna była również zmieniająca się pozycja Stanów Zjednoczonych. Państwo to przeżywało wewnętrzne trudności gospodarcze, borykając się ze wzrastającą inflacją i bezrobociem. Zmagało się też z deficytem bilansu płatniczego.

${ }^{1}$ Wprawdzie pojawiały się prace uwzględniające takie współzależności, ale takie podejście było rzadkie. Jako przykład można wymienić pracę Alberta Hirschmana, dotyczącą wykorzystywania przez Niemcy handlu międzynarodowego do rozszerzania wpływów w Europie Środkowej (A. Hir s chman, National Power and the Structure of Foreign Trade, Berkeley 1945) czy prace Charlesa Kindlebergera (np. Ch. K i n d l e b e r g e r, Foreign Trade and National Economy, New Haven 1962). Zob. więcej przykładów: P. Katzen ste in, R. Ke o h a ne, S. Kras ner, International Organization and the Study of World Politics, „International Organization”, Autumn 1998, s. 3-36.

${ }^{2}$ Zagadnienia te zostaną omówione szczegółowo w kolejnych rozdziałach pracy. 
Jednocześnie wzrastała siła ekonomiczna Europejskiej Wspólnoty Gospodarczej i Japonii. Ożywiły się także kontakty z blokiem komunistycznym i z Chinami, które wychodziły z izolacji na arenie międzynarodowej. Wzrastała rola tzw. Trzeciego Świata - można było zauważyć rywalizację mocarstw o wpływy polityczne i gospodarcze. Poza tym kraje bogate w ropę naftową w coraz większym stopniu wpływały na stosunki międzynarodowe ${ }^{3}$.

Umiędzynarodowienie systemu gospodarczego niosło pozytywne skutki, takie jak większa efektywność, specjalizacja i konkurencja. Rządzący państwami narodowymi musieli się jednak liczyć z poważnymi ograniczeniami, zwiększyła się bowiem podatność krajowych gospodarek na wydarzenia za granicą, na które rządy nie miały wpływu, to z kolei rodziło konflikty przenoszące się na sferę międzynarodowych stosunków politycznych. Nieporozumienia wynikały głównie z rywalizacji o zagraniczne rynki, warunki wzajemnego handlu i inwestycji oraz kwestie monetarne ${ }^{4}$. Kluczową rolę odegrała rosnąca świadomość obywateli państw demokratycznych co do związków polityki i gospodarki. Przedmiotem debaty publicznej stały się polityczne przyczyny trudności gospodarczych oraz ekonomiczne przesłanki działania państw lub grup interesów na arenie międzynarodowej. Zauważano „upolitycznienie” zagranicznych relacji gospodarczych i rosnące wpływy interesów ekonomicznych na politykę państw ${ }^{5}$. Proste podziały między państwem a rynkiem, sprawami wewnętrznymi i zagranicznymi, polityką i gospodarką nie tłumaczyły skomplikowanych procesów. Badanie stosunków międzynarodowych wymagało kompleksowego podejścia.

W pierwszej połowie lat 70. XX w. amerykańscy i brytyjscy naukowcy, tacy jak Richard Cooper, Susan Strange, Robert Keohane i Joseph Nye, zauważyli, że większość opracowań na temat stosunków międzynarodowych była niekompletna ${ }^{6}$. Twierdzili, że międzynarodowa polityka gospodarcza zaczęła odgrywać kluczową rolę w kształtowaniu relacji między państwami. Zauważono, że na arenie międzynarodowej państwo nie tylko działa w sferze politycznej i wojskowej, lecz także jest aktywnym aktorem stosunków gospodarczych. Doceniono wagę zagrożenia jego bezpieczeństwa ekonomicznego, dlatego dodano ważne kryterium siły państwa potencjał gospodarczy ${ }^{7}$. Pojawiały się również prace przedstawiające poszczególne problemy, zakładające zdecydowaną dominację jednego z czynników, gospodarczego lub politycznego. Takie podejście krytykowali Keohane i Nye w artykule napisanym wspólnie z Fredem Bergstenem wykazując, że „ani polityczny, ani ekonomiczny

${ }^{3}$ J. E. S p e r o, The Politics of International Economic Relations, New York 1999, s. 3-4.

${ }^{4}$ G. M. M e i e r, International Economics. The Theory of Policy, New York 1980, s. 3. Por. D. B a ldw in, International Political Economy and International Monetary Syastem, „International Organization", Autumn 1980, s. 512.

${ }^{5}$ R. G i l p i n, The Political Economy of International Relations, Princeton 1987, s. 4.

${ }^{6}$ C. Chavagne ux, Economics and Politics: Some Bad Reasons for a Divorce, „Review of International Political Economy", Winter 2001, s. 609-632.

${ }^{7}$ E. H a l iż a k, Międzynarodowe stosunki ekonomiczne, [w:] Stosunki międzynarodowe. Geneza, struktura, dynamika, red. E. Haliżak, R. Kuźniar, Warszawa 2006, s. 202. 
determinizm nie wytłumaczy zjawisk wyczerpująco" ${ }^{\prime \prime}$. Zauważyli, że często trudno nawet określić, czy jakieś działanie ma charakter polityczny czy gospodarczy.

Richard Cooper w pracy opublikowanej w 1968 r. zwrócił uwagę na coraz większą współzależność gospodarczą państw, postulując zorganizowanie ścisłej współpracy dla dobra całego systemu'. Z kolei Susan Strange zakwestionowała realistyczną teorię dotyczącą motywów działań państw narodowych. Wskazywała na zanik znaczenia relacji bilateralnych i wzrost multilateralizmu. Zwracała uwagę na innych aktorów stosunków międzynarodowych. Pisała, że jeśli badacze nie będą uwzględniali czynnika ekonomicznego, prace dotyczące polityki zagranicznej, studiów strategicznych i organizacji międzynarodowych nie będą oddawały rzeczywistego stanu rzeczy ${ }^{10}$. Robert Keohane i Joseph Nye sugerowali trzystopniową analizę stosunków międzynarodowych: na poziomie poszczególnych obszarów (politycznym, ekonomicznym, bezpieczeństwa), uwzględniającą wpływ czynników pozarządowych i transnarodowych oraz ukazującą związki między różnymi obszarami ${ }^{11}$.

Pionierskie prace tych autorów dały początek wyodrębnieniu się subdyscypliny w stosunkach międzynarodowych - międzynarodowej ekonomii politycznej (MEP, International Political Economy). Nazwę tę wprowadziła po raz pierwszy Susan Strange dopiero w latach 80. XX w. ${ }^{12} \mathrm{~W}$ polskiej literaturze przedmiotu spotyka się określenie ekonomia polityczna stosunków międzynarodowych (EPSM, Political Economy of International Relations $)^{13}$, zaczerpnięte z tytułu pracy Roberta

${ }^{8}$ R. Ke o h a n e, J. N y e, Power and Interdependence. World Politics in Transition, Boston 1977, s. 85. Zbigniew Landau zwrócił uwagę, że równie absurdalne są próby udowodnienia rozdzielności sfer gospodarczej i politycznej oraz szukanie za wszelką cenę motywów gospodarczych dla każdego wydarzenia politycznego, a politycznych - dla wszystkich działań gospodarczych (Z. Landau, Zwiq̨zki gospodarki z politykq, [w:] Nauki ekonomiczno-spoleczne i rozwój, red. K. Żukrowska, Warszawa 2008, s. 264).

${ }^{9}$ R. C o o p e r, The Economics of Interdependence: Economic Policy in the Atlantic Community, New York 1968. Autor był podsekretarzem stanu ds. gospodarczych w administracji Jimmy’ego Cartera. Pełnił wiele ważnych funkcji, m.in. w Radzie Stosunków Międzynarodowych (Council on Foreign Relations), w komitecie doradczym Instytutu Gospodarki Międzynarodowej (Institute for International Economics). Był także członkiem Komisji Trójstronnej, skupiającej osobistości świata biznesu, przemysłu, finansów, a także byłych wysokich urzędników państwowych i profesorów akademickich z Ameryki Północnej, Europy Zachodniej i Japonii. Jest profesorem Uniwersytetu Harvarda.

${ }^{10}$ S. S tr a n g e, International Economics and International Relations: A Case of Mutual Neglect, „International Affairs”, April 1970, s. 309.

${ }^{11}$ Transnational Relations and the World Politics, eds. R. Keohane, J. Nye, Jr, Boston 1972, s. 337344. Zob. także: R. K e o h a n e, J. N y e, Power and Interdependence..., s. 85.

${ }^{12}$ S. Strange, States and Markets. An Introduction to the International Political Economy, New York 1988. Na temat określeń tej subdyscypliny zob.: E. Haliżak, Ujęcie roli państwa $w$ ekonomii politycznej stosunków międzynarodowych, [w:] Państwo w teorii i praktyce stosunków międzynarodowych, red. M. Sułek, J. Symonides, Warszawa 2009, s. 24.

${ }^{13}$ E. Haliżak, Współzależność polityki i ekonomii w stosunkach międzynarodowych, [w:] Stosunki międzynarodowe w XXI wieku. Księga jubileuszowa z okazji 30-lecia Instytutu Stosunków Międzynarodowych Uniwersytetu Warszawskiego, red. E. Haliżak i in., Warszawa 2006, s. 41. 
Gilpina ${ }^{14}$. Jednak także Gilpin używa nazwy International Political Economy, która do czasów współczesnych jest przyjęta w opracowaniach anglojęzycznych. Dlatego w swojej pracy będę stosowała określenie „międzynarodowa ekonomia polityczna”.

Międzynarodowa ekonomia polityczna to nauka zajmująca się problemami międzynarodowymi, których nie można wytłumaczyć, analizując oddzielnie różne ich aspekty ${ }^{15}$. Susan Strange zdefiniowała tę dyscyplinę jako dotyczącą „społecznych, politycznych i ekonomicznych układów, mających wpływ na światowy system produkcji, wymiany, dystrybucji i różnorodnych wartości występujących w ich obrębie"16.

Helen Milner wyróżniła dwie definicje. Pierwsza, bardziej ogólna, wskazuje, że MEP to „wszystkie badania stosunków międzynarodowych oprócz badań nad bezpieczeństwem" ${ }^{17}$. Jednak określenie to wydaje się dość nieprecyzyjne, gdyż w badaniach nad bezpieczeństwem również uwzględniano wpływ czynników gospodarczych. Druga uwzględnia badanie „interakcji między rynkami i państwami, wpływ decyzji o charakterze politycznym na aktorów gospodarczych" i odwrotnie - sytuacji ekonomicznej na działania polityczne. Autorka opowiada się za definicją MEP zakładającą, że relacje gospodarcze są nierozdzielną częścią badań stosunków międzynarodowych. Należy uwzględnić przy tym nie tylko działania rządów państw narodowych, instytucji finansowych, korporacji i organizacji międzynarodowych, grup społecznych, lecz także instytucji niezwiązanych bezpośrednio z gospodarką, zajmujących się ochroną środowiska czy prawami człowieka. Ważnymi czynnikami są współpraca międzynarodowa na różnych polach i konflikty (w tym militarne, szczególnie ich ekonomiczne konsekwencje) ${ }^{18}$.

MEP rozwijająca się w ramach nauki o stosunkach międzynarodowych ma również zastosowanie w innych dyscyplinach. Bez uznania współzależności polityki i gospodarki nie sposób napisać dogłębnej pracy z historii dyplomacji, historii gospodarczej czy politologii. Zakres badań MEP nieustannie się rozszerza, wykorzystuje ona metody stosowane w innych naukach.

Według Roberta Gilpina, głównym zadaniem MEP jest przedstawianie wpływu światowej gospodarki rynkowej na relacje między państwami. Badacz koncentruje się również na sposobach używanych przez państwa w celu kształtowania sił rynkowych umożliwiających osiągnięcie własnych korzyści. W relacjach między państwami narodowymi a rynkami należy rozważać trzy aspekty. Pierwszym z nich jest sposób, w jaki współzależność gospodarcza wpływa na politykę międzynarodową i ulega jej

${ }^{14}$ R. G i l p in, The Political Economy...

${ }^{15}$ D. N. B al a a m, M. Ve s eth, Introduction to International Political Economy, New Jersey 2005, s. 3.

${ }^{16}$ S. St r a n g e, States and Markets..., s. 16.

${ }^{17} \mathrm{H}$. M il n e r, The Analysis of International Relations: International Political Economy and Formal Models of Political Economy, [w:] Cases, Numbers, Models: International Relations Research Methods, eds. D. F. Sprinz, Y. Wolinsky, Ann Arbor 2004, s. 284.

${ }^{18}$ Ibidem, s. 285-286. 
wpływom, szczególnie w warunkach istnienia lub braku politycznego przywództwa. „Założenie o ogromnym wpływie systemu rynkowego na wojnę lub pokój, porządek lub chaos, imperializm lub samostanowienie wywołuje ważne pytanie: czy liberalna gospodarka światowa wymaga istnienia hegemona, który zarządzałby systemem"19. Według autora jest to niezbędne, dlatego uważał wzrost Japonii i innych umacniających się gospodarek za poważne wyzwanie dla systemu oraz przede wszystkim dla Stanów Zjednoczonych i Europy Zachodniej.

Drugim aspektem badań są interakcje między zmianami politycznymi i gospodarczymi, które dają impuls intensyfikacji konkurencji pomiędzy państwami o wpływy gospodarcze w różnych częściach świata. Najważniejsza jest odpowiedź na pytanie, jak prosperity lub niestabilność ekonomiczna wpływa na relacje między nimi oraz jak czynniki polityczne działają na kształt i konsekwencje zmian strukturalnych gospodarki rynkowej. Można też badać, czy destabilizacja gospodarcza może być powodem radykalnych działań politycznych, takich jak ekspansja, rewolucja polityczna czy wojna. Naukowcy zajmują się również poszukiwaniem odpowiedzi na pytanie, jak zderzenie między dążeniem państw do wewnętrznej autonomii i potrzebą istnienia międzynarodowych zasad może być złagodzone.

Trzecim wymienionym przez Gilpina obszarem badawczym jest mierzenie wpływu rynku światowego na rozwój gospodarczy poszczególnych krajów oraz określenie wpływu państw na zasady i instytucje rządzące handlem, inwestycjami zagranicznymi, systemem monetarnym i innymi aspektami międzynarodowej ekonomii politycznej. Za tymi pozornie technicznymi kwestiami kryją się ważne zagadnienia polityczne, które wpływają na siłę, współzależność i dobrobyt poszczególnych państw. Handel powinien przynosić korzyści wszystkim stronom, jednak każde państwo stara się uzyskać nieproporcjonalnie duże zyski, chce mieć ważny głos w podejmowaniu decyzji związanych z zasadami rządzącymi międzynarodowym systemem monetarnym. Dlatego na każdym obszarze międzynarodowych relacji gospodarczych kwestie polityczne odgrywają istotną rolę ${ }^{20}$.

Helen Milner, kreśląc szerokie spektrum badawcze MEP, wyróżnia trzy dominujące tematy: 1) badania nad przyczynami odmiennej dynamiki rozwoju poszczególnych krajów i regionów; 2) wpływ międzynarodowych stosunków gospodarczych na politykę wewnętrzną państw i globalne współzależności; 3) sposoby wykorzystywania przez państwa potencjału politycznego i gospodarczego do realizacji celów w polityce wewnętrznej i międzynarodowej ${ }^{21}$.

Roger Tooze określa zakres badań MEP jako analizę współoddziaływania obszarów międzynarodowych stosunków gospodarczych, międzynarodowych stosunków politycznych oraz wewnętrznej polityki i gospodarki poszczególnych państw. Zwraca uwagę na handel międzynarodowy, międzynarodowe finanse, problemy

\footnotetext{
${ }^{19}$ R. G il p i n, The Political Economy..., s. 8-11.

${ }^{20}$ Ibidem, s. 12-24.

${ }^{21}$ Ibidem, s. 286-288.
} 
gospodarki światowej, relacje Północ-Południe i działanie wielonarodowych korporacji ${ }^{22}$.

Handel międzynarodowy znajdował się w centrum badań MEP ze względu na jego duże znaczenie polityczne. Analiza pozwala odnotować najważniejsze napięcia między państwem a rynkiem w danej epoce, a także dostrzec potencjalne konflikty międzynarodowe, które mogą wyniknąć z nieporozumień gospodarczych. Badając handel międzynarodowy, należy brać pod uwagę fakt, że granice rynków są dynamiczne i rzadko pokrywają się ze sztywnymi granicami państw - niektóre z nich mają globalny zasięg. Jednak handel międzynarodowy jest przedmiotem politycznego nadzoru. Analizując wpływ wymiany na stosunki międzynarodowe trzeba uwzględnić cele państw i grup interesów oraz siłę, dzięki której mogą je realizować. Nieodzowna jest także obserwacja zachowań poszczególnych aktorów w międzynarodowym systemie handlowym, który pozwala rozwiązywać potencjalne konflikty $^{23}$. W czasie zimnej wojny poza blokiem komunistycznym był on kształtowany przez hegemonię Stanów Zjednoczonych i stanowił przejaw strategii tego państwa w stosunkach Wschód-Zachód. W latach 80. i 90. XX w. MEP zajęła się badaniem integracji gospodarczej, uznając handel za narzędzie konsolidacji interesów regionalnych. W erze globalizacji i zaawansowanych technologii, handel rozpatrywany jest $w$ jeszcze szerszym, światowym kontekście.

Równie ważne wydają się wpływy polityczne na międzynarodowe finanse: politykę kursów wymiany, międzynarodowy przepływ kapitału, państwowe i globalne struktury polityczne oraz instytucje. Podczas zimnej wojny stosunki międzynarodowe rozpatrywano przede wszystkim w kontekście konfliktu Wschód-Zachód. Jednak wzrost znaczenia handlu i przepływu kapitału wymuszał również zajęcie się relacjami Północ-Południe (zakładając, że Północ to kraje rozwinięte, a Południe - rozwijające się, co nie zawsze pokrywa się z ich położeniem na mapie świata). Zainteresowanie wzbudzało też badanie relacji wewnątrzblokowych ze względu na polityczno-ekonomiczne napięcia między Stanami Zjednoczonymi a Europą Zachodnią i Japonią.

Podczas zimnej wojny, miejsce krajów rozwijających się na arenie międzynarodowej było podporządkowane rywalizacji między Wschodem a Zachodem. Publicysta gazety „New York Times”, Thomas Friedman, nazwał strategię stosowaną przez obie strony strategią "książeczki czekowej i szachownicy” (checkbook and the chessboard), co odnosiło się do pomocy gospodarczej tym krajom, by zapewnić sobie w nich wpływy i nie dopuścić do ich aliansu z zimnowojennym przeciwnikiem. Jako przykład takich działań można podać zaangażowanie się Stanów Zjednoczonych na Bliskim Wschodzie, a Europy Zachodniej w Afryce ${ }^{24}$. Po zakończeniu zimnej wojny

${ }^{22}$ R. To o z e, Perspectives and Theory: A Consumer's Guide, [w:] Key Concepts in International Political Economy, ed. D. A. Baldwin, vol. 1, Vermont 1993, s. 82.

${ }^{23}$ B. C o h e n, The Political Economy of International Trade, „International Organization”, Spring 1990, s. 281.

${ }^{24}$ A. Shonfield, The Economic Factor in International Relations, „International Affairs”, November 1970, s. 123. 
naukowcy badali relacje, według określenia Immanuela Wallersteina, między centrum (core) a peryferiemi (periphery) ${ }^{25}$. Brali pod uwagę rozwój gospodarczy, zjawisko tzw. neokolonializmu i neoimperializmu.

Korporacje wielonarodowe (multinational corporations - MNCs) od początku prowadzenia badań $w$ ramach MEP były postrzegane jako istotne elementy stosunków międzynarodowych. Raymond Vernon zdefiniował je w następujący sposób: „grono korporacji różnego pochodzenia narodowego, złączone poprzez więzy wspólnej własności i podlegające wspólnej strategii zarządzania"26. Według Elliota Goodmana, w latach 70. nie miała już zastosowania tradycyjna teoria handlu mówiąca, że państwa ustalają wszystkie jego warunki. Wielonarodowe korporacje eksportowały kapitał, technologię i techniki zarządzania. Państwo narodowe miało być tylko punktem odniesienia - działając na forum międzynarodowych organizacji gospodarczych i zawierając umowy międzypaństwowe liberalizujące wymianę 27 Z drugiej strony udowadniano, że przedsiębiorstwa pochodzące ze Stanów Zjednoczonych i Europy Zachodniej były powiązane z własnymi rządami przez „niewidzialne podanie ręki" (invisible handshake). Rządy państw zachodnich używały narzędzi politycznych, by stwarzać dogodne warunki na rynkach zagranicznych dla współpracujących z nimi firm, które w zamian działały w gospodarczym, a czasem politycznym interesie kraju pochodzenia ${ }^{28}$.

Po zakończeniu zimnej wojny wzrost „azjatyckich tygrysów” oraz rosnąca globalizacja produkcji i finansów zapoczątkowała badania nad rolą przedsiębiorstw wielonarodowych w alokacji kapitału i kontroli nad technologią. Coraz częściej kwestionowano ich silne związki z rządami rodzimych państw, bo to one same ustalały strategie biznesowe, niekoniecznie w interesie własnych rządów. Poza tym różnica między krajem pochodzenia (home country) i goszczącym (host country) była coraz bardziej płynna. W pewnym sensie wszystkie państwa gościły przedsiębiorstwa wielonarodowe, a także rywalizowały o kapitał, technologię i miejsca pracy na rynku światowym dla wielonarodowych inwestycji. Ponieważ ulokowanie aktywności gospodarczej było coraz mniej identyfikowane z granicami państwa narodowego, badania poszły w kierunku międzynarodowej polityki gospodarczej globalnych powiązań (International Political Economy of Global Commodity Chains - GCCs). Analizowano złożone sieci łączące niezależne przedsiębiorstwa w procesach skoordynowanej produkcji i dystrybucji. Niezależne firmy, dzięki rozwojowi technologii i komunikacji, często skupiały się na planowaniu i marketingu, a nie na produkcji. Zajmowały się nią inne niezależne przedsiębiorstwa.

\footnotetext{
${ }^{25}$ Więcej informacji na temat teorii Wallersteina zawarto w podrozdziale 1.3.

${ }^{26}$ R. Verno n, The Economic and Political Consequences of Multinational Enterprises, Boston 1972.

${ }^{27}$ E. R. G o o d m a n, The Impact of the Multinational Enterprise upon Atlantic Community, [w:] The New Europe and the United States. Partners or Rivals, ed. G. Mally, Lexington 1974, s. 247.

${ }^{28}$ R. Ke o hane, Van Doorn 0 oms, The Multinational Enterprise and World Political Economy, „International Organization”, Winter 1975, s. 120.
} 
Współcześnie badania MEP skupiają się wokół wielowymiarowego zjawiska globalizacji. Michael Veseth zauważył, że jest to wyraźne odejście od tradycyjnie rozpatrywanych stosunków międzynarodowych, w których głównymi aktorami są państwa. Dlatego MEP jest często postrzegana jako samodzielna dyscyplina. Stawia pytania o wpływ globalizacji na politykę, biznes, kulturę, technologię, środowisko, migracje, relacje płciowe, turystykę i wszelkie inne dziedziny życia. W tym kontekście często jest podważana dominująca rola państwa narodowego. Wielu naukowców uważa, że zostało ono znacznie osłabione przez procesy globalizacyjne. Twierdzą, że jest za małe, by samodzielnie i efektywnie radzić sobie z problemami globalnymi, a za duże, by dobrze administrować sprawami lokalnymi. Państwo egzystuje gdzieś pośrodku (in the „missing middle”), w globalnym porządku społecznym $^{29}$.

\subsection{Metody badawcze MEP}

MEP stara się wyjaśniać problemy międzynarodowe i globalne, używając interdyscyplinarnych metod analitycznych i teoretycznych. Kluczowa jest paralelna analiza gospodarcza i polityczna danej sytuacji, z zastosowaniem narzędzi wypracowanych przez ekonomię (zmienne i modele ekonomiczne) oraz nauki polityczne (kontekst polityczny). W stosunkach międzynarodowych wyróżnia się trzy główne metody analizy: studia przypadków (case studies), analizę statystyczną (statistical analysis) i tworzenie modeli formalnych (formal models) ${ }^{30}$.

Według Johna S. Odella, metody jakościowe, czyli studia przypadków, są najbardziej przydatne do tworzenia teorii w MEP. Definiując przypadek („przykład klasyfikacji wydarzeń lub zjawisk interesujących badacza") w określonej kwestii, np. negocjacji handlowych, Odell wyodrębnia dwie kategorie w ramach tej metody - studium pojedynczego przypadku i metodę porównawczą wielu przypadków (różnicowania). Ta pierwsza kategoria zawiera:

1. deskryptywne studium przypadku - jest to dokumentacja ważnego wydarzenia;

2. ilustrację teorii - autorzy udowadniają, że założenia danej teorii mają odzwierciedlenie w praktyce;

3. interpretację wybranych wydarzeń z zastosowaniem istniejących teorii metoda może prowadzić do potwierdzenia lub modyfikacji teorii;

4. studium przypadku, generujące nowe hipotezy.

${ }^{29}$ M. Ve s e th, International Political Economy, artykuł z UNESCO International Encyclopedia Project, 2004, dostępny przez: http://www.pugetsound.redu/x12490.xml.

${ }^{30}$ A. M i n t z, The Method-of-Analysis - a Problem in International Relations, [w:] New Directions for International Relations. Confronting the Method-of-Analysis Problem, eds. A. Mintz, B. Russet, Lanham 2005, s. 13. 
Metoda różnicowania zasadza się na „porównywaniu przypadków, w których występuje dane zjawisko z przypadkami podobnymi pod innym względem, w których dane zjawisko nie występuje"31.

Według Odella, badania jakościowe najlepiej służą budowaniu spójnej teorii, gdyż jej podstawę empiryczną stanowią realne zjawiska i wydarzenia. Metody jakościowe mogą dostarczyć więcej danych niż wyłącznie statystyczne, umożliwiają również umieszczanie zjawisk w szerszym kontekście, wyjaśnianie mechanizmów podejmowania decyzji. Analizując wiele przypadków, łatwiej stworzyć lub wybrać teorię najczęściej sprawdzającą się w praktyce. Odell zauważa także słabe strony tej metody - subiektywny wybór przypadków przez badaczy może prowadzić do wyciągania krańcowo różnych wniosków. Realia stosunków międzynarodowych dostarczają dowodów na potwierdzenie różnorakich teorii. Poza tym dane statystyczne w większym stopniu precyzują występowanie danego zjawiska i uwiarygodniają wnioski, dlatego autor postuluje uzupełnianie studiów przypadku zastosowaniem metod statystycznych. Takie rozwiązanie niweluje słabe strony obu metod ${ }^{32}$.

W MEP stosuje się także metody ilościowe, wykorzystując dane statystyczne. W większości prac autorzy badają, jak czynniki polityczne kształtują handel zagraniczny. Szczególnie dotyczy to globalnej dystrybucji władzy i kształtowania przez państwa systemu międzynarodowego handlu. Mierząc siłę wpływów państw, tradycyjnie bierze się pod uwagę takie czynniki, jak: wielkość i dynamikę PKB, liczbę ludności, wydatki militarne oraz dywersyfikację geograficzną eksportu i importu. Bada się również wpływ sojuszy i konfliktów na wymianę i inwestycje ${ }^{33}$. Wadą stosowania wyłącznie tej metody jest brak szerszego kontekstu, który zapewniają metody jakościowe.

W miarę rozwoju MEP coraz bardziej popularne stało się tworzenie modeli formalnych, w przeważającej mierze opartych na teorii racjonalnego wyboru. Zakłada ona, że racjonalne jednostki konsekwentnie realizują swoje cele, dysponując kompletną wiedzą o warunkach wpływających na ich decyzje. Aktorzy działają w taki sposób, by osiągnąć maksymalną użyteczność. Teoria oparta na tych założeniach ma wskazać najlepszą drogę do realizacji wyznaczonych celów. Tworzone modele formalne ułatwiają porównanie kosztów i korzyści, wynikających z konkretnych posunięć, a racjonalny aktor wybiera najlepsze $\mathrm{z}$ nich. Formalizacja polega więc na transformacji wszystkich czynników wpływających na decyzje aktorów stosunków międzynarodowych w dedukcyjny, matematyczny schemat - model. Zawiera on explicite założenia danej analizy; funkcje zysków i strat danego aktora; działania, jakie może podjąć na każdym etapie oraz posiadane przez niego informacje i przekonania na temat danej sytuacji. Wszystkie te czynniki wyrażone są za pomocą pojęć matematycznych.

31 J. S. 0 de ll, Case Study Methods in International Political Economy, [w:] Cases, Numbers, Models..., s. 65-70.

${ }^{32}$ Ibidem, s. 70-84.

${ }^{33}$ E. D. M a n s f i e l d, Quantitative Approaches to the International Political Economy, [w:] Cases, Numbers, Models..., s. 164-189. 
W MEP, stosując modele formalne, bada się najczęściej trzy obszary: teorię hegemonicznej stabilności (aby wykazać, w jakich okolicznościach najsilniejsze państwo i jego sojusznicy dążą do stworzenia otwartego systemu handlowego), zagraniczną politykę gospodarczą (aby przewidzieć preferencje poszczególnych aktorów) oraz uwarunkowania szeroko pojętej współpracy międzynarodowej (badanie przydatności instytucji). Milner wykazuje przydatność tworzenia modeli formalnych. Przyznaje jednak, że w pracach z zakresu MEP muszą być one uzupełniane obszernymi komentarzami werbalnymi. Za największą słabość tej metody uznaje założenie, że aktorzy dysponują kompletnymi informacjami o danej sytuacji. Ze względu na wielość czynników na nią wpływających jest to niemożliwe, więc przetwarzanie danych w proponowany sposób jest mało precyzyjne ${ }^{34}$.

W badaniu stosunków międzynarodowych stosuje się też metodę systemową. Jej cel stanowi stworzenie modelu zjawisk z uwzględnieniem wszystkich elementów kształtujących określoną rzeczywistość. Metoda decyzyjna polega na badaniu wpływu różnych ośrodków decyzyjnych na zmiany w systemie ${ }^{35}$. W MEP analizuje się sprzężenie czynników politycznych i gospodarczych w ramach systemu. Bardzo istotne jest funkcjonowanie ośrodków decyzyjnych (rządów państw, instytucji, organizacji międzynarodowych, wielonarodowych korporacji), od których decyzji zależy kształt wzajemnych relacji na wszystkich polach.

W najnowszych opracowaniach autorzy dostrzegają potrzebę łączenia różnorodnych metod, żeby podejść do badanego problemu z wielu punktów widzenia. Stosowanie tylko jednego schematu analizy prowadzi do sytuacji, w której autorzy, rozważając ten sam problem, dochodzą do sprzecznych wniosków, np. jedni twierdzą, że handel pomaga w utrzymaniu pokoju, inni uważają, że nie ma na to wpływu. Alex Mintz sądzi, że podważa to wiarygodność badań stosunków międzynarodowych, dlatego politycy tak rzadko korzystają z dorobku naukowców $^{36}$. Problem polega jednak na tym, że obie przytoczone tezy o wpływie handlu międzynarodowego na stosunki międzynarodowe można udowodnić, przytaczając konkretne przykłady relacji między państwami. W tym przypadku potrzebna jest kompleksowa analiza sytuacji, tj. historii wzajemnych relacji, otoczenia międzynarodowego, potencjału poszczególnych państw, łączących ich interesów politycznych i gospodarczych, czynników socjologicznych, kulturowych i wielu innych.

Bruce Russet postulował konieczność stosowania różnorodnej metodologii ze względu na większe możliwości badawcze we współczesnym świecie. Miał przede wszystkim na myśli masową dostępność materiałów i danych statystycznych (także poprzez internet), co pozwala w pełni uwzględniać czynniki ekonomiczne w stosunkach międzynarodowych. Dzięki temu uległa poprawie jakość

\footnotetext{
${ }^{34}$ H. M i l n e r, The Analysis of International Relations..., s. 293-300.

${ }^{35}$ A. J. C h o d u b s k i, Wstęp do badań politologicznych, Gdańsk 2006, s. 119.

${ }^{36}$ A. M in tz, op. cit., s. 5 .
} 
empirycznej analizy weryfikującej wypracowywane teorie. Z tym zjawiskiem wiąże się wymaganie łączenia metod badawczych (network analysis) i zastępowanie tradycyjnych schematów nowymi. Russet zauważa, że decydujący wpływ na zmiany w badaniu stosunków międzynarodowych miało zakończenie zimnej wojny i to nie tylko ze względu na przeobrażenia układu sił na świecie. Stwierdził, że naukowcy w większym stopniu zaczęli zwracać uwagę na implikacje polityki wewnętrznej państw i globalne skutki działań wszystkich aktorów stosunków międzynarodowych ${ }^{37}$.

\subsection{Główne nurty teoretyczne MEP}

Pierwsze teorie MEP opierały się na trzech głównych perspektywach badań stosunków międzynarodowych: realizmie (definiowanym jako merkantylizm/neomerkantylizm lub nacjonalizm gospodarczy), liberalizmie i marksizmie (określanym jako strukturalizm). Ich charakterystykę, według Roberta Gilpina, przedstawiono w tabeli 1.1.

Tabela 1.1. Charakterystyka głównych perspektyw MEP

\begin{tabular}{|l|l|l|l|}
\hline & \multicolumn{1}{|c|}{ Liberalizm } & \multicolumn{1}{|c|}{ Strukturalizm } & \multicolumn{1}{|c|}{ Merkantylizm } \\
\hline $\begin{array}{l}\text { Natura relacji } \\
\text { gospodarczych }\end{array}$ & Harmonia & Konflikt & Konflikt \\
\hline Aktorzy & $\begin{array}{l}\text { Gospodarstwa domowe } \\
\text { i firmy }\end{array}$ & Klasy ekonomiczne & Państwa narodowe \\
\hline $\begin{array}{l}\text { Cel aktywności } \\
\text { gospodarczej }\end{array}$ & Globalne bogactwo & Interesy klasowe & Interesy narodowe \\
\hline $\begin{array}{l}\text { Relacje pomiędzy polity- } \\
\text { ką i gospodarką }\end{array}$ & $\begin{array}{l}\text { Gospodarka powinna wpły- } \\
\text { wać na politykę i być od niej } \\
\text { niezależna }\end{array}$ & $\begin{array}{l}\text { Gospodarka wpły- } \\
\text { wa na politykę }\end{array}$ & $\begin{array}{l}\text { Polityka wpływa } \\
\text { na gospodarkę }\end{array}$ \\
\hline Teoria zmian & Dynamiczna stabilność & $\begin{array}{l}\text { Tendencja do desta- } \\
\text { bilizacji }\end{array}$ & $\begin{array}{l}\text { Przesunięcia w dys- } \\
\text { trybucji władzy }\end{array}$ \\
\hline
\end{tabular}

Źródło: R. Gil pi n, U.S. Power and the Multinational Corporation. The Political Economy of Foreign Direct Investment, New York 1975, s. 27.

Gilpin zauważył różnicę dotyczącą czynników gospodarczych i politycznych pomiędzy tymi teoriami. Liberałowie postrzegali gospodarkę jako rodzaj gry, w której wszyscy aktorzy wygrywają, natomiast w teoriach kładących nacisk na czynniki polityczne przedstawiono władzę jako cel sam w sobie, a gospodarkę tylko jako

${ }^{37}$ B. R u s s e t t, Four Methods and Five Revolutions, [w:] New Directions..., s. 21-23. 
jeden ze środków do jej zdobycia. Negowano wtedy założenie o równomiernych korzyściach - gdy jedno państwo je zdobywa, to drugie je traci ${ }^{38}$.

Realizm podkreślał rolę równowagi sił w stosunkach międzynarodowych, nadrzędność państwa i jego zmiennych interesów. Zakładał również, że celem państw jest utrzymanie, zwiększenie lub demonstracja siły. Dążą w ten sposób do zapewnienia sobie bezpieczeństwa. Ich działania są racjonalne: starają się realizować cele w miarę swoich możliwości. Ze względu na anarchiczny charakter systemu międzynarodowego i sprzeczne interesy, państwa nieustannie biorą udział w konfliktach bądź się do nich przygotowują ${ }^{39}$. Twórca szkoły realizmu - Hans Morgenthau twierdził, że strefy polityki i gospodarki są odmienne i rządzą nimi inne prawa. Jednak inny czołowy przedstawiciel tego nurtu - Edward Carr uznał, że te dwie strefy łączą się, a siła ekonomiczna jest instrumentem siły politycznej ${ }^{40}$. W latach 70 . ukształtował się neorealizm, reprezentowany przez Kennetha Waltza. W pracy Theory of International Politics („Teoria polityki międzynarodowej”) twierdził, że nie można postrzegać międzynarodowych relacji politycznych jedynie w kategoriach interakcji między państwami narodowymi. Postulował widzenie w nich systemu o precyzyjnej strukturze. Jego warunki kształtowane są poprzez zachowanie państw, a nie tylko poprzez ich miejsce w hierarchii. Siła nie jest, jak twierdzili realiści, środkiem i celem. Państwa dążą do zachowania bezpieczeństwa, więc dążenie do potęgi jest zachowaniem racjonalnym. Muszą $\mathrm{w}$ ten sposób zapewnić sobie odpowiednią pozycję w anarchicznym systemie, by mieć większy wpływ na jego kształtowanie. Oprócz siły militarnej, o roli państwa na arenie międzynarodowej decyduje populacja, bogactwa naturalne, potęga gospodarcza, stabilność polityczna i zdolności przywódcze liderów ${ }^{41}$.

Neomerkantylizm zakładał podporządkowanie gospodarki państwu i jego interesom - głównie związanym z dobrobytem wewnętrznym i międzynarodowym bezpieczeństwem gospodarczym. Jego zwolennicy podkreślali znaczenie potencjału gospodarczego, a nie militarnego. Według tej teorii, międzynarodowe relacje ekonomiczne mają charakter konfliktogenny i są zdominowane przez rosnącą ingerencję rządu w gospodarkę. Ponieważ relacje gospodarcze są determinowane przez politykę, ich badanie ma sens tylko w kontekście państw. Starają się one chronić swe gospodarcze interesy, a także pozycję polityczną i militarną, przed negatywnym wpływem zewnętrznych sił globalnego rynku. W tym celu wspierają sektory uważane za strategiczne, a także starają się kontrolować zagraniczne inwestycje ${ }^{42}$. Największym

${ }^{38}$ R. G il p i n, U.S. Power and the Multinational Corporation. The Political Economy of Foreign Direct Investment, New York 1975, s. 34-35.

${ }^{39} \mathrm{~J}$. C z a p u t o w i c z, Teorie stosunków międzynarodowych. Krytyka i systematyzacja, Warszawa 2008, s. 58-59.

${ }^{40}$ Ibidem, s. 79.

${ }^{41}$ K. W a l t z, Theory of International Politics, New York 1979. Por. J. C z a p u t o w i c z, op. cit., s. 181.

${ }^{42}$ F. L. B l o c k, The Origins of International Economic Disorder, Berkeley 1977. 
problemem $\mathrm{w}$ stosowaniu $\mathrm{w}$ badaniach teorii neomerkantylizmu jest oddzielenie interesów państwa od interesów prywatnych przedsiębiorstw i sił społecznych ${ }^{43}$. Współcześnie to one wytwarzają bogactwo, budujące siłę i prestiż państwa na arenie międzynarodowej.

Robert Gilpin jest uważany za głównego przedstawiciela realizmu postklasycznego. W przeciwieństwie do przedstawicieli klasycznego realizmu, określa system międzynarodowy nie jako anarchiczny, ale hegemonicznie zarządzany. Jego zdaniem to hegemoniczne mocarstwo jest odpowiedzialne za podtrzymywanie systemu światowego. Konstruując teorię zmiany systemu, podkreślał kluczowe znaczenie osłabienia potencjału ekonomicznego hegemona ${ }^{44}$.

W pracy Gilpina U.S. Power and the Multinational Corporation. The Political Economy of Foreign Direct Investment („Siła Stanów Zjednoczonych i korporacje wielonarodowe. Ekonomia polityczna zagranicznych inwestycji bezpośrednich"), zawarta jest neomerkantylistyczna koncepcja tłumaczenia współzależności oraz postrzeganie międzynarodowej polityki gospodarczej jako „wzajemnej i dynamicznej interakcji w stosunkach międzynarodowych w procesie dążenia do osiągnięcia dobrobytu i siły" ${ }^{\prime 5}$. Autor twierdził, że międzynarodowe stosunki gospodarcze mają charakter polityczny. Wysunął tezę, że współzależność gospodarek narodowych wytwarza ekonomiczną siłę, którą można określić jako potencjalną możliwość jednego kraju do zaszkodzenia innemu poprzez zerwanie z nim relacji handlowych i finansowych. Twierdził, że ekspansja amerykańskich korporacji może być rozumiana wyłącznie w kontekście globalnego systemu politycznego, ustanowionego po II wojnie światowej. Wyraził również zaniepokojenie pogorszeniem pozycji USA na arenie międzynarodowej, co porównywał ze zmierzchem imperium brytyjskiego i zasadniczymi zmianami w systemie światowym, które były jego konsekwencją ${ }^{46}$.

Gilpin przyznaje, że państwa narodowe są głównymi aktorami na arenie międzynarodowej, ale dodaje, że nie jedynymi, gdyż narodowy interes określają nie tylko elity polityczne, ale również gospodarcze, biorąc pod uwagę różnorodne czynniki takie jak: kultura, ideologia, położenie geograficzne, rozwój technologii militarnej i dystrybucja siły. Współpraca gospodarcza sprawia, że państwa nie tworzą rywalizujących ze sobą bloków ekonomicznych, dopóki pozostają w jednym systemie gospodarczym, gdyż przynosi im on nie tylko ograniczenia, ale możliwość rozwoju. Istnieje jednak niebezpieczeństwo, że jakieś państwo zdecyduje się na krótkowzroczne działania spowodowane doraźną sytuacją. Autor udowadnia, że każdy system gospodarczy jest oparty na określonym porządku, więc jego natura nie może być zrozumiała bez kontekstu

${ }^{43}$ The Theoretical Evolution of International Political Economy: A Reader, eds. G. T. Crane, A. Amawi, Oxford 1997, s. 13-20.

${ }^{44} \mathrm{~J}$. C z a p u to w i c z, op. cit., s. 201.

${ }^{45}$ R. G i l p in, U.S. Power and the Multinational Corporations..., s. 86.

${ }^{46}$ Ibidem, s. 19, 38. 
politycznego. Dlatego po zakończeniu II wojny światowej dominowała tendencja do zapewniania wolności inwestycji, a prymat wielonarodowych korporacji był odzwierciedleniem interesów politycznych i gospodarczych najsilniejszych aktorów (w systemie zachodnim - Stanów Zjednoczonych) ${ }^{47}$.

W 1975 r. Gilpin przedstawił trzy modele przyszłego rozwoju relacji międzynarodowych, odnosząc się do trzech szkół ekonomii politycznej: liberalizmu, marksizmu i merkantylizmu, zwanego tu nacjonalizmem gospodarczym. Podkreślał, że są to modele idealne, niewystępujące zwykle w czystej postaci, ale pomagające zrozumieć także reguły polityki ekonomicznej w stosunkach międzynarodowych. Nazwę pierwszego z nich, „zagrożona suwerenność” (sovereignty-at-bay), Gilpin zaczerpnął z tytułu książki Raymonda Vernona wydanej w 1971 r. Vernon przewidywał zderzenie między dwiema siłami: systemem państw narodowych, których zadaniem jest zabezpieczenie interesów obywateli i systemem przedsiębiorstw reagujących na rosnące możliwości zysku, pojawiające się wraz z postępem technologicznym. Stwierdził, że istniejące instytucje międzynarodowe nie radziły sobie z tym problemem, a brak skoordynowanych działań mógł okazać się destrukcyjny dla gospodarki światowej ${ }^{48}$.

Wykorzystując teorię Vernona, Gilpin nawiązywał do modelu liberalnego. Rosnące współzależności gospodarcze, postęp w komunikacji i transporcie sprawiają, że państwa narodowe staną się coraz bardziej anachroniczne. Można było przewidzieć, że stopniowo będą oddawały prerogatywy gospodarcze w ręce międzynarodowych korporacji. W przyszłości miał się rozstrzygnąć konflikt między siłami politycznego nacjonalizmu i siłami ekonomicznymi, które dążą do integracji gospodarczej całego świata. Wprawdzie w latach 70. dostrzegano przewagę sił politycznych, niemniej jednak w przyszłości miały „zwyciężyć” czynniki ekonomiczne, co miało zakończyć się powstaniem jakiejś formy rządu światowego. Autor zauważył, że już w latach 70. produkcja, marketing i inwestycje miały charakter ponadnarodowy. Stwierdził, że choć dobrobyt państwa był głównym celem rządów, w dobie gospodarki globalnej można go było osiągnąć wyłącznie uczestnicząc w zorganizowanym systemie światowym. Państwo narodowe musi więc oddawać część suwerenności, a rządy, by utrzymać się przy władzy, winny spełniać rosnące oczekiwania ekonomiczne obywateli i brać pod uwagę interesy międzynarodowych korporacji. Żeby system mógł działać sprawnie, państwa muszą starać się o zapewnienie możliwie stabilnego porządku politycznego, zarówno wewnętrznego, jak i zewnętrznego. Powiązania ekonomiczne zmniejszają również ryzyko konfliktu politycznego, szczególnie militarnego. Zgodnie z teorią liberalną, nieopłacalne są również „wojny gospodarcze". Przedstawiając te wnioski Gilpin przyznawał, że powojenny system stworzony przez Stany Zjednoczone stawał się nieadekwatny do rozwoju gospodarczego i wymagał zasadniczych zmian ${ }^{49}$.

\footnotetext{
${ }^{47}$ Ibidem, s. 86.

${ }^{48}$ R. Ve r n o n, Sovereignty-at-bay: the Multinational Spread of U.S. Enterprises, New York 1971.

${ }^{49}$ R. G i l p i n, Three Models of the Future, [w:] Key Concepts..., s. 36.
} 
Drugi model, nazwany przez autora „współzależnym” (dependencia) odnosił się do teorii marksistowskiej. Dzielił uczestników gospodarki światowej na "wykorzystujących” i „wykorzystywanych”, centra oraz peryferie władzy i finansów. Jest to odniesienie do pochodzącego z teorii marksistowskiej strukturalizmu.

Trzeci model, merkantylistyczny, nawiązuje do teorii realizmu. Gilpin zauważył, że źródłem zmian w stosunkach międzynarodowych jest zmierzch hegemonii Stanów Zjednoczonych w gospodarce światowej w latach 70. XX w., który powodował narastanie poważnych konfliktów między państwami kapitalistycznymi na polu gospodarczym. Badacz przewidywał, że w związku z tym wytworzy się nowy porządek gospodarczy, charakteryzujący się rosnącą konkurencją między czołowymi państwami - mocarstwami gospodarczymi. Rządy będą się starały osiągnąć porozumienia, by uzyskać maksymalne korzyści dla swojego kraju, nawet, jeżeli będzie się to działo kosztem innych. Taka postawa miała związek z polityką wewnętrzną poszczególnych graczy (dążenie do spadku bezrobocia czy zmniejszenia deficytu handlowego) lub polityką zagraniczną (współzależność bezpieczeństwa, jak to miało miejsce w przypadku Stanów Zjednoczonych i Europy Zachodniej). Zgodnie z tym modelem, interesy narodowe zdecydowanie przeważały nad globalnymi. Gospodarka światowa była w trakcie rozpadu na konkurujące ze sobą bloki handlowe, co skutkowało ograniczeniem promowania wolnego handlu w polityce zagranicznej Stanów Zjednoczonych. Niektórzy neomerkantyliści dostrzegali również dobre strony tworzących się bloków handlowych. Integracja tego typu miała charakter regionalny, co generowało współpracę sąsiedzką i zwiększało zdolność wypierania wrogich wpływów (np. Europa Zachodnia nie byłaby podatna na "finlandyzację") ${ }^{50}$.

Syntezą poglądów Gilpina była wydana w 1987 r. monografia pt. The Political Economy of International Relations („Ekonomia polityczna stosunków międzynarodowych"). Jej teoretyczna część ukazuje główne perspektywy przyjęte przez naukowców zajmujących się MEP. Autor zamieszcza także krytykę tych podejść. Przedstawia trzy najbardziej wpływowe teorie, czyli nowoczesnego systemu światowego, hegemonicznej stabilności ${ }^{51}$ i gospodarki dualistycznej. Wyprowadzona z liberalizmu teoria gospodarki dualistycznej (theory of the dual economy) postrzega ewolucję rynku jako skutek powszechnego dążenia do wzrostu efektywności i maksymalizacji bogactwa. Zakłada, że gospodarka, zarówno narodowa jak i światowa, musi być analizowana pod kątem dwóch niezależnych sektorów: nowoczesnego, z wysokim poziomem produktywności i charakteryzującego się ekonomiczną integracją oraz sektora tradycyjnego, ze świadczącymi o zacofaniu sposobami produkcji i lokalną samowystarczalnością. Teoria zakłada, że proces rozwoju gospodarczego powoduje wchłonięcie i transformację sektora tradycyjnego - modernizację struktur gospodarczych, społecznych i politycznych, czego

\footnotetext{
${ }^{50}$ Ibidem, s. 40-44.

${ }^{51}$ Teorie nowoczesnego systemu światowego i hegemonicznej stabilności zostały przedstawione w dalszych częściach rozdziału I.
} 
konsekwencją jest globalna integracja rynków i instytucji. Społeczeństwa naturalnie rozszerzają swą aktywność gospodarczą, chcą więc znoszenia wszelkich barier. Do tej modernizacji przyczynia się postęp w komunikacji i transporcie, rozwój instytucji gospodarczych i redukcja kosztów transakcji. Dominują gospodarki rynkowe oraz tendencja do włączania poszczególnych gospodarek narodowych do systemu gospodarki światowej ${ }^{52}$.

Gilpin zauważa, że analiza ideologii ekonomicznych prowadzi do trzech głównych tez. Po pierwsze, globalna lub ograniczona terytorialnie dystrybucja działań gospodarczych, szczególnie biorąc pod uwagę przemysł i technologię, jest głównym przedmiotem aktywności nowoczesnej dyplomacji państwowej. Za dyskusjami o handlu, zagranicznych inwestycjach i kwestiach monetarnych kryją się sprzeczne narodowe ambicje i dążenie do dominacji. Po drugie, międzynarodowy podział pracy jest produktem polityk poszczególnych państw. Mogą one nawet ignorować prawa rynku i robią to, gdy chcą wpłynąć na umiejscowienie konkretnej działalności gospodarczej. Po trzecie, z powodu tych zmian i nierównomiernego wzrostu narodowych gospodarek, zakładanie stabilności rynku jest problematyczne. Gilpin twierdzi, że w naturze systemu kapitalistycznego leży podkopywanie politycznych fundamentów, na których musi się opierać i dlatego tak ważna jest kwestia politycznego przywództwa, które zapewnia liberalny międzynarodowy ład gospodarczy ${ }^{53}$.

Autor podkreśla, że na rynek wpływają różnorodne czynniki, takie jak: struktura społeczeństwa, polityka rządów na poziomie wewnętrznym i zagranicznym, rozwój technologiczny itp. Powodują one ograniczenia lub stwarzają korzystne warunki do działania na polu gospodarczym. W dużym stopniu kształtuje je sam rynek - zmienia struktury społeczne, wpływa na relacje polityczne i stymuluje rozwój technologiczny. Zdaniem autora, świat wkroczył na drogę stałego wzrostu oraz współzależności. Ten proces może być zahamowany przez czynniki polityczne lub społeczne, ale tylko na krótką metę. Zbadanie sposobu kształtowania tych współzależności jest kluczowe dla zrozumienia dynamiki międzynarodowej ekonomii politycznej.

Gilpin przedstawia przykłady potwierdzające stawiane przez niego tezy. Ukazuje przesuwanie centrum dominacji politycznej i gospodarczej z Europy Zachodniej i Stanów Zjednoczonych ze względu na wzrost znaczenia Japonii i innych rosnących sił ekonomicznych w Azji, a także krajów rozwijających się. Zwraca uwagę na problem międzynarodowego zadłużenia, które szkodzi krajom mniej rozwiniętym w momencie spadku koniunktury na ich produkty eksportowe. Uzależniają się wtedy od pożyczkodawców, starających się narzucić im reguły uzdrowienia gospodarki. Nadmierne zadłużenie powoduje również negatywne skutki w krajach uprzemysłowionych, które obawiają się, że niewypłacalność nawet jednego z dłużników może spowodować panikę na rynkach finansowych. Gilpin przedstawia też związki

\footnotetext{
${ }^{52}$ R. G i l p i n, The Political Economy..., s. 66-67.

${ }^{53}$ Ibidem, s. 64.
} 
między polityką i ekonomią w takich aspektach, jak międzynarodowe kwestie monetarne, finansowe, handlowe, wpływ wielonarodowych korporacji, współzależności i rozwój gospodarczy ${ }^{54}$.

W 2001 r. Gilpin opublikował pracę zatytułowaną Global Political Economy: Understanding the International Economic Order („Globalna polityka ekonomiczna: zrozumienie międzynarodowego porządku gospodarczego" ${ }^{55}$. Analizuje w niej wpływ nowych sił politycznych, gospodarczych i technologicznych, które zmieniły świat po zimnej wojnie. Uznając doniosłość tych zmian, utrzymuje jednak pogląd o dominującej roli państwa narodowego: „żyjemy wciąż w świecie, w którym polityka państw narodowych i narodowe gospodarki są głównymi czynnikami determinującymi kwestie ekonomiczne"56. To wielkie mocarstwa ustalają zasady funkcjonowania gospodarki światowej, rywalizując ze sobą o dominację. Podkreślił wzrastającą rolę wielonarodowych korporacji, znaczenie rozwoju ekonomicznego i gospodarczego regionalizmu. To ostatnie zjawisko określił nawet jako bardziej charakterystyczne dla gospodarki światowej początku XXI w. niż globalizacja ${ }^{57}$.

Podstawowym założeniem liberalizmu jest zasadniczo harmonijna natura relacji gospodarczych. Największą wartość stanowi efektywność, stawiana nad innymi wartościami społecznymi. Koncepcję gospodarczą świata opierano na procesie równoważenia globalnego dobrobytu. Rola państwa sprowadza się do zapewnienia bezpiecznych politycznych ram działania umożliwiających realizację tych celów.

Teoria liberalna podkreśla wagę relacji państwo - społeczeństwo, a przede wszystkim międzynarodowe współzależności. Według liberałów, zachowanie państw odzwierciedla ich zmienne interesy. Rządy starają się osiągnąć wyznaczone cele w stosunkach międzynarodowych za pomocą prowokowania konfliktu lub organizowania współpracy, w zależności od aktualnej sytuacji i narzędzi polityki zagranicznej, które mają do dyspozycji. Muszą się przy tym liczyć z interesami innych państw. Teoria ta odrzuca więc założenie realizmu o nieuniknionym konflikcie interesów między państwami narodowymi, polityka współzależności polega bowiem na równoważeniu zysków i strat w relacjach międzynarodowych ${ }^{58}$.

Neoliberalizm, zwany też liberalnym instytucjonalizmem, zakłada konieczność współpracy państw w ramach instytucji międzynarodowych. Jego zwolennicy uznają kluczowe znaczenie państw, ale podkreślają wpływy niepaństwowych uczestników stosunków międzynarodowych, takich jak organizacje międzynarodowe, korporacje wielonarodowe, kościoły, związki zawodowe, organizacje pozarządowe itp. Według nich, anarchię konkurujących interesów wielu aktorów stosunków

${ }^{54}$ Ibidem, passim.

${ }^{55}$ R. Gilpin, Global Political Economy: Understanding the International Economic Order, Princeton 2001.

${ }^{56}$ Ibidem, s. 14.

${ }^{57}$ Ibidem, s. 3-18.

${ }^{58}$ A. Moravcsik, Taking Preferences Seriously: A Liberal Theory of International Politics, „International Organization”, Autumn 1997, s. 514-520. 
międzynarodowych mogą okiełznać międzynarodowe reżimy. Przedstawiciele neoliberalizmu koncentrowali się głównie na międzynarodowej polityce gospodarczej i analizie mechanizmów organizowania współpracy. Dyskutowali o znaczeniu europejskiej integracji, rosnącej roli korporacji wielonarodowych i wzrastającej międzynarodowej współzależności. Interesowano się również interakcją między wewnętrzną polityką gospodarczą państw i ich aktywnością na arenie światowej. Dostrzegano autonomię sił społecznych i instytucji politycznych. Za czołowego przedstawiciela neoliberalizmu uważa się Roberta Keohane'a ${ }^{59}$.

Termin „współzależność” pojawił się w nauce o stosunkach międzynarodowych pod koniec lat 60 . XX w. na określenie rosnących powiązań handlowych, inwestycyjnych i monetarnych gospodarek narodowych. Powodowało to zmniejszenie się autonomii państw, gdyż były narażone na coraz więcej negatywnych efektów ekonomicznych i miały coraz mniejszą możliwość panowania nad nimi. Współzależność dotyczyła także polityki zagranicznej i bezpieczeństwa ${ }^{60}$. Stworzyło to lepsze warunki międzynarodowej współpracy i konkurencji. Zwolennicy neoliberalizmu postulowali w związku z tym, by państwa, chcąc uniknąć konfliktów, jak najmniej ingerowały w strefę ekonomiczną. Postulat ten był oparty na przekonaniu o pokojowym charakterze relacji gospodarczych. Uważano za nieuniknione, że siły ekonomiczne zyskają przewagę nad politycznymi w stosunkach międzynarodowych ${ }^{61}$. Świadczył o tym znaczny wzrost przepływu kapitału i technologii, rozwój wielonarodowych przedsiębiorstw, zwiększenie znaczenia globalnych instytucji, także pozarządowych, większa otwartość granic oraz pojawienie się w polityce zagranicznej nowych czynników, takich jak prawa człowieka czy bezpieczeństwo energetyczne ${ }^{62}$.

Neoliberalizm podważał założenie, że państwa są jednolitymi, działającymi racjonalnie aktorami, wysuwając argumenty oparte na koncepcji pluralistycznej. Według niej, polityka państwa jest wynikiem kompromisu między sprzecznymi żądaniami różnych grup interesów. Dostrzegano również złożoność relacji międzynarodowych, w których przeplatają się m.in. kwestie bezpieczeństwa, gospodarcze, społeczne i ideologiczne. Neoliberałowie podkreślali, że państwa są potencjalnymi partnerami, a nie wrogami, gdyż mają wiele wspólnych interesów, dlatego współpraca między nimi jest możliwa i pożądana, a instytucje międzynarodowe odgrywają ważną rolę. Nie uznawali hierarchii celów państw - wszystkie są istotne i współzależne.

W latach 70. i 80. XX w. toczyła się debata między neorealistami i neoliberałami. Neorealiści wysuwali argumenty o podstawowym znaczeniu dystrybucji siły między państwami w systemie. Uważali, że współpraca między nimi jest trudna, gdyż silniejsze państwa czerpią z niej większe zyski. Twierdzili, że organizacje

\footnotetext{
${ }^{59}$ J. C z a p u t o w i c z, op. cit., s. 214-215, 238.

${ }^{60}$ R. C o o p e r, op. cit.

${ }^{61}$ The Theoretical Evolution..., s. 13.

${ }^{62}$ M. G r if fi t h s, T. O'C a ll a g h a n, International Relations. The Key Concepts, London 2001,
} s. 157. 
międzynarodowe mają znikome znaczenie. Priorytetem państwa jest bezpieczeństwo militarne, a kwestie ekonomiczne i społeczne mają znaczenie drugorzędne. Debata doprowadziła do zbliżenia stanowisk neorealistów i neoliberałów. Ci pierwsi zaczęli w większym stopniu doceniać znaczenie współpracy międzynarodowej, a ci drudzy - dominującą rolę państw narodowych ${ }^{63}$.

Amerykańscy naukowcy Robert Keohane i Joseph Nye wprowadzili pojęcia „wrażliwości” - sensitivity i „podatności na zranienia” - vulnerability. Pierwsze określenie dotyczy stopnia podatności państw na zmiany, mające miejsce w innych krajach, natomiast drugie określa, jakie koszty w wyniku tych zmian ponoszą poszczególne państwa. Autorzy wskazywali, że ich dystrybucja jest nierównomierna. Wypracowali również teorię złożonej współzależności - complex interdependence, która podważała główne założenia realizmu. Twierdzili, że nie tylko stosunki międzypaństwowe, lecz także działania innych aktorów wpływają na rządy i osłabiają ich zdolność autonomicznego kształtowania stosunków międzynarodowych. Keohane i Nye obalali przekonanie o hierarchicznym podziale polityki na priorytetową high politics, odnoszącą się do bezpieczeństwa i drugorzędną low politics relacji handlowych, nazywając ten podział anachronicznym. Utrzymywali, że zmiany gospodarcze nie zepchną polityki w cień, ale sprawią, że ulegnie ona zasadniczym przeobrażeniom.

Keohane i Nye zanegowali postrzeganie stosunków międzynarodowych wyłącznie poprzez interakcje między rządami państw narodowych. Postulowali, by badać relacje między aktorami pozarządowymi, rozumiejąc przez to konkretne podmioty, np. wielonarodowe korporacje, ale również określone czynniki (przepływ informacji, ludzi, kapitału itp.). Na określenie ogółu wzajemnych oddziaływań wprowadzili termin „relacje transnarodowe” (transnational relations).

Autorzy wyodrębnili pięć efektów oddziaływania relacji transnarodowych na politykę międzynarodową:

1. zmiana stosunku obywateli poszczególnych państw do relacji z zagranicą, co kształtowało politykę rządów;

2. łączenie się grup interesów z poszczególnych państw ponad granicami, by koordynować działania zmierzające do realizacji wspólnych celów;

3. pogłębianie się współzależności między rządami, które w pojedynkę nie są w stanie wpływać na światowy system polityczny i gospodarczy;

4. kreowanie przez rządy nowych instrumentów oddziaływania na inne państwa, np. wykorzystanie inwestorów do promocji interesów narodowych za granicą;

5. pojawienie się nowych uczestników stosunków międzynarodowych, których interesy mogą być rozbieżne z celami rządów państw narodowych ${ }^{64}$.

${ }^{63} \mathrm{~J}$. C z a p u t o w i c z, op. cit., s. 238-241.Więcej na temat rozbieżności między neorealistami a neoliberałami zob. D. A. B a l d w i n, Neorealism and Neoliberalism: The Contemporary Debate, New York 1993.

${ }^{64}$ Transnational Relations..., s. 337-344. Zob. także: R. Ke o hane, J. Nye, Power and Interdependence..., s. 85 . 
Strukturalizm analizował rozwój światowej polityki ekonomicznej jako całości, nie skupiając się na poszczególnych państwach. Zakładano, że najbogatsi kształtują i podtrzymują struktury systemu światowego w celu maksymalizacji zysków, co odbywa się kosztem peryferii ${ }^{65}$. Traktowano całościowo kwestie gospodarcze i polityczne, ale skupiano się na światowym systemie kapitalistycznym, a nie na narodach funkcjonujących w tym systemie ${ }^{66}$.

Ze strukturalizmu wywodzi się teoria zależności (dependence theory) i peryferiów (dependency theory). Różnicę między nimi tłumaczył James Caporaso. Dependence to skrajnie asymetryczna forma współzależności, np. gdy państwo polega w jakiejś dziedzinie całkowicie na innym aktorze stosunków międzynarodowych, który nie jest w żaden sposób od niego uzależniony. Natomiast dependency to proces włączania krajów rozwijających się do systemu kapitalistycznego, co powoduje zniekształcenia strukturalne i hamuje rozwój. Caporaso przeciwstawia obu tym teoriom koncepcję współzależności (interdependence), czyli zależności od wielostronnej kontroli, przyjętej dobrowolnie ze względu na wspólnotę interesów - przeciwieństwo autarkii i izolacjonizmu ${ }^{67}$.

Silnie opierająca się na marksizmie teoria nowoczesnego systemu światowego (Modern World System - MWS) zakłada, że rynek światowy to narzędzie ekonomicznej eksploatacji mniej rozwiniętych krajów przez zaawansowane gospodarki kapitalistyczne. MWS jest zdefiniowany przez Immanuela Wallersteina i oznacza „podział pracy, w którym produkcja i wymiana podstawowych dóbr jest niezbędna dla życia codziennego". Świat stanowi system, rządzący się określonymi prawami ekonomicznymi. Teoria zakłada prymat interesów gospodarczych i walki klas nad konfliktami politycznymi i społecznymi w determinowaniu zachowań ludzkich. W przeciwieństwie do klasycznego marksizmu, który rozpatruje sytuację wewnętrzną, teoria MWS zajmuje się analizą walki państw w wymiarze globalnym. Zakłada, że światowy kapitalizm, który jest podstawą systemu, wytwarza zahamowania rozwojowe, polityczne i gospodarcze dzięki wykorzystywaniu peryferii przez silne centra gospodarki światowej ${ }^{68}$.

Charakterystyczne dla rozwoju MEP było powstawanie perspektyw krytycznych wobec głównych nurtów. Podejście ekologiczne opierało się na założeniu, że środowisko naturalne to jeszcze jedna wartość, którą trzeba rozpatrywać (oprócz takich czynników, jak bezpieczeństwo, wolność i sprawiedliwość). Krytyka

\footnotetext{
${ }^{65}$ J. P e tr a s, Critical Perspectives on Imperialism and Social Class in the Third World, New York 1978.

${ }^{66}$ P. B a r a n, The Political Economy of Growth, New York 1957.

${ }^{67}$ J. A. C a p o ras o, Dependence, Dependency, and Power in the Global System: a Structural and Behavioral Analysis, „International Organization”, Winter 1978, s. 18-21. Caporaso opiera się na neomarksistowskiej teorii zależności Immanuela Wallersteina przedstawionej w dalszej części niniejszego rozdziału.

${ }^{68}$ I. Wallerstein, The Modern World System: Capitalist Agriculture and the Origins of European World Economy in the Sixteenth Century, New York 1974.
} 
feministyczna uświadamiała, że świat nie składa się tylko z państw i rynków czy proletariatu i burżuazji, lecz także z kobiet i mężczyzn. Analizując stosunki międzynarodowe należy więc brać pod uwagę dominację mężczyzn w instytucjach oraz stereotypy kulturowe przypisywane płciom ${ }^{69}$. Wielu badaczy twierdziło, że MEP jest nauką postmodernistyczną, gdyż obala pogląd, że ekonomiści mają zajmować się wyłącznie ekonomią, a politolodzy - polityką ${ }^{70}$. Postmoderniści twierdzili, że w naukach społecznych nie sposób stworzyć jednolite teorie, wyodrębnić stałe prawa rządzące życiem społecznym i ściśle zdefiniowanych aktorów. Stosunki międzynarodowe to mieszanka przeciwstawnych sił skonfliktowanych tożsamości, które wymykają się jakiejkolwiek klasyfikacji czy kontroli. Kwestionowali także istnienie suwerenności państw. Ważnym założeniem postmodernizmu było przekonanie, że wzrastający kapitalizm zmienia kulturę. Nie tylko badano handel, przepływ kapitału itp., lecz także szukano wpływu zmian polityczno-gospodarczych na sztukę, literaturę, popkulturę, która szczególnie w dobie globalizacji kształtuje społeczeństwa ${ }^{71}$.

W badaniach stosunków międzynarodowych stosowano koncepcję racjonalnego wyboru, zwaną także "gospodarczą teorią polityki” i zakładającą racjonalne zachowanie jednostek ${ }^{72}$. Obywatele, by żyć bezpiecznie i w dobrobycie, muszą mieć zapewnione rządy prawa, gwarantowane przez instytucję państwa. W związku z tym zachowują się racjonalnie, wspólnie działają na rzecz własnego dobra i rozwoju. Muszą być przy tym przekonani, że przestrzeganie reguł będzie dla nich korzystne.

Teorię racjonalnego wyboru stosuje się także do oceny zachowań grup interesów i ich wpływu na międzynarodową politykę gospodarczą, jest przydatna w badaniu działania instytucji globalnych. Według Roberta Keohane’a, instytucje to „stabilny zestaw połączonych ze sobą reguł (formalnych i nieformalnych) i procedur decyzyjnych, opisujących pożądane zachowania, ograniczające działania i kształtujące oczekiwania"73. Keohane twierdził, że podstawową rolą instytucji jest monitorowanie i przekazywanie informacji o działaniach wszystkich jej członków i wypełnianiu przez nich uzgodnionych postanowień.

Instytucjonalizm zakładał, że państwa koncentrują się nie na własnych korzyściach i zagrożeniu konfliktem, ale na zyskach ze współpracy w ramach instytucji. Aby osiągnąć długofalowe korzyści, zdając sobie sprawę z istniejących między nimi

${ }^{69}$ J. Steans, Gender and International Relations: Issues, Debates and Future Directions, Cambridge 2006.

${ }^{70}$ D. N. B a l a a m, M. V e s e th, op. cit., s. 108.

${ }^{71}$ The Theoretical Evolution..., s. 26-27.

72 Teoria racjonalnego wyboru została przedstawiona w pracach: Rational Choice, ed. J. Elster, New York 1986; Rational Choice Theory: Advocacy and Critique, eds J. Coleman, T. Fararo, Newbury Park 1992.

${ }^{73}$ R. Ke o h a n e, International Institutions: Two Approaches, „International Studies Quarterly” 1988, Vol. 32, No 4, s. 381. 
współzależności, rezygnują z części swej suwerenności, przekazując uprawnienia instytucjom.

W ramach instytucjonalizmu można wyodrębnić teorię reżimów i funkcjonalizm. Definicję reżimów sformułował Stephen Krasner. Jest to „zestaw zasad, norm i procedur decyzyjnych, wobec których oczekiwania aktorów są zbieżne na danym

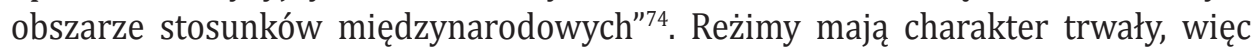
w ich ramach łatwiej zawierać wszelkie porozumienia. Według Krasnera, reżimy można określić na podstawie czterech elementów: zasad (przekonań dotyczących faktów i przyczynowości), norm (standardów zachowania), reguł (określonych sposobów wykonywania zadań) oraz procedur (najczęściej stosowanych sposobów wykonywania wspólnych postanowień) ${ }^{75}$.

Funkcjonalizm koncentruje się na celach i zadaniach, głównie organizacji. Rola rządów miała być systematycznie redukowana, gdyż liczne związki międzynarodowe sprawiały, że najważniejszym celem państw stała się integracja ${ }^{76}$. Teorię funkcjonalizmu przedstawił David Mitrany. Według niego, przekazywanie przez państwa w procesie integracji części suwerenności ponadnarodowym instytucjom za pomocą odgórnych, prawnych decyzji mijało się z celem. Jeżeli integracja ma być efektywna, konieczna jest naturalna, praktyczna współpraca, nieoparta na założeniach teoretycznych czy ideologii. Organizacje są kreowane w odpowiedzi na prawdziwe potrzeby. Ich powstawanie warunkuje rosnąca liczba wspólnych problemów łączących aktorów stosunków międzynarodowych. Mitrany podkreślał również konflikt między sferą polityczną a gospodarczą. Napięcie to powstaje, gdyż organizacje gospodarcze tworzą się w sposób naturalny, natomiast zasady działania organizacji politycznych należy wypracowywać i trudniej jest państwom ich przestrzegać. Mitrany twierdził, że państwo narodowe, ze swoim przywiązaniem do idei suwerenności, stanowiło źródło konfliktów i nieracjonalności w stosunkach międzynarodowych. Głosił tezę, że owocna współpraca gospodarcza pozwala rozwiązywać spory polityczne ${ }^{77}$.

Zwolennicy neofunkcjonalizmu zwracali uwagę, że instytucje, szczególnie integracyjne, zmieniają nastawienie grup interesów, które dążą do jak najściślejszej współpracy w ramach ugrupowań. Koncepcję tę przedstawił Ernst B. Haas, który krytykował tezę Mitrany'ego, że interesy polityczne i gospodarcze państwa są odmienne i sprzeczne. Uważał, że u źródeł procesu integracji leżą przesłanki o charakterze ekonomiczno-społecznym, które w sposób niezamierzony

${ }^{74}$ S. Kras ner, Regimes and the Limits of Realism: Regimes as Autonomous Variables, [w:] International Regimes, ed. S. Krasner, Ithaca 1983, s. 356.

${ }^{75} \mathrm{~J}$. C z a p u to w i c z, op. cit., s. 229-231.

${ }^{76}$ International Relations Theory, eds. P. Viotti, M. Kauppi, New York 1997, s. 52.

77 D. Mitrany, A Working Peace System, Chicago 1943. Na temat jego teorii zob. także: S. K o n o p a c k i, Funkcjonalistyczna teoria integracji politycznej D. Mitrany'ego, „Studia Europejskie” 1998, nr 2, s. 61-70. 
rozszerzają ją o strefę polityczną. Czasem jednak to motywy polityczne dają jej początek $^{78}$.

Konstruktywizm społeczny, w przeciwieństwie do analiz opartych na teorii racjonalnego wyboru, w największym stopniu uwzględnia czynniki historyczne i socjologiczne. Zwolennicy tego podejścia koncentrują się na procesach podejmowania i realizowania decyzji, badając „przekonania, role, tradycje, ideologie i modele wpływów" ${ }^{\prime 79}$. Antonio Gramsci zauważył, że podejmowanie decyzji i działania aktorów w gospodarce światowej zależą od ich przekonań wynikających z kultury i wiedzy, a także założeń, którymi kierują się najważniejsze instytucje systemu, te zaś są kształtowane przez hegemona, którego interesy wspierają. Także wolny handel przynosi korzyści państwom najsilniejszym, które go promują ${ }^{80}$.

Robert Cox, opierając się na pracach Gramsciego, zauważył możliwość niezależnego działania politycznego. Państwa funkcjonują samodzielnie, choć są ograniczane przez siły społeczne obecne w ich obrębie. Rozprzestrzenianie się kapitalizmu na świecie było ułatwione dzięki konkretnym interesom politycznym. Jednak globalizacja gospodarcza spowodowała „internacjonalizację państwa”, stopniową redefinicję interesu narodowego, dostosowanie się do wymogów globalnej produkcji i wzrostu sił urzędów, które za to odpowiadają (np. banków centralnych, ministerstw gospodarczych) $)^{81}$.

Aleksander Wendt, twórca teorii społecznej polityki międzynarodowej, przedstawiał system międzynarodowy jako konstrukcję społeczną. Podkreślał wagę czynnika kulturowego - twierdził, że decydujące znaczenie w relacjach międzypaństwowych ma postrzeganie innych państw narodowych jako przyjacielskich lub wrogich. Państwa kreują swój interes narodowy na podstawie postrzegania własnego miejsca w międzynarodowej społeczności, a więc tożsamości. Państwa utożsamiające się z określoną kulturą oddziałują na siebie i zmieniają się wzajemnie za pośrednictwem istniejących współzależności ${ }^{82}$.

Żadna teoria nie opisywała dynamiki sytuacji międzynarodowej w sposób doskonały, stąd postulat „otwartości teorii” (theoretical openess), wyartykułowany m.in. przez Jacoba Reuveny’ego. Według niego, badania naukowe powinny tłumaczyć konkretną sytuację bądź zjawisko, które nie zawsze zgadzają się z założoną teorią. Autor podkreśla również konieczność rezygnacji z podejścia ideologicznego ${ }^{83}$.

${ }^{78}$ E. B. H a a s, The Uniting Europe, Stanford 1958.

${ }^{79} \mathrm{~N}$. W o o d s, Międzynarodowa ekonomia polityczna w dobie globalizacji, [w:] Globalizacja polityki światowej. Wprowadzenie do stosunków międzynarodowych, red. J. Baylis, S. Smith, Kraków 2009, s. 414.

${ }^{80} \mathrm{~J}$. C z a p u to w i c z, op. cit., s. 164.

${ }^{81}$ R. C o x, Production, Power, and World Order: Social Forces in the Making of History, New York 1987.

${ }^{82}$ A. We n d t, Social Theory of International Relations, Cambridge 1999.

${ }^{83}$ Cyt. za: C. F. B e r g st e n, R. Ke o ha n e, J. N y e, International Economics and International Politics. A Framework for Analysis, [w:] World Politics and International Economics, eds. C. F. Bergsten, L. B. Krause, Washington 1975, s. 11. 


\subsection{Czynnik gospodarczy w polityce zagranicznej państwa}

Perspektywy MEP opierają się na obserwacji zmieniającej się sytuacji politycznej i gospodarczej. W tym podrozdziale skupię się na przedstawieniu wybranych teorii uwzględniających badanie wpływu czynników ekonomicznych na politykę zagraniczną państw narodowych. Można je zastosować do tłumaczenia mechanizmów podejmowania decyzji przez administrację Stanów Zjednoczonych w latach 70. XX w., szczególnie w relacjach transatlantyckich.

Brytyjska badaczka Susan Strange twierdziła, że międzynarodowy system gospodarczy rozwijał się szybciej niż polityczny, więc relacje polityczne musiały ulec zmianie. Nie zgadzała się z tezą, że doprowadzi to do zaniku państw narodowych, ale przewidywała nieuchronne przeobrażenia w polityce zagranicznej i wewnętrznej. W odpowiedzi na nowe wyzwania gospodarki światowej państwa miały zacieśniać współpracę albo stosować mechanizmy obrony własnych gospodarek. Jednak rządy musiały uwzględniać interesy innych krajów przy wyborze środków uzdrawiających ich własną gospodarkę. Nie mogły w dowolny sposób manipulować kursem waluty czy stopami procentowymi, gdyż wpływałoby to negatywnie na kondycję ekonomiczną innych państw. Takie jednostronne działania, bez konsultacji z partnerami, mogły sprowadzić działania odwetowe na polu gospodarczym (ograniczenia importu, wzrost ceł, wycofywanie się inwestorów), ale także rozbieżności w stosunkach politycznych.

Strange zauważyła wzrastającą rolę międzynarodowych organizacji gospodarczych, takich jak Międzynarodowy Fundusz Walutowy (MFW), Bank Światowy czy Układ Ogólny w sprawie Ceł i Handlu (GATT - General Agreement on Tariffs and Trade). Ciała te odgrywały pozytywną rolę w regulowaniu międzynarodowych relacji gospodarczych, ale osiągnięcie kompromisu w ich ramach nastręczało wiele trudności. Przedstawiciele państw narodowych dążyli do zapewnienia swojemu krajowi jak najkorzystniejszych warunków i jak największej swobody działania, jednak często przyjmowano rozwiązania kompromisowe ze względu na dużą współzależność członków organizacji. Autorka postulowała uwzględnienie roli międzynarodowych korporacji, które działały poza granicami państw narodowych i ustalały między sobą podział rynku światowego bądź o niego rywalizowały ${ }^{84}$.

David N. Baalam i Michael Veseth zwracali uwagę na interakcję państw i rynków w systemie międzynarodowym. Powodem napięć między tymi aktorami jest fakt, że państwo w większym stopniu kieruje się interesami politycznymi, zaś rynek - gospodarczymi (zyskiem). Dlatego istnieje sieć umów między aktorami związanymi z państwem i rynkiem. Ich działanie jest uzależnione od siły poszczególnych podmiotów. Autorzy wyróżnili trzy jej rodzaje: 1) siła w stosunkach wzajemnych (relational power), w sytuacji, gdy jeden aktor może wymusić na drugim określone działanie; 2) siła strukturalna (structual power) - możliwość kształtowania struktur

${ }^{84}$ S. S t r a n g e, International Economics..., s. 306-313. 
światowej polityki gospodarczej; 3) miękka i twarda siła (hard and soft power) - siła militarna i polityczna, umożliwiająca negocjacje oraz stosowanie negatywnych i pozytywnych bodźców ${ }^{85}$. Baalam i Veseth wyróżnili teorie stawiające na pierwszym miejscu system światowy (system-centered theories), państwo (state-centered theories) i społeczeństwo (society-centered theories). Postulowali łączenie wszystkich podejść argumentując, że we współczesnym świecie nie można analizować problemów wewnętrznych państwa bez poznania całego kontekstu światowego - w obszarze gospodarczym i politycznym ${ }^{86}$.

Edward Haliżak wyróżnia poszczególne obszary wzajemnych oddziaływań strefy politycznej i ekonomicznej. Pierwszym z nich jest właśnie rola czynnika ekonomicznego w polityce państw. Dokonując analizy należy uwzględniać zarówno czynniki ideologiczne, jak i ekonomiczne. Na czynnik ekonomiczny składa się gospodarka państw (jej aktywa i pasywa), procesy ekonomiczne (postęp techniczny, kursy walutowe, stopy procentowe, handel zagraniczny i in.), decyzje o alokacji czynników produkcji w kraju i za granicą oraz prawo i organizacje międzynarodowe.

Działania państwa o charakterze ekonomicznym oraz sytuacja gospodarcza na jego obszarze wpływają na relacje międzynarodowe. Państwo może je kształtować poprzez stosowanie sankcji ekonomicznych, ale też przyznając koncesje gospodarcze państwom otwartym na współpracę. W dobie współzależności ekonomicznych rządy starają się także zapewnić dostęp do rynków innych państw poprzez umowy lub integrację, są również zainteresowane ochroną interesów rodzimych firm za granicą ${ }^{87}$.

Harmonijna współpraca ekonomiczna wpływa pozytywnie na kształtowanie się stosunków między państwami, natomiast rozbieżności na tym polu mogą negatywnie oddziaływać na relacje polityczne. W takim przypadku rozwiązanie problemów jest zależne od wielu czynników. Pierwszy z nich stanowi stopień współzależności politycznej. Państwa połączone siecią wspólnych interesów na arenie międzynarodowej są bardziej skłonne do kompromisu w kwestiach ekonomicznych. W tym przypadku ważna jest również siła polityczna, często poparta przewagą militarną. Państwo dominujące $\mathrm{w}$ systemie sojuszy ma większe możliwości przeforsowania decyzji.

Drugi czynnik to stopień współzależności gospodarczych. Podobnie jak w przypadku powiązań politycznych, państwa funkcjonujące w jednym systemie gospodarki światowej wzajemnie siebie potrzebują. Należy przy tym rozpatrywać siłę ekonomiczną poszczególnych podmiotów. W momencie zmierzchu hegemonii gospodarczej Stanów Zjednoczonych, dynamicznego rozwoju Japonii i umocnienia się

\footnotetext{
${ }^{85}$ D. N. B a l a a m, M. V e s e th, op. cit., s. 13-21.

${ }^{86}$ The State and American Foreign Economic Policy, eds. G. J. Ikeberry, D. A. Lake, M. Mastanduno, Ithaca 1988, s. 4.

${ }^{87}$ E. H a l i ż a k, Współzależność polityki i ekonomii..., s. 41.
} 
integracji europejskiej pod koniec lat 60. XX w., siły w obrębie systemu zachodniego stały się bardziej wyrównane ${ }^{88}$.

Analizując uwarunkowania polityki zagranicznej USA, posługiwano się najczęściej perspektywami związanymi z realizmem. Teoria państwocentryczna - statyzm (statism) - zakładała, że państwo narodowe jest zintegrowane, zamyka się na kontakty zewnętrzne, co je wewnętrznie spaja i umacnia. Działa ono na arenie międzynarodowej, by wypracować dla siebie jak najkorzystniejsze warunki. Teoretycznie państwo jest jedyną instytucją polityczno-gospodarczą, mającą suwerenność zewnętrzną i wewnętrzną. Jednak realnie te jego atrybuty są ograniczone. Stephan Krasner podkreślał, że interesy ekonomiczne jednostek często pozostają w sprzeczności z interesem państwa ${ }^{89}$.

Teoria polityki biurokratycznej (bureacratic politics) podkreślała rolę administracji i biurokracji w kształtowaniu polityki. Również polityka zagraniczna państwa miała być efektem kompromisu między wieloma urzędami, a nawet jednostkami odpowiedzialnymi za jej kształtowanie. Różne ośrodki władzy forsują odmienne rozwiązania, dlatego kwestionowano istnienie jednolitej polityki zagranicznej państwa. Teoria ta nie zakłada, że zawsze interesy polityczne państwa dominują nad siłami gospodarczymi. Zauważa raczej skomplikowane współzależności między tymi dwoma obszarami. Patrząc przez pryzmat państwa, stara się wyjaśnić, w jakich okolicznościach interesy polityczne dominują nad gospodarczymi i odwrotnie. Perspektywa ta definiuje państwa jako związki sił instytucjonalnych, które ukształtowały się na przestrzeni dziejów, co powoduje, że różni je charakter struktur organizacyjnych oraz interesy narodowe. Jednak celem każdego z nich jest kontrola nad określonym terytorium. Są stworzone, by dominować nad wewnętrznymi siłami społecznymi i opierać się zagrożeniom zewnętrznym. Państwo pośredniczy między światowymi a wewnętrznym siłami polityczno-ekonomicznymi ${ }^{90}$.

Bliska politycznemu realizmowi jest teoria hegemonicznej stabilności (hegemonic stability). Jej nazwę do nauki o stosunkach międzynarodowych wprowadził Robert Keohane, lecz jej główne założenia wyartykułowali wcześniej w swoich pracach Charles Kindleberger, Robert Gilpin i Stephen Krasner ${ }^{91}$.

Hegemonem nazwano bogate i silne militarnie państwo, które podejmuje wysiłek dostarczania dóbr publicznych dla systemu międzynarodowego. Te dobra to stabilna waluta, bezpieczeństwo i system wolnego handlu, który działa tym lepiej, im więcej państw do niego należy. Zapewnienie trwania takiego systemu wymaga wielu nakładów, ale jest opłacalne dla hegemona nawet wtedy, gdy ponosi samodzielnie nieproporcjonalnie duże koszty, korzysta bowiem z dominującej pozycji w systemie

${ }^{88}$ Ibidem, s. 42.

${ }^{89}$ S. K r a s n e r, Defending the National Interest: Raw Materials, Investment and American Foreign Policy, Princeton 1978.

${ }^{90}$ The Theoretical Evolution..., s. 13.

${ }^{91} \mathrm{~J}$. C z a p u t o w i c z, op. cit., s. 203. 
światowym. Inne państwa uznają dominację hegemona z powodu jego prestiżu i statusu w międzynarodowym systemie politycznym, akceptują również reprezentowaną przez niego ideologię. Hegemon może powstrzymać inne państwa od nieuczciwego wykorzystywania istniejącego systemu, np. poprzez odmowę ponoszenia części kosztów jego funkcjonowania lub zabezpieczania interesów kosztem innych uczestników. Na polu ekonomicznym używa wpływów do stwarzania międzynarodowych reżimów, określających prawne i bezprawne zachowania, by ograniczyć potencjalne konflikty, zapewnić równość uczestników systemu lub ułatwiać zawieranie umów. Poza tym wzrost gospodarczy hegemona stanowi siłę napędową dla wzrostu pozostałych państw. To hegemon ma największe środki, by nabywać towary i usługi od swych partnerów oraz oferować im swoje inwestycje. Dokonuje również transferu wiedzy i technologii. Dzięki rozmiarowi gospodarki może stosować sankcje ekonomiczne, choćby przez ograniczanie dostępu do swojego rynku. Tak samo duże znaczenie ma wartość jego waluty. Jeśli stan gospodarki hegemona pogarsza się, wpływa to negatywnie na całość systemu. Jeżeli inne państwa zaczynają postrzegać działania hegemona jako służące wyłącznie jego interesom i uznają je za sprzeczne z ich własnymi celami, system hegemonii zostaje osłabiony. Dzieje się tak w przypadku, gdy obywatele mocarstwa-hegemona dojdą do przekonania, że inne kraje nie wywiązują się z warunków umowy lub koszty przywództwa zaczynają przewyższać korzyści ${ }^{92}$.

Koncepcja hegemonicznej stabilności skupia się na państwie narodowym, gdzie bezpieczeństwo jest najważniejszym elementem. Teoria zawiera ponadto analizę międzynarodowego handlu i finansów, umożliwiającą złożone wyjaśnianie pojawienia się i upadku wielkich mocarstw. Według teorii hegemonicznej stabilności, gdy przewaga mocarstwa ulega załamaniu, stworzony przez nie system międzynarodowy popada $\mathrm{w}$ chaos i konflikt, co z kolei zagraża bezpieczeństwu i dobrobytowi. Wynika to z faktu, że hegemonia jednego państwa stwarza i obala międzynarodowe zasady współpracy ${ }^{93}$. Jednak otwarty system międzynarodowy działa lepiej, gdy istnieje jedno państwo gotowe brać za niego odpowiedzialność. Charles Kindleberger, uważany za twórcę tej teorii, motywował np. pogłębianie się kryzysu w latach 30 . XX w. brakiem silnego pożyczkodawcy w międzynarodowym systemie finansowym ${ }^{94}$. Stephen Krasner utrzymywał z kolei, że państwo tracące hegemonię jest bardziej skłonne do działań chroniących własne interesy narodowe, a państwa rosnące $\mathrm{w}$ siłę mają tendencję do promowania zmian w systemie międzynarodowym ${ }^{95}$.

\footnotetext{
${ }^{92}$ R. G i l p i n, The Political Economy..., s. 66-73.

${ }^{93}$ M. Ve s e th, op. cit.

${ }^{94} \mathrm{Ch}$. K i n d l e b e r g e r, Manias, Panics, and Crashes. A History of Financial Crisises, New York 1978.

${ }^{95}$ S. K r a s ne r, American Policy and Global Economic Stability, [w:] America in the Changing World Political Economy, eds. W. Avevy, D. Rapkin, New York 1982.
} 
Nieodłącznym elementem gospodarki światowej jest międzynarodowa konkurencja. Nieuchronne staje się zwiększanie roli nowych państw, które są zdolne do rywalizacji z hegemonem. Paradoksalnie doprowadza to do osłabienia całego systemu, co wpływa na sferę polityczną. Hegemoniczny porządek jest niestabilny i należy się spodziewać jego powolnego rozkładu. Sytuację pogarszają koszty, jakie ponosi hegemon, finansując obronę militarną sojuszników oraz gospodarcze podtrzymywanie systemu, szczególnie, gdy inne państwa wykorzystują zobowiązania hegemona do realizacji własnych celów. Żeby uniknąć konfliktów gospodarczych, rzutujących na relacje polityczne, należało zawrzeć nowe, obowiązujące wszystkich porozumienie dotyczące zmian systemowych. Hegemon powinien dążyć do stałego zwiększania konkurencyjności swej gospodarki, np. stosując nowe technologie lub inwestując w nowoczesne gałęzie przemysłu ${ }^{96}$.

Mimo osłabienia hegemona, wykreowany przez niego system trwa. Wpływają na to następujące czynniki: siła inercji, brak alternatywy i ciągłe istnienie wspólnych interesów - wszystkie kraje mają świadomość korzyści, które czerpią nawet $\mathrm{z}$ osłabionego systemu. Poza tym łatwiej jest utrzymywać stary system niż wykreować nowy. Zazwyczaj potrzeba do tego hegemona, którego nie kreuje się z dnia na dzień. Gilpin wielokrotnie wyrażał opinię, że prawidłowe funkcjonowanie liberalnej gospodarki światowej wymaga politycznego przywództwa, mogącego zapewnić wspólne dobra, takie jak: stabilna waluta, promocja otwartych rynków oraz nadzór nad przestrzeganiem zobowiązań przez jej uczestników. Paradoksalnie demokratyczne rządy są częściej wystawiane na pokusę łamania reguł, gdyż są rozliczane z sytuacji gospodarczej w kraju przez społeczeństwa, które oczekują dbałości o interes narodowy, nawet, jeśli niekorzystnie odbije się to na partnerach handlowych. Problem w tym, że lider musi być gotowy do krótkoterminowego poświęcenia własnych interesów dla dobra systemu. Nie zawsze jest to społecznie akceptowane ${ }^{97}$.

Krytycy teorii hegemonicznej stabilności uważali, że wobec istnienia pluralistycznych systemów, nie przedstawia ona rzeczywistych relacji międzynarodowych. Wskazywali, że naturalnym porządkiem jest równowaga sił. Duncan Snidal podważał konieczność istnienia hegemona w kontekście organizacji współpracy międzynarodowej. Twierdził wręcz, że układa się lepiej, gdy jest on osłabiony ${ }^{98}$.

Bergsten, Keohane i Nye poddali krytyce tradycyjne założenie realizmu, że siła militarna ma zasadnicze znaczenie w polityce międzynarodowej. Przyjmując realistyczne założenie o jej wpływie na relacje gospodarcze wykazywali, że jest

${ }^{96}$ R. Gil p in, The Political Economy..., s. 72-80. Robert Keohane zgadzał się z tą konkluzją, uzasadniając potrzebę istnienia reżimów międzynarodowych (R. K e o han e, After Hegemony: Cooperation and Discord in International Political Economy, Princeton 1984). Na temat teorii związanych ze zmierzchem hegemonii USA zob. M. Tétrea ult, The Declining Hegemony Thesis, „Journal of Politics”, February 1987, s. 282-290.

${ }^{97}$ R. G il p i n, The Political Economy..., passim.

${ }^{98}$ A. G ałg a n e k, Koncepcje hegemonii w nauce o stosunkach międzynarodowych, „Przegląd Politologiczny" 2006, nr 1, s. 15. 
nieprzydatna do rozwiązywania niektórych kwestii (np. amerykańska siła nuklearna nie mogła w zasadniczy sposób wpłynąć na kształt reformy światowego systemu monetarnego). Państwo, dysponując siłą jednego rodzaju, może być słabsze na innych polach. Uzasadniali, że użycie środków militarnych na skalę światową było mało prawdopodobne, gdyż groziło zagładą nuklearną. Odwołując się do polityki odprężenia zauważyli, że w chwili spadku realnego zagrożenia konfliktem militarnym ważniejszymi celami rządów stają się zapewnienie dobrobytu obywatelom, utrzymanie autonomii politycznej i podkreślenie wysokiego statusu na arenie międzynarodowej. Do osiągania tych celów służą instrumenty ekonomiczne, pozwalające wywierać wpływ na decyzje istotne dla gospodarki światowej ${ }^{99}$.

Badacze amerykańscy zaproponowali wobec tego dwa poziomy analizy polityki zagranicznej. Poziom procesu miał obejmować krótkoterminowe działania $w$ ramach stałych instytucji oraz podstawowe założenia i oczekiwania. Na poziomie strukturalnym należało brać pod uwagę długoterminowe czynniki i warunki systemowe - ograniczenia i przywileje z nich wynikające. Innymi słowy, na poziomie strukturalnym należy badać, jak instytucje i globalna sytuacja warunkują reguły zachowań, wspierają lub niweczą założenia polityczne i gospodarcze państw lub innych aktorów stosunków międzynarodowych ${ }^{100}$.

Bergsten, Keohane i Nye wykazywali, że rządy ingerowały w międzynarodowe stosunki gospodarcze, obawiając się ich kształtowania przez przedsiębiorstwa wielonarodowe w sposób sprzeczny z interesami danego państwa. Z drugiej strony, zauważając potrzebę wzrostu handlu i inwestycji zagranicznych, powstrzymywały się od ograniczania ich działalności. Autorzy uważają, że wzrost współzależności powodował usytuowanie międzynarodowych kwestii gospodarczych wśród priorytetów polityki zagranicznej rządów.

Keohane i Nye zwrócili uwagę na ważny element współzależności, jakim były międzynarodowe organizacje, hamujące państwa członkowskie przed podejmowaniem działań godzących w interesy partnerów. Współzależność kreowała nowe źródła siły oraz sieć „,Wzajemnych asymetrycznych zależności” ${ }^{101}$. Rządy państw musiały uwzględniać czynnik ekonomiczny podczas kreowania polityki. Keohane i Nye twierdzili, że trudno określić jakąkolwiek transakcję mianem czysto rynkowej, gdyż odbywa się ona w określonym systemie politycznym i gospodarczym. Im lepiej te systemy działają, tym mniej kwestie polityczne oddziałują na ekonomiczne. Jeśli jednak występują spory i niewydolność systemu uniemożliwiająca ich rozwiązanie, decyzje podejmują politycy. Nieunikniona jest wtedy eskalacja rozbieżności. Pojawia się coraz więcej kwestii spornych, wzrasta zainteresowanie tymi problemami na najwyższym szczeblu władz państwowych, co z kolei

${ }^{99}$ C. F. B e rgsten, R. Ke ohane, J. Nye, International Economics and International Politics..., s. 6.

${ }^{100}$ Ibidem, s. 4-5.

${ }^{101}$ R. Ke o h a n e, J. N y e, Power and Interdependence..., s. 29. 
prowadzi do pogorszenia się relacji politycznych. Dążenie do ich poprawy jest niewątpliwie czynnikiem hamującym eskalację konfliktu gospodarczego i bodźcem do podjęcia negocjacji w celu osiągnięcia kompromisu. Keohane i Nye odnosili tę konkluzję do relacji międzynarodowych i wewnętrznych. Wysunęli tezę, że wzrastające upolitycznienie międzynarodowych relacji gospodarczych wynika z coraz powszechniejszej obecności ekonomicznych narzędzi nacisku w polityce zagranicznej.

Amerykańscy autorzy stwierdzili, że państwo nadal odgrywało dominującą rolę w międzynarodowych stosunkach gospodarczych. Najsilniejsze państwa mogły się bronić, gdy ich interesy gospodarcze były zagrożone. Najprostszą reakcję stanowiło zastosowanie sankcji ekonomicznych bądź zmiany wewnętrznej polityki gospodarczej, by niwelować skutki niekorzystnych działań państw trzecich. Istotnym wsparciem takich działań był potencjał militarny i możliwość oddziaływania politycznego na arenie międzynarodowej ${ }^{102}$.

Stephen D. Cohen definiował międzynarodową politykę gospodarczą jako „wysiłki państwa w celu zmian w sposobie przepływu towarów, usług i kapitału, który miałby miejsce, gdyby pozwolić działać wyłącznie siłom rynkowym"103. Wyróżnił pięć rodzajów działań państwa, czerpiąc z doświadczeń Stanów Zjednoczonych: 1) przedsięwzięcia długoterminowe, np. inicjowanie rundy negocjacyjnej na temat międzynarodowej liberalizacji handlu; 2) szybkie interwencje, np. pomoc dla kraju dotkniętego poważnym kryzysem finansowym, stanowiącym zagrożenie dla systemu; 3) dążenia do utrzymania obowiązujących warunków, np. odrzucenie wewnętrznych nacisków, mających spowodować wprowadzenie środków protekcjonistycznych (w tym miejscu należy zaznaczyć, że miały miejsce sytuacje, gdy państwo ulegało takim naciskom); 4) stosowanie nacisków na inne państwa, by bardziej otworzyły swe rynki na amerykański eksport; 5) wprowadzanie w życie programów gospodarczych uchwalanych przez Kongres ${ }^{104}$. Cohen podkreśla wagę międzynarodowej polityki gospodarczej twierdząc, że zawierają się w niej dwa najważniejsze cele państwa - bezpieczeństwo narodowe i wewnętrzny dobrobyt. Zauważył, że jej prowadzenie jest uwarunkowane czynnikami wewnętrznymi, przede wszystkim wymaganą przez elektorat interwencją w gospodarkę oraz zewnętrznymi - wzrostem wpływu kwestii ekonomicznych na relacje międzynarodowe ${ }^{105}$.

Rolę państwa w stosunkach międzynarodowych i wpływ czynnika ekonomicznego na kształtowanie jego polityki zagranicznej uwzględnił również Klaus Knorr w wydanej w 1975 r. pracy The Power of Nations. The Political Economy of International Relations („Siła narodów. Ekonomia polityczna stosunków międzynarodowych”).

102 Ibidem, s. 31-36.

${ }^{103}$ S. D. Co h e n, The Making of United States International Economic Policy. Principles, Problems, and Proposals for Reform, Westport 2000, s. 5.

104 Ibidem, s. 7.

105 Ibidem, s. 20-25. 
Autor wyróżnił trzy rodzaje siły państwa: militarną, ekonomiczną i polityczną zdolność rozszerzania wpływów ${ }^{106}$. Wykazywał, że państwo może użyć siły ekonomicznej, by zrealizować cele: zagrozić utratą przywilejów, wprowadzić sankcje ekonomiczne lub zachęcić ekonomicznymi koncesjami. Rząd używając narzędzi gospodarczych może mieć różne cele: 1) uzyskanie korzyści gospodarczych, np. poprzez ograniczenie importu, by chronić rodzimą produkcję; 2) przejęcie kontroli nad innymi państwami; 3) umocnienie siły militarnej (np. pomoc finansowa w zamian za bazy na terytorium innego państwa); 4) umocnienie sojuszy (np. poprzez inwestycje, poparcie dla integracji); 5) wsparcie dla przyjaznych i sprzymierzonych krajów (np. przyznanie kredytów na korzystnych warunkach, preferencyjne układy handlowe); 6) osłabienie potencjału krajów wrogich (np. embargo na dobra strategiczne); 7) okazanie niezadowolenia z polityki państwa i nałożenie kary (np. zawieszenie pomocy gospodarczej).

Autor wyróżnił następujące cele pomocy zagranicznej: 1) krótkoterminowe gospodarcze: promocja eksportu, znalezienie rynków zbytu dla nadwyżek produkcyjnych, stworzenie dobrych warunków do inwestycji; 2) krótkoterminowe polityczno-militarne: uzyskanie stref wpływów (rywalizacja z przeciwnikiem), wspieranie przywódców państw sprzymierzonych, poprawa bezpieczeństwa militarnego, propaganda, podkreślenie zainteresowania współpracą, umocnienie sojuszu; 3) długoterminowe polityczne i gospodarcze: zrównoważony rozwój, długotrwała współpraca, demokratyzacja ${ }^{107}$.

Rolę narzędzi gospodarczych w polityce zagranicznej państwa analizował David A. Baldwin w pracy Economic Statecraft ${ }^{108}$. Tytułowe pojęcie można tłumaczyć jako dyplomację gospodarczą, a konkretnie używanie instrumentów ekonomicznych przez państwo w polityce zagranicznej. Są to działania zmierzające do podniesienia pozycji międzynarodowej państwa poprzez promocję jego interesów. Celem autora było wykazanie, że te narzędzia, wbrew stereotypom, są skuteczne i w wielu przypadkach mogą stanowić alternatywę dla groźby użycia siły militarnej lub wojny. Według Baldwina, dyplomacja gospodarcza składa się z trzech elementów: 1) instrumentu użytego podczas próby wywarcia wpływu, 2) obszaru wpływu (inni uczestnicy stosunków międzynarodowych), 3) celu wpływu (pożądane zachowanie uczestnika stosunków międzynarodowych). Przedstawiając taką definicję, autor określa dyplomację gospodarczą jako akt o charakterze politycznym ${ }^{109}$. Za

${ }^{106}$ Podział Knorra ma odzwierciedlenie w pojęciach ukutych przez Josepha Nye'a: hard power - zdolność państwa do wywierania nacisku na innych aktorów za pomocą siły militarnej lub/i gospodarczej oraz soft power - „zdolność do pozyskiwania sojuszników i zdobywania wpływów dzięki atrakcyjności własnej kultury, polityki, ideałów politycznych" (J. Nye, Bound to Lead: The Changing Nature of American Power, New York 1990).

${ }^{107}$ K. K n o r r, The Power of Nations. The Political Economy of International Relations, New York 1975, s. 135-138, 169-170.

${ }^{108}$ D. A. B a l d w i n, Economic Statecraft, Princeton 1985.

${ }^{109}$ Ibidem, s. 32. 
najbardziej skuteczną technikę uprawiania dyplomacji gospodarczej uznał handel zagraniczny. Zgadzał się z Thomasem Schellingiem, że „szeroko pojęty handel (zawierający także inwestycje zagraniczne, transport, turystykę i zarządzanie przedsiębiorstwami), to główny składnik stosunków międzynarodowych. Dlatego polityka handlowa może antagonizować rządy, skłócić społeczeństwa, szkodzić gospodarce i wpływać na politykę poszczególnych państw"110. Decydenci starają się tak kształtować politykę handlową, by osiągnąć określone efekty bądź ich uniknąć. Baldwin zauważa, że większość autorów zwracało uwagę raczej na pomoc zagraniczną, która była bardziej nagłaśniana przez propagandę. Przyznaje, że w latach 1944-1962 stanowiła ona główną technikę dyplomacji gospodarczej stosowanej przez rząd Stanów Zjednoczonych. Przyczyniła się do odbudowy Europy Zachodniej (plan Marshalla) i miała na celu wspomaganie rozwoju państw Trzeciego Świata. Baldwin zauważa jednak, że głównym celem tej pomocy było wprowadzenie w tych krajach reguł wolnego handlu. Amerykanie używali polityki handlowej, by stworzyć system oparty na liberalizacji wymiany i eliminacji dyskryminujących praktyk. Najwięcej miejsca w swojej pracy poświęca Baldwin analizie skuteczności sankcji gospodarczych, opierając ją na konkretnych przypadkach, np. embarga na towary strategiczne wobec bloku wschodniego czy sankcji nałożonych przez Stany Zjednoczone na Kubę po przejęciu władzy przez Fidela Castro. Wykazuje, że działania te miały wielorakie cele, a brak skutków w postaci rozpadu bloku komunistycznego czy ustąpienia Castro nie oznaczają fiaska zastosowanych sankcji.

Baldwin zwraca też uwagę na wielość czynników składających się na siłę państw, obalając przekonanie, że powinna być ona mierzona przede wszystkim potencjałem militarnym. Jako części składowe potęgi państw wymienia: obszar geograficzny, populację, bogactwo, możliwości sprawnego działania rządu. Jeśli chodzi o politykę zagraniczną i wpływ na innych uczestników stosunków międzynarodowych, zależą one od potencjału aktora, którego działania mają być kształtowane. Dlatego autor postuluje rozróżnianie źródeł siły i możliwości jej użycia. Te same instrumenty gospodarcze mogą być skuteczne w powodowaniu zachowań pożądanych jednego państwa, nie zadziałają natomiast w przypadku innego aktora. Baldwin nie zgadza się również z poglądem, że wzrost siły jednego państwa może się dokonać tylko kosztem drugiego. Wykazuje, że szczególnie wzajemne wpływy gospodarcze mogą się przyczynić do wzrostu siły partnerów handlowych ${ }^{111}$.

W pracach z lat 70. podkreślano, że centralizacja wpływów państwa i sił społecznych ma decydujący wpływ na politykę zagraniczną. Autonomia organów państwowych sprawia, że choć są ograniczone przez różnorakie siły społeczne, mogą działać skutecznie ${ }^{112}$. Problemem współzależności polityki wewnętrznej i zagranicznej zajął się Peter Gourevitch. Uznając wpływ sytuacji w poszczególnych państwach

\footnotetext{
110 Ibidem, s. 206.

111 Ibidem, s. 21-24.

112 Between Power and Plenty, ed. P. Katzenstein, Madison 1978.
} 
na system międzynarodowy, zaproponował badanie wpływu odwrotnego: sytuacji międzynarodowej na politykę wewnętrzną. Podając wiele przykładów wzajemnego oddziaływania na różnych płaszczyznach, postulował uwzględnianie obu czynników w analizach, zarówno polityki wewnętrznej, jak i zagranicznej ${ }^{113}$.

Badacze MEP, tworząc teorie dotyczące kształtowania się polityki zagranicznej, wielokrotnie posługiwali się przykładem Stanów Zjednoczonych. Rozważano pozycję tego mocarstwa w stworzonym przez nie systemie. Większość naukowców przyjmowała założenie, że USA, mimo wewnętrznych trudności gospodarczych, wciąż były dominującą siłą w gospodarce światowej. Działania tego państwa w międzynarodowym handlu, transferze technologii, polityce monetarnej w dużym stopniu wpływały na inne państwa systemu zachodniego. Analizie zagranicznej polityki gospodarczej Stanów Zjednoczonych poświęcono jeden z tomów prestiżowego czasopisma „International Organization”"114. Autorzy wprowadzenia, John Ikenberry, David Lake i Michael Mastanduno, wyróżnili trzy podejścia naukowców analizujących to zagadnienie. Pierwsze z nich podkreśla rolę światowego systemu gospodarczo-politycznego (system-centered approach). Zgodnie z tym podejściem, kreatorzy amerykańskiej polityki zagranicznej działają w oparciu o przywileje i ograniczenia, jakie on stwarza. Zwolennicy takiej perspektywy odnoszą się często do teorii hegemonicznej stabilności. Abstrahują przy tym w dużym stopniu od polityki wewnętrznej i koncentrują się na opisie interakcji między państwami narodowymi. Jednak bez uwzględnienia wewnętrznych uwarunkowań, obraz tych relacji wydaje się niepełny ${ }^{115}$.

Druga grupa badaczy polityki handlowej USA zakładała, że jej kształt jest wynikiem zmagania między grupami społecznymi lub partiami politycznymi w danym państwie (society-centered approach). Mogą one zawierać ze sobą sojusze, jeśli mają wspólny cel. Urzędnicy i instytucje są jedynie wykonawcami polityki postulowanej przez najbardziej wpływowe środowiska, państwo jawi się jako podmiot pasywny. Krytycy tego podejścia argumentowali, że porozumienia między poszczególnymi grupami interesów są płynne. Przyznawali, że państwo musi się liczyć z ich naciskiem, ale jest zdolne do panowania nad postulatami i do ich łagodzenia, jeśli będą niezgodne z szerszymi celami polityki zagranicznej ${ }^{116}$.

Wielu naukowców analizowało zagraniczną politykę gospodarczą Stanów Zjednoczonych, opierając się na podejściu państwocentrycznym (state-centered approach). Określano państwo mianem „silnego” lub „słabego”, biorąc pod

${ }^{113}$ P. G o u r e v i t c h, The Second Image Reversed: the International Sources of Domestic Politics, „International Organization”, Autumn 1978, s. 881-912. Na ten temat zob. także: P. J. K a t z e n s t e i n, International Relations and Domestic Structure: Foreign Economic Policies of Advanced Industrial States, „International Organization”, Winter 1976, s. 2-45.

114 „International Organization”, Winter 1988.

${ }^{115}$ G. J. I k e n b e r r y, D. A. L a ke, M. M a s t a n d u n o, Introduction: Approaches to Explaining American Foreign Economic Policy, „International Organization”, Winter 1988, s. 1-6.

${ }^{116}$ Ibidem, s. 8. 
uwagę stopień centralizacji władzy i uprawnienia urzędników państwowych niezależnych uczestników procesu politycznego. Z tej perspektywy postrzegano Stany Zjednoczone jako państwo „słabe” (zdecentralizowane pod względem instytucjonalnym; urzędnicy, z niewielką autonomią, są kontrolowani przez społeczeństwo i muszą się liczyć z silną opozycją) ${ }^{117}$. Z tą tezą zgadzał się Stephen Krasner. Wykazywał, że po zakończeniu II wojny światowej priorytetem Stanów Zjednoczonych było ustanowienie reżimu minimalizującego zakłócenia przepływu towarów i kapitału. Udało się to zrealizować dzięki sile zewnętrznej, pozwalającej narzucać swoją koncepcję partnerom. Jednak słabość wewnętrznego systemu politycznego (w porównaniu z innymi uprzemysłowionymi państwami), objawiająca się dużymi wpływami grup interesów na rząd, ograniczała swobodę jego działania. Było to widoczne szczególnie w latach 70., kiedy Stany Zjednoczone traciły hegemonię w gospodarce światowej. Ze względu na wewnętrzne problemy ekonomiczne i spadek konkurencyjności produktów niektórych sektorów na rynkach zewnętrznych, nasiliły się żądania wprowadzenia środków protekcjonistycznych. Polityka Stanów Zjednoczonych stała się przez to niespójna, co prowadziło do destabilizacji światowego systemu gospodarczego ${ }^{118}$.

Judith Goldstein podkreślała, że polityka handlowa USA jest przede wszystkim oparta na instytucjonalnej idei wolnego handlu, mimo wewnętrznych problemów ekonomicznych i nacisków na wprowadzanie środków protekcjonistycznych. Zauważyła, że instytucje, także te nieformalne, są bardziej trwałe niż wpływy i koalicje grup interesów. Jednak autorka podkreśliła również obecność tradycji ochrony amerykańskiego rynku przez państwo, które wspierało mało konkurencyjne sektory w dostosowaniu się do reguł wolnego rynku. Praktyka taka była stosowana w epoce izolacjonizmu, a szczególnie w czasie wielkiego kryzysu gospodarczego w latach 30. XX w. ${ }^{119} \mathrm{Z}$ kolei David Lake ukazywał dylematy władzy wykonawczej, która musi jednocześnie liczyć się z oczekiwaniami elektoratu i regułami rządzącymi międzynarodowym systemem gospodarczym. Tak tłumaczy często występujące napięcia między amerykańską administracją a Kongresem, który wyrażał oczekiwania społeczeństwa ${ }^{120}$.

Jednak decydenci mieli możliwość niwelowania wpływów grup społecznych, stosując określone strategie. Państwo mogło stwarzać nowe instytucje, przekazując określone prerogatywy władzy wykonawczej ${ }^{121}$. Przykładem takiego działania były opisane w dalszej części niniejszej pracy ustawy handlowe (z 1962 i 1974 r.),

${ }^{117}$ Ibidem, s. 9-10.

118 S. Krasner, US Commercial and Monetary Policy: Unravelling the Paradox of External Strength and Internal Weakness, „International Organization”, Autumn 1977, s. 635-653.

${ }^{119}$ J. G o ld s t e i n, Ideas, Institutions, and American Trade Policy, „International Organization”, Winter 1988, s. 179-217.

${ }^{120}$ D. La ke, The State and American Trade Strategy in the Pre-hegemonic Era, „International Organization", Winter 1988, s. 33-58.

${ }^{121}$ G. J. I k e n b e r ry, D. A. L a ke, M. M a s ta n d u n o, op. cit., s. 12. 
które dawały prezydentowi większe uprawnienia do regulowania warunków wymiany podczas negocjacji na forum GATT. Władze państwowe, będąc odpowiedzialne za bezpieczeństwo i prowadzenie polityki zagranicznej, miały przez to specjalne uprawnienia do regulowania zagranicznych relacji gospodarczych. Dlatego administracja mogła definiować sprawy wewnętrzne, istotne dla stosunków międzynarodowych, przejmując tym samym prawo podejmowania ostatecznej decyzji. Przykładem przyjęcia takiej strategii jest kwestia polityki energetycznej przedstawiona przez Ikenberry'ego ${ }^{122}$ czy sprawa handlu z blokiem komunistycznym, ważna dla bezpieczeństwa narodowego, poruszona w artykule Mastanduno ${ }^{123}$. Państwo miało też największe możliwości mobilizowania grup społecznych do popierania jego celów, by stworzyć przeciwwagę dla opozycji ${ }^{124}$.

W latach 70. XX w. rozpoczęła się debata, czy USA zaangażowały się tak aktywnie na świecie, by zapewnić sobie bezpieczeństwo, czy żeby wykreować jak najszersze kontakty handlowe. Bergsten, Keohane i Nye stwierdzili, że nie można tego rozstrzygnąć, bo są to obszary ściśle ze sobą powiązane. Utrzymywali, że międzynarodowy system polityczny jest w dużym stopniu kształtowany przez system gospodarczy i vice versa ${ }^{125}$. Gilpin uważał, że światowy porządek polityczny, ustanowiony przez dominujące mocarstwo w celu zapewnienia bezpieczeństwa, stworzył przyjazne środowisko dla współzależności gospodarczych i ekspansji korporacji międzynarodowych. Udowadniał, że łącząc właściwe czynniki polityczne i gospodarcze można wytłumaczyć dominację USA, a także pochodzących stamtąd gigantycznych korporacji ${ }^{126}$.

Istotną rozważaną kwestią była sytuacja wewnętrzna w poszczególnych krajach. Wzrost inflacji i bezrobocia stanowił dla rządów problem gospodarczy i polityczny. W Stanach Zjednoczonych działały różne grupy interesów, które miały stosunkowo otwarty dostęp do procesu politycznego, szczególnie poprzez naciski na kongresmanów, którzy mogli być odwołani po demokratycznych wyborach. Politycy liczyli na ich pomoc w zbieraniu pieniędzy na kampanie wyborcze. Poza tym Stany Zjednoczone były krajem emigrantów, należało więc uwzględniać również interesy grup etnicznych. Starając się poprawić wewnętrzną sytuację gospodarczą, podejmowano decyzje często niekorzystne dla pozostałych uczestników międzynarodowego systemu gospodarczego, np. manipulowano kursem walut czy jednostronnie wprowadzano reguły regulujące import bądź eksport ${ }^{127}$.

${ }^{122}$ G. J. I k e n b e r r y, Market Solutions for State Problems: the International and Domestic Politics of American Oil, „International Organization”, Winter 1988, s. 151-178. Na ten temat zob. przypis 73 w podrozdziale 7.4.

${ }^{123}$ M. M a s t a n d u n o, Trade as the Strategic Weapon: American and Alliance Export Control Policy in the Early Postwar Period, „International Organization”, Winter 1988, s. 121-150.

${ }^{124}$ G. J. I ke n b e r ry, D. A. La ke, M. M a st an d un o, op. cit., s. 13.

${ }^{125}$ C. F. B e rg ste n, R. O. Ke o h a ne, J. S. Nye, International Economics and International Politics..., s. 24.

${ }^{126}$ R. G i l p i n, U.S. Power and the Multinational Corporations..., s. 84.

${ }^{127}$ P. Stern, Water's Edge. Domestic Politics and the Making of American Foreign Policy, Westport 1979, s. XI-XII. 
Bergsten, Keohane i Nye zauważyli, że wewnętrzny nacisk grup interesów kształtował gospodarczą politykę zagraniczną państwa, szczególnie Stanów Zjednoczonych. Na drugi plan schodził argument wspierania sojuszników w realizacji priorytetowego celu - bezpieczeństwa narodowego. W szczytowym okresie zimnej wojny powoływanie się na współzależność bezpieczeństwa pozwalało promować rozwój Europy Zachodniej i Japonii. Nie brano pod uwagę faktu, że w ten sposób tworzy się silna konkurencja dla amerykańskiej gospodarki. Koszty wydawały się akceptowalne, gdyż dzięki temu rozszerzano wpływy polityczne (zapobiegano rozprzestrzenianiu się komunizmu, tworzono amerykańskie bazy wojskowe i warunki działania dla wywiadu) i gospodarcze (zapewniano rynki zbytu i korzystne środowisko dla inwestorów). W dobie odprężenia koncepcja umacniania bezpieczeństwa narodowego poprzez wspieranie sojuszników w powszechnym odbiorze traciła znaczenie, ustępując miejsca krótkoterminowym celom: utrzymaniu siły dolara i dodatniego bilansu handlowego, zapobieganiu wzrostowi bezrobocia ${ }^{128}$.

Badacze MEP widzieli konieczność zintegrowanej analizy polityki wewnętrznej i zagranicznej państw. David Baldwin i Robert Kay zauważyli, że struktura stosunków międzynarodowych wpływa na zdolność przywódców państw do utrzymania władzy. Autorzy podkreślali, że dotyczy to zarówno stosunków politycznych, jak i gospodarczych. Jako przykład podali sytuację zmiany stanowiska amerykańskich związków zawodowych (American Federation of Labor and Congress of Industrial Organization - AFL-CIO), które początkowo popierały liberalizację międzynarodowego handlu, a w latach 70. opowiedziały się za działaniami protekcjonistycznymi rządu. Baldwin i Kay stwierdzili, że działania grup interesów stanowią poważne zagrożenie dla wolności handlu, wobec tego rządy muszą interweniować i szukać kompromisowych rozwiązań, gdyż koszty wprowadzenia środków doraźnych mogą być szkodliwe dla gospodarki narodowej w dłuższym okresie. Mogło to prowadzić do powstawania protekcjonistycznych bloków handlowych ${ }^{129}$.

Ciekawą teorię związków polityki z gospodarką przedstawił David Calleo, odnosząc ją bezpośrednio do stosunków transatlantyckich. Według niego, każde nowoczesne państwo narodowe jest złożone ze skomplikowanego systemu grup interesów, ideologii i instytucji. Jego stabilność opiera się na konsensusie tych wszystkich czynników, który jest bardzo kruchy. Takie zasady rządzą nie tylko relacjami politycznymi, lecz także gospodarką i stosunkami społecznymi. „Każdy model, który nie bierze pod uwagę politycznych uwarunkowań w państwach narodowych i zdaniach obywateli, nie ma nic wspólnego ze współczesną rzeczywistością" - przekonywał

${ }^{128}$ C. F. B e r g s t e n, R. K e o h a n e, J. N y e, International Economics and International Politics..., s. 23-30.

${ }^{129}$ D. A. B aldwi n, R. E. Kay, International Trade and International Relations, [w:] World Politics and International Economics..., s. 130. 
Calleo ${ }^{130}$. Jednak to rządy podejmują ostateczne decyzje, co prowadzi do sytuacji, kiedy każda nowoczesna gospodarka jest „zainfekowana” polityką (every economy is political economy). Państwa są skłonne brać udział w systemie międzynarodowych porozumień i organizacjach, dopóki nie będzie to zakłócało równowagi między interesami grup istniejących w jego obrębie i będzie przynosiło wymierne korzyści ${ }^{131}$.

Według Davida Calleo, wszystkie teorie zakładające małą lub zanikającą rolę państwa narodowego nie mogą być pomocne w zrozumieniu stosunków międzynarodowych, szczególnie transatlantyckich na początku lat 70. Uważał, że głoszenie takich poglądów oznaczało zgodę na hegemonię Stanów Zjednoczonych, gdyż podkreślanie interesu narodowego było jedyną obroną słabszych państw przed tą dominacją. Według niego, Amerykanie dążyli do jej utrzymania w stosunkach z Europą Zachodnią, próbując wywierać w ramach istniejącego systemu wpływ na jej politykę i gospodarkę. W ten sposób tłumaczył np. odkładanie przez Waszyngton reformy międzynarodowego systemu walutowego, choć już pod koniec lat 60. stał się on niewydolny. Calleo twierdził, że Stany Zjednoczone nie chciały dostosować systemu do nowych warunków i mimo deklaracji nie chciały dopuścić do ustanowienia prawdziwie partnerskich relacji z Europą Zachodnią ${ }^{132}$.

Calleo odniósł się także do koncepcji atlantyzmu (Atlanticist ideology) ${ }^{133}$, która zyskiwała popularność w kołach akademickich na początku lat 70. Główną jej tezą było przekonanie o nieuchronnej integracji rozwiniętych, kapitalistycznych gospodarek. Do klasycznych argumentów o wolności handlu i przepływu kapitału dodano rolę integracyjną międzynarodowych korporacji. Zmuszone przez transnarodowe interesy i instytucje kraje rozwinięte musiały dążyć do podejścia kosmopolitycznego. Integracja światowych rynków i produkcji łączyła narodowe gospodarki w sieć wielostronnych interesów tak silną, że wycofanie się z niej stawało się zbyt kosztowne, a w praktyce niemożliwe. Z tego wyprowadzano wniosek, że państwo narodowe przestawało być całością gospodarczą. Tylko Stany Zjednoczone miały wystarczający potencjał, by zachować suwerenność. Wymienione współzależności sprawiały, że amerykańskie interesy były również uzależnione od działań innych krajów kapitalistycznych, więc polityka amerykańska musiała odpowiadać na potrzeby partnerów. W miarę rozwoju instytucji międzynarodowych, takich jak NATO, MFW, GATT, inne kraje będą miały doskonałe fora do przekazywania swoich priorytetów do amerykańskiego „centrum”. Według Calleo, słabości tej koncepcji można upatrywać w wielu punktach. Po pierwsze, nawet w ramach EWG można było dostrzec różnice interesów narodowych poszczególnych członków.

${ }^{130}$ D. P. C all e o, American Foreign Policy and American European Studies: An Imperil Bias?, [w:] The United States and Western Europe. Political, Economic and Strategic Perspectives, ed. W. F. Hanrieder, Cambridge, Mass. 1974, s. 76.

${ }^{131}$ Ibidem, s. 60.

${ }^{132}$ Ibidem, s. 62.

${ }^{133}$ Więcej informacji na temat koncepcji współpracy atlantyckiej znajduje się w rozdziale II. 
Ponadto Wspólnoty Europejskie praktycznie bardzo wyraźnie rozgraniczały interesy amerykańskie od europejskich. Najważniejszym argumentem przeciwko tej teorii wydaje się fakt, że Europa nie chciała poddać się amerykańskiej hegemonii - ani gospodarczej, ani politycznej ${ }^{134}$. Jak zauważyła Linda Brady, w połowie lat 60. XX w. nastąpiły zmiany w układzie sił na świecie. W stosunkach transatlantyckich zwiększający się potencjał państw europejskich sprawił, że Stany Zjednoczone zostały zmuszone do negocjacji z sojusznikami. Państwa Europy Zachodniej nie były już skłonne bezwarunkowo popierać polityki zagranicznej USA, gdyż ich interesy, szczególnie gospodarcze, coraz częściej były sprzeczne ${ }^{135}$.

\subsection{Podsumowanie}

Wyodrębniająca się na początku lat 70. subdyscyplina nauki o stosunkach międzynarodowych, MEP, powstawała w oparciu o obserwacje dynamicznych zmian w gospodarce światowej. Zmierzch hegemonii Stanów Zjednoczonych objawiał się przyjęciem polityki odprężenia w stosunkach Wschód-Zachód i ogłoszeniem przez prezydenta Richarda Nixona doktryny o konieczności wzięcia większej odpowiedzialności przez sojuszników za bezpieczeństwo w różnych regionach świata. Badacze stosunków międzynarodowych zauważyli, że było to spowodowane w dużym stopniu wewnętrznymi problemami gospodarczymi Stanów Zjednoczonych. Warto odnotować, że pierwsze teorie MEP w latach 70. powstawały na podstawie analizy realiów współpracy i rywalizacji Stanów Zjednoczonych z partnerami gospodarczymi, głównie z Europą Zachodnią i Japonią.

Począwszy od lat 70. MEP przeżywała nieustanny rozkwit. Powstawały nowe teorie, uwzględniające interakcje czynników politycznych i gospodarczych na arenie międzynarodowej. Dostrzegano różnorodność i złożoność tych wpływów, biorąc pod uwagę nie tylko zmienność sytuacji politycznej i ekonomicznej na świecie, lecz także procesy wewnętrzne w obrębie państw narodowych i ich postrzeganie przez obywateli. Podważano nadrzędność państw w stosunkach międzynarodowych, wskazując na nowych aktorów. Współcześnie niezwykle rzadko powstają publikacje naukowe z tej dziedziny, skupiające się jedynie na relacjach politycznych, niebiorące pod uwagę uwarunkowań gospodarczych. Niewątpliwie w dobie globalizacji wzrosła również świadomość społeczna, dotycząca współzależności tych dwóch aspektów.

Niniejszej pracy starano się nie podporządkowywać konkretnej teorii, wykorzystując elementy różnych podejść do stworzenia jak najpełniejszego obrazu sytuacji. Ponieważ jej tematem jest wpływ zagadnień ekonomicznych na kreowanie polityki zagranicznej Stanów Zjednoczonych, siłą rzeczy to państwa narodowe znajdują

${ }^{134}$ D. P. C a l l e o, American Foreign Policy..., s. 67.

${ }^{135}$ L. B r a d y, The Politics of Negotiation: America's Dealings with Allies, Adversaries, and Friends, Chapel Hill 1991, s. 7-10. 
się na pierwszym planie jako aktorzy stosunków międzynarodowych. Jednak wielokrotnie okazuje się, że rządy muszą podporządkować politykę konkretnym grupom interesu lub wewnętrznym uwarunkowaniom politycznym. Choć niejednokrotnie próbują te wpływy hamować, ich możliwości działania są wyraźnie ograniczone. Realia pierwszej dekady lat 70. XX w. dostarczają dowodów na potwierdzenie zarówno podejścia realistycznego, jak i liberalnego. Zresztą nowoczesny liberalizm akceptuje często argumenty realistów o ważnej roli państw narodowych ${ }^{136}$. Starano się podkreślać rolę instytucji, łączących umowami członków systemu pod przywództwem Stanów Zjednoczonych. Również w tym przypadku możliwość egzekwowania przestrzegania reguł była ograniczona przez powiązania polityczne.

Wybierając metodologię, zastosowano elastyczność. Wiodącą metodą jest studium przypadku - oparte na dokumentach dowody ścierania się interesów politycznych i gospodarczych w procesie kształtowania polityki USA wobec Europy Zachodniej. Na tej podstawie formułowano tezy pracy. Jednakże często stosowano również metody ilościowe - to właśnie dzięki danym statystycznym często można było znaleźć odpowiedzi na pytania badawcze.

${ }^{136}$ J. M. G r i e c o, Cooperation among Nations. Europe, America, and Non-Tariff Barriers to Trade, Ithaca 1990, s. 30. 



\section{ROZDZIAŁ II}

\section{ZARYS POLITYCZNO-EKONOMICZNYCH RELACJI TRANSATLANTYCKICH PO II WOJNIE ŚWIATOWEJ (1945-1969)}

\subsection{Kształtowanie się powojennego systemu gospodarczego}

Po II wojnie światowej Stany Zjednoczone uzyskały bezprecedensową pozycję na arenie międzynarodowej. Jako jedyne mocarstwo biorące udział w wojnie wyszły z niej wzmocnione gospodarczo. W latach 1940-1945 dochód narodowy USA podwoił się ${ }^{1}$. Państwo to posiadało 75\% światowych rezerw złota, jego produkcja stanowiła połowę światowej, a eksport - jedną trzecią globalnego wywozu². Na terytorium Stanów Zjednoczonych nie toczyły się walki, kraj nie doznał zniszczeń wojennych, z jakimi borykały się w mniejszym lub większym stopniu wszystkie kraje europejskie. Rozwijana na wielką skalę produkcja na potrzeby armii czyniła z nich potęgę militarną. Pozycja ta została umocniona w sierpniu 1945 r., kiedy zademonstrowano w Hiroszimie i Nagasaki siłę rażenia bomby atomowej.

Nie można zapominać o negatywnych skutkach wojny (straty ludnościowe i rosnące zadłużenie wewnętrzne), jednak nie przeszkodziły one, by Stany Zjednoczone uzyskały status supermocarstwa. Państwa europejskie liczyły, że w nowej sytuacji geopolitycznej USA nie wycofają się w izolacjonizm, uznając utrzymanie stabilnej sytuacji na Starym Kontynencie za warunek konieczny swojego bezpieczeństwa.

Zakończenie działań wojennych przyniosło zasadniczą zmianę w stosunkach amerykańsko-europejskich. Upadły idealistyczne założenia prezydenta Franklina Delano Roosevelta o możliwości harmonijnej współpracy ze Związkiem Radzieckim. Było również oczywiste, że Wielka Brytania, która według amerykańskiego prezydenta miała zostać głównym „sponsorem” odbudowy gospodarczej Europy, sama potrzebowała wsparcia. Wydawało się, że tylko Stany Zjednoczone przez swoje zaangażowanie mogły uchronić Stary Kontynent przed gospodarczą recesją i wewnętrznymi konfliktami, a w rezultacie - przed włączeniem w radziecką strefę wpływów. Niechęć Amerykanów w czasie wojny do konkretnych dyskusji z ZSRR o przyszłości Europy sprawiła, że pierwsze lata pokoju przyniosły

\footnotetext{
${ }^{1}$ Dochód narodowy USA wynosił w 1940 r. 98 mld USD, a w 1945 r. - 213 mld (K. M i c h a ł e k, Amerykańskie stulecie. Historia Stanów Zjednoczonych Ameryki 1900-2001, Warszawa 2004, s. 228).

${ }^{2}$ A. P. D o b s o n., S. M a r s h, U.S. Foreign Policy since 1945, London 2000, s. 47.
} 
poważne napięcia międzynarodowe i zapoczątkowały rywalizację, nazwaną później zimną wojną ${ }^{3}$.

Upadek potęgi Niemiec i Japonii wytworzył lukę, którą supermocarstwa starały się wypełnić. Żadne z nich nie chciało pozwolić rywalowi na przejęcie wpływów w Europie i w Azji. ZSRR miał przy tym ułatwione zadanie. Ze względu na położenie mógł rozszerzać wpływy na sąsiednie kraje. Stany Zjednoczone musiały budować system sojuszy i tworzyć bazy wojskowe w różnych częściach świata. Postrzegały przy tym państwa europejskie jako potencjalnych sojuszników. Zdawały sobie sprawę z bliskości kulturowej, dążenia do utrzymania wartości demokratycznych, wspólnych celów politycznych i gospodarczych.

Według Roberta Gilpina, pod koniec II wojny światowej Stany Zjednoczone planowały organizację powojennego porządku opierając się na dwóch założeniach. Po pierwsze, decydenci twierdzili, że przyczyny wybuchu światowego konfliktu były w dużej mierze gospodarcze: niemożność odbudowy ekonomicznej Europy po I wojnie światowej oraz tworzenie się w dobie wielkiego kryzysu lat 30. XX w. rywalizujących ze sobą bloków gospodarczych. W związku z tym zakładali, że pokój będzie trwalszy $\mathrm{w}$ momencie stworzenia systemu wielostronnych relacji handlowych, co zagwarantuje wszystkim krajom równy dostęp do surowców i rynków. Główną przeszkodą do osiągnięcia tego celu przed II wojną światową było wprowadzanie przez poszczególne państwa dyskryminacyjnych środków: preferencji handlowych, kontroli wymiany, kontyngentów itp. Gilpin zauważył również, że Stany Zjednoczone kierowały się długą tradycją liberalnego ideału wolnego handlu, stanowiącego siłę zapewniającą pokojowe relacje między narodami. Twierdził, że był to główny powód przejęcia odpowiedzialności za powojenny system gospodarczy, a nie - jak wskazywało wielu ekspertów - chęć zapewnienia sobie wpływów gospodarczych na świecie poprzez kształtowanie zasad regulujących gospodarkę światową w sposób dla siebie korzystny. Autor jednak nie neguje, że również ten drugi powód był istotny dla amerykańskich decydentów. Gilpin wykazywał, że jeszcze w trakcie wojny Amerykanie podejmowali inicjatywy mające na celu demontaż brytyjskiego systemu dyskryminacji handlowej opartego na funkcjonowaniu Commonwealthu np. poprzez postanowienia Karty Atlantyckiej ${ }^{4}$.

${ }^{3}$ P. M a t e r a, R. M a t e r a, Stany Zjednoczone i Europa. Stosunki polityczne i gospodarcze 17762004, Warszawa 2007, s. 189. Na temat przyczyn zimnej wojny i jej charakterystyki zob. J. L. G a d d i s, Zimna wojna. Historia podzielonego świata, Kraków 2007, s. 20-49.

${ }^{4}$ R. Gil pin, The Politics of Transnational Economic Relations, „International Organization”, Summer 1971, s. 408-409. Karta Atlantycka została podpisana 14 sierpnia 1941 r. przez prezydenta Stanów Zjednoczonych Franklina D. Roosevelta i premiera Wielkiej Brytanii Winstona Churchilla. Określała ona cele wojenne sojuszników, także w kwestii powojennego ładu światowego. Przywódcy uznali m.in. prawo do wyboru formy rządu, przywrócenie suwerenności państwom, którym została ona odebrana. Zadeklarowali także dążenie do ułatwienia wszystkim państwom „korzystania z dostępu, na stopie równości, do handlu i surowców świata, potrzebnych im dla ich pomyślności gospodarczej” oraz zapewnienia „jak najściślejszej współpracy pomiędzy wszystkimi narodami w dziedzi- 
Stany Zjednoczone jeszcze wtedy nie brały pod uwagę powojennego osłabienia Wielkiej Brytanii, która nie miała już możliwości samodzielnego oddziaływania na światowy system polityczny i gospodarczy. Skutkiem II wojny światowej o długofalowych reperkusjach ekonomicznych był spadek znaczenia państw europejskich. Europa Środkowowschodnia znalazła się pod nadzorem Związku Radzieckiego, pokonane Niemcy zostały podzielone, a pozycja Francji, Wielkiej Brytanii i Włoch uległa osłabieniu w porównaniu z okresem sprzed wojny. Na Starym Kontynencie, obok doraźnych trudności, rysowały się coraz wyraźniej przeszkody strukturalne. Były one rezultatem zmiany układu sił między Europą a krajami zamorskimi. Stary Kontynent w ciągu stulecia czerpał ogromne korzyści z kolonii poprzez korzystny dla siebie handel oraz dzięki inwestycjom na zarządzanych obszarach.

W okresie powojennym większość państw musiała korzystać z pomocy zagranicznej, pochodzącej głównie ze Stanów Zjednoczonych. Była ona wtedy niezbędna, w dalszej perspektywie chodziło jednak o to, aby stosunki poszczególnych państw z Waszyngtonem stały się bardziej partnerskie. Jednostronną pomoc należało z czasem zastąpić współpracą. Zatem zaspokojenie rosnącego popytu inwestycyjnego i konsumpcyjnego było możliwe jedynie poprzez wyrównanie poziomów gospodarczych poszczególnych państw. Wiele w tym względzie mogły zdziałać organizacje międzynarodowe, które nie rezygnując z niesienia doraźnej pomocy, na plan pierwszy wysunęły zadania zmierzające do przeobrażenia ekonomiki światowej.

Jeszcze w czasie wojny, z inicjatywy Stanów Zjednoczonych, zwołano w lipcu 1944 r. w Bretton Woods konferencję Narodów Zjednoczonych poświęconą zagadnieniom finansowym i walutowym, w której brały udział 44 państwa. Utworzono wtedy Międzynarodowy Fundusz Walutowy (International Monetary Fund IMF) oraz Międzynarodowy Bank Odbudowy i Rozwoju (International Bank for Reconstruction and Development - IBRD) ${ }^{5}$. Podstawowymi celami nowego ładu walutowego były m.in.: przywrócenie wymienialności walut, stabilizacja ich kursów, wspieranie międzynarodowej współpracy monetarnej, utrzymywanie wzrostu handlu zagranicznego oraz zmniejszanie nierównowagi w bilansach płatniczych państw członkowskich ${ }^{6}$. W Bretton Woods ustalono również, że waluty państw przystępujących do porozumienia mogły być wymienialne na złoto dopiero po ich wymianie

nie gospodarczej, w celu zapewnienia wszystkim lepszych warunków pracy, postępu gospodarczego i bezpieczeństwa społecznego". Tekst Karty Atlantyckiej dostępny przez: http://avalon.law.yale. edu/wwii/atlantic.asp.

${ }^{5}$ W ramach Międzynarodowego Banku Odbudowy i Rozwoju działają trzy powiązane ze sobą instytucje: Bank Światowy (bank wspomagający rozwój), Międzynarodowa Korporacja Finansowa oraz Międzynarodowe Stowarzyszenie Rozwoju. W 1988 r. powstała jeszcze w jego ramach Wielostronna Agencja Gwarancji Inwestycji (Współczesna gospodarka światowa, red. A. Kisiel-Łowczyc, Gdańsk 1999, s. 330). Bank Światowy rozpoczął działaność w 1946 r., a MFW w 1947 r. Międzynarodowy Bank Odbudowy i Rozwoju został powołany do życia jako jedna z wyspecjalizowanych agend ONZ na mocy porozumienia w Bretton Woods w 1945 r. przez 44 państwa.

${ }^{6}$ P. M a t e ra, R. M a t e ra, op. cit., s. 187-188. 
na dolary. Wymienialność na złoto, w relacji 35 USD za uncję, zastrzeżono jedynie dla dolara amerykańskiego. System ten, zapewniając gospodarce światowej pieniądz międzynarodowy, ułatwiał obrót towarów i kapitału pomiędzy poszczególnymi krajami. Jego oparcie na dolarze amerykańskim utwierdzało hegemonię Stanów Zjednoczonych. Dopiero w 1958 r. europejskie waluty stały się wymienialne.

Wraz ze zmianami w międzykontynentalnych relacjach handlowych istniała silna potrzeba liberalizacji wymiany. Podczas rozmów dotyczących redukcji barier celnych w Londynie w 1946 r. zaproponowano utworzenie odrębnej agendy - Układu Ogólnego w sprawie Ceł i Handlu (General Agreement on Tariffs and Trade - GATT). Jej filarami stały się: zakaz dyskryminacji, ekspansja handlu przez znoszenie barier, międzynarodowy porządek handlowy i zasada wzajemności znoszenia barier handlowych. W porozumieniu zawarto także klauzulę zwaną escape clause. Była to klauzula włączana do traktatów handlowych, dająca możliwość wypowiedzenia umowy we wcześniejszym terminie w przypadku szczególnych okoliczności, nieprzewidzianych przez strony w momencie zawierania umowy lub niespełnienia przez którąś ze stron warunków porozumienia ${ }^{7}$.

Stany Zjednoczone, państwo inicjujące powstanie układu, dążąc do stworzenia systemu wolnego handlu, były skłonne do zmniejszenia barier handlowych na zasadzie wzajemności. Stanowiło to zachętę dla pozostałych państw, których gospodarki były zniszczone przez wojnę do przyjęcia reguł proponowanych przez USA. Amerykanie zgodzili się na dwa zapisy, które mogły prowadzić do dyskryminacyjnego traktowania ich towarów. Artykuł XII dopuszczał wprowadzenie tymczasowych środków protekcjonistycznych przez kraj, który zmagał się z dużym deficytem bilansu płatniczego. Artykuł XXIV pozwalał krajom tworzyć unie celne i strefy wolnego handlu ${ }^{8}$. Amerykanie przewidywali, że gdy ich partnerzy odbudują siłę ekonomiczną, system będzie działał sam - zostanie „odpolityczniony”, a Stany Zjednoczone nie będą musiały ponosić dodatkowych kosztów jego utrzymania. Jednak oddzielenie spraw handlowych od politycznych okazało się niemożliwe. Stany Zjednoczone same w przyszłości wielokrotnie używały nacisków politycznych, by uzyskać koncesje gospodarcze. Stosowały również środki dyskryminujące towary partnerów handlowych ${ }^{9}$.

Organizacja wolnego handlu zaczęła funkcjonować 30 października 1947 r., kiedy 23 kraje podpisały w Genewie układ ogólny. Owocem tych rozmów były 123 umowy bilateralne oraz porozumienia zawierające zmiany w wysokości 24 tys. taryf, obejmujących połowę światowego handlü ${ }^{10}$.

\footnotetext{
${ }^{7}$ K. B i a ł e c k i, A. D o r o s z, W. J a n u s z ki e w i c z, Słownik handlu zagranicznego, Warszawa 1986, s. 118.

${ }^{8}$ International Economic Relations of the Western World, 1959-1971, ed. A. Shonfield, vol. 1: Politics and Trade, London 1976, s. 90.

${ }^{9}$ D. A. B a l d w i n, Economic Statecraft, Princeton 1985, s. 209.

${ }^{10}$ J. S k o d l a r s k i, R. M a t e r a, Gospodarka światowa. Geneza i rozwój, Warszawa 2005, s. 209.
} 
Do głównych zadań powojennej odbudowy należało odnowienie transatlantyckich kontaktów handlowych. Wielką przeszkodą w realizacji tego celu była nierównowaga bilansu płatniczego Europy. W 1947 r. sięgnęła ona 7,5 mld USD deficytu. Jego duża część (4,8 mld USD) powstała w wyniku zmian w bilansie handlowym. Ujemne saldo było głównie skutkiem spadku eksportu europejskiego na rynki zamorskie. Dalsze 2,7 mld USD przypadało na tzw. wpływy „niewidoczne” (dochody z zagranicznych inwestycji, pożyczki udzielane przez Europę, usługi transportowe, turystyczne itp.), które wówczas gwałtownie zmalały. Z pomocą Europie pospieszyły Stany Zjednoczone, które w okresie 1945-1947 dostarczyły jej około 15 mld USD w formie kredytów lub bezzwrotnych pożyczek. Większość tych środków otrzymała Europa Zachodnia ${ }^{11}$. Mimo pomocy, Stary Kontynent nadal borykał się z trudnościami finansowymi. Poważne braki odczuwała Wielka Brytania, która była najbardziej zadłużona w Stanach Zjednoczonych. Trudności płatnicze występowały też we Francji, Szwecji, Belgii i Holandii.

System z Bretton Woods oraz GATT stanowiły główne filary powojennego systemu gospodarczego świata zachodniego. Stany Zjednoczone były jego pomysłodawcą i wzięły odpowiedzialność za jego podtrzymywanie. Oczekiwały, że będzie przynosił korzyści także ich gospodarce.

\subsection{Stany Zjednoczone jako promotor integracji europejskiej. Znaczenie planu Marshalla}

Po II wojnie światowej w Europie odżyło zainteresowanie ideą ścisłej współpracy. Erupcja nacjonalizmów i okrucieństwa w okresie konfliktu światowego spowodowała, że konieczne stało się przewartościowanie stosunków między narodami europejskimi tak, by mogły one w sposób pokojowy żyć obok siebie. Ogromne straty wojenne oraz zagrożenie ze strony ZSRR przekonywało przywódców państw, że koordynacja wysiłków w celu odbudowy Europy była dobrym pomysłem.

19 września 1946 r. Churchill przemawiając w Zurychu wyraził opinię o konieczności konsolidacji Europy Zachodniej, nie zamykając jednak dostępu do tej wspólnoty żadnemu państwu europejskiemu. To wtedy z ust Churchilla padły słowa o potrzebie budowy Stanów Zjednoczonych Europy ${ }^{12}$. Również Konrad Adenauer, przewodniczący Unii Chrześcijańsko-Demokratycznej (CDU) w brytyjskiej strefie okupacyjnej na terenie Niemiec, wypowiadał się w 1946 r. za jednością europejską, stanowiącą drogę do odbudowy gospodarczej i szansę przeciwstawienia się

\footnotetext{
${ }^{11}$ Do połowy 1947 r. Wielka Brytania otrzymała 4,4 mld USD, Francja - 1,9 mld, Holandia ponad $400 \mathrm{mln}$, Grecja i Włochy - ponad $300 \mathrm{mln}$, Belgia - ponad $200 \mathrm{mln}$, Polska - $90 \mathrm{mln}$, Czechosłowacja - 72 mln, Węgry - 30 mln (J. S k o d la r s k i, R. M a te r a, op. cit., s. 207).

12 Tekst przemówienia Churchilla w Zurychu z 19 września 1946 r., [w:] Krew, znój, łzy i pot. Sławne mowy Winstona Churchilla, red. D. Cannadine, Poznań 2001, s. 232-235.
} 
zagrożeniu radzieckiemu, przedkładając ją nad dążenia do szybkiego utworzenia jednolitego państwa niemieckiego ${ }^{13}$.

Te wypowiedzi zostały podchwycone przez Amerykanów. Byli oni zaniepokojeni sytuacją gospodarczą i polityczną w Europie i widzieli potrzebę udzielenia jej wsparcia. Niekorzystnym zjawiskiem było duże poparcie dla partii komunistycznych w niektórych państwach zachodnich (we Francji, Belgii i we Włoszech) i wejście ich członków do rządów. Było to m.in. wynikiem złej sytuacji gospodarczej w Europie. W Stanach Zjednoczonych obawiano się, że wywrą one duży wpływ na kształtowanie polityki zagranicznej tych państw. Pamiętano również, że w okresie międzywojennym pożyczki zaciągnięte przez Europę stały się jedną z najpoważniejszych przyczyn napięć w stosunkach transatlantyckich. Najlepszym sposobem na uniknięcie powtórzenia takiego scenariusza było udzielenie krajom Starego Kontynentu pomocy bezzwrotnej. Do tego potrzebna była zgoda i zrozumienie społeczeństwa amerykańskiego. Już ogłoszenie doktryny Trumana ${ }^{14}$ uświadomiło Amerykanom konieczność zasadniczych zmian w polityce zagranicznej. Jednak należało przekonać ich, że pieniądze wysłane do Europy nie będą zmarnowane i będzie to dla Stanów Zjednoczonych opłacalna inwestycja. Ponieważ Amerykanie w większości postrzegali Stary Kontynent jako konglomerat państw o rozbieżnych interesach, co prowadziło do częstych konfliktów, ich integracja mogła być argumentem przełamującym ten stereotyp ${ }^{15}$.

Strategia amerykańska nie zakładała długofalowego wspierania Europy i zapewnienia jej bezpieczeństwa. Planowano zachęcanie państw do politycznej i ekonomicznej integracji. Dzięki temu miała powstać „trzecia siła”, zdolna do odparcia radzieckiej presji, współpracująca ze Stanami Zjednoczonymi, lecz niepotrzebująca ich bezpośredniego zaangażowania. Zwolennikiem takiej opcji był George Kennan, szef Wydziału Planowania Polityki Zagranicznej w Departamencie Stanu. Jego wizja "trzech światów” rywalizujących ze sobą wyglądała jednak inaczej niż było to w rzeczywistości. Pierwszy blok miały tworzyć Stany Zjednoczone, Kanada i Wielka

${ }^{13}$ Adenauer opowiadał się za zespoleniem przemysłów francuskiego, belgijskiego i niemieckiego już po I wojnie światowej. Uważał, że wspólne interesy gospodarcze są najlepszą gwarancją trwałego pokoju.

1412 marca 1947 r. Truman wygłosił w Kongresie przemówienie, w którym zawarł założenia długofalowej polityki zagranicznej. Zyskały one miano doktryny Trumana. Była to deklaracja Stanów Zjednoczonych o woli bronienia pokoju i wolności narodów, którym zagrażała ekspansywna polityka Związku Radzieckiego. Wprawdzie kraj ten nie został przez Trumana wymieniony wprost, ale interpretacja słów o „wspieraniu wolnych ludów, które opierają się próbom ujarzmienia przez uzbrojone mniejszości lub naciski z zewnątrz" była jednoznaczna (The Truman Doctrine, [w:] Makings of America: the U.S. and the World, vol. 2: Since 1865, ed. J. Miller, Darby 1993, s. 312-315. Zob. także: Great Issues in American History. From Reconstruction to the Present Day, 1864-1969, ed. R. Hofstadter, New York 1969, s. 411-415).

${ }^{15}$ M. H o g a n, The Marshall Plan. America, Britain, and the Reconstruction of Western Europe, 1947-1952, Cambridge 1989, s. 37. Zob także: M. T r a c h t e n b e r g, A Constructed Peace. The Making of the European Settlement 1945-1963, New Jersey 1999, s. 56-62. 
Brytania, w drugim przewidywał udział pozostałych krajów Europy Zachodniej. Te „dwa światy” stanowiły opozycję wobec ZSRR i jego satelitów ${ }^{16}$.

28 kwietnia 1947 r. George Marshall, sekretarz stanu w administracji Trumana, stwierdził, że przeciągające się rokowania z ZSRR na temat przyszłości Europy opóźniają jej odbudowę. Zapowiedział, że Stany Zjednoczone zamierzają podjąć bardziej zdecydowane działania. Marshall obawiał się, że Stalin podtrzymywał rozmowy w celu zyskania na czasie, a i tak ich zerwanie było nieuniknione. Wreszcie w czerwcu 1947 r., w przemówieniu wygłoszonym na Uniwersytecie Harvarda, wezwał kraje europejskie do podjęcia kroków prowadzących do efektywnej współpracy gospodarczej i zadeklarował gotowość Waszyngtonu do udzielenia potrzebnej pomocy w odbudowie gospodarki europejskiej.

Marshall, świadomy konieczności stworzenia ścisłych więzów transatlantyckich, wysuwał publicznie argumenty o charakterze stricte ekonomicznym. Podkreślał, że jego plan „nie jest wymierzony przeciwko jakiemukolwiek krajowi lub doktrynie, tylko przeciw głodowi, biedzie, desperacji i chaosowi"17. Początkowo Stany Zjednoczone nie wykluczały udzielenia pomocy również krajom Europy Środkowej i Wschodniej, które znalazły się w strefie wpływów ZSRR. Robert Gilpin twierdził nawet, że te plany wzbudziły podejrzenia ZSRR i doprowadziły do dalszego wzrostu napięcia zimnowojennego ${ }^{18}$.

Stany Zjednoczone pragnęły umieścić w założeniach polityki zagranicznej Europę jako całość, wolną od poważniejszych rozbieżności. Dodatkową zaletą takiej polityki było istnienie na Starym Kontynencie idei integracji, więc propozycje z zewnątrz nie byłyby uważane za próbę narzucenia przez Waszyngton gotowych rozwiązań. Amerykanom szczególnie zależało na zaakceptowaniu Niemców jako przyjaznych partnerów, a nie potencjalnych wrogów, których należy osłabić. Włączenie Niemiec w proces integracji zapewniłoby poczucie bezpieczeństwa krajom europejskim oraz nie ograniczałoby rozwoju gospodarczego tego państwa. W Departamencie Stanu zakładano, że odbudowa Europy byłaby utrudniona bez silnych Niemiec, które z kolei nie mogły zrekonstruować swojego potencjału w izolacji od innych krajów ${ }^{19}$.

Oprócz aspektu politycznego, dużą rolę odgrywał czynnik gospodarczy. Po II wojnie światowej Stany Zjednoczone dominowały w produkcji i w handlu światowym. Jednak do utrzymania prosperity potrzebowały partnerów. Rada Doradców Ekonomicznych (The Council of Economic Advisers) ${ }^{20}$ pod koniec 1947 r. przygoto-

${ }^{16}$ J. L. H a r p e r, American Visions of Europe. Franklin D. Roosevelt, George F. Kennan and Dean G. Acheson, Cambridge 1994, s. 214.

17 The Marshall Plan 1947, [w:] Documents on European Union, eds. A. G. Harryvan, J. Van der Harst, Houndmills 1997, s. 45. Zob. także: Great Issues in American History..., s. 416-419.

${ }^{18}$ R. G il p i n, op. cit., s. 412.

${ }^{19}$ Więcej informacji na temat amerykańskich motywów zob. G. Lundestad, The United States and Western Europe since 1945. From "Empire" by Invitation to Transatlantic Drift, Oxford 2003, s. 30-40.

${ }^{20}$ Rada Doradców Ekonomicznych, utworzona w 1946 r., jest agencją działającą w ramach Biura Wykonawczego (Executive Office) prezydenta USA. Jej zadaniem jest doradzanie prezydentowi $\mathrm{w}$ formułowaniu zarówno wewnętrznej, jak i zagranicznej polityki gospodarczej. 
wała raport, z którego wynikało, że eksport amerykański pozbawiony zakrojonego na szeroką skalę programu pomocowego może zmniejszyć się w kolejnym roku nawet o 40\%. Jednak Departament Stanu był zdecydowany kontrolować europejskie wydatki - Amerykanie mieliby zatwierdzać wszystkie projekty przedstawiane przez kraje korzystające z pomocy. Oznaczało to ogromne wpływy polityczne Waszyngtonu, a dla Europy konieczność akceptowania głębokiej ingerencji w jej wewnętrzne sprawy ${ }^{21}$.

Ceną, jaką musiała zapłacić Francja, była zgoda na połączenie jej strefy okupacyjnej z Bizonią, a w przyszłości - na powstanie państwa zachodnioniemieckiego ${ }^{22}$. Musiała również zrezygnować z planów kontroli Zagłębia Saary i Nadrenii. Jednak w Paryżu po długiej politycznej debacie uznano, że współpraca Francji ze Stanami Zjednoczonymi była jedynym sensownym wyjściem. Obiecywano sobie, że Francja przejmie przewodnictwo w tworzących się strukturach europejskich, co w przyszłości pozwoli jej i całej Europie uniezależnić się od amerykańskiej dominacji.

Do nowej sytuacji musiała także przywyknąć Wielka Brytania, która zrezygnowała z prób utrzymania przedwojennego imperium kolonialnego, koncentrując się w większym stopniu na współpracy z innymi krajami Starego Kontynentu. Rząd brytyjski zastrzegał jednak, że nie zgodzi się na pełną integrację gospodarczą z Europą właśnie ze względu na zobowiązania wobec terytoriów zamorskich (np. zapewniał, że nie zrezygnuje z funta sterlinga). Dyplomacja amerykańska bezskutecznie próbowała w latach 50. przekonać Wielką Brytanię do zaangażowania się w proces integracji europejskiej. Jej stanowisko trafnie oddają słowa Churchilla z $1952 \mathrm{r}$.: „Kocham Francję i Belgię, ale nie powinniśmy być zredukowani do ich poziomu”23.

Za warunek konieczny do udzielenia pomocy Amerykanie uznali stworzenie przez państwa europejskie wspólnego planu jej zagospodarowania. W czerwcu i lipcu 1947 r. obradowała w Paryżu Konferencja Ministrów Spraw Zagranicznych Wielkiej Brytanii, Francji i ZSRR, na której miano ustosunkować się do planu Marshalla. Minister spraw zagranicznych Wielkiej Brytanii - Ernest Bevin i Francji

${ }^{21}$ Dlatego nieufność wobec planu Marshalla wyrażały np. lewica niemiecka i włoska, nazywając go „ekonomicznym narzędziem doktryny Trumana” (R. J. B a r n e t, The Alliance. America, Europe, Japan. Makers of the Postwar World, New York 1983, s. 116).

${ }^{22}$ Na konferencji w Poczdamie (17 lipca - 2 sierpnia 1945 r.) postanowiono podzielić Niemcy na cztery strefy okupacyjne: amerykańską, brytyjską, radziecką i francuską. Wyznaczono ponadto cztery sektory okupacyjne w Berlinie, który znajdował się w strefie radzieckiej. Na skutek narastających rozbieżności między Wschodem a Zachodem, 1 stycznia 1947 r. powstała Bizonia, łącząca strefę amerykańską z brytyjską. W listopadzie 1947 r. Stany Zjednoczone, Wielka Brytania i Francja zgodziły się na przyszłe zjednoczenie ich stref. Dało to początek Republice Federalnej Niemiec - 8 maja 1949 r. Rada Parlamentarna uchwaliła ustawę zasadniczą RFN. Równolegle, w radzieckiej strefie okupacyjnej, powstawały struktury państwa wschodnioniemieckiego. 7 października 1949 r. ogłoszono powstanie Niemieckiej Republiki Demokratycznej (E. C z i o m e r, Zarys historii Niemiec powojennych 19451995, Warszawa 1997, s. 3-57).

${ }^{23}$ Cyt. za: A. G r o s s e r, Les Occidentaux. Les pays d'Europe et les États-Unis depuis la guerre, Paris 1978, s. 156. 
- Georges Bidault, przychylili się do propozycji Marshalla dotyczącej utworzenia wspólnej organizacji gospodarczej i jednolitego planu odbudowy. Natomiast szef dyplomacji ZSRR - Wiaczesław Mołotow, odrzucił amerykańską pomoc twierdząc, że jej warunki zagrażają suwerenności przyjmujących ją krajów. Wkrótce do takiego samego kroku zostały zmuszone państwa znajdujące się w orbicie wpływów wschodniego mocarstwa. Natomiast przedstawiciele państw gotowych wziąć udział w planie Marshalla spotkali się na trwającej od 12 lipca do 22 września 1947 r. konferencji w Paryżu²4. Wynikiem obrad było utworzenie w kwietniu 1948 r. Organizacji Europejskiej Współpracy Gospodarczej (Organization for European Economic Cooperation - OEEC), w której skład weszło 16 państw ${ }^{25}$.

W ramach Planu Odbudowy Europy (European Recovery Programme) - taką nazwę oficjalnie nosił plan Marshalla - w latach 1948-1951 rozdysponowana została kwota 13,5 mld USD. Największą pomoc uzyskały Wielka Brytania (3,2 mld USD) i Francja (2,7 mld), a następnie Włochy (1,5 mld), RFN (1,4 mld), Holandia (1 mld), Grecja i Austria (po $700 \mathrm{mln}$ ). Pomoc amerykańska w ramach planu Marshalla stanowiła w niektórych krajach od 5\% do ponad 8\% ich dochodu narodowego. Pieniądze przeznaczone były na zakup produktów przemysłowych (za ponad 6 mld USD), ale też żywności i artykułów rolnych (za 5,5 mld) ${ }^{26}$.

\section{Wykres 2.1. Roczne stopy wzrostu PKB per capita wybranych krajów kapitalistycznych}

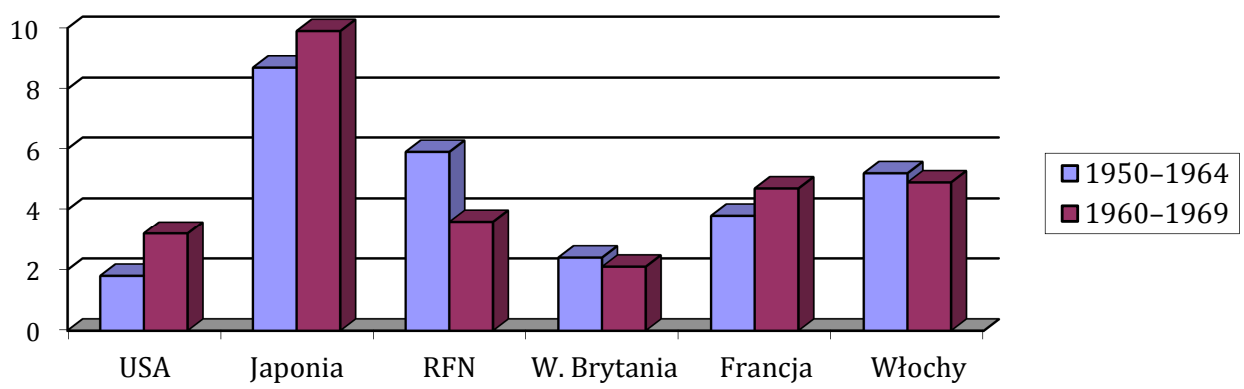

Źródło: V. Pe r lo, Unstable Economy: Booms and Recessions in the United States since 1945, London 1973, s. 193.

${ }^{24} \mathrm{Na}$ konferencji paryskiej były reprezentowane: Austria, Belgia, Dania, Francja, Grecja, Holandia, Irlandia, Islandia, Luksemburg, Norwegia, Portugalia, Szwajcaria, Szwecja, Turcja, Wielka Brytania i Włochy.

${ }^{25}$ W 1949 r. do OEEC przyjęto Republikę Federalną Niemiec, w 1955 r. jej członkiem została Jugosławia, a w 1958 r. Hiszpania (M. J. H o g a n, Blueprint for Recovery. The Fiftieth Anniversary of the Marshall Plan, „American Studies Journal”, Summer 1998, s. 14).

${ }^{26}$ D. H. Ald croft, The European Economy 1914-1990, London 1993, s. 118. Dokładne wyliczenia wykorzystania planu Marshalla przedstawia Michael Hogan. Według niego finansowa pomoc USA przeznaczona była głównie na import paliwa (1,5 mld USD), żywności i nawozów (3,2 mld USD), surowców i półproduktów (3,4 mld USD) oraz maszyn, sprzętu i pojazdów (1,8 mld USD). Zob. więcej: M. H o g a n, The Marshall Plan..., s. 41. 
Większość państw Europy Zachodniej odnotowała wzrost gospodarczy. Jego skalę (per capita) przedstawiono na wykresie 2.1. W latach 1946-1950 poziom wzrostu produkcji przemysłowej w Europie Zachodniej przekroczył o 50\% produkcję sprzed wojny ${ }^{27}$. Plan Marshalla spełnił swoje zadanie uczynienia z krajów Europy Zachodniej stabilnego partnera gospodarczego Stanów Zjednoczonych. Poprawa sytuacji ekonomicznej zmniejszała również popularność partii komunistycznych.

Ścisłe związki transatlantyckie zostały przypieczętowane utworzeniem 4 kwietnia 1949 r. Organizacji Paktu Północnoatlantyckiego (North Atlantic Treaty Organization - NATO ${ }^{28}$. Sojusz obronny o wyraźnym ostrzu antykomunistycznym połączył USA ze Starym Kontynentem, przełamując ostatnie izolacjonistyczne tabu - zobowiązanie się do obrony Europy i potraktowanie jej jako równoprawnego sojusznika. Państwa Starego Kontynentu osiągnęły cel, o który walczyły od czasów I wojny światowej - zdobyły amerykańskie gwarancje bezpieczeństwa. Wraz ze wstąpieniem do NATO niektórych państw, Europa mogła się skoncentrować na umacnianiu pozycji gospodarczej, w ramach coraz bardziej współzależnego systemu gospodarki światowej. Kolejne rundy GATT pozwoliły na ekspansję handlową, dolar stał się podstawą międzynarodowego systemu monetarnego, a międzynarodowe korporacje uzyskały korzystne warunki dla swojej działalności ${ }^{29}$. Jednak Stany Zjednoczone również skorzystały na zawarciu sojuszu: nie tylko otrzymały cenne bazy wojskowe w Europie, lecz także uzyskały duży wpływ na politykę wewnętrzną sojuszników.

\subsection{Koncepcje współpracy transatlantyckiej}

Po zakończeniu II wojny światowej pojawiły się postulaty umocnienia współpracy między Stanami Zjednoczonymi a Europą. Poza organizacjami już istniejącymi, sugerowano stworzenie dodatkowych struktur. Wśród koncepcji ich ustanowienia wyróżniał się atlantyzm (Atlanticism). Był definiowany przede wszystkim jako szczególne partnerstwo brytyjsko-amerykańskie i szerzej - współpraca Europy Zachodniej i Ameryki Północnej w ramach NATO. Jednak w najpowszechniejszym rozumieniu oznaczał postrzeganie Europy jako części „Zachodu” uznawanego za jedność o charakterze kulturowym, politycznym, militarnym, a także ekonomicznym (miały to być najbardziej uprzemysłowione demokracje świata).

U podstaw koncepcji atlantyzmu leżało założenie o zależności Europy od sojuszu ze Stanami Zjednoczonymi. Jej zwolennicy twierdzili, że tylko w taki sposób

\footnotetext{
${ }^{27}$ J. S k o d la r s ki, R. M a te r a, op. cit., s. 222.

${ }^{28}$ Jej członkami zostały: Belgia, Dania, Francja, Holandia, Islandia, Kanada, Luksemburg, Norwegia, Portugalia, Stany Zjednoczone, Wielka Brytania i Włochy.

${ }^{29}$ R. G i l p i n, op. cit., s. 412 . W 1949 r. odbyła się runda GATT w Annency, w 1951 r. - w Torquay, w latach 1955-1956 w Genewie, a latach 1960-1962 negocjowano obniżki kolejnych taryf celnych w ramach rundy Dillona.
} 
kraje Starego Kontynentu mogły angażować się w politykę światową. To podejście było oparte na przekonaniu, że państwa są potencjalnie agresywne wobec siebie, dlatego należy stworzyć instytucje koordynujące ich relacje, takie jak pakty bezpieczeństwa, sojusze i organizacje międzynarodowe. Europa nie mogła funkcjonować w odosobnieniu, ale tylko w ramach większego systemu. Na tej bazie wyodrębniły się trzy koncepcje atlantyzmu: unia federalna, konfederacja i partnerstwo.

Pierwszy raz stworzenie transatlantyckiej unii federalnej zaproponował Clarence Streit w pracy Union Now. A Proposal for a Federal Union of the Democracies of the North Atlantic („Unia teraz. Propozycja unii federalnej dla demokracji północnoatlantyckich") wydanej w 1939 r. Z nieskuteczności działania Ligi Narodów autor wyciągnął wniosek, że przyczyną było złe zarządzanie tą strukturą. Miał na myśli fakt, że nie posiadała ona centralnych organów władzy, opartych na realnej sile największych mocarstw światowych, które mogłyby działać w imieniu wszystkich krajów członkowskich. Udowadniał, że brak koordynacji politycznej i ekonomicznej państw w okresie międzywojennym spowodował niemożność zapobieżenia wybuchowi II wojny światowej. Autor uznawał za jedyny sposób uniknięcia konfliktów w przyszłości powstanie unii narodów atlantyckich (Union of Atlantic Nations), czyli ukonstytuowanie się zgromadzenia reprezentantów członków sojuszu atlantyckiego. Zauważał również trudności, np. niechęć narodów do obrony innych państw, szczególnie leżących daleko od ich granic. Receptą na takie podejście była unia polityczna i militarna. „Jest różnica między Ligą, która spodziewa się, że amerykańskie wojska przybędą do Europy by bronić Francji, podczas gdy Francja prowadzi własną politykę zagraniczną, a Unią, w której Amerykanin, Francuz, Anglik czy Holender będzie miał równy głos w kształtowaniu polityki zagranicznej tej organizacji. Nie będzie francuskiego, amerykańskiego, brytyjskiego czy holenderskiego terytorium i polityki, tylko unijne" - przekonywał Streit ${ }^{30}$.

Autor postulował uporządkowanie współpracy gospodarczej, która mogła być najtrudniejsza dla narodów po obu stronach Atlantyku. Wynikało to z faktu, że produkcja i handel nie były w rękach państwa, ale jednostek i korporacji. Niebezpieczne były też inklinacje rządów, by produkcję i handel uczynić bronią stanowiącą narzędzie nacisku na inne kraje. Ponieważ, zdaniem Streita, relacje gospodarcze były szczególnie konfliktogenne, za kluczowe uważał dążenie do „ekonomicznego rozbrojenia", do którego może doprowadzić tylko powstanie Unii. Nawet znoszenie barier handlowych nie gwarantuje, że któryś kraj nie wycofa się w pewnym momencie z układów, broniąc swego narodowego interesu. Podobnie było w przypadku kwestii monetarnych, gdyż narodowe waluty były również bronią w rękach państw. „Deprecjacja walut spada niczym deszcz - na biednych i bogatych"31, burzy zaufanie w stosunkach międzynarodowych, a rządy często stosują manipulację, by pobudzić

${ }^{30}$ C. K. Streit, Union Now. A Proposal for a Federal Union of the Democracies of the North Atlantic, New York 1939, s. 144.

${ }^{31}$ Ibidem, s. 146. 
swój eksport. Prowadzi to do deflacji i bezowocnych debat, czy najpierw redukować cła czy ustanowić stabilizację monetarną. Zdaniem autora, problemu tego nie da się rozwiązać, dopóki najbogatsze demokracje dbają tylko o interes narodowy. Dlatego kwestie te powinien koordynować jeden rząd Unii, mający miażdżącą przewagę w gospodarce światowej, z jednym budżetem i jedną rezerwą złota. Jeśli wykreuje wspólną walutę, będzie jej używał cały świat, co ustabilizuje globalną gospodarkę i ułatwi kontakty handlowe. Wyłoni się więc hegemon, który nie będzie używał władzy do uzyskania dominacji i wykorzystywania innych narodów, ale do pobudzania pokojowej współpracy, co zmniejszy, a nawet wyeliminuje niebezpieczeństwo wybuchu światowego konfliktu ${ }^{32}$. Koncepcja ta zyskała zainteresowanie Departamentu Stanu, jednak nie wzbudziła entuzjazmu w państwach europejskich, które bały się podporządkowania silniejszemu sojusznikowi. Przeciwstawiano jej europeizm (Europeanism) zakładający, że najpierw musi się dokonać silna integracja Europy, by można było ustanowić ściślejsze związki ze Stanami Zjednoczonymi ${ }^{33}$.

Koncepcja konfederacji atlantyckiej (Atlantic Confederation) zakładała oddanie na pewnych polach części suwerenności na rzecz wspólnego interesu. W konfederacji miały brać udział państwa należące do NATO. W ciągu paru lat po powstaniu Sojuszu w krajach członkowskich powstawały organizacje, których celem było przekonanie opinii publicznej o konieczności utworzenia instytucji umacniającej wspólną obronę i pokój. Organizacje te formalnie zjednoczyły się w 1954 r. tworząc Towarzystwo Paktu Atlantyckiego (Atlantic Treaty Association). W $1961 \mathrm{r}$. byli sekretarze stanu - Dean Acheson i Christian Herter - wyszli z inicjatywą konsolidacji grup popierających sojusz atlantycki i stworzenia Rady Atlantyckiej Stanów Zjednoczonych (Atlantic Council of the United States). Organizacja ta, działająca także współcześnie, miała na celu promowanie przywództwa Stanów Zjednoczonych w kształtowaniu stosunków międzynarodowych, opartego na Wspólnocie Atlantyckiej. W latach 60 . XX w. Rada wydała wiele oświadczeń na temat postrzegania przez opinię publiczną państw członkowskich Sojuszu i działania w celu propagowania konieczności angażowania się w sprawy międzynarodowe poprzez reklamy telewizyjne, artykuły w czasopismach akademickich i broszury. Wydano też wiele książek: pierwsza ukazała się w 1967 r. i była zatytułowana „Budowanie rynku amerykańsko-europejskiego: plan na lata 70. XX wieku" (Building the American-European Market: Planning for the $1970 s)^{34}$. Rada dostrzegała w pełni ogromny wpływ współpracy gospodarczej na pozostałe aspekty relacji transatlantyckich.

Konferencja Parlamentarzystów NATO obradująca w Paryżu w styczniu 1962 r. wydała deklarację, że należy dołożyć starań, by „powstała prawdziwa Wspólnota

${ }^{32}$ Ibidem, s. 144-146, 219-240.

${ }^{33}$ R. L. P f a l t z g r a f f, The Atlantic Community - A Conceptual History, [w:] Atlantic Community in Crisis. A Redefinition of the Transatlantic Relationship, eds. W. F. Hahn, R. L. Pfaltzgraff, New York 1979, s. 4.

${ }^{34}$ Informacja dostępna przez: http: www.acus.org. 
Atlantycka podejmująca współpracę nie tylko militarną, ale rozszerzająca ją na obszary polityczne, moralne i kulturalne" ${ }^{\prime 35}$. W deklaracji dopuszczono instytucjonalizację takiej współpracy w postaci Wysokiej Rady. Największym przeciwnikiem takiego rozwiązania był prezydent Francji - Charles de Gaulle. Sprzeciw ten podtrzymywali jego następcy. Zresztą także w innych krajach europejskich nie brakowało zwolenników prymatu integracji, „Europy europejskiej” i podejrzliwości wobec zamiarów Stanów Zjednoczonych ${ }^{36}$.

Trzecia koncepcja to partnerstwo atlantyckie (Atlantic Partnership) ${ }^{37}$. Głównym jej założeniem był postulat, by zjednoczona Europa koordynowała działania z USA. Dotyczyło to zwłaszcza polityki zagranicznej i jej dwóch współzależnych wymiarów - politycznego i gospodarczego. Potrzeba zinstytucjonalizowania partnerstwa została dostrzeżona, gdy w sojuszu zaczęły narastać nieporozumienia grożące jego spójności. Motto tej koncepcji, „dwa filary - wspólny cel”, miało przekonać Europejczyków do większej skuteczności skoordynowanych działań. Ewentualna instytucja partnerstwa nie miała mieć struktury multilateralnej, u jej podstaw leżały dwustronne konsultacje na linii Stany Zjednoczone - EWG. Główną przeszkodą w realizacji tego pomysłu był brak wspólnej europejskiej polityki zagranicznej ${ }^{38}$.

Plan Marshalla stanowił impuls do zjednoczenia europejskiego, ale bezpośrednia inicjatywa powołania Wspólnot Europejskich wychodziła od mieszkańców Starego Kontynentu. Wśród ojców integracji nie brakowało osobistości, które nie wyobrażały sobie istnienia nowych instytucji bez amerykańskiego wsparcia. Po II wojnie światowej rodzina europejska miała stać się częścią szerszej wspólnoty atlantyckiej. Taką wizję promował m.in. francuski polityk Jean Monnet. Mówił, że dążenie do jedności Europy może rozwijać współpracę z USA na podstawie względnej równowagi. Monnet pragnął bliższych stosunków ze Stanami Zjednoczonymi, nie tylko ze względu na podziw, jaki żywił dla tego kraju, ale także z obawy, iż rozluźnienie związków transatlantyckich mogłoby skłonić Waszyngton do zbliżenia politycznego do Moskwy z pominięciem interesów Starego Kontynentu ${ }^{39}$.

Wielkim orędownikiem zjednoczenia europejskiego $\mathrm{w}$ ramach ścisłego sojuszu ze Stanami Zjednoczonymi był kanclerz RFN Konrad Adenauer. Zwracał uwagę,

${ }^{35}$ R. L. P fal t z g r a ff, op. cit., s. 8.

${ }^{36}$ Ibidem.

${ }^{37}$ Po raz pierwszy partnerstwo atlantyckie zaproponował John F. Kennedy w tzw. Grand Design (więcej na ten temat w podrozdziale 2.5). Do tej koncepcji odwoływał się także prezydent Richard Nixon i jego doradca do spraw bezpieczeństwa narodowego Henry Kissinger, ogłaszając w 1973 r. propozycję „Nowej Karty Atlantyckiej”. Więcej informacji na ten temat znajduje się w rozdziale VI niniejszej pracy.

${ }^{38}$ R. L. P f a l t z g r a ff, op. cit., s. 8.

${ }^{39}$ Kierując w okresie II wojny światowej francusko-brytyjskim komitetem ds. zbrojeń, Monnet nawiązał przyjazne stosunki z politykami ze Stanów Zjednoczonych. Promował wtedy wizję Ameryki jako „wielkiego arsenału demokracji” (J. Łu kas z e w s ki, Cel: Europa. Dziewięć esejów o budowniczych jedności europejskiej, Warszawa 2002, s. 97). 
że położenie Europy między dwoma supermocarstwami - USA i ZSRR - sprawia, że musi się ona zjednoczyć po to, by odzyskać znaczenie gospodarcze i kulturowe oraz współdecydować w polityce światowej i zapewnić dobrobyt mieszkańcom. Adenauer mówil, że Europa nie będzie mogła w nieskończoność liczyć w każdej sprawie na Waszyngton. „Narody europejskie muszą przypomnieć sobie własną siłę i własną odpowiedzialność, choćby dlatego, iż nie można wymagać od Stanów Zjednoczonych, aby we własnej polityce myślały zwłaszcza o interesach europejski$\mathrm{ch}^{\prime 4}{ }^{4}$. Polityk zachodnioniemiecki nie negował wartości dotychczasowego amerykańskiego zaangażowania. Szczególnie cenił włączenie RFN do planu Marshalla i odbudowę gospodarki poprzez zastrzyk inwestycyjny. Przypominał, że to Waszyngton pierwszy przestał traktować przegrane Niemcy jako wroga. Nie powinny dziwić przyjazne stosunki między Adenauerem a politykami amerykańskimi, szczególnie z prezydentem Dwightem Eisenhowerem i sekretarzami stanu Deanem Achesonem i Johnem Fosterem Dullesem, który najmocniej z nich wspierał ideę jedności europejskiej.

\subsection{Postępy integracji europejskiej - wpływ na relacje trans- atlantyckie}

Wysiłki dyplomatyczne kluczowych polityków europejskich oraz życzliwość dyplomatów amerykańskich sprawiły, że od początku lat 50. XX w. realizacja wspólnego rynku nabierała coraz bardziej realnych kształtów. Amerykańscy doradcy odegrali ważną, choć nieformalną rolę w prowadzonych negocjacjach, promując zawarcie układów według zasad wolnego handlu. Po sukcesie, jakim było powołanie Europejskiej Wspólnoty Węgla i Stali - EWWiS (European Coal and Steal Community) w 1951 r., w kolejnych latach kraje założycielskie promowały koncepcję zintegrowania wszystkich działów gospodarki. Po konferencjach w Messynie (1955 r.) i Wenecji (1956 r.) sześć państw: Belgia, Holandia, Luksemburg, RFN, Francja i Włochy, zaakceptowało raport belgijskiego ministra spraw zagranicznych Paul-Henri Spaaka i ratyfikowała Traktaty Rzymskie, ogłoszone 25 marca 1957 r. Ustanawiały one Europejską Wspólnotę Gospodarczą - EWG (European Economic Community) oraz Europejską Wspólnotę Energii Atomowej - EURATOM (European Atomic Energy Community). Naczelnym celem Wspólnot miał być harmonijny i zrównoważony rozwój gospodarczy, podniesienie stopy życiowej oraz wspólna polityka gospodarcza, prowadząca w przyszłości do czterech wolności: swobodnego przepływu towarów, usług, kapitału i pracy.

Reakcja dyplomacji amerykańskiej na tak śmiałe polityczno-gospodarcze przedsięwzięcie była nadzwyczaj pozytywna. Waszyngton popierał powstanie

\footnotetext{
${ }^{40}$ Cyt. za: ibidem, s. 160-161.
} 
EWG, gdyż jej cele zgadzały się z założeniami liberalizmu. Zwiększanie wydajności kapitalistycznej gospodarki wraz ze wspieraniem przedsiębiorczości przez państwo przybliżało nowy system europejski do amerykańskiego rozumienia wolności ekonomicznej. Obserwując wydarzenia w Europie, Amerykanie mieli nadzieję, że stabilna i rozwijająca się w szybkim tempie Europa Zachodnia weźmie większą odpowiedzialność za obronę swojego terytorium, nie licząc wyłącznie na NATO. Z drugiej strony, wzmocnione państwa europejskie mogły zrezygnować z udziału w zimnej wojnie, będąc „trzecią siłą” niezaangażowaną w konflikt. Niepokój Waszyngtonu wzbudzała intensyfikacja handlu tych krajów ze Związkiem Radzieckim. Tylko w latach 1960-1961 RFN, Francja i Włochy wysłały do ZSRR towary i sprzęt warte miliard dolarów.

Po ogłoszeniu Traktatów Rzymskich kraje Europy Zachodniej, które nie weszły do EWG, zaczęły obawiać się skutków wspólnej polityki handlowej oraz unii celnej sześciu państw tworzących to ugrupowanie. Alternatywną koncepcję zgłosiła Wielka Brytania. W przeciwieństwie do EWG, jej projekt nie przewidywał powstania wspólnych organów. Konwencja Sztokholmska ogłoszona w 1959 r. ustanawiała Europejskie Stowarzyszenie Wolnego Handlu (European Free Trade Association EFTA), w którego, skład oprócz Wielkiej Brytanii, weszły: Austria, Dania, Norwegia, Portugalia, Szwecja i Szwajcaria. Powstanie dwóch ugrupowań gospodarczych nie oznaczało bynajmniej rywalizacji między krajami Europy Zachodniej. W latach 60 . widać było dążenie do współpracy tych dwóch organizacji, chociaż ich większemu zbliżeniu przeszkadzał niechętny rozszerzaniu EWG o nowe kraje prezydent Francji Charles de Gaulle ${ }^{41}$. EWG w latach 60 ., stając się najważniejszą organizacją tej części kontynentu, stawiała sobie obok celów gospodarczych także dalekosiężne cele polityczne. Amerykanie sceptycznie odnosili się do możliwości zjednoczenia Europy pod względem politycznym. Brali pod uwagę nie tylko silne poczucie odrębności poszczególnych narodów i ich słabość militarną, lecz także brak konkretnej wizji zjednoczonej Europy w roli mocarstwa na arenie międzynarodowej ${ }^{42}$.

\subsection{Stany Zjednoczone wobec perspektywy przystąpienia Wielkiej Brytanii do EWG}

W latach 60. ujawniały się różnice interesów, przede wszystkim związane z umocnieniem gospodarczym zachodu Starego Kontynentu, który zaczął konkurować ze Stanami Zjednoczonymi. Amerykanie wciąż jednak przychylnie patrzyli

\footnotetext{
${ }^{41}$ R. J. B a r n e t, op. cit., s. 193.

42 Jako dowód na niemożność sformułowania przez Europę Zachodnią wspólnej polityki zagranicznej, przytaczano fiasko projektu Europejskiej Wspólnoty Obronnej, a także niepowodzenia de Gaulle'a w wypracowaniu z RFN jednolitego stanowiska wobec USA (więcej na ten temat: P. M a te ra, R. M a te r a, op. cit., s. 206, 229).
} 
na perspektywę zjednoczonej Europy. Szczególnie pożądane z ich punktu widzenia było dążenie do ściślejszej integracji politycznej. Stany Zjednoczone wolałyby negocjować z Europą Zachodnią niż starać się o uzyskanie poparcia poszczególnych państw w najważniejszych sprawach polityki światowej ${ }^{43}$. Natomiast Brytyjczycy mogli się obawiać, że zjednoczona politycznie, kształtująca własną siłę militarną Europa jeszcze zmniejszy ich wpływy na świecie. Stanie się też atrakcyjniejszym partnerem dla Stanów Zjednoczonych, co położy kres „specjalnym stosunkom” brytyjsko-amerykańskim ${ }^{44}$. Prezydent USA, John F. Kennedy, na spotkaniach z premierem Wielkiej Brytanii, Haroldem Macmillanem mówił wprost, że wprawdzie łączą ich specjalne stosunki, ale są one ważniejsze dla Wielkiej Brytanii niż dla Stanów Zjednoczonych, więc Brytyjczycy powinni ściślej związać się z Europą ${ }^{45}$.

Pogłębiająca się integracja, a także dynamiczny rozwój gospodarczy poszczególnych państw europejskich nieuchronnie prowadziły do prób zmniejszenia zależności od Stanów Zjednoczonych. Z mocarstw europejskich Wielka Brytania była z pewnością najbardziej przychylna utrzymywaniu silnych więzów z USA. Podobne stanowisko zajmowała RFN ze względu na zagrożenie bezpieczeństwa ze strony ZSRR. Natomiast de Gaulle, prezydent Francji od 1958 r., dążył do ustanowienia bardziej partnerskich stosunków między Stanami Zjednoczonymi a krajami Europy Zachodniej. Próbował stworzyć europejską przeciwwagę dla dominacji amerykańskiej w sojuszu państw zachodnich. Wielka Brytania nie była jednak brana pod uwagę jako uczestnik tego planu, ponieważ de Gaulle postrzegał jej bliską więź ze Stanami Zjednoczonymi jako przeważającą przywiązanie do spraw Starego Kontynentu.

Na początku lat 60. pojawiły się przesłanki mogące zmotywować Londyn do starań o integrację ze Wspólnotami Europejskimi. Gospodarka brytyjska borykała się z licznymi problemami: spadkiem konkurencyjności, rosnącym deficytem bilansu płatniczego, zadłużeniem i trudnościami z utrzymaniem pozycji funta szterlinga - międzynarodowej waluty rezerwowej. Zajmowała wprawdzie piąte miejsce wśród najsilniejszych gospodarek świata, jednak wyprzedzały ją kraje należące do EWG: RFN (trzecie miejsce) i Francja (czwarte miejsce) ${ }^{46}$. W 1961 r. po raz pierwszy wartość eksportu brytyjskiego do Commonwealthu była mniejsza niż do krajów europejskich ${ }^{47}$. Eksperci twierdzili, że przynależność Wielkiej Brytanii do EWG znacznie podniosłaby jej pozycję gospodarczą, a także skuteczność całej organizacji ${ }^{48}$.

\footnotetext{
${ }^{43}$ A. B u c h a i i, Partners and Allies, „Foreign Affairs”, July 1963, s. 622.

${ }^{44} \mathrm{~S} . \mathrm{W}$ a r d, Kennedy, Britain, and the European Community, [w:] John F. Kennedy and Europe, eds. D. Brinkley, R. T. Griffiths, Baton Rouge 1999, s. 319.

${ }^{45}$ A. P. D o b s o n, Anglo-American Relations in the Twentieth Century. Of Friendship, Conflict and the Rise and Decline of Superpowers, London 1995, s. 126.

${ }^{46}$ P. D u i g n a n, L. H. G a n n, The United States and the New Europe 1945-1993, Oxford 1994, s. 67.

${ }^{47}$ G. Lu ndestad, "Empire" by Integration. The United States and European Integration, 1945-1997, New York 1998, s. 63.

${ }^{48}$ R. H. S. C r o s s m a n, British Labor Looks at Europe, „Foreign Affairs”, July 1963, s. 735.
} 
Staraniom brytyjskim z uwagą przyglądano się w Stanach Zjednoczonych. W dniach 1-2 czerwca 1961 r. Kennedy przebywał w Europie z wizytą, podczas której rozmawiał z francuskim prezydentem na temat możliwości przyjęcia Wielkiej Brytanii do EWG. Relacjonując wyniki tych rozmów Macmillanowi 5 czerwca w Londynie stwierdził, że starał się unikać wywierania jakiejkolwiek presji na de Gaulle’a, który sprawiał wrażenie, że jest przeciwny członkostwu Wielkiej Brytanii. Stwierdził, że ma ona jeszcze dużo problemów wewnętrznych, które powinna rozwiązać przed wstąpieniem do $\mathrm{EWG}^{49}$. Kennedy zachęcał Macmillana do podjęcia kroków w tym kierunku. Wyraził nadzieję, że to zmieni charakter Wspólnot - wzmocni je politycznie, spowoduje odejście od protekcjonizmu i większe otwarcie na kontakty gospodarcze z USA - Kennedy wspomniał nawet o możliwości podpisania transatlantyckiej umowy o wolnym handlu ${ }^{50}$. Poza tym w Waszyngtonie przewidywano, że obecność Wielkiej Brytanii zniweczy pomysł de Gaulle’a o stworzeniu "trzeciej siły” w świecie, co mogło doprowadzić do europejskich prób ułożenia na własną rękę stosunków z ZSRR, a tym samym osłabienia sojuszu atlantyckiego. Bardzo istotną kwestią był stosunek Wielkiej Brytanii do polityki handlowej. Ze wzglądu na powiązania z krajami EFTA i Commonwealthu w jej interesie było większe otwarcie się Wspólnot na zewnętrzne kontakty gospodarcze $\mathrm{e}^{51}$.

Mimo rosnącej konkurencji na rynkach światowych ze strony odradzającej się gospodarczo Europy Zachodniej, Kennedy wciąż zdecydowanie popierał jej dalszą integrację ${ }^{52}$. Choć jego doradca, wybitny ekonomista John Kenneth Galbraith przekonywał, że Stany Zjednoczone nie powinny wspierać bloku z tak wysokimi cłami jak EWG, prezydent podkreślał, że muszą to robić z powodów politycznych. George Ball, specjalista do spraw europejskich w Departamencie Stanu przyznawał, że istniał efekt dyskryminacyjny dla amerykańskich towarów, gdyż kraje EWG łączyła unia celna. Z drugiej strony przekonywał, że integracja powoduje polepszenie się sytuacji gospodarczej w Europie Zachodniej. W efekcie zwiększa się import z USA, co rekompensuje straty na cłach. Udowadniał także, że przedsiębiorstwa amerykańskie, już obecne na rynkach europejskich, były zadowolone z integracji ułatwiającej im robienie interesów. Jednak Ball zwracał również uwagę na artykułowane w prasie niepokoje w Stanach Zjednoczonych, na tle polityki rolnej EWG i dyskryminujących amerykański import umów z krajami trzecimi ${ }^{53}$.

${ }^{49}$ E. R. M a h a n, Kennedy, de Gaulle, and Western Europe, Gordonsville 2003, s. 98.

${ }^{50}$ A. P. D o b s o n, op. cit., s. 126.

${ }^{51}$ L. G e l b e r, A Marriage of Inconvenience, „Foreign Affairs”, January 1963, s. 321.

${ }^{52}$ Foreign Relations of the United States (FRUS), 1961-1963, vol. 13: Western Europe and Canada, memorandum z rozmowy Kennedy'ego z Adenauerem, 24 marca 1961, Washington D.C. 1994, dostępne także przez: http://history.state.gov/historicaldocuments/frus1961-63v13. Por. P. W i n a n d, Eisenhower, Kennedy, and the United States of Europe, Houndmills 1993, s. 166.

53 G. Lundestad, "Empire" by Integration..., s. 91-92. Por. S. Ward, op. cit., s. 326. Na temat wątpliwości amerykańskich dotyczących popierania rozszerzania EWG zob. także: A. Dür, Protection for Exporters: Power and Discrimination in Transatlantic Relations, 1930-2010, Ithaca 2010, s. 133-136. 
Proces tworzenia unii celnej EWG, a w jej ramach wspólnej taryfy celnej dla państw trzecich, powodował protesty Amerykanów. Podczas rund negocjacyjnych GATT (Dillona i Kennedy'ego) sprzeciwiali się jej powstaniu, uważając je za sprzeczne z regułami wolnego handlu promowanymi przez tę instytucję $e^{54}$. Waszyngton postulował, aby po „okresie ochronnym”, czyli rekonstrukcji gospodarki Starego Kontynentu po zniszczeniach wojennych, integrowała się ona z amerykańską, a nie zamykała się $\mathrm{w}$ formie protekcjonistycznego bloku handlowego. Najwięcej kontrowersji wzbudzała w USA Wspólna Polityka Rolna (Common Agriculture Policy - CAP) ze względu na duży udział w eksporcie artykułów rolnych (w 1958 r. stanowiły one $1 / 3$ amerykańskiego eksportu). W Kongresie istniało też silne lobby farmerskie. Jednak przedstawiciele amerykańskiej administracji tylko nieformalnie wyrażali zaniepokojenie w tej kwestii w kontekście przystąpienia Wielkiej Brytanii do EWG. Amerykanie obawiali się utrzymania preferencyjnych warunków handlu brytyjskiego z Commonwealthem i ich przyjęcia przez pozostałe kraje EWG. Jednak i w tej kwestii przewidziano kompromisowe rozwiązanie - planowano szeroką redukcję ceł podczas trwającej w Genewie rundy negocjacyjnej GATT ${ }^{55}$.

W 1962 r. weszła w życie nowa ustawa handlowa (Trade Expansion Act), która określała zakres kompetencji prezydenta podczas negocjacji w sprawie redukcji ceł. Szczególnie duże uprawnienia zyskiwał w przypadku, gdy partnerzy pokrywali zapotrzebowanie rynku światowego na dany towar w 80\%. Wprowadzenie takiego zapisu było w sposób oczywisty związane ze spodziewaną akcesją Wielkiej Brytanii do EWG, ponieważ w tym przypadku wspólny udział USA i EWG stanowiłby ponad $80 \%$ produkcji podstawowych dóbr ${ }^{56}$. Decydenci liczyli także, że w przypadku członkostwa Wielkiej Brytanii w EWG specjalne stosunki brytyjsko-amerykańskie rozszerzą się na całą Wspólnotę ${ }^{57}$. Spodziewano się pogłębienia współpracy z Europą Zachodnią, zrównoważenia francuskich wpływów i tym samym stabilizacji polityki Wspólnot ${ }^{58}$.

W przemówieniu wygłoszonym w Filadelfii 4 lipca 1962 r. Kennedy stwierdził, że ważnym celem amerykańskiej polityki zagranicznej będzie wspieranie rozwoju silnej i zjednoczonej Europy. Prezydent powiedział, że tylko zintegrowana Europa mogła być równym partnerem dla Stanów Zjednoczonych w działaniach mających na celu obronę wolnego świata. Wyraził też nadzieję na współpracę związaną

54 Tworzenie unii celnej zakończono w lipcu 1968 r. Wspólną politykę handlową EWG wprowadzono 1 stycznia 1970 r. (J. R u s z k o w s ki, E. G ór n i c z, M. Ż u r e k, Leksykon integracji europejskiej, Warszawa 1998, s. 156).

${ }^{55}$ G. L u n d e s t a d, "Empire" by Integration..., s. 93. Była to tzw. runda Dillona, od nazwiska sekretarza skarbu USA Douglasa Dillona, który był inicjatorem tych rozmów. Odbywała się w latach 1960-1962.

${ }^{56}$ J. P e l k m a n s, The Bickering Bigemony: GATT, [w:] Europe, America and the World Economy, ed. L. Tsoukalis, New York 1986, s. 85.

${ }^{57}$ Ibidem, s. 62.

${ }^{58}$ R. B o w i e, Tensions within the Alliance, „Foreign Affairs”, July 1963, s. 51. 
z liberalizacją handlu i rozwiązywaniem problemów monetarnych, wezwał wręcz do koordynacji polityki gospodarczej. Kennedy twierdził ponadto, że Europa Zachodnia powinna aktywnie uczestniczyć w polityce światowej, dzielić ze Stanami Zjednoczonymi odpowiedzialność, ale tylko pod warunkiem głębszego zjednoczenia politycznego. Ponieważ w opinii Kennedy'ego była to dość odległa perspektywa, proponował do czasu realizacji tego celu ściślejsze partnerstwo atlantyckie. Europa Zachodnia miała być „otwarta na zewnątrz, silnie związana z Ameryką” (outwardlooking Europe with a strong American connection) ${ }^{59}$. Według Kennedy'ego Europa nie była wtedy jeszcze równorzędnym partnerem dla USA - dopiero budowała swoją siłę. Kraje europejskie już wówczas chciały być traktowane jak równorzędni partnerzy, np. mieć większy wpływ na decyzje w $\mathrm{NATO}^{60}$.

Amerykanie, popierając głębszą integrację i rozszerzenie, kładli wyraźny nacisk na sojusz atlantycki. Chcieli, żeby w ramach istniejących organizacji utworzyć rodzaj grup koordynujących ich działania, złożonych z przedstawicieli USA, Wielkiej Brytanii, RFN i Francji. Ich członkowie mieli się konsultować i prezentować wspólne stanowisko na forum NATO, OECD czy GATT. Przywódcy europejscy dostrzegali potrzebę pogłębienia współpracy z USA, widząc możliwość wykorzystania inicjatywy Grand Design do realizacji własnych celów. Brytyjczycy liczyli, że w ten sposób osiągną równowagę w stosunkach z państwami EWG i z USA, RFN chciała umocnienia swej pozycji w sojuszu. Najbardziej sceptyczne było stanowisko francuskie. De Gaulle, obawiając się dominacji USA twierdził, że najpierw powinno nastąpić zjednoczenie polityczne Europy, najlepiej pod przywództwem Francji ${ }^{61}$.

Tymczasem, realizując własne zamierzenia, zachęcony przez Kennedy’ego, 31 lipca 1961 r. Macmillan ogłosił w Izbie Gmin decyzję o rozpoczęciu starań o członkostwo we Wspólnotach Europejskich ${ }^{62}$. Podczas negocjacji akcesyjnych zarówno „Szóstka”, jak i Wielka Brytania przyjęły bardzo sztywne pozycje negocjacyjne $^{63}$. Do końca 1962 r., mimo obaw związanych ze stanowiskiem de Gaulle’a, Amerykanie patrzyli raczej optymistyczne na wynik negocjacji. Brytyjczycy podkreślali, że trzeba unikać wypowiedzi sugerujących istnienie jakiegoś „bloku

${ }^{59}$ The Public Papers of the Presidents of the United States (PPP), John F. Kennedy, vol. 3: 1962, Washington D.C. 1963, przemówienie w Independence Hall, Philadelphia, 4 lipca 1962, dostępne także przez: htttp://www.presidency.ucsb.edu/ws/?pid=8756.

${ }^{60}$ R. B o w i e, op. cit., s. 56.

${ }^{61}$ J. G. G i a u q u e, Grand Designs and Visions of Unity, Chapel Hill 2002, s. 98-103.

${ }^{62}$ Ch. P r e s t o n, Enlargement \& Integration in the European Union, London 1997, s. 27.

${ }^{63}$ Brytyjczycy wysunęli trudne do zaakceptowania przez członków Wspólnoty warunki: 1) możliwość wypełniania zobowiązań wobec partnerów z EFTA; 2) ochrona interesów handlowych partnerów z Commonwealthu; 3) gwarancje dla pozycji brytyjskiego rolnictwa. Na wynik negocjacji mogła mieć też wpływ sytuacja wewnętrzna w Wielkiej Brytanii. Ponieważ przez lata Partia Konserwatywna była sceptyczna co do projektu integracji europejskiej, społeczeństwo czuło się zdezorientowane zmianą jej stanowiska. Wykorzystała to Partia Pracy, sprzeciwiając się w $1962 \mathrm{r}$. szybkiemu wstąpieniu Wielkiej Brytanii do Wspólnot (R. H. S. C r o s s m a n, op. cit., s. 740). 
anglosaskiego". Mogło to prowokować podejrzenia, że Wielka Brytania jako członek Wspólnot będzie odgrywała rolę adwokata amerykańskich interesów ${ }^{64}$. Jednak wydarzenia potwierdzały istnienie specjalnych stosunków między Londynem a Waszyngtonem. Traktat w Nassau z grudnia 1962 r., który przypieczętował współzależność Amerykanów i Brytyjczyków w dziedzinie zbrojeń nuklearnych ${ }^{65}$, utwierdził de Gaulle’a w przekonaniu o sprzeczności interesów francuskich i brytyjskich. Po zawarciu traktatu de Gaulle oskarżył Wielką Brytanię o „zdradę Europy"66. 14 stycznia 1963 r. francuski prezydent ogłosił, że Francja zawetuje wniosek Londynu o przystąpienie do EWG. Uważał, że po przyłączeniu Wielkiej Brytanii EWG stanie się „ogromną wspólnotą atlantycką zależną od Stanów Zjednoczonych, co jest przeciwieństwem francuskich dążeń i czysto europejskiego charakteru Wspólnoty"67. Kwestia wzmocnienia gospodarczego EWG była dla niego w tym przypadku drugorzędna. Przede wszystkim pragnął przywódczej roli Francji w tej organizacji, która była przez niego uważana za instrument realizacji własnej polityki, także rywalizacji z USA.

W Stanach Zjednoczonych weto de Gaulle'a przyjęto z dużym rozczarowaniem: cele, jakie przyświecały amerykańskiemu wsparciu dla integracji, zaczęły się załamywać. Europie nie udało się osiągnąć konsensusu, co było niepokojące choćby w obliczu zbliżającej się kolejnej rundy negocjacyjnej GATT. Amerykanie obawiali się, że brak wspólnego stanowiska może storpedować porozumienie. Niepokój wzbudzała również ujawniona przy tej okazji nadrzędność interesów narodowych nad rozwojem integracji, co mogło z kolei negatywnie wpłynąć na całokształt relacji transatlantyckich. Jednak nadzieję wzbudzał fakt, że państwa europejskie nie miały zamiaru poddawać się francuskiej hegemonii. Komisja Europejska wydała

${ }^{64}$ W 1961 r. senator William J. Fulbright powiedział, że wejście Wielkiej Brytanii do EWG nie tylko wzmocni tę organizację, ale „będzie ważnym krokiem w kierunku ustanowienia prawdziwej wspólnoty północnoatlantyckiej, która obejmie też Stany Zjednoczone”. Brytyjczycy chcieli, żeby Amerykanie powstrzymali się od tego typu wypowiedzi (M. B e l o ff, The United States and the Unity of Europe, London 1963, s. 111).

${ }^{65}$ Kennedy wycofał się z działań podjętych przez swego poprzednika w ramach zacieśniania współpracy nuklearnej z pozostałymi członkami NATO. Eisenhower zawarł układ z Wielką Brytanią, iż w zamian za umożliwienie budowy w Szkocji bazy amerykańskich łodzi podwodnych, dostarczy temu państwu pociski typu Skybolt. Jednak pod koniec 1962 r. Stany Zjednoczone zrezygnowały z ich produkcji - musiały rozważyć, co Wielka Brytania powinna otrzymać w zamian. Alternatywą były nowe rakiety Polaris, zdolne do przenoszenia pocisków jądrowych. Ponieważ Amerykanie nie chcieli, aby Wielka Brytania rozwijała własne siły nuklearne, zdecydowano się zawrzeć układ pozwalający Amerykanom na kontrolę ich rozbudowy. 21 grudnia 1962 r. na konferencji w Nassau premier Macmillan na spotkaniu z Kennedym zdecydował się na rozbudowę okrętów podwodnych o napędzie nuklearnym, wyposażonych w rakiety Polaris z brytyjskimi głowicami atomowymi. Tym samym Londyn zrezygnował z konstruowania własnych pocisków nośnych (A. G r o s s e r, op. cit., s. 262).

${ }^{66} \mathrm{G}$. L u n d e s t a d, "Empire" by Integration..., s. 66-67.

${ }^{67}$ Extracts from de Gaulle's veto, [w:] Documents on European Union..., s. 132. 
oświadczenie, że weto Francji ujawniło poważny kryzys Wspólnot - kryzys zaufania. Wyraziła sprzeciw wobec wykorzystywaniu weta w interesie jednego kraju ${ }^{68}$.

Kennedy, zgodnie z opinią Departamentu Stanu, unikał komentarzy wobec zaistniałej sytuacji. Amerykanie byli jednak zdania, że Wielka Brytania powinna dalej starać się o członkostwo, wypracowując jednoznaczną politykę w tej kwestii i być gotowa do większych poświęceń ${ }^{69}$. Nadzieję wiązano z negocjacjami GATT, które mogły przynieść liberalizację handlu korzystną dla Commonwealthu i ułatwić dalsze negocjacje Londynu ze Wspólnotami. Kennedy był zaniepokojony możliwością rozluźnienia się sojuszu atlantyckiego. W przemówieniu wygłoszonym we Frankfurcie w czerwcu 1963 r. zapewniał, że USA nie miały zamiaru zdominować organów decyzyjnych Wspólnot, raczej chciały widzieć Europę mówiącą jednym głosem, jak mocarstwo światowe, ściśle współpracujące ze Stanami Zjednoczonymi. Jego zdaniem, tylko zjednoczona Europa mogła zapobiec fragmentaryzacji sojuszu atlantyckiego. Wezwał do zacieśnienia współpracy obronnej, ekonomicznej, szczególnie podczas negocjacji na forum GATT oraz ustalenia wspólnych celów politycznych ${ }^{70}$.

W latach 60. zaostrzyła się rywalizacja gospodarcza między Stanami Zjednoczonymi a EWG. W marcu 1963 r. Kennedy, tłumacząc swą decyzję deficytem bilansu płatniczego, ogłosił podwyższenie ceł na dywany i szkło. W odpowiedzi EWG zawiesiła koncesje na import amerykańskich tworzyw sztucznych, ubrań z włókien sztucznych, lakierów i farb. Nawet zwolennicy wspierania europejskiej integracji zaczęli mieć wątpliwości. Ball wyraził opinię, że poparcie USA dla integracji powinno zależeć od tego, czy Europejczycy będą znosić cła i współpracować w kwestiach gospodarczych $^{71}$. Twierdził nawet, że Stany Zjednoczone powinny szukać porozumienia głównie z RFN, z powodów politycznych - by kraj ten nie uzyskał zbyt dużej samodzielności, i gospodarczych - jako że było to najprężniejsze państwo $\mathrm{EWG}^{72}$.

Rząd Partii Pracy ponowił próbę ubiegania się o członkostwo w EWG w kwietniu 1967 r. Jednak de Gaulle po raz kolejny zablokował plany Londynu. Dopiero po rezygnacji z urzędu i wyborze Georgesa Pompidou w 1969 r. stanowisko francuskie uległo zmianie ${ }^{73}$. Pozostali członkowie Wspólnot już wcześniej byli skłonni przyjąć Wielką Brytanię do swojego grona. 0 ponownym otwarciu negocjacji zadecydowano podczas szczytu w Hadze w grudniu $1969 \mathrm{r}^{74}$

${ }^{68}$ R. B ow i e, op. cit., s. 60.

${ }^{69}$ G. L u n d e s t a d, "Empire" by Integration..., s. 79.

${ }^{70}$ PPP, John F. Kennedy, vol. 4: 1963, przemówienie wygłoszone w Paulskirche we Frankfurcie, 25 czerwca 1963.

${ }^{71}$ G. L u n d e s ta d, "Empire" by Integration..., s. 94-95.

${ }^{72}$ G. W. B a l l, Slogans and Realities, „Foreign Affairs”, July 1969, s. 636.

${ }^{73} \mathrm{~W}$ rozmowie z Kissingerem Pompidou powiedział, że samodzielna polityka wschodnia kanclerza RFN Willy'ego Brandta skłoniła go do poparcia członkostwa Wielkiej Brytanii w EWG, żeby była przeciwwagą dla rosnących wpływów RFN (H. K i s s in g e r, White House Years, Boston 1979, s. 421).

${ }^{74}$ Więcej na ten temat w podrozdziale 3.6. 


\subsection{Rozłam w NATO}

Podczas prezydentury de Gaulle’a pojawiły się poważne rozbieżności między USA a Francją. W Stanach Zjednoczonych francuski prezydent był uważany za polityka o poglądach antyamerykańskich. 24 września 1958 r. de Gaulle, w listach do prezydenta Stanów Zjednoczonych Dwighta Eisenhowera i premiera Wielkiej Brytanii Harolda Macmillana, zażądał ustanowienia w ramach NATO dyrektoriatu trzech mocarstw. Odrzucenie francuskiej propozycji skłoniło go do próby stworzenia przeciwwagi dla dominacji anglosaskiej w sojuszu państw zachodnich. Francuski prezydent był przeświadczony o drugorzędnej roli jego kraju w Sojuszu. Odmowa Amerykanów w sprawie przyznania Francuzom możliwości współdecydowania o użyciu broni nuklearnej oraz utrata Algierii w 1962 r. doprowadziła go do wniosku, że przymierze z Waszyngtonem nie gwarantowało w sposób należyty bezpieczeństwa Francji. Obawiał się, że rząd Stanów Zjednoczonych, działając jednostronnie, mógł doprowadzić do wybuchu wojny nuklearnej, wciągając w nią państwa sojusznicze.

Dlatego też prezydent Francji zdecydował się na stopniowe ograniczanie udziału swojego kraju w siłach NATO. W 1959 r. wycofał flotę śródziemnomorską spod dowództwa Paktu i sprzeciwił się rozmieszczeniu na terenie Francji broni nuklearnej. Na początku marca 1966 r. Paryż oficjalnie ogłosił wyjście z wojskowych struktur Sojuszu. 29 marca 1966 r. francuskie siły zbrojne zostały wyłączone spod dowództwa NATO. Rząd deklarował jednak przestrzeganie postanowień Sojuszu Atlantyckiego. W wyniku tej decyzji, Rada NAT0 zmieniła siedzibę i przeniosła się z Paryża do Brukseli. Potwierdzeniem usamodzielnienia się Francji w sferze polityki zagranicznej była wizyta de Gaulle’a w ZSRR, rozpoczęta w czerwcu 1966 r. Był to krok w kierunku realizacji koncepcji utrzymania pokoju dzięki równowadze sił w Europie, bez udziału Stanów Zjednoczonych ${ }^{75}$.

Do eskalacji konfliktu z Amerykanami doprowadziła postawa francuskiego prezydenta, jednak główny powód zatargu nie był wyłącznie związany z polityką Paryża. Dominujący wpływ Stanów Zjednoczonych na Europę Zachodnią, szczególnie w kwestiach bezpieczeństwa i polityki zagranicznej, był nie do podważenia. Coraz częściej mówiono w Europie o amerykańskim unilateralizmie, przywołując narzucenie krajom NATO strategii „elastycznego reagowania"76, ryzykowanie wybuchem wojny atomowej podczas kubańskiego kryzysu rakietowego w 1962 r. czy zaangażowanie w konflikt wietnamski. Obawiano się też możliwości porozumienia

${ }^{75}$ Wprawdzie de Gaulle nie miał złudzeń w sprawie celów polityki ZSRR, jednak uważał, że poprzez realizację wspólnych interesów państwo to nie przestanie być zagrożeniem dla państw demokratycznych.

${ }^{76}$ W 1967 r. Pakt przyjął doktrynę „elastycznego reagowania”, która przewidywała, że ewentualny konflikt będzie miał $\mathrm{w}$ pierwszej fazie charakter konwencjonalny, nie opierano więc strategii na nuklearnym odstraszaniu. To sprawiło, że Amerykanie nie angażowali się w pomoc związaną z rozwojem potencjału atomowego sojuszników, ale wzmacniali nacisk na ich większy udział w siłach konwencjonalnych Sojuszu. 
amerykańsko-radzieckiego, co mogło zakończyć się „złożeniem” amerykańskiego parasola nuklearnego nad Starym Kontynentem ${ }^{77}$. USA angażowały się przecież w odpieranie wpływów komunistycznych w innych częściach świata. W połowie lat 60. nastąpiła eskalacja wojny w Wietnamie. Europa Zachodnia wydawała się Amerykanom obszarem stosunkowo bezpiecznym, tym bardziej, że była silna ekonomicznie, więc teoretycznie odporna na propagandę komunistyczną ${ }^{78}$.

Głównym problemem Waszyngtonu było prowadzenie niezwykle wyczerpującej wojny w Wietnamie, leżącym poza strefą obronną NAT0. Traumatyczny dla Stanów Zjednoczonych konflikt nie pozostał bez wpływu na stosunki amerykańskoeuropejskie. Stany Zjednoczone zaangażowały się w wojnę wietnamską w latach 50. XX w. Pomagały Francji, początkowo finansowo i logistycznie, w walce o utrzymanie jej przedwojennej kolonii. Polityka taka miała zapewnić obronę Indochin przed wpływami komunistycznymi. Eisenhower nie zdecydował się na interwencję zbrojną, nawet po upadku Dien Bien Phu w 1954 r., nie chcąc, żeby Stany Zjednoczone były kojarzone $\mathrm{z}$ francuskim kolonializmem. Jednak amerykańska administracja wciąż uznawała ten obszar za zagrożony wpływami komunistycznymi. Narastające problemy w Indochinach sprawiały, że kolejni prezydenci podtrzymywali amerykańską obecność w tym rejonie świata. Eskalacja konfliktu z udziałem Amerykanów miała miejsce za kadencji prezydenta Lyndona B. Johnsona, w 1964 r. Było to reakcją na coraz większą aktywność wspieranych przez rząd Wietnamu Północnego partyzantów Wietkongu, dążących do przejęcia południowej części kraju.

W myśl Paktu NATO, państwa europejskie nie były zobowiązane do poparcia USA w wojnie wietnamskiej. „U.S. News \& World Report” odnotował z dużą dozą ironii, że do 1966 r. Europejczycy w odpowiedzi na apele Johnsona wysłali do Wietnamu 23 profesorów z RFN, dwie holenderskie ekipy lekarzy i 11 brytyjskich instruktorów policji ${ }^{79}$. Stanowisko rządów państw Starego Kontynentu wobec amerykańskiej polityki w dużym stopniu było spowodowane dezaprobatą europejskich społeczeństw wobec wojny w Wietnamie. W tej sytuacji rządy europejskie, mimo nacisków amerykańskich, nie były chętne nawet do symbolicznego czy retorycznego poparcia tej wojny. Napięcia w relacjach transatlantyckich wzrosły w momencie wycofywania wojsk amerykańskich ze Starego Kontynentu (do 1968 r. wycofano 66 tys. żołnierzy). Był to sposób zmniejszenia kosztów zaangażowania w Wietnamie. W Waszyngtonie rozważano nawet utworzenie w ramach NATO unii płatniczej, mającej na celu zobligowanie rządów europejskich do dzielenia kosztów stacjonowania wojsk amerykańskich w ich krajach. Jednak sprawa ta nie została poruszona w rozmowach z sojusznikami, mogło to bowiem zaognić stosunki transatlantyckie.

77 Jak to obrazowo określił Nixon: „Druty parasola atomowego się łamią, więc Europejczycy i Japończycy zastanawiają się, czy jak spadnie deszcz, ten parasol się otworzy" (R. N i x o n, A Real War, New York 1980, s. 191).

${ }^{78}$ W. R. S c h ill i n g, American Arms and a Changing Europe: Dilemmas of Deterrence and Disarmament, New York 1973, s. 89.

${ }^{79}$ R. J. B a r n e t, op. cit., s. 265. 
W Europie Zachodniej w końcu lat 60. nasilały się protesty antywojenne. Wprawdzie sojusz transatlantycki przeżył już kilka kryzysów, ale nigdy nie były one wyartykułowane tak dobitnie. Do tamtej pory niezadowolenie nie wylewało się na ulicę, raczej było tłumione w zaciszu gabinetów. Tym razem, na fali społecznego poruszenia, wielu ludzi wyraziło rozczarowanie i nieufność do idealistycznej retoryki usprawiedliwiającej działania militarne USA. 21 października 1967 r. został ogłoszony Dniem Wietnamu. Odbyły się ogromne manifestacje we wszystkich stolicach zachodnioeuropejskich. Miały one charakter antyamerykański, choć w dużej mierze były inspirowane podobnymi wydarzeniami za Oceanem, gdzie w tym samym dniu tysiące protestujących przeciwko wojnie oblegało Pentagon ${ }^{80}$.

Na potępienie wojny złożyło się wiele czynników: ogromna liczba ofiar wśród ludności cywilnej, metody walki (np. stosowanie napalmu), wspieranie niedemokratycznych rządów Wietnamu Południowego oraz wprowadzanie w błąd światowej opinii publicznej. Rosło przekonanie o agresywnym charakterze polityki Stanów Zjednoczonych, wbrew głoszonym przez polityków hasłom niesienia światu wolności. Wojna wietnamska poważnie nadszarpnęła autorytet Stanów Zjednoczonych w Europie.

\subsection{Problem dzielenia kosztów obrony}

W 1950 r. w Europie (głównie w RFN) stacjonowało około 100 tys. amerykańskich żołnierzy, a w apogeum - w 1953 r. - 400 tys. $^{81}$ Pierwsza poważna debata na temat sensu utrzymywania tak pokaźnego kontyngentu miała miejsce w $1951 \mathrm{r}$. w senackich komitetach spraw zagranicznych i sił zbrojnych (Senate Foreign Relations Committee, Senate Arm Services Committee). Impulsem do zainicjowania rozmów była rezolucja zgłoszona w lutym 1951 r. przez republikańskiego senatora Kennetha Wherry'ego. Postulował on, by nie można było wysłać sił lądowych do Europy w ramach NATO bez zgody Kongresu. Po burzliwej dyskusji ustalono, że prezydent nadal będzie podejmował decyzję w tej sprawie, jednak Senat zastrzegł sobie prawo monitorowania tej kwestii. 4 kwietnia 1951 r. zaakceptowano desygnowanie Dwighta Eisenhowera na stanowisko dowódcy sił NAT0 w Europie (Supreme

${ }^{80}$ W 1965 r. poparcie społeczeństwa amerykańskiego dla działań rządu było duże - wynosiło 83\%. W 1967 r. Johnson już nie cytował w przemówieniach wyników sondaży, gdyż 63\% obywateli było przekonanych o pogarszaniu się sytuacji w Wietnamie. Było to spowodowane brakiem perspektyw zakończenia konfliktu oraz znaczącym powiększeniem kontyngentu wojskowego w Azji Południowo-Wschodniej (z 358 tys. żołnierzy w listopadzie 1966 r. do 474 tys. w grudniu 1967 r.). Poparcie dla polityki Johnsona wyraźnie malało - w styczniu 1968 r. 78\% społeczeństwa żywiło przekonanie, że USA przegrywają wojnę (A. G r o s s e r, op. cit., s. 319).

${ }^{81}$ G. F. Tr e v e r to n, The Dollar Drain and American Forces in Germany. Managing the Political Economics of Alliance, Athens 1978, s. 3. 
Allied Commander, Europe - SACEUR) oraz wysłanie dodatkowych 4 dywizji na Stary Kontynent. Podkreślano jednocześnie, że Europejczycy powinni znacznie zwiększyć wydatki na wspólną obronę. Wielu senatorów podzielało zdanie, że aby to osiągnąć, należało dążyć do uzbrojenia RFN ${ }^{82}$.

W 1957 r. Rada NAT0 zgodziła się, że deficyty bilansów płatniczych poszczególnych krajów, wynikające ze stacjonowania wojsk za granicą, powinny być rekompensowane. To stwierdzenie nie przełożyło się jednak na konkretne działania w ramach Sojuszu ${ }^{83}$, poważne problemy amerykańskiego deficytu budżetowego wystąpiły bowiem dopiero w 1958 r. Zawyżony kurs dolara sprawił, że Stany Zjednoczone zaczęły tracić konkurencyjność na rynkach światowych. Wzrastał również amerykański import. Wśród obywateli USA coraz bardziej powszechne było przekonanie, że sytuacja taka wynikała z nadmiernego zaangażowania środków w obronę sojuszników, dlatego pomysł redukcji sił za granicą - ku zaniepokojeniu Europejczyków - zyskiwał coraz większe poparcie w Kongresie.

Sprawa dzielenia obciążeń stała się istotnym elementem stosunków transatlantyckich na początku lat 60. XX w. Amerykanie twierdzili, że Europa Zachodnia uzyskała wystarczająco wysoki poziom rozwoju gospodarczego, by mogła wnosić proporcjonalnie większy wkład finansowy we wspólną obronę. W memorandum przygotowanym przez Departament Stanu w lutym 1961 r. stwierdzono, że „deficyt bilansu płatniczego całkowicie wynika $\mathrm{z}$ wydatków na obronę wolnego świata"84. W listopadzie 1960 r. sekretarz skarbu w administracji Dwighta Eisenhowera, Robert Anders, podczas wizyty w Bonn zaproponował, żeby RFN płaciła $650 \mathrm{mln}$ USD rocznie $w$ ramach rekompensaty za stacjonowanie amerykańskich wojsk. Adenauer odmówił twierdząc, że takie żądania wysuwa się wobec państw okupowanych, a nie sojuszniczych ${ }^{85}$. Stany Zjednoczone podniosły ponownie tę kwestię po roku fiskalnym $1961^{86}$, kiedy zauważono, że zagraniczne wydatki na obronę wyniosły 3 mld USD, z czego 600 mln przeznaczono na utrzymanie sił militarnych w RFN. Jesienią 1961 r. RFN zgodziła się w ramach rekompensaty dokonać zakupu sprzętu militarnego w USA ${ }^{87}$.

${ }^{82}$ S. R. S 1 o a n, NATO, the European Union, and the Atlantic Community: the Transatlantic Bargain Challenged, Lanham 2005, s. 23-24. Remilitaryzacja RFN stała się możliwa od października 1954 r., kiedy Unia Zachodnia została przekształcona w Unię Zachodnioeuropejską po włączeniu do niej RFN i Włoch. 9 maja 1955 r. RFN została przyjęta do NATO.

${ }^{83}$ National Archives and Record Administration, College Park, MD (NARA), Nixon Presidential Materials Staff (NPMS), National Security Council (NSC) Insitutional, "H" Files, Study Memorandums (1969-1974), raport NSSM 170, 2 kwietnia 1973, box H-129.

${ }^{84}$ L. S. K a p l a n, NATO Divided, NATO United. The Evolution of an Alliance, Westport 2004, s. 49.

${ }^{85}$ G. F. Treverto n, op. cit., s. 32.

${ }^{86}$ Do 1976 r. rok fiskalny w Stanach Zjednoczonych zaczynał się 1 lipca, a kończył 30 czerwca. Od 1976 r. trwa od 1 października do 30 września. W dalszej części pracy, odnosząc się do okresu obowiązywania umów offsetowych, mam na myśli lata fiskalne.

${ }^{87}$ G. F. Trevert o n, op. cit., s. 33. 
W 1965 r. RFN nie wywiązała się w całości z przewidzianego na ten rok offsetu. Stany Zjednoczone, które były coraz bardziej zaangażowane w Wietnamie, zareagowały w zdecydowany sposób. Sekretarz obrony Robert McNamara zagroził redukcją sił amerykańskich, choć Departament Stanu odradzał podjęcie takiej unilateralnej decyzji. Wciąż poważnie traktowano w Waszyngtonie możliwość ataku państw bloku komunistycznego na Niemcy Zachodnie ${ }^{88}$.

W 1966 r. nastąpiło powiększenie się deficytu bilansu płatniczego Stanów Zjednoczonych, a także kryzys w Wielkiej Brytanii. Poza tym NATO zostało osłabione przez wystąpienie Francji ze struktur wojskowych. W Departamencie Stanu padła wtedy propozycja utworzenia w ramach NATO unii płatniczej oraz schematu dzielenia kosztów obrony. Jednak tego pomysłu z powodów politycznych nigdy formalnie nie przedstawiono sojusznikom ${ }^{89}$.

Także RFN nie odnotowała dużego wzrostu PKB, a ponieważ była już wystarczająco silna militarnie, jej zakupy amerykańskiego sprzętu znacznie zmalały ${ }^{90}$. McNamara stwierdził wtedy, że poziom sił amerykańskich stacjonujących w RFN będzie zależał od wielkości offsetu. Determinację Amerykanów zmierzającą do uzyskania podziału kosztów obrony potwierdziło wystąpienie senatora Mike’a Mansfielda - lidera Demokratów - w sierpniu 1966 r. Poddał on po raz pierwszy pod obrady rezolucję zakładającą „znaczną redukcję” sił USA w Europie ${ }^{91}$.

Od października 1966 r. ruszyły trójstronne negocjacje (z udziałem RFN, Stanów Zjednoczonych i Wielkiej Brytanii) na temat offsetu. W listopadzie 1966 r. kanclerz Ludwig Erhard i prezydent USA Lyndon B. Johnson uzgodnili w Waszyngtonie plan offsetu. Amerykański prezydent, ze względu na priorytetowe znaczenie wojny w Wietnamie, potrzebował żołnierzy i środków finansowych. Podkreślał jednak, że nie zamierzał rezygnować z gwarancji bezpieczeństwa dla Europy, choć coraz częściej w Stanach Zjednoczonych wskazywano, że siła nuklearna była dostatecznym zabezpieczeniem, wobec czego siły konwencjonalne na Starym Kontynencie były zbyt duże.

Rozmowy zakończyły się kompromisem ogłoszonym 28 kwietnia $1967 \mathrm{r}$. Zgodzono się, że Stany Zjednoczone wycofają 35 tysięcy żołnierzy, a Wielka Brytania - 6,5 tys. RFN zobowiązała się do dalszych zakupów militarnych w USA, nie określono jednak konkretnie ani sumy na to przeznaczonej, ani ilości sprzętu. Poza tym bank centralny RFN (Bundesbank) zobowiązał się do zakupu papierów wartościowych, wydanych przez Departament Skarbu na sumę $500 \mathrm{mln}$ USD i do publicznego ogłoszenia, że powstrzyma się od wymieniania dolarów na złoto ${ }^{92}$.

${ }^{88}$ A. W. D e P o r t e, Europe Between the Superpowers. The Enduring Balance, New Haven 1979, s. 202.

${ }^{89}$ R. M o r r is, Uncertain Greatness: Henry Kissinger and American Foreign Policy, New York 1977, s. 76.

${ }^{90}$ NARA, NPMS, NSC Insitutional "H" Files, Study Memorandums (1969-1974), raport NSSM 170, 2 kwietnia 1973, box H-129.

${ }^{91}$ L. S. K a p l a n, op. cit., s. 50.

${ }^{92}$ G. F. T r e vert o n, op. cit., s. 39. 
To zakończyło konflikt na poziomie dyplomatycznym, ale opinia publiczna w Stanach Zjednoczonych zwiększała naciski, by rząd wymógł na Europejczykach bardziej sprawiedliwy podział kosztów wspólnej obrony. Sytuacja monetarna była wciąż niestabilna i deficyt amerykańskiego bilansu płatniczego stale się powiększał. W 1968 r. ruszyły kolejne, tym razem bilateralne, bez udziału Brytyjczyków, rozmowy offsetowe. Przebiegały one bez większych problemów. RFN, uzależniona od amerykańskiej obrony, miała niekorzystną pozycję negocjacyjną. Wskazywano wprawdzie, że zwiększony odpływ dolarów ze Stanów Zjednoczonych nie wynikał z wydatków na obronę, lecz głównie z inwestycji prywatnych firm w Europie, jednak argumenty te nie były brane pod uwagę. Umowę zawarto w czerwcu $1968 \mathrm{r}$. Wysokość offsetu miała wynieść łącznie 785 mln USD na kolejny rok fiskalny, z czego 500 mln USD było przeznaczone na zakup amerykańskich obligacji skarbowych przez Bundesbank, a 125 mln miały nabyć instytucje prywatne. Kwotę na zakup broni oszacowano na 100 mln USD, a Lufthansa miała zakupić amerykańskie Boeingi za 60 mln USD ${ }^{93}$.

Według Roberta Gilpina, relacje Stanów Zjednoczonych z RFN (które nazywa „najważniejszymi w gospodarce światowej”) były najlepszą ilustracją współzależności polityki i gospodarki. Polegały na swoistej wymianie gwarancji obrony w zamian za zapewnienie przez RFN swobodnego dostępu na jej rynek - a tym samym na rynek EWG - dla towarów i inwestycji amerykańskich. RFN zobowiązywała się również wielokrotnie przechowywać rezerwy walutowe w USD i nie żądać ich wymienialności na złoto ${ }^{94}$.

W 1968 r. Stany Zjednoczone rozpoczęły ograniczone wycofywanie wojsk - 75\% jednej dywizji wróciło do USA, lecz dwie brygady były gotowe do natychmiastowego powrotu w razie zagrożenia. Po sowieckiej inwazji na Czechosłowację w sierpniu 1968 r. część wojsk wróciło do Europy. W ciągu 8 lat po zwiększeniu kontyngentu spowodowanym drugim kryzysem berlińskim ${ }^{95}$ amerykańskie siły w Europie zostały zredukowane o około 100 tys. osób, z tego część wróciła po wystąpieniu Francji z NATO96.

${ }^{93}$ Nie wszyscy byli jednak zadowoleni z osiągniętego kompromisu. Charakterystyczna była wypowiedź Mansfielda, który stwierdził, że kupując amerykańskie obligacje skarbowe RFN jeszcze na tym zyska, więc nie można było w tym przypadku mówić o offsecie (G. F. T r e v e r t o n, op. cit., s. 40).

${ }^{94}$ R. G il p i n, op. cit., s. 414.

9510 listopada 1958 r. Nikita Chruszczow zażądał zmiany dotychczasowego statusu Berlina. 27 listopada sprecyzował wymagania w nocie wysłanej do pozostałych trzech mocarstw posiadających w nim swe strefy. Stwierdził, że miasto powinno zostać wolne i zdemilitaryzowane. Nota była utrzymana $\mathrm{w}$ formie ultimatum. Chruszczow zagroził, że jeśli w ciągu pół roku porozumienie w tej sprawie nie zostanie osiągnięte, ZSRR podpisze z NRD traktat pokojowy, przekazując jej kontrolę dróg dojazdowych do Berlina. Stany Zjednoczone zdecydowały się rozpocząć negocjacje w tej sprawie, które spowodowały poważne napięcia z władzami RFN, Były one zaniepokojone możliwością zbyt daleko idących ustępstw amerykańskich, a nawet rezygnacją z utrzymywania związków Berlina ze światem zachodnim. Jednak rozmowy zakończyły się fiaskiem, a jego widocznym znakiem była budowa muru berlińskiego 13 sierpnia 1961 r. (P. M a t e r a, R. M a t e r a, op. cit., s. 226-229).

${ }^{96}$ A. B a ke r F ox, Domestic Pressures in North America to Withdraw Forces From Europe, [w:] European Security and the Atlantic System, eds. W. T. R. Fox, W. R. Schilling, New York 1973, s. 202. 
Krytyka tych posunięć, płynąca z państw Europy Zachodniej, irytowała Amerykanów, którzy ponosili największe koszty utrzymania NATO. Pod koniec 1968 r. Departamenty Stanu i Obrony ogłosiły wspólny raport, według którego Stany Zjednoczone wydawały na obronę sojuszników 5 mld USD rocznie, z czego ok. 30\% w Europie. Senator John Sherman Cooper ogłosił na forum Zgromadzenia Północnoatlantyckiego w 1968 r., że koszty istnienia NATO, ponoszone przez USA, z uwzględnieniem wszystkich typów płatności, wynoszą średnio od 12 do 15 mld USD ${ }^{97}$.

\subsection{Intensyfikacja relacji gospodarczych między Stanami Zjedno- czonymi a EWG w latach $60 . \mathrm{XX}$ w.}

W latach 60. coraz wyraźniejsza stawała się gospodarcza triadyzacja świata kapitalistycznego. Na groźnego konkurenta USA wyrastała Japonia, a europejskie ambicje objawiły się powstaniem takich ugrupowań, jak EWG i EFTA, które w końcu lat 60. podjęły współpracę, tworząc wspólnie (jeszcze nieformalnie) nową regionalną siłę. Wraz z postępującym procesem integracyjnym Europy znoszono taryfy celne między członkami Wspólnot Europejskich oraz - wobec protekcjonizmu amerykańskiego ustalano bariery celne godzące w eksport Stanów Zjednoczonych. Jednym z charakterystycznych trendów okresu 1956-1968 była łatwość przepływu kapitału i technologii z krajów wysoko rozwiniętych do państw o niższym szczeblu zaawansowania technologicznego. Z doświadczeń i pomocy USA bardzo skorzystała Europa, a restrukturyzacja przemysłu w najszybszym tempie dokonała się w RFN i we Włoszech. Inwestycje poczynione w latach 40 . i 50. zaczęły szybko procentować.

\subsubsection{Handel}

Osłabienie nastrojów zimnowojennych po 1956 r. przyczyniło się do rozwoju międzynarodowego handlu. Wielkość obrotów handlowych między 1950 a 1970 r. zwiększyła się niemal czterokrotnie. Oprócz pewnej normalizacji w stosunkach Wschód-Zachód, sprzyjały temu kolejne porozumienia w sprawie likwidacji barier celnych, zawierane na forum GATT. W 1956 r. zakończyła się trzecia runda negocjacyjna, a w latach 1960-1962 odbyła się czwarta ${ }^{98}$.

${ }^{97}$ Jeśli bierze się pod uwagę roczne koszty stacjonowania sił USA w Europie, włączając również obsługę cywilną i koszty stacjonowania Szóstej Floty, wydatki były mniejsze - 2,9 mld USD. Jednak uwzględniając siły utrzymywane na terenie Stanów Zjednoczonych (ekwiwalent mniej więcej dwóch dywizji), gotowe do użycia w czasie realnego zagrożenia, szacunki sięgają nawet 25 mld USD. Stąd wynikają rozbieżności danych w różnych źródłach (A. B a k e r F o x, op. cit., s. 204).

${ }^{98}$ P. M a te ra, R. M a te r a, op. cit., s. 242-245. 
Stany Zjednoczone nie były jednak do końca usatysfakcjonowane ich wynikami, dlatego Kennedy wystąpił z propozycją utworzenia Wspólnoty Atlantyckiej, o wymiarze polityczno-gospodarczym. Waga tego przemówienia polegała na uznaniu przez USA państw tworzących Wspólnoty Europejskie za równorzędnych partnerów. Skończył się już okres „idealistyczny”, kiedy to Ameryka, promując integrację zachodu Starego Kontynentu, nie brała pod uwagę skutków przyszłej rywalizacji ze swoimi „podopiecznymi”. Kennedy wiedział, że jeśli nie zostaną ustalone korzystne dla obu stron warunki współpracy, Stany Zjednoczone będą musiały stawić czoła silnej europejskiej konkurencji. Przykładem poważnego sporu handlowego może być tzw. „wojna kurczakowa” (chicken war) trwająca w latach 19621964. W 1962 r. EWG podniosła cła na import kurczaków, co przyniosło duże straty producentom z USA, dla których ten rynek był do tej pory bardzo lukratywny ${ }^{99}$. Rok później prezydent Lyndon Johnson podjął decyzję o działaniach odwetowych - nałożono cła na produkty szczególnie ważne dla europejskich eksporterów: skrobię ziemniaczaną (i pochodzące od niej dekstryny), brandy i lekkie ciężarówki. Mimo długotrwałości sporu, nie wpłynął on negatywnie na relacje transatlantyckie $w$ interesie gospodarczym i politycznym obu stron leżało prowadzenie negocjacji i jak najszybsze osiągnięcie kompromisu ${ }^{100}$.

Tabela 2.1. Wartość handlu USA (w mln USD) z wybranymi krajami w latach 1965-1969

\begin{tabular}{|c|c|c|c|c|c|c|c|c|c|c|}
\hline & \multirow{2}{*}{$\begin{array}{c}1965 \\
\mathrm{E}\end{array}$} & \multirow[b]{2}{*}{ I } & \multicolumn{2}{|c|}{1966} & \multicolumn{2}{|c|}{1967} & \multicolumn{2}{|c|}{1968} & \multicolumn{2}{|c|}{1969} \\
\hline & & & $\mathbf{E}$ & I & $\mathbf{E}$ & I & $\mathbf{E}$ & I & $\mathbf{E}$ & I \\
\hline Belux & 650 & 494 & 690 & 568 & 704 & 584 & 796 & 766 & 960 & 683 \\
\hline Dania & 209 & 147 & 184 & 202 & 205 & 183 & 207 & 223 & 205 & 260 \\
\hline Francja & 971 & 615 & 1007 & 698 & 1025 & 690 & 1078 & 842 & 1195 & 842 \\
\hline RFN & 1650 & 1341 & 1674 & 1796 & 1706 & 1955 & 1702 & 2721 & 2142 & 2603 \\
\hline Irlandia & 69 & 58 & 86 & 94 & 77 & 130 & 87 & 108 & 118 & 123 \\
\hline Włochy & 893 & 620 & 909 & 743 & 973 & 856 & 1120 & 1102 & 1262 & 1204 \\
\hline Japonia & 2080 & 2414 & 2364 & 2963 & 2695 & 2999 & 2950 & 4054 & 3490 & 4888 \\
\hline Holandia & 75 & 319 & 72 & 304 & 78 & 311 & 89 & 331 & 99 & 392 \\
\hline Wielka Brytania & 1615 & 1405 & 1737 & 1786 & 1960 & 1710 & 2179 & 2052 & 2335 & 2120 \\
\hline ZSRR & 45 & 43 & 42 & 50 & 60 & 41 & 58 & 58 & 106 & 52 \\
\hline Kanada & 5643 & 4832 & 6661 & 6125 & 7165 & 7107 & 8057 & 8924 & 9137 & 10384 \\
\hline
\end{tabular}

E - eksport, I - import

Źródło: Yearbook of International Trade Statistics, 1969, New York 1971, s. 878.

${ }^{99}$ Np. w 1962 r. 25\% importu drobiu RFN pochodziło ze Stanów Zjednoczonych (D. I k e n s o n, Ending the „Chicken War". The Case for Abolishing the 25 Percent Truck Tariff, dostępne przez: http:// www.cato.org/pubs/tbp/tbp-017.pdf).

${ }^{100}$ A. W. D e P o r t e, op. cit., s. 199. 
Głównym celem tzw. „rundy Kennedy'ego” (piątej rundy GATT, toczącej się w latach 1964-1967) miało być zmniejszenie ceł na produkty rolne i przemysłowe w wymianie transatlantyckiej ${ }^{101}$. Propozycję prezydenta wywołał spadek dynamiki eksportu do Europy. EWG była drugim partnerem handlowym USA po Kanadzie, więc obniżenie poziomu wywozu powodowało nierównowagę $\mathrm{w}$ wymianie. W latach 1958-1969 nastąpił dynamiczny wzrost transatlantyckich kontaktów gospodarczych. Eksport USA na zachód Starego Kontynentu wzrósł o 142\%, podczas gdy cały eksport wzrósł o 109\%. Warto zaznaczyć, że największą dynamikę zanotowano w wywozie produktów nierolniczych - powiększył się o 174\%. W tym czasie eksport do USA stanowił ok. 33\% wywozu EWG. W 1969 r. eksport produktów przemysłowych z USA do EWG wzrósł o 18\% w stosunku do roku poprzedniego i ta tendencja się utrzymywała. Odwrotny trend zanotowano, jeśli chodzi o wywóz produktów rolnych - w 1966 r. spadł o 19\%. W latach 1966-1967 nastąpił dynamiczny wzrost importu tych produktów z EWG i EFTA przez wiele krajów reszty świata. Wtedy też wysoki dodatni bilans handlowy Stanów Zjednoczonych z europejskimi partnerami uległ zmniejszeniu. W 1963 r. wynosił on 2,4 mld USD, a w 1968 - tylko 200 mln USD. Choć w 1969 r. wzrósł znów do 1,1 mld USD, już za dwa lata po raz pierwszy bilans był ujemny ${ }^{102}$.

Amerykanie kwestionowali reguły Wspólnej Polityki Rolnej EWG, ale również w Stanach Zjednoczonych istniał protekcjonizm w rolnictwie. W latach 40. i 50. polityka rolna w USA była dostosowana do wewnętrznych cen i dochodów, a nie do ekspansji handlu zagranicznego. Wspierano wysokie ceny i stosowano, bez wyraźnych efektów, ograniczenia produkcji. Spowodowało to kumulację zapasów z nadprodukcji w rękach rządu, który zaczął wprowadzać, mimo sprzeciwów płynących z Kongresu, bezpośrednie subsydia eksportowe ${ }^{103}$.

Zaproponowana przez Kennedy'ego obniżka ceł o 50\% początkowo była nie do przyjęcia przez kraje europejskie, gdyż średni poziom amerykańskich stawek celnych wynosił 7,1\%, a EWG - 5,7\%. Negocjacje nie były łatwe, gdyż EWG obawiała się zalewu rynku towarami zza Oceanu. Dodatkową przeszkodą był opór de Gaulle’a wobec inicjatywy Wspólnoty Atlantyckiej Kennedy'ego. Francuski prezydent był zdania, że nadszedł właściwy moment, by zacząć budowę „europejskiej Europy", niezależnej politycznie i gospodarczo od USA ${ }^{104}$.

${ }^{101}$ D. L e e, Endgame at the Kennedy Round: A Case Study of Multilateral Economic Diplomacy, [w:] Diplomacy, Vol. 3, eds. C. Jönsson, R. Langhorne, London 2005, s. 270-285.

102 NARA, NPMS, NSC Institutional "H" Files, Study Memorandums (1969-1974), analiza Departamentu Stanu, Aneks I: Relacje gospodarcze USA/EWG, 21 kwietnia 1970, box H-164. Por. History of the U.S. Economy since World War II, eds. H. G. Vatter, J. F. Walker, M. E. Shape, New York 1996, s. 446.

${ }^{103}$ International Economic Relations of the Western World, 1959-1971, ed. A. Shonfield, Vol. 1: Politics and Trade, London 1976, s. 320, 336.

${ }^{104}$ K. L. N e l s o n, The Making of Détente. Soviet-American Relations in the Shadow of Vietnam, Baltimore 1995, s. 57. 
Mimo trudności związanych z osiągnięciem kompromisu, „runda Kennedy'ego” przyniosła poważne redukcje ceł na niektóre towary. Wraz ze wzrostem efektywności i modernizacją europejskiego przemysłu, amerykańska produkcja przestała stanowić dla niego zagrożenie. Objawiło się to spadkiem eksportu amerykańskiego, szczególnie w $1968 \mathrm{r}^{105} \mathrm{~W}$ wyniku porozumień na forum GATT zredukowano taryfy celne między USA, Kanadą i praktycznie całą Europą Zachodnią (najpierw z EWG, a potem także z EFTA) od 30\% do nawet 50\% na większość produktów wymiany między zainteresowanymi stronami ${ }^{106}$.

Runda Kennedy'ego trwała cztery lata, pozwoliło to na bardzo dokładne rozpatrzenie każdego problemu i wypracowanie kompromisów. Negocjatorzy mieli czas dobrze poznać się nawzajem, a także zrozumieć argumenty partnerów, co przyniosło bardzo dobre rezultaty. Pozytywnym aspektem rozmów był fakt, że kraje w nich uczestniczące były członkami jeszcze innych organizacji, na których forum poruszano jednocześnie problemy gospodarcze (np. Organizacji Współpracy Gospodarczej i Rozwoju OECD - Organization for Economic Cooperation and Development ${ }^{107}$ czy MFW ${ }^{108}$. „Runda Kennedy'ego” nie zlikwidowała jednak wszystkich problemów natury handlowej. Stany Zjednoczone wprowadzały kontyngenty i wywierały presję na inne kraje, by te przyjmowały „dobrowolne ograniczenia” na import towarów przemysłowych (Voluntary Restraint Agreements) - umowy, w których zobowiązywali się do ograniczenia eksportu określonych produktów na rynek USA. W 1968 r. uległy temu kraje EWG i Japonia ${ }^{109}$. Sprawiło to, że Europejczycy zaczęli szukać nowych rynków zbytu w Afryce i w krajach basenu Morza Śródziemnego, zawierając preferencyjne traktaty o wolnym handlu.

Należy pamiętać, że gospodarki państw europejskich były bardziej uzależnione od wymiany niż Stany Zjednoczone, gdyż dochody z nią związane stanowiły dla nich większy procent PKB. Dla USA było to tylko $4 \%$, a dla RFN - ponad $18 \%{ }^{110}$.

Po II wojnie światowej Stany Zjednoczone notowały zdecydowanie dodatni bilans handlowy i nadwyżki w produkcji przemysłowej (oprócz przemysłu naftowego). Jednak już w 1960 r. miały bilans ujemny w handlu żywnością i podstawowymi produktami przemysłowymi. Poza tym Stany Zjednoczone stanęły w obliczu

${ }^{105}$ W 1968 r. bilans handlowy Stanów Zjednoczonych był jeszcze dodatni, ale nadwyżka spadła z ponad 2,5 mld USD (w 1967 r.) do 600 mln USD (w 1968 r.).

106 Według wyliczeń negocjatorów, dzięki porozumieniom na forum GATT oraz decyzjom ugrupowań regionalnych, dynamika handlu towarami przemysłowymi w latach 60. zwiększyła się od 12\% (między Kanadą i USA) do 18\% w krajach Europy Zachodniej.

10714 grudnia 1960 r. Kanada i Stany Zjednoczone dołączyły do członków OEEC, podpisując konwencję OECD. Nowa organizacja oficjalnie rozpoczęła działalność 30 września 1961 r., kiedy konwencja weszła w życie. Jej celem było wspieranie wzrostu gospodarczego państw członkowskich.

${ }^{108}$ A. Sho nfi eld, The Economic Factor in International Relations, "International Affairs”, November 1970, s. 121.

${ }^{109}$ J. E. S p e r o, The Politics of International Economic Relations, New York 1999, s. 87.

110 Dla porównania: Wielka Brytania 13,1\%, Francja 10,5\%, Włochy 13\%, Japonia 9\% (A. W. D e P o r t e, op. cit., s. 200). 
rosnącej konkurencji z Europy, Azji i Ameryki Łacińskiej. Wzbudziło to zaniepokojenie związków zawodowych, zaczynających domagać się od rządu wprowadzenia środków prowadzących do ochrony miejsc pracy. Stwarzało to niebezpieczeństwo nacisku na stosowanie polityki protekcjonistycznej, ale należy zwrócić uwagę, że interesy poszczególnych przemysłów były odmienne. Te, których wewnętrzne operacje były zagrożone przez zagraniczną konkurencję (dotyczyło to „starych” przemysłów, takich jak samochodowy czy stalowy), domagały się ograniczeń importu. Jednak gałęzie uzależnione od eksportu (np. związane z high-tech) były za utrzymaniem otwartego rynku. Podobne stanowisko zajmowali farmerzy, domagając się przy tym ograniczenia europejskiego protekcjonizmu.

Obszarem rywalizacji między Stanami Zjednoczonymi a EWG były także kraje bloku wschodniego. Kwestie polityczne w okresie powojennym ciążyły na stosunkach gospodarczych (zwłaszcza handlowych) między państwami zaangażowanymi w zimną wojnę. Od 1948 r. Stany Zjednoczone zastosowały ograniczenia wywozowe wobec krajów zza „żelaznej kurtyny”. Przejawem wojny gospodarczej było embargo na tzw. dobra strategiczne. Lista towarów objętych zakazem wywozu do krajów komunistycznych została po 1950 r. rozszerzona. W 1951 r. USA wypowiedziały układy handlowe z ZSRR i jego krajami satelickimi.

Amerykanie uważali, że wymiana Wschód-Zachód powinna być ograniczona, jeśli chodzi o produkty strategiczne i kredyty długoterminowe, bowiem mogły być one użyte dla wrogich celów ${ }^{111}$. Natomiast Europejczycy twierdzili, że bliższe relacje gospodarcze przyczynią się do wzmocnienia procesu odprężenia. Ta różnica zdań znalazła odzwierciedlenie we wskaźnikach wymiany. Już na początku lat 60 . niepokój Waszyngtonu wzbudzała intensyfikacja handlu krajów EWG z ZSRR. W latach 1960-1961 RFN, Francja i Włochy wysłały do ZSRR towary i sprzęt warte miliard dolarów ${ }^{112}$. Ta tendencja utrzymywała się przez kolejne lata. W 1966 r. wartość handlu RFN z krajami bloku wschodniego wynosiła 2 mld USD, Wielkiej Brytanii - 1 mld, a Stanów Zjednoczonych tylko 375 milionów ${ }^{113}$. Amerykanie uważali, że ich sojusznicy byli zbyt optymistycznie nastawieni do możliwości zmiany sowieckiego systemu. Przynoszące duże zyski relacje gospodarcze ze Wschodem mogły również sprawić, że nie zawsze chętnie popieraliby Stany Zjednoczone w zimnowojennych zmaganiach. Poza tym w Waszyngtonie zauważano, że Stany Zjednoczone, ograniczając swe kontakty gospodarcze z powodów politycznych, tracą duży rynek zbytu.

Oprócz intensyfikacji wymiany, kraje Europy Zachodniej dążyły do odgrywania bardziej samodzielnej roli w stosunkach międzyblokowych. Najbardziej

${ }^{111}$ M. J. S o d o r o, US-Soviet Relations: Detente or Cold War, [w:] Economic Relations with the Soviet Union. American and West German Perspective, ed. A. E. Stent, Westview Press, Boulder 1989, s. 22 .

112 W. L a F e b e r, America, Russia, and the Cold War 1945-1992, New York 1992, s. 205.

${ }^{113}$ W. R. B u r g e s s, J. R. H u n tl e y, Europe and America. The Next Ten Years, New York 1970, s. 157. 
spektakularne przyjazne gesty w stronę państw zza „żelaznej kurtyny” wykonał zachodnioniemiecki polityk Willy Brandt. Już jako minister spraw zagranicznych, którym został w 1966 r., zauważał konieczność ustanowienia bliskich stosunków między RFN a blokiem radzieckim, w tym z NRD. W 1967 r. podjął rozmowy sondażowe z ZSRR oraz nawiązał stosunki dyplomatyczne z Rumunią, a rok później z Jugosławią. Planowanie takiej polityki było możliwe dzięki odprężeniu między USA a ZSRR. Brandt myślał jednak o usamodzielnieniu się RFN. Twierdził, że dzięki otwarciu na Wschód, państwo to będzie mogło samo pilnować swoich interesów, a nie tylko polegać na Stanach Zjednoczonych, które grały kartą niemiecką w zależności od potrzeb własnej polityki zagranicznej. Ubolewał, że RFN była „gigantem ekonomicznym, a politycznym Pigmejem"114. Brandt pragnął zmniejszyć napięcie, które tworzyło atmosferę permanentnego zagrożenia bezpieczeństwa RFN, a także stworzyć warunki do pokojowego zjednoczenia Niemiec. Tę ostatnią kwestię odsuwał na bliżej nieokreśloną przyszłość.

Amerykanie obawiali się, że działając zbyt samodzielnie, Brandt poczyni zbyt wielkie ustępstwa wobec ZSRR. Sami również nie wykluczali kompromisowych rozwiązań, lecz za ewentualne koncesje pragnęli uzyskać korzystne dla siebie porozumienia. Kissinger uważał, że aktywność państw Europy Zachodniej w kontaktach z ZSRR mogła doprowadzić do jej „finlandyzacji” i rozmycia podziału na dwa antagonistyczne bloki. Skutkowałoby to osłabieniem sojuszu, którego ważnym celem była obrona przed wschodnim mocarstwem ${ }^{115}$. Brandt zdawał sobie sprawę, że nie osiągnie wiele bez amerykańskiego wsparcia. Jednak Ostpolitik była czytelnym znakiem zmiany tendencji w polityce zagranicznej krajów europejskich ${ }^{116}$.

\subsubsection{Inwestycje}

Stany Zjednoczone pozostawały niekwestionowanym liderem w światowym eksporcie kapitału. Inwestycje tego kraju za granicą stanowiły w okresie 19561970 60\% wszystkich międzynarodowych transakcji. Ich wartość wzrosła dziesięciokrotnie między rokiem 1950 a $1975^{117}$.

Korporacje ze Stanów Zjednoczonych zaspokajały rosnący popyt na nowoczesne technologie oraz dobra konsumpcyjne. Przedsiębiorstwa amerykańskie wykorzystywały przewagę wynikającą ze skali produkcji. W latach 1950-1968 amerykańskie bezpośrednie inwestycje zagraniczne (BIZ) w Europie wzrosły po-

${ }^{114}$ R. J. B a r n e t, op. cit., s. 289.

${ }^{115}$ M. D e l P e r o, Eccentric Realist: Henry Kissinger and the Shaping of American Foreign Policy, Ithaca 2009, s. 95.

${ }^{116}$ H. J. M o r g e $\mathrm{n}$ th a u, The United States and Europe in a Decade of Détente, [w:] The United States and Western Europe, ed. W. Hanrieder, Cambridge, Mass. 1974, s. 7.

${ }^{117}$ P. M a ter a, R. M a te r a, op. cit., s. 250. 
nad 11-krotnie: z 1,7 mld USD do ponad 19 mld. Rząd USA starał się je ograniczyć, gdyż powodowały deficyt w bilansie płatniczym. Już w $1965 \mathrm{r}$. wprowadzono dobrowolny program powstrzymywania odpływu kapitału (Voluntary Capital Restraint Program). Najbardziej restrykcyjnym środkiem był program kontroli inwestycji zagranicznych, wprowadzony przez prezydenta Johnsona w styczniu 1968 r., zgodnie z którym amerykańskie inwestycje bezpośrednie w Europie mogły być dokonywane wyłącznie z dochodów i funduszy uzyskanych za granicą. Przedsiębiorstwa mające więcej niż $10 \%$ inwestycji za granicą, nie mogły angażować się w transakcje transferu kapitału do innego kraju bez pozwolenia sekretarza handlu, który mógł nakazać sprowadzenie zarobionych środków z powrotem do USA ${ }^{118}$. Decyzja ta, podjęta przez Johnsona w ostatnim roku urzędowania, była bardzo źle przyjęta przez korporacje ponadnarodowe. Kłóciła się też z tradycyjną wizją amerykańskiego liberalizmu gospodarczego.

Wykres 2.2. BIZ Stanów Zjednoczonych (w mld USD) w 1966 r.

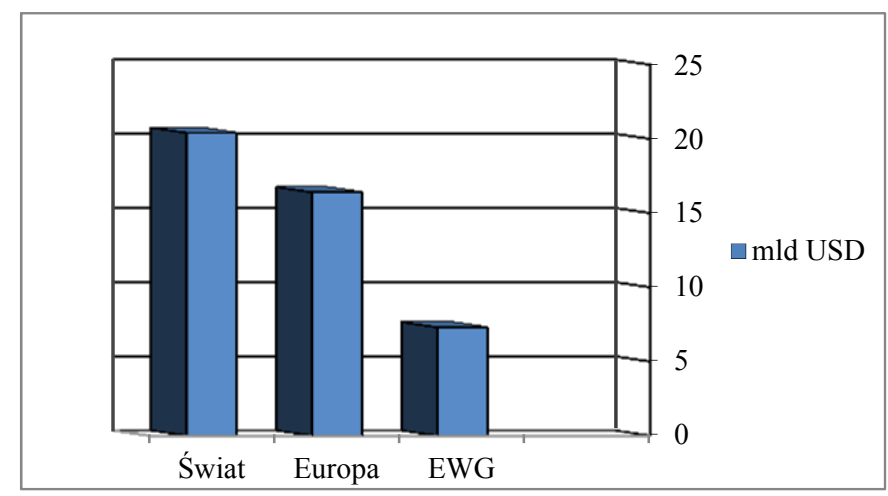

Źródło: US Direct Investment Abroad, 1966. Final Data, Washington 1967.

Odpływ kapitału do EWG był większy niż dochody z tych inwestycji wracające do USA o ok. 500-800 mln USD. Dopiero w 1968 r. ta sytuacja się zmieniła - Stany Zjednoczone zaczęły odczuwać korzyści z tych inwestycji. W tym samym roku odpływ kapitału wynosił 425 mln USD, a napływ - 438 mln USD. Stwierdzono, że ta tendencja zostanie utrzymana ${ }^{119}$. Między 1960 a 1969 r. roczna stopa wzrostu zarobków zagranicznych filii wielonarodowych przedsiębiorstw pochodzących z USA na całym świecie wynosiła $11,1 \%$, a wzrost profitów po podatkach $-6,1 \%$. Te dochody nie wynikały, jak się powszechnie sądzi, z eksploatacji i przetwarzania ropy

118 J. N. B e hrm a n, National Interests and the Multinational Enterprise. Tensions Among the North Atlantic Countries, Eaglewood Clifs 1970, s. 90.

119 NARA, NPMS, NSC Institutional "H" Files, Study Memorandums (1969-1974), analiza Departamentu Stanu, aneks I: relacje gospodarcze między USA a EWG, 21 kwietnia 1970, box H-164. 
w krajach nisko rozwiniętych. Do końca 1969 r. tylko 8\% dochodów przynosiło górnictwo i hutnictwo, a nakłady związane z ropą stanowiły 28\% całości bezpośrednich inwestycji przedsiębiorstw wielonarodowych. Blisko 75\% wynosiły inwestycje w fabryki i przedsiębiorstwa handlowe, przy czym niemal wszystkie były ulokowane w Europie Zachodniej ${ }^{120}$.

W 1967 r. europejskie spółki po raz pierwszy zwiększyły procentowo inwestycje bezpośrednie w USA w stosunku do tego, co zainwestowały amerykańskie firmy w Europie, ale wartość inwestycji pochodzących ze Stanów Zjednoczonych i tak do 1970 r. była dwukrotnie wyższa.. BIZ państw europejskich w Stanach Zjednoczonych wykazywały również tendencję rosnącą (wzrost w latach 1950-1968 z 3,3 mld USD do 10,8 mld). Do 1969 r. wartość aktywów posiadanych przez Europejczyków w USA wrosła o 20\%, a amerykańskich o $10 \%{ }^{121}$.

Ogromne inwestycje amerykańskie spowodowały, że spora część sektorów przemysłowych w krajach europejskich znalazła się pod kontrolą firm z USA. Filie przedsiębiorstw amerykańskich kontrolowały np. 75\% europejskiego rynku komputerowego, produkowały $50 \%$ francuskiego sprzętu telekomunikacyjnego, posiadały ponad 30\% niemieckich rafinerii naftowych i zatrudniały $6 \%$ brytyjskiej siły roboczej. Przewaga kapitału amerykańskiego sprawiała, że duże korporacje eliminowały konkurencyjne, mniejsze firmy europejskie. Występował również tzw. „drenaż mózgów" - przejmowanie wysoko wykwalifikowanej kadry, która masowo emigrowała do Stanów Zjednoczonych.

Charakterystyczne dla połowy lat 60. XX w. obawy i ambicje Europejczyków przedstawił wydawca paryskiego tygodnika „L'Express”, Jean-Jacques ServanSchreiber, w wydanej w $1968 \mathrm{r}$. książce American Challenge. The Impact of American Industry and Culture on Europe and the World („Amerykańskie wyzwanie. Wpływ amerykańskiego przemysłu i kultury na Europę i świat"). Udowadniał w niej, że Europa Zachodnia stała się „kolonią” Stanów Zjednoczonych, gdyż jej obszar został praktycznie zaanektowany pod względem gospodarczym przez amerykańskie przedsiębiorstwa. Servan-Schreiber przewidywał, że amerykański przemysł w Europie stanie się trzecią pod względem wielkości światową siłą gospodarczą. Apelował, aby Europejczycy zmienili ten stan rzeczy, ucząc się od obywateli zza Oceanu sposobów osiągania gospodarczej wydajności ${ }^{122}$.

Poszczególne kraje europejskie podjęły działania zmierzające do ograniczenia ekspansji kapitału zza Oceanu. Władze francuskie w 1963 r. ogłosiły zatrzymanie nowych, zagranicznych inwestycji, jeśli uznają, że groziłoby to dominacją obcego kapitału w poszczególnych sektorach gospodarki ${ }^{123}$. Jednak EWG nie skoordynowa-

${ }^{120}$ E. R. G o o d m a n, The Fate of the Atlantic Community, New York 1975, s. 453.

${ }^{121}$ Ibidem, s. 455.

122 J.-J. S e r va n - S c h r e i b e r, American Challenge. The Impact of American Industry and Culture on Europe and the World, New York 1968, passim.

${ }^{123}$ J. N. B e h r m a n, op. cit., s. 134. 
ła polityki w tej kwestii, co czyniło działania pojedynczych krajów bezsensownymi, gdyż inwestując np. w RFN, przedsiębiorstwa amerykańskie miały swobodny dostęp również do rynku francuskiego ${ }^{124}$.

\subsubsection{Kryzys światowego systemu monetarnego}

Z transatlantyckim handlem i inwestycjami nierozerwalnie łączyła się kwestia światowego systemu monetarnego, już w latach 60. pojawiły się bowiem oznaki kryzysu systemu z Bretton Woods, który był coraz mniej adekwatny do potrzeb gospodarki światowej. Powodowały to w dużej mierze dwa czynniki. Pierwszy z nich stanowił brak wystarczających rezerw złota na rynku światowym, występujący z powodu niezwykle dynamicznego wzrostu wymiany, drugim był koniec hegemonii Stanów Zjednoczonych w gospodarce światowej. Wobec tego USA z coraz większą niechęcią godziły się na oparcie światowego systemu monetarnego na ich walucie, co miało negatywne skutki dla sytuacji wewnętrznej ze względu na powiększający się deficyt bilansu płatniczego. Obawy związane z wywozem kapitału z USA były spowodowane powstaniem w latach 60 . tzw. rynku eurodolarów. W Europie Zachodniej, w przeciwieństwie do Stanów Zjednoczonych, były bardzo wysokie stopy procentowe, co przyciągało na Stary Kontynent pokaźny międzynarodowy kapitał. To z kolei powodowało napięcia w międzynarodowym systemie monetarnym ${ }^{125}$.

Zbyt duży napływ USD niepokoił także kraje europejskie, gdyż przechowywały rezerwy walutowe w dolarach z powodu małej ilości złota na rynku. Miały prawo wymienić je na złoto, ale w praktyce było to niemożliwe, gdyż przewyższały one wartością ilość tego kruszca posiadaną przez amerykański rząd. Bezprecedensowy wzrost wymiany handlowej wymagał zwiększenia ilości pieniądza - złota nie przybywało w takim samym tempie. Zgodnie z zasadami systemu z Bretton Woods, kursy miały być utrzymane w określonych ramach. Narodowe instytucje finansowe musiały interweniować, kupując lub sprzedając zagraniczne waluty. W przypadku dużego napływu dolarów na rynki europejskie banki centralne musiały je kupować, żeby powstrzymać zbyt wysoki kurs swojego pieniądza.

Na pogorszenie się pozycji USD miała wpływ pośrednio polityka de Gaulle’a, który zdecydował się na wymianę tej waluty uzyskanej z nadwyżki handlowej na

${ }^{124}$ Na przykład General Motors Corporation, nie mogąc zainwestować we Francji, przeniosła fabryki do Belgii.

${ }^{125}$ R. A. P a s t o r, Congress and the Politics of U.S. Foreign Economic Policy (1929-1976), Berkeley 1980, s. 207; C. F. B erg s te n, Toward a New International Economic Order: Selected Papers of C. F. Bergsten, 1972-1974, Lexington 1975, s. 313. Zob. także: FRUS 1969-1976, vol. 3 - Foreign Economic Policy, 1969-1979, International Monetary Policy, 1969-1972, Washington D.C. 2002, streszczenie raportu na temat amerykańskiego bilansu płatniczego, dok. 1, dostępne także przez: www.state.gov/r/pa/ho/frus/nixon. 
złoto. W 1965 r. rząd francuski dokonał wymiany 300 mln USD $^{126}$. De Gaulle wzywał do powrotu do parytetu złota i „detronizacji” dolara, odgrywającego rolę światowej waluty rezerwowej. Twierdził, że dzięki temu skończyłaby się dominacja amerykańskich firm na rynku światowym, co zrównałoby szanse konkurencji przedsiębiorstw europejskich. Zdając sobie sprawę, że nic nie osiągnie w pojedynkę, francuski prezydent starał się pozyskać poparcie RFN. Chciał również nawiązać z tym państwem ścisłą współpracę w dziedzinie nauki, technologii i przemysłu, by zmniejszyć europejską zależność od USA na tych polach ${ }^{127}$. Jednakże RFN nie była chętna do przyjęcia ostentacyjnie antyamerykańskiej polityki. Stało się to także pod naciskiem rządu Stanów Zjednoczonych, który przypominał, że siły amerykańskie stacjonowały w tym kraju, dopóki RFN była gotowa do pomocy w zmniejszaniu amerykańskiego deficytu bilansu płatniczego ${ }^{128}$.

W grudniu 1961 r. powstała Grupa Dziesięciu (G10), złożona z ministrów finansów Belgii, Holandii, Francji, RFN, Włoch, Szwecji, Kanady, Japonii, Wielkiej Brytanii i Stanów Zjednoczonych. Ustanowili oni Porozumienie Ogólne o Pożyczkach (General Agreement to Borrow) z funduszem 6 mld USD, by podtrzymywać kursy walutowe. G10 stała się również forum do dyskusji w sprawie przeprowadzenia przyszłej reformy światowego systemu monetarnego ${ }^{129}$.

Po pięciu latach negocjacji, w 1966 r., by dostarczyć środków umożliwiających pokrycie rosnących potrzeb wymiany międzynarodowej, G10 zgodziła się na stworzenie jednostki używanej w międzynarodowych rozliczeniach między bankami centralnymi - tzw. specjalnych praw ciągnienia (Special Drawing Rights - SDR) w ramach MFW ${ }^{130}$. Jeden SDR był równy dolarowi amerykańskiemu. Członkom MFW otworzono rachunki SDR-ów, na których mieli odpowiednią ilość nowych jednostek proporcjonalną do swoich wkładów udziałowych. Za SDR-y poszczególne państwa mogły kupować od innych uczestników systemu waluty wymienialne na spłaty zobowiązań zagranicznych ${ }^{131}$.

Jednak to posunięcie nie rozwiązywało zasadniczego problemu. Wciąż większość krajów uprzemysłowionych dokonywała rozliczeń w USD, co powodowało

${ }^{126}$ T. Ke m p, The Climax of Capitalism. The U.S. Economy in the Twentieth Century, New York 1990, s. 189.

12722 stycznia 1963 r. de Gaulle podpisał z Adenauerem porozumienie o współpracy między Francją a RFN, zwane traktatem elizejskim. Układ ten przewidywał częste konsultacje szefów rządów i dowódców sił militarnych obu państw, a także współpracę w dziedzinie gospodarczej, kulturalnej i naukowej. Tak daleko idące zbliżenie w dobie ostrej krytyki przez de Gaulle’a polityki USA mogło być odebrane za Oceanem jako przedsięwzięcie o ostrzu antyamerykańskim. Bundestag wprawdzie zgodził się na przyjęcie porozumienia $\mathrm{z}$ Francją, ale dodał do niego wstęp, w którym podkreślił związki RFN z USA i NATO, a także wypowiedział się za włączeniem w struktury zjednoczonej Europy Wielkiej Brytanii. Zastrzeżenia parlamentu RFN osłabiły wymowę traktatu elizejskiego (P. M a t e r a, R. M a te r a, op. cit., s. 234-235).

${ }^{128}$ R. Gil p i n, op. cit., s. 415.

${ }^{129}$ W 1964 r. do G10 dołączyła Szwajcaria, lecz nazwa Grupy się nie zmieniła.

${ }^{130}$ J. E. S p e r o, op. cit., s. 40-41.

${ }^{131}$ J. G ł u c h o w s k i, Międzynarodowe stosunki finansowe, Warszawa 1997, s. 19. 
„eksport” inflacji ze Stanów Zjednoczonych i zachwianie porządku gospodarki światowej. Administracja Johnsona wywierała presję na rządy europejskie, żeby te zmuszały banki centralne do trzymania rezerw w dolarach i nie dopuszczały do spekulacji. Szczególnym naciskom były poddawane władze RFN, by podniosły kurs marki wobec dolara w celu stworzenia lepszych warunków dla eksportu z USA ${ }^{132}$. Państwa europejskie spodziewały się, że rząd amerykański dokona dewaluacji swojej waluty, dlatego Francja nie chciała zgodzić się na dewaluację franka, a RFN na rewaluację marki. Powodowało to poważne napięcia w stosunkach transatlantyckich ${ }^{133}$.

Dewaluacja funta w $1967 \mathrm{r}$., a także ataki spekulacyjne na francuskiego franka od wiosny 1968 r. spowodowały wzrost ceny złota do 44 USD za uncję. W związku z zaistniałą sytuacją, w marcu 1968 r. wprowadzono tzw. „two-tier” gold market, czyli dwa poziomy handlu złotem. Na oficjalnym rynku transakcji międzyrządowych utrzymano wymienialność na poziomie 35 USD za uncję złota, a poza nim ceny złota miały być kształtowane przez siły rynkowe ${ }^{134}$.

\subsection{Podsumowanie}

Relacje transatlantyckie $\mathrm{w}$ pierwszych dekadach po zakończeniu II wojny światowej należy rozpatrywać w kontekście rywalizacji zimnowojennej. 0 ile ZSRR utrzymywał pod kontrolą blok komunistyczny za pomocą groźby użycia siły militarnej, o tyle Stany Zjednoczone zapewniały bezpieczeństwo sojusznikom. Równie ważnym spoiwem były relacje gospodarcze. Dlatego w czasach zimnej wojny interakcje czynników politycznych i gospodarczych miały kluczowe znaczenie w stosunkach między Stanami Zjednoczonymi, Europą Zachodnią i Japonią ${ }^{135}$. Współpraca na polu gospodarczym skutkowała zacieśnianiem się tych relacji, natomiast nieporozumienia wpływały negatywnie także na polityczne i militarne kwestie łączące sojuszników.

Po zakończeniu działań wojennych Stany Zjednoczone zdecydowanie wspierały europejską odbudowę i integrację. Chciały w ten sposób zapewnić sobie poparcie silnych sojuszników w rywalizacji z blokiem komunistycznym. Nie oznaczało to

${ }^{132}$ A. Gros s e r, op. cit., s. 327.

${ }^{133}$ D. P. C a $1 \mathrm{l}$ e o, NATO Costs and U.S. Economic Imbalances, [w:] Economic and Strategic Issues in U.S. Foreign Policy, eds. C. L. Holtfrerich, W. de Gruyter, New York 1989, s. 167. Dyskusja na ten temat odbyła się w amerykańskim Senacie 6 października 1969 r. (Congressional Record. Proceeding and Debates of the First Session of the $91^{\text {st }}$ Congress, vol. 115, part 21, posiedzenie Senatu z 6 października 1969, dostępne przez: http://www.archive.org/stream/congressionalrec115lunit\#page/n1/mode/ 2up).

${ }^{134}$ A. Gro s s e r, op. cit., s. 327. Więcej na temat reform monetarnych w latach $60 \mathrm{XX}$ w. Zob. R. T r i f f i n, The Thrust of History in International Monetary Reform, „Foreign Affairs”, April 1969, s. $478-493$.

${ }^{135}$ R. G i l p i n, op. cit., s. 409-410. 
bynajmniej wycofania się sił amerykańskich ze Starego Kontynentu. Ich obecność miała gwarantować bezpieczeństwo rozwojowi jedności europejskiej, aż do momentu, gdy obywatele państw ją tworzących będą myśleć o sobie bardziej w kategoriach „Zachodnich Europejczyków” niż nacjonalistów. Na drugi plan odsunięto obawy, że Europa może się stać w przyszłości niebezpiecznym konkurentem, choć przedwojenne koncepcje integracyjne były wymierzone właśnie w dominację gospodarczą Stanów Zjednoczonych ${ }^{136}$. Liczono, że odbudowana gospodarczo i politycznie Europa nie będzie dążyła do rywalizacji ze Stanami Zjednoczonymi, a wręcz przeciwnie - weźmie współodpowiedzialność za politykę światową, odciążając swego sojusznika ${ }^{137}$.

Źródeł rodzących się rozbieżności w stosunkach transatlantyckich należy poszukiwać w narastających problemach natury ekonomicznej. Najważniejsze z nich to osłabienie pozycji amerykańskiego dolara i tendencje protekcjonistyczne po obu stronach Atlantyku. Mimo widocznych sukcesów negocjacji na forum GATT, część problemów pozostała nierozwiązana. Postęp integracji EWG i związane z nim korzystne warunki wymiany wewnątrz Wspólnoty powodowały poczucie dyskryminacji wśród amerykańskich producentów dóbr przemysłowych i farmerów, którzy z tego powodu tracili konkurencyjność na europejskich rynkach. Prowokowało to pytanie, czy Stany Zjednoczone nadal powinny bezwarunkowo wspierać pogłębianie współpracy państw Starego Kontynentu. Nie panowała również zgoda w kwestii handlu z blokiem komunistycznym. Stany Zjednoczone były bardziej zdeterminowane do ograniczania kontaktów z zimnowojennymi rywalami, podczas gdy państwa Europy Zachodniej sukcesywnie je rozszerzały ${ }^{138}$.

W latach 60. dostrzeżono, że wzrost potęgi EWG może stanowić potencjalne zagrożenie dla amerykańskich interesów gospodarczych. Wiosną 1966 r. Robert Schaetzel, ambasador amerykański przy Komisji Europejskiej w Brukseli, pisał na ła-

${ }^{136}$ Richard Nicolaus Coudenhove-Kalergi w 1923 r. opublikował pracę zatytułowaną „PanEuropa”. Konieczność powstania Unii Paneuropejskiej uzasadniał potrzebą przeciwstawienia się zagrożeniu ze strony Rosji, a także szkodzącej gospodarce europejskiej konkurencji gospodarki amerykańskiej. Z kolei plan organizacji obejmującej wszystkie państwa europejskie, które należały do Ligi Narodów, został zgłoszony przez francuskiego ministra spraw zagranicznych Aristide’a Brianda w Genewie 5 września 1929 r. Rządy krajów Starego Kontynentu miały rozważyć udział w instytucji, nazywanej potocznie Unią bądź Federacją Europejską. Briand zapewniał, że jego projekt nie był wymierzony przeciwko państwom pozaeuropejskim i deklarował otwarcie na współpracę, jednak niektóre jego założenia mogły budzić wątpliwości za Oceanem. Szczególne zaniepokojenie Amerykanów powodował projekt unii celnej między krajami przyszłej organizacji, co ich zdaniem prowadziło do dyskryminacji handlu zagranicznego z innymi kontynentami, gdyż towary pochodzące spoza Europy nie mogły być konkurencyjne dla nieoclonych dóbr. W dzienniku „New York Times” powiedziano wprost, że Francuzi postrzegają tę organizację jako próbę obrony przed amerykańską dominacją gospodarczą (P. M a te r a, Francja w polityce zagranicznej Stanów Zjednoczonych w latach 1929-1933, Toruń 2003, s. 70-78).

${ }^{137}$ A. G r o s s e r, op. cit., s. 157.

${ }^{138}$ M. J. S o d o r o, op. cit., s. 22. 
mach „Foreign Affairs”: „Trzeba się liczyć z istnieniem europejskiego nacjonalizmu. Nie możemy oczekiwać, że stanowisko europejskie będzie zupełnie wolne od antyamerykanizmu"139. Jego zdaniem, wynikało to ze skupienia się Europy Zachodniej na własnych interesach, szczególnie na pogłębianiu integracji. Twierdził, że chęć równoważenia potęgi USA stanowiła jeden z ważnych bodźców tego procesu, dlatego nie można uniknąć konfliktów we wzajemnych stosunkach. Przyznał jednak, że interesy Europy Zachodniej i USA były w wielu punktach zbieżne, dlatego poważne rozejście się dróg partnerów uważał za mało prawdopodobne. Ostrzegał jednak, że sytuacja zależności Starego Kontynentu od obrony amerykańskiej groziła popadnięciem w neutralizm, a jedynym sposobem jej uniknięcia było dzielenie odpowiedzialności w dziedzinie bezpieczeństwa. Miało to polegać na większym zaangażowaniu się Europy na tym polu, ale także na dopuszczeniu krajów Starego Kontynentu do realnego wpływu na decyzje w kwestiach obrony ${ }^{140}$.

Wzrastający napływ kapitału oraz konieczność utrzymywania sił militarnych w różnych częściach świata powodowała rosnący deficyt amerykańskiego bilansu płatniczego. Tymczasem obserwowano radykalne protesty w Europie przeciwko zaangażowaniu Stanów Zjednoczonych w Wietnamie oraz związany z tym narastający antyamerykanizm i podważanie wiarygodności amerykańskiego przywództwa. NATO było często nazywane narzędziem amerykańskiego protektoratu nad zachodem Starego Kontynentu, chociaż paradoksalnie społeczeństwa europejskie były niechętne zwiększaniu możliwości obronnych swoich krajów poprzez przeznaczanie większych kwot na cele militarne ${ }^{141}$. Rozczarowanie postawą krajów sojuszniczych, połączone z deficytem bilansu płatniczego, skutkowało podejmowanymi w Kongresie próbami wymuszenia wycofania znacznej ilości amerykańskich sił z Europy Zachodniej ${ }^{142}$.

Opisane rozbieżności w relacjach transatlantyckich narastały, powodując coraz większe napięcia. W Stanach Zjednoczonych zauważano konieczność wypracowania nowej polityki wobec sojuszników. Należało przy tym wziąć pod uwagę zmieniającą się sytuację polityczną i gospodarczą na świecie. Z tym zadaniem miała się zmierzyć administracja Richarda M. Nixona, który zwyciężył w wyborach z listopada 1968 r.

${ }^{139}$ R. S c h a e t z e l, The Necessery Partnership, „Foreign Affairs”, April 1966, s. 426.

${ }^{140}$ Ibidem, s. 423-430..

${ }^{141}$ C. B e ll, The Diplomacy of Détente. The Kissinger Era, New York 1977, s. 99.

${ }^{142}$ L. S. K a p l a n, NATO and the United States. The Enduring Alliance, New York 1994, s. 111. 
ROZDZIAŁ III

\section{EUROPA ZACHODNIA W POLITYCE STANÓW ZJEDNOCZONYCH NA POCZĄTKU KADENCJI RICHARDA M. NIXONA (STYCZEŃ-GRUDZIEŃ 1969)}

\subsection{Sojusz atlantycki w koncepcjach Nixona i Kissingera}

Richard Milhous Nixon, który po wygranych wyborach w 1968 r. objął urząd prezydenta Stanów Zjednoczonych, podczas długiej kariery politycznej zdobył duże doświadczenie $w$ polityce międzynarodowej ${ }^{1}$. Sformułował jej nową koncepcję we współpracy ze swymi doradcami. Określał polityczne priorytety na podstawie obserwacji zmian sytuacji politycznej i gospodarczej na świecie. Zauważał, że amerykańska przewaga militarna, która pozwalała Stanom Zjednoczonym angażować się we wszystkich częściach świata, stopniowo malała. Było to spowodowane nie tylko postępem ZSRR w wyścigu zbrojeń i perspektywą posiadania przez Chiny siły nuklearnej. Nixon zauważył również nadmierne koszty przywództwa w demokratycznym świecie. Jego zdaniem miało to negatywny wpływ na amerykańską gospodarkę. Szczególnie zwracał uwagę na wydatki wojenne w Wietnamie. Poza tym, mimo ponoszenia ciężarów politycznych, militarnych i ekonomicznych, postrzeganie Stanów Zjednoczonych w świecie ulegało pogorszeniu. „Dwadzieścia lat temu, po zwycięstwie w II wojnie światowej, byliśmy poważani w całym świecie. Dziś każdego dnia nasza flaga jest opluwana, biblioteka palona, ambasada obrzucona kamieniami w jakieś części globu"2 - zauważył Nixon w 1967 r.

By odbudować prestiż i umocnić wewnętrznie swój kraj, prezydent był zdecydowany na odprężenie w stosunkach z ZSRR. Jednak za priorytet uznawał „honorowe" zakończenie wojny w Wietnamie. Chciał to osiągnąc poprzez negocjacje z władzami Wietnamu Północnego, licząc na pomoc Moskwy. Pragnął również prowadzić rozmowy rozbrojeniowe i ustanowić korzystne relacje handlowe ze wschodnim supermocarstwem. Należy jednak zaznaczyć, że Nixon nie wierzył

\footnotetext{
${ }^{1}$ Nixon został wybrany do Izby Reprezentantów w 1946 r. W 1950 r. został senatorem, a od 1952 r. pełnił funkcję wiceprezydenta w administracji Dwighta D. Eisenhowera. W 1960 r. kandydował na urząd prezydenta z ramienia Partii Republikańskiej, jednak uległ swojemu przeciwnikowi Johnowi F. Kennedy'emu.

${ }^{2}$ Foreign Relations of the United States (FRUS) 1969-1976, vol. 1: Foundations of Foreign Policy, Washington D.C. 2003, przemówienie Nixona do członków Bohemian Club, San Francisco, 29 lipca 1967, dok. 2, dostępne także przez: www.state.gov/r/pa/ho/frus/nixon.
} 
w możliwość zakończenia zimnowojennej rywalizacji, ani nie miał złudzeń co do z totalitarnego charakteru ustroju ZSRR. Chciał doprowadzić do sytuacji, w której Stany Zjednoczone będą mogły rozmawiać z Moskwą z pozycji siły, co pomoże przeforsować własne warunki porozumień.

Analizując sowiecką politykę zagraniczną, Nixon widział szansę zdobycia takiej korzystnej pozycji negocjacyjnej. „Komunistyczne Chiny są zagrożeniem dla Wschodu; ZSRR potrzebuje przyjaciół na Zachodzie [...] Liderzy sowieccy mają dziś trzy główne cele w polityce zagranicznej: wciąż są komunistami i dążą do tworzenia komunistycznego świata; walczą z Chińczykami o przywództwo w tym świecie. Chcą to osiągnąć bez wojny. Pragną jednak również wewnętrznego postępu gospodarczego. Będą współpracowali z nami tylko wtedy, kiedy będzie to służyło tym celom"3. Nixon uważał, że Stany Zjednoczone powinny wykorzystać tę sytuację, utrzymując przewagę militarną, rozwijając handel ze Wschodem i nawiązując stosunki dyplomatyczne z ChRL ${ }^{4}$.

Według Nixona, kluczowym elementem amerykańskiej polityki zagranicznej powinna się stać także konsolidacja sojuszu z Europą Zachodnią. Wiedział, że relacje polityczne pogorszyły się w latach 60. Już podczas kampanii prezydenckiej krytykował swojego poprzednika Lyndona B. Johnsona za lekceważenie NATO. Twierdził, że Stany Zjednoczone podejmowały działania mogące mieć wpływ na europejskie bezpieczeństwo bez konsultacji z sojusznikami. Zadeklarował, że zaprzestanie pouczania aliantów i będzie słuchać ich opinii ${ }^{5}$.

Nixon uważał, że relacje transatlantyckie pogorszyły się głównie z powodu silnej wewnętrznej opozycji w krajach europejskich przeciwko wojnie w Wietnamie. Uznawał to za główny powód niechęci polityków z zachodu Starego Kontynentu do popierania dyplomacji amerykańskiej. Za głębszy motyw tej sytuacji przyjmował fakt, że siła gospodarcza państw Europy Zachodniej skłaniała je do prowadzenia bardziej niezależnej polityki zagranicznej. Wyraził również zaniepokojenie przyszłością NATO w dobie détente, cytując słowa premiera Wielkiej Brytanii Harolda Macmillana: „sojusze są silne dzięki strachowi, a nie miłości". Zauważył, że w Europie zmniejszyły się obawy przed bezpośrednim atakiem ZSRR, choć jego zdaniem było to poczucie bardzo złudne. Nixon widział możliwość dezintegracji jedności Zachodu, co uznawał z kolei za bardzo kuszący cel dla dyplomacji sowieckiej. Szczególne zagrożenie stanowiła możliwość rozciągnięcia się wpływów ZSRR na RFN. Było to spowodowane prowadzeniem przez Bonn niezależnej polityki wschodniej. Amerykański prezydent stwierdził, że wobec tego wzmacnianie NATO powinno się stać najwyższym priorytetem polityki zagranicznej USA ${ }^{6}$. Powodem takiej konstatacji stało się również przeko-

\footnotetext{
${ }^{3}$ Ibidem.

${ }^{4}$ Ibidem.

${ }^{5}$ L.S. K a p l a n, NATO and the United States. The Enduring Alliance, New York 1994, s. 112.

${ }^{6}$ FRUS, 1969-1976, vol. 1, przemówienie Nixona do członków Bohemian Club, San Francisco,
} 29 lipca 1967, dok. 2. 
nanie Nixona, że koordynacja polityki amerykańskiej i europejskiej była nieodzowna do osiągnięcia założeń odprężenia.

W przemówieniu inauguracyjnym 20 stycznia 1969 r. Nixon podkreślał ważną rolę Stanów Zjednoczonych w utrzymywaniu pokoju na świecie. Zadeklarował chęć rozpoczęcia wielowymiarowego dialogu z ZSRR. By zrealizować ten cel, oczekiwał współpracy: „Niech wszystkie narody wiedzą, że podczas tej prezydentury nasze linie komunikacyjne są otwarte" ${ }^{\prime 7}$ - zapewniał prezydent. Celem Nixona było stworzenie „nowej struktury pokoju”, umożliwiającej zmniejszenie zimnowojennego napięcia. Nie oznaczało to rezygnacji z przywództwa czy wycofania się w izolacjonizm, ale realizację precyzyjnie sformułowanego interesu narodowego i dokładniej przemyślane decyzje o zaangażowaniu środków i prestiżu na arenie międzynarodowej. Oczekiwał od sojuszników ponoszenia większej odpowiedzialności za własne bezpieczeństwo ${ }^{8}$.

Głównym współpracownikiem Nixona na polu polityki zagranicznej był jego doradca do spraw bezpieczeństwa narodowego, Henry Kissinger. Jego wiedza na temat zawiłości polityki europejskiej była nie do przecenienia9. Mimo różnicy zdań pojawiającej się czasem między Nixonem a Kissingerem, politycy ci potrafili osiągnąć konsensus i wspólnie tworzyć wytyczne dla amerykańskiej dyplomacji. Obaj chcieli zakończyć zaangażowanie w Wietnamie, ograniczające swobodę działania w polityce międzynarodowej, bez szkód dla amerykańskiego przywództwa w wolnym świecie i bez umacniania izolacjonizmu w Stanach Zjednoczonych ${ }^{10}$.

Kissinger podzielał opinię Nixona o roli sojuszu atlantyckiego, powodach jego dezintegracji i konieczności jego reorganizacji. W pracy opublikowanej w $1966 \mathrm{r}$. zatytułowanej The Troubled Partnership: A Re-appraisal of the Atlantic Alliance („Burzliwe partnerstwo: przewartościowanie sojuszu atlantyckiego”) wyraził główny postulat dotyczący relacji amerykańsko-europejskich: nieodzowność utworzenia równoprawnego partnerstwa ${ }^{11}$. Zaproponował również konkretne działania, mające doprowadzić do osiągnięcia tego celu. Po pierwsze zauważył, że dominacja Stanów Zjednoczonych w NATO stworzyła sytuację, w której Europejczycy byli

${ }^{7}$ The Public Papers of the Presidents of the United States: Richard Nixon (PPP), vol. 1: 1969, Washington D.C. 1969, przemówienie inauguracyjne, 20 stycznia 1969, dok.1, dostępne także przez: http://www.nixonfoundation.org.

${ }^{8}$ R. J. B a r n e t, The Alliance. America, Europe, Japan. Makers of the Postwar World, New York 1983, s. 298. W tym oświadczeniu Nixon przedstawił główne tezy swojej doktryny, po raz pierwszy zaprezentowanej publicznie w lipcu 1969 r. na wyspie Guam (więcej na ten temat: E. C. R a v e n a l, Large-Scale Foreign Policy Change: The Nixon Doctrine as History and Portent, Berkeley 1989).

${ }^{9}$ Kissinger był doradcą prezydenta do spraw bezpieczeństwa narodowego w latach 1969-1975. W okresie 1973-1977 pełnił funkcję sekretarza stanu w administracjach Richarda Nixona i Geralda Forda (od sierpnia 1974 r.).

${ }^{10}$ L.S. K a p l a n, op. cit., s. 110.

${ }^{11}$ H. K is s in ge r, The Troubled Partnership: A Re-appraisal of the Atlantic Alliance, New York 1966, passim. 
przekonani o wyłącznie amerykańskiej odpowiedzialności za utrzymanie bezpieczeństwa. Skutkowało to niechęcią do zwiększania wydatków na cele militarne i brakiem poparcia dla wielu działań amerykańskich w świecie. By zmienić tę sytuację, Kissinger proponował wprowadzenie „kary za brak współpracy” w postaci odmowy pomocy lub konfrontacji Europejczyków z możliwością wycofania amerykańskich wojsk stacjonujących na Starym Kontynencie. Jednocześnie należało przyznać sojusznikom większy wpływ na planowanie i podejmowanie decyzji w NATO. Był jednak przeciwnikiem wykorzystywania struktur tej organizacji jako forum konsultacji lub instrumentu dyplomacji. Motywował to militarnym charakterem i brakiem elastyczności tej organizacji.

Przyszły doradca Nixona apelował o „wspólną koncepcję polityczną” twierdząc, że „nie jest czymś naturalnym, że główne decyzje dotyczące obrony obszaru tak potencjalnie wpływowego jak Europa Zachodnia są podejmowane trzy tysiące mil od niego" ${ }^{\prime 2}$. Jednak w przeciwieństwie do Nixona utrzymywał, że nawet zjednoczona Europa nie miała wizji polityki globalnej, więc powinna przyjmować amerykańskie koncepcje w tym zakresie, zamiast podejmować próby ich torpedowania. Uważał, że takie niezależne i niekontrolowane działania mogły być destrukcyjne dla amerykańskiego interesu narodowego. Popierał pogłębienie integracji europejskiej, ale ostrzegał, że amerykańska dyplomacja nie powinna podejmować prób wpływania na ten proces - Europejczycy muszą sami ustalić jego zasady. Naciski amerykańskie mogłyby tylko to utrudniać ${ }^{13}$. Europa niekoniecznie musi być zjednoczona na sposób federalny, by być partnerem USA. Twierdził, powołując się na przykład blokowania przez de Gaulle’a członkostwa Wielkiej Brytanii we Wspólnotach, że państwom europejskim było jeszcze daleko do politycznej jedności. Zauważył, że skupiają się one na kwestiach gospodarczych, by uniknąć „arcytrudnego” zagadnienia koordynacji politycznej ${ }^{14}$. Dzieje Europy wskazywały, że pokój na Starym Kontynencie zależy od harmonijnej współpracy między Wielką Brytanią, Francją i Niemcami. Stany Zjednoczone muszą działać, by nie dopuścić do rywalizacji między nimi. Nie mogą wyróżniać jednego państwa-partnera, gdyż mogło to doprowadzić do sytuacji, że będzie ono musiało wybierać między sojuszem ze Stanami Zjednoczonymi a poprawnymi relacjami z Francją. Kissinger miał na myśli zaniechanie podkreślania tradycyjnych „specjalnych stosunków" z Wielką Brytanią, jednocześnie nazywając Francję głównym oponentem polityki amerykańskiej w Europie Zachodniej. W związku z tym oceniał, że Stanom Zjednoczonym lepiej będzie współpracować z Europą zjednoczoną w konfederacji, niż ze ściśle zintegrowanym „bliźniaczym filarem” sojuszu. Wtedy Amerykanie będą mogli utrzymać wpływ na wiele centrów decyzyjnych, a nie przekonywać jedno ponadnarodowe ciało ${ }^{15}$.

\footnotetext{
12 Ibidem, s. 38.

${ }^{13}$ Ibidem, s. 40.

${ }^{14}$ Ibidem, s. 236.

${ }^{15}$ Ibidem, s. 242.
} 
Kissinger uważał za szczególnie istotną koordynację polityki wobec bloku wschodniego. Sugerował, że alianci powinni wziąć odpowiedzialność za poprawę relacji z krajami Europy Środkowowschodniej, zostawiając stosunki z ZSRR w gestii Stanów Zjednoczonych. Twierdził, że było to konieczne, gdyż zachodni Europejczycy mogliby ugiąć się pod sowiecką presją, krzyżując plany Amerykanów, zdolnych rozmawiać ze wschodnim supermocarstwem z pozycji siły ${ }^{16}$. Wyartykułował potrzebę ulepszenia mechanizmów konsultacyjnych i przyznawał, że Stany Zjednoczone często działały unilateralnie (np. narzucając zmiany doktryn strategicznych NATO), co powodowało osłabienie wzajemnego zaufania. „W następnej dekadzie stawianie Stanów Zjednoczonych w roli jedynego architekta polityki atlantyckiej nie będzie już możliwe [...]. Wprowadzenie równowagi pomiędzy integracją a autonomią będzie największym wyzwaniem dla nowych stosunków atlantyckich" - konkludował Kissinger ${ }^{17}$. Mimo deklaracji o konieczności ustanowienia partnerskich relacji, w jego poglądach wyraźnie przebija chęć utrzymania kontroli nad sojusznikami poprzez wpływy na poszczególne rządy, by wyegzekwować decyzje jak najbardziej zgodne z amerykańskim interesem. W tym kontekście jest wątpliwe, czy Kissinger naprawdę zadał słynne pytanie o telefon do Europy ${ }^{18}$. Peter Rodman, jego bliski współpracownik w NSC twierdził, że na pewno nie było to zgodne z jego zapatrywaniami ${ }^{19}$.

Poglądy Nixona i Kissingera na przyszłą politykę wobec sojuszników z NAT0, choć różniły się w paru kwestiach, zdawały się obiecujące dla krajów Europy Zachodniej. Lecz wciąż to Stany Zjednoczone narzucały warunki współpracy, przewidując dla Europejczyków możliwość działania tylko w ramach ściśle określonych obszarów. Warto też pamiętać, że w dobie détente priorytetami dla amerykańskiej polityki zagranicznej były jednak relacje z ZSRR i Chinami. Na tym polu Amerykanie potrzebowali europejskiego wsparcia lub choćby pewności, że sojusznicy nie będą działać na arenie międzynarodowej bez porozumienia z nimi. Stąd też w przedstawionych wyżej założeniach dominuje aspekt polityczny. Nixon zwracał wprawdzie uwagę na gospodarczą siłę Europy Zachodniej, nie czynił tego jednak w kontekście obaw przed rywalizacją - raczej uznawał za dowód możliwego partnerstwa. Wątek ekonomiczny w relacjach transatlantyckich bardzo rzadko był obecny także w wywodach Kissingera z lat 60. Tymczasem kwestii gospodarczych nie sposób pominąć, bowiem w coraz większym stopniu wpływały na całość relacji między Stanami Zjednoczonymi a Europą Zachodnią.

${ }^{16}$ H. K i s s in g e r, White House Years, Boston 1979, s. 94.

${ }^{17}$ H. K i s s in g e r, Central Issues of American Foreign Policy, [w:] American Foreign Policy: Three Essays, New York 1969, s. 79.

18 „Do kogo mam zadzwonić, jeśli chcę rozmawiać z Europą?” (Who do I call if I want to speak to Europe?) - miał zapytać Kissinger.

${ }^{19}$ R. J. L i e b e r, The European Union and the United States: Threats, Interests and Values, s. 17, dostępny przez: aei.pitt.edu/9577/01/ACES_paper-Lieber.pdf. 


\subsection{Podejmowanie decyzji w polityce zagranicznej}

Za kadencji Nixona pozycja Departamentu Stanu była stosunkowo słaba. Prezydent, posiadający doświadczenie w kontaktach z zagranicą, traktował priorytetowo osobistą kontrolę nad amerykańską dyplomacją. Ustawa o bezpieczeństwie narodowym (National Security Act) z 1947 r. stworzyła mechanizm pozwalający prowadzić politykę zagraniczną z Białego Domu. Rada Bezpieczeństwa Narodowego (National Security Council - NSC), powołana do koordynacji tego procesu, była forum planowania i formułowania rekomendacji dla prezydenta ${ }^{20}$. Nixon polegał w największym stopniu na opinii doradcy ds. bezpieczeństwa narodowego - Henry'ego Kissingera ${ }^{21}$.

System funkcjonowania NSC w tym okresie zmienił się, choć wykorzystano elementy wprowadzane przez Eisenhowera i Johnsona. Grupa doradcza wyższych urzędników z różnych departamentów (Senior Interdepartment Group - SIG), istniejąca za kadencji Johnsona, została zastąpiona przez Grupę Badawczą NSC (NSC Review Group) oraz Komitet Podsekretarzy (NSC Under Secretaries Committee). Przy formułowaniu dyrektyw NSC korzystała z raportów międzydepartamentalnych grup roboczych (Interdepartment Groups). Powstała nowa struktura doradcza, dająca większe kompetencje doradcy ds. bezpieczeństwa narodowego kosztem prerogatyw Departamentu Stanu. Kissinger przewodniczył Grupie Badawczej, która przygotowywała dokumenty przed poddaniem ich pod obrady NSC. Pisał podsumowania wszystkich proponowanych opcji i praktycznie decydował, które z nich zostaną przedstawione prezydentowi. Współpracownicy Kissingera przygotowywali także projekt strategii bezpieczeństwa, streszczali dokumenty agencji rządowych i podejmowali studia nad rozwiązywaniem poszczególnych problemów. W wyniku tych prac powstawały memoranda (National Security Study Memoranda - NSSM), przedstawiające konkretne kwestie i opcje działań, wraz z plusami i minusami wymienianych rozwiązań. Za zgodą prezydenta, Kissinger opracowywał memoranda decyzyjne dotyczące bezpieczeństwa narodowego (National Security Decision Memorada - NSDM). NSC przygotowywała również raporty dotyczące polityki zagranicznej, przedstawiane rokrocznie Kongresowi przez prezydenta. W erze Kissingera niemal potrojono liczebność członków NSC (z 12 do 34). Departament Stanu, na którego czele stał William Rogers, był zdecydowanie na drugim planie w kreowaniu polityki zagranicznej USA ${ }^{22}$. Nawet Komitet Podsekretarzy, któremu

${ }^{20}$ Przewodniczącym NSC był prezydent. Regularny udział w jej obradach brali: wiceprezydent, sekretarze stanu, skarbu, obrony i doradca prezydenta ds. bezpieczeństwa narodowego, a także szef połączonych sztabów i szef wywiadu. Na jej obrady mogli też być zaproszeni inni wysocy urzędnicy, w zależności od charakteru omawianych spraw.

${ }^{21}$ J. A. G a r r i s o n, Games Advisors Play. Foreign Policy in the Nixon and Carter Administrations, College Station 1999, s. 4.

${ }^{22}$ Ibidem, s. 7-9. Zobacz także: D. A c h e s o n, The Eclipse of the State Department, „Foreign Affairs", July 1971, s. 594-606. 
przewodniczył podsekretarz stanu, stopniowo tracił na znaczeniu. Jednocześnie rozrastała się skomplikowana struktura komitetów w ramach NSC, które były kontrolowane przez Kissingera.

Kissinger twierdził, że Nixon celowo desygnował Rogersa, mało doświadczonego w kwestiach polityki zagranicznej, by podkreślić, że to prezydent będzie kontrolował relacje między Departamentem Stanu a NSC, a przede wszystkim będzie nadzorował politykę zagraniczną. Jednak to Kissinger najczęściej towarzyszył prezydentowi podczas rozmów na najwyższym szczeblu i był wysyłany z kluczowymi misjami dyplomatycznymi. Dzięki specjalnie utworzonym tajnym kanałom dyplomatycznym Departament Stanu był nieświadomy wielu działań amerykańskiej dyplomacji. Między doradcą ds. bezpieczeństwa narodowego i sekretarzem stanu utrzymywała się nieprzyjazna rywalizacja, kontakty miały charakter czysto formalny, nie było mowy o konstruktywnej dyskusji prowadzącej do ustalanie jednolitej strategii.

Według Michaela Raoula-Duvala, członka personelu Białego Domu, „Nixon nie ufał Departamentowi Stanu pod kierownictwem Billa [Williama] Rogersa"23, a najważniejsze decyzje były podejmowane w Białym Domu. Kenneth Rush, ambasador w RFN w latach 1969-1972 wspominał, że nigdy nie ustalał spotkań z prezydentem za pośrednictwem Departamentu Stanu, lecz pośrednikiem był Kissinger, zwykle obecny przy tych rozmowach. Twierdził również, że brak zaufania dla Rogersa wynikał z podejrzeń Nixona, że Departament Stanu dopuszcza do „przecieków” ważnych informacji do prasy. Rush utrzymywał jednak, że to „Henry [Kissinger] był mistrzem manipulacji mediami”24 i to od niego pochodziło większość informacji o polityce zagranicznej, które wykorzystywali dziennikarze.

22 września 1973 r. Kissinger został sekretarzem stanu, jednocześnie utrzymując stanowisko prezydenckiego doradcy ds. bezpieczeństwa narodowego. Jego pozycja została jeszcze bardziej umocniona.

Analizując amerykańską politykę zagraniczną, należy również pamiętać o roli Kongresu. Jego opinia nie tylko z założenia odzwierciedla oczekiwania opinii publicznej, ale także ją kształtuje. Według amerykańskiej konstytucji, Kongres odgrywał szczególną rolę w kształtowaniu relacji gospodarczych z zagranicą (artykuł I, sekcja VIII) ${ }^{25}$. Podczas kadencji Nixona, wraz z intensyfikacją tych relacji, a tym samym większych rozbieżności z partnerami, wpływ Kongresu w tej dziedzinie był znaczący. Często stał on w opozycji wobec planów administracji. Członkowie legislatywy uskarżali się regularnie na brak informacji ze strony administracji, koniecznych do podejmowania adekwatnych do sytuacji decyzji ${ }^{26}$.

${ }^{23}$ M. R a o u l - D u v a l, Foreign Policy and the Bureaucracy, [w:] Portraits of American Presidents, vol. 6: The Nixon Presidency, ed. K.W. Thompson, Lanham 1987, s. 285.

${ }^{24}$ K. R u s h, An Ambassador's Perspective, [w:] Portraits of American Presidents..., s. 337.

25 Tekst polski Konstytucji Stanów Zjednoczonych Ameryki można odnaleźć np. [w:] G. B. T in d a l l, D. E. S h i, Historia Stanów Zjednoczonych, Poznań 2002, s. 1399-1415.

${ }^{26}$ J. K. J a v i t s, The Congressional Presence in Foreign Relations, „Foreign Affairs”, January 1970, s. $225,230-234$. 


\subsection{Pierwsza wizyta Nixona w Europie}

Poprzednik Nixona na urzędzie prezydenta, Lyndon B. Johnson, rzadko składał wizyty zagraniczne, a jeśli wyjeżdżał, to najczęściej w celu dyskutowania problemu wojny wietnamskiej. Nixon był zdania, że z tego powodu europejscy przywódcy mogli czuć się ignorowani. Dlatego zdecydował się na podróż po stolicach zachodnioeuropejskich tuż po inauguracji ${ }^{27}$. Zadeklarował, że głównym celem wizyty miało być potwierdzenie zaangażowania we wzmocnienie relacji transatlantyckich, a przede wszystkim - zdefiniowanie wspólnych celów. Zapewniał, że „przyszłość krajów Europy Zachodniej nie może być projektowana tylko w Stanach Zjednoczonych. Mam zamiar dyskutować, a nie proponować; jadę pracować, a nie uczestniczyć w ceremoniale"28. Przekonywał, że wizyta ta rozpocznie serię spotkań i konsultacji. Jednak przyznawał także, że nie oczekuje po rozmowach z przywódcami rozwiązania wszystkich problemów w relacjach transatlantyckich. Według Roberta Dalleka, Nixon dzięki wizycie chciał wykreować swój wizerunek przywódcy wolnego świata i zwiększyć autorytet. Stany Zjednoczone miały w tym czasie wiele trudnych do rozwiązania kwestii w polityce zagranicznej, a Europa wydawała się nowemu prezydentowi obszarem, na którym można było łatwo udowodnić, że był on zdolny nadać nową jakość stosunkom międzynarodowym ${ }^{29}$.

W zleconym przez Nixona raporcie ekspertów z 1969 r. zatytułowanym Foreign Economic Trends („Trendy gospodarcze za granicą”) zauważono, że nie można było dłużej mówić o podziale między relacjami politycznymi i gospodarczymi z zagranicą. Wynikało to z coraz ściślejszej i bardziej złożonej interakcji między handlem zagranicznym, międzynarodowymi inwestycjami i wewnętrzną polityką gospodarczą oraz coraz wyraźniejszą skłonnością Europy do protekcjonizmu i zawierania preferencyjnych umów handlowych z krajami trzecimi ${ }^{30}$. Jednak Nixon wiedział, że poruszenie tych problemów zniweczyłoby cel jego wizyty. Z drugiej strony zdawał sobie sprawę, że drażliwe problemy, głównie o podłożu gospodarczym, mogły w decydujący sposób wpłynąć na kształt relacji transatlantyckich. W żadnym wypadku nie było możliwe uniknięcie rozmów na te tematy w niedalekiej przyszłości.

Nixon przebywał w Europie od 24 lutego do 2 marca 1969 r. W tym czasie odwiedził kolejno: Brukselę, Londyn, Bonn, Berlin Zachodni, Rzym i Paryż. W siedzibie

${ }^{27}$ W. B u n dy, A Tangled Web. The Making of Foreign Policy in the Nixon Presidency, London 1998, s. 59. Tad Szulc zauważył, że także John F. Kennedy złożył pierwszą wizytę zagraniczną właśnie w Europie w czerwcu 1961 r. Nixon bardzo cenił umiejętność Kennedy’ego utrzymywania dobrych relacji z zagranicznymi przywódcami i zdobywania ich zaufania (T. S z u lc, The Illusion of Peace. Foreign Policy in the Nixon Years, New York 1978, s. 32).

${ }^{28}$ PPP, Richard Nixon, vol. 1, oświadczenie w sprawie wizyty w Europie Zachodniej, 6 lutego 1969, dok. 35.

${ }^{29}$ R. D a l l e k, Nixon and Kissinger. Partners in Power, New York 2007, s. 112.

${ }^{30}$ FRUS, 1969-1976, vol. 3: Foreign Economic Policy, 1969-1972; International Monetary Policy, 1969-1972, Washington D.C. 2002, opinia konsultantów, dok. 26. 
NAT0 w Brukseli, przemawiając przed Radą Północnoatlantycką, przedstawił plan rozpoczęcia rozmów rozbrojeniowych z ZSRR zapewniając, że będą one poprzedzone konsultacjami z członkami NATO i nic nie zostanie uzgodnione bez ich wiedzy. Zauważył również konieczność zmian funkcjonowania Sojuszu, odzwierciedlających rosnącą pozycję gospodarczą krajów zachodnioeuropejskich. Nie biorąc pod uwagę poglądów Kissingera, uznał spotkania NATO za właściwe forum do kształtowania wspólnej polityki ${ }^{31}$. Te deklaracje uspokoiły Europejczyków obawiających się, że spotkania na szczycie USA-ZSRR mogły doprowadzić do ustanowienia swoistego „kondominium” w polityce światowej, co spowodowałoby spadek zainteresowania Amerykanów sprawami europejskimi i zmniejszenie motywacji do obrony Starego Kontynentu. Co do kwestii powiększenia wydatków na obronę, Europejczycy dostrzegali taką konieczność, lecz politycy zgromadzeni w Brukseli sceptycznie odnosili się do możliwości zmian budżetowych w swoich krajach, dlatego utrzymywali, że siły amerykańskie nie powinny być redukowane ${ }^{32}$.

Nixon był szczególnie zadowolony z wizyty w Londynie. Zapewnił brytyjskiego premiera Harolda Wilsona, że między ich krajami wciąż istnieją „specjalne stosunki"33. Podczas spotkania z członkami brytyjskiego rządu Nixon rozmawiał o przyszłości NATO, stosunkach Wschód-Zachód i perspektywie przystąpienia Wielkiej Brytanii do Wspólnot Europejskich. Oświadczył, że nie będzie starał się wywrzeć presji na de Gaulle'a, by tym razem Francja nie sprzeciwiła się rozszerzeniu integracji, gdyż mogło to odnieść skutek przeciwny do zamierzonego. Wilson był zadowolony z postawy amerykańskiej. Tłumaczył niemożność zwiększenia przez jego kraj wydatków na obronę silnym oporem społecznym. Premier obawiał się, że wzmocnienie militarne Europy mogło spowodować stopniowe wycofywanie wojsk amerykańskich ze Starego Kontynentu. Brytyjczycy mówili z niepokojem o przyszłych negocjacjach USA z ZSRR i ograniczeniu broni strategicznych. Nixon jednak zapewnił, że będą one prowadzone bez pośpiechu w celu uzyskania jak najlepszych warunków ${ }^{34}$.

Relacje z RFN były kluczowe dla dyplomacji amerykańskiej, ponieważ kraj ten stanowił najbardziej prawdopodobny cel ewentualnego ataku ZSRR. Waszyngton patrzył z niepokojem na samodzielną politykę wschodnią prowadzoną przez kanclerza Willy'ego Brandta. Niemcy Zachodnie były najsilniejszym gospodarczo państwem w EWG, a tym samym potencjalnym rywalem USA. Politycy zachodnioniemieccy, mimo dobrych relacji z USA, byli w tym czasie rozdrażnieni wymaganymi przez Waszyngton rekompensatami za stacjonowanie na ich terytorium sił amerykańskich ${ }^{35}$. Nixon apelował do Niemców, by przyczyniali się do umacniania sił NATO

${ }^{31}$ PPP, Richard Nixon, vol. 1, uwagi wygłoszone na forum Rady Północnoatlantyckiej w Brukseli, 24 lutego 1969, dok. 68.

${ }^{32}$ H. K i s s in g e r, White House Years..., s. 79.

${ }^{33}$ PPP, Richard Nixon, vol. 1, uwagi przy wyjeździe z Wielkiej Brytanii, 26 lutego 1969, dok. 76.

${ }^{34} \mathrm{H}$. K i s s in g e r, White House Years..., s. 95.

${ }^{35}$ Ibidem, s. 97. 
i stabilizacji gospodarczej na świecie. Osobną kwestią było amerykańskie poparcie dla bezpieczeństwa i niezależności Berlina Zachodniego. W lutym 1969 r. ZSRR utrudniał dostęp do miasta, gdyż nie chciał dopuścić, by wybory prezydenta RFN odbyły się w Berlinie Zachodnim ${ }^{36}$. Nixon po raz kolejny potwierdził niezmienne zaangażowanie USA w tę sprawę. Dał do zrozumienia, że Niemcy nie powinni się uginać pod żadną presją i zostawiać Amerykanom negocjacje z ZSRR. Zapewnił, że będą one poprzedzone konsultacjami z politykami z Bonn ${ }^{37}$.

W Rzymie Nixon poświęcił wiele miejsca w swoich wystąpieniach publicznych kwestii amerykańskiego poparcia dla europejskiej jedności. Odbył także rozmowy z prezydentem Giussepe Saragatem i premierem Mariano Rumorem. Włosi, podobnie jak inni przywódcy europejscy, nakłaniali Nixona do jak najszybszego rozpoczęcia rozmów z ZSRR ${ }^{38}$. Ostatnim, ale uznawanym przez Nixona za najważniejszy ${ }^{39}$, przystankiem w europejskiej podróży był Paryż. Z powodu decyzji de Gaulle'a o wycofaniu sił francuskich spod dowództwa NAT0 w 1966 r., stosunki amerykańsko-francuskie pozostawały napięte. Nixon miał bardzo dużo szacunku dla francuskiego prezydenta - sądził, że jest wielkim mężem stanu i pragnął poprawy relacji. Francuskie próby aktywizacji Europejczyków w polityce światowej również wydawały się zharmonizowane z amerykańskim celem. Podczas pobytu Nixona w Paryżu obaj prezydenci spotykali się wielokrotnie - oficjalnie i prywatnie. De Gaulle uważał, że Stany Zjednoczone powinny jak najszybciej skonstruować plan wycofania się z Wietnamu i nie pozwolić, by ChRL pozostawała w izolacji. Zaoferował pomoc w rozpoczęciu negocjacji z obydwoma krajami. Trzeba podkreślić, że de Gaulle nie myślał wcale, że kraje komunistyczne były gotowe do demokratycznych reform, ale postrzegał dialog z nimi jako absolutną koniecznośćc ${ }^{40}$. Według Tada Szulca, tajne rozmowy Kissingera z politykami Wietnamu Północnego i Chin miały swój początek po wizycie Nixona w Paryżu, gdyż de Gaulle dotrzymał słowa i ułatwił nawiązanie kontaktów ${ }^{41}$. Francuski prezydent stwierdził także, że ZSRR nie stanowił już tak poważnego zagrożenia dla Europy Zachodniej, jak po II wojnie światowej - jego władze były zajęte głównie napięciami w stosunkach z Chinami. Dlatego też Moskwie zależało na pokojowych kontaktach z Zachodem. Zdaniem de Gaulle’a, Stany Zjednoczone powinny wykorzystać tę okazję. Stwierdził, że

36 Dzięki propozycji Nixona rozpoczęcia negocjacji czterech sygnatariuszy układów poczdamskich na temat Berlina, wybory prezydenckie zostały przeprowadzone bez przeszkód w marcu $1969 \mathrm{r}$.

${ }^{37}$ PPP, Richard Nixon, vol. 1, przemówienie w Bundestagu w Bonn, 26 lutego 1969, dok. 78; przemówienie w fabryce Siemensa w Berlinie Zachodnim, 27 lutego 1969, dok. 82. Por. P. D i c k s o n, Kissinger and the Meaning of History, Cambridge 1978, s. 112.

${ }^{38}$ PPP, Richard Nixon, vol. 1, uwagi przy wyjeździe z Rzymu, 28 lutego 1969, dok. 86.

${ }^{39} \mathrm{~W}$ swoich wspomnieniach Nixon opisał szczegółowo z całej europejskiej wizyty tylko pobyt w Paryżu (R. N i x o n, The Memoirs of Richard Nixon, New York 1978, s. 371).

${ }^{40}$ R. N i x o n, The Memoirs..., s. 373.

${ }^{41}$ T. S z u l c, op. cit., s. 34. 
Europejczycy nie wierzyli w natychmiastowe użycie przez Amerykanów siły nuklearnej w ich obronie. Uważał to za główny powód wzajemnej nieufności ${ }^{42}$. Nixon był mile zaskoczony szczerą rozmową i przyjaznym traktowaniem. Zaproponował de Gaulle'owi ominięcie oficjalnych kanałów dyplomatycznych w dwustronnych konsultacjach, szczególnie w kwestiach monetarnych. Amerykański prezydent podkreślił, że nie oferował takiego rozwiązania ani Brytyjczykom, ani Niemcom, sugerując istnienie „specjalnych relacji” z de Gaullem ${ }^{43}$. Stosunki amerykańskofrancuskie, przynajmniej w kontaktach liderów obu państw, uległy rzeczywiście wyraźnej poprawie. Dowodem na to była wizyta de Gaulle’a na obiedzie w amerykańskiej ambasadzie ${ }^{44}$.

Głównym celem europejskiej wizyty Nixona miało być stworzenie nowej jakości w kontaktach z sojusznikami z NATO i przywrócenie zaufania. Z tego punktu widzenia zakończyła się ona sukcesem. Nixon zrobił dobre wrażenie na europejskich przywódcach dzięki swojemu doświadczeniu i solidnej wiedzy na temat sytuacji międzynarodowej, a także poprzez zapewnienie o wysokiej randze sojuszu atlantyckiego w polityce USA ${ }^{45}$. Deklaracja de Gaulle'a, dotycząca pomocy w nawiązaniu kontaktów z Wietnamem Północnym i ChRL może stanowić przykład efektywności głoszonej przez Nixona polityki konsultacji. Charakterystyczne jest, że nie poruszał on, przynajmniej publicznie, problemu narastającej rywalizacji ekonomicznej, która budziła duży niepokój za Oceanem i była szeroko dyskutowana przez członków amerykańskiej administracji.

\subsection{Sytuacja gospodarcza w Stanach Zjednoczonych i jej wpływ na relacje transatlantyckie}

Nowa administracja musiała zmagać się z problemami gospodarczymi. Od czasu objęcia prezydentury przez Nixona w Stanach Zjednoczonych wzrastała inflacja, bezrobocie i deficyt bilansu płatniczego (BOP). Konkurencyjność gospodarki amerykańskiej zaczęła maleć na rzecz krajów Europy Zachodniej i Japonii. Według Kissingera, powodowało to napięcia w relacjach transatlantyckich na skalę niespotykaną w latach $60 .{ }^{46}$ Nixon wobec tego podkreślał konieczność zmiany zasad sojuszu atlantyckiego i zapowiedział działania zgodne z interesem narodowym USA. Kwestie gospodarcze przyczyniały się do osłabienia solidarności z sojusznikami, co sprzyjało ujawnianiu się dotychczas drugoplanowych rozbieżności.

\footnotetext{
${ }^{42}$ R. N i x o n, The Memoirs..., s. 374.

${ }^{43}$ FRUS, 1969-1976, vol. 3, memorandum rozmowy Nixona z de Gaullem w Paryżu, 2 marca 1969, dok. 7.

${ }^{44}$ W. B u n d y, op. cit., s. 59.

${ }^{45}$ Ibidem, s. 60.

${ }^{46}$ H. K i s s in g e r, White House Years..., s. 418.
} 
Istotnym problemem gospodarki amerykańskiej była rosnąca inflacja ${ }^{47}$. Ponadto deficyt bilansu płatniczego USA spowodował spadek zaufania do dolara. Państwa europejskie zaczęły domagać się wymiany zgromadzonych rezerw dolarowych na złoto. Tymczasem zadłużenie rządu amerykańskiego było dwukrotnie wyższe niż posiadane rezerwy złota. Niemal automatycznie spowodowało to inflację, która za pośrednictwem dolara została „wyeksportowana” do krajów dokonujących rozliczeń w amerykańskiej walucie ${ }^{48}$. Stany Zjednoczone odrzucały możliwość dewaluacji dolara, opowiadając się za systemem opartym na ustalonych, ulegających zmianom tylko w wyjątkowych wypadkach, kursach wymiany ${ }^{49}$. Tymczasem nadal spadało zaufanie do amerykańskiej waluty. Inwestorzy pozbywali się jej, lokując kapitał w złocie, którego cena na wolnym rynku wzrosła do 40 USD za uncję. Wystąpiła też spekulacja na kursie DM, gdyż do RFN napłynęło bardzo dużo dolarów ${ }^{50}$.

Europejscy liderzy byli zaniepokojeni, że malejące zaufanie do USD zachwieje międzynarodowym systemem walutowym i zmniejszy wartość ich rezerw. W każdej chwili spodziewano się, że rząd amerykański zdecyduje się na dewaluację dolara, by poprawić bilans płatniczy i zmniejszyć inflację. Z kolei Amerykanie obawiali się, że zachodnioeuropejskie banki centralne zażądają wymiany ogromnych rezerw na złoto, którego zabrakłoby w amerykańskim skarbcu. To spowodowałoby upadek całego systemu monetarnego, z niewyobrażalnymi konsekwencjami dla gospodarki światowej. Dlatego Amerykanie chcieli, żeby państwa europejskie powstrzymywały się od wymiany dolarów na złoto. Woleliby, żeby Europejczycy kupowali amerykańskie towary lub dokonali rewaluacji własnych walut. Takie działania poprawiłyby konkurencyjność amerykańskiego eksportu i przyczyniłyby się do zmniejszenia deficytu w bilansie płatniczym ${ }^{51}$.

Rządy europejskie, będąc pod polityczną presją, mogły rozważać zgodę na takie warunki, lecz pozostawali jeszcze prywatni inwestorzy. Zaczęli oni sprzedawać posiadane dolary i nabywać inne waluty, najczęściej niemiecką markę. Taka spekulacja oznaczała jeszcze większe zagrożenie inflacyjne dla USA ${ }^{52}$.

${ }^{47}$ Stopa inflacji w Stanach Zjednoczonych wynosiła 1,5\% w 1965 r., w 1966 r. - 3\%, w 1967 r. 2,8\%, w 1968 r. - 4,2\%, a w 1969 r. już 5,4\%. Dane dostępne przez: http://inflationdata.com.

${ }^{48}$ D. A. Walker, Some Underlying Problems for International Monetary Reform, [w:] The United States and Western Europe. Political, Economic and Strategic Perspectives, ed. W. F. Hanrieder, Cambridge, Mass. 1974, s. 166-168.

${ }^{49}$ C. F. B e rg ste n, R. O. Ke o h a n e, J. S. N y e, International Economics and International Politics. A Framework for Analysis, [w:] World Politics and International Economics, eds. C. F. Bergsten, L. B. Krause, Washington 1975, s. 3.

${ }^{50}$ G. M. M e i e r, International Economics. The Theory of Policy, New York 1980, s. 133.

${ }^{51}$ D. P. C a ll e o, Since 1961. American Power in a New World Economy, [w:] Economics and the World Power. An Assessment of American Diplomacy since 1789, eds. W. H. Becker, S. F. Wells, Jr, New York 1984, s. 379-410.

52 Ibidem, s. 394. 
Amerykańscy eksperci alarmowali, że Stany Zjednoczone, podtrzymując stały kurs wymiany dolara, płacą za realizację europejskich celów gospodarczych i tym samym wspierają najgroźniejszych konkurentów. Twierdzili, że jak najszybciej należało wprowadzić SDR-y, oparte na wielu walutach, jako jednostkę rozrachunkową i rezerwową. Miały one zastąpić złoto, a fakt, że nie będą zależne od jednej waluty miał doprowadzić do uzdrowienia systemu ${ }^{53}$. Podobne stanowisko zajął C. Fred Bergsten, doradca Kissingera do spraw zagranicznej polityki gospodarczej. Zauważał on konieczność jak najszybszej reformy światowego systemu monetarnego argumentując, że istniejący powoduje problemy o charakterze politycznym w poszczególnych krajach ${ }^{54}$.

Deficyt bilansu płatniczego stanowił istotny problem gospodarki amerykańskiej. Wzrastał on głównie ze względu na duże koszty utrzymywania sił militarnych na całym świecie - największą rolę odgrywały wydatki na wojnę w Wietnamie - i odpływ kapitału spowodowany stosunkowo niskimi stopami procentowymi w Stanach Zjednoczonych. W tym przypadku należy również brać pod uwagę inwestycje amerykańskie w Europie, szybko rosnące mimo restrykcji ograniczających eksport kapitału, nałożonych przez Kongres w latach $60 .{ }^{55}$

Ta tendencja była zresztą również niepokojąca dla krajów Starego Kontynentu. Europejczycy twierdzili, że Amerykanie przejmują zbyt wiele przedsiębiorstw, co w ich mniemaniu groziło utratą niezależności ich gospodare ${ }^{56}$. Rzeczywiście, w gospodarce atlantyckiej dominowały międzynarodowe korporacje, mające korzenie w Stanach Zjednoczonych.

Napływ amerykańskich inwestycji bezpośrednich (BIZ) do Europy był imponujący: w latach 1958-1968 wzrosły one z 2 mld USD do 13 mld. Dalsze spadki stóp procentowych w USA w latach 1969-1970 powiększały pulę tzw. eurodolarów ${ }^{57}$, co utrud-

${ }^{53}$ FRUS, 1969-1976, vol. 3, opinia konsultantów, dok. 26.

${ }^{54}$ C. F. B ergsten, International Monetary Reform and U.S. Balance of Payments, [w:] U.S. Foreign Economic Policy for the 1970s: A New Approach to New Realities. A Policy Report by An National Planning Association Advisory Committee, Washington 1971, s. 114. Największy deficyt bilansu płatniczego USA odnotowały na początku lat 70. W $1970 \mathrm{r}$. wynosił on 9,8 mld USD, w $1971 \mathrm{r}$. już 29,8 mld., w 1972 r. odnotowano nadwyżkę 10,2 mld (W. M. S c a m m e l l, The International Economy since 1945, New York 1980, s. 181).

${ }^{55} \mathrm{~W} 1968$ r. prezydent Johnson wydał rozporządzenie wykonawcze (Executive Order) ustalające obowiązkowe pułapy dla inwestycji zagranicznych, żeby zatrzymać dolary w USA. Nie przyniosło to jednak ograniczenia wywozu kapitału na wielką skalę (W. M. S c a m m el l, op. cit., s. 181).

${ }^{56}$ FRUS, 1969-1976, vol. 3, Cooper i Bergsten do Kissingera, 28 stycznia 1969, dok. 3.

${ }^{57}$ Eurodolary to „dolary amerykańskie znajdujące się w bankach poza USA, lokowane za granicą lub pożyczone państwom trzecim" (Wielki słownik wyrazów obcych PWN, red. M. Bańko, Warszawa 2006, s. 337). Rynek eurodolarowy powstał w latach 60. Banki europejskie przechowywały duże ilości amerykańskiej waluty (był to skutek deficytu bilansu płatniczego USA). Poza tym, europejskie stopy procentowe od depozytów krótkoterminowych były znacznie wyższe niż w Stanach Zjednoczonych. Termin „eurodolary” jest używany współcześnie także wobec dolarów lokowanych w państwach pozauropejskich (Współczesna gospodarka światowa, red. A. Kisiel-Łowczyc, Gdańsk 1999, s. 165). 
niało Europejczykom stabilizację narodowych systemów monetarnych ${ }^{58}$. Europejczycy również chętnie lokowali kapitał w Stanach Zjednoczonych. Jednak ok. 75\% inwestorów stanowiły osoby prywatne, posiadające amerykańskie papiery wartościowe, niedążące do osiągnięcia kontroli nad amerykańskimi przedsiębiorstwami. W Europie inwestorami były głównie amerykańskie korporacje, których wartość produkcji za granicą przewyższała wartość eksportu USA (w 1967 r. czterokrotnie, a w 1969 r. już pięciokrotnie). Można z tego wyprowadzić wniosek, że działalność tych przedsiębiorstw była ważniejsza dla transakcji Stanów Zjednoczonych na rynku światowym niż handel zagraniczny. Dotyczyło to także dochodów amerykańskiego budżetu" ${ }^{59}$.

Tabela 3.1. Międzynarodowe transakcje Stanów Zjednoczonych (w mln USD)

\begin{tabular}{|c|c|c|c|c|c|c|c|c|}
\hline \multirow{2}{*}{ Rok } & \multicolumn{3}{|c|}{ Handel towarami } & \multirow{2}{*}{$\begin{array}{c}\text { Dochód } \\
\text { z inwestycji }\end{array}$} & \multirow{2}{*}{$\begin{array}{l}\text { Transakcje } \\
\text { militarne }\end{array}$} & \multirow{2}{*}{$\begin{array}{c}\text { Bilans } \\
\text { handlu } \\
\text { towarami } \\
\text { i usługami }\end{array}$} & \multirow{2}{*}{$\begin{array}{c}\text { Bilans } \\
\text { rachunku } \\
\text { bieżącego }\end{array}$} & \multirow{2}{*}{$\begin{array}{c}\text { Aktywa } \\
\text { zagraniczne } \\
\text { USA (odpływy } \\
\text { kapitału) }\end{array}$} \\
\hline & eksport & import & bilans & & & & & \\
\hline 1965 & 26461 & 21510 & 4951 & 5349 & -2122 & 8378 & 5431 & -5716 \\
\hline 1966 & 29310 & 25493 & 3817 & 5047 & -2935 & 6092 & 3031 & -7321 \\
\hline 1967 & 30666 & 26866 & 3800 & 5273 & -3226 & 5838 & 2583 & -9757 \\
\hline 1968 & 33626 & 32991 & 635 & 5990 & -3143 & 3693 & 611 & -10977 \\
\hline 1969 & 36414 & 35807 & 607 & 6043 & -3328 & 3524 & 399 & -11585 \\
\hline 1970 & 42469 & 39866 & 2603 & 6231 & -3354 & 5773 & 2331 & -9337 \\
\hline 1971 & 43319 & 45579 & -2260 & 7271 & -2893 & 2423 & -1433 & -12475 \\
\hline 1972 & 49381 & 55797 & -6416 & 8192 & -3420 & -1742 & -5795 & -14497 \\
\hline 1973 & 71410 & 70499 & 911 & 12153 & -2070 & 11224 & 7140 & -22874 \\
\hline 1974 & 98306 & 103811 & -5505 & 15503 & -1653 & 9392 & 1962 & -34745 \\
\hline
\end{tabular}

Źródło: J. E. S p e r o, The Politics of International Economic Relations, New York 1999, s. 138-139.

W Europie nie było formalnych ograniczeń inwestycji. Jednak władze Francji i Wielkiej Brytanii rozpatrywały poszczególne przypadki większych przepływów kapitału. Podejmując decyzję o dopuszczeniu zagranicznych przedsiębiorstw, rozważano, czy nie zagrażało to rodzimym firmom ${ }^{60}$. Poza tym, jako jedyna z EWG, Francja opowiedziała się za regulacją inwestycji na terenie całego EWG. Twierdzono, że amerykańskie korporacje były odpowiedzialne za napływ krótkoterminowego kapitału spekulacyjnego i używanie europejskich rynków kapitałowych do wy-

\footnotetext{
${ }^{58}$ R. A. P a s t o r, Congress and the Politics of U.S. Foreign Economic Policy (1929-1976), Berkeley 1980, s. 207.

${ }^{59}$ E. R. G o o d m a n, The Fate of the Atlantic Community, New York 1975, s. 452.

${ }^{60}$ J. E. S p e r o, The Politics of International Economic Relations, New York 1999, s. 129.
} 
kupywania francuskiego przemysłu. Francuzi zastrzegali sobie wprawdzie prawo odmowy przejęcia istniejących firm lub nowych inwestycji w kluczowych sektorach przemysłu, ale tak samo traktowali inwestycje europejskie, więc amerykańskie przedsiębiorstwa działające we Francji nie były dyskryminowane ${ }^{61}$.

Odpływ dolarów ze Stanów Zjednoczonych powodował presję, zarówno w USA, jak i w Europie, na wewnętrzną regulację ograniczającą działania zagraniczne biznesu. Szczególnie dotyczyło to odpływu kapitału i ograniczenia inwestycji amerykańskich w Europie ${ }^{62}$. Mimo zaniepokojenia wzrostem amerykańskich inwestycji, trudno było Europejczykom wprowadzać jakieś restrykcje. Amerykanie, mając trudności z inwestowaniem w jednym z krajów Wspólnot, przenosili się do innego, gdyż i tak mogli sprzedawać swe towary bez barier na terenie całego rynku Wspólnot ${ }^{63}$. Rząd amerykański chciał natomiast zmniejszać deficyt bilansu płatniczego przez nakładanie kontroli na odpływ kapitału z USA do Europy. Takie działanie było zgodne z założeniem teorii klasycznej ekonomii, że BOP jest kształtowany przez międzynarodowy handel. Było ono błędne w dobie ogromnych inwestycji: nie brano pod uwagę, że BIZ generują także duże dochody dla budżetu państwa, a blokada kapitału może zmniejszyć wpływy od wielonarodowych przedsiębiorstw. Dochody roczne z inwestycji zagranicznych tych przedsiębiorstw były o wiele większe niż ich roczny eksport kapitału ${ }^{64}$.

Nieporozumienia dotyczące warunków wymiany stanowiły jeden z najpoważniejszych problemów w stosunkach transatlantyckich. Ustalenie nowych zasad leżało w interesie Stanów Zjednoczonych. Nixon uważał, że należało je negocjować na zasadzie wzajemności, dlatego chciał otrzymać od Kongresu szerokie uprawnienia do znoszenia, podwyższania lub obniżania ceł. Ustawa o rozszerzaniu kontaktów handlowych (Trade Expansion Act) z 1962 r., chroniąca wolny handel, przestała obowiązywać w $1967 \mathrm{r}^{65}$

Należy wziąć pod uwagę bezprecedensowy wzrost wartości wymiany handlowej w latach 60 . oraz coraz ściślejsze powiązania między najbardziej uprzemysłowionymi krajami świata ${ }^{66}$. Można też było zauważyć upodabnianie się gospodarek,

${ }^{61}$ International Economic Relations of the Western World, 1959-1971, ed. A. Shonfield, vol. 1: Politics and Trade, London 1976, s. 155.

${ }^{62} \mathrm{~W}$ latach 60 . obustronne ograniczenia były jeszcze dość restrykcyjne, ale w kolejnej dekadzie wiele krajów europejskich bardziej otworzyło się na amerykańskie inwestycje. W Stanach Zjednoczonych ustawa regulująca zasady inwestycji (International Investment and Trade in Service Act) została przyjęta dopiero w 1976 r. (J. E. S p e r o, op. cit., s. 129).

${ }^{63}$ R. Vernon, The Economic and Political Consequences of Multinational Enterprise: An Anthology, Boston 1972, s. 178.

${ }^{64}$ W 1971 r. do budżetu Stanów Zjednoczonych wpłynęło 10 mld USD z podatków od przedsiębiorstw inwestujących za granicą. Kapitał, który został wyeksportowany w tym okresie stanowił tylko połowę tej sumy (E. R. G o o d m a n, op. cit., s. 453).

${ }^{65}$ S. Y. H a m m o nd, Changing Bargaining Relations in the Atlantic Alliance, [w:] The United States and Western Europe..., s. 225.

66 Obroty między najbardziej uprzemysłowionymi krajami zwiększyły się czterokrotnie w latach 1963-1973. 
np. występował podobny koszt pracy, produkcyjność itp. Powodowało to narastanie konkurencji w handlu, szczególnie samochodami, stalą, tekstyliami. Państwa uprzemysłowione rywalizowały o rynki zbytu i o intratne inwestycje na rynkach krajów rozwijających się ${ }^{67}$. Goodman pisał wręcz o integracji transatlantyckiego systemu gospodarczego. Miał na myśli współzależność i wrażliwość gospodarek poszczególnych państw na posunięcia innych członków ekonomicznej wspólnoty atlantyc$\mathrm{kiej}^{68}$. Ulegały także zmianie warunki brane pod uwagę przez tradycyjne teorie ekonomiczne. Zakładały one, że międzynarodowa aktywność gospodarcza opiera się na handlu. Każde państwo produkuje określone dobra, przeznaczone na eksport. Każdy specjalizuje się w tym, w czym może uzyskać przewagę na rynku, a sukces producentów przekłada się na dobrobyt danego kraju i kreuje w nim miejsca pracy. Pod koniec lat 60. nastąpił znaczny wzrost liczby przedsiębiorstw wielonarodowych $^{69}$, organizujących produkcję ponad granicami państwowymi. Korporacje, zamiast eksportować produkty, eksportowały kapitał, technologię i metody zarządzania. W takich operacjach granice nie stanowiły przeszkody, choć państwa starały się stosować środki ograniczające taką działalnośćc ${ }^{70}$.

Pod koniec lat 60. handel wewnętrzny w EWG rozwijał się bardzo dynamicznie. Odnotowywano coraz większe dysproporcje w porównaniu z wymianą z USA (tabela 3.2). Korzystne warunki, ustalone między zintegrowanymi państwami Starego Kontynentu, powodowały przesunięcie handlu. W lipcu $1968 \mathrm{r}$. wprowadzono wspólną taryfę celną, co utrudniało dostęp towarom amerykańskim na rynki państw EWG. Sprawiało to, że wartość wymiany transatlantyckiej stopniowo malała.

Tabela 3.2. Wartość wymiany handlowej wewnątrz EWG i EWG-USA (w mld USD)

\begin{tabular}{|l|c|c|}
\hline & EWG & EWG-USA \\
\hline Styczeń-marzec 1968 r. & 6,8 & 14,3 \\
\hline Styczeń-marzec 1969 r. & 8,5 & 12,0 \\
\hline
\end{tabular}

Źródło: D. C a ll e o, The Atlantic Fantasy: The U.S., NATO, and Europe, Baltimore 1970, s. 93.

Istotnym elementem sporu był handel produktami rolniczymi. W EWG obowiązywała Wspólna Polityka Rolna (Common Agriculture Policy - CAP), która weszła w życie 30 lipca 1962 r. Zabezpieczała ona wewnętrzny wolny handel tymi produktami. W jej ramach ustanowiono wspólny system wspierający dochody rolników przez coroczne ustalanie jednolitych cen na większość produktów. Istniały

\footnotetext{
${ }^{67}$ J. E. S p e r o, op. cit., s. 87.

${ }^{68}$ E. R. G o o d m a n, op. cit., s. 451.

${ }^{69}$ Raymond Vernon tak definiuje przedsiębiorstwo wielonarodowe: „grupa korporacji różnego pochodzenia narodowego złączonych wspólną własnością i podporządkowująca się wspólnej strategii zarządzania" (R. V e r n o n, op. cit., s. 19).

${ }^{70}$ E. R. G o o d m a n, op. cit., s. 452 .
} 
też preferencje dla dostaw wewnętrznych zapewniane przez minimalne ceny importowe, zakupy subsydiowane $\mathrm{w}$ celu uzyskania gwarantowanej ceny minimalnej, subsydia konsumenckie i eksportowe. Stosowano też kontyngenty importowe, wzmocnione w kilku wypadkach przez cła dla krajów trzecich. To sprawiało, że ceny produktów rolnych na terenie EWG były prawie dwukrotnie wyższe niż ceny na rynku światowym ${ }^{71}$. Z tego wynikała konieczność subsydiowania eksportu, by sprzedać nadwyżki, które powstawały w wyniku CAP.

Ustalenie takiej polityki było ważne dla integracji europejskiej, gdyż warunki rozwoju rolnictwa poszczególnych krajów Wspólnot bardzo się różniły. CAP powodowała spadek eksportu produktów rolnych ze Stanów Zjednoczonych o ok. 40\% ${ }^{72}$. W USA większość farm była nastawiona na eksport, więc CAP poważnie godziła $\mathrm{w}$ ich interesy. W latach 50 . organizacje zrzeszające rolników wywierały skuteczną presję, by zablokować ustawy protekcjonistyczne. W momencie wejścia w życie CAP zmieniły swą postawę. Ku protekcjonizmowi skłaniały się również związki zawodowe pracowników przemysłu. Kończyła się era nieograniczonego poparcia wewnętrznego w USA dla wolnego handlu ${ }^{73}$.

Kolejną kwestią sporną było podpisywanie przez EWG preferencyjnych umów handlowych z krajami śródziemnomorskimi, afrykańskimi, Bliskiego Wschodu, Ameryki Łacińskiej, a także państwami bloku wschodniego (z ZSRR włącznie). Łączyło się to z rozszerzeniem europejskich wpływów gospodarczych, powodowało napięcia w stosunkach z USA ${ }^{74}$. Było to postrzegane jako dyskryminacja amerykańskiego eksportu, sprzeczna z regułami GATT. Niezadowolenie z takiego stanu rzeczy ujawniało się również w Kongresie. Nixon brał pod uwagę te protesty. Szczególnie niepokojące było łączenie przyznania przez Europę korzystniejszych warunków wymiany z obecnością amerykańskich wojsk na Starym Kontynencie. Nawet kongresmani wcześniej przychylni utrzymaniu sił w Europie mogli zmienić zdanie, gdyż działania EWG godziły bezpośrednio w interesy ich wyborców ${ }^{75}$. Polityczna rola USA w dobie zimnej wojny wykluczała zdecydowane odwetowe poczynania wszak działałyby przeciw własnym sojusznikom. Konflikt handlowy uważano także za niebezpieczny ze względu na silne transatlantyckie powiązania gospodarcze. Jednak malejąca konkurencyjność powodowała wewnątrz USA naciski na wprowadzanie środków protekcjonistycznych ${ }^{76}$.

Europejczycy mieli zastrzeżenia dotyczące zagranicznej polityki handlowej USA. Postulowali, aby Amerykanie zrezygnowali z takich narzędzi promowania własnych produktów, jak „dobrowolne ograniczenia”, czyli kontyngenty importowe

${ }^{71}$ International Economic Relations of the Western World..., s. 308.

${ }^{72}$ H. B. M a lm gre n, Coming Trade Wars? (Neo-Mercantilism and Foreign Policy), „Foreign Policy", Winter 1970-1971, s. 121.

${ }^{73}$ Ibidem, s. 126.

${ }^{74}$ D. P. C a $1 \mathrm{l}$ e o, The Imperious Economy, Cambridge 1982, s. 122.

${ }^{75}$ FRUS, 1969-1976, vol. 3, Bergsten do Kissingera, 14 kwietnia 1969, dok. 19.

${ }^{76}$ D. P. C a l l e o, The Imperious Economy..., s. 127. 
na pewne kategorie żywności, akceptowane przez partnerów handlowych często w wyniku silnej presji Waszyngtonu. Kontrowersyjne były też regulacje American Selling Price (ASP), narzucająca stałe ceny na wybrane produkty przemysłu chemicznego ${ }^{77}$, czy Buy American Act - ustawa z 1933 r. dotycząca procedur realizowania zamówień amerykańskiej administracji w rodzimych firmach ${ }^{78}$.

Dopóki deficyt amerykańskiego bilansu płatniczego był stosunkowo niewielki, inne kraje korzystały na jego istnieniu. Pomagał on gospodarkom zachodnioeuropejskim i japońskiej rozwijać się szybko, praktycznie bez strat dla ich bilansów płatniczych. Ułatwił też demontaż restrykcji związanych z handlem i płatnościami ${ }^{79}$. Kiedy pod koniec lat 60 . XX w. deficyt znacznie wzrósł, stało się to niebezpieczne dla gospodarek ściśle powiązanych z amerykańską. Partnerzy USA naciskali, żeby został zrównoważony, gdyż brak działań ze strony amerykańskiej powodował obniżanie się wartości dolara ${ }^{80}$. Szczególnie zależało na tym rządowi RFN. Przypominał, że pod naciskiem Stanów Zjednoczonych doprowadził do ograniczenia nadwyżki bilansu płatniczego poprzez zmniejszenie dodatniego bilansu handlowego o $1 \mathrm{mld}$ USD i wprowadzenie specjalnych środków podatkowych ${ }^{81}$. RFN, utrzymując dodatni bilans płatniczy, była wyjątkiem wśród najsilniejszych gospodarek świata zachodniego. Wielka Brytania i Francja odnotowały deficyt, nastąpiła też dewaluacja franka (pod koniec sierpnia 1969 r.) i rewaluacja zachodnioniemieckiej marki (w październiku 1969 r. $)^{82}$.

Zapowiedziane na konferencji w Rio de Janeiro w 1966 r. wprowadzenie SDRów nie weszło jeszcze w życie. Głównym oponentem była Francja, która starała się w tym celu wykorzystać różnice między Stanami Zjednoczonymi a państwami Europy Zachodniej ${ }^{83}$. Waszyngton dążył do utrzymania dominującej pozycji swej waluty w światowym systemie monetarnym i utrzymania jej uprzywilejowanej pozycji. Konieczność utrzymywania stałego kursu miała negatywny wpływ na amerykańską gospodarkę, co skłaniało administrację Nixona do wprowadzenia SDR-ów,

77 W latach 60. i 70. ASP dotyczył głównie produktów przemysłu chemicznego. Na towar importowany nakładano cło $\mathrm{w}$ takiej wysokości, by nie był tańszy od podobnego produktu wytworzonego na terenie Stanów Zjednoczonych (E. S. K a p l a n, American Trade Policy 1923-1995, London 1996, s. 81).

${ }^{78}$ M. L i e b l e r G i b s o n, Conflict and Consensus in American Trade Policy, Washington 2000, s. 82.

${ }^{79}$ D. A. W a l ke r, Some Underlying Problems for International Monetary Reform, [w:] The United States and Western Europe..., s. 173.

${ }^{80}$ FRUS, 1969-1976, vol. 3, Kennedy do Nixona, 15 grudnia 1969, dok. 34.

${ }^{81}$ National Archives and Record Administration, College Park, MD (NARA), Nixon Presidential Materials Staff (NPMS), National Security Council (NSC) Files, Country Files - Europe (Germany), Fessenden do Departamentu Stanu, 21 stycznia 1969, box 681.

${ }^{82}$ NARA, NPMS, NSC Institutional "H” Files, Study Memorandums (1969-1974), CIA: przegląd najważniejszych wydarzeń na świecie w 1969 r., box H-164.

${ }^{83}$ Ibidem, odpowiedź Departamentu Stanu na coroczny raport prezydenta o amerykańskiej polityce zagranicznej, 15 grudnia 1969. 
jeśli stałoby się to na korzystnych dla Amerykanów warunkach ${ }^{84}$. Odpowiedź na pytanie, czy międzynarodowy system walutowy miał być oparty na stałych (popieranych przez USA) czy płynnych kursach walut (jak chciały niektóre państwa europejskie) stała się problemem wręcz ideologicznym. USA pragnęły ponadto większych uprawnień dla MFW dotyczących kontroli systemu ${ }^{85}$. Amerykanom zależało na współpracy RFN we wprowadzaniu SDR-ów. Bonn jednak sprzeciwiało się ich pełnej aktywizacji, aż do czasu, kiedy główne waluty, szczególnie dolar, nie będą stabilne $^{86}$. Także Francuzi twierdzili, że zlikwidowanie amerykańskiego deficytu bilansu płatniczego było warunkiem koniecznym, by rozpocząć reformę międzynarodowego systemu walutowego. Utrzymywali, że Europa pośrednio ponosiła koszty zaangażowania USA w Wietnamie poprzez przyjmowanie niechcianych dolarów ${ }^{87}$.

Poszczególne kraje EWG odmiennie postrzegały reformę systemu monetarnego. Na początku kadencji Nixona nie było wiadomo, czy Europa będzie zdolna stworzyć alternatywę dla amerykańskiej dominacji w międzynarodowym systemie walutowym, czy zaakceptuje system dolarowy. W przypadku decyzji o odejściu od systemu Bretton Woods problem stanowiła konieczność zmian CAP, ceny produktów rolnych były bowiem ustalane względem jednostek złota, które odzwierciedlały aktualną wartość dolara. Wobec tego każdy członek EWG, modyfikujący kurs wymiany swej waluty, musiał zaakceptować zmiany w cenach żywności i subsydiów dla rolników. Przyszły premier brytyjski, lider Partii Konserwatywnej, Edward Heath, wskazywał, że państwa EWG musiały wobec tego podjąć kroki w celu integracji polityki monetarnej i fiskalnej lub znaleźć sposób dostosowania między członkami, który nie zniszczyłby istniejących porozumień ${ }^{88}$.

Amerykańskie problemy gospodarcze $\mathrm{w}$ dobie ogromnych współzależności w gospodarce światowej występowały również, w mniejszym lub większym stopniu, w krajach europejskich. Każdy z nich, w zależności od specyfiki systemu gospodarczego i społecznego, podejmował inne środki w celu stabilizacji sytuacji. George Ball ${ }^{89}$ zauważał, że coraz większe różnice między systemem amerykańskim a europejskim utrudniały współpracę transatlantycką. Miał na myśli rosnącą rolę związków zawodowych na Starym Kontynencie i presję społeczną, mającą spowodować większe angażowanie się rządu w gospodarkę. Ball twierdził, że przez to Europa

${ }^{84}$ A. G i o li t t i, Politics and the Money System, [w:] Transatlantic Crisis. Europe and America in the 1970s., ed. J. Godson, London 1974, s. 35.

${ }^{85}$ The New Europe and the United States. Partners or Rivals, ed. G. Mally, Lexington 1974, s. XX.

${ }^{86}$ NARA, NPMS, NSC Files, Country Files - Europe (Germany), Fessenden do Departamentu Stanu, 21 stycznia 1969, box 681.

${ }^{87}$ NARA, NPMS, NSC Institutional "H" Files, Study Memorandums (1969-1974), Odpowiedź Departamentu Stanu na coroczny raport prezydenta o amerykańskiej polityce zagranicznej, 15 grudnia 1969, box H-164.

${ }^{88}$ E. H e a th, Realism in British Foreign Policy, „Foreign Affairs”, October 1969, s. 46.

${ }^{89}$ George W. Ball pełnił funkcję podsekretarza stanu ds. gospodarczych i rolnictwa (Undersecretary of State for Economic and Agricultural Affairs) w administracjach Kennedy'ego i Johnsona. 
będzie brnęła w „quasi-socjalizm”, w którym mechanizmy rynkowe tracą znaczenie. Przewidywał, że jeżeli taka tendencja się utrzyma, będzie to powodowało coraz częstsze konflikty gospodarcze między USA a Europą, co będzie również negatywnie rzutowało na relacje polityczne ${ }^{90}$.

\subsection{Nieporozumienia dotyczące handlu i przepływu inwestycji}

Od początku rządów Nixona amerykańskie koła biznesowe naciskały na zniesienie wprowadzonych przez Johnsona ograniczeń inwestowania za granicą ${ }^{91}$ Administracja, rozważając ten postulat, brała pod uwagę różne aspekty. Z jednej strony BIZ negatywnie wpływały na amerykańską gospodarkę - występowało przenoszenie miejsc pracy i wywóz technologii oraz wzrastał deficyt BOP, z drugiej przynosiły duże zyski dla budżetu. Dlatego też Nixon przychylał się do opinii, że należało dążyć do znoszenia kontroli ${ }^{92}$.

$\mathrm{Na}$ ten temat toczyła się w łonie administracji zacięta dyskusja. Głównym argumentem przeciwników zniesienia kontroli był spadek inwestycji w samych Stanach Zjednoczonych. Ostrzegali, że taka decyzja będzie miała wpływ na politykę zagraniczną - państwa europejskie obawiały się zbyt dużego napływu dolarów, spodziewając się jego dewaluacji. Na Starym Kontynencie wciąż patrzono z niepokojem na przejęcia europejskich przedsiębiorstw przez amerykańskie korporacje ${ }^{93}$.

Uwolnienie inwestycji przez Stany Zjednoczone mogło utrudnić rozmowy na temat przyszłej reformy monetarnej. Rogers proponował rozpoczęcie konsultacji z państwami europejskimi na ten temat. Paul Volcker, podsekretarz skarbu ds. międzynarodowych relacji monetarnych, był temu przeciwny twierdząc, że i tak różnice interesów były zbyt duże, by można było osiągnąć konsensus. Przeważył jednak głos szefa FED Williama Martina, który opowiedział się za rozmowami z Europejczykami na szczeblu politycznym, a nie na międzynarodowych forach gospodarczych, takich jak np. G10 ${ }^{94}$. Motywem sformułowania tej koncepcji była chęć wywierania nacisku politycznego na poszczególne kraje. Tylko w ten sposób Amerykanie mogli osiągnąć cel - nie chcieli konfrontacji ze wszystkimi członkami Wspólnot jednocześnie. Wiedzieli również, że na forach gospodarczych EWG miała lepszą pozycję ze względu na siłę ekonomiczną.

${ }^{90}$ G. W. B all, Diplomacy for the Crowded World. An American Foreign Policy, Boston 1976, s. $170-171$.

${ }^{91} 1$ stycznia 1968 r. wprowadzono ograniczenie wywozu kapitału do 100 tys. USD, w sierpniu 1968 r. podwojono dopuszczalną kwotę (Foreign Investments Rules to Be Waived for "Hundreds" of Small Firms, Stans Says, „The Wall Street Journal”, 6 marca 1969).

${ }^{92}$ R. N. C o o p e r, The Economics of Interdependence: Economic Policy in the Atlantic Community, New York 1968, s. 99.

${ }^{93}$ FRUS, 1969-1976, vol. 3, Cooper i Bergsten do Kissingera, 28 stycznia 1969, dok. 3.

${ }^{94}$ NARA, NPMS, NSC Files, Subject Files, Bergsten do Kissingera, 13 marca 1969, box 309. 
Sekretarz skarbu David Kennedy polecił Volckerowi, by podczas pobytu w Europie przeprowadził indywidualne konsultacje ${ }^{95}$. Volcker chciał demonstracyjnie pominąć w swej podróży Paryż twierdząc, że Francuzi byli głównymi przeciwnikami koncepcji amerykańskich, więc należy im okazać wyraźną dezaprobatę. Jednak pod naciskiem Bergstena zobowiązał się odwiedzić również stolicę Francji. Bergsten chciał uniknąć pogorszenia stosunków politycznych, ale także nie dopuścić, żeby działania Francji doprowadziły do podniesienia ceny złota ${ }^{96}$.

Kissinger wskazywał wielowymiarowy wpływ decyzji o zniesieniu ograniczeń inwestycyjnych na politykę zagraniczną. Przewidywał, że spowoduje ona zwiększenie się deficytu bilansu płatniczego USA, czego coraz bardziej obawiały się kraje europejskie. Zwracał też uwagę na ambiwalentny stosunek państw Starego Kontynentu do amerykańskich inwestycji - chętnie przyjmowały technologię i nowe techniki zarządzania, ale z powodu centralnej pozycji dolara w systemie monetarnym oskarżały USA o „imperializm dolarowy” i bały się eksportu inflacji zza oceanu ${ }^{97}$.

W memorandum dla Kissingera z 20 listopada 1969 r. Bergsten ponaglał go do podjęcia decyzji o ograniczeniach inwestycyjnych. Informował, że domagali się tego biznesmeni, którzy chcieli dostosować plany na 1970 r. do decyzji administracji. Wskazywał, że stopniowa liberalizacja rekomendowana przez Kennedy'ego była rezultatem kompromisu między sekretarzem handlu, Mauricem H. Stansem (który dążył do jak najmniejszej kontroli korporacji) a doradcą prezydenta do spraw gospodarczych, Arthurem Burnsem i FED-em przeciwnym takiemu rozwiązaniu ze względu na powiększający się deficyt BOP. Bergsten przyznawał, że każda liberalizacja niosła ryzyko nieporozumień w stosunkach z Europą, gdyż słaba kondycja amerykańskiego bilansu płatniczego mogła spowodować konieczność podjęcia drastycznych unilateralnych środków (np. zawieszenie wymienialności dolara na złoto). Bergsten uważał, że Europejczycy mogli mieć pretensję do rządu Stanów Zjednoczonych, że nie podjął środków zapewniających stabilizację BOP, czym przyspieszał pojawienie się kryzysu monetarnego $0^{98}$. Bergsten zdawał sobie sprawę z zagrożeń dla polityki zagranicznej, wyraźnie jednak preferował tymczasowe spełnienie postulatów amerykańskich biznesmenów sugerując, przynajmniej w tamtym czasie, priorytetowe znaczenie zapewnienia nowej administracji wewnętrznego poparcia politycznego.

Nixon zdecydował się na stopniowe znoszenie tych ograniczeń ${ }^{99}$. Departament Skarbu uważał, że dalsza liberalizacja mogła się przyczynić do zwiększenia deficytu. Podano, że deficyt BOP na dzień 14 maja 1969 r. wynosił 4 mld USD i wykazywał

${ }^{95}$ FRUS, 1969-1976, vol. 3, memorandum rozmowy między Kennedym a Volckerem, 11 marca 1969, dok. 8.

${ }^{96}$ NARA, NPMS, NSC Files, Subject Files, Bergsten do Kissingera, 13 marca 1969, box 309.

${ }^{97}$ FRUS, 1969-1976, vol. 3, Kissinger do Nixona, 17 marca 1969, dok. 12.

${ }_{98}$ NARA, NPMS, NSC Files, Subject Files, Bergsten do Kissingera, 20 listopada 1969, box 309.

${ }^{99}$ D. P. C a ll e o, Since 1961..., s. 418. Por. Foreign Investments Rules to Be Waived for "Hundreds" of Small Firms, Stans Says, „The Wall Street Journal”, 6 marca 1969. 
tendencje wzrostowe. Nixon nie ugiął się, podtrzymując politykę wypracowaną w wyniku konsensusu wewnątrz administracji.

Andreas Dür określił politykę handlową Stanów Zjednoczonych i państw EWG, stosowaną w czasie rządów Nixona, jako „protekcjonizm sektorowy”. Administracja amerykańska starała się chronić sektory mniej konkurencyjne na rynkach światowych za pomocą negocjowania z partnerami dobrowolnych ograniczeń importu, grożąc wprowadzeniem kontyngentów. Także EWG stosowała różnorakie bariery, wspierając eksporterów. Obie strony stosowały środki protekcjonistyczne, szczególnie broniąc producentów stali, tekstyliów i produktów rolniczych. Dür twierdzi, że Kongres był bardziej podatny na naciski grup interesów. Zanikał też podział między polityką handlową a zagraniczną, co było spowodowane rosnącą współzależnością w gospodarce światowej. Państwa EWG musiały się natomiast zmagać z rosnącą konkurencją ze strony Japonii i problemem bezrobocia. Coraz bardziej popularna stawała się tam koncepcja „państwa dobrobytu”, która implikowała większą rolę rządu w gospodarce. Jednocześnie można było obserwować przywiązanie do idei wolnego handlu, który był korzystny dla wielonarodowych korporacji i chroniony przez reżim GATT. Występowała swoista koegzystencja protekcjonizmu (ujawniającego się szczególnie w dobie kryzysów) i liberalizmu ${ }^{100}$.

W memorandum NSC, dotyczącym polityki handlowej z 28 marca 1969 r., podkreślono chęć dalszej liberalizacji handlu światowego. Zauważono jednak zmiany, które należało brać pod uwagę przy formułowaniu polityki. Wśród nich wymieniono rosnącą współzależność, zwiększenie się wartości wymiany, rozwój komunikacji oraz rozszerzanie się obszarów działalności i wpływów korporacji wielonarodowych. W ten sposób sytuacja gospodarcza w jednym kraju miała duży wpływ na jego partnerów handlowych, zwłaszcza, gdy poszczególne rządy ograniczały import, by wesprzeć rodzimą produkcję. Zwrócono uwagę, że chociaż amerykański eksport do krajów EWG podwoił się w latach 60., to ograniczenia wynikające z zasad rządzących europejskim blokiem handlowym sprawiały, że Stany Zjednoczone czekała konfrontacja, która mogła się przekształcić nawet w „wojnę handlową". Zalecano rozpoczęcie konsultacji oraz uwzględnianie przez obie strony ochrony wzajemnych, ściśle powiązanych interesów i podejmowanie odpowiedzialnych decyzji, by nie dopuścić do przeniesienia się nieporozumień na obszar relacji politycznych.

Oceniono, że największe wyzwanie stanowią problemy handlu produktami rolnymi, gdyż społeczna, polityczna i gospodarcza presja, której podlegało wspieranie tego sektora po obu stronach Atlantyku, doprowadziła do wzrostu produkcji we wszystkich krajach rozwiniętych. Rządy, szczególnie europejskie, wprowadziły dużo środków protekcjonistycznych, jak kontyngenty czy subsydia. Grupy rolnicze były bardzo wpływowe. Nawet w najbardziej uprzemysłowionych krajach rządzący

${ }^{100}$ A. D ü r, Protection for Exporters: Power and Discrimination in Transatlantic Relations, 19302010, Ithaca 2010, s. 131-132. 
woleli ponosić koszty utrzymywania wysokich cen, gdyż w przeciwnym razie straciliby dużą grupę wyborców. Zauważono jednak możliwość osiągnięcia konsensusu w tej kwestii, gdyż konieczność zmian była przedmiotem dyskusji, zarówno w Stanach Zjednoczonych, jak i w Europie.

Amerykanie starali się zwalczać protekcjonizm w rolnictwie na forum GATT, żądając od Europejczyków rekompensat, ale także równoważąc cłami ceny tańszych, subsydiowanych produktów. Chronili własny rynek przed tanim importem (np. mięsa i produktów mlecznych) oraz wywierali naciski na inne kraje, by także nie importowały subsydiowanych produktów (np. starano się przekonać Japonię, by nie przyjmowała francuskiej pszenicy). Przyznano jednak, że takie działania miały bardzo ograniczone skutki.

W raporcie ze spotkania NSC przedstawiono kilka propozycji rozwiązania najpoważniejszych problemów handlowych w relacjach transatlantyckich. Pierwsza $\mathrm{z}$ nich zawierała sugestię kontynuowania dążenia do liberalizacji handlu, przy jednoczesnym wzmożeniu wysiłków na rzecz ochrony rynku wewnętrznego. Stwierdzono, że metoda wywierania łagodnego nacisku mogła okazać się skuteczna, gdyż kraje partnerskie byłyby skłonne do modyfikowania polityki, gdy nie będą stosowane drastyczne środki odwetowe. Ostrzegano jednak, że nawet minimalne zwiększenie presji mogło doprowadzić do konfliktu handlowego. Z powodu niezwykłej politycznej delikatności problemu ograniczenia subsydiów, wykazywano też wady prób wprowadzenia ścisłej kontroli rolnictwa zgodnie z regułami GATT.

W NSC rozważano też zawarcie porozumienia zakładającego stopniowe znoszenie subsydiów. Brak wywiązywania się z umowy skutkowałby karą proporcjonalną do wielkości subsydiów, która miałaby być wpłacana na fundusz pomocowy dla krajów rozwijających się. Przewidywano też wprowadzenie zobowiązania do ograniczenia preferencyjnych układów handlowych. Nie mogły one dotyczyć większej części wymiany globalnej na poszczególne produkty. Postulowano ograniczenia monopoli handlowych (np. we włoskim i francuskim przemyśle tytoniowym), które miały wyłączne przywileje eksportowe i importowe. Kraje uprzemysłowione miałyby konsultować się przed planowanymi zmianami w programach dotyczących rolnictwa. Zauważono jednak, że podobne rozwiązania były już proponowane bezskutecznie na różnych międzynarodowych forach. Trudno byłoby również zdobyć poparcie amerykańskich rolników i Kongresu nawet dla tak ograniczonych środków ${ }^{101}$.

Podczas spotkania NSC podniesiony został problem dostosowania podatków importowych. Był on szczególnie palący w relacjach z EWG. Polegał on na opodatkowywaniu dóbr przy okazji odprawy celnej niezależnie od tego, czy zostało od nich pobrane cło $^{102}$. Na przykład eksporterzy napojów alkoholowych i samo-

${ }^{101}$ NARA, NPMS, NSC Insitutional "H" Files, National Security Council Meetings, William Watts do Kissingera, 28 marca 1969, box H-026.

102 Podatek ten musiał zapłacić importer, faktycznie wpływał jednak na podniesienie ceny wwożonego towaru, ograniczając jego konkurencyjność na danym rynku (K. B i a ł e c k i, A. D o r o s z, W. J a n u s z k i e w i c z, Słownik handlu zagranicznego, Warszawa 1986, s. 198). 
chodów na rynek amerykański, oprócz cła musieli zapłacić podatek równy wewnętrznemu cłu lub podatkowi, który płacili producenci tych samych towarów w USA. Amerykańscy eksporterzy tych produktów byli zwolnieni z wewnętrznego cła, opłat akcyzowych i podatków od sprzedaży, nałożonych na konsumpcję wewnętrzną. Jednak europejskie podatki konsumpcyjne były wyższe niż amerykańskie (stanowiły np. 12,2\% PKB Francji, a tylko 4,6\% amerykańskiego) i dotyczyły większości produktów, więc amerykańscy eksporterzy płacili więcej na granicy. Europejczycy planowali dalsze podwyżki podatków importowych, gdyż EWG dążyła do ujednolicenia systemu podatków konsumpcyjnych VAT. W Stanach Zjednoczonych jednostronne podniesienie podatku importowego było niemożliwe, jako niezgodne z regułami GATT ${ }^{103}$.

Nixon planował także odejście od polityki izolacji państw obozu komunistycznego i ożywienie z nimi handlu. Podczas spotkania rządowego Komitetu do Spraw Polityki Gospodarczej (The Cabinet Committee on Economic Policy - CCEP) 14 kwietnia 1969 r. nakazał współpracownikom podjęcie działań przygotowujących nowe układy handlowe, regulujące szczególnie handel produktami rolnymi z Europą Wschodnią. Polecił, by do tych państw udał się sekretarz rolnictwa, Clifford M. Hardin ${ }^{104}$. Jednak wciąż prawo amerykańskie ograniczało handel ze Wschodem. Nawiązanie bardziej ożywionych stosunków handlowych było ograniczone przez funkcjonującą od 1949 r. ustawę - Export Control Act, zobowiązującą prezydenta do ograniczania eksportu do krajów komunistycznych. Jednocześnie obowiązywał program koordynacji polityki Zachodu w kwestii utrzymania embarga na dobra strategiczne dla ZSRR. W jego ramach utworzono dwa komitety - Ministerialną Grupę Konsultacyjną (Ministerial Consultative Group - MCG) i Komitet Koordynacyjny (Coordinating Committee for Multilateral Export Controls - COCOM). Zadaniem MCG było wytyczanie celów politycznych, COCOM zaś ustalał listę towarów objętych embargiem ${ }^{105}$. Już w latach 60 . biznesmeni z Europy Zachodniej, wspierani przez swoje rządy, znaleźli sposoby, by interpretować na swoją korzyść postanowienia COCOM i wywierali nacisk na administrację USA, by zmieniła zdanie o zakazie eksportu poszczególnych towarów do krajów bloku wschodniego. Ustawa o kontroli eksportu wygasała 30 czerwca 1969 r., co stwarzało szansę liberalizacji ustawodawstwa ${ }^{106}$.

Departament Stanu uświadamiał Nixonowi, że stosunek do handlu z blokiem komunistycznym miał bardzo duże znaczenie dla relacji amerykańsko-

${ }^{103}$ NARA, NPMS, NSC Insitutional "H" Files, National Security Council Meetings, William Watts do Kissingera, 28 marca 1969, box H-026.

${ }^{104}$ FRUS, 1969-1976, vol. 3, Bergsten do Kissingera, 14 kwietnia 1969, dok. 19.

${ }^{105}$ F. D. Hol z m a n, R. Le g vold, The Economics and Politics of East-West Relations, „International Organization", Winter 1975, s. 277-283.

106 P. J. F u n i g i e ll o, American-Soviet Trade in the Cold War, Chapell Hill 1988, s. 179. Por. W. J. L a n g, U.S. Export Control Policy. Executive Autonomy versus Congressional Reform, New York 1989, s. 45. 
-zachodnioeuropejskich. Stwierdzono, że Europejczycy przewiązywali do niego o wiele większą wagę niż USA. Dla Stanów Zjednoczonych zniesienie ograniczeń ułatwiłoby zmniejszenie deficytu BOP. Amerykanie wciąż starali się utrzymać zasadę wielostronnej kontroli eksportu towarów strategicznych. Departament Stanu przewidywał narastanie konfliktów na tym tle w sojuszu ${ }^{107}$. Potencjalne skutki polityczne stosunków gospodarczych Europy Zachodniej ze Wschodem były łatwe do przewidzenia. W razie gdyby Stany Zjednoczone chciały nałożyć sankcje ekonomiczne na kraje bloku wschodniego, ich sojusznicy mogliby odmówić przyłączenia się do nich, gdyż przyniosłoby to zbyt duże straty dla ich gospodarek ${ }^{108}$.

Podczas spotkania NSC 9 kwietnia, na którym rozmawiano o kwestiach handlowych, Nixon zapowiedział rozpoczęcie starań w Kongresie o specjalne uprawnienia dla prezydenta w sprawie podejmowania szybkich decyzji o znoszeniu ceł, liberalizacji, escape clause i warunków przyznawania pomocy przedstawicielom biznesu i pracownikom, których posady byłyby zagrożone przez konkurencyjny import. Nixon chciał również eliminacji innych regulacji, np. ASP. Sekretarz handlu, Stans, który miał udać się z wizytą do Europy, otrzymał polecenie zbadania możliwości zorganizowania w czerwcu spotkania pod auspicjami GATT, dotyczącego problemów handlu światowego. Stans miał oświadczyć, że Stany Zjednoczone będą się ubiegać o lepsze układy handlowe z partnerami, dlatego administracja chciała przeforsować konkretne ustawy w Kongresie. Miał też wysondować, jakie są plany Europejczyków dotyczące handlu z blokiem komunistycznym i poinformować, że Stany Zjednoczone chciały zmieniać stanowisko w tej kwestii na bardziej liberalne. Nixon podkreślił, że administracja musiała bardziej zadbać o interesy amerykańskiego biznesu za granicą, nawet, jeśli spowodują one zmiany w założeniach amerykańskiej polityki zagranicznej ${ }^{109}$. Było to bardzo zdecydowane stwierdzenie, określające priorytetowe znaczenie relacji gospodarczych w stosunkach transatlantyckich. Trzeba jednak podkreślić, że Nixon wypowiedział się w ten sposób w gronie najbliższych doradców. Oficjalnie głosił wciąż prymat współpracy politycznej i konieczność partnerstwa w umacnianiu światowego pokoju.

${ }^{107}$ NARA, NPMS, NSC Institutional "H" Files, National Security Council Meetings, Departament Stanu do Nixona, 14 maja 1969, box H-021.

${ }^{108}$ Te przewidywania sprawdziły się za kadencji prezydenta Ronalda Reagana. Po wprowadzeniu stanu wojennego w Polsce 13 grudnia 1981 r., Reagan zdecydował się na ogłoszenie sankcji ekonomicznych wobec ZSRR m.in. na dostawę technologii związanej z produkcją i transportem ropy naftowej oraz gazu. Prezydent zdecydował się na uderzenie w sektor, na którym najbardziej zależało państwom Europy Zachodniej w stosunkach ze Wschodem. Przyłączenie się do sankcji oznaczałoby dla nich konieczność rezygnacji z projektu budowy rurociągu gazowego, biegnącego z Półwyspu Jamalskiego do RFN, Francji, Włoch, Holandii i krajów skandynawskich. Kraje europejskie odmówiły respektowania decyzji Stanów Zjednoczonych (P. M a t e r a, R. M a t e r a, Stany Zjednoczone i Europa. Stosunki polityczne i gospodarcze 1776-2004, Warszawa 2007, s. 301-302).

${ }^{109}$ NARA, NPMS, NSC Insitutional, "H" Files, National Security Council Meetings, wnioski ze spotkania NSC na temat handlu zagranicznego, 9 kwietnia 1969, box H-021. 
Stans przedstawił wyniki misji w Europie w memorandum skierowanym do CCEP. Stwierdził, że Europejczycy z zadowoleniem przyjęli amerykańską chęć konsultacji w sprawach gospodarczych. Przekazał im, że Amerykanie byli bardzo zaniepokojeni ich protekcjonizmem i można było spodziewać się rosnącego oporu przeciwko temu w USA. Mówił też o pozytywnym stosunku poszczególnych krajów do negocjacji na temat znoszenia barier pozataryfowych. Stans zapewnił, że prezydent podejmie działania w celu obniżenia inflacji i zniwelowania zbyt wysokiego deficytu BOP. Według relacji sekretarza handlu, Europejczyków usatysfakcjonowała deklaracja, że administracja rozważała dopuszczenie zawierania preferencyjnych układów handlowych z krajami mniej rozwiniętymi (Less Developed Countries - LDC) i zwiększenie możliwości handlu Wschód-Zachód. Obawiali się jedenak możliwego zwiększenia się amerykańskiego protekcjonizmu ${ }^{110}$. Z relacji Stansa wynikało, że starał się przedstawić Europejczykom przede wszystkim pozytywne perspektywy współpracy transatlantyckiej. Unikał wysuwania roszczeń do czasu planowanych na przyszłość negocjacji.

Decyzję dotyczącą handlu ze Wschodem, po dyskusji w gronie NSC, Nixon przedstawił w National Security Study Memorandum (NSSM) z 28 maja 1969 r. Stwierdził, że relacje te będą się kształtować w zależności od stosunków z ZSRR i krajami bloku komunistycznego. W związku z tym ocenił, że nie istniała w tamtym czasie żadna przyczyna uzasadniająca zmianę ustawy o kontroli wymiany (Exchange Control Act) z 1947 r. lub upoważnianie prezydenta, by rozszerzył na te kraje klauzulę najwyższego uprzywilejowania (KNU). Prezydent stwierdził, że Stany Zjednoczone powinny być przygotowane na większe otwarcie, jeśli ogólne stosunki polityczne z tymi krajami ulegną zauważalnej poprawie. Powinno się jednak stopniowo skracać listę eksportowanych towarów objętych kontrolą w ramach istniejącej legislacji. Tak szybko, jak to możliwe, USA powinny dostosować ją do listy ustalonej z innymi krajami w ramach COCOM, z wyjątkiem tych produktów, nad których eksportem USA były w stanie utrzymać jednostronną kontrolę, czyli na towary dostępne tylko z amerykańskich źródeł. Zadeklarował, że Stany Zjednoczone nie będą wywierać presji na inne kraje, by nie prowadziły wobec Wschodu bardziej liberalnej polityki - zostawiał im w tej kwestii wolną rękę ${ }^{111}$. Decyzja ta nie była satysfakcjonująca dla amerykańskich przedsiębiorców. Postrzegając kraje bloku wschodniego jako potencjalne rynki zbytu, naciskali oni na władze, aby zniesiono najbardziej restrykcyjne ograniczenia. Doprowadziło to do uchwalenia przez Kongres i podpisania przez Nixona 30 grudnia 1969 r. nowej ustawy - Export Administration Act. Najważniejszą zmianą w stosunku do poprzedniej, było ograniczanie eksportu tylko takich towarów, które mogły stanowić „ważny wkład w powiększenie potencjału militarnego innego kraju [...], co może negatywnie wpłynąć na bezpieczeństwo Stanów Zjednoczonych". Poza tym,

${ }^{110}$ Ibidem, Stans do Gabinetowego Komitetu Polityki Ekonomicznej NSC, 2 maja 1969.

${ }^{111}$ NARA, NPMS, NSC Insitutional "H" Files, National Security Decision Memorandums (19691974), NSDM 15, 28 maja 1969, box H-210. 
zgodnie z wcześniejszymi zapowiedziami Nixona, zadecydowano o zmianie kryteriów ustalania procedur przyznawania licencji eksportowych, biorąc pod uwage dostępność poszczególnych dóbr także z innych krajów ${ }^{112}$.

\subsection{Integracja europejska - perspektywy rozszerzenia}

Za prezydentury Nixona stanowisko Stanów Zjednoczonych wobec integracji europejskiej uległo modyfikacji. Choć oficjalnie prezydent ją popierał, dynamiczna sytuacja polityczna i gospodarcza na świecie implikowała zmianę amerykańskiego postrzegania rozszerzenia Wspólnot. Utrata hegemonicznej pozycji USA na rynku światowym, wpłynęła na ich stosunek do EWG, w tym do poszerzenia tej organizacji o Wielką Brytanię ${ }^{113}$. Jednak zaraz po objęciu prezydentury w styczniu $1969 \mathrm{r}$. Nixon deklarował w liście do brytyjskiego premiera, Harolda Wilsona: „Przez ostatnie dekady źródłem siły sprawy wolności były bliskie stosunki między brytyjskim premierem a prezydentem Stanów Zjednoczonych [...]. Pragnę, by te relacje były podtrzymywane i wzmacniane"114.

13 października 1969 r. prezydent polecił poszczególnym departamentom przygotowanie raportu na temat możliwych skutków przystąpienia Wielkiej Brytanii do EWG. Departament Stanu stwierdził, że konieczne było poparcie dla tego procesu. Zapewniano, że korzyści polityczne i gospodarcze funkcjonowania Wspólnot przeważają nad krótkoterminowymi problemami, które rozszerzenie stwarzało dla USA ${ }^{115}$. Wątpliwości Waszyngtonu, dotyczące skutków rozszerzenia EWG, wynikały z zarzutów, że organizacja ta stawała się protekcjonistycznym blokiem handlowym, a tymczasem celem USA była jak największa liberalizacja handlu. Amerykańscy dyplomaci coraz częściej angażowali się w jej obronę, nie zważając na postulaty amerykańskiego biznesu, który obawiał się, że działania rządu popsują dochodowe interesy w Europie ${ }^{116}$.

WWaszyngtonie liczono, że nowy prezydent Francji - sprawujący urząd od czerwca 1969 r. Georges Pompidou - będzie chciał poprawić relacje z USA ${ }^{117}$. Jednocześnie

112 S. N. B rus h, Implementation of Export Administration Act of 1969, dostępny przez: http://heinonline.org/HOL/LandingPage?collection=journals\&handle=hein.journals/conlr4\&div $=11 \&$ id $=$ \&page.

${ }^{113}$ H. K i s s in g e r, White House Years..., s. 418.

${ }^{114}$ Cyt. za: A. P. D o b s o n, Anglo-American Relations in the Twentieth Century. Of Friendship, Conflict and the Rise and Decline of Superpowers, London 1995, s. 138.

${ }^{115}$ NARA, NPMS, NSC Institutional "H” Files, Study Memorandums (1969-1974), memorandum Theodore'a L. Eliota dla Kissingera, 28 października 1969, box H-164.

${ }^{116}$ D. P. C a ll e o, The Atlantic Fantasy: The U.S., NATO, and Europe, Baltimore 1970, s. 141.

$117 \mathrm{~W}$ rozmowie z Kissingerem Pompidou powiedział, że samodzielna polityka wschodnia kanclerza RFN Brandta skłoniła go do poparcia członkostwa Wielkiej Brytanii w EWG, żeby była przeciwwagą dla rosnących wpływów RFN (H. K i s s i n g e r, White House Years..., s. 421). 
zdawano sobie sprawę, że był kontynuatorem polityki de Gaulle’a, a więc będzie mu zależało na niezależności Francji w polityce zagranicznej, co, według NSC, mogło oznaczać dążenie do wypierania wpływów amerykańskich z Europy. NSC zalecała konsultacje z Paryżem we wszystkich najistotniejszych kwestiach polityki zagranicznej ${ }^{118}$.

Podczas szczytu w Hadze w grudniu 1969 r., oprócz ponownego otwarcia negocjacji z kandydatami do Wspólnot, przywódcy ogłosili ambitne plany wzmocnienia integracji - postawiono sobie za cel realizację w latach 70. unii walutowej i ekonomicznej. Znacznie skromniej przedstawiał się plan współpracy politycznej - ograniczał się do stworzenia mechanizmu konsultacyjnego ${ }^{119}$. Zapowiadane na szczycie w Hadze pogłębienie integracji ekonomicznej EWG, wraz z planowanym rozszerzeniem, budziło w Stanach Zjednoczonych obawy przed dalszym zaostrzeniem się rywalizacji. Nixon podkreślał konieczność zmiany zasad sojuszu atlantyckiego i zapowiedział działania przede wszystkim zgodne z interesem narodowym USA.

\subsection{Wpływ nieporozumień gospodarczych na współpracę militarną}

Celem stacjonowania amerykańskich wojsk w Europie Zachodniej było zapewnienie jej bezpieczeństwa: ZSRR, atakując ją, musiał się liczyć z konfliktem ze Stanami Zjednoczonymi. Ważnym aspektem było również utrzymanie wpływów na Starym Kontynencie. Poza tym obecność amerykańska w RFN miała chronić Europę przed zbytnim usamodzielnieniem się tego państwa. W momencie zaangażowania w innych rejonach świata, przede wszystkim w Wietnamie, w Stanach Zjednoczonych zaczęto rozważać znaczną redukcję sił stacjonujących w Europie. Jednak Waszyngton wstrzymywał tę decyzję ze względu na planowane negocjacje rozbrojeniowe z ZSRR - Amerykanie chcieli najpierw uzyskać od tego państwa adekwatne redukcje wojsk stacjonujących w Europie Wschodniej ${ }^{120}$. Dlatego perspekty-

118 NARA, NPMS, NSC Institutional Files, Study Memorandums, National Security Study Memorandum (NSSM) 55, 2 czerwca 1969, box H-151. W raporcie przygotowanym przez NSC na początku prezydentury Pompidou zauważono, że był on przychylny przyjęciu Wielkiej Brytanii do Wspólnot, utrzymaniu wojsk amerykańskich w Europie, a także dążył do utworzenia unii monetarnej między członkami EWG. Jednak zauważono również, że nie chciał powrotu Francji do struktur wojskowych NATO, wciąż lansował koncepcję „Europy Ojczyzn”, wskazywał na konieczność wycofania wojsk amerykańskich z Wietnamu. Obawiał się, że Stany Zjednoczone i ZSRR porozumieją się nie biorąc pod uwagę europejskich interesów. W sprawie konfliktu bliskowschodniego popierał negocjacje tylko z udziałem czterech mocarstw, skłaniając się ku stronie arabskiej. Zauważono także, że utrzymuje dobre kontakty z ZSRR i blokiem wschodnim, chcąc działać jako mediator (NARA, NPMS, NSC Files, Country Files - Europe (France), ocena polityki zagranicznej prezydenta Pompidou, box 676).

${ }^{119}$ A. G r o s s e r, Les Occidentaux. Les pays d'Europe et les États-Unis depuis la guerre, Paris 1978, s. 337.

${ }^{120}$ G. F. Tr e v e r t o n, The Dollar Drain and American Forces in Germany. Managing the Political Economics of Alliance, Athens 1978, s. 26. 
wa jednostronnego wycofania wojsk była mało prawdopodobna, choć w Kongresie można było obserwować dążenia do takiego rozwiązania. Z jednej strony wypowiadano się za koniecznością utrzymania sił w Europie, z drugiej podkreślano, że podział odpowiedzialności za obronę w NATO był niesprawiedliwy, a Europa nie była już najważniejszym obszarem ochrony bezpieczeństwa USA ${ }^{121}$.

Umocnienie się pozycji ekonomicznej Europy Zachodniej i zacieśniające się zależności w gospodarce światowej powodowały, że Stany Zjednoczone musiały bardziej liczyć się ze zdaniem swoich sojuszników. Nie mogły już używać w kontaktach z nimi nacisków na polu gospodarczym ze względu na utratę hegemonii w tym zakresie, ale wciąż dominowały na polu militarnym. Kwestia zależności bezpieczeństwa Europy Zachodniej od amerykańskiej obrony była coraz częściej podnoszona przez decydentów z Waszyngtonu, gdy chcieli uzyskać od sojuszników jakieś ustępstwa.

Także amerykańska opinia publiczna zadawała pytanie, czy Stany Zjednoczone, wobec trudności, jakie przeżywała ich gospodarka, nie płaciły zbyt dużo za europejskie bezpieczeństwo. To pytanie miało też swoje uzasadnienie polityczne. W okresie narastających protestów przeciwko amerykańskiemu zaangażowaniu w Wietnamie, antyamerykanizm wśród obywateli Europy Zachodniej osiągnął niespotykany dotychczas poziom. Kwestionowano nawet sens istnienia NATO, nazywanego nieraz narzędziem amerykańskiej dominacji. Paradoksalnie, Europejczycy byli również przeciwni zwiększeniu przez ich rządy wydatków na obronę ${ }^{122}$. Chociaż żaden rząd Europy Zachodniej nie postulował ograniczenia współzależności obronnej w ramach NATO, w USA takie nastroje powodowały rozczarowanie i kwestionowanie zasadności finansowania obrony „niewdzięcznych Europejczyków”.

Amerykańska Agencja Informacyjna (US Information Agency) dostarczała danych o nastrojach opinii publicznej w Europie. W raporcie z 4 kwietnia 1969 r. zauważono, że po inwazji wojsk Układu Warszawskiego w Czechosłowacji w sierpniu 1968 r. w Europie Zachodniej zmniejszyło się poczucie bezpieczeństwa. Zwracano uwagę na drażliwą kwestię rekompensat (offsetu), płaconych przez rząd RFN za stacjonowanie wojsk amerykańskich na terenie tego państwa. Niemcy postrzegali je jako ograniczanie suwerenności. Zamiast zwiększania kwoty offsetu rekomendowano wynegocjowanie współpracy z Bonn w kwestiach monetarnych ${ }^{123}$.

Nixon był przeciwny zmniejszeniu kontyngentu wojsk amerykańskich w Europie. Przewidział wprawdzie dzielenie odpowiedzialności za obronę ${ }^{124}$, lecz

${ }^{121}$ Congressional Record. Proceeding and Debates of the First Session of the $91^{\text {st }}$ Congress, vol. 115, part 21, posiedzenie Senatu z 2 października 1969, dostępne przez: http://www.archive. org/stream/congres-sionalrec115lunit\#page/n1/mode/2up.

${ }^{122}$ C. B e ll, The Diplomacy of Detente. The Kissinger Era, New York 1977, s. 99.

${ }^{123}$ NARA, NPMS, NSC Insitutional "H" Files, National Security Council Meetings, Rogers do Nixona, 8 grudnia 1969, box H-026.

${ }^{124}$ Amerykanie ponosili gros kosztów działania NATO. W 1968 r. Stany Zjednoczone wydały na obronę blisko 80 mld USD (9,2\% PKB). Całość wydatków NATO wynosiła 104 mld USD. Z krajów 
obiecał, że USA nie opuści sojuszników, dopóki nie będą gotowi do zapewnienia sobie bezpieczeństwa. Na początku jego prezydentury nie można było zakładać, że w najbliższej przyszłości Europa Zachodnia osiągnie taką zdolność. Jednak presja wewnętrzna zmusiła prezydenta do podjęcia konkretnych zobowiązań. W maju 1969 r. zaakceptował wnioski z raportu przedstawionego przez NSC, że powinna być przeprowadzona stopniowa redukcja oddziałów stacjonujących w Europie. Poszczególne etapy tej akcji każdorazowo należało konsultować z sojusznikami ${ }^{125}$. W raporcie przygotowanym przez Komitet Podsekretarzy na temat programu redukcji kosztów rozmieszczenia wojsk w Europie REDCOSTE (Reduction the Costs in Europe) zaznaczono, że jego pełna implementacja pozwoli zaoszczędzić około 158 mln USD. Zwrócono uwagę, że koszty polityczne takiego przedsięwzięcia będą trudne do oszacowania, gdyż będzie to oznaczało „widoczną redukcję sił w Europie, wycofanie jednostek działających $w$ ramach NATO [...], pogorszenie zdolności obronnych, co może być odebrane przez sojuszników jako oznaka zmniejszenia zainteresowania się Stanów Zjednoczonych współpracą w ramach NAT0"126. W analizie podkreślono, że w czasie negocjacji rozbrojeniowych z ZSRR raczej powinno się wzmacniać siły konwencjonalne w Europie, jeżeli Stany Zjednoczone planowały prowadzić rozmowy z pozycji siły. Jednak program REDCOSTE został zaaprobowany przez prezydenta 5 czerwca 1969 r. Plan przewidywał wycofanie do $1972 \mathrm{r}$. ok. 27400 żołnierzy amerykańskich i 800 osób z obsługi cywilnej.

Uzasadnienie tej decyzji deficytem BOP było chybione. W 1969 r. w Europie stacjonowało 255 tys. amerykańskich żołnierzy, z których 200 tys. przebywało na terytorium RFN ${ }^{127}$. Koszty utrzymania tych wojsk wynosiły około 1 mld USD rocznie, a całość amerykańskich wydatków na zbrojenia w 1969 r. dochodziła do 79 mld dolarów ${ }^{128}$. W 1969 r. rząd RFN zaoferował pakiet offsetowy na dwa lata (jego wartość sięgała 700 mln USD rocznie), pokrywający około $75 \%$ amerykańskich wydatków ${ }^{129}$. Niemcy zgodzili się również powstrzymać od wymiany swych rezerw dolarowych na złoto ${ }^{130}$. Oznaczało to, że rekompensowali lwią część kosztów stacjonowania amerykańskich wojsk w Europie ${ }^{131}$.

Na dorocznym spotkaniu Zgromadzenia Parlamentarnego NATO (Zgromadzenia Północnoatlantyckiego) zwrócono uwagę na konieczność wzmocnienia sił w ra-

europejskich najwięcej środków na obronę przeznaczała Francja - ponad 6 mld USD, co stanowiło 5,3\% jej PKB (W. B u r g e s s, J. R. H u n t l e y, Europe and America. The Next Ten Years, New York 1970, s. 174).

${ }^{125}$ FRUS, 1969-1976, vol. 3, Richardson do Nixona, 26 maja 1969, dok. 22.

${ }^{126}$ Ibidem.

${ }^{127}$ Dane dostępne przez: www.heritage.org/Research/NationalSecurity.

${ }^{128}$ C. F. B e r g s t e n, Toward a New International Economic Order: Selected Papers of C. F. Bergsten, 1972-1974, Lexington 1975, s. 329.

${ }^{129}$ FRUS, 1969-1976, vol. 3, Bergsten do Kissingera, 24 marca 1969, dok. 13. Por. NARA, NPMS, NSC Files, Subject Files, Bergsten do Kissingera, 3 grudnia 1970, box 309.

${ }^{130}$ C. F. B e r g s t e n, op. cit., s. 329.

${ }^{131} \mathrm{Na}$ temat offsetu: patrz kolejny podrozdział. 
mach organizacji, kierując ten postulat głównie do państw europejskich ${ }^{132} .29$ października 1969 r. senator Charles Percy wygłosił przemówienie na temat negatywnych skutków stacjonowania wojsk amerykańskich w Europie dla amerykańskiego BOP - przedstawiciele wszystkich krajów zgodzili się, że pomoc umożliwiająca ich utrzymanie była niezbędna. Wszyscy członkowie NATO zobowiązali się do podniesienia swych wydatków wojskowych o 1 mld dolarów rocznie ${ }^{133}$.

Tymczasem w Kongresie zdecydowano się na konkretne działania. Przewodniczący większości senackiej, Mike Mansfield, 1 grudnia 1969 r. po raz kolejny zgłosił rezolucję wzywającą do znacznej redukcji wojsk amerykańskich w Europie. Argumentował, że pozwoli to zniwelować deficyt bilansu płatniczego. Zdecydował się na ten krok mimo wynegocjowanej z RFN korzystnej umowy offsetowej i zwiększenia wydatków na obronę członków NATO. Mansfield podjął akcję z powodów politycznych, chcąc zadowolić opinię publiczną. Nawet, jeśli Europa przeznaczyłaby jeszcze więcej środków na obronę, nie zadowoliłoby to zwolenników wycofania z niej wojsk ${ }^{134}$. Motywem działań Kongresu była chęć wymuszenia na EWG koncesji na polu gospodarczym, szczególnie większe otwarcie rynku na towary amerykańskie. Zdaniem kongresmanów, eksport z USA podlegał dyskryminacji, więc fakt nieobciążania konkurenta kosztami obrony budził zrozumiałą irytację. Jednak administracja Nixona okazała dezaprobatę wobec inicjatywy Mansfielda. Podsekretarz stanu Elliott Richardson 20 stycznia 1970 r. złożył bardzo zdecydowane oświadczenie o potrzebie zatrzymania amerykańskich sił w Europie ${ }^{135}$.

\subsection{Kwestia niemieckiego offsetu}

Założenia polityki Nixona wobec RFN były zdeterminowane zarówno czynnikami politycznymi, jak i gospodarczymi. Niepokój Waszyngtonu wzbudzała prowadzona przez to państwo tzw. polityka wschodnia (Ostpolitik). Willy Brandt, minister spraw zagranicznych, a od 21 października 1969 r. kanclerz RFN, podjął zdecydowane kroki w celu poprawy relacji z krajami komunistycznymi. Twierdził, że dzięki otwarciu na Wschód RFN będzie mogła lepiej zadbać o swoje interesy. Według Brandta, Stany Zjednoczone nie mogły wypełnić zadowalająco tego zadania, gdyż

${ }^{132}$ A. B a k e r F o x, Domestic Pressures in North America to Withdraw Forces From Europe, [w:] European Security and the Atlantic System, eds. W. T. R. Fox, W. R. Schilling, New York 1973, s. 206.

${ }^{133}$ NARA, Nixon Presidential Materials Project (NPMP), White House Central Files (WHCF), IT International Organization, NATO, przemówienie senatora Percy'ego na forum Zgromadzenia NATO, 29 października 1969, box 3.

${ }^{134}$ S. H of f m a n n, Toward a Common European Foreign Policy?, [w:] The United States and Western Europe..., s. 96.

${ }^{135}$ A. B a ke r F o x, op. cit., s. 224. 
ich cele nie zawsze były zbieżne z niemieckimi. Chciał przede wszystkim doprowadzić do spadku napięcia, które stwarzało atmosferę permanentnego zagrożenia dla bezpieczeństwa jego $\mathrm{kraju}^{136}$. Amerykanie obawiali się, że Brandt, działając niezależnie, może poczynić zbyt daleko idące ustępstwa wobec ZSRR. Zdawali sobie jednak sprawę, że nie osiągnie zbyt wiele bez amerykańskiego wsparcia ${ }^{137}$.

Na początku kadencji Nixon otrzymał raport na temat najważniejszych zagadnień w polityce wobec RFN. Na wstępie znalazło się stwierdzenie, że kraj z uwagi na polepszającą się sytuację gospodarczą stawał się wiodącą siłą w Europie. Stany Zjednoczone chciały z nim współpracować, w związku z tym należało go traktować po partnersku. Problemy zawarte $w$ raporcie można podzielić na wzajemnie przenikające się kategorie: militarną - kwestia utrzymania poziomu amerykańskich sił w RFN i związany z tym offset; polityczną - sprawy związane z détente (konsultacje na temat rozmów między USA i ZSRR, traktat o nierozprzestrzenianiu broni nuklearnej, kwestia dostępu do Berlina, Ostpolitik, losy dalszej integracji europejskiej) oraz ekonomiczną - walka z protekcjonizmem i szukanie rozwiązań w celu uniknięcia kryzysu monetarnego ${ }^{138}$. 0 ile w kwestiach o charakterze politycznym RFN była zależna od USA (np. w sprawie zapewnienia swobodnego dostępu do Berlina) lub odgrywała rolę drugoplanową (np. negocjacje rozbrojeniowe z ZSRR), o tyle w zagadnieniach gospodarczych była równorzędnym partnerem, z którym współpraca była niezbędna. Michael Wolffsohn twierdził, że od 1969 r. rząd RFN coraz bardziej angażował się w „gaullistowską" politykę Europy Zachodniej ${ }^{139}$. Stanley R. Sloan porównał RFN do dziecka uwalniającego się spod władzy dorosłych i dostrzegał zagrożenie, że państwo to będzie budować politykę na antyamerykanizmie ${ }^{140}$.

Amerykanie naciskali, żeby podczas negocjacji o offsecie mających się rozpocząć w lutym 1969 r., wypracować porozumienie długofalowe, zapewniając dyskretne poparcie dla Ostpolitik. Planowano jednak przyjąć elastyczne stanowisko negocjacyjne, by nie psuć relacji z Bonn ${ }^{141}$. Rząd RFN planował rewaluację DM - liczono, że korzystnie wpłynie to na amerykański eksport. Poza tym w RFN zbliżały się wybory, a w związku z tym władze tego kraju nie byłyby skłonne do ustępstw. Podsekretarz stanu Richardson twierdził, że należało rozpatrywać problem niemieckiego offsetu w kontekście działań, które podejmuje RFN na międzynarodo-

${ }^{136}$ R. B a r n e t, op. cit., s. 289.

${ }^{137}$ H. J. M o r g e $\mathrm{n}$ th a u, The United States and Europe in a Decade of Détente, [w:] The United States and Western Europe..., s. 7.

${ }^{138}$ NARA, NPMS, NSC Files, Country Files - Europe (Germany), Fessenden do Departamentu Stanu, 21 stycznia 1969, box 681.

${ }^{139}$ M. Wo lff s o h n, West-Germany's Foreign Policy in the Era of Brandt and Schmidt, 19691982. An Introduction, New York 1986, s. 27.

${ }^{140}$ S. R. S 1 o a n, United States-German Relations: A Contemporary Perspective, [w:] United StatesGerman Relations. Past and Present, Washington 1984, s. 22.

${ }^{141}$ NARA, NPMS, NSC Files, Country Files - Europe (Germany), Fessenden do Departamentu Stanu, 21 stycznia 1969, box 681. 
wym rynku finansowym. Takie stanowisko popierała też Rada Bezpieczeństwa Narodowego.

Departament Skarbu proponował zwiększenie wymagań wobec RFN. W liście do Nixona z 19 lutego 1969 r. Kissinger ostrzegał, że taka polityka niosła zagrożenie poważną konfrontacją. Administracja Johnsona już doprowadziła do zawarcia umowy na niekorzystnych dla RFN warunkach - Niemcy mieli rekompensować 100\% kosztów, jakie niosła obecność wojsk amerykańskich dla bilansu płatniczego Stanów Zjednoczonych. Byli także zobowiązani do zakupu obligacji skarbowych oraz sprzętu militarnego w USA, a w 1967 r. zobowiązali się nie wymieniać dolara na złoto z amerykańskiego skarbca, co Kissinger uznał za najbardziej istotne ustępstwo. Zachęcał do umiarkowania w sprawie offsetu i koncentracji na zapewnieniu współpracy RFN w kwestiach monetarnych. Miał na myśli wprowadzenie SDR-ów jako głównej jednostki rezerwowej, płynność kursów walutowych oraz rewaluację marki niemieckiej. Zaproponował, żeby przez rok obserwować, czy RFN wywiązuje się ze zobowiązań i przekonać Kongres, że pozyskanie sojusznika w światowej polityce walutowej było bardziej korzystne niż zwiększanie wartości rekompensaty ${ }^{142}$.

W liście do Kissingera Bergsten zauważył, że naciski na renegocjację umowy offsetowej prowadziły do pogorszenia amerykańsko-niemieckich relacji politycznych, gdyż w RFN powszechnie uważano offset za przejaw okupacji. Bergsten zauważył, że Stany Zjednoczone powinny budować dobre relacje z największą potęgą gospodarczą Europy, zamiast antagonizować Niemców zwiększaniem wymagań ${ }^{143}$. Nixon zaakceptował ten punkt widzenia i zdecydował, że w 1969 r. amerykańscy negocjatorzy nie będą domagać się zwiększenia wartości offsetu, jako że nowa umowa miała zacząć obowiązywać dopiero w lipcu $1971 \mathrm{r}^{144}$ Poza tym RFN, choć wciąż priorytetowo traktowała gwarancje obrony ze strony USA, coraz silniej zakorzeniała się w Europie. Oznaczało to zbieżność interesów gospodarczych w grupie państw zrzeszonych w EWG, często sprzecznych z amerykańskimi. Odnotowano także nadwyżkę w bilansie płatniczym w wysokości 4,6 mld USD w pierwszym kwartale 1969 r., a w drugim $-4,9$ mld.

Administracja Nixona była jednak wciąż pod presją Kongresu w sprawie podjęcia działań zmierzających do renegocjacji umowy offsetowej. Podczas spotkania rządowego Komitetu do Spraw Polityki Gospodarczej (Cabinet Committee on Economic Policy) w kwietniu 1969 r., Nixon ostrzegał, że kongresmani ze Środkowego Zachodu, dotychczas popierający stacjonowanie wojsk amerykańskich w Europie, byli bliscy zmiany zdania, jeśli EWG nie zmodyfikuje polityki handlowej, która szkodziła interesom stanów, które reprezentowali ${ }^{145}$. W dużej mierze te naciski przyczyniły się do usztywnienia stanowiska amerykańskiego podczas rozmów na ten temat z Niemcami.

\footnotetext{
142 Ibidem, Kissinger do Nixona, 19 lutego 1969.

143 FRUS, 1969-1976, vol. 3, Bergsten do Kissingera, 24 marca 1969, dok. 13.

${ }^{144}$ Ibidem, nota edytorska, dok. 18.

145 Ibidem, Bergsten do Kissingera, 14 kwietnia 1969, dok. 19.
} 
Negocjacje podjęte w kwietniu 1969 r. okazały się znacznie trudniejsze niż te w 1968 r. Bergsten radził, aby zwracać uwagę na naciski Kongresu związane z zawarciem korzystnej umowy, a także na fakt, że deficyt bilansu płatniczego Stanów Zjednoczonych mógł spowodować problemy w relacjach gospodarczych i politycznych. Warto przypomnieć, że Bergsten nie widział wcześniej związku między stacjonowaniem wojsk amerykańskich w Europie a deficytem BOP. Departamenty Skarbu i Obrony, a także z pewnymi zastrzeżeniami Departament Stanu chciały, żeby RFN wydała w USA sumę równą wydatkom amerykańskim $\mathrm{w}$ ich kraju związanym z obronnością (na sprzęt wojskowy, szkolenie niemieckiego personelu wojskowego w USA itp.) ${ }^{146}$.

Niemiecki rząd przedstawił inną propozycję. Nowa umowa offsetowa miała obowiązywać przez dwa lata. Wartość rekompensaty szacowano na $700 \mathrm{mln}$ USD rocznie, co stanowiło 75\% całości wydatków militarnych USA w RFN. Zawierała dostawy cywilne (70 mln USD) i militarne (350 mln). Proponowano też dziesięcioletnią umowę międzyrządową, dotyczącą „pożyczki na bezpieczeństwo narodowe”. Zgodnie z nią rząd RFN miał przekazać Stanom Zjednoczonym pieniądze w DM, a rząd USA miał spłacać niewielkie odsetki. Bergsten, który przedstawiał niemiecką propozycję Kissingerowi zauważył, że nie było to korzystne, gdyż wartość DM rosła, więc odsetki byłyby coraz wyższe. Poza tym obawiał się niezadowolenia w Kongresie z powodu zaciągania pożyczek za granicą na finansowanie amerykańskich operacji militarnych poza obszarem USA.

RFN miała też dokonać bezpośrednich inwestycji w USA na określoną sumę, a niemiecki rząd zobowiązał się zakupić amerykańskie papiery wartościowe i sprzedać je niemieckim firmom. Pożyczki w różnej formie opiewały na $300 \mathrm{mln}$ USD. Bergsten uważał, że i ta propozycja nie była do zaakceptowania przez Kongres, który mógł uznać, że prowadzi to do wykupywania przez Niemców amerykańskich przedsiębiorstw. Strona niemiecka proponowała też zakup większej liczby obligacji skarbu USA, które nabywali już od dwóch lat. Bundesbank miał kontynuować zobowiązanie do powstrzymania się od żądania od Stanów Zjednoczonych wymiany dolarów na złoto.

Bergsten próbował sformułować amerykańską kontrpropozycję. Odrzucił zdecydowanie pomysł, by RFN spłacała granty związane z planem Marshalla, gdyż było to politycznie nie do zaakceptowania przez niemiecki rząd. Proponował jednak współpracę w dziedzinie nauki i technologii, zagwarantowanie poparcia dla jak najszybszego wprowadzenia SDR-ów oraz, po wyborach w październiku 1969 r., zgodę na rewaluację $\mathrm{DM}^{147}$.

11 kwietnia Kissinger spotkał się z szefem dyplomacji RFN - Brandtem. Tematem rozmów była sprawa traktatu o nierozprzestrzenianiu broni masowego

${ }^{146}$ NARA, NPMS, NSC Files, Country Files - Europe (Germany), Bergsten do Kissingera, 24 marca 1969, box 681.

${ }^{147}$ Ibidem, Bergsten do Kissingera, 8 kwietnia 1969. 
rażenia, kwestia zapewnienia swobodnego dostępu do Berlina, perspektywy organizacji Konferencji Bezpieczeństwa i Współpracy w Europie (KBWE), ale także offset. Dobór poruszanych zagadnień nie był przypadkowy. Rola USA we wszystkich wymienionych zagadnieniach politycznych była kluczowa i nieodzowna dla interesów RFN. Kissinger wyraził gotowość do negocjacji, chociaż nie bezwarunkowego przyjęcia całości niemieckiej propozycji offsetowej ${ }^{148}$. Helmut Sonnenfeldt - członek NSC, monitorujący kontakty z Europą - w rozmowie z Dirkiem Onckenem z ambasady RFN w Waszyngtonie przekonywał do osiągnięcia rychłego porozumienia, zaznaczając, że należy negocjować długoterminowy układ w tej sprawie. Oncken jednak stwierdził, że przewidziana na długi okres umowa byłaby niekorzystna dla jego rządu ze względu na często zmieniające się warunki w gospodarce światowej, szczególnie w sferze finansów. Dlatego należało dostosowywać do nich każdorazowo porozumienie offsetowe. Sonnenfeldt podkreślił konieczność utrzymania politycznej kontroli nad negocjacjami, by nie stracić szerszego kontekstu offsetu i nie pogorszyć wzajemnych stosunków na innych polach. Sonnenfeldt ostrzegał, że nieporozumienia dotyczące tej kwestii mogły niekorzystnie odbić się także na polityce wewnętrznej obu państw. Amerykanie, jego zdaniem, nie chcieliby powtórki sytuacji z 1966 r., kiedy kanclerz Ludwig Erhard musiał zrezygnować z funkcji, między innymi przez niemożność znalezienia w budżecie środków na wypełnienia umowy offsetowej z $1966 \mathrm{r}^{149}$

Postulaty Bergstena, by uzyskać od RFN zapewnienie o współpracy na polu monetarnym nie zostały zrealizowane. Zresztą Samuels, który prowadził negocjacje offsetowe, nie poruszył nawet kwestii monetarnych w kontekście możliwej współpracy, którą Amerykanie mogliby uznać za część offsetu. Co więcej, w RFN rządziła wtedy Wielka Koalicja (SPD i CDU) i na skutek sprzeciwu SPD RFN nie zdecydowała się na rewaluację DM, jak tego chcieli Amerykanie. Kanclerz Kurt Kiesinger i minister finansów Franz Josef Strauss tłumaczyli, że byłoby to zbyt wielkie polityczne ryzyko, gdyż nie zgadzały się na to ministerstwa gospodarcze. Mimo to Amerykanie nie podjęli żadnych działań w sprawie rekompensat, obawiając się poważnych nieporozumień z RFN.

Kissinger w liście do Nixona podkreślał polityczny charakter offsetu. Przedstawiał różne możliwe opcje rozwiązania problemu. Negocjacje mogły się zakończyć jeszcze przed wizytą kanclerza Kiesingera w Waszyngtonie, planowaną na

${ }^{148}$ Ibidem, Sonnenfeldt do Kissingera, 11 kwietnia 1969.

${ }^{149}$ Słaba pozycja Erharda jako kanclerza sprawiła, że Bundesbank nie chciał współpracować i udzielić pożyczki na wypełnienie zobowiązań offsetowych. W związku z tym kanclerz zrezygnował z urzędu. Zastąpił go Kurt Kiesinger, który stworzył Wielką Koalicję socjaldemokratów i chrześcijańskich demokratów (doszła do władzy 1 grudnia 1966 r.). Zdołał przeforsować zgodę w parlamencie na zwiększenie budżetu w celu wypełnienia tych zobowiązań (H. Z i m m e r m a n n, Money and Security: Troops, Monetary Policy and West Germany's Relations with the United States and Britain, 1950-1971, Cambridge 2002, s. 210-212), NARA, NPMS, NSC Files, Country Files - Europe (Germany), Sonnenfeldt do Kissingera, 23 kwietnia 1969, box 681. 
22-23 czerwca, ale można było je przedłużać w celu uzyskania lepszych warunków. Doradca ds. bezpieczeństwa narodowego przypomniał o możliwości wykorzystania offsetu do nawiązania współpracy z RFN w kształtowaniu reformy światowego systemu monetarnego. Przekonywał, że nawet lepsze warunki offsetu nie przyczyniłyby się w znaczącym stopniu do poprawy amerykańskiego BOP. Uznał, że RFN nie bała się wycofania amerykańskich wojsk, gdyż negocjatorzy z powodów politycznych nie używali tego argumentu. Radził, żeby mimo to dążyć do uzyskania lepszej oferty niż wynegocjowane przez poprzednie administracje, by uspokoić Kongres. Uważał jednak, że nie należy żądać zbyt wiele ${ }^{150}$.

W umowie offsetowej z lipca 1969 r. uwzględniono udzielane przy wsparciu rządu RFN kredyty dolarowe dla niemieckich inwestorów w USA (200 mln USD). Poza tym Stany Zjednoczone zapewniły sobie dwuletnią umowę, która pokrywała większość kosztów - ok. 80\%, z czego 61\% realizowano, kupując towary i usługi w USA, szczególnie sprzęt wojskowy. Ogólna kwota rekompensat wyniosła 1,5 mld USD na 2 lata. Terminy płatności pożyczek zaciągniętych w RFN przez USA zostały wydłużone do 8-10 lat (wcześniej maksymalnie wynosiły 4,5 roku). Zostały również ustalone korzystne dla strony amerykańskiej odsetki - 3,5-4\%. Krytycy twierdzili, że było to rozwiązanie krótkoterminowe, niemogące zrównoważyć amerykańskich problemów budżetowych. Przeciwnicy nadmiernych wymagań offsetowych w USA obawiali się, oprócz pogorszenia relacji z Bonn, niemieckiego żądania wymiany dolarów na złoto. Presję, mającą spowodować zwiększenie offsetu, uważano za ingerencję w wewnętrzne sprawy $\mathrm{RFN}^{151}$.

\subsection{Podsumowanie}

Poważne rozbieżności między Stanami Zjednoczonymi a Europą Zachodnią pod koniec lat 60. wystąpiły z dwóch podstawowych powodów. Po pierwsze, Europejczycy utracili zaufanie do amerykańskiego przywództwa. Oskarżali Stany Zjednoczone o unilateralizm i deklarowali gotowość prowadzenia bardziej niezależnej polityki zagranicznej. Było to możliwe w warunkach rozpoczynającej się epoki odprężenia w stosunkach amerykańsko-radzieckich. Drugi czynnik powodujący nieporozumienia był związany z sytuacją gospodarczą w Stanach Zjednoczonych i krajach Europy Zachodniej w połączeniu ze zmianami funkcjonowania systemu gospodarki światowej.

Doktryna Nixona, zakładająca dzielenie z sojusznikami odpowiedzialności za bezpieczeństwo, była przejawem zmierzchu hegemonii Stanów Zjednoczonych. Decydujący wpływ na to miały dwa czynniki: zmniejszenie poczucia zagrożenia ze

\footnotetext{
${ }^{150}$ NARA, NPMS, NSC Files, Country Files - Europe (Germany), Kissinger do Nixona, 2 czerwca 1969, box 681.

${ }^{151}$ A. B a ke r F ox, op. cit., s. 211. Por. G. F. Tre ve rt o n, op. cit., s. 43.
} 
strony ZSRR oraz wzrost siły gospodarczej Europy Zachodniej i Japonii. Osłabienie państw Starego Kontynentu po II wojnie światowej i wynikająca stąd potencjalna podatność na wpływy ZSRR powodowała, że Stany Zjednoczone przyznawały sojusznikom koncesje gospodarcze i akceptowały tworzenie przez nich zamkniętego systemu ekonomicznego. Pod koniec lat 60 . decydenci amerykańscy zauważyli, że powoduje to straty dla rodzimych eksporterów. Coraz mniej korzystna okazywała się również dominacja dolara w światowym systemie monetarnym. Deficyt bilansu płatniczego w USA sprawił, że państwo to zaczęło domagać się od Europejczyków odciążenia amerykańskiej gospodarki. Pozycja hegemona, zarówno na polu militarnym, jak i ekonomicznym, stawała się zbyt kosztowna.

0 zmierzchu amerykańskiej dominacji świadczył fakt, że Stany Zjednoczone nie mogły narzucić pozostałym uczestnikom systemu zmian zgodnych z ich interesem. Także państwa europejskie w nowej sytuacji pragnęły większej samodzielności. Wytworzyła się swoista współzależność: obie strony chciały utrzymać sojusze, próbując kształtować je zgodnie z własną koncepcją, co wymagało kompromisów. Zbigniew Brzeziński, dostrzegając te problemy, postulował stworzenie „prawdziwego, a nie werbalnego partnerstwa". Jego elementem miało być przede wszystkim konkretne zdefiniowanie roli Europy Zachodniej na arenie międzynarodowej, by mogła dążyć do jednego celu ze Stanami Zjednoczonymi, oraz wspólne starania o zbliżenie do krajów Europy Wschodniej ${ }^{152}$.

${ }^{152}$ Z. B r z e z i ń s k i, America and Europe, „Foreign Affairs”, October 1970, s. 17. 

ROZDZIAŁ IV

\section{RELACJE TRANSATLANTYCKIE W DOBIE KRYZYSU MONETARNEGO (STYCZEŃ 1970 - SIERPIEŃ 1971)}

\subsection{Ewolucja stanowiska Stanów Zjednoczonych wobec rozszerzenia EWG}

Wobec perspektywy rozszerzenia Wspólnot, w Stanach Zjednoczonych rozpoczęły się dyskusje na temat wpływu tego wydarzenia na stosunki transatlantyckie. 23 stycznia 1970 r. odbyło się spotkanie specjalnej grupy roboczej NSC, podczas którego rozmawiano o ewentualnych zmianach w polityce Stanów Zjednoczonych wobec Europy Zachodniej. Priorytetem miało być zapewnienie jej bezpieczeństwa, a jednocześnie promowanie zdolności sojuszników do wzięcia części odpowiedzialności za politykę światową. W tym kontekście najczęściej mówiono o roli trzech państw: Wielkiej Brytanii, RFN i Francji. Określono najważniejsze kwestie wpływające na wzajemne relacje: zmianę ekipy rządzącej we Francji, Ostpolitik, presję Europy Zachodniej na zwołanie KBWE oraz naciski Kongresu na redukcję sił amerykańskich stacjonujących na Starym Kontynencie. Głównym przedmiotem dyskusji była jednak integracja europejska. Zauważono, że o ile w wymiarze gospodarczym można było zaobserwować jej postępy, perspektywy zjednoczenia politycznego były odległe. Także utworzenie przez Europejczyków systemu obrony niezależnego od USA było mało prawdopodobne.

Zgodzono się jednak, że w miarę upływu czasu Stany Zjednoczone będą musiały coraz bardziej liczyć się ze zdaniem sojuszników i pozwolić im na współdecydowanie. Podkreślano wielką wagę przyłączenia do EWG Wielkiej Brytanii, która miała stanowić siłę wzmacniającą Wspólnotę, będąc państwem pozostającym $\mathrm{w}$ „specjalnych stosunkach" z USA. Postulowano powstrzymanie się od wywierania wpływu na wewnątrzeuropejski proces negocjacyjny, gdyż mogło to przynieść skutki odwrotne do zamierzonych. W dyskusji NSC pojawiło się niewiele obaw o rywalizację ekonomiczną - dominowały elementy polityczne: przede wszystkim zastanawiano się, jak wykorzystać EWG i jej jedność w polityce wobec ZSRR ${ }^{1}$.

\footnotetext{
${ }^{1}$ National Archives and Record Administration, College Park, MD (NARA), Nixon Presidential Materials Staff (NPMS), National Security Council (NSC) Insitutional "H” Files, Senior Review Group Meetings, polityka USA wobec Europy, 23 stycznia 1970, box H-041.
} 
Wobec rozbieżności wewnątrz administracji, Kissinger zarządził wiosną $1970 \mathrm{r}$. formalne, międzyagencyjne rozmowy na temat relacji z Europą. Departamenty gospodarcze przedstawiły scenariusz wydarzeń po rozszerzeniu EWG o Wielką Brytanię. Obawiano się, że powstanie wtedy „gospodarczy potwór”, który zdominuje handel światowy, będzie narzucał warunki planowanej reformy międzynarodowego systemu walutowego i rozszerzał swe „macki” na Trzeci Świat. Przewidywano, że jeśli wszystkie byłe kolonie brytyjskie i kraje EFTA otrzymają preferencyjne warunki wymiany z EWG, spowoduje to katastrofalne skutki dla amerykańskiej gospodarki. Żądano, by Nixon wygłosił przemówienie, w którym miał uzależnić poparcie dla rozszerzenia EWG od zniesienia przez to ugrupowanie systemu preferencji dla państw trzecich. Departament Stanu był przeciwny takiemu rozwiązaniu. Jego przedstawiciele uważali, że członkostwo Wielkiej Brytanii będzie niezwykle korzystne dla interesów Stanów Zjednoczonych. Nie chcieli, żeby w momencie usunięcia najpoważniejszej przeszkody - groźby weta francuskiego - amerykański rząd blokował tę inicjatywę².

W raporcie przedłożonym Kissingerowi 23 kwietnia 1970 r., odpowiedzialny w Departamencie Stanu za kontakty z Europą Martin Hillenbrand zawarł możliwe implikacje rozszerzenia EWG dla Stanów Zjednoczonych. Według niego, wejście Wielkiej Brytanii było konieczne dla dalszego rozwoju EWG, gdyż w przeciwnym wypadku proces integracyjny zostałby zahamowany. Nastąpiłaby wtedy fragmentaryzacja gospodarcza Europy, co byłoby bardzo niekorzystne dla amerykańskich interesów. Przyznał, że rozszerzenie będzie miało negatywny skutek dla działalności małych przedsiębiorstw. Mimo to ważniejsze były pozytywne efekty długofalowe. Wejście nowych członków miało spowodować, że EWG stanie się bardziej liberalna i odpowiedzialna - będzie w większym stopniu brała pod uwagę interesy partnerów handlowych. Hillenbrand przypominał, że eksport Stanów Zjednoczonych do EWG wzrósł o 143\% od początku istnienia tej organizacji. Zysk z tej wymiany dla USA wynosił rocznie ok. 1 mld USD. Poza tym kraje Wspólnot były najatrakcyjniejszym miejscem inwestycji dla amerykańskich przedsiębiorstw - ich wartość wzrosła w tym samym okresie dziewięciokrotnie.

Hillenbrand zauważył straty wynikające z rozszerzenia dla amerykańskiego rolnictwa, głównie dla eksportu zboża. Przewidywał jednak, że Wielka Brytania może wpływać na redukcję cen produktów rolnych w ramach CAP. Rekomendował obronę amerykańskich interesów na forum GATT i OECD. Jednocześnie powinny być prowadzone bilateralne negocjacje z poszczególnymi członkami EWG. Alternatywnymi sposobami miały być stworzenie mechanizmu konsultacyjnego, który zobowiązywałby EWG do informowania Waszyngtonu o bieżących planach oraz ogłoszenie sprzeciwu wobec rozszerzenia CAP na nowych członków bez rekompensat dla USA. Dodatkowym warunkiem było żądanie, by rządy europejskie nie podejmowały decyzji dotyczących kursów walutowych bez wcześniejszego

\footnotetext{
${ }^{2}$ H. K i s s i n g e r, White House Years, Boston 1979, s. 425-427.
} 
skonsultowania tych posunięć na forum MFW lub G10. Hillenbrand odrzucał ten ostatni scenariusz, mógł on bowiem wytworzyć w Europie przekonanie, że Stany Zjednoczone zasadniczo zmieniły stosunek do integracji i sprowokować poważne napięcia polityczne ${ }^{3}$.

21 kwietnia Departament Stanu przedstawił NSC szczegółowy raport na temat skutków rozszerzenia EWG, przewidywanych dla Stanów Zjednoczonych. W dziedzinie handlu oceniono, że negatywne efekty będą krótkoterminowe i obejmą jedynie zmiany taryf celnych. Przypomniano, że po ostatnich rundach negocjacyjnych GATT europejskie taryfy celne były umiarkowane: średnio na poziomie 8-10\%, czyli zmniejszyły się o połowę w porównaniu z 1957 r., kiedy powstała EWG. Przyznano, że niektóre gałęzie amerykańskiego przemysłu mogły ponieść straty, gdy nastąpi zniesienie barier między EWG a EFTA. Natomiast czynnikiem rekompensującym po wstąpieniu Wielkiej Brytanii miało być obniżenie jej ceł do poziomu EWG oraz zaniechanie preferencyjnego handlu z Commonwealthem. Departament Stanu oceniał (podkreślając, że był to najgorszy scenariusz rozwoju wypadków), że straty dla amerykańskich producentów dóbr przemysłowych wyniosą ok. $300 \mathrm{mln}$ USD. Stanowiło to $4 \%$ całego amerykańskiego eksportu nierolniczego do tych krajów w 1968 r. Średni przyrost eksportu USA do krajów EWG i EFTA w latach 1961-1968 wynosił 7,6\% i pomniejszał tę stratę do $70 \mathrm{mln}^{\mathrm{USD}}{ }^{4}$. Kwota ta mogła jeszcze ulec redukcji ze względu na inflację w Wielkiej Brytanii, spowodowaną podwyżką cen żywności w momencie przyjęcia CAP.

Tabela 4.1. Bilans skutków rozszerzenia EWG dla amerykańskiego eksportu produktów nierolniczych (w mln USD) - maksymalne straty (-) i zyski (+)

\begin{tabular}{|l|c|c|}
\hline \multicolumn{1}{|c|}{ Eksport USA } & EWG 10 & $\begin{array}{c}\text { EWG + EFTA (w ramach } \\
\text { układu o wolnym handlu) }\end{array}$ \\
\hline Wielka Brytania & +23 & -3 \\
\hline Dania, Norwegia i Irlandia & -20 & -29 \\
\hline Kraje EWG 6 & -156 & -282 \\
\hline Kraje EFTA & +16 & -57 \\
\hline Kraje Commonwealthu & +66 & +66 \\
\hline Ogółem straty wynikające ze zmiany ceł & -71 & -305 \\
\hline
\end{tabular}

Źródło: NARA, NPMS, NSC Insitutional, "H" Files, Senior Review Group Meetings, Raport Departamentu Stanu na temat skutków rozszerzenia EWG, 21 kwietnia 1970, box H-041.

\footnotetext{
${ }^{3}$ NARA, NPMS, NSC Institutional "H" Files, Study Memorandums (1969-1974), Hillenbrand do Kissingera, 21 kwietnia 1970, box H-164.

${ }^{4}$ NARA, NPMS, NSC Insitutional "H" Files, Senior Review Group Meetings, raport Departamentu Stanu na temat skutków rozszerzenia EWG, 21 kwietnia 1970, box H-041.
} 
Departament Stanu przypominał, że negatywny wpływ na amerykański eksport będą miały preferencyjne umowy EWG z państwami trzecimi. Przewidywano, że straty z tego tytułu wyniosą od 50 do 100 mln USD, lecz szacunki te były niedokładne, gdyż nie znano jeszcze dokładnej treści tych umów. Zakładano również wzrost produkcyjności w krajach EWG, co miało sprawić, że towary stamtąd pochodzące będą bardziej konkurencyjne od amerykańskich na rynkach światowych $^{5}$.

Bilans potencjalnych zysków i strat dla amerykańskiego eksportu produktów nierolniczych przedstawiono $\mathrm{w}$ tabeli 4.1. Można zauważyć, że w przypadku rozszerzenia EWG o Wielką Brytanię, Irlandię, Danię i Norwegię prognozowano wzrost wywozu do Wielkiej Brytanii, krajów EFTA i Commonwealthu, zmniejszyłaby się za to wartość eksportu do Danii, Norwegii, Irlandii i „starych” krajów EWG. Sytuacja wyglądałaby podobnie $\mathrm{w}$ wyniku działania układu o wolnym handlu między poszerzoną EWG a EFTA, z tym, że spadek wartości wywozu dotyczyłby również wymiany z Wielką Brytanią i krajami EFTA. W obu przypadkach w wyniku zmiany ceł wartość amerykańskiego eksportu uległaby zmniejszeniu.

Według ekspertów Departamentu Stanu, trudno było ocenić, jaki będzie efekt rozszerzenia dla handlu produktami rolniczymi. Po wejściu Wielkiej Brytanii ceny mogły się obniżyć, jednak takiej opcji była zdecydowanie przeciwna RFN. Eksport amerykański do krajów aspirujących do członkostwa mógł znacząco spaść. W momencie tworzenia raportu wywóz był wart 600 mln USD rocznie, a mógł w najgorszym przypadku obniżyć się do $100 \mathrm{mln}$. Nie można było także określić, jakie efekty będzie miało rozszerzenie dla amerykańskich BIZ. Wynosiły one w dziesięciu krajach europejskich (po ewentualnym przystąpieniu Wielkiej Brytanii, Irlandii, Danii i Norwegii) ponad 16 mld USD. Szacowano, że po rozszerzeniu BIZ wzrosną o 37\% w $1970 \mathrm{r}$. Warunkiem korzyści dla amerykańskich inwestorów był brak zmian w polityce inwestycyjnej krajów europejskich. Do 1970 r. tylko Francja stosowała restrykcje, obejmujące inwestowanie w niektóre sektory i przejęcia istniejących firm. Jednak inne kraje EWG naciskały na zmianę tych przepisów, gdyż uważały je za niezgodne z Traktatami Rzymskimi. Departament Stanu przewidywał, że członkostwo Wielkiej Brytanii, która była otwarta na amerykańskie inwestycje, prawdopodobnie jeszcze zliberalizuje stanowisko EWG.

W raporcie Departamentu Stanu stwierdzono, że Europa umocni pozycję w polityce światowej, a jej siła gospodarcza umożliwi zwiększenie odpowiedzialności za obronę i pomoc krajom rozwijającym się. Jednocześnie przewidywano, że będzie zbyt zaabsorbowana rozwojem integracji, by stać się aktywnym graczem na arenie międzynarodowej. Stwierdzono, że jedność polityczna Wspólnot nie dokona się w najbliższym czasie, choć integracja gospodarcza skutkowała siłą rzeczy zbliżeniem politycznym. Wysunięto również tezę, że kraje EWG będą zbliżały się do Europy Wschodniej, co mogło powodować napięcia w stosunkach transatlantyckich.

\footnotetext{
${ }^{5}$ Ibidem.
} 
Zauważono, że pozytywnym skutkiem rozszerzenia będzie równoważenie przez Wielką Brytanię, być może wspólnie z Francją, wpływów RFN we Wspólnotach.

Departament Stanu podkreślił, że Amerykanie wciąż dysponowali wieloma narzędziami wpływu na Europę ze względu na rozwinięte stosunki polityczne, militarne i gospodarcze. Szczególnie skuteczne mogły się okazać działania na forum GATT. Możliwy był także nacisk poprzez OECD, MFW czy G10. W Stanach Zjednoczonych była przygotowywana nowa ustawa handlowa. Departament Stanu zalecał w rozmowach z przedstawicielami krajów EWG używanie argumentu, że jeśli Europejczycy chcą uniknąć amerykańskiego protekcjonizmu i zależy im na kształcie ustawy umożliwiającym duże obniżki ceł, muszą uznać amerykańskie postulaty ${ }^{6}$. W zaleceniach Departamentu Stanu nie było mowy o stosowaniu środków politycznych, rekompensujących straty USA w wyniku rozszerzenia EWG - przewidywano używanie narzędzi i forów gospodarczych.

W oświadczeniu Departamentów Handlu, Skarbu i Rolnictwa z 22 kwietnia 1970 r. zanegowano niektóre z tych rekomendacji. Stwierdzono, że powiększenie EWG spowoduje zmniejszenie kosztów produkcji w krajach Wspólnoty, a europejski przemysł stanie się bardziej konkurencyjny na rynku światowym. Rozszerzenie CAP na czterech nowych członków będzie miało bardzo zły wpływ na światowy handel towarami rolnymi. Zakwestionowano też obliczenia strat dla gospodarki amerykańskiej. Stwierdzono, że prognozy te opierały się na niepewnych przesłankach. Departamenty gospodarcze przewidywały, że Wspólnota będzie rozszerzała wpływy na rynkach światowych kosztem USA. Jako przykład podano, że dzięki CAP EWG stała się głównym eksporterem zbóż. Przyznano jednak, że mało prawdopodobna była dyskryminacja amerykańskich firm działających w Europie. Rekomendowano przyjęcie strategii wspierania integracji z powodów politycznych, przy jednoczesnym zabezpieczaniu amerykańskich interesów poprzez powoływanie się na zasady GATT, naciskanie na korzystne dla USA zmiany w CAP jeszcze przed rozszerzeniem oraz starania o utworzenie stałego mechanizmu konsultacyjnego, by amerykańska administracja była uprzedzana o posunięciach Wspólnot i mogła je wcześniej negocjować. Przedstawiciele departamentów gospodarczych chcieli również poruszyć kwestię warunków obecności wojsk USA w Europie (w celu wymuszenia rekompensaty za straty w handlu) ${ }^{7}$.

Najbardziej radykalna opinia wpłynęła do NSC z biura Specjalnego Przedstawiciela ds. Handlu (Special Trade Representative - STR). Sugerowano, że należało wykorzystywać wszystkie powiązania - gospodarcze, finansowe, polityczne i obronne, żeby Europejczycy byli świadomi, że jeśli będą szkodzić gospodarce amerykańskiej, mogą się spodziewać pogorszenia relacji na tych wszystkich polach. Postulowano, aby w czasie negocjacji między EWG a Wielką Brytanią zapewnić

\footnotetext{
${ }^{6}$ Ibidem.

${ }^{7}$ NARA, NPMS, NSC Institutional "H" Files, Study Memorandums (1969-1974), oświadczenie Departamentów Handlu, Skarbu i Rolnictwa, 22 kwietnia 1970, box H-164.
} 
o determinacji obrony amerykańskich interesów na forum GATT i żądać stworzenia mechanizmów konsultacyjnych ${ }^{8}$.

W łonie administracji amerykańskiej godzinami trwały dyskusje, czy w ostatecznym oświadczeniu powinno się znaleźć zdanie, że integracja może spowodować (could cause) lub spowoduje (would cause) problemy dla gospodarki. Departament Stanu próbował przekonać prezydenta o konieczności powstrzymania się od artykułowania jakichkolwiek obaw. Jednak zbliżające się wybory do Kongresu wykluczyły taką opcję. Nixon chciał udowodnić, że Republikanie wykazują stanowczość w obronie amerykańskich interesów gospodarczych.

Wydarzenia w Kongresie wskazywały na zapotrzebowanie społeczne na takie działania. Przygotowywano restrykcyjną ustawę o kontyngentach na import niektórych produktów. Nastąpiła mobilizacja eksporterów artykułów rolniczych, domagających się przeciwdziałania dyskryminacyjnej wspólnej polityce rolnej EWG9 Nawet zwykle broniący zdecydowanie interesów gospodarki amerykańskiej Peter M. Flanigan, doradca prezydenta ds. międzynarodowych spraw gospodarczych (Assistant to the President for International Economic Affairs), radził skonsultować się z Europejczykami, obawiając się retorsji. Komisja Europejska już w czerwcu groziła odwetem handlowym, jeśli USA wprowadziłyby restrykcje na tekstylia albo na buty ${ }^{10}$. Kissinger pisał do Nixona 2 lipca 1970 r., że może to mieć bardzo negatywny wpływ na amerykańską politykę zagraniczną. Stwierdził, że EWG może odpowiedzieć restrykcjami na import żywności, a prowadzone z Hiszpanią negocjacje na temat utrzymania na jej terytorium amerykańskich baz wojskowych mogą się załamać11.

W memorandum dla prezydenta z 30 czerwca 1970 r. Kissinger zauważył, że konieczne było wypracowanie jednego oświadczenia, gdyż poszczególne departamenty prezentowały publicznie różne opinie, co powodowało wątpliwości dotyczące stanowiska USA wobec postępów integracji. Departamenty odpowiedzialne za gospodarkę były inspirowane przez środowiska biznesowe, Kongres i skargi środowisk rolniczych. Departament Stanu chciał uniknąć osłabienia politycznego sojuszu, szczególnie obawiał się, żeby kolejnymi oświadczeniami Stany Zjednoczone nie utrudniały i tak już skomplikowanych negocjacji akcesyjnych Wielkiej Brytanii. Kissinger stwierdził, że najlepszym rozwiązaniem było odnoszenie się USA do konkretnych kwestii, a nie do całości rozszerzenia. Żeby to osiągnąć, należało utworzyć mechanizm konsultacyjny z EWG, umożliwiający dyskutowanie poszczególnych spraw na bieżąco. Komitet Podsekretarzy różnych agencji powinien nazwać te problemy i w razie niemożności ustalenia stanowiska zwracać się do prezydenta.

${ }^{8}$ Ibidem, Stanowisko i rekomendacje Specjalnego Reprezentanta Handlowego w sprawie rozszerzenia EWG, 23 kwietnia 1970.

${ }^{9}$ A. D ü r, Protection for Exporters: Power and Discrimination in Transatlantic Relations, 19302010, Ithaca 2010, s. 138-139.

${ }^{10}$ NARA, NPMS, NSC Files, Subject Files: Trade General, Bergsten do Kissingera, 15 czerwca 1970, box 401.

${ }^{11}$ Ibidem, Kissinger do Nixona, 2 lipca 1970. 
Kissinger przewidywał, że EWG zgodzi się na konsultacje, bo sama była zainteresowana rozmowami na temat przewidywanych restrykcji w handlu USA, a także informacjami na temat wyników negocjacji rozbrojeniowych między Stanami Zjednoczonymi a ZSRR. Stwierdził, że prezydent powinien zebrać wszystkie dane oraz wyraźnie powiedzieć, że Amerykanie będą domagać się rekompensat i dążyć do zbliżenia stanowisk departamentów ${ }^{12}$.

Sugestie Kissingera przedstawione w memorandum zostały zaakceptowane przez Nixona. 3 lipca 1970 r. wydano memorandum decyzyjne (NSDM 68) na temat polityki Stanów Zjednoczonych wobec EWG, w którym zawarto zasady postępowania wobec jej rozszerzenia. Odnosiły się one nie tylko do Wspólnoty, lecz także do krajów EFTA i beneficjentów nowych preferencyjnych układów handlowych z EWG. Poparto przyjęcie nowych członków, akceptując pewne, lecz nie nadmierne, koszty gospodarcze, które miały ponieść Stany Zjednoczone. Zapowiedziano dokonanie oceny tych strat. Jeśli warunki handlu z EWG zostałyby uznane za dyskryminujące, rząd amerykański zastrzegł sobie prawo podjęcia odpowiednich działań, szczególnie dochodzenie swoich praw na forum GATT. Wezwano negocjujące kraje, by brały pod uwagę interesy państw trzecich oraz zasady międzynarodowego systemu handlowego. By osiągnąć konsensus, kraje europejskie miały zaproponować sposoby konsultacji i informowania Waszyngtonu nie tylko o decyzjach związanych z rozszerzeniem, ale wszystkich, które mogłyby wpłynąć na amerykańskie interesy. Poinformowano, że odpowiedzialny za prowadzenie negocjacji i przedstawienie sprawy opinii publicznej był ze strony amerykańskiej Komitet Podsekretarzy ${ }^{13}$. Ostateczny kształt dokumentu zaakceptowany przez Nixona nie różnił się od projektu NSC, który można uznać za kompromisowy w porównaniu ze stanowiskiem Departamentu Stanu i agencji gospodarczych.

Relacje brytyjsko-amerykańskie układały się bardzo dobrze za rządów Harolda Wilsona. Jednak stan ten zmienił się w roku 1970, kiedy Partia Konserwatywna dość niespodziewanie wygrała wybory. Na czele rządu brytyjskiego staną Edward Heath ${ }^{14}$. Był on głównym negocjatorem w latach 1961-1963, kiedy Wielka Brytania bez powodzenia starała się o członkostwo we Wspólnotach Europejskich. Przyjął politykę zdecydowanego zwrotu w kierunku Europy i, pomny wcześniejszych doświadczeń, nie chciał eksponować szczególnych związków ze Stanami Zjednoczonymi ${ }^{15}$. Jego zdanie podzielał nowy minister spraw zagranicznych, Alec Douglas-Home. Nie oznaczało to, że dążono do zerwania sojuszu z USA. Przeciwnie - Heath uważał, że zintegrowana Europa powinna odegrać większą rolę w NATO, stając się prawdziwym partnerem

12 NARA, NPMS, NSC Insitutional "H” Files, National Security Decision Memorandums (19691974), Kissinger do Nixona, 30 czerwca 1970, box H-217.

${ }^{13}$ Ibidem, NSDM 68, polityka Stanów Zjednoczonych wobec EWG, 3 lipca 1970.

${ }^{14}$ Heath miał za złe Amerykanom upokorzenie Wielkiej Brytanii w czasie kryzysu sueskiego z 1956 r. Krytykował wtedy na forum parlamentu postawę Stanów Zjednoczonych w imieniu Partii Konserwatywnej.

${ }^{15}$ Ch. P r e s t o n, Enlargement and Integration in European Union, New York 1997, s. 31-32. 
USA, a nie „obrażającym się podopiecznym”"16. Deklarował nawet, że Wielka Brytania mogła wziąć część odpowiedzialności za obronę Dalekiego Wschodu i Zatoki Perskiej, a Stany Zjednoczone nie powinny dźwigać całego ciężaru powstrzymywania komunizmu. Uważał również, że jego kraj, będąc w EWG, zdoła skutecznie pomóc krajom rozwijającym się, także z Commonwealthu. Heath mówił o Europie otwartej na resztę świata, świadomej swych globalnych zobowiązań, a nie o Europie protekcjonistycznej ${ }^{17}$. Przekonywał przywódców państw członkowskich EWG, szczególnie Pompidou, że nie był „koniem trojańskim” Stanów Zjednoczonych. Dlatego po objęciu stanowiska nie odbył od razu podróży do Waszyngtonu. Pierwsze spotkanie z Nixonem miało miejsce w Chequers we wrześniu 1970 r. Było ono czysto kurtuazyjne z udziałem brytyjskiej królowej, w której obecności nie podejmowano palących kwestii. Kolejne spotkanie przywódców, mające miejsce następnego dnia, było bardzo krótkie. Brytyjski premier odrzucił pomoc USA w procesie negocjacji. Stwierdził, że jego kraj łączył swą przyszłość z Europą - i nie był to manewr taktyczny, ale postawa wynikająca z głębokiego przekonania o słuszności tej strategii. Sugerował, że pragnął mieć takie same stosunki ze Stanami Zjednoczonymi, jak inni europejscy liderzy ${ }^{18}$.

Nixon dążył jednak do utrzymania specjalnych stosunków. Kissinger w swoich wspomnieniach zauważył podobieństwa między amerykańskim prezydentem a brytyjskim premierem. Obaj przeszli długą i niełatwą drogę kariery politycznej oraz byli „podejrzliwymi samotnikami”. Ich poglądy na temat polityki zagranicznej zbiegały się w wielu kwestiach, dlatego rozmowy nie były tak trudne, jak można się było spodziewać. Niechęć Heatha do nawiązania bliższych relacji była dla Nixona rozczarowaniem tym bardziej, że na początku kadencji Brandt i Pompidou byli postrzegani jako przywódcy dążący do zbliżenia z Amerykanami, co dawało nadzieję na konstruktywny transatlantycki dialog ${ }^{19}$.

Ważnym przedmiotem dyskusji stał się amerykański protekcjonizm, gdyż Stany Zjednoczone były najważniejszym partnerem handlowym Wielkiej Brytanii $^{20} .13$ sierpnia 1970 r. Kongres uchwalił bardzo restrykcyjną ustawę celną zgłoszoną przez wpływowego szefa Komisji Budżetowej Izby Reprezentantów (House Ways and Means Committee) Wilbura Millsa. Ustalała ona wysokie bariery na import tekstyliów, butów, ropy i futer. Poza tym znacznie zwiększyła zakres działania escape clause i możliwość wprowadzenia restrykcji importowych, jeśli import naruszałby interesy amerykańskiego przemysłu ${ }^{21}$. Część obostrzeń mogła

${ }^{16}$ J. C a m p b e l l, Edward Heath. A Biography, London 1993, s. 336.

${ }^{17}$ Ibidem, s. 337.

${ }^{18}$ H. K i s s i n g e r, op. cit., s. 933-934.

${ }^{19} \mathrm{~J}$. C a m p b ell, op. cit., s. 342.

${ }^{20}$ Wartość eksportu Zjednoczonego Królestwa do tego kraju wynosiła 2,2 mld USD. Na drugim miejscu plasowała się RFN, do której wywożono towary warte 900 mln USD. USA dominowały także jako importer (2,7 mld USD), przed Kanadą, gdzie Wielka Brytania nabywała towary warte 1,2 mld USD (NARA, NPMS, NSC Files, President Trips, UK, box 470).

${ }^{21}$ Za naruszenie tych interesów uznano przypadki, gdy import stanowił od 15\% konsumpcji wewnętrznej danego produktu lub wzrósł o 3 punkty procentowe w ciągu ostatniego roku, lub 
być zniesiona przez prezydenta z powodu ochrony bezpieczeństwa narodowego, jeśli uznałby, że nie ma zagrożenia dla rynku wewnętrznego lub jeśli kontyngenty miałyby spowodować zbyt duży wzrost cen. Jednak decyzja prezydenta mogła być zawetowana przez Kongres w ciągu $60 \mathrm{dni}$. Restrykcje te mogły zostać również zniesione w przypadku zadeklarowanych przez partnerów handlowych dobrowolnych ograniczeń importowych. Była także możliwość, w ramach rekompensaty, obniżenia ceł na inne produkty do $20 \%{ }^{22}$. Jednak w odpowiedzi EWG zagroziła działaniami odwetowymi przeciw amerykańskim produktom rolniczym. Była to sytuacja tym bardziej niebezpieczna, że od 1967 r. eksport tych dóbr do krajów EWG spadł o 47\% ${ }^{23}$. Latem i jesienią 1970 r. mówiono nawet o możliwości „wojny handlowej" między EWG a USA.

Londyn był zaniepokojony skutkami ustawy Millsa. Kontyngenty na tekstylia i buty dotyczyłyby importu brytyjskiego o wartości 87 mln USD, a rozszerzenie działania escape clause zagroziłoby eksportowi o wartości $175 \mathrm{mln}$ USD. Cała ustawa Millsa dotykała ok. 12\% brytyjskiego eksportu. Nixon zapewniał Heatha, że wystąpi przeciwko każdej ustawie, która wprowadzałaby kontyngenty, oprócz tych na tekstylia, gdyż był to tzw. sektor wrażliwy ${ }^{24}$.

Brytyjczycy uważali, że ustawa Millsa stanowiła zagrożenie dla całego handlu światowego i w związku z nią rozpoczną się „wojny handlowe”. Twierdzili, że mimo licznych deklaracji Stany Zjednoczone odwracały się od zasady wolnego handlu. Brytyjski minister handlu i przemysłu zapewniał jednak, że Londyn powstrzyma się od działań odwetowych, których domagali się biznesmeni ${ }^{25}$. Konfederacja Przemysłu Brytyjskiego (Confederation of British Industry) - podobnie jak inne europejskie stowarzyszenia przedsiębiorców - wystosowała list do Nixona z apelem, by działania Stanów Zjednoczonych nie zepsuły dobrych relacji: ożywionych kontaktów handlowych i korzystnych warunków dla inwestycji amerykańskich w Europie. W liście znalazło się stwierdzenie, że jeśli Stany Zjednoczone będą stosowały protekcjonizm, to rządy europejskie wprowadzą restrykcje ${ }^{26}$. Był to przykład czynnego wywierania presji przez aktorów pozapaństwowych. Rząd

o 5 punktów w ciągu 2 lat oraz gdy import doprowadził do redukcji zysków lub wzrostu bezrobocia w danym przemyśle (C. F. B e r g s t e n, Crisis in U.S. Trade Policy, „Foreign Affairs”, July 1971, s. 620).

${ }^{22}$ NARA, NPMS, NSC Files, Subject Files: Trade General, Bergsten do Kissingera, 13 sierpnia 1970, box 401.

${ }^{23}$ Foreign Relations of the United States (FRUS) 1969-1976, vol. 3: Foreign Economic Policy, 1969-1972; International Monetary Policy, 1969-1972, Washington D.C. 2002, Hardin do Rogersa, 18 lipca 1970, dok. 42. dostępne także przez: www.state.gov/r/pa/ho/frus/nixon.

${ }^{24}$ Milton Friedman wspominał, że już w czasie kampanii wyborczej, by zyskać popularność w stanach południowych, Nixon zapowiadał podniesienie ceł na tekstylia. Osobiście uważał jednak, że było to błędne posunięcie jeśli chodzi o relacje gospodarcze z zagranicą (M. Frie dman, R. D. F r i e d m a n, Two Lucky People. Memoirs, Chicago 1998, s. 386).

${ }^{25}$ NARA, NPMS, NSC Files, President's Trips, UK, box 470.

${ }^{26}$ NARA, NPMS, NSC Files, VIP Visits, Hardin do Nixona, 16 grudnia 1970, box 942. 
brytyjski, ze względów politycznych, nie mógł wprost grozić sankcjami, jednak przedsiębiorcy nie musieli brać pod uwagę złożonych, międzyrządowych relacji sojuszniczych.

W memorandum z 16 kwietnia 1971 r. sekretarz handlu Maurice Stans przedstawił negatywne skutki rozszerzenia EWG dla handlu amerykańskiego. Przewidywał, że europejskie firmy staną się bardziej konkurencyjne, gdy zwiększy się przepływ technologii z Wielkiej Brytanii, szczególnie w przemyśle lotniczym i komputerowym. Zmniejszy się wtedy znacznie import tych produktów z USA. Przypomniał, że EWG już wcześniej stosowała nieuczciwe praktyki: dyskryminujące zasady zamówień publicznych, bezpośrednie subsydia, prawo o firmach europejskich, mające ułatwić fuzje przedsiębiorstw w krajach Wspólnot. Wprawdzie wiele przedsiębiorstw amerykańskich, szczególnie międzynarodowe korporacje, korzystało na integracji i było zadowolonych z rozszerzenia, ale istniało niebezpieczeństwo, że w przyszłości nie będą one traktowane na równi z firmami europejskimi. Stans niepokoił się, że jeśli chodzi o warunki handlu i inwestycje, Stany Zjednoczone stają się coraz bardziej zależne od decyzji podejmowanych przez $\mathrm{EWG}^{27}$.

Przed planowanym kolejnym spotkaniem Nixona z Heathem, Kissinger informował, że premier borykał się z problemami wewnętrznymi, gdyż reforma sektora przemysłowego spowodowała strajki. W związku z przystąpieniem do EWG, Heath chciał obciąć wydatki rządowe i ograniczyć rolę państwa w gospodarce, a rolnictwo dostosować do wyższych cen produktów, obowiązujących we Wspólnocie. Od 1 lipca $1971 \mathrm{r}$. brytyjski rząd planował przenieść ciężar wspierania rolnictwa ze skarbu państwa na konsumentów przez podniesienie minimalnych cen importowych i wprowadzenie zmiennych kontyngentów na import zboża. Na takie kroki potrzebował zgody Stanów Zjednoczonych i innych partnerów handlowych, by uniknąć problemów w GATT. Jednak, zdaniem Kissingera, Nixon powinien odmówić ze względu na prawdopodobne protesty amerykańskich rolników ${ }^{28}$.

W grudniu 1970 r. Heath złożył wizytę w Waszyngtonie. Podczas spotkania z Nixonem powtórzył, że nie chciał uchodzić za „konia trojańskiego” USA, a Wielka Brytania zamierzała pełnić we Wspólnotach konstruktywną rolę, respektując też amerykańskie interesy. Nie zgodził się w związku z tym na bilateralne rozmowy z Amerykanami o sprawach Wspólnego Rynku. Kissinger zauważył, że żaden powojenny brytyjski premier nie rozmawiał w tak ostry sposób z Amerykanami - określił to nawet mianem rewolucji w brytyjskiej polityce zagranicznej ${ }^{29}$.

${ }^{27}$ NARA, Nixon Presidential Materials Project (NPMP), White House Central Files (WHCF), IT International Organization, Economic Community-Common Market (EEC) 1969-1970, memorandum sekretarza handlu do Petersona, 16 kwietnia 1971, box 2.

${ }^{28}$ NARA, NPMS, NSC Files, Vip Visits, Kissinger do Nixona, 15 grudnia 1970, box 942.

${ }^{29}$ H. K i s s in g e r, op. cit., s. 937. 


\subsection{Rozbieżności gospodarcze między USA a EWG}

W pierwszym raporcie na temat polityki zagranicznej, przedstawionym Kongresowi przez prezydenta 18 lutego 1970 r., dominował wątek gospodarczy. Nixon oświadczył, że sojusz atlantycki wymagał zasadniczego przeobrażenia. Stwierdził, że odzyskanie przez Europę Zachodnią siły gospodarczej nadwerężyło międzynarodowy system monetarny i handlowy. Był przekonany, że „utrzymanie pokoju ma także wymiar ekonomiczny" ${ }^{30}$, więc konflikty i brak współpracy mogły być niebezpieczne nie tylko dla relacji gospodarczych, lecz także politycznych. Podkreślił, że Europy nie można traktować jako całości i zapowiedział politykę nawiązywania stosunków bilateralnych z poszczególnymi państwami. Prezydent stwierdził jednak, że chociaż cena zjednoczenia Europy była wysoka, Stany Zjednoczone mogły poświęcić swoje interesy gospodarcze dla tego celu ${ }^{31}$.

Przedstawiciele departamentów odpowiedzialnych za kwestie ekonomiczne byli niezadowoleni z tego ostatniego stwierdzenia. Uważali, że nie zachęcało ono Europejczyków do zmian polityki, które w obliczu trudności przeżywanych przez amerykańską gospodarkę były konieczne. Zastępca sekretarza stanu do spraw gospodarczych (Deputy Under Secretary for Economic Affairs), Nathaniel Samuels, komentował: „nie sądzę, żeby można było mówić o poświęcaniu krótkoterminowych korzyści gospodarczych dla długofalowych celów politycznych [...]. Wątpimy, czy jest taka potrzeba. Europa jest wystarczająco silna, by radzić sobie sama. Natomiast rząd Stanów Zjednoczonych jest zaniepokojony stratami, które przynosi nam polityka EWG. Powinniśmy przyjąć strategię bardziej zdecydowanej ochrony naszych interesów handlowych niż do tej pory"32. Także przedstawiciel USA przy organach Wspólnot w Brukseli, Robert Schaetzel, zauważał, że postrzeganie integracji Starego Kontynentu uległo zasadniczej zmianie: od entuzjazmu do „irytacji, frustracji i rosnących obaw”33. 0 priorytetowym znaczeniu poprawy politycznych stosunków z Europą był natomiast przekonany Departament Stanu, wspierany przez NSC. Uważano, że nie należało tracić z oczu tego celu przez nieporozumienia na tle ekonomicznym. Jednak pozycja Departamentu Stanu, na czele z Williamem Rogersem, była stosunkowo słabsza niż Departamentów Skarbu, Handlu czy Rolnictwa ${ }^{34}$.

Charakterystycznym przykładem dylematów Stanów Zjednoczonych, polegających na rozstrzygnięciu, czy ważniejsze były interesy gospodarcze czy polityczne

${ }^{30}$ The Public Papers of the Presidents of the United States: Richard Nixon (PPP), vol. 2: 1970, Washington D.C. 1971, pierwszy roczny raport dla Kongresu na temat polityki zagranicznej USA na lata 70., 18 lutego 1970, dok. 45, dostępne także przez: http://www.nixonfoundation.org/.

${ }^{31}$ Ibidem.

${ }^{32}$ E. R. G o o d m a n, The Fate of the Atlantic Community, New York 1975, s. 171-172.

${ }^{33}$ Ibidem, s. 173.

${ }^{34}$ G. W. B all, Diplomacy for the Crowded World. An American Foreign Policy, Boston 1976, s. $170-171$. 
w stosunkach z Europą Zachodnią, był przypadek negocjowania przez Hiszpanię preferencyjnego układu handlowego z EWG. Argumenty za jego blokowaniem przedstawił w liście do Nixona sekretarz rolnictwa Clifford M. Hardin. Stwierdzał, że decyzja, jaką prezydent podejmie w tej kwestii wpłynie na całą amerykańską zagraniczną politykę handlową. Przekonywał, że jeśli Stany Zjednoczone nie sprzeciwią się stanowczo zawarciu układu z Hiszpanią, nic nie powstrzyma EWG od negocjowania podobnych umów z Izraelem, Austrią, Jugosławią i krajami EFTA ${ }^{35}$. Za zdecydowaną reakcją opowiadał się też sekretarz handlu Martin Stans. Namawiał prezydenta do decyzji o nałożeniu sankcji na EWG, jeśli nie zrekompensuje strat związanych z tym układem $^{36}$. Ewentualna umowa między EWG a Hiszpanią ewidentnie byłaby złamaniem podstawowej zasady GATT - prowadzenia handlu ze wszystkimi członkami porozumienia na zasadzie klauzuli najwyższego uprzywilejowania ${ }^{37}$. Zgoda na taki precedens była bardzo niebezpieczna dla amerykańskiej polityki handlowej. Przed podjęciem decyzji o ostrym sprzeciwie powstrzymywały Amerykanów rozmowy z Madrytem o przedłużeniu umowy z 1953 r., dotyczącej korzystania z baz na terytorium Hiszpanii. Wygasała ona we wrześniu 1970 r., a negocjacje na ten temat trwały bez skutku od wiosny $1969 \mathrm{r}$.

W końcu Nixon zdecydował się ogłosić trzyletnie moratorium na działania odwetowe USA wobec preferencyjnej umowy handlowej między EWG a Hiszpanią. Spotkało się to z krytyką Bergstena. Twierdził, że decyzja ta będzie zinterpretowana przez środowiska związane z polityką handlową jako kompletna porażka w bronieniu amerykańskich interesów. Prezydent wybrał opcję rekomendowaną jedynie przez Departament Obrony. Protestowały także Departamenty Rolnictwa i Skarbu oburzone, że decyzja została podjęta bez konsultacji z nimi ${ }^{38}$. Na podstawie analizy tego przypadku widać wyraźnie, że na początku kadencji Nixona zwyciężał jednak czynnik polityczny, choć już duża część administracji forsowała uwzględnienie w większym stopniu aspektów ekonomicznych.

Za główny problem w transatlantyckich relacjach gospodarczych Departament Stanu uznał zawieranie przez EWG preferencyjnych układów handlowych (PUH) z krajami trzecimi. Jednak natychmiast zastrzegł, że otwarty sprzeciw wobec nich mógł spowodować negatywne konsekwencje w relacjach transatlantyckich. Stwierdził, że z powodów politycznych EWG i tak musi zawrzeć takie umowy z Izraelem i krajami arabskimi. Europejczycy tłumaczyli, że ich celem było nie tylko zdobywanie nowych rynków zbytu, lecz także utrzymywanie wpływów

${ }^{35}$ NARA, NPMS, NSC Institutional "H" Files, Study Memorandums, Hardin do Nixona, 29 stycznia 1970.

${ }^{36}$ Ibidem, Stans do Kissingera, 16 stycznia 1970.

${ }^{37}$ Oznaczało to obowiązek stworzenia takich samych warunków dla wszystkich partnerów handlowych i zakaz dyskryminacji. Nie dotyczyło to krajów połączonych układem o wolnym handlu lub unią celną.

${ }^{38}$ NARA, NPMS, NSC Institutional "H" Files, Study Memorandums, Bergsten do Kissingera, 9 marca 1970, box H-170. 
politycznych i zapobieganie zbliżeniu tych krajów do ZSRR. Blokowanie PUH przez Stany Zjednoczone Europejczycy uznaliby za nieuzasadnioną ingerencję w ich strategię.

Hillenbrand z Departamentu Stanu przedstawił wobec tego trzy opcje działania. Pierwsza zakładała rezygnację z przedstawiania sprawy na forum GATT i negocjowanie nieformalnego porozumienia, mającego na celu wyeliminowanie dyskryminacji towarów amerykańskich na rynkach europejskich. Było to wyjście korzystne dla relacji z EWG, lecz stwarzało precedens nieprzestrzegania klauzuli najwyższego uprzywilejowania dla wszystkich członków GATT i mogło spowodować negatywne reakcje społeczne w USA. Druga opcja odnosiła się do określenia czasu na dostosowanie się EWG do reguł GATT. Trzecim rozwiązaniem mogło być ogłoszenie amerykańskiego stanowiska, że układy preferencyjne były niezgodne z zasadami GATT. Jednak Amerykanie mieliby zrezygnować z poddania tego pod arbitraż, jeśli Europejczycy wyraziliby gotowość do przyznania im rekompensat. Departament Stanu uznał, że można było również zrezygnować z roszczeń pod warunkiem, że EWG zawrze układy tylko z krajami uznawanymi za rozwijające się. Przewidywano też możliwość ogłoszenia zdecydowanego sprzeciwu wobec umów niezgodnych z artykułem XXIV GATT (pozwalający krajom tworzyć unie celne i strefy wolnego handlu), jeśli EWG nie miałaby dokładnego planu zawarcia z danym krajem układu o wolnym handlu lub przyjęcia go do Wspólnot. Ten warunek uznano za zbyt trudny do spełnienia ${ }^{39}$.

Grupa Robocza NSC przegotowała projekt dotyczący polityki USA wobec EWG, do którego miały odnieść się poszczególne departamenty. Znalazła się tam propozycja, by Stany Zjednoczone działały w celu stworzenia stałego mechanizmu konsultacyjnego z EWG w sprawach handlowych. Za koordynację tych spotkań odpowiadał Komitet Podsekretarzy, złożony z przedstawicieli różnych departamentów. Podstawą negocjacji miało być stanowisko, że rząd USA w pełni popierał rozszerzenie, akceptował związaną z nim część kosztów gospodarczych, ale jednocześnie był zdecydowany chronić własne interesy, podkreślając szczególnie prawa wynikające $\mathrm{z} \mathrm{GATT}^{40}$.

W odpowiedzi na ten projekt sekretarz rolnictwa Clifford Hardin zwrócił uwagę, że sprzeciw wzbudzają relacje EWG z krajami EFTA i preferencyjne układy handlowe z krajami trzecimi, które były wówczas negocjowane. Twierdził, że USA nie powinny popierać takich praktyk - mogły zgodzić się tylko na rozszerzanie KNU, co było zgodne z zasadami GATT. Kraje rozwijające się, które spełniały warunki Konferencji Narodów Zjednoczonych ds. Handlu i Rozwoju (United Nations Conference on Trade and Development - UNCTAD), powinny zawierać umowy z EWG.

${ }^{39}$ NARA, NPMS, NSC Institutional “H” Files, Study Memorandums (1969-1974), Hillenbrand do Kissingera, 21 kwietnia 1970, box H-164.

${ }^{40}$ NARA, NPMS, NSC Insitutional "H" Files, Senior Review Group Meetings, Bergsten do Kissingera, 22 maja 1970, box H-041. 
Departament Rolnictwa nie chciał zaakceptować stwierdzenia, że z powodów politycznych i obronnych Stany Zjednoczone były gotowe ponosić koszty wzmocnienia Wspólnot. Hardin był przekonany, że to zachęca Europę do łamania reguł GATT. Zwrócił uwagę na szkodliwość CAP dla gospodarki USA. Proponował uzupełnienie projektu NSC o zapis, że Stany Zjednoczone uważają swobodę eksportu produktów rolnych za priorytet ${ }^{41}$. Uważał, że Amerykanie nie będą bronić swych interesów na forum GATT, gdyż z powodów politycznych i tak wstrzymują się od używania tego narzędzia. Zauważył, że na forum GATT każdy kraj posiada jeden głos, więc szanse Stanów Zjednoczonych na zmianę taktyki EWG były nikłe Europa mogła zmobilizować więcej głosów niż USA. Jako przykład podał fakt, że w przypadku planowanych preferencyjnych umów z Hiszpanią czy Izraelem, chociaż prezydent podjął decyzję, że Stany Zjednoczone powinny się im sprzeciwić, nie zdecydowano się na taki krok z obawy przed odrzuceniem wniosku. Zdaniem Hardina, w oświadczeniu powinno być wyraźnie powiedziane, że jeśli nie będzie reakcji na posunięcia sprzeczne z zasadami GATT i interesami USA, rząd amerykański zastosuje inne środki i będzie bardziej asertywny w egzekwowaniu swoich praw. Na koniec sekretarz rolnictwa zwracał uwage, że polityka gospodarcza EWG wpływała na cały światowy handel produktami rolnymi i że jeśli największy rynek zbytu, jakim była Europa, zacznie się zamykać i hołdować protekcjonizmowi, wystąpią nadwyżki na amerykańskim rynku ${ }^{42}$. W podobnym tonie, nie uznając argumentów przedstawionych przez Departament Stanu, wypowiedziały się wspólnie Departamenty Skarbu i Handlu ${ }^{43}$.

Postrzeganie przez społeczeństwo amerykańskie integracji europejskiej stawało się coraz bardziej nieprzychylne. Nawet związki zawodowe, do tamtej pory opowiadające się za wolnym handlem i zjednoczoną Europą, dołączyły do obozu protekcjonistów. Nixon zdawał sobie z tego sprawę, lecz nadal chciał formalnie popierać integrację Starego Kontynentu i utrzymać dobre stosunki z sojusznikami. Wiedział, że jeśli Amerykanie i Europejczycy będą w permanentnym konflikcie na tle gospodarczym, umocni się wzajemna niechęć społeczeństw po obu stronach Atlantyku. To z kolei w sposób nieunikniony wywoła wzrost protekcjonizmu w handlu i zniszczenie osiągnięć powojennej liberalizacji oraz poważne konflikty polityczne ${ }^{44}$.

Podczas rozmów dyplomatów amerykańskich z przedstawicielami EWG ustalono mechanizm konsultacyjny. Spotkania miały się odbywać co pół roku, w miarę możliwości w tym samym składzie z obu stron. Negocjacje rozpoczęły się

\footnotetext{
${ }^{41}$ Za najważniejsze produkty eksportowe uznano soję (Hardin żądał zapewnienia utrzymania eksportu bezcłowego) i zboże (postulował obniżenie jego ceny przez EWG).

${ }^{42}$ NARA, NPMS, NSC Insitutional "H” Files, Senior Review Group Meetings, Hardin do Kissingera, 8 czerwca 1970, box H-041.

${ }^{43}$ Ibidem, Oświadczenie Departamentów Skarbu, Handlu i Rolnictwa, 22 kwietnia 1970.

${ }^{44}$ R. G. L i v in g s t o n, A Washington Look at Europe, [w:] The United States and Western Europe. Political, Economic and Strategic Perspectives, ed. W. F. Hanrieder, Cambridge, Mass. 1974, s. 289.
} 
10 października 1970 r. Na czele delegacji europejskiej stanął Ralph Dahrendorf, komisarz EWG odpowiedzialny za relacje międzynarodowe i handel zagraniczny. Przedstawicielom USA, reprezentującym różne departamenty, przewodził zastępca podsekretarza stanu (Deputy Under Secretary of State) Nat Samuels. Dahrendorf niepokoił się tendencjami amerykańskiej polityki handlowej. Mówił o protekcjonizmie $\mathrm{w}$ rolnictwie, układach preferencyjnych i ustawie Millsa. Twierdził, że planowana nowa ustawa handlowa mogła doprowadzić do wzrostu protekcjonizmu ze strony USA, a w konsekwencji do załamania handlu światowego. Nie groził wprost działaniami odwetowymi, niemniej jednak stwierdził, że w takim przypadku Europa byłaby zdolna do wspólnej akcji. Największe obawy wzbudzał znajdujący się w ustawie handlowej escape clause i subsydia eksportowe dla amerykańskich firm (Domestic International Sales Corporation - DISC), uznawane przez Europejczyków za subsydiowanie eksportu i pogwałcenie zasad GATT. Amerykanie zadeklarowali, że poprą rozszerzenie EWG pod warunkiem respektowania przez organizację amerykańskich interesów. Dahrendorf zaapelował, aby przed akcesją nowych krajów nie poruszać tego tematu, gdyż mogłoby to storpedować rozszerzenie. Obiecał jednak, że Europejczycy będą mieli na uwadze amerykański postulat. Amerykanie zwracali uwagę na konieczność ograniczenia CAP, np. poprzez obniżenie cen zboża, co byłoby korzystne również dla Wielkiej Brytanii. Dahrendorf zastrzegł, że takie posunięcie uważa za politycznie niemożliwe. Na krytykę PUH Europejczycy odpowiadali wykazywaniem ich politycznej przydatności ${ }^{45}$.

Podczas rozmów 6 listopada 1970 r. dyskusja koncentrowała się wokół amerykańskiego ustawodawstwa handlowego. Kissinger relacjonował, że choć reprezentanci EWG unikali bezpośrednich gróźb, to jednak zapowiadali reakcję na niekorzystne dla siebie postanowienia ustawy Millsa. Zadeklarowali, że jeśli USA wycofają się z tych ograniczeń importu, Europa pomoże USA w negocjacjach z Japonią na temat handlu tekstyliami. Co do cen produktów rolniczych w ramach CAP, EWG wykluczała ich obniżenie ${ }^{46}$. Kissinger zapewnił Dahrendorfa, że polityka handlowa administracji Nixona będzie oparta na wolnym rynku, co europejski komisarz uznał za najważniejszą deklarację wyniesioną z negocjacji. Rzeczywiście, większość innych wątków była powtórzeniem konkluzji z pierwszej rundy konsultacyjnej. Bergsten w liście do Kissingera zauważył, że choć proceduralny przebieg rozmów z przedstawicielami EWG był prawidłowy i został uruchomiony cenny mechanizm konsultacyjny, sporne punkty okazały się niemożliwe do rozwiązania z politycznego punktu widzenia. Bergsten przewidywał, że wpłynie to negatywnie na ogólne stosunki transatlantyckie w najbliższym czasie ${ }^{47}$. Pozytywnym wydarzeniem było za to odrzucenie ustawy

${ }^{45}$ NARA, NPMS, NSC Insitutional "H" Files, National Security Decision Memorandums (19691974), Kissinger do Nixona, 29 października 1970, box H-217.

${ }_{46}$ NARA, NPMS, NSC Files, Subject Files: European Common Market, Kissinger do Nixona, 6 listopada 1970, box 322 .

${ }^{47}$ Ibidem, Bergsten do Kissingera, 16 października 1970. 
Millsa w grudniu $1970 \mathrm{r}^{48}$ Nixon nalegał, by amerykańscy negocjatorzy uzyskali jakieś konkretne zobowiązania, żeby Kongres nie zarzucił im bierności. Rokowania ciągnęły się jednak bez konkretnego rezultatu przez ponad rok ${ }^{49}$.

Można stwierdzić, że Amerykanie, popierając przez lata integrację europejską, nie zadbali o zapewnienie sobie wpływu na jej kształt, przynajmniej, jeśli chodzi o stosowanie środków protekcjonistycznych. Na początku lat 70. na takie działania było już za późno - struktury i strategie europejskie już okrzepły, przynosząc dobrobyt krajom członkowskim EWG. Europa nie była skłonna zrezygnować z utrwalonych przywilejów. Rządy poszczególnych państw spodziewały się niepokojów społecznych w momencie decyzji o rezygnacji z nich na rzecz wolnego handlu. Niektóre programy, np. CAP, były filarami integracji i przekonywały społeczeństwa o istnieniu wspólnych, ponadnarodowych interesów. Nie chcąc burzyć podstaw Wspólnot, Amerykanie działali bardzo ostrożnie, unikając środków przymusu gospodarczego i politycznego. Natomiast EWG liczyła, że rynek Stanów Zjednoczonych wciąż będzie niezmiennie otwarty dla jej produktów.

Przejawem dążeń do wyraźnego oddzielania kwestii politycznych i gospodarczych w rozmowach z Amerykanami był opublikowany i przyjęty przez przedstawicieli wszystkich krajów członkowskich 27 października 1970 r. raport Étienne’a Davignona na temat przyszłej wspólnej polityki zagranicznej członków EWG. W związku z tym ustanowiono specjalny komitet przy Radzie Ministrów Wspólnot Europejskich (RMWE) ${ }^{50}$. Nieformalne spotkania ministrów spraw zagranicznych były przygotowywane przez dyrektorów politycznych (political directors) z ministerstw poszczególnych krajów członkowskich. Rekomendowano, by rządy mówiły jednym głosem w sprawach międzynarodowych. Ustalono, że spotkania ministrów spraw zagranicznych miały się odbywać przynajmniej co pół roku, a jeszcze częściej na niższych szczeblach, zapowiadano także regularne konsultacje ambasadorów $^{51}$. Kolejnym dowodem dążeń do konsolidacji polityki europejskiej była intensywna współpraca Eurogrupy w ramach $\mathrm{NATO}^{52}$.

${ }^{48}$ G. B o s s u a t, Europe and United States, 1944-2006: Two Destinies in an Uncertain World, Berkeley 2006, Paper 060530, dostępny przez: eScholarship Repository, University of California, http://repositories.cdlib.org/ies/060530.

${ }^{49}$ H. K i s s i n g e r, op. cit., s. 429.

${ }^{50}$ Rada Ministrów Wspólnot Europejskich (od 1993 r. Rada Unii Europejskiej) jest głównym organem decyzyjnym. Składa się z ministrów poszczególnych resortów (w zależności od omawianych zagadnień) państw członkowskich. Przewodniczącym Rady jest minister spraw zagranicznych kraju sprawującego prezydencję (J. R u s z k o w s k i, E. G ó r n i c z, M. Ż u r e k, Leksykon integracji europejskiej, Warszawa 1998, s. 181-182).

${ }^{51}$ Tekst raportu Davignona dostępny przez: www.ena.lu/davignon-report-luxembourg-27october-1970-020002259.html.

${ }^{52}$ Europejska Grupa NATO (Eurogrupa) powstała w 1969 r. Jej celem była aktywizacja państw europejskich na forum Sojuszu i ich większy wpływ na podejmowanie decyzji. W skład Eurogrupy wchodzili ministrowie obrony Belgii, Danii, Grecji, Holandii, Luksemburga, Norwegii, RFN, Turcji, Wielkiej Brytanii i Włoch. Była to jednostka o charakterze nieformalnym. Działalność sprowadzała 
Dla Amerykanów tego typu posunięcia wydawały się niekorzystne. Niewątpliwie wspólna polityka zagraniczna ułatwiłaby rozmowy z EWG, choćby dlatego, że mógłby być zneutralizowany opozycyjny głos Francji. Jednakże Amerykanie uważali, że wprowadzenie w życie tej deklaracji było mało prawdopodobne w najbliższej przyszłości. Mogła być ona odczytywana w Waszyngtonie jako dążenie do uniezależnienia się na arenie międzynarodowej od Stanów Zjednoczonych. Poza tym była to próba wytrącenia Amerykanom z ręki ważnego narzędzia - bilateralnych negocjacji z poszczególnymi państwami członkowskimi. Okazało się to niezwykle istotne również w rozmowach na tematy gospodarcze. Biorąc pod uwagę jednolite stanowisko Europejczyków, trudno było podjąć szybko jakąkolwiek decyzję, a używanie argumentów politycznych przez Amerykanów w celu uzyskania ustępstw ekonomicznych byłoby znacznie utrudnione.

Departament Stanu uważał, że w odpowiedzi na decyzje Wspólnot Stany Zjednoczone powinny zaproponować konsultacje z Europą w postaci formalnego forum. Miała to być struktura bardziej stała niż odbywające się wcześniej nieformalne konsultacje Dahrendorf-Samuels. Jednak uwzględniając rosnące napięcia gospodarcze, Rogers wątpił, że w tamtym czasie był dobry moment na taką propozycję. Rozważał ustanowienie stałej reprezentacji EWG w Waszyngtonie, ale do tego też podchodził sceptycznie ze względu na długie procedury wyznaczania takiej delegacji ${ }^{3}$.

W styczniu 1971 r. Nixon powołał do życia nową strukturę, Radę do spraw Międzynarodowych Stosunków Gospodarczych (Council on International Economic Affairs - CIEP). Ta decyzja była przejawem rosnącego znaczenia czynnika gospodarczego w polityce zagranicznej. Świadczył o tym również skład CIEP - znalazły się w niej osoby zajmujące się sprawami politycznymi i gospodarczymi, mające wypracowywać wspólną strategię w relacjach z zagranicą. Jej dyrektorem został Peter Peterson $^{54}$.

Tad Szulc na łamach dziennika „New York Times” stwierdził, że światu grozi poważny konflikt gospodarczy, gdyż Stany Zjednoczone miały poważne nieporozumienia na tym polu także z Japonią. Określił cel nowo powstałej CIEP jako połączenie pomocy

się do spotkań między członkami, którzy ustalali stanowisko na forum NATO oraz koordynowali współpracę militarną (P. Matera, R. M ate ra, Stany Zjednoczone i Europa. Stosunki polityczne i gospodarcze 1776-2004, Warszawa 2007, s. 263).

53 NARA, NPMS, NSC Files, Subject Files: European Common Market, memorandum Departamentu Stanu, 23 stycznia 1971, box 322.

${ }^{54}$ Obradom CIEP przewodniczył prezydent. Rada składała się z sekretarzy: stanu, skarbu, rolnictwa, handlu i pracy. Ponadto tworzyli ją: dyrektor Biura Zarządzania i Budżetu (Office of Management and Budget), szef Rady Doradców Ekonomicznych (Council of Economic Advisers), doradca prezydenta do spraw bezpieczeństwa narodowego, dyrektor wykonawczy Rady Spraw Wewnętrznych (Domestic Policy Council) i specjalny przedstawiciel handlowy (Special Trade Representative). W sierpniu 1971 r. zdecydowano o włączeniu w skład CIEP sekretarza obrony (FRUS, 1969-1976, vol. 3, nota edytorska, dok. 49). 
gospodarczej i militarnej, spraw międzynarodowego handlu i sytemu monetarnego, fiskalnego i inwestycji. We wszystkich kwestiach miał być brany pod uwagę czynnik polityczny. Zauważył, że częste rozbieżności zdań w tych sprawach w obrębie administracji Nixona powodowały trudności z wypracowaniem spójnego stanowiska. Do tego dochodził brak koordynacji polityki zagranicznej między Białym Domem a Departamentem Stanu. Szulc wyraził nadzieję, że dzięki Radzie uda się tego uniknąć. Uznał, że decyzja o jej utworzeniu była słuszna, gdyż tradycyjne problemy bezpieczeństwa i dyplomacji zaczęły być przyćmiewane przez rosnący protekcjonizm i strach przed wojną handlową. Dostrzegł także zmiany w tradycyjnej amerykańskiej filozofii wolnego handlu. Przewidywał skutki polityczne konfliktu gospodarczego z Europą Zachodnią: kraje EWG mogły zintensyfikować współpracę z blokiem komunistycznym i zmienić priorytety polityki zagranicznej na wzór zachodnioniemieckiej Ostpolitik ${ }^{55}$.

Szulc podkreślił, że w Waszyngtonie panowało przekonanie, że zbliżenie gospodarcze mogło spowodować zacieśnienie się więzów politycznych. Jego zdaniem, rząd amerykański działał w celu realizacji takiego scenariusza, używając siły politycznej do wymuszenia ustępstw gospodarczych. 24 stycznia 1971 r., z inicjatywy amerykańskiej, miały się zacząć we Frankfurcie nad Menem rozmowy z Japonią i EWG o umowie dobrowolnego ograniczenia eksportu stali do USA. Amerykanie wywierali także presję na RFN, by ograniczono tam subsydia dla rolników. Szulc stwierdził, że taki krok mógłby poważnie zaszkodzić i tak już niestabilnemu rządowi Brandta, czego administracja amerykańska nie brała pod uwagę. Poza tym z misją w Europie przebywał doradca sekretarza stanu ds. gospodarczych, Philip H. Trezise, który rozmawiał z przedstawicielami Komisji Europejskiej w Brukseli o planowanych przez EWG układach preferencyjnych z Tunezją, Izraelem i Hiszpanią. Negocjacje te nie przynosiły większych rezultatów, co wywołało dodatkowe napięcie w stosunkach transatlantyckich ${ }^{56}$.

Raport na temat polityki zagranicznej, przedstawiony Kongresowi przez Nixona 25 lutego 1971 r., wyraźnie różnił się od poprzedniego. Prezydent ewidentnie uległ wpływom departamentów ekonomicznych. Zauważył, że pewność siebie Europy Zachodniej na polu gospodarczym i konflikty na tym tle, niszczące zaufanie w stosunkach transatlantyckich, przekładały się na grunt polityczny. Mówił o trudnościach związanych z rozszerzeniem EWG dla gospodarki amerykańskiej. Stwierdził, że nie sprawdziło się założenie o dzieleniu odpowiedzialności za losy świata przez silną gospodarczo Europę. Planowane rozszerzenie EWG i pogłębienie integracji przedstawił jako wyzwanie dla Stanów Zjednoczonych, choć utrzymywał, że nie będą ingerowały w jej przebieg. Potwierdził wsparcie dla tego procesu, lecz zauważył, że USA nie mogły dłużej przymykać oczu także na zagrożenia, gdyż EWG rozwijała tożsamość polityczną oddzielnie od Ameryki. Szczególne niebezpieczeństwo dla rozwoju dobrych stosunków transatlantyckich widział jednak na polu ekonomicznym.

\footnotetext{
${ }^{55}$ T. S z u l c, Foreign Policy: the Economic Problem, „New York Times”, 20 stycznia 1971.

${ }^{56}$ Ibidem.
} 
Nixon silnie podkreślił, że konfrontacyjna postawa Europy wzbudza sprzeciw społeczny w jego kraju. Z goryczą przypomniał, że Amerykanie, promując powojenną integrację Starego Kontynentu, liczyli na współpracę w dziedzinie liberalizacji handlu. Tymczasem EWG stosowała nieuczciwe, według ustaleń GATT, praktyki w momencie kłopotów gospodarczych swego sojusznika. Nie do zaakceptowania był także fakt, że zamykająca się gospodarczo Europa liczyła jednocześnie na amerykańskie zaangażowanie polityczne. „Czy atlantycką wspólnotę bezpieczeństwa i obrony można pogodzić z coraz bardziej regionalną polityką gospodarczą EWG?" 57 - pytał Nixon.

\subsection{Handel i inwestycje}

Na początku lat 70. XX w. nastąpiła zmiana charakteru międzynarodowych relacji gospodarczych. W pierwszych powojennych dekadach zasadniczą kwestią było znoszenie ceł. W latach 70. główną przeszkodą w wolnym handlu były bariery pozataryfowe, protekcjonizm w polityce rolnej i regulacja przepływu BIZ. Ważny czynnik stanowiły zmiany w międzynarodowym systemie walutowym wprowadzenie SDR-ów i plany modyfikacji zasad ustalonych w Bretton Woods. Kluczowym czynnikiem była utrata przez Stany Zjednoczone hegemonii w gospodarce światowej ${ }^{58}$.

Coraz trudniejsze dla prezydenta USA stawało się łagodzenie konfliktów przy użyciu argumentów o charakterze politycznym. Dlatego też Stany Zjednoczone, mimo nacisków wewnętrznych, powstrzymywały się od „wojny na subsydia”. Wspierały jednak swoich rolników. W 1970 r. na podstawie ustawy o rolnictwie (Agricultural Act) przyznano środki farmerom, którzy zredukowali areały upraw ${ }^{59}$. Poza tym amerykańskie prawo pozwalało na ustalanie kontyngentów ilościowych na produkty spożywcze, których wytwarzanie mogło być ograniczone przez zagraniczną konkurencję ${ }^{60}$. Jednak do 1970 r. środki przeznaczane przez rząd amerykański na utrzymanie wysokich cen podstawowych zbóż zostały zmniejszone, a stałe dochody rolników pochodziły z bezpośrednich płatności dla farmerów ${ }^{61}$.

${ }^{57}$ PPP, Richard Nixon, vol. 3: 1971, Washington D.C. 1972, drugi roczny raport dla Kongresu na temat polityki zagranicznej Stanów Zjednoczonych, 25 lutego 1971, dok. 75, dostępne także przez: http://www.nixonfoundation.org.

${ }^{58}$ C. F. B erg ste n, U.S. Trade Policy: Revolutions of a Decade, [w:] Foreign Affairs in the Seventies. A Symposium of Young Professionals in Foreign Affairs: 1971, ed. C. F. Bergsten, Medford 1971, s. $100-106$.

${ }^{59}$ T. J o s ling, Agricultural Policies and World Trade, [w:] Europe, America and the World Economy, ed. L. Tsoukalis, New York 1986, s. 56.

${ }^{60}$ D. E v a n s, The Politics of Trade. The Evolution of the Superbloc, London 1974, s. 52.

${ }^{61}$ International Economic Relations of the Western World, 1959-1971, ed. A. Shonfield, vol. 1: Politics and Trade, London 1976, s. 320, 336. 
Do zaproponowanego przez prezydenta tekstu nowej ustawy handlowej została dodana poprawka, która odzwierciedlała nastroje protekcjonistyczne w Izbie Reprezentantów. Proponowano wprowadzanie automatycznych restrykcji handlowych na produkty mogące stanowić zbyt dużą konkurencję dla przedsiębiorców amerykańskich na rynku wewnętrznym. Ustawa została jednak odrzucona przez Kongres. Za protekcjonizmem opowiadał się coraz częściej mały biznes, który nie był zależny od eksportu, ale ucierpiał z powodu konkurencji zagranicznej na rynku wewnętrznym ${ }^{62}$.

Do 1970 r. wartość amerykańskich inwestycji bezpośrednich w Europie była dwukrotnie większa niż państw europejskich w Stanach Zjednoczonych, ale inwestycje europejskie rosły w szybszym tempie. Rezultatem tej dynamiki stał się wzrost transatlantyckich zależności gospodarczych ${ }^{63}$.

W USA wzrastała liczba filii przedsiębiorstw, szczególnie pochodzących ze Starego Kontynentu. W latach 1962-1964 europejskie firmy za granicą miały 676 filii, w latach 1965-1967 liczba ta się podwoiła, a w okresie 1968-1970 było ich już 2083. Natomiast liczba amerykańskich filii za granicą utrzymywała się mniej więcej na stałym poziomie. Wzrastała też rola korporacji wielonarodowych (multinational corporations - MNCs). Były to firmy, które wysyłały nie tylko towary i przenosiły produkcję, lecz także kapitał, technologię i techniki marketingowe poza granice państwa, w którym powstały. Szczególnie aktywne okazały się korporacje amerykańskie, inwestujące głównie w krajach OECD ${ }^{64}$. Około 20\% największych amerykańskich korporacji prowadziło działalność głównie za granicą. Wiele z nich było silnie uzależnionych od rządowych kontraktów związanych z obronnością. W Kongresie pojawiły się postulaty, by wywierać na nie presję powodującą ich koncentrację na rodzimym rynku ${ }^{65}$. W czerwcu $1971 \mathrm{r}$. podczas dyskusji nad tą kwestią w Senacie pojawiały się opinie, że wielkie zagraniczne korporacje działające na rynku USA miały uprzywilejowaną pozycję, gdyż amerykańskie przedsiębiorstwa były związane prawami antytrustowymi. Postulowano wtedy wprowadzenie środków ograniczających działalność zagranicznej konkurencji ${ }^{66}$.

Robert Gilpin twierdził, że rząd Stanów Zjednoczonych chciał, aby inwestycje amerykańskie były lokowane w miejscach umożliwiających wspieranie celów polityki zagranicznej. USA miały utrzymać udział w rynku światowym, zapewnić silną pozycję kapitału za granicą, rozprzestrzeniać ekonomiczne i polityczne wartości (wolny handel, demokrację) i kontrolować dostęp do najważniejszych surowców, szczególnie do ropy ${ }^{67}$.

${ }^{62}$ Ibidem, s. 135.

${ }^{63}$ E. R. G o o d m a n, op. cit., s. 455.

${ }^{64}$ J. E. S p e r o, The Politics of International Economic Relations, New York 1999, s. 106.

${ }^{65}$ D. E v a n s, op. cit., s. 10.

${ }^{66}$ Congressional Record. Proceeding and Debates of the First Session of the $92^{\text {nd }}$ Congress, vol. 117, part 17, posiedzenie Senatu z 25 czerwca 1971, dostępne przez: http://www.archive.org/ stream/congressional-rec117junit\#page/n0/mode/2up.

${ }^{67}$ R. G i l p i n, U.S. Power and Multinational Corporation. The Political Economy of Foreign Direct Investments, New York 1975, s. 147. 
Inwestycje generowały również ogromne zyski: kraje europejskie w 1970 r. zanotowały dochód z inwestycji w USA sięgający 4,8 mld USD ${ }^{68}$. W 1970 r. przychody dla budżetu Stanów Zjednoczonych z inwestycji wielonarodowych korporacji wyniosły 6 mld USD, co poprawiło bilans płatniczy o ponad 2 mld USD. Jeśli podsumować opłaty i dochody z amerykańskich BIZ - BOP zyskał 4,6 mld USD ${ }^{69}$.

Gilpin twierdził, że integracja gospodarcza czyniła próby powstrzymania korporacji międzynarodowych nieskutecznymi. Jedynym niebezpieczeństwem, choć w tamtym czasie mało prawdopodobnym, była skoordynowana akcja wszystkich krajów Wspólnoty. Jednak również w tej kwestii grały rolę względy polityczne. Można było założyć, że RFN, polegająca na Stanach Zjednoczonych w kwestiach obronnych, będzie blokować niekorzystne dla Amerykanów decyzje pozostałych członków $\mathrm{EWG}^{70}$.

W raporcie dla Kongresu na temat polityki zagranicznej z 25 lutego 1971 r. Nixon zwrócił uwagę na niepokojącą zmianę tendencji w Kongresie, który przychylał się do rozwiązań o charakterze protekcjonistycznym, odrzucając w 1970 r. umiarkowaną ustawę handlową. Przypomniał, że oprócz podwyższania ceł istniały inne rozwiązania, mogące wspierać amerykańskich eksporterów. Pierwszym z nich była escape clause, która została trzykrotnie zastosowana w 1970 r. Przywołał też klauzulę prawa handlowego, przewidującą pomoc finansową i techniczną dla firm, które poniosły straty w wyniku zwiększonego importu, również zastosowaną w trzech przypadkach.

Prezydent podkreślił, że jego administracja postrzegała wolny handel jako absolutny priorytet, gdyż liberalizacja wymiany była w interesie Stanów Zjednoczonych i całego świata. Jako przykład przytoczył fakt, że amerykańscy rolnicy eksportowali aż 25\% produkcji. Przyznał jednocześnie, że zarówno Stany Zjednoczone, jak i EWG utrzymywały bariery w handlu artykułami rolniczymi - USA podchodziła restrykcyjnie do importu produktów nabiałowych, a Europa do importu zboża. Wspomniał też o zawieranych przez EWG preferencyjnych układach handlowych z krajami śródziemnomorskimi, co stanowiło dyskryminujące ograniczenie dla eksportu amerykańskich cytrusów. Zauważał, że w takiej sytuacji ustępstwa muszą być poczynione przez obie strony.

W dobie ścisłych powiązań międzynarodowych przewidywał, że jeśli Stany Zjednoczone będą nakładać restrykcje importowe, mogą spodziewać się działań odwetowych. Zauważył, że ponieważ USA były liderem gospodarczym świata, wprowadzone przez nie restrykcje mogły mieć destrukcyjny skutek dla innych państw, co przyniosłoby nie tylko pogorszenie relacji ekonomicznych, ale i politycznych. Wyraził jednak nadzieję, że liberalizacja handlu leży we wspólnym interesie i kwestie sporne zostaną rozwiązane w czasie planowanych negocjacji.

${ }^{68}$ L. H. C l a r k, Speaking of Business, „,Wall Street Journal”, 31 maja 1972.

${ }^{69}$ E. R. G o o d m a n, The Impact of the Multinational Enterprise upon Atlantic Community, [w:] The New Europe and the United States. Partners or Rivals, ed. G. Mally, Lexington 1974, s. 249.

${ }^{70}$ R. G i l p i n, Three Models of the Future, [w:] Key Concepts in International Political Economy, ed. D. A. Baldwin, vol. 1, Vermont 1993, s. 45. 
Nixon przekonywał kongresmanów, żerząd amerykański niezachowywałsię biernie wobec Europy. Przypomniał, że pod presją Waszyngtonu w 1970 r. Europejczycy zredukowali bariery dla eksportu niektórych amerykańskich produktów. Wymienił też naciski, by EWG obniżyła ceny zboża i nie podejmowała żadnych działań mogących zagrozić sprzedaży amerykańskiej soi, tytoniu i cytrusów. Wspomniał także o przekonywaniu Wielkiej Brytanii do modyfikacji stanowiska negocjacyjnego w sprawie polityki rolnej w kierunku korzystnym dla USA. Zapowiedział dążenie do wprowadzenia prawa antydumpingowego, by chronić amerykański przemysł przed niskimi cenami produktów z importu oraz promocję programów dobrowolnych ograniczeń eksportu mięsa i stali na rynek USA. Ta ostatnia kwestia łączyła się z wywieraniem presji na najważniejszych partnerów handlowych. Prezydent stwierdził wprost, że relacje gospodarcze z Europą Zachodnią były nierozłączne z relacjami politycznymi i militarnymi. Słowa te można odczytywać jako apel do Kongresu o zaniechanie uchwalania protekcjonistycznych ustaw, ale również ostrzeżenie dla Europejczyków, którzy przecież także z uwagą słuchali tego raportu. Hamując działania Kongresu, prezydent zadziałał więc jednocześnie wbrew opinii Departamentu Stanu i NSC, które przestrzegały przed łączeniem kwestii politycznych i ekonomicznych ${ }^{71}$.

3 kwietnia 1971 r. przewodniczący Komisji Wspólnot Europejskich, Franco Maria Malfatti, spotkał się z Nixonem w Waszyngtonie. Prezydent podkreślił poparcie rządu amerykańskiego dla idei wolnego handlu, ale uznał, że w Stanach Zjednoczonych zaistniały poważne polityczne przeszkody, by bezwarunkowo promować taką politykę. Stwierdził, że bez wsparcia ze strony Europejczyków, mimo jego osobistych wysiłków, będą uchwalane ustawy protekcjonistyczne. Nixon zwrócił uwagę na zmianę nastrojów w Kongresie - nawet osoby, które znał z okresu, gdy sam był jego członkiem, zdecydowani zwolennicy wolnego handlu, popierały projekty wymierzone przeciwko importowi. Ustawa handlowa, zaproponowana przez administrację, przepadła w Kongresie. Nixon przewidywał taki sam scenariusz dla kolejnej propozycji. Stwierdził, że choć ograniczenie przez EWG przywozu tekstyliów i cytrusów wydaje się niewielkim problemem, sprawa ta wywołała żywą dyskusję w Kongresie. Obecny na spotkaniu Peterson zauważył, że pozornie drugorzędne kwestie mogły stanowić poważną przeszkodę w osiągnięciu porozumień. Informował, że był wręcz zasypywany listami od kongresmanów żądających wywierania nacisku na Europejczyków w sprawie handlu owocami cytrusowymi. Prezydent przekonywał, że Stany Zjednoczone mogły w tych okolicznościach coraz bardziej zamykać się na handel z krajami, z którymi toczą największe spory na tym polu - miało to dotyczyć szczególnie EWG i Japonii.

Malfatti zauważył, że trzeba rozróżnić dwie sprawy: polityczny nastrój w USA (jego zdaniem Kongres wyolbrzymiał problem) i długoterminowy rozwój sytuacji. Zapewnił, że robi wszystko, co w jego mocy, by rozwiązać problem handlu

\footnotetext{
${ }^{71}$ PPP, Richard Nixon, vol. 3, drugi roczny raport dla Kongresu na temat polityki zagranicznej Stanów Zjednoczonych, 25 lutego 1971, dok. 75.
} 
cytrusami. Poinformował, że Włochy były gotowe zrezygnować z preferencyjnych warunków zakupu cytrusów z Afryki Północnej, jeśli nie stracą na handlu butami, gdy Stany Zjednoczone zrezygnują z wprowadzania kontyngentów. Malfatti rozmawiał z ministrami spraw zagranicznych „Szóstki”, którzy zgodzili się, że po zakończeniu negocjacji i ewentualnym rozszerzeniu EWG należało zorganizować rundę GATT (dla której proponował nazwę „runda Nixona”) i omówić wszystkie palące sprawy w celu zapobieżenia protekcjonizmowi. Do najważniejszych kwestii zaliczył: bariery pozataryfowe, opłaty celne, ochronę środowiska i pomoc krajom rozwijającym się.

Nixon z zadowoleniem przyjął tę deklarację, ale utrzymywał, że EWG musiała najpierw wykonać gest dobrej woli w stosunku do Stanów Zjednoczonych, np. znieść choćby jedną opłatę celną istotną dla amerykańskich eksporterów. Przewidywał, że miałoby to bardzo pozytywny efekt polityczny, gdyż zmieniłoby nastroje w Kongresie, który będzie skłonny przyjąć korzystną dla liberalizacji wymiany światowej ustawę handlową. Malfatti stwierdził, że będzie trudno wytłumaczyć Europejczykom, dlaczego to oni mają ustąpić pierwsi. Tłumaczył, że EWG była $\mathrm{w}$ trudnym momencie formowania instytucji i negocjacji rozszerzeniowych, ale wyraził nadzieję, że będzie w stanie spełnić amerykańskie postulaty ${ }^{72}$.

Obaj politycy używali w negocjacjach na temat handlu argumentów politycznych. Nixon wskazywał na nastroje w Kongresie, a Malfatti sugerował, że gdy ulegnie naciskom amerykańskim, może być zagrożony proces integracji. Warto jednak zauważyć, że w rozmowie poruszano kwestie zagrożeń i korzyści związanych wyłącznie ze wzajemnym handlem - nie padały groźby rozluźnienia sojuszu.

W czerwcu 1971 r., na spotkaniu ministerialnym w Paryżu, przedstawiciele krajów OECD skupili się na problemie międzynarodowej wymiany. Sekretarz stanu USA Rogers zadeklarował, że Stany Zjednoczone były gotowe podejmować trudne decyzje polityczne w celu osiągnięcia kompromisu. Tego samego wymagały od swoich europejskich partnerów. Podkreślił związek amerykańskich zobowiązań obronnych z problemem deficytu bilansu płatniczego. Zaznaczył, że Stany Zjednoczone, by poprawić ten wskaźnik potrzebowały liberalizacji handlu z EWG i Japonią.

Wprawdzie Rogers nie mówił wprost o możliwości wycofania wojsk z Europy, lecz wyraźnie połączył tę polityczną kwestię z przyszłymi negocjacjami handlowymi. Po majowej akcji senatora Mansfielda w Kongresie ${ }^{73}$ Europejczycy nie mogli obojętnie przyjąć tego oświadczenia. Sekretarz Generalny OECD, Emile van Lennep, zaproponował utworzenie Grupy Wysokiego Szczebla, która koordynowałaby negocjacje na temat handlu. Ze strony Stanów Zjednoczonych udział w jej pracach miał wziąć William Eberle - specjalny przedstawiciel ds. negocjacji handlowych (Special Representative for Trade Negotiations $)^{74}$.

${ }^{72}$ NARA, NPMS, NSC Files, Subject Files: European Common Market, memorandum z rozmowy Nixona z Malfattim, 13 kwietnia 1971, box 322.

${ }^{73}$ Patrz podrozdział 4.4 .

${ }^{74}$ NARA, NPMP, NSC Files, HAK Office Files, HAK Administrative and Staff Files, Haig do Ehrlichmanna, 16 grudnia 1971, box 15. 


\subsection{Trudności gospodarcze Stanów Zjednoczonych}

W latach 1968-1971 r. zarządzanie międzynarodowym systemem walutowym było sparaliżowane. Banki centralne nie mogły dłużej kontrolować ogromnych przepływów kapitałów. G10 nie osiągała porozumienia na ten temat ze względu na różne narodowe interesy jej członków. W 1969 r. zapadła w MFW decyzja stworzenia w ciągu trzech lat międzynarodowych rezerw walutowych wartości 9,5 mld USD w SDR-ach ${ }^{75}$, które zostały aktywowane 1 stycznia 1970 r. Jeszcze w tym samym roku MFW zaplanował utworzenie dodatkowych rezerw walutowych wartych 3,5 mld USD w formie SDR-ów ${ }^{76}$.

Na początku 1970 r. kraje EWG ogłosiły powstanie Wspólnego Funduszu Rezerwy Monetarnej (Common Monetary Reserves Pool). Dzięki niemu państwa doświadczające przejściowego deficytu bilansu płatniczego miały otrzymywać środki na jego pokrycie. Zapowiadano zacieśnienie współpracy w przezwyciężaniu innych problemów wewnętrznych, np. ustalenie tolerowanego poziomu inflacji. Pojawiły się spekulacje o możliwym powstaniu Europejskiego Banku Centralnego i wspólnej waluty, która by mogła rywalizować z dolarem jako waluta rezerwowa ${ }^{77}$. Kwestie monetarne mogły w każdej chwili spowodować konflikt między Stanami Zjednoczonymi a Europą Zachodnią. W grudniu 1970 r. Francuzi poinformowali o planie natychmiastowej wymiany 129 mln USD na złoto. Tłumaczyli, że chcą pokryć w ten sposób składkę w złocie w MFW. Zapewniali, że nie był to powrót do polityki wykupu złota przez Bank Francji w celu osłabienia dolara ${ }^{78}$. Jednak argumenty te wydawały się Amerykanom nieprzekonujące. Bergsten przypominał, że Francuzi dysponowali dużą rezerwą złota o wartości 3,5 mld USD. Niepokoił się, że za przykładem Francji mogą pójść inne kraje, gdyż deficyt amerykańskiego bilansu płatniczego miał przekroczyć w 1970 r. 10 mld USD (liczony na bazie transakcji) lub 5 mld (z uwzględnieniem zmian rewaloryzacyjnych), co wzbudzało za granicą niepokój o wartość rezerw ${ }^{79}$.

Tymczasem w 1971 r. amerykański deficyt bilansu płatniczego znacznie wzrósł (zob. tabela 4.2). Wzbudziło to niepokój w Europie. Brytyjski premier Edward Heath

${ }^{75}$ NARA, NPMS, NSC Institutional "H" Files, Study Memorandums (1969-1974), odpowiedź Departamentu Stanu na roczny raport prezydenta o amerykańskiej polityce zagranicznej, 15 grudnia 1969, box H-164.

${ }^{76}$ M. D e Vri e s, J. H o r s e fi e l d, The International Monetary Fund, 1966-1971: The System Under Stress, Washington 1976, s. 173.

${ }^{77}$ W. R. B u r g e s s, J. R. Huntley, Europe and America. The Next Ten Years, New York 1970, s. 102. Por. C. F. B e r g s t e n, Toward a New International Economic Order: Selected Papers of C. F. Bergsten, 1972-1974, Lexington 1975, s. 346.

${ }^{78}$ Amerykanie kojarzyli deklarację francuską z polityką de Gaulle'a z lat 1963-1965, kiedy Francuzi wykupili złoto za 2 mld USD, znacznie uszczuplając amerykańskie rezerwy.

${ }^{79}$ NARA, NPMS, NSC Files, Country Files - Europe (France), Bergsten do Kissingera, 10 grudnia 1970, box 677. 
odmówił nawet spotkania z Nixonem w celu konsultacji przed zbliżającą się wizytą prezydenta w Chinach i ZSRR, dopóki Nixon nie zwoła spotkania G10. Grupa miałaby dyskutować na temat międzynarodowych konsekwencji amerykańskich problemów gospodarczych oraz tendencji protekcjonistycznych w tym kraju ${ }^{80}$. W marcu 1971 r. odbyła się konferencja przedstawicieli siedmiu banków centralnych (Belgii, RFN, Włoch, Holandii, Szwajcarii, Wielkiej Brytanii i USA). Bankierzy zobowiązali się, że nie będą sprzedawali złota odbiorcom prywatnym i powstrzymają się od nabywania go od producentów. Cena za uncję miała pozostać na poziomie 35 USD. W wyniku tego porozumienia spadała cena złota na wolnym rynku, co pozwoliło tymczasowo zahamować niekorzystne trendy ${ }^{81}$.

Tabela 4.2. Bilans płatniczy Stanów Zjednoczonych w latach 1960-1971 (w mln USD)

\begin{tabular}{|c|c|c|}
\hline \multirow{2}{*}{} & \multicolumn{2}{|c|}{ Sposób obliczania } \\
\cline { 2 - 3 } & $\begin{array}{c}\text { na bazie transakcji (official } \\
\text { transaction basis) }\end{array}$ & $\begin{array}{c}\text { uwzględniający zmiany } \\
\text { rewaloryzacyjne (liquidity } \\
\text { basis)* }\end{array}$ \\
\hline 1960 & -3403 & -3676 \\
\hline 1961 & -1348 & -2251 \\
\hline 1962 & -2650 & -2864 \\
\hline 1963 & -1934 & -2713 \\
\hline 1964 & -1534 & -2696 \\
\hline 1965 & -1289 & -2447 \\
\hline 1966 & +219 & -2151 \\
\hline 1967 & -3418 & -4683 \\
\hline 1968 & +1641 & -1610 \\
\hline 1969 & +2702 & -6122 \\
\hline 1970 & -9839 & -3851 \\
\hline 1971 & -29765 & -22002 \\
\hline
\end{tabular}

* W Stanach Zjednoczonych bilans płatniczy był liczony na dwa sposoby. Przy obliczeniach na bazie transakcji (official transaction basis) brano pod uwagę zmiany płatności tylko dla zagranicznych banków centralnych. Drugi sposób uwzględnia zmiany rewaloryzacyjne (liquidity basis), a także płatności dla prywatnych instytucji przechowujących swe rezerwy w dolarach. W obu przypadkach wlicza się zmiany w oficjalnych rezerwach, np. złota (D. P. C a l l e o, The Atlantic Fantasy: The U.S., NATO, and Europe, Baltimore 1970, s. 86).

Źródło: International Economic Relations of the Western World, 1959-1971, ed. A. Shonfield, vol. 1: Politics and Trade, London 1976, s. 423; por. G. F. T r e v e r t o n, The Dollar Drain and American Forces in Europe. Managing the Political Economics of Alliance, Athens 1978, s. 11.

${ }^{80}$ C. F. B e r g s t e n, Toward a New International Economic Order..., s. 346.

${ }^{81}$ A. G r o s s e r, Les Occidentaux. Les pays d'Europe et les États-Unis depuis la guerre, Paris 1978, s. 327. 
Zdobywająca coraz szersze poparcie opinia, że amerykańska polityka zagraniczna powinna być dostosowywana do zmian sytuacji gospodarczej powodowała obawy, że spójność sojuszu atlantyckiego mogła zostać zachwiana. W roku 1971, pierwszy raz od 1893 r., Stany Zjednoczone zanotowały deficyt handlowy. Wzmogło to roszczenia eksporterów wobec administracji dotyczące bardziej zdecydowanego upominania się o interesy gospodarcze USA ${ }^{82}$.

Głównym zwolennikiem wywierania nacisku, także politycznego, na Europę był sekretarz skarbu John Connally, który twierdził, że w ówczesnej sytuacji gospodarczej USA trzeba było zmienić starą zasadę poświęcania interesów ekonomicznych, gdy wchodziły one w konflikt z celami dyplomatycznymi ${ }^{83}$. Podczas wizyty w Monachium w maju 1971 r. stwierdził wprost: „obecnie wydajemy blisko 9\% PKB na obronę, prawie 5 mld USD na obronę za granicą, głównie w Europie. Wiemy, że jest to cena, jaką płacimy za przywództwo, ale te koszty trzeba dzielić. Nasza gospodarka już nie dominuje w wolnym świecie i opinia publiczna dłużej na to nie pozwoli" 84 .

W kwietniu i maju 1971 r. malejące stopy procentowe w Stanach Zjednoczonych spowodowały kolejną falę odpływu kapitału. W latach 1969 i 1971 wysiłki RFN w celu kontroli inflacji były bardzo utrudnione przez konieczność przyjmowania dużej ilości dolarów, by utrzymać uzgodniony kurs marki niemieckiej. Pod koniec lat 60 . kurs dolara amerykańskiego był zawyżony z powodu inflacji powstałej przez wydatki na wojnę w Wietnamie. Przyczyniły się do tego również zmiany kursów wymiany w innych krajach. Wysoki kurs dolara skutkował szybkim odpływem inwestycji z USA i prowadził do wzrostu wartości amerykańskiego importu przy jednoczesnym spadku eksportu. Administracja Stanów Zjednoczonych, chcąc uniknąć wewnętrznych problemów politycznych, była niechętna przeprowadzeniu dewaluacji dolara, raczej wywierała naciski, by inne kraje rewaluowały swe waluty. Europejczycy sprzeciwili się takiemu rozwiązaniu, zachęcając USA do walki z inflacją, "eksportowaną" na Stary Kontynent. Europejczycy dążyli do zmiany systemu monetarnego, określając go jako hegemoniczny, preferujący amerykańską walutę. Jednak Stany Zjednoczone nie były gotowe do rezygnacji z dominacji $w$ tej dziedzinie $e^{85}$.

W memorandum dla Nixona z 5 maja 1971 r. Kissinger informował, że Belgia, RFN Szwajcaria, Austria i Holandia zawiesiły w tym dniu wszystkie operacje dolarowe w swoich bankach centralnych. Zrobiono to ze względu na ogromny napływ dolarów, który 4 maja tylko w RFN sięgnął 1 mld USD. Wynikało to ze spekulacji, zmniejszającej realną wartość tej waluty. Kissinger stwierdził, że za taki stan rzeczy były odpowiedzialne m.in. publiczne komentarze na ten temat urzędników

\footnotetext{
${ }^{82}$ FRUS, 1969-1976, vol. 3, Bergsten do Kissingera, 21 kwietnia 1971, dok. 64.

${ }^{83}$ S. N iv o la, Commercializing Foreign Policy? American Trade Policy, Then and Now, „The Brookings Reviev", Spring 1997, s. 37.

${ }^{84}$ Cyt. za: H. K i s s i n g e r, White House Years..., s. 952.

${ }^{85}$ D. P. C a ll e o, op. cit., s. 89.
} 
niemieckiego ministerstwa finansów. Zapowiadano spotkanie w tej sprawie rządu RFN - przypuszczano, że władze podejmą decyzję o upłynnieniu kursu DM na określony czas poprzez zwiększenie marginesu dopuszczalnych wahań kursów. Przeciw takiemu działaniu silnie oponowała Francja, która nie chciała żadnych zmian w kursach walut na rynkach europejskich, nawet, jeśli byłaby to wspólna decyzja EWG. Kissinger przypuszczał, że taka różnica stanowisk mogła mieć polityczne konsekwencje dla EWG, np. Francuzi mogli grozić sprzeciwem wobec wstąpienia Wielkiej Brytanii do Wspólnot. Drugą alternatywą był zorganizowany nacisk Wspólnoty na Stany Zjednoczone, by podjęły zdecydowane kroki w celu zahamowania inflacji. Kissinger, który w większości przypadków opowiadał się za prymatem realizacji celów politycznych, tym razem radził nie podejmować żadnych motywowanych politycznie kroków. Stwierdził, że najważniejsza jest ochrona amerykańskich interesów ekonomicznych ${ }^{86}$.

Więcej zrozumienia dla europejskiego punktu widzenia wykazał Bergsten. Pisał do Kissingera o wpływie kryzysu monetarnego na politykę zagraniczną USA. Twierdził, że europejscy politycy odpowiedzialni za kwestie monetarne oraz prywatni finansiści winą za ten stan rzeczy obarczali Stany Zjednoczone. Przyznał, że w tym przypadku mieli rację. W porównaniu do sztywnych stóp procentowych, Amerykanie prowadzili od 1970 r. zbyt mało restrykcyjną politykę monetarną. Spowodowało to masowy odpływ kapitału do Europy. Bergsten przeczuwał, że Peterson planował wprowadzenie kontroli inwestycji, co mogło poważnie zaszkodzić stosunkom z EWG. Apelował do Kissingera, by usilnie starał się temu zapobiec, a także bardzo ostrożnie i stopniowo redukować kontrolę wywozu kapitału. Zdawał sobie jednak sprawę, że urzędnicy odpowiedzialni za kwestie finansowe: George Shultz, dyrektor Biura Zarządzania i Budżetu (Office of Management and Budget), Paul McCracken, szef Rady Doradców Gospodarczych (Council of Economic Advisers) i Peter M. Flanigan, doradca prezydenta ds. międzynarodowych spraw gospodarczych (Assistant to the President for International Economic Affairs) byli za natychmiastowym zniesieniem kontroli. Bergsten obawiał się, że w dobie pogłębiającego się kryzysu monetarnego prezydent mógł ulec ich sugestiom, co z kolei uznano by w państwach europejskich za bardzo agresywny krok przeciwko ich interesom gospodarczym. Bergsten przyznał, że reforma sytemu była nieunikniona, ale należało ją przeprowadzić tak, żeby nie zaszkodzić partnerom ${ }^{87}$.

Tak jak przewidywał Kissinger, w maju 1971 r. władze RFN zdecydowały się upłynnić kurs swojej waluty, co spowodowało jej dalsze umocnienie i nową falę spekulacji, która osłabiała pozycję sprzedawanego na wielką skalę dolara amerykańskiego. To z kolei groziło destabilizacją międzynarodowego systemu walutowego. Jednostronna decyzja rządu niemieckiego nie mogła poprawić sytuacji w długim

${ }^{86}$ NARA, NPMS, NSC Files, Subject Files, Kissinger do Nixona, 5 maja 1971, box 309.

${ }^{87}$ NARA, NPMS, NSC Files, Subject Files: Foreign Policy, Bergsten do Kissingera, 24 maja 1971, box 329 . 
okresie: tylko upłynnienie wszystkich głównych walut mogło spowodować przełom, ale było to politycznie niemożliwe ${ }^{88}$.

Członek NSC - Ernest Johnston - przekazał 10 maja 1971 r. Kissingerowi raport o politycznych reperkusjach europejskiego kryzysu monetarnego. Przede wszystkim trudności te spowodowały negatywny stosunek do Stanów Zjednoczonych z powodu utrzymywania deficytu bilansu płatniczego. Z kolei Kongres skrytykował RFN za decyzję o rewaluacji marki. Stwierdzono, że zwiększa to koszty stacjonowania wojsk amerykańskich na niemieckim terytorium. Johnston naciskał, by administracja jak najszybciej tonowała takie nastroje. Wskazywał, że spory monetarne spowodowały nie tylko wzrost napięcia w stosunkach transatlantyckich, lecz także wewnątrz EWG - toczyły się burzliwe rozmowy o wspólnej polityce monetarnej, a co gorsza powstało zagrożenie niepowodzeniem negocjacji akcesyjnych z Wielką Brytanią ${ }^{89}$.

\subsection{Wpływ sytuacji gospodarczej w USA na kwestie obronne}

W lutym 1970 r., w raporcie dla Kongresu na temat polityki zagranicznej, Nixon zauważył większą samodzielność krajów Europy Zachodniej na arenie międzynarodowej. Twierdził, że z tego powodu należy dokonać istotnych zmian w funkcjonowaniu sojuszu. Zwrócił uwagę, że amerykańskie wysiłki podejmowane w celu zapewnienia Europie bezpieczeństwa, pozostawały w dużej dysproporcji do poczynań aliantów, którzy nie dbali o podniesienie zdolności obronnych. Chodziło głównie o wydatki na cele militarne, co skutkowało przewagą Układu Warszawskiego, szczególnie w siłach konwencjonalnych (tabela 4.3). Prezydent obawiał się, że proces odprężenia zwiększy poczucie bezpieczeństwa, co sprawi, że państwa europejskie w ogóle zaniedbają jakiekolwiek działania w tym kierunku. Ostrzegł, że nawiązanie dialogu z ZSRR nie oznaczało, że zagrożenie z jego strony już minęło ${ }^{90}$.

Kissinger, jeszcze nie będąc doradcą prezydenta, proponował, żeby Stany Zjednoczone wspierały wysiłki Europy w budowie zintegrowanych sił nuklearnych opartych na potencjale Francji i Wielkiej Brytanii. Ale taki scenariusz był mało prawdopodobny ze względu na opór w Kongresie. USA raczej chciały umocnić kontrolę nad siłami nuklearnymi, uznając je za najlepsze narzędzie wpływów w Europie. Zresztą stworzenie europejskiej obrony nuklearnej w ramach Wspólnot było niemożliwe, gdyż Francja chroniła zdecydowanie swą odrębność w tej kwestii. Poza tym Europejczycy nie chcieliby, żeby był to substytut amerykańskich gwarancji bezpieczeństwa ${ }^{91}$.

${ }^{88}$ A. W. D e P o r te, Europe Between the Superpowers. The Enduring Balance, New Haven 1979, s. 205.

${ }^{89}$ NARA, NPMS, NSC Files, Subject Files: European Common Market, Johnston do Kissingera, 10 maja 1971, box 322 .

${ }^{90}$ PPP, Richard Nixon, vol. 2, pierwszy roczny raport dla Kongresu na temat polityki zagranicznej USA na lata 70., 18 lutego 1970, dok. 45.

${ }^{91}$ A. B u c h a i i, Partners and Allies, „Foreign Affairs”, July 1963, s. 625. 
Tabela 4.3. Wydatki na obronę i potencjał militarny wybranych państw oraz ugrupowań w $1970 \mathrm{r}$.

\begin{tabular}{|l|r|r|r|r|r|}
\hline & EWG & $\begin{array}{c}\text { Europejskie } \\
\text { państwa } \\
\text { NAT0 }\end{array}$ & USA & ZSRR & $\begin{array}{c}\text { Pozostałe } \\
\text { państwa Układu } \\
\text { Warszawskiego }\end{array}$ \\
\hline $\begin{array}{l}\text { Wydatki na obronę } \\
\text { (w mld USD) }\end{array}$ & 23,1 & 24,6 & 76,5 & 53,9 & 61,9 \\
\hline $\begin{array}{l}\text { Żołnierze } \\
(\text { w mln) }\end{array}$ & 2 & 2,9 & 2,7 & 3,375 & 2,682 \\
\hline ICBM $^{1}$ & - & - & 1054 & 1540 & - \\
\hline IRBM $^{2}$ & 9 & 9 & - & 700 & - \\
\hline SLBM $^{3}$ & 36 & 80 & 656 & 830 & - \\
\hline Bombowce strategiczne & 5343 & 6650 & 1100 & 11600 & - \\
\hline Czołgi & 2800 & 3600 & 8500 & 8700 & 10336 \\
\hline Lotnictwo taktyczne & & & & & \\
\hline
\end{tabular}

${ }^{1}$ ICBM: Intercontinental Ballistic Missiles - międzykontynentalne pociski balistyczne, ${ }^{2}$ IRBM: Intermediate-Range Ballistic Missiles - pociski balistyczne średniego zasięgu, ${ }^{3}$ SLBM: SubmarineLaunched Ballistic Missiles - pociski rakietowe wystrzeliwane z okrętów podwodnych.

Źródło: Final Report of Committee of Nine Presented to the North Atlantic Assembly in Ankara, Turkey, October 27, 1973, [w:] The New Europe and the United States. Partners or Rivals, ed. G. Mally, Lexington 1974, s. 389.

Na spotkaniu z dowódcami NATO w Neapolu we wrześniu 1970 r. Nixon oświadczył, że Stany Zjednoczone nie wycofają się z obrony Europy. Wnioskował, żeby zwiększała raczej wydatki na obronę niż płaciła Stanom Zjednoczonym za stacjonowanie ich wojsk. Wypowiedź prezydenta odnosiła się do doniesień europejskiej prasy sugerujących, że USA chciały otrzymać jakieś rekompensaty w zamian za zaangażowanie militarne. Nixon zdementował te stwierdzenia i postulował, by Europejczycy budowali własną siłę - wtedy amerykańska opinia publiczna uznałaby, że podział kosztów obrony był sprawiedliwy ${ }^{92}$. Było to poparcie dla tzw. opcji brytyjskiej przeciw niemieckiej - RFN chciała rekompensować koszty i polegać na obronie USA. Na forum Rady Północnoatlantyckiej, w grudniu 1970 r., europejskie państwa członkowskie NAT0 przyjęły pięcioletni program modernizacji sił zbrojnych, zwiększenia wydatków na sprzęt wojskowy i zadeklarowały przeznaczenie dodatkowego 1 mld USD na program poprawy obronności (European Defense Improvement Program) w ciągu następnych 5 lat. Zobowiązali się także do przyłączenia się do planu modernizacji infrastruktury

${ }^{92}$ H. Ki s s ing e r, op. cit., s. 400. Por. NARA, NPMS, NSC Institutional "H" Files, Study Memorandums (1969-1974), Laird do Kissingera, 7 października 1970, box H-164. 
NATO i wydania 420 mln USD na wspólne projekty, by polepszyć komunikację i lepiej chronić bazy lotnicze. Dwa dni potem Nixon oświadczył, że Stany Zjednoczone utrzymają na niezmiennym poziomie wojska w Europie do 1972 r., z wyjątkiem sytuacji, gdy podpiszą układ o redukcji sił z ZSRR ${ }^{93}$.

Mimo deklaracji prezydenta, senator Mansfield wciąż wypowiadał się w Senacie za koniecznością redukcji wojsk stacjonujących w Europie, ze względu na deficyt bilansu płatniczego. Bergsten twierdził, że jego postulat z ekonomicznego punktu widzenia był absurdalny. Deficyt BOP był szacowany na 3 do 5 mld USD (Bergsten wziął pod uwagę mniejszy, oparty na liquidity basis), a realny koszt utrzymywania wojsk w Europie, po odliczeniu niemieckiego offsetu, wynosił znacznie mniej. Wycofanie wojsk dla poprawy BOP o niewielką sumę nazwał "krokiem kryminalnym”. Wezwał, by dokładnie określić powody deficytu bilansu płatniczego. Mówił, że negatywnym skutkiem takiego posunięcia będzie osłabieniu sojuszu z Europejczykami. W ZSRR wycofanie wojsk mogłoby być odebrane jako spadek gotowości do obrony Starego Kontynentu ${ }^{94}$. Wielu doradców Nixona zgadzało się z tymi wnioskami udowadniając, że deficyt BOP wynikał głównie z kryzysu systemu monetarnego, zbyt dużego odpływu USD za granicę (głównie w formie inwestycji i z powodu rosnącego importu) oraz wydatków na wojnę w Wietnamie. Przyznawano, że sumy przeznaczone na obronę Europy były relatywnie niewielkie. Pojawiały się jednak również opinie, że siły amerykańskie miały odstraszać ewentualny atak ZSRR, pełniąc głównie funkcje polityczne - stanowić dowód solidarności Stanów Zjednoczonych z Europą. Zadawano pytanie, czy w związku z tym na Starym Kontynencie musiało stacjonować ponad 300 tys. żołnierzy ${ }^{95}$.

Sytuacja gospodarcza miała duży wpływ na toczące się od 2 kwietnia 1971 r. negocjacje kolejnej umowy offsetowej między Stanami Zjednoczonymi a RFN. W tym samym czasie rozpoczęły się zresztą negocjacje o porozumieniu czterech mocarstw w sprawie dostępu do Berlina. Stawiało to RFN w bardzo niekorzystnej sytuacji. Administracja Nixona, biorąc pod uwagę nastroje w Kongresie, przyjęła twarde stanowisko. Zażądała bezpośrednich płatności, zakupu przez RFN odrzutowców typu Phantom za 1,1 mld USD, przeznaczenia 186 mln USD na renowację kwater żołnierzy stacjonujących w RFN i zakup przez Bundesbank amerykańskich obligacji skarbowych za 670 mln USD, przy czym Bonn miało zgodzić się na przyjęcie za nie niższych odsetek niż rynkowe - różnicę miał finansować rząd RFN ${ }^{96}$. Willy Brandt w liście do Nixona z 12 maja tłumaczył, że kryzys monetarny ostatnich tygodni spowodował

${ }^{93}$ A. B a k e r F o x, Domestic Pressures in North America to Withdraw Forces From Europe, [w:] European Security and the Atlantic System, ed. W. T. R. Fox, W. R. Schilling, New York 1973, s. 226. Por. G. F. Treverto n, The Dollar Drain and American Forces in Germany. Managing the Political Economics of Alliance, Athens 1978, s. 44.

${ }^{94}$ FRUS, 1969-1976, vol. 3, Bergsten do Kissingera, grudzień 1970, dok. 48.

${ }^{95}$ K. K n o r r, Economic Factors in Future Arrangements for European Security, [w:] European Security..., s. 11-12.

${ }^{96}$ G. F. Treverton, op. cit., s. 45. Por. NARA, NPMS, NSC Insitutional "H" Files, Study Memorandums (1969-1974), raport NSSM 170, 2 kwietnia 1973, box H-129. 
duże problemy dla gospodarki RFN z powodu działalności spekulantów. W związku $\mathrm{z}$ tym apelował o zmniejszenie żądań offsetowych ${ }^{97}$. Nixon jednak nie był skłony do ustępstw argumentując, że jeśli RFN nie zrekompensuje w dużej mierze strat dla amerykańskiego bilansu płatniczego, Kongres doprowadzi do wycofania sił z RFN, choć zapewnił, że zrobi wszystko, by do tego nie doszło ${ }^{98}$.

Przekonanie Kongresu o wzroście kosztów obrony Europy, zachęciło Mansfielda do podjęcia jeszcze jednej próby. 11 maja $1971 \mathrm{r}$. przedłożył propozycję poprawki do ustawy o siłach zbrojnych (Military Selective Service Act) z 1967 r., zakładającej znaczną redukcję sił amerykańskich na Starym Kontynencie do 31 grudnia $1971 \mathrm{r}$. Tym razem przegłosowanie poprawki było bardzo prawdopodobne ze względu na pogarszającą się współpracę Nixona z Senatem ${ }^{99}$. Prezydent sam przyczynił się do przedłużania dyskusji w Kongresie. W raporcie na temat polityki zagranicznej z lutego $1971 \mathrm{r}$. wypowiedział się przeciw perspektywie wycofania wojsk z Europy. Mimo to przyznał, że stacjonowanie sił amerykańskich w Europie miało negatywne konsekwencje dla bilansu płatniczego, gdyż ich utrzymanie było droższe za granicą niż w USA ${ }^{100}$. To ostatnie zdanie pokazuje, że choć Nixon zdawał sobie sprawę z politycznej szkodliwości wycofywania sił ze Starego Kontynentu, nie chciał zrezygnować z używania tego argumentu w stosunkach z sojusznikami. Była to próba wykazania, że administracja była zdeterminowana, by bronić amerykańskich interesów oraz sygnał dla sojuszników, że chcąc utrzymania dotychczasowego poziomu zaangażowania militarnego USA w Europie, powinni przemyśleć ustępstwa na polu ekonomicznym. Nixon uważał poza tym, że Europejczycy nie chcą zwiększyć wydatków na własną obronę obawiając się, że Amerykanie wycofają wtedy więcej swoich sił. Woleli zresztą polegać na siłach nuklearnych, co było sprzeczne z koncepcją amerykańską ${ }^{101}$.

Jednak w momencie realnego zagrożenia akceptacją poprawki Mansfielda, Nixon podjął przeciw temu zdecydowaną akcję. 12 maja Biały Dom wydał oświadczenie, że będzie to miało negatywny wpływ na struktury NATO oraz na negocjacje z ZSRR i Chinami ${ }^{102}$. Dzień później prezydent spotkał się z grupą wysokich urzędników swej własnej i byłych administracji. Większość z nich przyznało, że wycofanie wojsk z Europy byłoby wielkim błędem. Nixon zdobył także poparcie byłych prezydentów: Harry'ego Trumana i Lyndona B. Johnsona, byłego sekretarza stanu Deana Achesona, George'a Balla i innych ekspertów polityki zagranicznej ${ }^{103}$.

${ }^{97}$ NARA, NPMS, NSC Files, Presidental Correspondence 1969-1974, Brandt do Nixona, 12 maja 1971, box 753 .

${ }^{98}$ Ibidem, Nixon do Brandta, 14 maja 1971.

${ }^{99}$ G. W. B a ll , The Past Has Another Pattern. Memoirs, New York 1982, s. 450.

${ }^{100}$ PPP, Richard Nixon, vol. 3, drugi roczny raport dla Kongresu na temat polityki zagranicznej Stanów Zjednoczonych, 25 lutego 1971, dok. 75.

${ }^{101}$ D. M ö c k l i, European Foreign Policy during the Cold War: Heath, Brandt, Pompidou and the Dream of Political Unity, London 2008, s. 144.

${ }^{102} \mathrm{H}$. K i s s in g e r, op cit., s. 939.

${ }^{103}$ G. W. B a l l, The Past Has Another Pattern..., s. 449. 
Nixon zaprezentował swoje stanowisko w liście otwartym do szefa senackiej komisji wojskowej (Senate Committee on Armed Services), Johna C. Stennisa. Prezydent przyznał, że koszty obrony mogłyby być dzielone bardziej sprawiedliwie, lecz przypomniał, że amerykańscy negocjatorzy wciąż prowadzili dialog z Europejczykami na ten temat. Wspomniał również o rozmowach z RFN w sprawie zwiększenia offsetu nawet do 2 mld USD i o drugiej fazie realizacji Europejskiego Programu Poprawy Obronności, który miał zostać sfinalizowany podczas spotkania NATO w grudniu 1971 r. Nixon zwrócił uwagę, że sekretarz generalny NAT0 Manilio Brosio wybierał się do Moskwy, by rozmawiać o traktacie na temat redukcji sił zbrojnych w Europie ${ }^{104}$. Poza tym rozpoczynała się trudna faza rozmów czterech mocarstw na temat statusu Berlina i zbliżały się negocjacje o redukcji broni strategicznych (Strategic Arms Limitation Talks - SALT). Nixon przekonywał, że wycofanie wojsk z Europy osłabi pozycję negocjacyjną Zachodu ${ }^{105}$.

Ujawniały się wtedy różnice między prezydentem a Kongresem w kwestii priorytetów polityki zagranicznej. Także w samej administracji zdania były podzielone. Biuro Zarządzania i Budżetu opowiadało się za bezwarunkową redukcją, Departament Skarbu preferował zawieranie dwustronnych umów na temat dzielenia kosztów utrzymania wojsk amerykańskich, a Departament Stanu brał pod uwagę w większym stopniu postulaty Europejczyków ${ }^{106}$. Na kształtowanie się opinii zwolenników wycofania wojsk dominujący wpływ miała kalkulacja ekonomiczna, natomiast Nixon, Kissinger i Rogers brali pod uwagę konsekwencje polityczne.

Opiniotwórcze dzienniki, takie jak „New York Times” czy „Washington Post”, także drukowały opinie przeciwne pomysłowi Mansfielda. „Washington Post” zamieścił alarmistyczny list Brosio, który twierdził, że realizacja postulatu senatora zniszczy wiarygodność i morale NATO. Zniweczy również zasadność obowiązującej w Sojuszu strategii elastycznego reagowania, gdyż znacznie osłabi siły konwencjonalne ${ }^{107}$.

Robert E. Hunter, ekspert w dziedzinie stosunków transatlantyckich, udowadniał nie tylko polityczny, ale i ekonomiczny bezsens wycofywania sił amerykańskich z Europy. Na początku lat 70. stanowiły one ok. 310 tys. ludzi: 5 dywizji działało na Europejskim Froncie Centralnym (European Central Front), ponadto rozmieszczone były siły lotnicze, 7-10 tys. głowic atomowych i okręty Szóstej Floty na Morzu Śródziemnym. Koszty ich utrzymania, wliczając siły pomocnicze stacjonujące w USA, wynosiły w roku fiskalnym 1971 ok. 14 mld USD, z czego 7-8 mld było bezpośrednio przekazywanych na siły stacjonujące w Europie i na Szóstą Flotę.

${ }^{104}$ Niespodziewane wsparcie dla stanowiska Nixona przyszło z Moskwy. 15 maja $1971 \mathrm{r}$. sekretarz generalny KC KPZR Leonid Breżniew wysłał list, w którym wyraził gotowość do rozpoczęcia negocjacji na temat traktatu o wzajemnej i zrównoważonej redukcji sił zbrojnych w Europie (Mutual and Balanced Force Reductions in Europe - MBFR). (H. K i s s in g e r, op. cit., s. 946).

${ }^{105}$ PPP, Richard Nixon, vol. 3, Nixon do Stennisa, 23 listopada 1971, dok. 368.

${ }^{106}$ A. B a ke r F o x, op. cit., s. 227.

${ }^{107}$ PPP, vol. 3, Richard Nixon, oświadczenie na temat amerykańskich wojsk w Europie, 15 maja 1971, dok. 168. 
Hunter obliczył, że wydatki te dodają do deficytu amerykańskiego bilansu płatniczego 1,8 mld USD w roku fiskalnym $1971 \mathrm{r}$., a redukcja sił o połowę pozwoliłaby zaoszczędzić $60 \mathrm{mln}$ USD rocznie. Była to kwota stosunkowo niewielka, biorąc pod uwagę niemiecki offset, który wynosił rocznie 760 mln USD. Dodatkowo zmniejszenie kontyngentu zredukowałoby sprzedaż amerykańskiego sprzętu militarnego do Europy, co skutkowałoby dodatkowymi stratami. Ekspert przekonywał, że przeniesienie części tych sił do Stanów Zjednoczonych mogło być bardziej kosztowne dla budżetu. Poza tym, nawet w momencie znacznego wycofania, USA wciąż musiałyby utrzymywać na Starym Kontynencie swoje bazy.

Poza kwestiami ekonomicznymi Hunter zauważył, że stacjonowanie tych sił leżało w interesie europejskiego, ale przede wszystkim amerykańskiego bezpieczeństwa, także poza obszarem Europy, gdyż np. Szósta Flota strzegła dodatkowo stabilnej sytuacji na Bliskim Wschodzie. Obawiał się olbrzymich kosztów politycznych wywołanych taką decyzją, gdyż Wspólnoty Europejskie nie były zdolne do utworzenia wystarczających sił równoważących zmniejszenie amerykańskiego wsparcia. Pytanie, czy zaangażowanie USA w obronę Europy Zachodniej było warunkowe i zależne od kondycji gospodarczej Stanów Zjednoczonych, zadawaliby nie tylko europejscy sojusznicy, lecz także główny oponent w zimnej wojnie - ZSRR.

W tym czasie Europa Zachodnia prowadziła też własną politykę odprężenia w relacjach z blokiem wschodnim. Istniała realna groźba "finlandyzacji” osłabionych sojuszników. Hunter zauważał, że w Europie rosło poczucie spychania przez Waszyngton stosunków transatlantyckich na dalszy plan. Zaapelował, żeby to zmienić, np. umożliwiając europejskim członkom NAT0 większy wpływ na podejmowanie decyzji w tej organizacji. Wtedy chętniej rozważyliby zwiększenie nakładów finansowych. Był to lepszy środek niż szantażowanie wycofaniem sił - przekonywał Hunter ${ }^{108}$.

Głosowanie nad poprawką Mansfielda odbyło się 19 maja 1971 r. Mimo że została odrzucona (stosunkiem głosów 61 do 36), Amerykanie nadal starali się wywierać naciski na Europę. W negocjacjach z Europą Zachodnią propozycja łączenia kwestii obronnych ze współpracą ekonomiczną była stale obecna. Wciąż używano obalanego przez ekspertów argumentu o decydującym wpływie kosztów utrzymywania wojsk w Europie na deficyt amerykańskiego bilansu płatniczego. Po odrzuceniu poprawki Mansfielda stało się oczywiste, że cele polityczne były w tym przypadku dla Amerykanów ważniejsze niż ekonomiczne. Zachodnioeuropejscy członkowie NATO zadeklarowali przeznaczanie większych środków na obronę, lecz było do przewidzenia, że nie zrezygnują z amerykańskich gwarancji bezpieczeństwa. Także utworzenie w najbliższym czasie niezależnych sił europejskich było z wielu powodów niemożliwe. George Ball uważał, że działo się tak dlatego, iż Europa bardziej skupiała się na integracji gospodarczej niż na wspólnym bezpieczeństwie. Spadło również poczucie

${ }^{108}$ R. E. H u n t e r, U.S. Defense Commitments in Europe and Asia During the 1970s: Military and Political Factors in Economic Policy, [w:] U.S. Foreign Economic Policy for the 1970s: A New Approach to New Realities. A Policy Report by National Planning Association Advisory Committee, Washington 1971, s. 162-171. 
zagrożenia bezpośrednią agresją ze strony ZSRR - w tym przekonaniu umacniały też Europejczyków coraz lepsze kontakty gospodarcze ze Wschodem ${ }^{109}$.

W lipcu 1971 r. strona niemiecka zaproponowała offset na łączną sumę 1 mld 729 mln USD, na który miały się składać zakupy sprzętu militarnego w USA za 929 mln USD, korzystne pożyczki z Bundesbanku w kwocie 572 mln USD oraz środki z budżetu RFN - 228 mln USD. Jednak przedstawiciele Stanów Zjednoczonych uznali, że kwota ta była zbyt mała ${ }^{110}$. Stanowisko RFN było również nieugięte: negocjator Michael Herbst stwierdził, że strona niemiecka nie mogła już więcej zaproponować, a naciski amerykańskie mogły spowodować poważne konsekwencje polityczne doprowadzić do konfrontacji, której efekty trudno było przewidzieć. Radził zakończenie negocjacji, gdyż spór stawał się zbyt spektakularny i mógł zagrozić pozycji Zachodu w rozmowach w sprawie Berlina ${ }^{111}$.

Nieformalna rozmowa Rogersa z Herbstem z 6 sierpnia 1971 r. w opinii sekretarza stanu nieco zmniejszyła napięcie. Herbst jednak wciąż utrzymywał, że jeśli Amerykanie zmuszą jego kraj do przyjęcia większej kwoty offsetu, spowoduje to problemy polityczne i budżetowe. Był rozczarowany, że strona amerykańska nie doceniła oferty RFN włączenia do offsetu środków budżetowych, co do tamtej pory było sprawą wielce kontrowersyjną. W negocjacjach offsetowych brał też udział sekretarz skarbu John Connally. Argumentował, że Kongres USA zwracał uwagę na zagraniczne wydatki, dlatego uzyskanie korzystnych warunków offsetu było dla Amerykanów szczególnie istotne ${ }^{112}$. Przy tej okazji Connally nie wspomniał ani słowem o planach ogłoszenia zawieszenia wymienialności dolara na złoto, które miało zostać ogłoszone za 9 dni ${ }^{113}$.

\subsection{Znaczenie relacji gospodarczych z Europą Wschodnią w stosunkach transatlantyckich}

Od 1954 r. do połowy 1971 r. wartość handlu między krajami kapitalistycznymi a socjalistycznymi wzrosła ponad siedmiokrotnie, z 3,5 mld USD do 25 mld USD. Udział tej wymiany $\mathrm{w}$ handlu światowym wzrósł $\mathrm{w}$ tym okresie od 4\% do $10 \%{ }^{114}$. Już pod koniec lat 60. stosunki gospodarcze Wschód-Zachód były coraz bardziej znormalizowane. Lista towarów objętych zakazem wymiany, narzucana głównie pod wpływem Stanów Zjednoczonych, ulegała skróceniu, polepszyły się warunki udzielania kredytów.

${ }^{109}$ G. W. B a ll, Diplomacy..., s. 170-171.

${ }^{110}$ NARA, NPMS, NSC Files, Country Files - Europe (Germany), Eliot do Kissingera, 29 lipca 1971, box 683.

${ }^{111}$ Ibidem, Rush do Departamentu Stanu, 15 lipca 1971.

${ }^{112}$ Ibidem, Rogers do Departamentu Stanu, 6 sierpnia 1971.

${ }^{113}$ Patrz podrozdział 4.7.

${ }^{114}$ V. P e r l o, Unstable Economy: Booms and Recessions in the United States since 1945, London 1973, s. 204. 
Jednocześnie zaostrzała się konkurencja między korporacjami o udziały na rynkach wschodnich. Były one szczególnie atrakcyjne - ze względu na centralnie planowaną gospodarkę można było zawierać umowy z rządami na długoterminowe dostawy, co sprawiało, że wartość handlu w obydwu kierunkach stale rosła. Przykładem takiego porozumienia była umowa między ZSRR a krajami Europy Zachodniej na ogromne dostawy gazu w zamian za sprzęt potrzebny do jego eksploatacji i przesyłania ${ }^{115}$.

Wartość amerykańskiego eksportu na Wschód wzrosła o 40\% w 1970 r. w porównaniu z rokiem poprzednim ${ }^{116}$, lecz wciąż kraje Europy Zachodniej były na tym polu bardziej aktywne. W 1970 r. eksport USA do bloku wschodniego wynosił $334 \mathrm{mln}$ USD (co stanowiło 0,8\% całości wywozu), podczas gdy Francji - $745 \mathrm{mln}$, Wielkiej Brytanii - $858 \mathrm{mln}$, a RFN - $1590 \mathrm{mln}^{117}$.

W 1971 r. wartość wymiany USA ze Wschodem wynosiła 613 mln USD, co stanowiło 2,5\% handlu Wschód-Zachód i niecałe 1,5\% wymiany USA ${ }^{118}$. Gros amerykańskiego eksportu stanowiły artykuły spożywcze, a wartość handlu z europejskimi państwami zależnymi od ZSRR była większa niż z samym wschodnim mocarstwem ${ }^{119}$. Natomiast kraje Europy Zachodniej wywoziły głównie towary przemysłowe i kapitał ${ }^{120}$.Z uwagi na aspekty polityczne, Stany Zjednoczone niechętnie patrzyły na rozwój międzyblokowego handlu w Europie i próbowały hamować jego rozwój (szczególne naciski w tej sprawie wywierał Departament Obrony). Także amerykańskie koncerny naftowe obawiały się konkurencji ZSRR na rynkach światowych, a producenci zaawansowanej technologii (np. firma IBM) nie chcieli dopuścić, by najnowsze rozwiązania były wykorzystywane w krajach socjalistycznych. Przedsiębiorstwa ponadnarodowe działające w Europie nie przestrzegały zakazów sprzedaży, dopóki mogły ich uniknąć, wysyłając towary spoza terytorium Stanów Zjednoczonych. Według szacunków Departamentu Stanu, wartość tego wywozu trzykrotnie przewyższała eksport bezpośredni z USA w tym kierunku ${ }^{121}$. Według Michaela Mastanduno, Stany Zjednoczone nie wywierały zbyt silnego nacisku, by ograniczyć międzyblokowe kontakty w Europie, nie chcąc antagonizować sojuszników. Amerykańscy decydenci uznali, że priorytetem było utrzymanie spójności sojuszu, a interweniować należało tylko w najbardziej oczywistych przypadkach, szczególnie przy próbach transferu technologii ${ }^{122}$.

${ }^{115}$ Przykładem intratnego kontraktu był także układ zawarty przez włoskiego Fiata z radziecką Wołgą na dostawę sprzętu i nowych rozwiązań technologicznych, wart kilka milionów dolarów (V. P e r l o, op. cit., s. 205).

${ }^{116}$ A. M a n i a, Détente i polityka Stanów Zjednoczonych wobec Europy Wschodniej styczeń 1969styczeń 1981, Kraków 2003, s. 54.

${ }^{117}$ Ibidem. Por. P. S. W a n d y c z, The United States and Poland, Boston 1980, s. 396.

${ }^{118}$ V. P e r l o, op. cit., s. 206.

${ }^{119}$ A. M a n i a, op. cit., s. 54 .

${ }^{120}$ G. F. Tre vert o n, Making the Alliance Work. The United States and Western Europe, Ithaca 1985, s. 63-64.

${ }^{121}$ V. P e r l o, op. cit., s. 205

${ }^{122}$ M. M a s ta n d u n o, Trade as the Strategic Weapon: American and Alliance Export Control Policy in the Early Postwar Period, „International Organization”, Winter 1988, s. 121-150. 
Uważając kraje bloku wschodniego za potencjalne rynki zbytu, amerykańscy przedsiębiorcy naciskali na władze, aby zniesiono najbardziej restrykcyjne ograniczenia, zawarte w ustawie o kontroli eksportu (Export Control Act). Twierdzenie o konieczności intensyfikacji handlu USA z blokiem wschodnim stawało się coraz bardziej popularne, szczególnie $\mathrm{w}$ dobie recesji na początku lat 70. Publicysta magazynu „Time” udowadniał, że działanie takie poprawiłoby relacje polityczne ze Wschodem, bo "gruby komunista to pokojowy komunista"123. Biorąc pod uwagę te nastroje, Sonnenfeldt zachęcał Kissingera do rozpoczęcia prac nad memorandum na ten temat ${ }^{124}$. W NSC utworzono grupę ds. polityki gospodarczej wobec Europy Wschodniej, która miała je przygotować.

Konsultacje między sojusznikami $\mathrm{w}$ tej sprawie odbywały się regularnie. Z punktu widzenia Stanów Zjednoczonych nie można było dopuścić, by każde państwo w kontaktach ze Wschodem działało na własną rękę ${ }^{125}$. Amerykanie z niepokojem obserwowali coraz bardziej ożywione kontakty przywódców zachodnioeuropejskich z władzami ZSRR i krajów Europy Środkowowschodniej ${ }^{126}$. Dlatego też sprzeciwiali się prośbie Francji, by mogła dostarczać do Polski sprzęt i technologię do produkcji obwodów elektrycznych. Departament Stanu zwrócił się do NSC o cofnięcie zakazu wydanego w październiku 1970 r. przez COCOM. Jednak Stans uważał, że powinien on być podtrzymany, gdyż technologia mogłaby być wykorzystana przez wrogie mocarstwo przeciwko Stanom Zjednoczonym. Poza tym komponenty tego sprzętu pochodziły w całości lub w większości z USA, więc sprzedaż ich przez firmy europejskie byłaby dyskryminacją amerykańskich producentów, którzy nie mogli ich wysyłać do państw bloku wschodniego ${ }^{127}$.

W lutym 1970 r., w raporcie dla Kongresu na temat polityki zagranicznej, Nixon stwierdził, że na nieporozumieniach w sojuszu transatlantyckim zyskają kraje komunistyczne ${ }^{128}$. Słowa te można odnieść do obaw o zbytnie uzależnienie się Europejczyków od kontaktów z ZSRR. Szczególnie aktywny na tym polu był Brandt, którego wizyty za „żelazną kurtyną" miały prowadzić do zawierania traktatów z państwami bloku wschodniego $0^{129}$.

${ }^{123}$ NARA, NPMS, NSC Files, Subject Files: Trade General General, artykuł z magazynu „Time”, 16 listopada 1970 , box 401.

${ }^{124}$ NARA, NPMS, NSC Insitutional "H” Files, Senior Review Group Meetings, polityka USA wobec Europy, 23 stycznia 1970, box H-041.

${ }^{125}$ G. F. Tr e v e r t o n, Making the Alliance Work..., s. 63-64.

${ }^{126}$ Pompidou 6 października 1970 r. przebywał z wizytą w Moskwie, we wrześniu $1971 \mathrm{r}$. Brandt spotkał się na Krymie z Breżniewem, a sowiecki przywódca w październiku 1971 r. odwiedził Francję (A. G r o s s e r, op. cit., s. 341).

${ }_{127}$ NARA, NPMS, NSC Files, Country Files - Europe (France), Stans do Kissingera, 12 lutego 1971, box 678.

${ }^{128}$ PPP, Richard Nixon, vol. 4: 1972, Washington D.C. 1974, pierwszy roczny raport dla Kongresu na temat polityki zagranicznej Stanów Zjednoczonych, 18 lutego 1970, dok. 45, dostępne także przez: http://www.nixonfoundation.org/:

${ }^{129}$ A. G r o s s e r, op. cit., s. 341. 
W kwietniu 1970 r. Brandt udał się z wizytą do Waszyngtonu, by wysondować stosunek polityków amerykańskich wobec Ostpolitik. Radykalne i samodzielne posunięcia Brandta budziły niepokój w Stanach Zjednoczonych. Wprawdzie Amerykanie również działali w kierunku détente, lecz obawiali się rozluźnienia współpracy RFN z NATO (już wycofanie się Francji osłabiało Sojusz), a nawet z EWG. Ciągle straszyło widmo traktatu z Rapallo z 1922 r. - porozumienia dwóch niezadowolonych ze swojego miejsca w układzie międzynarodowym mocarstw: Niemiec i ZSRR. Kissinger niepokoił się, że łatwe ustępstwa niemieckiego kanclerza zburzą amerykańską koncepcję porozumienia z ZSRR „z pozycji siły”. Wiedział, że umowa z RFN przysparza atutów wschodniemu mocarstwu. Twierdził, że polityka Brandta miała na celu przygotowanie gruntu do przyszłego zjednoczenia Niemiec bez pomocy Amerykanów, choć kanclerz nie wspominał o takich dążeniach ${ }^{130}$.

Jednak Amerykanie zdecydowali się udzielić wsparcia RFN. Kiedy okazało się, że niemiecka polityka mogła przynieść pozytywne efekty, Kissinger zaangażował się w jej popieranie, często nieoficjalnymi kanałami dyplomatycznymi ${ }^{131}$. Obawy związane z aktywizacją RFN na arenie międzynarodowej rozwiewał stopniowo sam Brandt, który zaczął wypełniać założenia polityki amerykańskiej. Działania kanclerza zmierzały do umocnienia europejskiego status quo. Mimo to Amerykanie wciąż byli zaskakiwani szybkim tempem działania dyplomacji zachodnioniemieckiej. W sierpniu 1970 r. podpisano układ o nieagresji RFN-ZSRR, a w grudniu $1970 \mathrm{r}$. porozumienie z Polską ${ }^{132}$. Były to bilateralne umowy, zawierane bez konsultacji z mocarstwami zachodnimi. Pod presją Waszyngtonu Brandt musiał się zgodzić na „wyhamowanie szalonego biegu do Moskwy”133, jak to określił były sekretarz stanu Dean Acheson.

W przygotowanym przez Departament Stanu raporcie stwierdzono, że ZSRR dążył do zwiększenia wpływów w Europie Zachodniej, wykorzystując rozbieżności europejsko-amerykańskie. Czynił to niezwykle dyskretnie, by nie zniechęcić Zachodu, np. poprzez propozycję zorganizowania KBWE. Dążył jednak do „finlandyzacji" zachodniej części Starego Kontynentu. Bardzo ważny dla ZSRR był czynnik ekonomiczny. Brandt relacjonował, że podczas wizyty w Moskwie premier Aleksiej Kosygin wypytywał go bardzo dokładnie o możliwości zacieśnienia współpracy gospodarczej, szczególnie udziału RFN w projektach eksploatacji radzieckich zasobów mineralnych i energetycznych ${ }^{134}$.

\footnotetext{
${ }^{130}$ M. F r a n k e l, Bonn: Pursuing a New Identity, „New York Times”, 14 grudnia 1971.

${ }^{131}$ Kissinger wiedział, że bez współpracy Stanów Zjednoczonych, ani RFN, ani ZSRR, nie mogłyby prowadzić polityki odprężenia w Europie.

${ }_{132}$ G. Mally, Pan-European Relationship and the United States, [w:] The New Europe and the United States..., s. 354.

${ }^{133}$ Cyt. za: R. J. B a r n e t, The Alliance. America, Europe, Japan. Makers of the Postwar World, New York 1983, s. 294.

${ }^{134}$ NARA, NPMS, NSC Institutional “H” Files, Study Memorandums (1969-1974), memorandum Departamentu Stanu, 14 sierpnia 1970, box H-164.
} 
W Waszyngtonie analizowano także polityczny aspekt zbliżenia Europy Zachodniej ze Wschodem. Robert Ellsworth, stały reprezentant USA przy Radzie NATO, w liście do Nixona stwierdził, że relacje transatlantyckie wchodziły w decydującą fazę. Według niego, trudno było przewidzieć, jak na te stosunki wpłynie ratyfikowanie przez RFN traktatu z ZSRR. Obawiał się, że pojawi się pytanie, czy w Europie nie stacjonuje zbyt wielu amerykańskich żołnierzy, szczególnie, jeśli dojdzie do skutku porozumienie w sprawie KBWE. Sojusz mógłby także ulec rozluźnieniu z powodu kłopotów na Bliskim Wschodzie i sporów handlowych z Europą. Ellsworth zalecał, by jak najszybciej ustalić mechanizm konsultacyjny, za pomocą którego sojusznicy porozumiewaliby się w kwestiach polityki wschodniej ${ }^{135}$.

Mimo nacisków ze strony sekretarzy stanu, obrony i handlu, a także Kongresu, by podjąć środki w celu liberalizacji zasad handlu ze Wschodem, Nixon jeszcze w marcu 1971 r. wydał decyzję powstrzymania się od takich kroków ${ }^{136}$. Należy pamiętać, że trwały wtedy rozmowy rozbrojeniowe z ZSRR, podczas których Stany Zjednoczone chciały negocjować z pozycji siły. Ustępstwa w takim momencie były politycznie niewskazane ${ }^{137}$.

\subsection{Przesłanki „Szoku Nixona”}

30 czerwca 1971 r. dyrektor CIEP, Peter Peterson, przedstawił prezydentowi memorandum zatytułowane "Stany Zjednoczone w zmieniającej się gospodarce światowej" (US in the Changing World Economy). Zauważono w nim, że kurczył się amerykański udział w bogactwie światowym, wobec tego „sprawy gospodarcze powinny zdobyć przewagę nad tradycyjną dyplomatyczną kurtuazją"138. Oznaczało to w praktyce zachęcenie amerykańskiej dyplomacji do wywierania bardziej zdecydowanego nacisku na partnerów handlowych, bez obaw o pogorszenie relacji politycznych. Przykładem takich działań była presja na RFN, by dokonała dewaluacji marki, na co zgodziła się w lipcu 1971 r. George Shultz podkreślał, że Stany Zjednoczone powinny przestać płacić za dobrą koniunkturę sojuszników, patrząc przez palce na ich praktyki szkodzące amerykańskim interesom. „Święty Mikołaj umarł”139 - podsumował Shultz.

${ }^{135}$ Ibidem, Ellsworth do Nixona, 13 sierpnia 1970.

${ }^{136}$ NARA, NPMS, NSC Insitutional "H" Files, National Security Decision Memorandums (19691974), NSDM 99, handel Wschód- Zachód, 1 marca 1971, box H-217.

${ }^{137}$ Jednak w dobie narastającej konkurencji o rynki zbytu, nie chciano stawiać barier eksporterom towarów nie uznawanych za strategiczne. Jeszcze w $1971 \mathrm{r}$. Kongres przyjął ustawę upoważniającą Import-Export Bank, by udzielał kredytów firmom chcącym prowadzić taką działalność (K. K n o r r, The Power of Nations. The Political Economy of International Relations, New York 1975, s. 143-144).

${ }^{138}$ FRUS, 1969-1976, vol. 3, nota edytorska, dok. 67.

${ }^{139}$ R. A. P a s t o r, Congress and the Politics of U.S. Foreign Economic Policy (1929-1976), Berkeley 1980, s. 129. 
Sekretarz skarbu John Connally proponował nałożenie zwiększonych ceł na import i zawieszenie wymienialności dolara na złoto. Kissinger stanowczo sprzeciwiał się takim rozwiązaniom. Uważał, że jednostronne działania wpłyną destabilizująco na relacje transatlantyckie, gdyż zostaną odczytane w Europie jako arogancki pokaz siły. Oddaliłoby to znacznie perspektywę stworzenia prawdziwego partnerstwa i podważyło zaufanie do Stanów Zjednoczonych w roli lidera. Przypomniał, że zachęcano sojuszników do przechowywania rezerw w dolarach - zawieszenie ich wymienialności na złoto spowodowałoby wielkie straty w krajach, które były lojalne wobec USA ${ }^{140}$. Departament Stanu wyraził podobną opinię.

Jednak rozwój sytuacji w 1971 r. nie skłaniał Nixona do akceptacji tych argumentów. W maju i w sierpniu odnotowano kolejne spadki wartości dolara, pogłębiał się także deficyt bilansu płatniczego USA, głównie poprzez rekordowy odpływ kapitału z USA i deficyt handlowy. Spowodowało to wzrost presji w Kongresie, by wycofać wojska amerykańskie z Europy, coraz częściej mówiono także o konieczności wprowadzenia działań o charakterze protekcjonistycznym. Eksperci wzywali do jak najszybszego podjęcia rozmów z krajami G10 o konieczności zmian parytetów wymiany walut. Jednak kraje posiadające nadwyżki w bilansie płatniczym (np. RFN) nie odczuwały potrzeby dokonywania rewaloryzacji swych walut - ich niskie kursy pozwalały im rozwijać eksport. Państwa, których waluty miały zbyt wysoki kurs, zaniżały go, by zwiększyć możliwości wywozu ${ }^{141}$. Stany Zjednoczone, zgodnie z porozumieniami z Bretton Woods, musiały pozostawać na tym polu pasywne. Amerykańskie produkty traciły przez to konkurencyjność na rynkach światowych, co podsycało inflację. Rządy europejskie były zaś niechętne wprowadzaniu płynnych kursów, dążąc do stabilizacji własnych walut. Poza tym istniało prawdopodobieństwo masowych żądań wymiany dolarów na złoto - latem 1971 r. Brytyjczycy podjęli taki krok, domagając się wymiany 3 mld USD ${ }^{142}$.

9 sierpnia 1971 r. wartość dolara spadła w relacji do niemieckiej marki do najniższego poziomu w powojennej historii. Był to nowy impuls dla spekulantów. Wtedy Nixon podjął decyzję o zdecydowanej reakcji. W kolejnym roku zamierzał ubiegać się o reelekcjęi potrzebował spektakularnego sukcesu gospodarczego. 15 sierpnia $1971 \mathrm{r}$,, bez konsultacji z sojusznikami, nałożył dziesięcioprocentowy podatek importowy i ogłosił zawieszenie wymienialności dolara na złoto ${ }^{143}$. Decyzja ta została przeforsowana przez najbliższych doradców ekonomicznych prezydenta, zwanych „Trojką": Connally'ego, McCrackena i Shultza. Prezydent zwołał ich na naradę 13 sierpnia do Camp David. Wśród obecnych zdecydowanym przeciwnikiem odejścia od standardu złota był tylko szef Zarządu Rezerw Federalnych (Federal Reserve Board) - Arthur

${ }^{140}$ FRUS, 1969-1976, vol. 3, Kissinger do Nixona, 17 marca 1969, dok. 12.

${ }^{141}$ Przykładem może być dewaluacja funta szterlinga w listopadzie $1967 \mathrm{r}$.

${ }^{142}$ A. P. D o b s o n, The Politics of the Anglo-American Economic Special Relationship 1940-1987, New York 1988, s. 231.

${ }^{143}$ J. A. N a t h a n, J. K. 0 l i v e r, United States Foreign Policy and World Order, Boston 1985, s. 374. 
Burns. Jednak Nixon, który zwykle liczył się z jego radami, tym razem nie wziął ich pod uwagę ${ }^{144}$. Wśród uczestników spotkania nie było żadnej osoby odpowiedzialnej za politykę zagraniczną. Z Rogersem konsultowano się telefonicznie, ale jego wpływ na prezydenta był znikomy, natomiast Kissinger przebywał wtedy w Paryżu na rozmowach pokojowych z przedstawicielami Wietnamu Północnego.

Decyzja Nixona była zaskoczeniem dla innych krajów. Rogers poinformował Kanadyjczyków i Japończyków, głównych partnerów handlowych USA, godzinę przed przemówieniem prezydenta, dyrektor MFW, Pierre-Paul Schweitzer, otrzymał tę wiadomość parę minut przed jego wygłoszeniem ${ }^{145}$. Nixon napisał do Pompidou tego samego dnia, 15 sierpnia, że wieczorem ogłosi decyzję, nie było już więc możliwości manewru ani negocjacji. Prezydent miał nadzieję, że Pompidou uzna ten krok za leżący w interesie wszystkich krajów, gdyż przyspieszy wprowadzenie koniecznych zmian. Poinformował, że wydał polecenie Connally'emu, żeby skontaktował się z ministrami francuskimi w sprawie dalszych kroków reformy systemu monetarnego i negocjacji handlowych. Podsekretarz skarbu, Paul Volcker, został wysłany do Londynu, planował też spotkania z ministrami finansów Francji, Włoch, RFN, Kanady i Japonii ${ }^{146}$. Argumenty prezydenta nie mogły być jednak zaakceptowane przez Europejczyków. Decyzja Nixona stanowiła wyraźny dowód braku zaufania i postawienia partnerów handlowych przed faktem dokonanym. Posunięcie to uderzyło głównie w Europę Zachodnią i Japonię.

Specjaliści od międzynarodowych relacji gospodarczych już od początku kadencji Nixona zauważali, że brak porozumienia w kwestiach ekonomicznych zaczął dominować w relacjach transatlantyckich, co mogło spowodować napięcia polityczne. W liście do Kissingera z 1 kwietnia 1969 r. Bergsten wskazywał, że perspektywy porozumienia z Europą w kwestii reformy światowego systemu monetarnego były dość odległe. Obawiał się, że w tej sytuacji Stany Zjednoczone będą musiały prędzej czy później podjąć unilateralne działania, by ratować pozycję dolara, co z kolei zostanie negatywnie przyjęte w Europie i będzie miało niekorzystny wpływ na sojusz ${ }^{147}$.

Milton Friedman wspominał, że po wygranych przez Nixona w 1969 r. wyborach, będąc w sztabie doradców ekonomicznych, spotkał się z prezydentem-elektem i przedstawił mu raport z propozycją rozwiązania problemu deficytu bilansu płatniczego. Uważał, że czas pierwszych tygodni urzędowania nowej administracji był najlepszy do wprowadzenia zmian. Friedman sugerował upłynnienie kursu dolara, ostrzegając, że jeśli nie zostanie to zrobione od razu, nastąpi kryzys, który utrudni taką decyzję. W memorandum Friedmana znalazła się też propozycja zniesienia

${ }^{144}$ M. F r i e d m a n, R. D. Fr i e d m a n, op. cit., s. 384. Nixon przyznał po latach, że decyzję tę podjął „wbrew instynktowi” (R. N i x o n, A Real War, New York 1980, s. 238).

${ }^{145}$ G. F. Tr e v e r t o n, Making the Alliance Work..., s. 146.

${ }^{146}$ NARA, NPMS, NSC Files, Country Files - Europe (France), Nixon do Pompidou, 15 sierpnia 1971, box 679 .

${ }^{147}$ NARA, NPMS, NSC Files, Subject Files, Bergsten do Kissingera, 1 kwietnia 1969, box 309. 
wszelkich restrykcji na inwestycje zagraniczne dla amerykańskich korporacji i na zagraniczne pożyczki dla banków komercyjnych. Postulował też wydanie oficjalnego oświadczenia, że Stany Zjednoczone nie będą angażować się w transakcje wymiany złota, by wpłynąć na kursy wymiany między USD a innymi walutami. Nixon, przyjmując opinię Arthura Burnsa, nie wyraził na to zgody. Friedman twierdził, że uczynienie tego 15 sierpnia 1971 r., w dużo gorszych warunkach było krokiem spóźnionym, a przez to błędnym ${ }^{148}$. Takie posunięcie było więc rozpatrywane od dawna. Musieli sobie zdawać z tego sprawę Europejczycy, lecz prawdopodobnie uznali, że Amerykanie nie odważą się podjąć unilateralnej decyzji.

Reakcje za granicą były niezwykle negatywne. 0 ile Europejczycy mogli przyjąć z zadowoleniem zamrożenie cen i płac na 90 dni (co mogło oznaczać, że Stany Zjednoczone rozpoczynają poważną walkę z inflacją), o tyle decyzje monetarne i ograniczające import były dla nich nie do zaakceptowania ${ }^{149}$. Rozpoczął się najpoważniejszy kryzys w relacjach gospodarczych świata zachodniego od II wojny światowej. Jeśli bierzemy pod uwagę zabezpieczenie interesów gospodarczych USA, ten ruch był uzasadniony, jednak sposób jego ogłoszenia był fatalny, łamiący zasady relacji z sojusznikami, będącymi najważniejszymi partnerami gospodarczymi $^{150}$. Kraje europejskie nie miały pewności, jakie dalsze kroki podejmą Stany Zjednoczone. Spowodowało to kryzys zaufania, kluczowego dla prawidłowego funkcjonowania gospodarki światowej. Zaufanie było także istotne w relacjach politycznych. Europejczycy przekonali się, że Nixon był zdolny do podjęcia unilateralnych kroków i przestali wierzyć w deklarowaną na początku kadencji chęć budowania równorzędnego partnerstwa, ale przede wszystkim chęć konsultacji. „Szok Nixona”, jak zaczęto nazywać decyzję prezydenta, został odebrany jako deklaracja wojny gospodarczej. Europejczycy nie mogli się pogodzić z konstatacją Amerykanów, że to oni ponosili winę za problemy gospodarcze USA. Uważali, że były one spowodowane głównie presją inflacyjną, powstałą w wyniku finansowania wojny w Wietnamie ${ }^{151}$.

W Stanach Zjednoczonych w większym stopniu koncentrowano się na polityce wewnętrznej kosztem ważnego celu deklarowanego przez Nixona na początku prezydentury - dążenia do naprawy stosunków transatlantyckich. Osobą, która przekonała prezydenta do tak radykalnej decyzji był Connally. Ball zauważył, że teoria sekretarza skarbu zasadzała się na przekonaniu, że kraje Europy Zachodniej chciały wykorzystać amerykańską gospodarkę do realizacji partykularnych interesów. Connally wielokrotnie powtarzał, że Stany Zjednoczone były wystarczająco silne, by narzucać warunki innym państwom. Jednak przekonanie to było nie do końca prawdziwe. Stany Zjednoczone stały się w latach 70. coraz bardziej zależne gospodarczo

\footnotetext{
${ }^{148}$ M. Fr i e d m a n, R. D. F r i e d m a n, op. cit., s. 376.

${ }^{149}$ Ibidem, s. 147.

${ }^{150}$ International Economic Relations of the Western World..., s. 73.

${ }^{151}$ E. R. G o o d m a n, The Fate..., s. 173.
} 
od relacji zewnętrznych, szczególnie od handlu zagranicznego. Potrzebowały współpracy państw europejskich w rozwiązywaniu problemów o charakterze ekonomicznym: reformy systemu walutowego i stopniowej likwidacji barier handlowych. Unilateralna decyzja Nixona z sierpnia 1971 r. zmniejszyła szanse porozumienia w tych kwestiach. Kissinger uważał, że „szok Nixona” był najbardziej aroganckim posunięciem, użytym kiedykolwiek wobec europejskich sojuszników. Przekonał prezydenta, że powinien zdymisjonować kontrowersyjnego sekretarza skarbu, który „kroczył przez arenę międzynarodową jak rewolwerowiec z westernowego saloonu", psując sojusze ${ }^{152}$.

Ważnym aspektem „szoku Nixona” była rezygnacja Stanów Zjednoczonych z przywództwa w międzynarodowym systemie monetarnym. Mimo że dolar faktycznie słabł, jednak wielkość gospodarki USA i duża liczba amerykańskich aktywów za granicą gwarantowały, że będzie to wciąż główna waluta rezerwowa świata kapitalistycznego ${ }^{153}$. Stany Zjednoczone zachowywały się biernie w czasie kryzysu monetarnego, nie podejmując inicjatywy w opracowywaniu wspólnej strategii jego zażegnania. Był to kolejny dowód na zmierzch hegemonii USA nie tylko w gospodarce światowej, lecz także przywództwa politycznego Zachodu.

Decyzja Nixona sprowokowała pytanie o długofalową politykę zagraniczną Stanów Zjednoczonych. W Europie obawiano się nawet powrotu tego państwa do zasad izolacjonizmu, brano też pod uwagę, że Waszyngton mógł częściej używać siły politycznej i militarnej, by osiągnąć swe cele gospodarcze. Byłoby to odwrócenie poprzedniej tendencji w strategii wobec Europy: korzystanie z siły gospodarczej w celu osiągnięcia priorytetu politycznego - umocnienia sojuszu atlantyckiego. Dowodem zmian w amerykańskiej polityce może być raport Prezydenckiej Komisji ds. Międzynarodowej Polityki Handlowej i Inwestycyjnej z lipca 1971 r. Znalazło się tam stwierdzenie, że plan Marshalla miał zły wpływ psychologiczny na relacje USA z sojusznikami, gdyż ogłaszając go nie brano pod uwagę amerykańskich interesów gospodarczych $^{154}$.

\subsection{Podsumowanie}

W czerwcu 1971 r. prezydent wygłosił oświadczenie, nazywane „drugą doktryną Nixona". Według niego, świat zmieniał się z bipolarnego na wielobiegunowy, wyłaniały się bowiem nowe mocarstwa: oprócz Stanów Zjednoczonych i ZSRR zwiększało się znaczenie i wpływy Europy Zachodniej, Japonii i Chin. Tezę tę sformułował, biorąc pod uwagę nie tylko znaczenie polityczne nowych centrów, lecz także ich

152 G. W. B a ll, Diplomacy..., s. 156. Connally został zdymisjonowany 12 czerwca 1972 r.

${ }^{153}$ E. R. G o o d m a n, The Fate..., s. 171.

${ }^{154}$ A. Sh on field, International Economic Relations. The Western System in the 1960s and 1970s, Beveryhills-London 1976, s. 35. 
wzrastającą siłę w gospodarce światowej ${ }^{155}$. Stwierdził, że Europa Zachodnia i Japonia, choć były przyjaciółmi i sojusznikami, jednak również bardzo poważnymi i twardymi konkurentami ${ }^{156}$. Charakterystyczne było wymienienie ich $w$ jednym rzędzie z ZSRR i ChRL jako rywali.

Planowane rozszerzenie EWG niepokoiło Amerykanów. Zjednoczona Europa coraz śmielej chroniła interesy regionalne w systemie monetarnym i handlowym. Waszyngton chciał, aby te systemy pozostawały otwarte dla wszystkich uczestników gospodarki światowej i działały, tak jak w okresie powojennym, na korzyść USA. Natomiast Europa na początku lat 70. uznała, że sztuczne podtrzymywanie hegemonii USA, podczas gdy pojawili się inni silni gracze w gospodarce światowej, było bezzasadne.

W komentarzach politycznych, a także w artykułach w czasopismach naukowych formułowano stwierdzenia, że kwestie handlowe i finansowe zastępowały w stosunkach transatlantyckich tradycyjne problemy dyplomatyczne i zagadnienia bezpieczeństwa. Coraz częściej zarówno we wzajemnych relacjach, jak i w polityce światowej, stosowano narzędzia gospodarcze. Zauważono też istotną zmianę w międzynarodowych stosunkach ekonomicznych - EWG stała się w miejsce Stanów Zjednoczonych największym podmiotem gospodarczym ${ }^{157}$. Specjalista od stosunków międzynarodowych i biznesu, Harald Malmgren, zauważył, że pozytywne czynniki ułatwiające rozwój, takie jak położenie geograficzne, klimat, bogactwa naturalne, miały mniejsze znaczenie ze względu na coraz bardziej swobodny przepływ towarów, kapitału, usług i surowców. Te trendy powodowały, że kwestie handlowe i finansowe stały się coraz ważniejsze i bardziej konfliktogenne w stosunkach międzynarodowych. Zwrócił również uwagę na współzależności i konieczność dostosowania się poszczególnych państw do ustaleń międzynarodowych instytucji.

Malmgren z niepokojem odnotowywał, że Amerykanie podejmowali coraz bardziej radykalne kroki w obronie swych producentów poprzez naciski, by ograniczyć import poszczególnych produktów. Zmuszali również partnerów do „dobrowolnych" ograniczeń importowych, grozili wprowadzeniem restrykcyjnych środków dotyczących handlu zagranicznego. Coraz bardziej zamknięta na swobodną wymianę była także Europa Zachodnia. Działo się tak, gdyż decyzje obu stron w kwestiach gospodarczych były przedmiotem żywotnego zainteresowania grup interesów, firm, pracowników i rolników, mających bardzo duży wpływ na kształtowanie polityki poszczególnych krajów. Kissinger tłumaczył, że jeżeli

${ }^{155}$ R. L. P f a l t z g r a f f, The Atlantic Community - A Conceptual History, [w:] Atlantic Community in Crisis. A Redefinition of the Transatlantic Relationship, eds. W. F. Hahn, R. L. Pfaltzgraff, New York 1979, s. 19.

${ }^{156}$ E. R. G o o d m a n, The Fate..., s. 172.

${ }^{157}$ H. B. M a l m g r e n, Coming Trade Wars? (Neo-Mercantilism and Foreign Policy), „Foreign Policy", Winter 1970-1971, s. 115. 
jakaś grupa interesów w USA była dotknięta restrykcjami europejskimi, otrzymywała poparcie innych środowisk, co prowadziło do wzmożonych nacisków na Kongres ${ }^{158}$. Rosnący protekcjonizm powodował z kolei sprzeciw partnerów handlowych. Malmgren przepowiadał negatywne konsekwencje polityczne takich działań stwierdzając, że sprawy gospodarcze coraz bardziej wpisywały się w główny nurt polityki zagranicznej ${ }^{159}$. Najbardziej widocznym skutkiem była wyraźna zmiana stanowiska Waszyngtonu w kwestii rozszerzenia EWG i pogłębiania się integracji europejskiej.

Niepokojące były również groźby wycofania części wojsk amerykańskich z Europy, a realne niebezpieczeństwo realizacji tego scenariusza ujawniło się w momencie głosowania nad poprawką Mansfielda. W raporcie dla Kongresu na temat polityki zagranicznej w 1970 r., przedstawionym 25 lutego 1971 r., Nixon wspomniał, że aspekt gospodarczy relacji z Europą Zachodnią był ściśle powiązany ze stosunkami politycznymi i militarnymi ${ }^{160}$. Używanie takiego argumentu było niezgodne z opinią Departamentu Stanu. Także Kissinger sprzeciwiał się takiej strategii. Wskazywał, że poparcie amerykańskiego społeczeństwa dla obrony Europy stanowiło zbyt duże osiągnięcie, by je zniweczyć. Jednak spektakularne wycofanie oddziałów było politycznie niemożliwe w dobie zimnej wojny. Oznaczałoby to poważne osłabienie sojuszu atlantyckiego i wystawienie przez USA aliantów na zagrożenie infiltracją ze strony ZSRR ${ }^{161}$. Wiedzieli o tym zarówno Amerykanie, jak i Europejczycy, którzy z biegiem czasu przestali reagować na groźby Waszyngtonu, jeśli były wysuwane przy okazji omawiania nieporozumień gospodarczych.

„Szok Nixona” można uznać za cezurę początkową okresu zmiany systemu zachodniego. Konieczna była nie tylko reforma systemu monetarnego. Kres porządku opartego na hegemonii dolara implikował również konieczność zmian w stosunkach handlowych. Kissinger ostrzegał, że działając unilateralnie administracja amerykańska znajdzie się pod presją nastrojów społecznych, co ograniczy jej zdolność podejmowania decyzji opartych na racjonalnych przesłankach ${ }^{162}$. Taka sama sytuacja dotyczyła rządów Europy Zachodniej, które mogły być zmuszone do podjęcia działań odwetowych.

„Szok Nixona”, zwany także „amerykańskim monetarnym Wietnamem”, był nie tylko ekonomicznym, lecz także politycznym atakiem na kraje europejskie. W wyniku zewnętrznej decyzji musiały one zmienić politykę monetarną i kursy wymiany walut. Było to niezwykle trudne, gdyż biznesmeni w poszczególnych krajach byli

${ }^{158}$ NARA, NPMS, NSC Files, Country Files - Europe (France), rozmowa Kissingera z Alphandem, 14 grudnia 1970, box 677.

${ }^{159}$ H. B. M a l m g r e n, op. cit., s. 135.

${ }^{160}$ PPP, Richard Nixon, vol. 3, drugi roczny raport dla Kongresu na temat polityki zagranicznej Stanów Zjednoczonych, 25 lutego 1971, dok. 75.

${ }^{161}$ FRUS, 1969-1976, vol. 3, Peterson do Rogersa, 5 czerwca 1971, dok. 66.

162 Ibidem, raport Departamentu Stanu, 16 marca 1971, dok. 56. 
przyzwyczajeni do promocji eksportu przez rząd. Decyzja Nixona okazała się triumfem koncepcji dominacji czynników ekonomicznych nad politycznymi w amerykańskiej dyplomacji. Zwolennicy modelu merkantylistycznego stosunków międzynarodowych uważali, że polityka amerykańska przyniosła potwierdzenie ich teorii w praktyce. 



\section{ROZDZIAŁ V}

\section{WSPÓŁPRACA TRANSATLANTYCKA W DOBIE TWORZENIA NOWEGO ŚWIATOWEGO ŁADU EKONOMICZNEGO (SIERPIEŃ 1971 - STYCZEŃ 1973)}

\subsection{Droga do porozumienia smithsoniańskiego}

W dobie narastania problemów gospodarczych w Stanach Zjednoczonych, administracja Nixona w większym stopniu zaczęła brać pod uwagę fakt, że relacje zagraniczne wpływały na prowadzenie wewnętrznej polityki ekonomicznej. Pierwszą konkluzją było obwinianie za ten niekorzystny stan rzeczy sojuszników i partnerów handlowych. „Szok Nixona” stał się ewidentnym przykładem próby poprawy sytuacji wewnętrznej kosztem Europy Zachodniej i Japonii. Jednocześnie Stanom Zjednoczonym zależało na poprawnych relacjach gospodarczych i politycznych. Współzależność na tych polach skłoniła Waszyngton do poszukiwania kompromisu.

Już 16 sierpnia 1971 r. Nixon wystosował listy do przywódców europejskich, tłumacząc Nową Politykę Gospodarczą ${ }^{1}$. Brandt odpowiedział mu dopiero 20 września. W RFN miały w tym czasie miejsce gwałtowne protesty eksporterów, gdyż ogłoszony przez Nixona podatek importowy dotykał 90\% wywozu do USA, zaś spadek wartości USD nie dawał nadziei na poprawę sytuacji. Badania opinii publicznej wykazywały, że tylko 30\% niemieckiego społeczeństwa popiera sojusz z USA, podczas gdy $50 \%$ opowiadało się za neutralnością ${ }^{2}$. Brandt przewidywał, że podatek importowy może bardzo negatywnie odbić się na gospodarce RFN, która już ucierpiała z powodu postulowanej przez Stany Zjednoczone rewaloryzacji DM (jej wartość wzrosła o 7\%). Kanclerz zadeklarował jednak gotowość współpracy w przygotowaniu reformy monetarnej ${ }^{3}$.

Bardziej asertywnie wyraził swe niezadowolenie premier Wielkiej Brytanii, Edward Heath. Stwierdził, że Europa Zachodnia nie mogła dłużej liczyć na Stany Zjednoczone, które dążyły do politycznej dominacji nad sojusznikami. Wychodząc

\footnotetext{
${ }^{1}$ National Archives and Record Administration, College Park, MD (NARA), Nixon Presidential Materials Staff (NPMS), National Security Council (NSC) Files, Presidental Correspondence 19691974, Nixon do Brandta, 16 sierpnia 1971, box 753.

${ }^{2}$ NARA, NPMS, NSC Files, Country Files - Europe (Germany), Sonnenfeldt do Kissingera, 11 listopada 1971, box 683 .

3 NARA, NPMS, NSC Files, Presidental Correspondence 1969-1974, Brandt do Nixona, 20 września 1971, box 753.
} 
poza spory monetarne sugerował, że Waszyngton planował zmniejszenie obecności militarnej na Starym Kontynencie, szukając porozumienia z ZSRR i ChRL. Te podejrzenia brały się stąd, że Nixon ogłaszając Nową Politykę Gospodarczą nie brał pod uwagę interesów innych państw, których stabilność gospodarcza była zagrożona przez jednostronne działania USA. Heath wzywał pozostałych członków Wspólnot do podjęcia działań w celu zabezpieczenia dobrobytu i obrony ${ }^{4}$. Altiero Spinelli, włoski komisarz EWG, stwierdził natomiast, że posługując się "szokiem Nixona” Stany Zjednoczone próbowały przerzucić na Europę ciężar swej zagranicznej polityki gospodarczej ${ }^{5}$.

Po obu stronach Atlantyku zdawano sobie sprawę, że nie należy dążyć do konfrontacji, lecz znaleźć wspólnie jak najlepsze wyjście z zaistniałej sytuacji. Poważny konflikt między Stanami Zjednoczonymi a Europą Zachodnią był politycznie trudny do wyobrażenia w dobie zimnej wojny. Należy również zauważyć, że nie tylko rządy, lecz także korporacje ponadnarodowe były aktorami w gospodarce światowej. Interesy Ameryki i Europy były tak ściśle powiązane i tak intratne, że obie strony chciały uniknąć konfliktów. Chociaż politycy mogli ulegać emocjom i hołdować narodowym interesom, w końcu musieli rozważyć konsekwencje rozłamu.

Według Bergstena, nie można było przesądzać, które podejście przeważy: emocjonalne czy pragmatyczne. Jako przykład zwycięstwa czynnika irracjonalnego podał przeforsowanie przez Connally'ego działań podjętych przez Nixona w sierpniu 1971 r. Twierdził, że był to zgubny skutek upolitycznienia kwestii monetarnych i handlowych ${ }^{6}$. Uważał, że decyzja prezydenta rozpoczęła negatywny zwrot w amerykańskiej polityce ekonomicznej, przyczyniła się bowiem do promowania tendencji protekcjonistycznych w gospodarce i izolacjonistycznych w polityce, co mogło być w przyszłości szkodliwe zarówno dla amerykańskiej prosperity, jak i dla pozycji Stanów Zjednoczonych na świecie. Przyznawał, że istniały powody, by podjąć kroki chroniące amerykańskie interesy, lecz decyzje Nixona były zbyt daleko idące. Obawiał się negatywnej reakcji państw europejskich: przypomniał, że np. Dania w odpowiedzi wprowadziła podatek importowy, a długofalowym skutkiem mogło być porozumienie państw europejskich $\mathrm{w}$ celu utrudnienia działania amerykańskich korporacji na ich terenie. Za jeszcze poważniejsze uznawał konsekwencje dla amerykańskiej polityki zagranicznej: zauważył, że ewentualne działania odwetowe państw Starego Kontynentu wzmocnią zwolenników redukcji sił wojskowych w Europie. Przewidywał, że spowoduje to spadek zaufania dla amerykańskich gwarancji obrony, co mogło z kolei sprawić, że państwa europejskie - szczególnie RFN - będą bardziej skłonne do zawierania układów z ZSRR bez konsultacji z USA.

\footnotetext{
${ }^{4}$ Transatlantic Gaullism, „New York Times”, 22 października 1971.

${ }^{5}$ International Economic Relations of the Western World, 1959-1971, ed. A. Shonfield, vol. 1: Politics and Trade, London 1976, s. 74.

${ }^{6}$ C. F. B e r g s t e n, Toward a New International Economic Order: Selected Papers of C.F. Bergsten, 1972-1974, Lexington 1975, s. 319-320.
} 
„Cała Europa popadnie w neutralizm bądź w neogaullizm” - ostrzegał Bergsten. W związku z tym istniała obawa, że rozwijający się proces integracji będzie miał ostrze antyamerykańskie. Ekspert zwrócił uwagę, że negocjacje z ZSRR i Chinami, przy jednoczesnych działaniach na szkodę najlepszych sojuszników, mogą niepokoić Europejczyków i negatywnie działać na transatlantyckie relacje. „Trzeba jak najszybciej zawrzeć kompromis i znieść te niedorzeczne działania protekcjonistyczne!" - apelował Bergsten ${ }^{8}$.

Również Ralf Dahrendorf na łamach dziennika "New York Times” tłumaczył, „dlaczego Europa jest zszokowana”. Przyznał, że miał świadomość trudnej sytuacji w USA jak również tego, że amerykańska prosperity była konieczna z punktu widzenia utrzymania postępu w wolnym świecie. Jednak wciąż uważał decyzję Nixona za drastyczną, gdyż podatek importowy miał dotknąć ok. 90\% europejskiego eksportu do Stanów Zjednoczonych. Zapowiadał, że skieruje się on do innych części świata, gdyż eksporterzy stracą zaufanie do stałości warunków wymiany z USA. Odnosząc się do proponowanej reformy monetarnej, Dahrendorf stwierdził, że wymuszanie jej przyspieszenia przez „szok Nixona” nie miało sensu, gdyż Zachód nie był jeszcze politycznie i merytorycznie przygotowany do jej wprowadzenia9.

W sierpniu 1971 r. z Europy dochodziły sygnały zapowiadające działania odwetowe. Rząd RFN zaproponował, by kursy wszystkich walut europejskich zostały dostosowane do siebie, a ich wartość w stosunku do USD miała zostać upłynniona. Rząd francuski odrzucił tę inicjatywę - nie udało się podjąć w związku z tym wspólnych działań w celu zminimalizowania skutków decyzji Nixona. Jednak kraje EWG chciały wypracować jednolite stanowisko wobec USA. Solidarność z ich decyzjami zadeklarowała również Wielka Brytania ${ }^{10}$. Rząd Stanów Zjednoczonych nie chciał dopuścić do utworzenia takiego „wspólnego frontu”. Podkreślał bilateralne związki z poszczególnymi krajami europejskimi oraz zależność Europy od USA w kwestii bezpieczeństwa, stawiając szczególnie RFN przed wyborem między EWG a USA. Jednak państwa europejskie nie zamierzały poddać się amerykańskim żądaniom. We wrześniu EWG zdołała wypracować wspólne stanowisko, które miało być zaprezentowane podczas negocjacji z USA. Zapowiedziano rewaluację głównych europejskich walut pod warunkiem obniżenia wartości USD w relacji do złota i zniesienia podatku importowego ${ }^{11}$.

${ }^{7}$ C. F. B e r g s te n, The New Economics and US Foreign Policy, Washington 1972, s. 206.

${ }^{8}$ Ibidem, s. 199-210. Do podobnych kroków nawoływał publicysta dziennika „New York Times" zauważając, że jeśli Stany Zjednoczone nie wahają się negocjować z ZSRR i Chinami, tym bardziej powinny doprowadzić do kompromisu ze swoimi sojusznikami („New York Times”, 18 sierpnia 1971).

${ }^{9}$ R. D a h r e n d o r f, Why Europe is Shocked?, „New York Times”, 1 września 1971.

${ }^{10}$ A. G r o s s e r, Les Occidentaux. Les pays d'Europe et les États-Unis depuis la guerre, Paris 1978, s. 331.

${ }^{11}$ P.Y. H a m m o n d, Changing Bargaining Relations in the Atlantic Alliance, [w:] The United States and Western Europe. Political, Economic and Strategic Perspectives, ed. W. F. Hanrieder, Cambridge, Mass. 1974, s. 225. 
15 i 16 września 1971 r. odbyły się w Londynie spotkania ministrów finansów i szefów banków centralnych krajów G10. Do tego czasu wiele państw upłynniło kursy swoich walut argumentując, że siły rynku ustalą ich prawdziwą wartość. Spotkanie zakończyło się bez żadnych konkretnych konkluzji - zbyt wielkie było niezadowolenie partnerów gospodarczych USA. Europejczycy grozili nawet możliwością nałożenia nowych barier na wymianę z USA. Nixon początkowo wcale nie dążył do złagodzenia napięcia. Na konferencji prasowej 16 września stwierdził, że zniesienie podatku importowego było uzależnione nie tylko od reformy systemu monetarnego, lecz także od bardziej sprawiedliwego dzielenia kosztów obrony w ramach NATO. Było oczywiste, że ta ostatnia kwestia nie mogła być rozwiązana w krótkim czasie, więc wystąpienie Nixona można interpretować jako próbę wzmocnienia amerykańskiej pozycji negocjacyjnej i pozyskanie poparcia opinii publicznej. Jego posunięcie zostało dobrze przyjęte w Stanach Zjednoczonych. Nawet środowiska biznesowe uznały „szok” za mniejsze zło, obawiano się bowiem zwiększania barier celnych lub zwiększonej kontroli przepływu kapitału ${ }^{12}$.

Także w Londynie Connally zażądał koncesji handlowych od EWG w zamian za zniesienie dziesięcioprocentowego podatku importowego. Chciał także, by państwa europejskie i Japonia przyjęły więcej amerykańskich towarów oraz dokonały rewaluacji walut, co pozwoliłoby wspierać amerykański eksport, a tym samym pomóc w zrównoważeniu bilansu płatniczego. Wspomniał też o przejęciu przez Europę większej odpowiedzialności finansowej za obronę w ramach NATO i wezwał do szybkiego ustanowienia bardziej elastycznego systemu monetarnego. Sekretarz skarbu żądał także, by EWG zawiesiła negocjacje z EFTA o strefie wolnego handlu i zmieniła zasady CAP na mniej dyskryminacyjne dla krajów trzecich. Wymagania te były w tamtym czasie nierealne, lecz Amerykanie chcieli wykorzystać niepewność w Europie ${ }^{13}$.

Przedstawiciele EWG i Japonii nie chcieli się zgodzić na te warunki twierdząc, że oznaczałoby to dla ich krajów zagrożenie deficytem BOP. Wezwali Stany Zjednoczone, by skoncentrowały się na dostosowaniu kursów walutowych poprzez dewaluację dolara. Europejczycy argumentowali, że amerykański deficyt bilansu płatniczego pochodził głównie z ogromnych kosztów wojny w Wietnamie i dużego odpływu kapitału związanego z amerykańskimi inwestycjami na świecie. Na Starym Kontynencie nie widziano powodu jego finansowania. Spotkanie zakończyło się fiaskiem. Napięcie w stosunkach transatlantyckich zaczęto porównywać do okresu początku lat 30 . XX w., kiedy w dobie wielkiego kryzysu gospodarczego nie zastosowano wspólnych środków zaradczych, co spowodowało katastrofalne skutki

12 D. P. C a ll e o, Since 1961. American Power in a New World Economy, [w:] Economics and the World Power. An Assessment of American Diplomacy since 1789, eds. W. H. Becker, S. F. Wells, Jr, New York 1984, s. 420.

${ }^{13}$ B. C o h e n, The Revolution in Atlantic Economic Relations. The Bargain Comes Unstuck, [w:] The United States and Western Europe..., s. 107-109. 
gospodarcze i polityczne. Państwa europejskie podejmowały też konkretne działania w celu ochrony gospodarek: Wielka Brytania zmniejszyła stopy procentowe, by osłabić funta i powstrzymać nadmierne zwiększanie jego wartości w stosunku do dolara, zaś Francja i Japonia wprowadziły ścisłą kontrolę wymiany ${ }^{14}$.

Tylko dzięki jednomyślności Europejczycy zdołali skłonić Amerykanów do odstąpienia od żądań wysuwanych przez Connally'ego ${ }^{15}$. Na corocznym spotkaniu MFW, które odbyło się pod koniec września, Connally uzależnił rezygnację z podatku importowego od przeprowadzenia reformy międzynarodowego systemu monetarnego. Główne kraje uprzemysłowione miały zaakceptować dewaluację dolara, płynne kursy walut i redukcję barier handlowych. Rząd amerykański doszedł bowiem do wniosku, że wprowadzenie czynnika politycznego, jakim de facto było dzielenie kosztów obrony, było zbyt ryzykowne dla spoistości sojuszu ${ }^{16}$. Poza tym, bez współpracy z Europejczykami nie była możliwa zmiana systemu walutowego, nie mówiąc już o poważnych konsekwencjach politycznych w dobie détente. Jednak i ta koncepcja została odrzucona, gdyż większość krajów europejskich preferowało ustanowienie stałych kursów wymiany.

8 października 1971 r. Kissinger spotkał się z Dahrendorfem. Europejski polityk zaznaczał, że deficyt bilansu płatniczego w Stanach Zjednoczonych nie był spowodowany polityką europejską i problem ten nie mógł być rozwiązywany poprzez żądanie od EWG rekompensat. Zaakceptował konieczność ustalenia nowych kursów walutowych w stosunku do dolara, ale wskazywał, że będzie to miało negatywny wpływ na wewnątrzeuropejski handel i na konkurencyjność na rynkach krajów trzecich. Przewidywał, że spowoduje to problemy polityczne wewnątrz Wspólnot. Odmówił przyznania USA jednostronnych koncesji w wymianie handlowej.

Na spotkaniu Partii Konserwatywnej w październiku 1971 r. premier Edward Heath stwierdził, że Wspólnoty powinny jak najszybciej wypracować wspólną politykę zagraniczną, obronną i gospodarczą ${ }^{17}$. W tym czasie Wielka Brytania prowadziła negocjacje o przystąpieniu do EWG. Zdecydowane opowiedzenie się Londynu po stronie interesów europejskich budziło zaniepokojenie w Waszyngtonie, dotyczące perspektyw utrzymania z Londynem „specjalnych stosunków” i możliwości ich rozszerzenia na „specjalne stosunki” z całą EWG. W Waszyngtonie liczono, że Wielka

${ }^{14}$ R. K l e i m a n, Reaction Abroad: He Wants “An Awful Lot for Very Little”, „New York Times”, 12 września 1971.

${ }^{15}$ Był to niewątpliwy sukces EWG, tym bardziej, że w październiku $1971 \mathrm{r}$. Stanom Zjednoczonym udało się skłonić Japonię do ograniczenia eksportu tkanin syntetycznych do USA (A. S h o n fi eld, International Economic Relations. The Western System in the 1960s and 1970s, Beveryhills-London 1976, s. 36-38).

${ }^{16}$ International Economic Relations of the Western World..., s. 89.

${ }^{17}$ A. Lewiss, Heath Sees Signs of Trade War, „New York Times”, 17 października 1971. 0 poziomie wzburzenia świadczy drastyczna wypowiedź brytyjskiego premiera o Connallym, który został ranny podczas zamachu na Kennedy’ego: „wtedy zamordowano niewłaściwego człowieka” (J. C a m p b e l l, Edward Heath. A Biography, London 1993, s. 343). 
Brytania będzie działać tonująco podczas negocjacji handlowych i prób stworzenia nowych zasad światowego systemu monetarnego ${ }^{18}$.

Ambasador amerykański w Paryżu, Arthur K. Watson, w liście do Departamentu Stanu niepokoił się opóźniającym się rozwiązaniem kryzysu monetarnego. Przewidywał, że mogło to mieć negatywny wpływ na interesy amerykańskie w Europie, a szczególnie we Francji. Relacjonował, że od „szoku Nixona” francuski rząd zachowywał się dość powściągliwie, jednak zmiana zaszła na początku listopada. Wysocy urzędnicy zaczęli ostrzegać Amerykanów, że jeśli szybko nie określą warunków porozumienia, opinia publiczna zwróci się przeciwko nim, co będzie miało nieodwracalny wpływ na amerykańskie interesy polityczne i gospodarcze w tym kraju. Watson zauważył coraz ostrzejszą krytykę polityki monetarnej Stanów Zjednoczonych we francuskiej prasie. Niepokoił się, że Francuzi rozważali podjęcie środków wymierzonych w amerykańskie korporacje. Byli przekonani, że Amerykanie celowo blokowali rozwiązanie kryzysu do momentu wyborów w USA.

Także przedstawiciele ambasady brytyjskiej twierdzili, że jeśli następne spotkanie ministrów G10 będzie bezproduktywne, ich rząd straci nadzieję na porozumienie na tym forum i będzie szukał innych alternatyw. Watson obawiał się również możliwości wprowadzenia przez EWG subsydiów eksportowych i bardziej restrykcyjnej polityki wobec importu z USA. Wyraził opinię, że kolejne spotkania pogłębiają rozbieżności, a im dłużej trwają negocjacje, tym bardziej było prawdopodobne, że Europejczycy podejmą środki przeciwko amerykańskim interesom na Starym Kontynencie ${ }^{19}$.

Tymczasem Kissinger, bez wiedzy Departamentu Stanu, planował spotkania bilateralne Nixona z przywódcami Francji, Wielkiej Brytanii i RFN. Z prezydentem Georgesem Pompidou miał się spotkać 13 i 14 grudnia na Azorach, z Heathem na Bermudach 20 i 21 grudnia, a z Brandtem w Key Biscayne 28 i 29 grudnia $^{20}$. Taki układ był z pewnością korzystny dla dyplomacji amerykańskiej - łatwiej było przekonać pojedynczych przywódców, obiecując koncesje bądź grożąc konsekwencjami.

17 listopada 1971 r. Francja i RFN osiągnęły nieformalne porozumienie w kwestii stanowiska w negocjacjach z Amerykanami. Rozbieżności między Paryżem a Bonn narastały od momentu, gdy w maju 1971 r. RFN zdecydowała jednostronnie o rewaluacji DM. Poza tym Francja opowiadała się za ustaleniem sztywnych kursów walut we Wspólnocie, podczas gdy strona niemiecka postulowała ich upłynnienie. Ostatecznie zgodzono się, że należy postulować dewaluację USD, dokonać rewaluacji DM, natomiast parytet franka wobec złota miał pozostać niezmienny.

\footnotetext{
${ }^{18}$ The British Connection, „New York Times”, 24 grudnia 1971.

${ }^{19}$ NARA, Nixon Presidential Materials Project (NPMP), NSC Files, HAK Office Files, Country Files - Europe, Watson do Departamentu Stanu, 15 listopada 1971, box 56.

${ }^{20}$ Ibidem, Kissinger do Watsona, 18 listopada 1971.
} 
Kolejne spotkanie G10 miało miejsce w grudniu 1971 r. w Rzymie. Tym razem Europejczycy domagali się jak najszybszej dewaluacji dolara, a Connally postulował ustalenie realnych kursów wymiany walut. Sprzeciwili się temu Francuzi, którzy pragnęli utrzymać parytet złota dla franka na poziomie z 1969 r. Europejczycy wciąż oskarżali Stany Zjednoczone o szkodzenie ich gospodarkom. Domagali się zwołania spotkania na szczycie. Jednak pozycja negocjacyjna Europy Zachodniej stopniowo słabła, gdyż jej liderzy nie zdołali wypracować wspólnego stanowiska. Przedstawiciele każdego państwa próbowali bronić własnych interesów. Pompidou obawiał się, że Brandt z powodów politycznych będzie bardziej skłonny do kompromisu z Amerykanami. Poza tym dyplomaci amerykańscy dążyli do zachwiania jednomyślnością EWG, próbując prowadzić dwustronne rozmowy z przedstawicielami RFN. Państwo niemieckie było bardziej zależne od USA niż Francja: zależało mu na wsparciu Stanów Zjednoczonych dla polityki wschodniej i na utrzymaniu niezmiennej obecności wojsk amerykańskich na swoim terytorium ${ }^{21}$. Brandt wzywał inne kraje europejskie, by nie wycofywały się z powodu kryzysu monetarnego z zaangażowania w negocjacje handlowe z USA. „Szok Nixona” spowodował, że Stany Zjednoczone, broniąc własnych interesów, demontowały europejską współpracę. Rozbieżności w kwestiach monetarnych poszczególnych krajów EWG osłabiły wspólne stanowisko wobec USA 22 .

Francuzi okazali się najbardziej zdecydowanymi oponentami utworzenia nowego systemu monetarnego na amerykańskich warunkach. Z tego powodu spotkanie Nixona z Pompidou na Azorach 13-14 grudnia było kluczowe dla osiągnięcia ewentualnego porozumienia. Prezydenta w tych rozmowach wspierał Kissinger, ze względu na widoczny wpływ sporu gospodarczego na relacje polityczne. W grudniu to on tymczasowo przejął mandat negocjacyjny od Connally'ego. Kissinger zdecydował o wysunięciu argumentów politycznych. Chciał uwypuklić taki właśnie wymiar porozumienia transatlantyckiego w kwestiach gospodarczych. Zadeklarował, że Amerykanie byli gotowi do natychmiastowego zniesienia dziesięcioprocentowego podatku importowego; w tym kontekście dyskutowano kwestię dostosowania kursu dolara do franka. Kissinger stwierdził, że z politycznego punktu widzenia oba kraje powinny osiągnąć także porozumienie w sprawach handlu, szczególnie dotyczącego produktów rolniczych. Nixon dodał, że jeśli problem monetarny zostanie rozwiązany, nastąpi również poprawa na innych polach ${ }^{23}$. Doradca prezydenta podkreślił szczególną rolę Francji w Europie i zapewnił, że widzi w niej lidera przyszłego kompromisu, gdyż porozumienie transatlantyckie zależało w dużej mierze od stosunków amerykańsko-francuskich ${ }^{24}$. Widoczny jest tu nie tylko ton pochlebczy

\footnotetext{
${ }^{21}$ A. Sh on fi el d, op. cit., s. 42.

${ }^{22}$ M. F r a n k e l, US and Common Market, „New York Times”, 18 grudnia 1971.

${ }^{23}$ NARA, NPMP, NSC Files, HAK Office Files, Country Files - Europe, memorandum z rozmowy Nixona z Pompidou na Azorach, 13 grudnia 1971, box 56.

${ }^{24}$ S. B e r s t e i n, J.-P. R i o u x, The Pompidou Years 1969-1974, Cambridge 2000, s. 26.
} 
i zaspokajanie francuskich ambicji przywództwa w Europie, lecz także sugestia zagrożenia przyjaznych relacji transatlantyckich. Wprawdzie Kissinger nie wspomniał o możliwości wycofania sił amerykańskich z Europy, ale była to kwestia żywo dyskutowana w tym czasie w Kongresie.

Pompidou zaakcentował jedność Europy podkreślając, że państwa EWG chciały bronić wspólnie parytetów walutowych i nie zgodzą się na ich ustalenie na podstawie bilateralnych umów z USA ${ }^{25}$. Jego stanowisko było zdecydowane: jeśli porozumienie nie zostanie osiągnięte, nastąpi rywalizacja między USA a EWG na polu monetarnym. Nixon podczas rozmów winił Connally'ego za zbyt wygórowane żądania amerykańskie podczas negocjacji z Europejczykami. Stwierdził, że sekretarz skarbu stawiał nierealne warunki, które zostaną zmienione, gdyż Francja i Stany Zjednoczone miały wspólny cel: efektywną reformę systemu monetarnego. Pompidou odparł, że był to problem bardziej polityczny i zadeklarował gotowość do konstruktywnych rozmów ${ }^{26}$. Ostatecznie zgodził się na tymczasową płynność dolara pod warunkiem, że w bliskiej perspektywie zostaną ustalone nowe, sztywne kursy wymiany. Przystał również na rewaluację franka, jeśli RFN zrobi to samo z marką. Przyjął też nowe kursy wymiany, zaproponowane przez Connally'ego. W zamian Nixon zgodził się na dewaluację dolara i zniesienie podatku importowego. Osiągnięty na Azorach kompromis otworzył drogę do tzw. porozumienia smithsoniańskiego (Smithsonian Agreement ${ }^{27}$.

Ministrowie finansów i dyrektorzy banków centralnych państw G10 spotkali się w Instytucie Smithsoniańskim (Smithsonian Institution) w Waszyngtonie 17 i 18 grudnia $1971 \mathrm{r}^{28}$ Zgodzili się na podjęcie środków w celu zrównoważenia międzynarodowego systemu monetarnego. Zaakceptowali schemat kursów wymiany, co pociągało za sobą rewaluację bądź dewaluację poszczególnych walut. Nowy parytet dolara ustalono na 38,8 USD za uncję złota. Frank francuski i funt szterling utrzymały parytet względem złota, frank belgijski i gulden holenderski zostały zrewaluowane o 2,8\%, marka niemiecka i frank szwajcarski o 4,6\%, a jen o 7,7\%. W relacji do dolara główne waluty zostały zrewaloryzowane: frank francuski o 8,5\%, marka o 13,58\% ${ }^{29}$. Przedstawiciele państw G10 zgodzili się ponadto, że odstępstwa od nowych kursów były dopuszczalne w granicach 2,25\% powyżej i poniżej ustalonych pułapów. Zaapelowali do innych krajów o dostosowanie polityki monetarnej

\footnotetext{
${ }^{25}$ NARA, NPMP, NSC Files, HAK Office Files, Country Files - Europe, memorandum z rozmowy Kissingera z Pompidou na Azorach, 13 grudnia 1971, box 56.

${ }^{26}$ Ibidem, memorandum z rozmowy Nixona, Kissingera Pompidou na Azorach, 15 grudnia 1971.

${ }^{27}$ G. F. Tre ve r t o n, Making the Alliance Work. The United States and Western Europe, Ithaca 1985, s. 147.

${ }^{28}$ Na spotkaniu byli także obecni: przedstawiciel Szwajcarskiego Banku Narodowego Edwin Stopper, sekretarz generalny OECD Emille van Lennep, główny menadżer Banku Rozrachunków Międzynarodowych René Larre i wiceprezydent Komisji EWG Raymond Barre.
}

${ }^{29}$ A. Gr o s s e r, op. cit., s. 331. 
do powyższych zasad ${ }^{30}$. Delegaci Stanów Zjednoczonych obiecali natychmiastowe zniesienie podatku importowego ${ }^{31}$.

Po zawarciu porozumienia, Nixon rozmawiał z przywódcami Wielkiej Brytanii i RFN. Spotkanie z Heathem na Bermudach 20 grudnia uznano za symboliczny koniec „specjalnych stosunków” amerykańsko-brytyjskich. Wprawdzie podatek importowy miał zostać zniesiony, ale brytyjski premier zdawał sobie sprawę, że dewaluacja dolara będzie miała negatywne konsekwencje dla gospodarki brytyjskiej w kolejnych latach ${ }^{32}$. Wyróżnienie Francji przez Nixona - negocjacje z Pompidou przed zawarciem porozumienia smithsoniańskiego - było symptomem zmian w amerykańskiej strategii wobec Europy Zachodniej.

Przed spotkaniem z Brandtem Amerykanie brali pod uwagę jego konstruktywną postawę $w$ kwestiach monetarnych. Jednocześnie pamiętano, że sprzeciwiał się rozmowom z USA na temat redukcji cen zboża przez EWG. Kissinger radził Nixonowi, by przekazał Brandtowi, że warunkiem przyjęcia przez Kongres dewaluacji dolara będą krótkoterminowe koncesje handlowe ze strony EWG ${ }^{33}$. Brandt bardzo się niepokoił brakiem mechanizmu do rozwiązywania problemów handlowych między USA a krajami EWG ${ }^{34}$. Jednak w Key Biscayne nie rozmawiano prawie wcale o drażliwych problemach gospodarczych - wiodącym tematem była wizyta Nixona w Moskwie planowana na maj 1972 r. Nixon skupił się na zapewnianiu Brandta, że nie zostaną tam podjęte decyzje zagrażające bezpieczeństwu RFN ${ }^{35}$.

Brytyjski politolog Thomas Geiger był przekonany, że ubocznym skutkiem „Szoku Nixona” był silny impuls do formowania się bloków handlowych, które w przyszłości mogły zahamować liberalizację światowego handlu. Mogło to wywołać zaostrzenie konkurencji, gdyż EWG była zdolna odpowiedzieć środkami dyskryminującymi amerykański eksport. 0 ile zniesienie wymienialności dolara na złoto można było uzasadnić, o tyle podatek importowy i DISC były odbierane przez państwa europejskie i Japonię jako kroki nieuzasadnione, za to poważnie szkodzące ich interesom gospodarczym. Dodatkowym zadrażnieniem stosunków były warunki zniesienia tych restrykcji postawione przez Connally'ego. W Europie uważano je za próbę przerzucenia na nią kosztów reformy światowego systemu monetarnego,

30 The Public Papers of the Presidents of the United States: Richard Nixon (PPP), vol. 4: 1972, Washington D.C. 1974, trzeci roczny raport dla Kongresu na temat polityki zagranicznej USA, 9 lutego 1972, dok.56, dostępne także przez: http://www.nixonfoundation.org.

${ }^{31}$ December Smithsonian Agreement of the Group of Ten. Document A: Press Communiqué of Ministerial Meeting, 18 grudnia 1971, dostępny przez: http://www.gold.org/value/reserve_asset/ history/monetary_history/vol3/1971dec.html.

32 J. C a m p b e ll, op. cit., s. 343.

${ }^{33}$ NARA, NPMS, NSC Files, VIP Visits, memorandum NSC na temat przyszłego spotkania z Brandtem, 23 grudnia 1971, box 916.

${ }^{34}$ NARA, NPMS, NSC Files, Country Files - Europe (Germany), ustalenia przed spotkaniem Nixona z Brandtem, 21 grudnia 1971, box 684.

${ }^{35}$ NARA, NPMS, NSC Files, VIP Visits, box 916. 
co miało bardzo negatywny skutek dla relacji transatlantyckich. Stany Zjednoczone podjęły decyzję unilateralnie, użyły też instrumentów gospodarczych, by zmusić inne państwa do dostosowania się do ich postulatów. Także przywołanie argumentu o konieczności bardziej sprawiedliwego dzielenia kosztów obrony było niefortunne i mogło być postrzegane jako szantaż polityczny. Geiger wysunął tezę, że przez te działania rząd USA osłabił organizacje, które powstały z inicjatywy amerykańskiej - GATT i MFW ${ }^{36}$.

Niektórzy analitycy twierdzili, że Stany Zjednoczone nie mogły narzucić warunków przedstawionych przez Connally'ego z powodów politycznych, gdyż nie chciano doprowadzić do konfliktu z sojusznikami ${ }^{37}$. Niewątpliwie ten czynnik był istotny, lecz w korespondencji ambasadorów krajów europejskich z decydentami w Waszyngtonie dominują obawy o pogorszenie się stosunków gospodarczych. Poza tym Europejczycy zdołali wprowadzić do porozumienia smithsoniańskiego korzystne dla siebie zapisy, opierając się presji o charakterze politycznym.

\subsection{Problemy monetarne i plany ustalenia nowych zasad handlu światowego}

Po porozumieniu z grudnia w $1971 \mathrm{r}$. Stany Zjednoczone zrezygnowały z uprzywilejowanej pozycji dolara. Chociaż został on oficjalnie zdewaluowany, Amerykanie nie ograniczyli jego odpływu na inwestycje do innych krajów lub na wydatki związane z utrzymaniem sił militarnych za granicą. Wciąż zagraniczne banki centralne trzymały swe rezerwy w dolarach. USA skorzystały na dewaluacji w tym sensie, że poprawiły swoje szanse eksportowe. Nie przyniosło to znacznego zmniejszenia deficytu bilansu płatniczego, a dolar pozostał główną walutą światowego systemu walutowego ${ }^{38}$.

W 1972 r. nastąpiły ponownie masowe przepływy pieniężne i znów wystąpiła presja na ustalone parytety walutowe. W lutym 1972 r. Departament Skarbu

${ }^{36}$ T. G e i g e r, Toward a World of Trade Blocks, [w:] U.S. Foreign Economic Policy for the 1970s: A New Approach to New Realities. A Policy Report by An National Planning Association Advisory Committee, Washington 1971, s. 71. Teza Geigera o nieuchronności tworzenia się bloków regionalnych potwierdzają tendencje w gospodarce światowej. Oprócz umacniania się integracji europejskiej, już w latach 60. XX w. obserwujemy powstawanie organizacji integracyjnych w Ameryce Łacińskiej i Azji. Ich najprężniejszy rozwój przypada na lata 90. XX w. Również Stany Zjednoczone zdecydowały się na zainicjowanie regionalnych układów o wolnym handlu, których uwieńczeniem było powstanie w 1994 r. Północnoamerykańskiej Strefy Wolnego Handlu (North American Free Trade Agreement NAFTA), łączącej Stany Zjednoczone, Kanadę i Meksyk.

${ }^{37}$ A. W. D e P o r t e, Europe Between the Superpowers. The Enduring Ballance, New Haven 1979, s. 206.

${ }^{38}$ D. P. C a 11 e o, American Foreign Policy and American European Studies: An Imperil Bias?, [w:] The United States and Western Europe..., s. 66. 
przedstawił propozycję modyfikacji kursu USD. Podkreślono, że w porozumieniu smithsoniańskim nie tylko zmieniono kursy walut, lecz także stwierdzono, że powinno jak najszybciej dojść do negocjacji między Komisją Europejską, Japonią, Kanadą i USA na tematy monetarne.

Natomiast Francuzi niepokoili się, że znaczny spadek wartości dolara nastąpił krótko po porozumieniu smithsoniańskim, obawiali się w związku z tym stałej presji na USD. Uważali, że niskie stopy procentowe obowiązujące w USA sprawią, że dolary będą znów na masową skalę lokowane za granicą. Zmuszało to kraje europejskie do zakupu amerykańskiej waluty, by utrzymać jej wartość w granicach ustalonych w grudniu 1971 r. Francja obawiała się, że promowanie niskich stóp procentowych było celowym działaniem Connally'ego. Wobec tego w Paryżu rozważano dewaluację franka, co mogło zniszczyć porozumienie monetarne. W tym samym czasie w Kongresie pojawiły się postulaty, by jednocześnie dokonać kolejnego obniżenia kursu USD. Jednak zdawano sobie sprawę, że ignorowanie porozumienia smithsoniańskiego storpeduje współpracę skierowaną na tworzenie nowego systemu monetarnego ${ }^{39}$. Członek NSC, Robert Hormats, w liście do Kissingera zwrócił uwagę na polityczny aspekt tego zjawiska. Uważał, że poprawa stosunków amerykańsko-francuskich, która nastąpiła po spotkaniu Nixona z Pompidou na Azorach, mogła zostać zaprzepaszczona. Wzywał do przestrzegania porozumienia smithsoniańskiego ${ }^{40}$.

Obawy francuskie zostały wyartykułowane w liście Pompidou do Nixona z 4 lutego 1972 r. Francuski prezydent stwierdził, że po upływie zaledwie sześciu tygodni od spotkania na Azorach, Stany Zjednoczone odchodziły od warunków porozumienia. Zarzucił im utrzymywanie dużego deficytu budżetowego i niskich stóp procentowych, co nie dawało szans na podtrzymanie uzgodnionej wartości dolara. Nic nie zostało też zrobione w celu kontroli przepływu kapitału ${ }^{41}$. Także rządy innych krajów europejskich były zaniepokojone tym stanem rzeczy. Choć powszechnie widziano potrzebę zdania się na siły rynkowe, ze względu na nieprzewidywalną politykę monetarną USA, rządy wciąż kształtowały kurs walut ${ }^{42}$.

W raporcie dla Kongresu dotyczącym polityki zagranicznej w 1971 r., ogłoszonym 9 lutego 1972 r., Nixon zwrócił uwagę na niebezpieczeństwo podziału świata na wzajemnie dyskryminujące się bloki handlowe, co oprócz oczywistych problemów dla gospodarki światowej przyniosłoby niewyobrażalne napięcia polityczne. Nixon stwierdził, że dzięki jego śmiałej decyzji została zachowana jedność atlantycka, gdyż

${ }^{39}$ Congressional Record. Proceeding and Debates of the Second Session of the $92^{\text {nd }}$ Congress, vol. 118, part 6, posiedzenie Senatu z 2 marca 1972, dostępne przez: http://www.archive.org/stream/ congressionalrec118eunit\#-page/n169/mode/1up.

${ }^{40}$ NARA, NPMS, NSC Files, Country Files - Europe (France), Hormats do Kissingera, 24 stycznia 1972, box 678 .

${ }^{41}$ NARA, NPMS, NSC Files, Presidental Correspondence 1969-1974, Pompidou do Nixona, 4 lutego 1972, box 752 .

${ }^{42}$ N. Th y g e s e n, Flexible Exchange Rates and the Monetary Policies, [w:] Europe, America and the World Economy, ed. L. Tsoukalis, New York 1986, s. 175. 
wzajemne oskarżenia o złą politykę gospodarczą prowadziły do poważnych napięć. Był przekonany, że mogłoby to znacznie osłabić sojusz atlantycki, co byłoby niepożądane w dobie zbliżających się negocjacji USA-ZSRR. Oczywiście „szok Nixona” wprowadził niemały zamęt, dlatego retoryka ta wydaje się przewrotna.

Prezydent zauważył, że decyzja z 15 sierpnia przyczyniła się do uniknięcia kryzysu monetarnego, była ponadto korzystna dla amerykańskiego bilansu handlowego. Dewaluacja dolara poprawiła możliwości eksportowe, co dawało nadzieję na owocne negocjacje handlowe, przewidziane na lata 1972-1973. Jednak Nixon przyznał, że warunki wymiany pozostawiają jeszcze wiele do życzenia - rząd USA musiał się liczyć z naciskami grup biznesmenów produkujących na eksport i niesłabnącymi tendencjami protekcjonistycznymi w Kongresie. Prezydent, podobnie jak rok wcześniej, zadeklarował dążenie do równoważenia interesów wewnętrznych i zewnętrznych. Zapowiedział też, że jak najszybciej podda pod głosowanie Kongresowi dewaluację dolara wobec złota oraz usunięcia podatku importowego ${ }^{43}$.

Warto zauważyć, że raport był przedstawiany w lutym 1972 r., a zobowiązania do dwóch ostatnich kwestii zostały podjęte już w grudniu 1971 r. Nixon wyraźnie zwlekał z przedłożeniem ich pod obrady Kongresowi, mając nadzieję na uzyskanie od partnerów ustępstw handlowych. Pokazuje to, jak głębokie było przekonanie, że kraje zachodnioeuropejskie prędzej czy później ugną się pod amerykańską presją, nie mając pewności, jakie dalsze kroki podejmą Stany Zjednoczone. Powodowało to kryzys zaufania we wzajemnych relacjach.

Mimo że w grudniu 1971 r. zobowiązano się do współpracy w przygotowywaniu reformy monetarnej, najbardziej uprzemysłowione państwa świata nie podejmowały konkretnych działań w tym kierunku jeszcze przez cały rok. Od 1972 r. w ramach MFW działał Komitet Rady Gubernatorów do spraw reformy tej instytucji (Committee of the IMF Board of Governors on IMF Reform and Related Issues), zwany Komitetem Dwudziestu. Składał się on z przedstawicieli G10 i dziesięciu reprezentantów krajów rozwijających się, lecz jego prace nie przynosiły wymiernych rezultatów ${ }^{44}$.

W tym czasie w EWG planowano pogłębienie integracji. Po spotkaniu BrandtPompidou na początku 1972 r., 21 marca 1972 r., przedstawiono plan unii ekonomicznej i monetarnej. Zmniejszono w nim margines fluktuacji między walutami Wspólnego Rynku do 2,25\% ${ }^{45}$. Europejczycy ponaglali również Amerykanów do działań w celu uzgodnienia nowego światowego porządku monetarnego. Egon Bahr, minister spraw zagranicznych RFN, pisał do Kissingera 28 marca 1972 r., że

${ }^{43}$ PPP, Richard Nixon, vol. 4, trzeci roczny raport dla Kongresu na temat polityki zagranicznej USA, 9 lutego, 1972, dok. 56.

${ }^{44}$ Na temat szczegółów prac Komitetu Dwudziestu zob. J. W il l 1 i a m s o n, The Failure of World Monetary Reform 1971-1974, New York 1977.

${ }^{45}$ E. L. M or s e, European Monetary Union and American Foreign Economic Policy, [w:] The United States and Western Europe..., s. 195. 
jeśli dolar zostanie po raz kolejny zdewaluowany, Europejczycy zrezygnują z niego jako waluty rezerwowej ${ }^{46}$. Już w czerwcu 1972 r. znów miały miejsce spekulacje na rynku walut. Kraje EWG stosowały mechanizm zwany „wąż w tunelu” (snake in the tunnel), polegający na utrzymywaniu małego marginesu fluktuacji między walutami i szerszego w stosunku do walut krajów trzecich. Wtedy Wielka Brytania, Dania, a wkrótce także Włochy wycofały się ze wspólnej operacji i ustaliły odrębne płynne kursy walutowe.

W raporcie CIA oceniono, że dostosowanie kursów walut uzgodnionych na podstawie umowy smithsoniańskiej nie przyniosło jeszcze oczekiwanego wpływu na bilanse płatnicze krajów zachodnich. Stany Zjednoczone nie mogły się pozbyć deficytu handlowego, a RFN i Japonia miały nadwyżki. Obserwowano wprawdzie duży napływ funduszy do USA po grudniu 1971 r., ale atak na dolara, który miał miejsce po kryzysie funta szterlinga w czerwcu 1972 r., zniweczył wcześniejszą poprawę. Wciąż pojawiały się tendencje spekulacyjne, które były częściowo hamowane za sprawą masowego wykupywania przez banki centralne dolarów i funtów. Wprowadzono także kontrolę i ograniczenia w krajach, do których napływało zbyt dużo kapitałư ${ }^{47}$.

Podczas spotkania z Kissingerem 22 lipca 1972 r. minister gospodarki RFN, Helmut Schmidt, chciał przyspieszyć rozpoczęcie dyskusji o problemach monetarnych, argumentując to trudną sytuacją ekonomiczną w jego kraju. Kissinger stwierdził wprawdzie, że nie jest ekspertem w tej kwestii, lecz wyraził zrozumienie jej wpływu na atmosferę polityczną w RFN. Schmidt przypomniał o negatywnych skutkach politycznych „szoku Nixona” w Europie. Zwrócił uwagę, że niemiecki bank centralny musiał skupować dolary, których kurs był płynny, by ich wartość nie spadła poniżej 3,15 w stosunku do DM. Powodowało to inflację, która wzrosła do 5,4\%. Schmidt wykluczył możliwość kolejnej rewaluacji DM w 1972 r. Ostrzegł, że wobec zbliżających się wyborów rząd RFN mógł się zdecydować na zaprzestanie skupowania USD i regulację handlu i napływu kapitału. Potwierdził, że te środki zostaną podjęte, jeśli Stany Zjednoczone nie będą dążyć do umocnienia wartości USD. Kissinger ostrzegł, że unilateralna akcja Europy spowoduje oburzenie w USA, gdyż coraz częściej do głosu dochodzili izolacjoniści. Schmidt zapewnił, że RFN dążyła, aby EWG była jak najbardziej otwarta na dobre relacje gospodarcze z USA ${ }^{48}$.

Na spotkaniu Komitetu Dwudziestu MFW duże poruszenie wywołało wystąpienie Nixona i sekretarza skarbu George’a Shultza we wrześniu 1972 r. Skrytykowano propozycję międzynarodowych sankcji gospodarczych nakładanych na kraje, które

${ }^{46}$ NARA, NPMS, NSC Files, Country Files - Europe (Germany), Bahr do Kissingera, 28 marca 1972, box 684 .

${ }^{47}$ NARA, NPMS, NSC Institutional "H” Files, Study Memorandums (1969-1974), CIA - przegląd najważniejszych wydarzeń międzynarodowych w 1972, box H-164.

${ }^{48}$ Poprzednik Schmidta, Karl Schiller, zrezygnował 7 lipca 1972 r. ze stanowiska z powodu problemów wewnętrznych, spowodowanych kryzysem walutowym (NARA, NPMS, NSC Files, Country Files - Europe (Germany), memorandum z rozmowy Kissingera i Schmidta, 22 lipca 1972, box 684). 
odmówią podjęcia akcji przeciw utrzymywaniu się w nich deficytu lub nadwyżki bilansu płatniczego. Nie przyjęto też propozycji ustalenia obiektywnych kryteriów, w jakich przypadkach należało je wprowadzićn ${ }^{49}$. Amerykanie postulowali, by wszyscy członkowie MFW automatycznie dewaluowali lub rewaluowali swe waluty w celu utrzymaniu stabilnych bilansów płatniczych, a złoto jako podstawa rezerw było stopniowo zastępowane SDR-ami. Większość państw europejskich sprzeciwiało się takiemu rozwiązaniu ${ }^{50}$.

W dniach 19-21 października 1972 r. odbył się w Paryżu szczyt EWG, na którym padła propozycja zawiązania unii ekonomicznej i monetarnej. Pompidou podkreślił, że nie byłby to przejaw integrowania się Europy w opozycji do USA. Taką interpretację nazwał absurdalną. Jednak uważał, że Europa w dyskusji nad reformą systemu monetarnego powinna wypracować „własne, odrębne stanowisko”, uwzględniając nie interesy amerykańskie, ale realia gospodarki światowe ${ }^{51}$. Pompidou sugerował tym samym, że Europa mogłaby wywierać presję na Stany Zjednoczone, gdyż jej siła gospodarcza uprawniała do forsowania własnych rozwiązań. Po zakończeniu szczytu ogłoszono rozpoczęcie prac nad koordynacją kursów wymiany i wsparcia walutowego ${ }^{52}$. W raporcie CIA oceniono, że choć perspektywa realizacji tych założeń była daleka, lecz EWG podejmowała kroki w tym kierunku, np. członkowie zmniejszyli maksymalne różnice między kursami swoich walut ${ }^{53}$.

Coraz bardziej palącym problemem stawały się spory handlowe. Istniały one również w latach 50. i 60., ale Stany Zjednoczone nigdy nie pozwalały, by wpływały one destrukcyjnie na integrację europejską, tworzenie spójnego sojuszu atlantyckiego czy podtrzymywanie liberalnego systemu handlowego. W $1971 \mathrm{r}$. ta ostatnia kwestia została postawiona pod znakiem zapytania, gdyż obie strony przejawiały tendencje protekcjonistyczne. W Europie obawiano się, by stosunki gospodarcze z EWG nie stały się tematem przewodnim nadchodzącej prezydenckiej kampanii wyborczej w 1972 r., w której Nixon starał się o reelekcję. Dezaprobata w Stanach Zjednoczonych była tym bardziej widoczna, im gorsza była sytuacja ekonomiczna w kraju. Wzmagały się naciski na „dobrowolne” ograniczenia eksportu i wprowadzanie kontyngentów na poszczególne towary. W 1962 r. było ich tylko 7, na początku 1970 r. już 67. W 1969 r. restrykcje importowe dotyczyły towarów wartości 6,5 mld USD, co stanowiło 18\% całego importu Stanów Zjednoczonych. W Kongresie dominowały nastroje protekcjonistyczne. Były one spowodowane naciskami biznesmenów i farmerów, którzy oskarżali rząd o tolerowanie dyskryminacji amerykańskiego

\footnotetext{
${ }^{49}$ NARA, NPMS, NSC Institutional “H” Files, Study Memorandums (1969-1974), CIA - przegląd najważniejszych wydarzeń międzynarodowych w 1972, box H-164.

${ }^{50}$ The New Europe and the United States. Partners or Rivals, ed. G. Mally, Lexington 1974, s. XX.

${ }^{51}$ G. Po m pid o u, France, Europe, and America. Opening Address to the European Summit Conference, 19 października 1972 r., [w:] The New Europe and the United States..., s. 11-12.

${ }^{52}$ E. L. M o r s e, op. cit., s. 195.

${ }^{53}$ NARA, NPMS, NSC Institutional "H" Files, Study Memorandums (1969-1974), CIA - przegląd najważniejszych wydarzeń międzynarodowych w 1972, box H-164
} 
eksportu. Z drugiej strony uzyskanie przez prezydenta specjalnych uprawnień w negocjacjach handlowych interesowało biznesmenów po obu stronach Atlantyku. Naciskano, by rozmowy rozpoczęły się w $1973 \mathrm{r}^{54}$

Wymiana transatlantycka była bardzo ważna dla USA. Miały one dodatni bilans handlowy z EWG w latach 1958-1971. Średniorocznie wynosił on 1 mld USD. Od powstania EWG eksport USA do EWG wzrósł o 194\% (podczas, gdy z pozostałymi krajami o 126\%). W 1972 r. deficyt USA w handlu z Europą wyniósł 165 mln USD. Eksport Stanów Zjednoczonych do EWG stanowił 25\% całości wywozu, a import 23\%. Wartość handlu wzrosła pięciokrotnie w latach 1958-1972 - z 5 mld USD do 25 mld $^{55}$. Średnia wspólnotowa taryfa celna EWG na towary przemysłowe od początku 1972 r. wynosiła 7,6\% i była niższa niż narzucana przez USA ${ }^{56}$.

Od „szoku Nixona”, mimo retorycznych prób łagodzenia konfliktu transatlantyckiego, także administracja amerykańska była bardziej zdeterminowana do obrony narodowych interesów gospodarczych, poświęcając dobre stosunki polityczne. Przemawiając do władz MFW i Banku Światowego 25 września 1972 r., Nixon stwierdził: „jak każdy przywódca chcę widzieć zwiększanie się liczby miejsc pracy na całym świecie. Ale nie mogę zgodzić się na eksport miejsc pracy z USA, spowodowany niesprawiedliwością światowego systemu handlowego" ${ }^{\prime 57}$.

W latach 70. kraje europejskie chciały zwiększyć ekspansję na rynkach światowych. Dzięki CAP mogły zaproponować niższe ceny produktów rolnych - stały się ich eksporterem netto. Natomiast prosperowanie amerykańskiego rolnictwa w dużej mierze uzależnione było od eksportu. Amerykańscy farmerzy i biznesmeni mieli swoich rzeczników w Kongresie, którzy protestowali przeciw europejskim praktykom. Do Senatu docierało wiele listów od zaniepokojonych przedsiębiorców, że ograniczenia EWG w dostępie na rynek groziły przemysłowi cytrusowemu i tytoniowemu ${ }^{58}$. W archiwum w Waszyngtonie można odnaleźć przykłady takich interwencji. John Palmer, szef Tobacco Associates, wysłał raport do członka CIEP, Deana Hintona, o skutkach europejskiego ustawodawstwa dla eksportu amerykańskiego tytoniu. Hinton przyjął raport zapewniając, że dostarczy argumentów w negocjacjach z EWG ${ }^{59}$. Działania te były w wielu przypadkach skuteczne, np. EWG zgodziła się na zawieszenie części opłat celnych na eksportowane z USA świeże cytrusy ${ }^{60}$.

${ }^{54}$ NARA, NPMP, White House Central Files (dalej: WHCF), IT International Organization, Economic Community-Common Market (EEC) 1969-1970, Kendall (prezes Pepsico) do Flanigana, 8 marca 1972, box 2.

${ }^{55}$ The New Europe and the United States..., s. XVIII.

${ }^{56}$ NARA, NPMP, WHCF, IT International Organization, Economic Community-Common Market (EEC) 1969-1970, Hormats do Kissingera, 26 listopada 1971, box 2

${ }^{57}$ P. Y. H a m m o n d, op. cit., s. 226.

${ }^{58}$ NARA, NPMP, WHCF, IT International Organization, Economic Community-Common Market (EEC) 1969-1970, Sonnenfeldt do Kissingera, 9 lutego 1971, box 2.

\footnotetext{
${ }^{59}$ Ibidem, Palmer do Hintona, 6 sierpnia 1971.

${ }^{60}$ Ibidem, Peterson do Chilesa, 9 sierpnia 1971.
} 
Pod naciskiem Kongresu, specjalny przedstawiciel handlowy przy EWG 10 grudnia 1971 r. wypowiedział się na łamach „Washington Post”, że liberalizacja CAP w sposób korzystny dla amerykańskich eksporterów będzie jednym z warunków USA przy negocjacjach monetarnych. Trzeba podkreślić, że zgoda EWG na taką zmianę była mało prawdopodobna - sami przedstawiciele administracji amerykańskiej zdawali sobie sprawę, że CAP była jednym z głównych spoiw EWG ${ }^{61}$. Europejczycy twierdzili, że rezygnacja z tej polityki spowodowałoby rozpad Wspólnoty, a rolnicy europejscy „nie chcą być złożeni jako ofiara na ołtarzu dobrych stosunków z USA”62. Przewidywano jednak stopniowe zmiany w CAP. Spodziewano się, że w momencie przystąpienia do EWG Wielkiej Brytanii, będącej importerem żywności, nie będzie się ona godziła ponosić zbyt dużych kosztów związanych z CAP ${ }^{63}$.

11 lutego 1972 r. Stany Zjednoczone, EWG i Japonia wydały deklarację o rozpoczęciu negocjacji handlowych w 1973 r., dotyczących znoszenia barier celnych na produkty rolne i przemysłowe. EWG dążyła do ustalenia ogólnych zasad, jednak Stany Zjednoczone pragnęły negocjować warunki dla poszczególnych towarów ${ }^{64}$. Utworzono specjalny komitet, mający zająć się ustalaniem warunków negocjacji (Trade Negotiating Committe). Do rozmów zaproszono również kraje spoza GATT, także rozwijające $s i e ̨^{65}$. Wyodrębniono najważniejsze problemy w relacjach atlantyckich. Europejczycy sugerowali, że z negocjacjami handlowymi należało połączyć rozmowy o reformie międzynarodowego systemu walutowego. Argumentowano, że przy częstych zmianach kursów wymiany niemożliwe było przeprowadzenie sprawiedliwej redukcji ceł ${ }^{66}$, co było konieczne w momencie zmian kursów walut. Dlatego strony wykazywały wolę ustępstw. EWG zobowiązała się do redukcji $15 \%$ taryf zewnętrznych w ciągu kolejnych dwóch lat dla eksporterów, którzy nie korzystali z układów preferencyjnych. Zaakceptowano także podjęcie dyskusji na forum GATT w sprawie skutków rozszerzenia EWG dla krajów trzecich i ewentualnych rekompensat. Nie zgodzono się jednakże na żadną modyfikację CAP. Stany Zjednoczone obiecały podjąć starania w celu ograniczenia programu American Selling Price i zmodyfikować metody określania wysokości ceł ${ }^{67}$.

Ustępstwa obu stron były konieczne. Mimo że Stany Zjednoczone wysuwały wiele zastrzeżeń do polityki handlowej EWG, same wprowadzały od lat 60 .

${ }^{61}$ Ibidem, Hardin do Petersona, 3 września 1971.

${ }^{62}$ C. H. F a r n s w o r th, US and Europe Touchy on Trade Aims, „New York Times”, 31 grudnia 1971.

${ }^{63}$ Ibidem.

${ }^{64}$ Leading Issues in International Economic Policy, eds. C. F. Bergsten, W. G. Tyler, Lexington 1973, s. 131.

${ }^{65}$ S. D. C o h e n, The European Community and the General Agreement on Tariffs and Trade, Washington 1975, s. 11.

${ }^{66}$ Ibidem, s. 23.

${ }^{67}$ NARA, NPMS, NSC Files, Subject Files, propozycja zwiększenia wartości dolara przedstawiona przez Departament Skarbu, 25 lutego 1972, box 309. 
wiele środków protekcjonistycznych, takich jak restrykcje importowe, „dobrowolne" ograniczenia eksportu narzucane partnerom handlowym, kontyngenty itp. W Kongresie dyskutowano możliwość wprowadzania automatycznych ograniczeń dla sprowadzania produktów, które były konkurencyjne i zagrażały amerykańskiej produkcji. Takie rozwiązanie forsowały mniejsze przedsiębiorstwa, nieuzależnione od eksportu i nieinwestujące za granicą. Jednak sprzeciw większych i wielonarodowych spółek, obawiających się działań odwetowych, blokował tę inicjatywę ${ }^{68}$.

Stany Zjednoczone opowiadały się za utworzeniem w ramach OECD grupy roboczej, która zajmowałaby się jednocześnie problemami handlu i monetarnymi. Przeciwni takiemu rozwiązaniu byli Francuzi - uważali, że najpierw należało rozwiązać problemy monetarne, gdyż bez tego nie sposób było wypracować porozumienia ${ }^{69}$. Kolejne spotkania negocjacyjne $\mathrm{w}$ tej sprawie między przedstawicielami USA a EWG odbyły się 27 i 28 kwietnia 1972 r. w Brukseli. Podsekretarz stanu John Irwin relacjonował, że Europejczycy byli bardzo pewni siebie w związku z powiększeniem swojego potencjału po rozszerzeniu planowanym na styczeń $1973 \mathrm{r}$. Odniósł wrażenie, że nie zgodzą się na ustępstwa, jeśli Stany Zjednoczone nie wystąpią pierwsze z inicjatywą ${ }^{70}$.

W czerwcu 1972 r. w Paryżu gościł specjalny przedstawiciel handlowy Stanów Zjednoczonych, William Eberle, który spotkał się z reprezentantami rządu francuskiego odpowiedzialnymi za stosunki handlowe. Francuzi byli zaniepokojeni pogłoskami, że Stany Zjednoczone przed wyborami prezydenckimi nie podejmą żadnych działań w celu stabilizacji kursu USD, a ewentualne kroki zostaną podjęte tylko w zamian za jednostronne koncesje handlowe przyznane przez partnerów. Stwierdzili, że w takim przypadku perspektywy owocnych negocjacji nie rysowały się optymistycznie. Nixon nie uzyskał od Kongresu uprawnień do ustępstw w kwestiach handlowych, a Europejczycy nie poczynią ich jednostronnie. Jean René Bernard, doradca do spraw gospodarczych i finansowych prezydenta Pompidou, sformułował cztery zasady, których należało przestrzegać, by nie storpedować negocjacji handlowych w 1973 r.: 1) kwestie handlowe i monetarne powinny być dyskutowane osobno; 2) należało unikać podejścia sektorowego, tzn. zawierania porozumień w sprawie konkretnych produktów, np. w formie "dobrowolnych ograniczeń" importu tekstyliów; 3) nie podejmować tematu fundamentalnych zmian w CAP; 4) nie wymuszać na Europejczykach zobowiązania, że ostatecznym celem negocjacji handlowych były zerowe cła. Bernard przekonywał, że wspólna zewnętrzna taryfa celna EWG była konieczna dla trwałości Wspólnoty. Francuzi obawiali się, że Stany

\footnotetext{
${ }^{68}$ A. S h o n fi i l d, op. cit., s. 35.

${ }^{69}$ NARA, NPMS, NSC Files, Country Files - Europe (France), Irwin do Departamentu Stanu, 25 maja 1972, box 679.

${ }^{70}$ NARA, NPMS, NSC Files, Subject Files: Trade General, raport Irwina, 27-28 kwietnia 1972, box 402 .
} 
Zjednoczone dążyły do utworzenia transatlantyckiej strefy wolnego handlu, czemu byli zdecydowanie przeciwni ${ }^{71}$.

Amerykanie starali się doprowadzić do bilateralnych rozmów z poszczególnymi państwami europejskimi. Preferowali taką formę zamiast przekonywania przedstawicieli EWG, obawiając się dominującego głosu Francji, której stanowisko najbardziej różniło się od amerykańskiego. Lecz, jak donosił ambasador w Paryżu Watson, Pompidou rozumiał, że nie uda mu się przekonać wszystkich państw EWG do konfrontacyjnej polityki wobec USA i że w związku z tym Francja mogła być izolowana ${ }^{72}$. Jednak Francuzi podkreślali dominującą rolę Komisji Europejskiej, będącej stroną negocjacji. Uważali, że najlepszym forum do prowadzenia dyskusji był GATT.

Eberle poinformował o staraniach Nixona, by uzyskać szerokie uprawnienia w podejmowaniu decyzji podczas rozmów. Konieczna była nowa ustawa handlowa, umożliwiająca prezydentowi łagodzenie skutków protekcjonistycznych przepisów i obniżanie ceł. W tym kontekście czynnik polityczny - zharmonizowanie działań amerykańskich z polityką Nixona wobec Europy - miał odgrywać dużą rolę ${ }^{73}$. Eberle podkreślił, że Amerykanie najpierw musieli wiedzieć, jakie będą możliwe obszary negocjacyjne. Francuzi zauważyli, że w przypadku EWG sytuacja była jeszcze bardziej skomplikowana: Komisja musiała uzyskać mandat na reprezentowanie interesów dziesięciu krajów ${ }^{74}$. Jean Chapelle, odpowiedzialny za zagraniczne relacje gospodarcze w Ministerstwie Gospodarki i Finansów, zareagował negatywnie na propozycję, by ustalić szerokie porozumienie między USA a EWG przed formalnym rozpoczęciem rundy negocjacyjnej oraz uniknąć napięć politycznych w ich trakcie. Uznał, że różnice stanowisk były zbyt fundamentalne, żeby można je było zniwelować. Prawdziwym powodem niechęci Francuzów stała się jednak obawa przed presją, jaką Stany Zjednoczone mogły wywierać na przedstawicieli państw europejskich w celu rozbicia jednolitego stanowiska EWG. Zgadzali się jedynie na wcześniejsze sformułowanie swoistego zbioru zasad (code of good conduct) w handlu zbożem, który mógłby zawierać np. podział rynków zbytu, by zapobiec konfliktom na tym tle ${ }^{75}$. W liście do Kissingera Hormats zauważał, że nieufność Europy wobec

${ }^{71}$ NARA, NPMS, NSC Files, Country Files - Europe (France), Memorandum z rozmowy w ambasadzie amerykańskiej w Paryżu, 16 czerwca 1972, box 679.

${ }^{72}$ Ibidem, Watson do Departamentu Stanu, 20 września 1972.

${ }^{73}$ NARA, NPMS, NSC Files, Subject Files: Trade General, Hormats do Kissingera, 14 grudnia 1972, box 402.

${ }^{74}$ Norwegia ostatecznie nie przystąpiła do EWG. W referendum na ten temat, przeprowadzonym 26 września 1972, 53,3\% obywateli opowiedziało się przeciw integracji.

${ }^{75}$ Rywalizacja toczyła się o trzy główne rynki: Chiny, kraje basenu Morza Śródziemnego oraz ZSRR wraz z blokiem wschodnim. Zaproponowano, by Stany Zjednoczone eksportowały na rynek chiński, EWG - krajów Morza Śródziemnego, a wpływy w bloku wschodnim zostałyby podzielone (NARA, NPMS, NSC Files, Country Files - Europe (France), Memorandum z rozmowy w ambasadzie amerykańskiej w Paryżu, 16 czerwca 1972, box 679). 
USA była tak duża, że wchodziły w grę tylko negocjacje z EWG jako całością - bilateralne rozmowy były wykluczone ${ }^{76}$.

$\mathrm{W}$ przygotowanym na prośbę prezydenta raporcie o relacjach z Europą Departament Stanu dostrzegł, że presja wynikająca z sytuacji gospodarczej w USA wpływała negatywnie na wzajemne stosunki. Odnotowano, że także wiele krajów europejskich wciąż borykało się z dużą inflacją, niektóre znajdowały się wręcz w gospodarczej stagnacji. Na rynku europejskim było wciąż za dużo niechcianych dolarów, co podsycało inflację i niweczyło reformy polityki monetarnej w poszczególnych krajach. Wzrastała przez to niechęć do amerykańskich inwestorów prywatnych. Europejczycy byli przekonani, że Stany Zjednoczone prowadzą agresywną politykę gospodarczą, skarżyli się na zbyt restrykcyjne egzekwowanie przepisów antydumpingowych. Obawiali się, że Stany Zjednoczone chciały wymusić unilateralne koncesje w handlu poprzez przewagę na polu monetarnym. Departament Stanu ostrzegał, że w takiej atmosferze łatwo o wzrost nastrojów protekcjonistycznych ${ }^{77}$.

Prognozy te okazały się uzasadnione. Ustawa Hartke-Burke (Foreign Trade and Investment Act) poddana pod obrady Kongresu 28 września 1972 r. nie stanowiła dobrej wróżby przez mającymi się odbyć negocjacjami handlowymi ${ }^{78}$. Był to projekt zaproponowany przez amerykańskie związki zawodowe AFL-CIO. Ustawa miała na celu ograniczenia importu i wprowadzenie ulg podatkowych dla niektórych firm eksportowych. Kontyngentami zamierzano objać cały import we wszystkich kategoriach, dla wszystkich krajów. Miały one być równe przeciętnej wartości importu danego towaru z lat 1965-1969 i podlegać zmianom w celu utrzymania równowagi między importem i produkcją krajową. Proponowano również zniesienie ulg podatkowych od zysków uzyskanych za granicą ${ }^{79}$.

Jeden z promotorów ustawy, członek Izby Reprezentantów James A. Burke, tłumaczył na łamach „New York Times”, że chociaż był zwolennikiem wolnego handlu, brak działań chroniących rodzimy przemysł doprowadziłby do upadku takich działów jak przemysł elektroniczny czy obuwniczy. Stwierdził, że wolny handel na świecie stawał się powoli fikcją ze względu na tworzenie się bloków handlo$w_{y c h}{ }^{80}$. Na łamach gazety wypowiadali się też wielcy przemysłowcy. Henry Ford ostrzegał, że przyjęcie przez Kongres ustawy Hartke-Burke będzie de facto wypowiedzeniem wojny handlowej. Ponieważ wartość eksportu USA do EWG wynosiła 8 mld USD rocznie, Ford wątpił, czy ustawa zostanie uchwalona, gdyż z pewnością

${ }^{76}$ NARA, NPMS, NSC Files, Subject Files: Trade General, Hormats do Kissingera, 14 grudnia 1972, box 402.

${ }^{77}$ NARA, NPMS, NSC Institutional “H” Files, Study Memorandums (1969-1974), raport na temat relacji Stanów Zjednoczonych z Europą przygotowany przez Departament Stanu, 18 grudnia 1972, box $\mathrm{H}-164$.

${ }^{78}$ Ustawę zgłosili James A. Burke - członek Izby Reprezentantów z Massachusetts i Vance Hartke - senator z Indiany (obaj byli członkami Partii Demokratycznej).

${ }^{79}$ G. W i l c k e, Ford Assails Protectionist Bill, „New York Times”, 4 października 1972.

${ }^{80}$ J. A. B u r ke, Hartke-Burke Bill, „New York Times”, 19 kwietnia 1972. 
na tak daleko idące ograniczenia Europa odpowiedziałaby środkami odwetowymi ${ }^{81}$. Rzeczywiście, zgłoszenie projektu było jedynie środkiem nacisku na państwa EWG, żeby były bardziej skłonne do przyjęcia amerykańskich postulatów w nadchodzących negocjacjach handlowych w ramach GATT ${ }^{82}$.

Przykładem sporu gospodarczego, który miał przełożenie na relacje polityczne, była sprawa zakupu przez amerykańskie firmy lotnicze samolotu Concorde. W grudniu 1972 r. Federalna Administracja ds. Lotnictwa (Federal Aviation Administration) planowała wprowadzenie prawa o dopuszczalnym poziomie hałasu, co mogło przeszkodzić amerykańskim spółkom w zakupie europejskiego samolotu. Sprawa miała podtekst polityczny, gdyż Concorde był wspólnym produktem Wielkiej Brytanii i Francji - symbolem przyjaźni między tymi państwami oraz integrowania się Europy. Pompidou i Heath byli zaniepokojeni amerykańskimi planami. Wystosowali list do Nixona informując, że decyzja Agencji spowoduje blokadę sprzedaży tych samolotów do USA. Helmut Sonnenfeldt, członek NSC odpowiadający za sprawy europejskie, rekomendował, żeby podjąć wysiłki w celu certyfikacji europejskiego samolotu, gdyż w przeciwnym wypadku wpłynie to negatywnie na relacje z Paryżem i Londynem ${ }^{83}$. Mimo to Concorde nie został nabyty - Amerykanie tłumaczyli, że rząd nie miał na to wpływu, a zadecydował wolny rynek. Jednak Europejczycy nie przyjęli tego argumentu ${ }^{84}$.

Amerykanie starali się jak najlepiej poznać stanowisko krajów europejskich, a szczególnie wpływ Francji na jego kształtowanie. W grudniu 1972 r. Nixon polecił przygotować NSC raport określający, w których dziedzinach europejskiej polityki rola Francji była wiodąca, ze szczególnym uwzględnieniem przyszłych międzynarodowych negocjacji handlowych ${ }^{85}$. W tej sprawie wypowiedział się sekretarz wykonawczy (Executive Secretary) w Departamencie Stanu, Theodore L. Eliot. Stwierdził,

${ }^{81}$ G. W i l c ke, op. cit.

${ }^{82}$ Policy Aspects of Foreign Investment by US Multinational Corporations, [w:] The Multinational Corporation. Studies on US Foreign Investment, Office of International Investments, vol. 1, March 1972, US Department of Commerce, Washington 1972, s. 1-5.

${ }^{83}$ NARA, NPMS, NSC Institutional “H” Files, Study Memorandums (1969-1974), Sonnenfeldt do Kissingera, 15 grudnia 1972, box H-195.

${ }^{84}$ Ibidem, Eliot do Kissingera, 17 kwietnia 1973. Kolejną kwestią sporną dotyczącą przemysłu lotniczego była tzw. sprawa GE (General Electric) - SNECMA (francuska firma produkująca silniki lotnicze). Te dwie firmy postanowiły wspólnie wyprodukować 10-tonowy silnik. Amerykanie zastanawiali się, czy zezwolić na jego eksport, bo GE wyprodukowała podobny silnik do bombowca B-1 dzięki środkom rządowym. Departament Obrony był skłonny wyrazić zgodę, ale tylko pod warunkiem rekompensat. Francuzi byli rozgoryczeni, gdyż w obawie przed konkurencją dla rodzimych producentów samolotów, Amerykanie odrzucili prośbę finansowego wkładu w zakup części dla europejskich samolotów Airbus i Dessault Mercure (NARA, NPMS, NSC Insitutional "H" Files, Senior Review Group Meetings, streszczenie raportu Departamentu Stanu nt. relacji amerykańskofrancuskich, 25 kwietnia 1973, box H-041).

${ }^{85}$ NARA, NPMS, NSC Insitutional "H" Files, Study Memorandums (1969-1974), Kissinger do NSC, 26 grudnia 1972, box H-195. 
że polityka zagraniczna Pompidou była podobna do prowadzonej wcześniej przez de Gaulle’a. Podkreślił jednak, że Francja była otwarta na współdziałanie z USA, jako przykład podając udział w przygotowaniu konferencji pokojowej kończącej amerykańskie zaangażowanie w Wietnamie i deklarację udziału w pomocy dla Azji Południowo-Wschodniej. Nie było jednak żadnych przesłanek, by spodziewać się zgody Francji na choćby ograniczoną dyskusję w sprawie utworzenia nowej instytucji - gospodarczego forum europejsko-amerykańskiego ${ }^{86}$.

Po wizycie w Europie w grudniu 1972 r. Robert Hormats przygotował memorandum o wynikach rozmów. Stwierdził, że zdołał poruszyć zasadnicze kwestie: do jakiego stopnia Europejczycy byli gotowi wziąć pod uwagę w polityce gospodarczej aspekty polityczne i bezpieczeństwa w stosunkach ze Stanami Zjednoczonymi oraz przedyskutować kierunki rozwoju integracji europejskiej, relacji gospodarczych z USA i sposoby rozwiązania innych poważnych problemów. Europejczycy zdawali sobie sprawę z negatywnego wpływu sporów gospodarczych na stosunki polityczne i bezpieczeństwo. Podkreślali jednak, że Wspólnota zdecydowała o wypracowaniu jednolitego stanowiska w kwestiach handlowych i monetarnych. W związku z tym Stany Zjednoczone prowadząc rozmowy bilateralne musiały liczyć się z faktem, że żaden kraj nie podejmie kluczowej decyzji, jeśli nie uzyska zgody innych członków EWG. Również w kwestiach politycznych i bezpieczeństwa, choć każde państwo samo kształtowało własną politykę, Europejczycy starali się koordynować działania. Hormats informował, że w każdej odwiedzonej przez niego stolicy podkreślano, że rozwiązywanie problemów ekonomicznych miało podtekst polityczny. Doradca Pompidou, Bernard, podkreślił, że negocjacje handlowe nie rozwiążą wszystkich problemów w tej dziedzinie, ale będą miały ogromne znaczenie dla kształtowania się politycznych relacji transatlantyckich. Dlatego Stany Zjednoczone nie powinny wywierać nacisków na EWG, wykorzystując szantaż polityczny wobec RFN, gdyż mogło to doprowadzić do izolacji tego państwa we Wspólnotach, co uważał za bardzo niebezpieczny scenariusz ${ }^{87}$.

Hormats był zdania, że to Europejczycy byli bardziej odpowiedzialni za konflikty gospodarcze, dlatego powinni pierwsi ustąpić, by stało się możliwe ustanowienie sprawiedliwego ładu gospodarczego. Przekonywał, że koszt działań odwetowych USA, np. wprowadzenie ustaw protekcjonistycznych, będzie dla Europy o wiele bardziej dotkliwy niż spełnienie amerykańskich postulatów. Radził jednak nie wywierać presji związanych z fundamentalnymi dla integracji europejskiej porozumieniami gospodarczymi. Uważał, że postulaty amerykańskie powinny być rozważane na najwyższym szczeblu w poszczególnych państwach europejskich. Stwierdził, że najbardziej skutecznym sposobem osiągnięcia porozumienia mogą być spotkania z szefami państw poszczególnych rządów. W ten sposób można było wysondować

${ }^{86}$ Ibidem, Eliot do Kissingera, 17 kwietnia 1973.

${ }^{87}$ NARA, NPMS, NSC Files, Subject Files: European Common Market, Hormats do Kissingera, 18 grudnia 1972, box 322 . 
(a nawet do pewnego stopnia kształtować) wspólne europejskie stanowisko podczas rozmów handlowych. Sądził, że Europejczycy powinni zobowiązać się do informowania Amerykanów o swoich planach, zanim EWG podejmie decyzję w takich dziedzinach, jak polityka przemysłowa czy preferencyjne układy handlowe.

Hormats przedstawił także stanowiska poszczególnych rządów europejskich. Berndt von Staden z niemieckiego MSZ podkreślał, że eliminacja sporów gospodarczych była konieczna, by utrzymać dobre relacje obronne. Wprawdzie nie był przekonany, że uda się je rozwiązać, ale zauważył, że Francji coraz bardziej zależało na umocnieniu związków obronnych, co mogło ją skłonić do większej elastyczności. Nie spodziewał się jakiegoś przełomu, ale widział możliwość stworzenia odpowiedniego klimatu do przyszłego porozumienia. Uważał, że trudno będzie dyskutować jednocześnie o kwestiach politycznych, militarnych i ekonomicznych, gdyż istniały odrębne kanały dyplomatyczne do ich rozwiązywania. Politycy niemieccy obiecywali za to dyskretne wywieranie wpływu na Francuzów, by zmodyfikowali swe stanowisko.

Podobne deklaracje padły w Londynie. Według Hormatsa, Brytyjczycy również doceniali wagę czynnika ekonomicznego w bezpośrednich relacjach z USA i stosunkach EWG-USA. Kenneth Robinson z Foreign Office twierdził, że kwestie polityczne i bezpieczeństwa powinny być rozstrzygane na poziomie bilateralnym, ale nie chciał w ten sposób omawiać spraw handlowych. Tłumaczył, że Wielka Brytania, stając się członkiem EWG, musiała podporządkować się wspólnej decyzji tej organizacji. Uważał, że przygotowaniem wielostronnych rozmów handlowych powinni zajmować się urzędnicy wyższego szczebla, gdyż tylko w takim przypadku będzie możliwe wzięcie pod uwagę czynnika politycznego, a nie tylko formalnych uzgodnień technicznych ${ }^{88}$.

Jeśli chodzi o cło zewnętrzne, Francuzi traktowali je, według słów Hormatsa, „teologicznie”, jako spoiwo EWG, a Niemcy i Brytyjczycy byli bardziej skłonni do negocjacji o jego obniżeniu. Palącą kwestią stała się też sprawa układów handlowych z pozaeuropejskimi krajami śródziemnomorskimi, dających Europejczykom preferencyjny dostęp na ich rynki. RFN i Wielka Brytania były gotowe z niego zrezygnować, ale skłaniały się do utrzymania uprzywilejowanego dostępu produktów z tych krajów na rynki europejskie. Do takiego rozwiązania mogły przekonać również Francję pod warunkiem, że Stany Zjednoczone je zaakceptują i nie zgłoszą protestu na forum GATT. W sprawie reformy monetarnej także Francuzi prezentowali największy sceptycyzm. Twierdzili, że nie była ona możliwa w najbliższym czasie, gdyż w Stanach Zjednoczonych wciąż utrzymywał się deficyt bilansu płatniczego, a rosnąca inflacja w Europie sprawiała, że wkrótce stanie się to problemem także na Starym Kontynencie. Wzywali, aby Amerykanie przestali wywierać presję na dostosowanie kursów do poziomu rezerw walutowych.

Z relacji Hormatsa wynika, że najbardziej liczące się państwa EWG miały odmienne zdania w sprawie możliwości osiągnięcia porozumień handlowych ze

${ }^{88}$ Ibidem. 
Stanami Zjednoczonymi. Wyróżniało się konfrontacyjne stanowisko francuskie politycy starali się stworzyć wrażenie niezłomnej jedności europejskiej w gotowości do stawiania twardych warunków. Zarówno Niemcy, jak i Brytyjczycy byli bardziej otwarci na ustępstwa, choć podkreślali konieczność podjęcia wspólnej decyzji EWG w sprawach warunków międzynarodowego handlu. Mogło to mieć dla USA dwojaki skutek. Z jednej strony pozycja negocjacyjna Europy została umocniona, ale można było liczyć na szybsze osiągnięcie kompromisu przy braku konieczności przekonywania każdego państwa z osobna. Hormats sugerował, że taka sytuacja była korzystna dla Stanów Zjednoczonych - jeśli tylko Francja będzie sprzeciwiała się rozwiązaniom proponowanym przez USA, inne kraje europejskie mogły przekonać ją do zmiany zdania. Ostrzegł jednak, by nie podejmować prób skłócenia członków EWG oraz radził, by także w kwestiach ekonomicznych prowadzić rozmowy bilateralne. Zauważył, że Europejczykom również zależało na posiadaniu wiedzy o amerykańskich planach negocjacyjnych. Popierali też ideę uwzględniania czynników politycznych podczas prowadzenia negocjacji o charakterze gospodarczym. Przedstawiciele RFN proponowali nawet cykliczne spotkania amerykańskiego sekretarza stanu z ministrami spraw zagranicznych EWG, poprzedzone nieformalnym lunchem przed spotkaniami ministerialnymi NATO. Jednak pozostali członkowie Wspólnot byli przeciwni tworzeniu choćby wrażenia powiązań NATO z EWG. Poza tym na takim forum każdy kraj mógłby prezentować własne stanowisko w kwestiach gospodarczych, co kłóciło się z ustaleniami EWG. Pojawiła się również propozycja powołania stałego mechanizmu konsultacyjnego, by zastąpić nieformalne spotkania Irwin-Dahrendorf. Jean Monnet proponował powołanie amerykańskoeuropejskiego „Komitetu Mędrców” (Committee of Wisemen), który miał wskazać, jakie problemy powinny być dyskutowane, by umocnić transatlantyckie porozumienie. Brytyjczycy uważali, że najlepszym rozwiązaniem była dyskusja na forum OECD, na którym mogli być obecni przedstawiciele wszystkich państw $\mathrm{EWG}^{89}$.

Departament Stanu stał na stanowisku, że dyplomacja amerykańska powinna z biegiem czasu zastępować poparcie dla integracji europejskiej dążeniem do instytucjonalizacji stosunków transatlantyckich. Jednak pierwszym krokiem powinny być bilateralne rozmowy z przedstawicielami Wielkiej Brytanii, Francji i RFN. Przed rozpoczęciem wielostronnych negocjacji handlowych należało wywierać subtelną, aczkolwiek wzrastającą presję na Europę, by była otwarta na kompromis, szczególnie w kwestii rolnictwa. Ostrzegano jednak przed używaniem w tym celu szantażu politycznego: zauważono, że rządy krajów europejskich, podobnie jak rząd amerykański, musiały brać pod uwagę presję lobby rolników. Rekomendowano również wstrzymanie się ze skargą na forum GATT na preferencyjne układy handlowe zawierane przez EWG, gdyż mogło to storpedować dalekosiężne cele polityczne i gospodarcze ${ }^{90}$.

${ }^{89}$ Ibidem.

${ }^{90}$ NARA, NPMS, NSC Institutional "H" Files, Study Memorandums (1969-1974), raport na temat relacji Stanów Zjednoczonych z Europą przygotowany przez Departament Stanu, 18 grudnia 1972, box $\mathrm{H}-164$. 
Departament Handlu zwracał uwagę, że w formowaniu polityki amerykańskiej zbyt mało eksponuje się fakt, że kwestie monetarne i handlowe były coraz ważniejsze w relacjach z Europą, w związku z czym należało bardziej energicznie rozwiązywać nieporozumienia na tych polach. Postulowano użycie presji ekonomicznej i politycznej dla wyegzekwowania amerykańskich postulatów. Przewidywano wprawdzie krótkotrwałe napięcia w stosunkach politycznych, lecz zauważono, że bez kompleksowej reformy systemu gospodarczego i tak ulegałyby one pogorszeniu. Przekonywano, że w chwili zażegnania groźby poważnego kryzysu gospodarczego ścisły sojusz transatlantycki automatycznie się odbuduje. Oceniono opcje przedstawione przez Departament Stanu jako zbyt radykalne. Zaproponowano, by potwierdzić wspólne interesy polityczne i obronne, a w tym samym czasie forsować amerykańskie priorytety gospodarcze. Zgodzono się, że nowa instytucja współpracy transatlantyckiej byłaby pomocna, lecz na jej forum należało skupić się na kwestiach ekonomicznych. Uznano, że bardziej efektywne będą rozmowy bilateralne z przedstawicielami poszczególnych państw europejskich ${ }^{91}$.

\subsection{Inwestycje i przedsiębiorstwa wielonarodowe}

Od zakończenia II wojny światowej Stany Zjednoczone pozostawały największym inwestorem na świecie. Ich udział w światowych BIZ wynosił ponad 50\%. Choć państwa Europy Zachodniej zwiększały aktywność na tym polu (szczególnie dynamiczny wzrost odnotowała RFN), jednak nie mogły zagrozić pozycji USA (wykres 5.1).

Wykres 5.1. BIZ wybranych krajów jako procent światowych BIZ

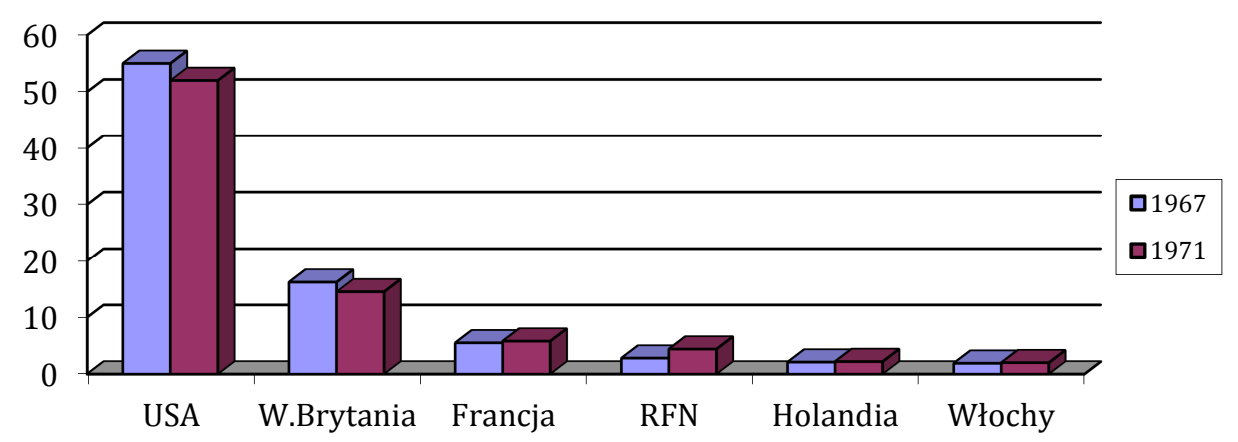

Źródło: R. Gil pi in, U.S. Power and the Multinational Corporation. The Political Economy of Foreign Direct Investment, New York 1975, s. 13.

${ }^{91}$ Ibidem, komentarz Departamentu Handlu dla NSC w sprawie współpracy USA-Europa, 4 stycznia 1973. 
Znacząca część amerykańskich inwestycji była lokowana w Europie Zachodniej (w 1974 r. ponad 40\%). W latach 1965-1974 ich wartość wzrosła o 70\% (tabela 5.1).

Tabela 5.1. BIZ Stanów Zjednoczonych na świecie i w Europie Zachodniej (w mld USD)

\begin{tabular}{|c|c|c|c|}
\hline & 0gółem & Europa Zachodnia & $\begin{array}{c}\text { Inwestycje w Europie } \\
\text { (\% światowych) }\end{array}$ \\
\hline 1965 & 49,5 & 14 & 28,2 \\
\hline 1968 & 61,9 & 19,9 & 32,0 \\
\hline 1969 & 68 & 22,2 & 32,6 \\
\hline 1970 & 75,5 & 21 & 27,8 \\
\hline 1971 & 82,8 & 28,7 & 34,6 \\
\hline 1972 & 89,8 & 31,7 & 35,2 \\
\hline 1973 & 101,3 & 38,3 & 37,7 \\
\hline 1974 & 110 & 44,7 & 40,5 \\
\hline
\end{tabular}

Źródło: Historical Statistics of the United States, vol. 1: Governance and International Relations, New York 2006, s. 473.

Tabela 5.2. BIZ w USA ( $w$ mln USD)

\begin{tabular}{|l|r|r|r|r|r|r|r|r|}
\hline & $\mathbf{1 9 6 2}$ & $\mathbf{1 9 6 8}$ & $\mathbf{1 9 6 9}$ & $\mathbf{1 9 7 0}$ & $\mathbf{1 9 7 1}$ & $\mathbf{1 9 7 2}$ & $\mathbf{1 9 7 3}$ & $\mathbf{1 9 7 4}$ \\
\hline Ogółem & 7612 & 10815 & 11818 & 13270 & 13704 & 14363 & 17748 & 21746 \\
\hline Europa Zachodnia & 5247 & 7750 & 8510 & 9554 & 10070 & 10441 & 12159 & 14098 \\
\hline Wielka Brytania & 2474 & 3400 & 3496 & 4127 & 4435 & 4581 & 5437 & 6126 \\
\hline EWG* $^{*}$ & 1675 & 2790 & 3306 & 3555 & 3757 & 3874 & 4479 & 5380 \\
\hline
\end{tabular}

* Od 1 stycznia 1973 r. członkiem EWG stała się także Wielka Brytania. Jednak ze względu na jej wyraźnie większą aktywność inwestycyjną na terenie USA dane za lata 1973-1974 są podawane odrębnie. Wśród pozostałych członków Wspólnoty najwięcej inwestowała w Stanach Zjednoczonych Holandia.

Źródło: R. B. L e f t w i c h, FDI in the USA, 1962-1971, s. 30; i d e m, FDI in the USA in 1972, s. 50; i d e m, FDI in the US in 1973, s. 7; I. M. M a n te l, FDI in the US in 1974, [w:] Foreign Investments in the United States. Department of Commerce and Department of Treasury Estimates, ed. M. Wilkins, New York 1977, s. 60.

Najwięcej inwestycji napływało do USA z krajów europejskich - w latach 60. i 70. stanowiły ponad 70\% wszystkich BIZ (tabela 5.2). Jednak biorąc pod uwagę ich wartość, wciąż o wiele więcej kapitału płynęło na Stary Kontynent ze Stanów Zjednoczonych (tabele 5.1 i 5.2). 
W 1971 r. do USA napłynął kapitał o wartości 12,7 mld USD, co stanowiło wzrost o 11,4\% w porównaniu z rokiem poprzednim. Wciąż jednak Stany Zjednoczone o wiele więcej inwestowały na świecie niż wynosiła wartość napływających do nich BIZ. W większości krajów europejskich tendencja ta była odwrotna (tabela 5.3).

Tabela 5.3. Bilans wartości inwestycji zagranicznych dla wybranych krajów (w mln USD) różnica między napływem a odpływem

\begin{tabular}{|l|r|r|}
\hline & $\mathbf{1 9 7 0}$ & $\mathbf{1 9 7 5}$ \\
\hline Francja & -249 & +227 \\
\hline RFN & -278 & -1348 \\
\hline Wielka Brytania & -460 & +369 \\
\hline Stany Zjednoczone & -6121 & -11583 \\
\hline Beluks & +162 & +722 \\
\hline Dania & +75 & +189 \\
\hline Włochy & +496 & +287 \\
\hline Holandia & +18 & -1048 \\
\hline
\end{tabular}

Źródło: Obliczenie własne na podstawie: J. E. S p e ro, The Politics of International Economic Relations, New York 1999, s. 108, 110.

Szczególnie aktywnymi inwestorami były korporacje wielonarodowe. Zaostrzały konkurencję i dążyły do monopolizacji rynków. Ze względu na swą mobilność i elastyczność mogły stosunkowo szybko, bez brania pod uwagę interesów danego państwa, przenieść się całkowicie lub częściowo do innego kraju ${ }^{92}$.

Pojawiało się pytanie, czy firmy te nie ograniczają kontroli państwa nad gospodarką. Kindleberger zauważał, że ich bezprecedensowa ekspansja powodowała problemy polityczne, gdyż próbowały wpływać na rządy, by dostosowywały prawo do ich swobodnego działania. Dlatego stanowiły wyzwanie dla państw narodowych. W Stanach Zjednoczonych wpływy jednej korporacji mogły być równoważone przez inną, miały one także wspólny cel: popierały liberalną politykę, by ich inwestycje zagraniczne nie stały się przedmiotem działań odwetowych rządów państw je przyjmujących. Jednak przedstawiciele wielonarodowych korporacji mogli również wpływać na politykę krajów, w których inwestowały, łącznie ze zmianą nieprzyjaznego rządu, przede wszystkim poprzez finansowanie kampanii wyborczych ${ }^{93}$. W latach 70. zauważano konieczność zawarcia międzynarodowego porozumienia w sprawie regulacji działalności tych firm, gdyż akcje poszczególnych rządów w celu

92 D. M. Ray, Corporations and American Foreign Relations, „The Annals of the American Academy of Political and Social Science", September 1972, s. 86.

${ }^{93}$ Ibidem, s. 80-92. 
nakładania kontroli na przepływ kapitału lub poprawienie bilansu płatniczego mogły ze sobą kolidować i prowadzić do konfliktów ${ }^{94}$.

Z przesłuchań senackiej podkomisji zajmującej się zagadnieniem rozwoju przedsiębiorstw międzynarodowych wyłania się pozytywny obraz ich działalności. Doceniono wagę korporacji w polityce zagranicznej ze względu na to, że udzielały informacji o sytuacji politycznej i gospodarczej kraju, w którym działały. Czasem pomagały także we wprowadzaniu polityki promowanej przez amerykańską administrację, jeśli leżało to w ich interesie $e^{95}$. Również Nixon spotykał się wielokrotnie z szefami korporacji zapewniając, że rząd Stanów Zjednoczonych popierał ich rozwój i doceniał pozytywny wpływ na rozwój amerykańskiej gospodarki ${ }^{96}$.

W czasie kadencji Nixona odnotowywano szybko rosnącą przewagę wartości eurodolarów nad wartością rezerw dolarowych USA - w 1972 r. było ich siedmiokrotnie więcej (tabela 5.4). W raporcie działającego przy Departamencie Handlu Biura Inwestycji Zagranicznych (Office of International Investments) z marca $1972 \mathrm{r}$. zauważono, że należy podjąć działania zachęcające w większym stopniu do inwestowania w USA. Miało to spowodować poprawę bilansu płatniczego poprzez „powrót" eurodolarów do kraju ${ }^{97}$.

Tabela 5.4. Eurodolary, rezerwy dolarowe i bilans płatniczy USA (w mld USD)

\begin{tabular}{|l|r|r|r|r|r|r|r|r|r|}
\hline & $\mathbf{1 9 6 4}$ & $\mathbf{1 9 6 8}$ & $\mathbf{1 9 6 9}$ & $\mathbf{1 9 7 0}$ & $\mathbf{1 9 7 1}$ & $\mathbf{1 9 7 2}$ & $\mathbf{1 9 7 3}$ & $\mathbf{1 9 7 4}$ & $\mathbf{1 9 7 9}$ \\
\hline $\begin{array}{l}\text { Wartość netto rynku } \\
\text { eurodolarów }\end{array}$ & 9 & 25 & 44 & 57 & 71 & 91 & 132 & 177 & 475 \\
\hline Rezerwy dolarowe USA & 16,67 & 15,71 & 16,96 & 14,48 & 12,16 & 13,15 & 14.38 & 16,6 & 20,20 \\
\hline Bilans płatniczy USA & $-0,1$ & $-1,29$ & $-3,94$ & $-3,98$ & $-10,47$ & $-11,5$ & 0,9 & $-5,58$ & $-18,9$ \\
\hline
\end{tabular}

Źródło: D. C a ll e o, S. S tr a n g e, Money and World Politics, [w:] Paths to International Political Economy, ed. S. Strange, London 1984, s. 96.

Urzędnicy Biura Inwestycji Zagranicznych zauważyli, że przedsiębiorstwa wolały działać za granicą, gdyż w Stanach Zjednoczonych było za dużo mechanizmów hamujących ich rozwój, takich jak podatek antytrustowy (antitrust tax) czy większe koszty pracy. Najchętniej inwestowano na terenie EWG. Spowodowało to duże zmiany w zarządzaniu przedsiębiorstwami i napływ nowych technologii oraz wzrost konkurencyjności eksportu krajów europejskich, zarówno w samych Stanach

${ }^{94} \mathrm{R}$. K e o h a n e, V a n D o o r n 0 o m s, The Multinational Firm and International Regulations, [w:] World Politics and International Economics, eds. C. F. Bergsten, L. B. Krause, Washington 1975, s. 196. Więcej przykładów wpływu korporacji na politykę zagraniczną państw: J. S. N y e, Multinational Corporations in World Politics, „Foreign Affairs”, October 1974, s. 155-175.

${ }^{95}$ J. E. S p e r o, The Politics of International Economic Relations, New York 1999, s. 124.

${ }^{96}$ J. G a n n o n, High Level Friends, „Wall Street Journal”, 13 stycznia 1972.

${ }^{97}$ Policy Aspects of Foreign Investment..., s. 1-2. 
Zjednoczonych, jak i na rynkach światowych. Nawiązując do pracy Jeana-Jacquesa Servana-Schreibera American Challenge konkludowano, że autor zapomniał, iż to Amerykanie eksportowali technologię i choć wykupywali europejskie firmy, to zwiększali ich wydajność, a tym samym przyczyniali się do wzrostu gospodarczego Europy ${ }^{98}$.

Projekt ustawy Hartke-Burke, oprócz ograniczeń importowych, zawierał propozycję zacieśnienia kontroli nad wszystkimi BIZ i ścisłą regulację transferu amerykańskiej technologii przez firmy z USA działające za granicą. Chciano też zwiększyć podatki od operacji finansowych dokonywanych poza Stanami Zjednoczonymi oraz wprowadzić kontrolę i ograniczenie odpływu amerykańskiego kapitału. Protesty związków zawodowych przeciw przenoszeniu produkcji za granicę spowodowały, że projekt ustawy zawierał klauzulę o regulacjach działalności korporacji wielonarodowych. Stwierdzono, że to one były odpowiedzialne za wzrost konkurencyjności towarów europejskich, co hamowało wzrost gospodarczy w USA, przyczyniało się do spadku poziomu życia i wzrostu bezrobocia ${ }^{99}$.

W raporcie Departamentu Stanu znalazło się stwierdzenie, że Europejczycy, chcąc wprowadzać w rodzimych firmach nowoczesną technologię, mogli z czasem bardziej zachęcać amerykańskie firmy do inwestowania. Zauważono, że nałożenie ograniczeń na wywóz rozwiązań technologicznych prawdopodobnie spowoduje negatywne nastawienie do amerykańskich inwestorów, co z kolei będzie miało wpływ na obszar polityczny, militarny i gospodarczy ${ }^{100}$.

Także pracownicy Biura Inwestycji Zagranicznych nie zgadzali się z działaniami proponowanymi $\mathrm{w}$ ustawie. $\mathrm{W}$ raporcie stwierdzono, że deficyt amerykańskiego bilansu handlowego nie wynikał z działania korporacji wielonarodowych afiliowanych w USA. Powodem była nierównowaga kursów między USD a innymi czołowymi walutami. Zwrócono uwagę, że amerykańskie BIZ tworzą 25\% amerykańskiego eksportu i tym samym działają stymulująco na amerykańską gospodarkę i zatrudnienie, a ograniczenie działalności MNCs nie spowoduje wzrostu zatrudnienia w USA, lecz zwiększy konkurencyjność przedsiębiorstw zagranicznych. Dlatego należało jak najszybciej znieść wszystkie istniejące jeszcze restrykcje na BIZ i nie wprowadzać nowych.

Biuro Inwestycji Zagranicznych zwróciło również uwagę na znaczenie przedsiębiorstw wielonarodowych $\mathrm{w}$ polityce zagranicznej Stanów Zjednoczonych. Przewidywano, że mogły stymulować dobrobyt w krajach rozwijających się i rozszerzać w nich amerykańskie wpływy polityczne. Odnosiło się to również do państw OECD. W związku z tym postulowano dążenie do zawierania porozumień

${ }^{98}$ Ibidem, s. 3-5.

${ }^{99}$ Ibidem.

${ }^{100}$ NARA, NPMS, NSC Institutional "H" Files, Study Memorandums (1969-1974), raport na temat relacji Stanów Zjednoczonych z Europą przygotowany przez Departament Stanu, 18 grudnia 1972, box H-164. 
z poszczególnymi rządami, by zapewnić swobodne działanie dla tych korporacji. Należało zapewnić wpływ państwa na ich działalność, żeby nie psuły relacji politycznych. Zwrócono uwagę, że np. we Francji rząd parokrotnie interweniował, aby nie dopuścić do wchłonięcia przez amerykańskie przedsiębiorstwa rodzimych firm w sektorze zaawansowanej technologii. Nawet w Wielkiej Brytanii, jednym z krajów absorbujących najwięcej amerykańskiego kapitału (ok. 10\% PKB i 17\% brytyjskiego eksportu było przypisywane firmom amerykańskim), pojawiły się postulaty kontroli i obrony suwerenności gospodarczej. Także Stany Zjednoczone próbowały nałożyć ograniczenia na brytyjską firmę Petroleum-Standard Oil działającą w Ohio. Zdaniem Biura Inwestycji Zagranicznych, było to dowodem, że rządy miały problem z dostosowaniem się do nowych zjawisk w gospodarce światowej, szczególnie do wzrostu znaczenia wielonarodowych korporacji. Rekomendowano podjęcie rozmów z krajami europejskimi, gdyż poprzez wielostronne porozumienia na forum Banku Światowego, OECD i GATT, można było wypracować zasady działania tych przedsiębiorstw bez szkody dla wzajemnych relacji politycznych ${ }^{101}$.

\subsection{Offset i Ostpolitik}

W aspekcie politycznym i militarnym szczególnie istotne dla Waszyngtonu były relacje z RFN. Brandt, dążąc do unormowania stosunków z blokiem wschodnim, zaakceptował lansowaną przez Kissingera strategię linkage (sprzężenia), która polegała na tym, że zgoda na współpracę zależała od ustępstw drugiej strony $\mathrm{w}$ innej dziedzinie ${ }^{102}$. Według schematu tej polityki, Brandt za warunek ratyfikacji porozumienia z Polską uznał stworzenie przez ZSRR dobrych warunków dostępu do Berlina Zachodniego. W tej ostatniej kwestii kanclerz musiał uzyskać poparcie Waszyngtonu, gdyż porozumienie w sprawie Berlina musiało być zaakceptowane przez przedstawicieli czterech mocarstw: USA, Wielkiej Brytanii, Francji i ZSRR. Biorąc pod uwagę blok zachodni, tylko Stany Zjednoczone mogły rozmawiać z ZSRR z pozycji siły. Decydenci z Waszyngtonu liczyli, że ta zależność pozwoli utrzymać pod kontrolą realizację Ostpolitik, ale również będzie dawała możliwość nacisku na RFN w celu akceptacji przez to państwo porozumienia offsetowego zgodnego $\mathrm{z}$ amerykańskimi żądaniami.

Gdy Brandt rozpoczął starania zmierzające do zawarcia układu normalizującego stosunki RFN-NRD, Nixon oświadczył, że Stany Zjednoczone nie będą ingerowały w jego działania. Amerykanie doszli do wniosku, że próby powstrzymania Bonn przed realizacją samodzielnej polityki mogły sprawić, że państwo to rozluźni związki ze strukturami zjednoczonej Europy i NATO, próbując wykorzystywać

${ }^{101}$ Policy Aspects of Foreign Investment..., s. 80-84.

${ }^{102}$ H. K i s s i n g e r, Dyplomacja, Philip Wilson, Warszawa 2002, s. 784. 
antagonizmy między stronami konfliktu zimnowojennego. Poza tym, jak okazało się na przykładzie sprawy Berlina, odprężenie mogło przynieść pozytywne dla Zachodu skutki. Dlatego Amerykanie, mimo zastrzeżeń do Ostpolitik, zaakceptowali poczynania RFN, uznając je za niemiecki wkład do strategii détente. Jednak wciąż podejrzliwie patrzyli na działania swego sojusznika, który rozpoczął negocjacje z wrogim blokiem nie pytając uprzednio o zgodę Waszyngtonu. Gdy Brandt dziękował Nixonowi za pomoc w uzyskaniu poparcia NATO dla jego polityki, prezydent odpowiedział chłodno, że oznaczało to tylko brak sprzeciwu, a nie pełną aprobatę ${ }^{103}$.

Kwestią, która ciążyła negatywnie na relacjach transatlantyckich był impas w negocjacjach na temat offsetu z RFN. 3 września 1971 r. podpisano porozumienie w sprawie Berlina ${ }^{104}$, które stanowiło ważną kartę przetargową dla przedstawicieli Stanów Zjednoczonych. Jednak strona niemiecka wiedziała, że rozwiązanie tego problemu było kluczowe także dla Waszyngtonu ${ }^{105}$ i nie ugięła się pod presją polityczną. Amerykanie podejrzewali, że Niemcy chcieli wykorzystać fakt, że Stany Zjednoczone potrzebowały ich współpracy w opracowywaniu reformy światowego systemu monetarnego i uzyskać korzystne warunki umowy offsetowej.

W liście do Rogersa z 30 października 1971 r. sekretarz obrony Melvin R. Laird poinformował, że po rozmowie z ministrem obrony RFN Helmutem Schmidtem w Brukseli skłaniał się do zmodyfikowania stanowiska w sprawie offsetu. Schmidt obawiał się, że część offsetu pochodząca z niemieckiego budżetu zmniejszy środki przeznaczone na działanie Ministerstwa Obrony i zostanie przekazana amerykańskiemu Departamentowi Skarbu, co osłabi zdolności obronne RFN, nie poprawiając amerykańskich. Poinformował Lairda, że chciał uzyskać dodatkowe środki w wysokości 300 mln DM do niemieckiego budżetu obronnego. Skarżył się, że amerykańscy negocjatorzy nie byli tym zainteresowani, choć część tych środków miano przeznaczyć na remont baraków, w których stacjonowali amerykańscy żołnierze. Według Lairda, byłoby to lepsze rozwiązanie niż przekazanie dużych sum na program offsetowy. Byłoby to również zgodne z postulatem Nixona, by sojusznicy zwiększali wydatki na obronę, a bezpośrednie wsparcie amerykańskiego budżetu było też drażliwą kwestią polityczną, niepopularną wśród niemieckiej opinii publicznej. Laird przekonywał, że w związku z tym Schmidt nie zaakceptuje amerykańskich żądań, a w razie nieustannych nacisków poda się do dymisji. Stwierdził, że byłoby to destrukcyjne dla amerykańsko-niemieckich relacji politycznych. Dopuszczał nawet próby negocjowania większej kwoty offsetu, ale postulował rezygnację z żądania

${ }^{103}$ H. K i s s in g e r, White House Years, Boston 1979, s. 409.

${ }^{104}$ Tekst porozumienia: NARA, NPMP, NSC Files, HAK Office Files, European Unity, 3 września 1971, box 15. Więcej na ten temat zob. S. M. H e r s h., The Price of Power. Kissinger in the Nixon White House, New York 1984, s. 415-422.

${ }^{105}$ Sprawa dostępu do Berlina Zachodniego była wielokrotnie przyczyną poważnego wzrostu napięcia między USA a ZSRR, szczególnie podczas dwóch tzw. kryzysów berlińskich (1948-1949; 1958-1961). 
przekazywania środków dla amerykańskiego budżetu ${ }^{106}$. Rogersa nie trzeba było przekonywać do ustępstw, gdyż jeszcze po koniec września opowiadał się za przyjęciem propozycji RFN z sierpnia 1971 r. Twierdził, że jeśli rozmowy będą się przeciągać, w Kongresie przybędzie zwolenników redukcji sił w Europie. Obawiał się, że dyskusja mogła się rozszerzyć na aspekty międzynarodowego bezpieczeństwa. Jednak Departament Skarbu był przeciwny zbyt daleko idącym ustępstwom ${ }^{107}$.

Porozumienie w sprawie offsetu zostało podpisane dopiero 10 grudnia $1971 \mathrm{r}$. w Brukseli. Formalnie czas jego realizacji obejmował okres od 1 lipca 1971 r. do 30 czerwca 1973 r. Całkowita kwota rekompensaty na 2 lata wynosiła 2 mld USD. Zawierała wydatki rządu RFN na zakup sprzętu i usług militarnych w USA, inwestycje w infrastrukturę (np. zakwaterowanie) dla wojsk amerykańskich stacjonujących na jej terytorium oraz kredyt Bundesbanku dla rządu USA pod zastaw obligacji ${ }^{108}$.

W przemówieniu z 6 maja 1972 r. Nixon stwierdził, że utrzymanie współpracy między Europą Zachodnią i Stanami Zjednoczonymi, także na polu militarnym, w kontekście silnych nacisków w Kongresie nie mogło być traktowane jako pewne. Zauważył jednak, że Europejczycy zdawali sobie sprawę, że jednostronne wycofanie wojsk było niekorzystne także dla USA. Osłabiłoby to ich pozycję na Starym Kontynencie oraz możliwości negocjacji z ZSRR. Stwierdził, że przywódcy europejscy nie poddają się, poza mniej znaczącymi wyjątkami, amerykańskim gospodarczym naciskom. Nixon był przeciwny wycofaniu wojsk amerykańskich z Europy. Wyraził jednocześnie nadzieję, że w kwestii bardziej sprawiedliwego dzielenia kosztów obrony zostanie osiągnięty konsensus ${ }^{109}$.

Kissinger, choć był przeciwny wycofywaniu wojsk amerykańskich i uważał tę operację za szkodliwą, w rozmowach z Europejczykami nie wahał się używać nacisków. Na spotkaniu z politykami RFN w Monachium 10 września 1972 r., pytany o perspektywę takiego rozwiązania nie zaprzeczył i pouczał rozmówców, że należy zawrzeć bardziej sprawiedliwą umowę dzielenia kosztów obrony. „Nie możecie używać naszych wojsk do prowadzenia niezależnej polityki odprężenia" - mówił Kissinger - „nie możecie też oczekiwać, że Stany Zjednoczone będą was wspierać, gdy EWG jest naszym największym konkurentem gospodarczym"110. Stwierdził, że po wyborach prezydenckich w USA należałoby dokonać przeglądu wzajemnych

${ }^{106}$ NARA, NPMS, NSC Files, Country Files - Europe (Germany), Laird do Rogersa, 30 października 1971, box 683. Por. Ibidem, Memorandum z rozmowy Laird - Schmidt, 26 października 1971.

${ }^{107}$ Ibidem, Sonnenfeldt do Kissingera, 30 września 1971.

${ }^{108}$ Foreign Relations of the United States (FRUS) 1969-1976, vol. 3: Foreign Economic Policy, 1969-1972; International Monetary Policy, 1969-1972, Washington D.C. 2002, Rogers do Departamentu Stanu, 10 grudnia 1971, dok. 86, dostępne także przez: www.state.gov/r/pa/ho/frus/ nixon.

${ }^{109}$ PPP, Richard Nixon, vol. 4, oświadczenie na temat dobrowolnych ograniczeń eksportu do USA przez zagranicznych producentów stali, 6 maja 1972, dok. 143.

${ }^{110}$ NARA, NPMP, NSC Files, HAK Office Files, HAK Trip Files, protokół z rozmowy Franza Heuba, Franza-Josepha Straussa, Kissingera i Sonnenfeldta, 10 września 1972, box 24. 
relacji, gdyż w przeciwnym razie partykularne spory rok po roku będą osłabiać sojusz atlantycki, a problemy gospodarcze mogą spowodować niemożność utrzymania związku obronnego. Kissinger stwierdził, że gdyby nie podejście Nixona, Stany Zjednoczone byłyby z europejskimi sojusznikami w stanie poważnego sporu politycznego ${ }^{111}$.

W raporcie na temat relacji z Europą przygotowanym przez Departament Stanu zauważono, że sojusznicy mniej obawiali się ataku ze strony ZSRR, choć niepokoiła ich przewaga sił konwencjonalnych po stronie wschodniego mocarstwa. Obawy wzbudzały też dążenia Kongresu do redukcji obecności sił amerykańskich w Europie oraz to, że Stany Zjednoczone użyją planowanego porozumienia w sprawie traktatu o wzajemnej i zrównoważonej redukcji sił zbrojnych w Europie (Mutual and Balanced Force Reductions in Europe - MBFR) jako pretekstu do realizacji tego planu ${ }^{112}$.

\subsection{Stany Zjednoczone wobec postępu integracji europejskiej}

Po „szoku Nixona” w Europie Zachodniej nasiliły się dążenia do bliższej integracji, by przeciwdziałać unilateralnym posunięciom Stanów Zjednoczonych. Angażowała się w nie również negocjująca członkostwo we Wspólnotach Wielka Brytania. W przemówieniu wygłoszonym 16 października 1971 r. Heath podkreślił, że priorytetem brytyjskiej polityki zagranicznej była integracja. Doceniając rolę Stanów Zjednoczonych, jako przywódcy wolnego świata stwierdził jednak, że kraj ten nie mógł ponosić całej odpowiedzialności i podejmować wszystkich decyzji. Dlatego zachęcał kraje europejskie do mobilizacji w celu zapewnienia sobie bezpieczeństwa. Zapowiedział wsparcie dla wspólnej polityki zintegrowanej Europy, by miała ona więcej do powiedzenia na arenie międzynarodowej ${ }^{113}$.

Analogiczne stwierdzenia padały z ust ministra spraw zagranicznych RFN, Waltera Scheela, który zapowiadał, że kolejny szczyt EWG będzie poświęcony pogłębianiu integracji, ze szczególnym naciskiem na współpracę polityczną. Miał być tam omawiany projekt unii gospodarczej i walutowej, zahamowany przez kryzys monetarny ${ }^{114}$.

Teksty w podobnym tonie ukazywały się w prasie francuskiej. W „Le Monde” autor artykułu Europa: Jedność albo amerykanizacja André Fontaine zauważał, że bez

${ }^{111}$ Ibidem.

112 NARA, NPMS, NSC Institutional "H" Files, Study Memorandums (1969-1974), raport na temat relacji Stanów Zjednoczonych z Europą przygotowany przez Departament Stanu, 18 grudnia 1972, box H-164

${ }^{113}$ NARA, NPMP, NSC Files, HAK Office Files, European Unity, przemówienie Heatha na konferencji Unionists Associations, 16 października 1971, box 15.

${ }^{114}$ Ibidem. 
pogłębionejunifikacji Europa stanie sięjedynie „aneksem do StanówZjednoczonych”. W bliższej współpracy w ramach Wspólnot widział szansę prowadzenia aktywniejszej polityki wschodniej, której celem miało być zakończenie podziału Europy na dwa bloki. Autor obawiał się przejmowania przez firmy amerykańskie coraz większej liczby europejskich przedsiębiorstw. Mogło to doprowadzić do całkowitej kontroli gospodarki europejskiej. Przewidywał masowy wyjazd naukowców francuskich do USA oraz kształtowanie gustów przez popkulturę zza Oceanu ${ }^{115}$.

Pod koniec grudnia $1971 \mathrm{r}$. rozszerzenie EWG stało się przedmiotem rozmowy polityków amerykańskich z niemieckimi. Scheel poinformował, że kiedy się to dokona, będą się odbywały częstsze konsultacje polityczne w ramach Wspólnot, także w kwestiach bezpieczeństwa. Jak zauważył Rogers, Kongres amerykański mógł uznać, że wobec zwiększenia się możliwości obronnych Starego Kontynentu częściowe wycofanie sił amerykańskich byłoby uzasadnione ${ }^{116}$. Stwierdzenie to było ewidentnie podyktowane obawą przed ściślejszą współpracą i emancypacją Europy. Charakterystyczne jest także to, że w rozmowie z Scheelem nie padło ani jedno słowo o gospodarczych skutkach rozszerzenia, choć odbyła się ona w czasie eskalacji rozbieżności na tym polu. Jednak z lektury korespondencji między urzędnikami administracji waszyngtońskiej wynika, że postrzegano zagrożenia związane z przystąpieniem nowych członków głównie przez pryzmat rywalizacji ekonomicznej: przewidywano, że silniejszy blok europejski mógłby odpowiadać na amerykańskie negatywne posunięcia w sposób grożący równowadze w gospodarce światowej ${ }^{117}$.

Słabością EWG był z pewnością brak wspólnej polityki zagranicznej i obronnej. Konieczność dążenia do tego celu zauważył Heath podczas spotkania z Nixonem na Bermudach 20 i 21 grudnia 1971 r. Brytyjski premier był zdania, że najpierw państwa EWG powinny wypracować wspólną politykę zagraniczną, a dopiero potem koordynować ją z celami USA. Zapewnił jednocześnie, że choć zjednoczona Europa z pewnością będzie konkurencyjna wobec Stanów Zjednoczonych, jednak na pewno nie będzie konfrontacyjna. Heath z dużym entuzjazmem wypowiadał się także o perspektywie zorganizowania wspólnej europejskiej obrony ${ }^{118}$.

Nixon w tej rozmowie znalazł potwierdzenie planów coraz większej emancypacji Europy Zachodniej. Analizując jednak realną sytuację, nie mógł być zbytnio zaniepokojony, że cele przedstawione przez Heatha zostaną zrealizowane w bliskiej perspektywie. Zbyt silna była na kontynencie europejskim tradycja realizacji partykularnych narodowych celów, które w owym czasie rzeczywiście w wielu

${ }^{115}$ Ibidem, tłumaczenie artykułu: A. F o n t a i n e, Europe: Unity or Americanization, „Le Monde”, 26 listopada 1971.

${ }^{116}$ NARA, NPMS, NSC Files, Country Files - Europe (Germany), memorandum z rozmowy przedstawicieli Departamentu Stanu i MSZ RFN, 28 grudnia 1971, box 684.

${ }_{117}$ S. D. C o h e n, The European Community and the General Agreement on Tariffs and Trade, Washington 1975, s. 9.

${ }^{118}$ H. K i s s i n g e r, White House Years..., s. 960. 
aspektach zasadniczo się różniły. Nie było też aprobaty społeczeństw w sprawie zwiększania wydatków na obronę i jej koordynację. Mimo prób prowadzenia bardziej niezależnej polityki na arenie międzynarodowej, poszczególne państwa europejskie nie mogły osiągnąć znaczących rezultatów bez wsparcia USA. Odbywały się wprawdzie spotkania ministrów spraw zagranicznych, zgodnie z postulatami komisji Davignona, ale nie zawsze udawało się osiągnąć konsensus. Państwa EWG zjednoczyły wysiłki w celu przygotowania obrad KBWE, nie mogły się za to porozumieć w kwestii wspólnego stanowiska wobec USA. Bez wątpienia pozytywnie układała się współpraca na polu kontaktów gospodarczych z zagranicą w ramach Komisji Europejskiej. Przykładem mogą być krytykowane przez USA preferencyjne układy handlowe ${ }^{119}$. W 1972 r. eksport krajów EWG do państw pozaeuropejskich osiągnął wartość 62 mld USD, przewyższając wartość wywozu USA ${ }^{120}$.

W raporcie na temat polityki zagranicznej, ogłoszonym 9 lutego 1972 r., Nixon zaostrzył żądania wobec EWG w kontekście jej rozszerzenia. Domagał się rekompensaty za straty, jakie w wyniku tego procesu poniosą Stany Zjednoczone. Przyznał jednak, że mimo deficytu handlowego, Stany Zjednoczone również musiały spełnić roszczenia partnerów, m.in. zmniejszyć bariery ograniczające import produktów rolnych. Wyraził gotowość do ustępstw w dziedzinie handlu, jednak można wyczytać wyraźną sugestię, że z powodów politycznych EWG powinna zrezygnować z ostrej rywalizacji z USA. Amerykański prezydent przekonywał, że uniknięcie konfliktów było możliwe. Zapewnił o poparciu USA dla planowanego rozszerzenia, choć wymienił związane z tym problemy gospodarki amerykańskiej. Przytoczył słowa Heatha, który zadeklarował, że nowi członkowie EWG będą dążyć do ustanowienia wspólnej polityki europejskiej, zarządzania kontaktami z resztą świata, koordynacją handlu, finansów i obrony. Nixon zauważył, że rozwój Wspólnot w takim kierunku zapowiada poważne zmiany w stosunkach transatlantyckich. Będąc realistą uznał, że znaczna przewaga Stanów Zjednoczonych i automatyczne poparcie Europy Zachodniej dla wszystkich ich działań już się zakończyło. Miał jednak nadzieję, że w związku z tym nie dojdzie do żadnego poważnego rozłamu. Widział tylko jeden sposób osiągnięcia tego celu: „zdanie sobie sprawy z politycznej konieczności dostosowania spornych interesów ekonomicznych"121. Podobną sugestię sformułował w kontekście przewidzianych jesienią 1973 r. negocjacji handlowych USA-EWG: „Potrzebujemy nowego potwierdzenia naszych wspólnych interesów, by nadać negocjacjom gospodarczym kierunek polityczny"122.

${ }^{119}$ S. H o ff m a n n, Toward a Common European Foreign Policy?, [w:] The United States and Western Europe...., s. 88-89.

${ }^{120}$ NARA, NPMS, NSC Institutional "H" Files, Study Memorandums (1969-1974), raport na temat relacji Stanów Zjednoczonych z Europą przygotowany przez Departament Stanu, 18 grudnia 1972, box H-164.

${ }^{121}$ PPP, Richard Nixon, vol. 4, trzeci roczny raport dla Kongresu na temat polityki zagranicznej USA, 9 lutego, 1972, dok. 56.

122 Ibidem. 
W czerwcu 1972 r. w Paryżu na wspomnianym już spotkaniu Eberle'ego z politykami francuskimi, Jean Pierre Brunet odpowiedzialny za sprawy gospodarcze we francuskim MSZ zarzucił Amerykanom, że choć oficjalnie popierają europejską integrację, wyrażająza dużo zastrzeżeń, dotyczących jej rezultatów.Zauważył,żepaństwazachodnioeuropejskie byłynajbliższymi sojusznikamiStanówZjednoczonych na świecie, więc Amerykanie powinni wspierać silne i niezależne Wspólnoty. Eberle stwierdził, że był to jeden z priorytetów dla Waszyngtonu, a sprzeciw budził jedynie kierunek, w którym zmierzała integracja - stworzenie zamkniętego bloku handlowego, niechętnego do dzielenia odpowiedzialności za sytuację na świecie ${ }^{123}$.

Odpowiedzią na amerykańskie obawy wobec poszerzenia EWG był artykuł kanclerza RFN Willy'ego Brandta, opublikowany w „Foreign Affairs” w kwietniu 1972 r. Przyznał, że Stany Zjednoczone mogły być zaniepokojone perspektywą rozszerzenia Wspólnot, przede wszystkim, że ich polityka handlowa doprowadzi do dalszych strat dla amerykańskiego bilansu płatniczego, co mogło doprowadzić nawet do „wojny handlowej”. Uważał jednak, że obawy te były przesadne, gdyż w ostatnich latach wzrósł eksport amerykański (także kapitału) do Europy. Problem deficytu bilansu płatniczego wynikał przede wszystkim z kryzysu walutowego, możliwego do opanowania poprzez wspólne działania największych gospodarek. Kanclerz RFN stwierdził, że właśnie wzrost potęgi gospodarczej Europy Zachodniej był głównym punktem możliwej rywalizacji między Stanami Zjednoczonymi a EWG. Utrzymywał jednak, że nie można do tego doprowadzić ze względu na transatlantyckie współzależności polityczne, strategiczne i obronne.

Brandt przyznał, że nie sposób wykreślić podziału między gospodarką a polityką. W związku z tym należało dążyć do konsensusu i nie dopuścić do osłabienia sojuszu w wyniku sporów ekonomicznych. Przypomniał swoją inicjatywę utworzenia specjalnego organu amerykańsko-europejskiego, koordynującego taki gospodarczy dialog. Wskazał jednak, że mogłaby ona wzbudzić wśród członków Wspólnot zaniepokojenie nadmiernym wpływem Stanów Zjednoczonych na ich decyzje ekonomiczne. Podkreślał, że umocnienie EWG umożliwi prawdziwe partnerstwo, co było ważnym postulatem administracji amerykańskiej. Przekonywał, że Europejczykom również zależy na liberalizacji handlu światowego, co oznacza, że pozostaną otwarci na wymianę przede wszystkim z USA i Japonią. Według Brandta, spory przy tak dużej współzależności były zjawiskiem naturalnym. Odpierał też oskarżenia o protekcjonizm - uważał, że było możliwe korzystne dla obu stron porozumienie nawet $\mathrm{w}$ dziedzinie handlu artykułami rolnymi, znajdującymi się pod szczególną ochroną Wspólnoty. Stwierdzał, że preferencyjne układy handlowe EWG z krajami rozwijającymi się nie szkodzą amerykańskim interesom handlowym, a dzięki nim Europa wspiera kraje gospodarczo i politycznie słabsze.

${ }^{123}$ NARA, NPMS, NSC Files, Country Files - Europe (France), memorandum z rozmowy w ambasadzie amerykańskiej w Paryżu, 16 czerwca 1972, box 679. 
Jego zdaniem zjednoczona i wzmocniona Europa Zachodnia mogła odgrywać ważną rolę w świecie, ale zawsze będzie działać w sojuszu z USA, gdyż wzajemnie się potrzebują ${ }^{124}$.

Tymczasem wciąż trwały rozmowy na temat rekompensaty strat gospodarki amerykańskiej, mających powstać w wyniku rozszerzenia EWG. Amerykanie zdawali sobie sprawę, że szanse głębszych zmian, np. rezygnacji EWG ze wspólnej polityki rolnej bądź uzyskania znacznych ułatwień w dostępie na rynek europejski, były bardzo niewielkie. Administracja wywierała presję, by nie rezygnować z twardych warunków. Pod koniec 1972 r. miały się odbyć wybory prezydenckie. Nixon utrzymywał, że społeczeństwo powinno być przekonane, że jego administracja będzie w każdych okolicznościach bronić amerykańskich interesów handlowych. Europejczycy w końcu zgodzili się na pewne koncesje, np. w maju 1972 r. producenci z EWG, Wielkiej Brytanii i Japonii zobowiązali się „dobrowolnie” ograniczyć eksport stali na okres trzech lat ${ }^{125}$. Komentator dziennika "New York Times” stwierdził, że rząd USA, by uzyskać to porozumienie zagroził, że w razie odmowy Kongres przegłosuje ustawy protekcjonistyczne. Zdecydowanie skrytykował takie postępowanie twierdząc, że godzi ono w podstawy funkcjonowania międzynarodowego wolnego handlu ${ }^{126}$. Jednak rząd Stanów Zjednoczonych wciąż uznawał ustępstwa konkurentów handlowych za zbyt znikome, by można było mówić o sukcesie negocjacyjnym. Zaniepokojenie Waszyngtonu wzrosło, gdy 22 lipca 1972 r. EWG i EFTA zawarły układ o wolnym handlu produktami przemysłowymi.

Na spotkaniu CIEP, 11 września 1972 r., po raz kolejny odbyła się dyskusja na temat możliwych środków wywarcia nacisku na EWG. Dyrektor CIEP, Peter Peterson, optował za tym, by zagrozić wycofaniem części wojsk amerykańskich, jeśli państwa europejskie odmówią przyznania Stanom Zjednoczonym korzystniejszych warunków handlowych. Tradycyjnie takiemu rozwiązaniu sprzeciwił się sekretarz stanu William Rogers. Nixon tym razem poparł Rogersa oświadczając, że przez najbliższe tygodnie nie będzie publicznie poruszał problemu handlu, tym bardziej w kontekście bezpieczeństwa. Zauważył istnienie realnej groźby, że posiadająca kontakty gospodarcze na całym świecie Europa Zachodnia odwróci się od Stanów Zjednoczonych. Prezydent obawiał się, że polityka handlowa Wspólnot może się stać antyamerykańska, co z pewnością przeniosłoby się na grunt polityczny. Nixon stwierdził, że dobre relacje polityczne z Europą Zachodnią były wciąż priorytetowe dla USA. „Dobrze zadbamy o nasze interesy, kiedy będziemy prowadzić twarde negocjacje tak, by nie przekroczyć granicy, za którą partnerzy zwrócą się przeciw nam i zerwą z nami" ${ }^{127}$ - powiedział prezydent.

${ }^{124}$ W. B r a n d t, Germany's “Westpolitik”, „Foreign Affairs”, April 1972, s. 419-426.

125 PPP, Richard Nixon, vol. 4, oświadczenie na temat dobrowolnych ograniczeń eksportu do USA przez zagranicznych producentów stali, 6 maja 1972, dok. 143.

126 „New York Times”, 13 maja 1972.

${ }^{127}$ FRUS, 1969-1976, vol. 3, memorandum z obrad CIEP, 11 września 1972, dok. 100. 
Czynnik polityczny, o którym mówił Nixon, ograniczał skuteczność presji amerykańskiej. Wynikało to jednak z faktu, że żądania Waszyngtonu były bardzo daleko idące i godziły w priorytety polityki gospodarczej EWG. W czasie kolejnej rundy rozmów 5 i 6 października 1972 r. Amerykanie podjęli problem preferencyjnych układów handlowych, zawieranych przez EWG z państwami trzecimi. Stwierdzili, że naruszały one interesy Stanów Zjednoczonych i postulowali, by w przyszłości zaniechali zawierania takich umów. Europejczycy niechętnie ustosunkowali się do takiej propozycji. Planowali zawierać nowe korzystne układy handlowe z krajami śródziemnomorskimi i z państwami EFTA. Argumentowali, że państwa te w przeciwnym razie poniosą znaczne straty gospodarcze $\mathrm{w}$ wyniku rozszerzenia EWG. Wysuwali argument, że to może je oddalić od Zachodu i skłonić do współpracy z blokiem komunistycznym. Jednak Amerykanie nie byli przekonani. Stwierdzili, że jeśli także Stany Zjednoczone nie otrzymają znaczących rekompensat, zgłoszą sprawę do rozpatrzenia na forum GATT ${ }^{128}$.

Doradca Nixona do spraw międzynarodowych relacji ekonomicznych, Peter Flanigan, negatywnie oceniał postawę Europejczyków wobec amerykańskich żądań, ale wiązał duże nadzieje z wejściem do Komisji EWG przedstawicieli Wielkiej Brytanii, Irlandii i Danii ${ }^{129}$. Radził zorganizowanie dyskretnych spotkań w Brukseli z poszczególnymi komisarzami EWG ${ }^{130}$. Pragnął w ten sposób budować lobbing w celu uzyskania bardziej przychylnego stanowiska dla postulatów USA. Zupełnie inaczej postawę Europejczyków oceniała NSC. Przypominano, że Stany Zjednoczone od dawna zachęcały Wspólnoty do wzięcia politycznej odpowiedzialności za rejon Morza Śródziemnego ${ }^{131}$. Departament Stanu zgadzał się z takim punktem widzenia. Wskazywał, że skutki polityczne tych umów były o wiele ważniejsze niż gospodarcze.

Na szczycie EWG w Paryżu mówiono o konieczności koordynacji polityki zagranicznej. 21 października 1972 r. przywódcy wydali komunikat o zamiarze utworzenia do końca dekady Unii Europejskiej, podkreślając jednocześnie wolę bliskiej współpracy z USA, także w kwestiach gospodarczych - likwidowania barier handlowych i reformy światowego systemu monetarnego ${ }^{132}$.

Jednak Amerykanie sceptycznie podchodzili do tej deklaracji. Robert Schaetzel, ambasador USA przy Wspólnotach Europejskich, zrezygnował w październiku 1972 r. ze stanowiska i otwarcie mówił o „powolnym spadku zrozumienia między USA a Europą" ${ }^{133}$. Twierdził, że każda ze stron ponosi część winy, gdyż rozwiązując wewnętrzne problemy nie bierze pod uwagę wpływu tych poczynań na sytuację po

${ }^{128}$ Ibidem, Irwin do Nixona, 7 października 1972, dok. 102.

${ }^{129}$ Norwegowie odrzucili członkostwo we Wspólnotach w referendum 26 września $1972 \mathrm{r}$.

${ }^{130}$ FRUS, 1969-1976, vol. 3, Flanigan do Nixona, 11 października 1972, dok. 103.

${ }^{131}$ Ibidem, Sonnenfeldt i Hormats do Kissingera, 16 października 1972, dok. 104.

132 PPP, Richard Nixon, vol. 4, oświadczenie na temat współpracy Stanów Zjednoczonych ze Wspólnotą Europejską, 27 października 1972, dok. 378.

${ }^{133}$ E. R. G o o d m a n, The Fate of the Atlantic Community, New York 1975, s. 173. 
drugiej stronie Atlantyku. Zdaniem Schaetzela, prowadziło to także do widocznego osłabienia związków politycznych, kulturalnych i obronnych ${ }^{134}$.

Hormats informował, że podczas wizyty w Europie poznał stanowisko wszystkich krajów EWG, zgodnie z którym gospodarka amerykańska nie ucierpi z powodu rozszerzenia do tego stopnia, by wymagało to rekompensaty. W Londynie został pouczony, że Stany Zjednoczone musiały znaleźć kompromis między tym, co uważały za sprawiedliwe, a tym, co mogły uzyskać. Zbyt wygórowane żądania mogły bowiem doprowadzić do impasu w rozmowach. Hormats uważał, że administracja powinna dyskutować nad problemami gospodarczymi z EWG w całości, choć nie wykluczał konieczności rozmów bilateralnych i wywierania presji na poszczególne państwa, jeśli okaże się to konieczne dla amerykańskiego interesu narodowego. Ostrzegł, że jeśli Stany Zjednoczone nie wystąpią z jakąś pozytywną, wspierającą integrację inicjatywą współpracy, Europa wybierze opcję francuską - wzmocnienia Wspólnot, by skuteczniej przeciwstawiać się amerykańskiej presji ${ }^{135}$.

\subsection{Aspekty polityczno-gospodarcze zbliżenia ze Wschodem}

Ważną kwestią w stosunkach transatlantyckich była emancypacja Europy Zachodniej w kontaktach z blokiem komunistycznym. Parła ona do zawarcia układu MBFR i zorganizowania KBWE. Waszyngton nie chciał dopuścić, by sojusznicy ulegli "finlandyzacji” i przyjmowali warunki strony sowieckiej bez konsultacji. W październiku 1971 r. Pompidou udał się z wizytą do Moskwy. Był to czas rozbieżności transatlantyckich po „szoku Nixona” i w Waszyngtonie odebrano to jako demonstrację niezależności. Jednak zdawano sobie sprawę, że Pompidou nie miał złudzeń co do możliwości samodzielnego działania państw zachodnioeuropejskich w stosunkach z ZSRR. Francuski prezydent z niepokojem obserwował bowiem politykę wschodnią RFN i wolał, żeby była prowadzona pod kontrolą USA ${ }^{136}$. W związku z tym sojusznicy musieli działać bardzo ostrożnie i nie dopuścić, by rozbieżności w tej kwestii osłabiły ich pozycję negocjacyjną wobec ZSRR.

Przykładem takiej współpracy transatlantyckiej było wsparcie Stanów Zjednoczonych dla Ostpolitik. To dzięki akceptacji Waszyngtonu 3 września 1971 r. zawarto układ o swobodnym dostępie do Berlina, na którym najbardziej zależało RFN, ale także Amerykanom. Warto zwrócić uwagę na aspekt gospodarczy Ostpolitik. Rozwinięcie stosunków handlowych z blokiem wschodnim wzmacniało zawarte porozumienia polityczne i dawało perspektywę pozyskania nowych rynków. Jeszcze

134 Ibidem.

135 NARA, NPMS, NSC Files, Subject Files: European Common Market, Hormats do Kissingera, 18 grudnia 1972 , box 322.

${ }^{136}$ S. B e r s t e i n, J.-P. R i o u x, op. cit., s. 26. 
w 1962 r. RFN wysyłała na Wschód towary stanowiące 4\% swego eksportu, w 1971 - 4,3\%, ale w 1975 - już 7,9\% ${ }^{137}$.

Stosunki Wschód-Zachód były głównym tematem spotkania Nixona z Brandtem 28 i 29 grudnia 1971 r. w Key Biscayne. Kanclerz wyraził opinię, że nie można łączyć handlu ze Wschodem z relacjami politycznymi z blokiem komunistycznym. Wbrew obawom Nixona zapewniał, że ożywione stosunki na tym polu nie osłabią sojuszu atlantyckiego. Twierdził, że kontakty handlowe mogły przyspieszyć zmiany polityczne w Europie Wschodniej. Nixon z dużym sceptycyzmem odniósł się też do planowanej KBWE, lecz Brandt wypowiadał się entuzjastyczne o tym przedsięwzię$\mathrm{ciu}^{138}$.

James E. Dougherty uważał, że Europa Zachodnia nie musiała obawiać się „finlandyzacji", dopóki Stany Zjednoczone wspierały ją politycznie i militarnie. Jednak ZSRR starał się wykorzystać transatlantyckie rozbieżności, by Europa zwątpiła w determinację USA do wspierania jej integracji i utrzymania wojsk na jej terytorium. Dlatego Moskwa promowała „pokojowe współistnienie”, którego ważnym elementem był wiążący strony handel i inwestycje. ZSRR potrzebował nowoczesnej technologii, a Europa źródeł energii i surowców oraz lukratywnych kontraktów na ich wydobywanie. Autor przewidywał, że strona radziecka będzie podsycała niechęć do amerykańskich firm wielonarodowych działających w Europie ${ }^{139}$.

$\mathrm{W}$ przygotowanym na prośbę prezydenta raporcie o relacjach z Europą Departament Stanu zauważył, że choć Europa Zachodnia sama aktywnie handluje z blokiem wschodnim, obawia się kontaktów USA-ZSRR, nie tylko politycznych, lecz także gospodarczych ${ }^{140}$. Robert Hormats po wizycie w Europie relacjonował Kissingerowi, że ta kwestia była jednym z ważnych problemów w relacjach między Europą Zachodnią i Stanami Zjednoczonymi. Wynikało to z przeświadczenia, że obie strony mogły ulegać pokusie eliminowania się wzajemnie z eksportu w tym kierun$\mathrm{ku}$, proponując państwom bloku wschodniego lepsze warunki kredytowe. Obawiał się także ostrej rywalizacji o najlepsze inwestycje. EWG zgłosiła chęć przestrzegania wspólnej polityki handlowej (Common Commercial Policy) w stosunku do krajów Europy Wschodniej. Hormats zauważył, że również Stany Zjednoczone powinny skoordynować działania gospodarcze na tym obszarze z Europą Zachodnią ${ }^{141}$.

${ }^{137}$ M. Wo lff f o h n, West-Germany's Foreign Policy in the Era of Brandt and Schmidt, 19691982. An Introduction, New York 1986, s. 26.

${ }^{138}$ H. K i s s i n g e r, White House Years..., s. 954-966.

${ }^{139}$ J. E. D o u g h e r ty, The Soviet Strategy of Finlandization of Western Europe - the External Process, [w:] Atlantic Community in Crisis. A Redefinition of the Transatlantic Relationship, ed. W. F. Hahn, R. L. Pfaltzgraff, New York 1979, s. 198-206.

${ }^{140}$ NARA, NPMS, NSC Institutional "H" Files, Study Memorandums (1969-1974), raport na temat relacji Stanów Zjednoczonych z Europą przygotowany przez Departament Stanu, 18 grudnia 1972, box H-164.

${ }^{141}$ NARA, NPMS, NSC Files, Subject Files: European Common Market, Hormats do Kissingera, 18 grudnia 1972, box 322 . 
Wykres 5.2. Handel Stanów Zjednoczonych z Europą Wschodnią (bez ZSRR) w mln USD

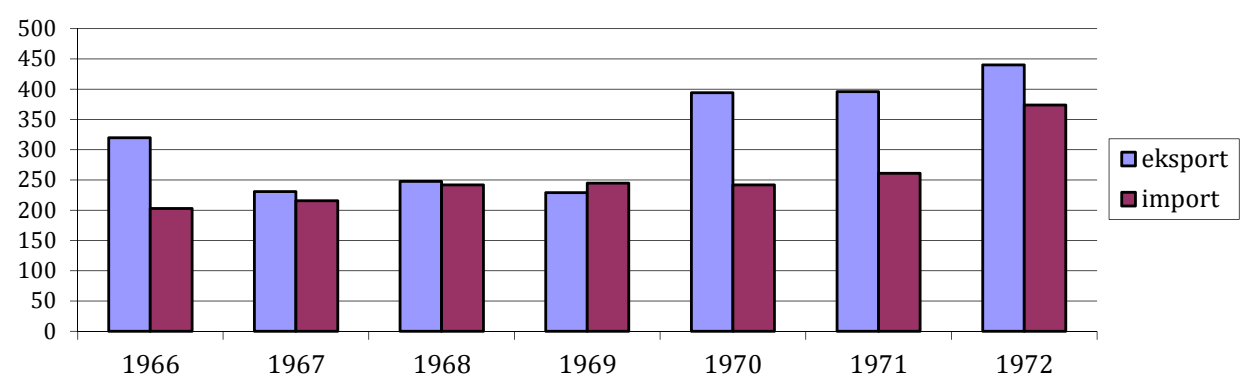

Źródło: NARA, NPMS, NSC Insitutional "H” Files, Senior Review Group Meetings, raport Grupy ds. Polityki Gospodarczej wobec Europy Wschodniej, 1 lutego 1973, box H-041.

Tabela 5.5. Handel Stanów Zjednoczonych z ZSRR w latach 1963-1972

\begin{tabular}{|c|c|c|c|c|}
\hline \multirow{2}{*}{} & \multicolumn{2}{|c|}{ Wartość handlu w mIn USD } & \multicolumn{2}{c|}{ Procent handlu USA } \\
\cline { 2 - 5 } & $\mathbf{E}$ & $\mathbf{I}$ & $\mathbf{E}$ & $\mathbf{I}$ \\
\hline 1963 & 22,9 & 21,2 & 0,1 & 0,1 \\
\hline 1964 & 46,4 & 21,5 & 0,6 & 0,1 \\
\hline 1965 & 44,3 & 42,7 & 0,2 & 0,2 \\
\hline 1968 & 57,4 & 58,1 & 0,2 & 0,2 \\
\hline 1969 & 104,8 & 51,5 & 0,3 & 0,1 \\
\hline 1970 & 118,4 & 72,2 & 0,3 & 0,2 \\
\hline 1971 & 160,6 & 56,8 & 0,4 & 0,1 \\
\hline 1972 & 550,3 & 95,8 & 1,3 & 0,2 \\
\hline
\end{tabular}

E - eksport, I - import

Źródło: R. Sku rs ki, Trade with the Soviet Union and Eastern Europe, [w:] U.S. Trade in the Sixties and Seventies. Continuity and Change, eds. K. Jameson, R. Skurski, Lexington 1974, s. 103.

Europa Zachodnia nie widziała tak wielkiej potrzeby nakładania embarga na towary strategiczne jak USA. Licząc na rozszerzenie kontaktów handlowych z blokiem komunistycznym, nie chciała budować razem ze Stanami Zjednoczonymi strategii łączącej politykę z gospodarką. Nixon i Kissinger chcieli wykorzystać potrzeby gospodarcze państw komunistycznych (szczególnie pozyskania nowej technologii) do wyegzekwowania ustępstw politycznych. Amerykanie w tym przypadku przedkładali cele polityczne nad gospodarcze, w przeciwieństwie do europejskich sojuszników, dlatego wartość ich handlu z blokiem wschodnim była znikoma (wykres 5.2 i tabela 5.5). Uważali, że Europa Zachodnia, intensyfikując 
handel z blokiem wschodnim, wspiera wrogi obóz. Europie Zachodniej trudno jednak było zrezygnować z tych intratnych kontaktów, poza tym bardziej niż Stanom Zjednoczonym zależało jej na dostawach energii z ZSRR. Można też wziąć pod uwagę fakt, że obawiając się wpływu porozumienia supermocarstw na zmniejszenie ich bezpieczeństwa, starano się utrzymywać dobre stosunki z Moskwą na polu gospodarczym. Jednak trzeba również zauważyć wzajemną nieufność: ZSRR obawiał się, że poprzez intensyfikację wymiany Europa Zachodnia zwiększy wpływy w państwach Europy Środkowowschodniej, podważając jego dominację, przywódcy zachodni niepokoili się z kolei, że ZSRR będzie się starał wywoływać spory pomiędzy członkami EWG ${ }^{142}$.

\subsection{Podsumowanie}

W dobie prac nad przygotowaniem reformy światowego systemu monetarnego i kolejnej rundy GATT można było zauważyć w Stanach Zjednoczonych załamanie się konsensusu w sprawie polityki „dobrej woli” wobec Europy Zachodniej. Ogromne napięcia w czasie negocjacji po „szoku Nixona” ujawniły sprzeczne interesy partnerów po obu stronach Atlantyku. Co więcej, dały impuls państwom europejskim do wypracowania wspólnego stanowiska w celu przeciwstawienia się polityce amerykańskiej, co budziło poważne obawy Waszyngtonu. Nie była to próba do końca udana - Amerykanie wciąż dysponowali narzędziami nacisku w stosunkach bilateralnych z poszczególnymi rządami, lecz można było się spodziewać, że w miarę pogłębiania się integracji będą one coraz mniej skuteczne. Rosnąca siła gospodarcza EWG pozwoliła jej skutecznie opierać się presji USA w sprawach dla niej kluczowych, jak np. utrzymanie w niezmiennym kształcie Wspólnej Polityki Rolnej.

Zobowiązanie do utrzymania wartości dolara kłóciło się z realnymi potrzebami wewnętrznej polityki gospodarczej i zwiększaniem konkurencyjności amerykańskiego eksportu. Prowadziło to nie tylko do zmian polityki ekonomicznej wobec sojuszników, lecz także do konstatacji, że nie można się kierować prymatem bezpieczeństwa i relacji politycznych nad interesami gospodarczymi.

Edward R. Fried z Brooking Institution 15 października 1971 r. przedstawił Petersonowi raport na temat dzielenia kosztów obrony w NATO. Stwierdził, że Stany Zjednoczone powinny podporządkować zagraniczną politykę gospodarczą celom politycznym. Jako przykład możliwości negatywnego wpływu gospodarki na politykę podał prawdopodobną perspektywę „wojny handlowej” z Europą, która mogła wpłynąć na transatlantyckie stosunki polityczne i obronne. Poza tym obawy

${ }^{142}$ F. D. H o l z m a n, R. L e g v o l d, The Economics and Politics of East-West Relations, [w:] World Politics and International Economics, eds. C. F. Bergsten, L. B. Krause, Washington 1975, s. 294, 305. 
związane z wejściem Wielkiej Brytanii do EWG (ze względu na przewidywane straty w rolnictwie) mogły zmienić stanowisko USA wobec integracji europejskiej ${ }^{143}$.

Rzeczywiście, porównując stanowisko administracji amerykańskich w latach 60. i 70. wobec perspektywy członkostwa Wielkiej Brytanii w EWG, można zauważyć istotne różnice. Prezydent Kennedy w większym stopniu brał pod uwagę czynnik polityczny - jedność Europy Zachodniej i jej współpracę z USA. Członkostwo Wielkiej Brytanii w EWG było jak najbardziej akceptowane i stanowiło szansę scementowania sojuszu atlantyckiego. W czasie sprawowania urzędu przez Nixona wyraźnie dochodził do głosu czynnik ekonomiczny - obawiano się, że Wielka Brytania nie przyczyni się do wzmocnienia sojuszu, lecz do wsparcia poważnego konkurenta. Ostatecznie przeważył jednak czynnik polityczny - prezydent zdecydował, że nie można stosować zbyt daleko idących nacisków. Nixon wciąż deklarował poparcie dla pogłębiania integracji europejskiej, choć jako pierwszy prezydent USA zdecydowanie artykułował obawy związane z tym procesem.

Umacnianie się EWG, będącej jednym z głównych graczy w gospodarce światowej, wpływało na większą aktywność w polityce zagranicznej. Najlepszym przykładem była zachodnioniemiecka Ostpolitik, którą kanclerz Willy Brandt podbudowywał, intensyfikując kontakty gospodarcze z państwami bloku komunistycznego. W Stanach Zjednoczonych rosło przekonanie o konieczności stworzenia mechanizmu konsultacyjnego, który uniemożliwiłby europejskim sojusznikom zbyt samodzielne działania na tym obszarze, mogące pozostawać w sprzeczności z celami dyplomacji amerykańskiej. Ambicje europejskie starano się skoncentrować na większym zaangażowaniu się w umacnianie sojuszu atlantyckiego, także w kwestii dzielenia kosztów obrony.

${ }^{143}$ NARA, NPMP, WHCF, IT International Organization, NATO, Fried do Petersona, 15 października 1971, box 3 . 
ROZDZIAŁ VI

\section{PRÓBY INSTYTUCJONALIZACJI WSPÓŁPRACY TRANSATLANTYCKIEJ W „ROKU EUROPY” (STYCZEŃ - PAŹDZIERNIK 1973)}

\subsection{Relacje Stanów Zjednoczonych z rozszerzoną EWG}

Wielka Brytania, Irlandia i Dania stały się członkami Wspólnot Europejskich od 1 stycznia 1973 r. Rozszerzenie EWG zostało oficjalnie pozytywnie przyjęte w Stanach Zjednoczonych. Wprawdzie Amerykanie mogli być zadowoleni z decyzji o rozszerzeniu EWG o Wielką Brytanię, ich najwierniejszego europejskiego sojusznika, lecz zdawano sobie sprawę, że nie spowoduje to automatycznego zniknięcia rozbieżności. W Waszyngtonie zauważono jednak, że po włączeniu Wielkiej Brytanii skończyła się francuska dominacja w organizacji. W raporcie CIA przypominano, że stosunki transatlantyckie zdominowały spory o politykę handlową. Istniały obawy, że EWG przyjmie niekorzystną dla Stanów Zjednoczonych politykę finansową i inwestycyjną. Oczekiwano jednak negocjacji handlowych zaplanowanych na jesień 1973 r., które miały wyjaśnić wszystkie kwestie ${ }^{1}$.

Zaraz po rozszerzeniu osobą odpowiedzialną za sprawy zagraniczne w Komisji Europejskiej został Brytyjczyk Christopher Soames. Jego celem było prowadzenie negocjacji handlowych i monetarnych ze Stanami Zjednoczonymi. Soames, który był zięciem Winstona Churchilla, miał bardzo dobre kontakty dyplomatyczne z Amerykanami. Dzięki temu Brytyjczycy od początku zdobyli ważną pozycję we Wspólnotach. Jednak sytuacja gospodarcza w kraju wciąż była trudna. W 1972 r. tylko Włochy miały niższą stopę wzrostu $(2,75 \%)$ niż Wielka Brytania $(3,25 \%)^{2}$.

Miesiąc po rozszerzeniu Wspólnot Stany Zjednoczone miał odwiedzić Heath. W liście do Kissingera szef Zarządu Rezerw Federalnych Arthur Burns stwierdził, że należy wykorzystać wpływ Wielkiej Brytanii w EWG, by jej przedstawiciele tłumaczyli amerykańskie stanowisko w sprawie negocjacji handlowych oraz szczególną rolę grup interesów w USA. Twierdził, że Europejczycy nie doceniali politycznej

\footnotetext{
${ }^{1}$ National Archives and Record Administration, College Park, MD (NARA), Nixon Presidential Materials Staff (NPMS), National Security Council (NSC) Institutional "H" Files, Study Memorandums (1969-1974), CIA - przegląd najważniejszych wydarzeń międzynarodowych w 1972, box H-164.

2 Taki sam poziom wzrostu gospodarczego odnotowano w RFN (3,25\%). Najlepszy wskaźnik miała Francja: 5,5\% (C. L. S u l z b e r g e r, The New Europe, „New York Times”, 10 stycznia 1973).
} 
wagi pogorszenia się bilansu handlowego USA, ze względu na koncentrację na sprawach wewnętrznych. W większości krajów europejskich był to czas wyborów, poza tym priorytet stanowiło dla nich rozszerzenie ${ }^{3}$.

Przed planowaną rozmową Nixona z brytyjskim premierem Kissinger stwierdził, że z uwagi na istnienie specjalnych stosunków, niektóre sprawy można omawiać z Heathem swobodniej niż z przedstawicielami innych krajów europejskich. Wskazał też istnienie wspólnych interesów, np. Wielka Brytania nie popierała CAP w ówczesnym kształcie z powodu wzrostu cen zboża i konieczności dopłacania do rolnictwa innych członków, szczególnie Francji i RFN. Kissinger nie radził jednak liczyć na to, że Wielka Brytania będzie adwokatem USA w EWG. Zaproponował wyjaśnienie kwestii bezpieczeństwa, koordynacji działań dotyczących KBWE i rozbrojenia. Ważnym punktem miało być określenie relacji gospodarczych z rozszerzoną EWG oraz poruszenie problemów handlowych i monetarnych. Kissinger stwierdzał, że Nixon musiał przekonać Heatha, że wspólne interesy bezpieczeństwa Zachodu były nadrzędne i EWG powinna zgodzić się na gospodarcze koncesje dla USA. Tylko w tym przypadku rząd amerykański mógł utrzymać wewnętrzne poparcie dla silnego zaangażowania w NATO i szeroko rozumiane partnerstwo atlantyckie. Prezydent miał obiecać, że będzie o to zdecydowanie walczył, ale od Europejczyków oczekiwał politycznej dojrzałości. Miał na myśli poświęcenie rywalizacji gospodarczej na rzecz umocnienia sojuszu, gdyż czysto techniczne podejście do sprawy, bez uwzględnienia kwestii politycznych, mogło się zakończyć fiaskiem wszelkich negocjacji. Nixon miał jednak zapewnić Heatha, że Amerykanie nie będą szantażowali Europejczyków wycofaniem wojsk. Kissinger uważał, że było to konieczne, gdyż Europejczycy obawiali się, że Amerykanie chcieli podporządkować sojusz stosunkom z ZSRR ${ }^{4}$. Niepokoili się również zbyt wygórowanymi oczekiwaniami USA w kwestiach gospodarczych, które mogły zniszczyć jedność Europy. Jednocześnie zdawali sobie sprawę, że w przypadku braku porozumienia Stany Zjednoczone zaczną stosować protekcjonizm $^{5}$.

Po rozszerzeniu Wspólnot Stany Zjednoczone liczyły straty związane z tym faktem. Wielka Brytania, Dania i Irlandia wchodząc do EWG musiały zaakceptować wspólną taryfę zewnętrzną. Powodowało to dla ich partnerów handlowych wzrost ceł na towary rolnicze i spadek na przemysłowe. Według punktu 6 artykułu XXIV układu GATT, po podwyższeniu barier celnych na poszczególne towary, strona poszkodowana powinna otrzymać rekompensatę ${ }^{6}$. Stany Zjednoczone domagały się m.in. utrzymania korzyści uzyskanych w negocjacjach GATT na eksport poszczególnych produktów. Gdyby którejś z nich nie dało się zachować, żądały

\footnotetext{
${ }^{3}$ NARA, NPMS, NSC Files, VIP Visits, Burns do Kissingera, 24 stycznia 1973, box 942.

${ }^{4}$ M. S m i t h, Western Europe and the United States. The Uncertain Alliance, London 1984, s. 84.

${ }^{5}$ NARA, NPMS, NSC Files, VIP Visits, Kissinger do Nixona, 31 stycznia 1973.

${ }^{6}$ Artykuł XXIV określał tryb tworzenia preferencyjnych porozumień handlowych w formie unii celnej i strefy wolnego handlu. Pełny tekst GATT dostępny przez: http://www.wto.org.
} 
odszkodowania. EWG utrzymywała, że ta zasada nie miała zastosowania, gdyż po rozszerzeniu cła były mniejsze niż w przypadku, gdyby EWG ustaliła średnią stawkę dla wszystkich produktów objętych unią celną. Europejczycy twierdzili, że wzrost barier w handlu artykułami rolniczymi między Stanami Zjednoczonymi a Wielką Brytanią amortyzował spadek brytyjskich taryf celnych na produkty przemysłowe. Według Departamentu Stanu, to dyplomacja francuska nakłoniła EWG do przyjęcia takiego stanowiska ${ }^{7}$. Amerykanie jednak nie chcieli ustąpić. Jeszcze w styczniu 1973 r. przygotowano listę produktów, których eksport miał się zmniejszyć ze względu na rozszerzenie. Domagali się obniżenia ceł na te towary lub inne, równie ważne dla gospodarki USA. Zażądali, by negocjacje na ten temat zakończyły się do września $1974 \mathrm{r}$. W przeciwnym wypadku grozili działaniami odwetowymi, zgodnie z prawem przysługującym im na podstawie GATT ${ }^{8}$. Tłumaczyli, że ustępstwa ze strony europejskiej były istotne dla administracji ze względu na naciski Kongresu - głównym problemem był wzrost ceł na cytrusy i tytoń. Od marca $1973 \mathrm{r}$. rozpoczęły się negocjacje na ten temat między EWG a Stanami Zjednoczonymi.

Departament Stanu przypomniał, że Wspólnoty zawarły preferencyjne układy handlowe z krajami EFTA: Austrią, Portugalią, Islandią, Szwecją i Szwajcarią, które weszły w życie od 1 stycznia 1973 r. Poza tym na akceptację rządów czekały układy z Finlandią i Norwegią. Te umowy przewidywały obniżenie ceł na produkty przemysłowe i całkowite ich wyeliminowanie do $1977 \mathrm{r}$. Planowano zawieranie podobnych układów z krajami afrykańskimi. Powodowało to bardziej dynamiczny, w porównaniu z USA, wzrost wymiany krajów europejskich (tabela 6.1).

Tabela 6.1. Wartość importu i eksportu EWG, EFTA i USA w latach 1962-1973 (w mld USD)

\begin{tabular}{|l|c|c|c|c|c|c|r|r|r|r|r|r|}
\hline \multirow{2}{*}{} & \multicolumn{2}{|c|}{1962} & \multicolumn{2}{c|}{1969} & \multicolumn{2}{c|}{1970} & \multicolumn{2}{c|}{1971} & \multicolumn{2}{c|}{1972} & \multicolumn{2}{c|}{1973} \\
\cline { 2 - 13 } & I & E & I & E & I & E & I & E & I & E & I & E \\
\hline EWG & 35,7 & 34,2 & 75,4 & 75,5 & 88,2 & 88,5 & 99,6 & 100,8 & 152,5 & 153,0 & 213,6 & 209,7 \\
\hline EFTA & 24,5 & 20,3 & 41,5 & 35,6 & 47,8 & 40,2 & 55,2 & 47,8 & 31,7 & 27,1 & 43,2 & 37,5 \\
\hline USA & 16,3 & 21,4 & 35,8 & 37,4 & 39,7 & 42,5 & 45,5 & 43,4 & 55,2 & 48,9 & 68,6 & 70,2 \\
\hline
\end{tabular}

E - eksport, I - import.

Źródło: Monthly Bulletin of Statistics, October 1969-1974, New York 1969-1974.

7 NARA, NPMS, NSC Insitutional "H" Files, Study Memorandums (1969-1974), raport Departamentu Stanu: przegląd najważniejszych kwestii w stosunkach amerykańsko-francuskich, 11 maja 1973, box H-195.

${ }^{8}$ NARA, Nixon Presidential Materials Project (NPMP), White House Central Files (WHCF), Subject Files, Countries (CO), Flanigan do Nixona, 28 stycznia 1973, box 31.

${ }^{9}$ NARA, NPMS, NSC Files, Country Files - Europe (France), Cooper i Hormats do Kissingera, 6 lipca 1973, box 680 . 
Dynamiczna ekspansja europejskiego handlu prowadziła do sytuacji, że Stany Zjednoczone pozostawały ważnym, ale nie dominującym partnerem. Udział tego państwa w wymianie krajów EWG, które handlowały przede wszystkim między sobą na preferencyjnych warunkach, systematycznie malał. W 1969 r. eksport 9 krajów europejskich do USA stanowił średnio 9,2\% ich wymiany, a w 1973 r. tylko 6,4\%. Import zmalał odpowiednio z 8,6\% do 7,1\% (por. tabela 6.2).

Tabela 6.2. Wymiana z USA jako procent całości wymiany państw członkowskich EWG

\begin{tabular}{|l|r|r|c|c|}
\hline \multirow{2}{*}{} & \multicolumn{2}{|c|}{1969} & \multicolumn{2}{c|}{1973} \\
\cline { 2 - 5 } & E & \multicolumn{1}{c|}{ I } & E & I \\
\hline Beluks & 6,9 & 7,6 & 5,6 & 5,6 \\
\hline Dania & 8,4 & 7,6 & 5,2 & 6,7 \\
\hline Francja & 5,4 & 8,5 & 4,7 & 8,3 \\
\hline RFN & 9,3 & 10,5 & 8,4 & 8,4 \\
\hline Irlandia & 10,6 & 8,8 & 9,9 & 6,8 \\
\hline Włochy & 10,8 & 11,3 & 8,5 & 10,0 \\
\hline Holandia & 4,5 & 9,7 & 3,5 & 8,9 \\
\hline Wielka Brytania & 12,3 & 13,3 & 11,8 & 9,9 \\
\hline
\end{tabular}

Źródło: Obliczenia własne na podstawie: Yearbook of International Trade Statistics, 1969, New York 1971, s. 86, 238, 284, 318, 407, 425, 587, 867; Yearbook of International Trade Statistics, 1974, New York 1975, s. 98, 221, 273, 303, 463, 416, $645,854$.

Preferencyjne układy handlowe nie tylko otwierały EWG dla towarów z krajów rozwijających się, lecz także dawały Wspólnocie nowe rynki zbytu. Wielka Brytania sprzeciwiała się takiej wzajemności, lecz Francja argumentowała, że był to krok w kierunku układu o wolnym handlu, a w takim przypadku reguły GATT nie wymagały przyznania rekompensat dla krajów trzecich. Jednak Amerykanie sprzeciwiali się takiej interpretacji. Twierdzono, że tylko europejskie kraje śródziemnomorskie oraz Izrael i Turcja miały szansę w dającej się przewidzieć przyszłości na zawarcie układu o wolnym handlu z EWG. Wskazywano, że Europejczycy będą zmuszali kraje słabiej rozwinięte do zakupu ich drogich produktów. Równie niepokojące dla Waszyngtonu było tworzenie przez EWG własnego bloku handlowego, który mógł znacznie osłabić amerykańską gospodarkę. EWG utrzymywała, że PUH były zgodne z GATT, więc krajom trzecim nie należały się żadne rekompensaty. Natomiast Stany Zjednoczone twierdziły, że były one dyskryminujące dla ich eksportu, więc były sprzeczne z regułami. Argumentowano, że nie były to układy o wolnym handlu, gdyż nie przewidywały liberalizacji handlu produktami rolnymi. Europejczycy ripostowali, że handel 
towarami innymi niż rolnicze stanowił 90\% wzajemnej wymiany, a w GATT został zapisany wymóg zwolnienia z ceł „przeważającej części” (substantially all) handlu.

3 stycznia 1973 r. Stany Zjednoczone przedstawiły w raporcie na forum GATT twarde stanowisko przeciwko układom zawartym przez EWG z Hiszpanią i Izraelem ${ }^{10}$. Żeby uniknać nieporozumień politycznych, Waszyngton nie zamierzał jednak wszczynać formalnej procedury w GATT, tylko prowadzić bezpośrednie rozmowy z EWG, by uzyskać korzystne dostosowania. Poza tym udowodnienie, że porozumienia te nie spełniały wymagań stawianych układom o wolnym handlu byłoby trudne, przez co wygranie sprawy przez Stany Zjednoczone - bardzo wątpliwe. Departament Stanu liczył, że podczas mających się rozpocząć we wrześniu wielostronnych rozmów handlowych, EWG i EFTA obniżą taryfy celne, co rozwiąże problem $^{11}$.

W lipcu 1973 r. William Eberle rozmawiał z doradcą Pompidou do spraw gospodarczych Michaelem Freyche. Eberle podkreślił, że Stany Zjednoczone przywiązywały dużą wagę do kwestii rekompensat za straty związane z rozszerzeniem EWG. Freyche odpowiedział, że tej sprawy nie powinno się poruszać w dobie kryzysu monetarnego. Zarzucał Amerykanom, że podkreślają szkodliwość dla swej gospodarki 3\% zmiany w cłach, podczas gdy od marca 1973 r. wartość USD spadła o 20\%, co w znacznie większym stopniu wpłynęło negatywnie na gospodarki europejskie. Przyjął argumenty Eberlego, że Kongres wywierał silną presję na zawarcie porozumienia w tej sprawie, lecz poinformował, że rząd francuski również działał pod coraz silniejszym naciskiem przedstawicieli sektora prywatnego, by podjął jakąś akcję rekompensującą spadek wartości dolara. Freyche ostrzegł, że jeśli rząd amerykański nie podejmie w tej sprawie żadnych działań do 26 lipca, kiedy miało się odbyć spotkanie Rady EWG, Europejczycy nie zgodzą się na żadne rekompensaty. Eberle jednak twierdził, że najpierw EWG powinna poczynić ustępstwa, gdyż poprawiłoby to nastroje w Kongresie. Freyche ironicznie replikował, że to Europejczykom przydałby się dowód na dobre intencje Stanów Zjednoczonych. Jednak poprosił o listę produktów, na które, według Amerykanów, miałyby być obniżone cła ${ }^{12}$.

Pod wpływem amerykańskich nacisków, Francja, najbardziej przeciwna rekompensatom, zmieniła zdanie. Na posiedzeniu RMWE 24 lipca $1973 \mathrm{r}$. jej przedstawiciele zgodzili się, że należy stworzyć listę koncesji i przedstawić do września ostateczną propozycję. Modyfikacja stanowiska Paryża nie tylko była spowodowana troską o dobre stosunki polityczne z USA, lecz także miała doprowadzić Amerykanów do ustępstw w rozmowach na temat reformy monetarnej $j^{13}$.

${ }^{10}$ NARA, NPMS, NSC Files, Subject Files: European Common Market, Hormats do Kissingera, 18 grudnia 1972, box 322 .

${ }^{11}$ NARA, NPMS, NSC Files, VIP Visits, analiza Departamentu Stanu relacji USA-RFN, 20 kwietnia 1973, box 916.

${ }^{12}$ NARA, NPMS, NSC Files, Country Files - Europe (France), Sonnenfeldt do Kissingera, 25 lipca 1973, box 679 .

${ }^{13}$ Ibidem. 


\subsection{Negocjacje monetarne i handlowe}

W styczniu i lutym 1973 r. znów zaczęły się, znane sprzed „szoku Nixona”, spekulacje przeciwko dolarowi. W styczniu tego roku został on zdewaluowany po raz drugi w ciągu dwóch lat, tym razem o 10\%. Do marca 1973 r. wszystkie główne waluty światowe miały podlegać płynnym kursom regulowanym przez rynek. W Stanach Zjednoczonych nastąpił wzrost inflacji i ogromny odpływ dolarów na rynki zagraniczne, a Komitet Dwudziestu wciąż nie mógł wypracować planu reformy systemu ${ }^{14}$. Krajom EWG trudno było utrzymać wspólną politykę płynnych kursów walutowych. Przywódcy Europy Zachodniej zastanawiali się nad jednoczesnym negocjowaniem o kwestiach handlu i międzynarodowego systemu monetarnego. Ich ścisły związek był oczywisty, jednak w stosunkach USA-Europa rozpatrywano je osobno.

9 lutego Brandt poinformował Nixona, że kryzys monetarny, związany z dewaluacją dolara, bardzo niekorzystnie wpłynął na sytuację w RFN. Podkreślił, że jego rząd, spełniając zobowiązania porozumienia smithsoniańskiego, dwa razy zgodził się na dewaluację DM. Deutsche Bank interweniował również w styczniu, dzięki czemu było możliwe utrzymanie kursu dolara wobec marki. Stwierdził, że rząd amerykański, doceniając tę lojalność, powinien jak najszybciej podjąć działania wspierające wartość swej waluty, bowiem gospodarka niemiecka ucierpiała na skutek napływu wielkich ilości zdewaluowanych dolarów ${ }^{15}$. Brandt wspomniał również o możliwości podjęcia przez EWG koordynacji polityki monetarnej.

Nixon w liście do Heatha poparł dążenie Europy do podjęcia wspólnych działań na polu monetarnym. Stwierdził jednak, że jakakolwiek akcja europejska mogąca mieć istotny wpływ na światowy system monetarny mogła być podjęta tylko po konsultacjach z Japonią i USA. Podobny list otrzymał od amerykańskiego prezydenta Brandt ${ }^{16}$.

9 marca 1973 r. zaplanowano rozmowy między Stanami Zjednoczonymi a EWG. Europejczycy chcieli bronić istniejących kursów wymiany walut twierdząc, że w przeciwnym wypadku nie będzie możliwe powstrzymanie spekulacji. Na spotkaniu ministrów finansów EWG Helmut Schmidt zaakceptował propozycję wspólnych płynnych kursów walutowych, choć początkowo był niechętny ponoszeniu kosztów utrzymywania przez RFN słabszych walut. Brytyjczycy zamierzali przystać na takie rozwiązanie pod warunkiem otrzymania pożyczki na utrzymanie kursu funta w przypadku zagrożenia jego stabilności. Włosi odrzucili propozycję, nie wykluczając przyjęcia jej w przyszłości. Minister finansów Francji Valéry Giscard d’Estaign nie sprzeciwił się, ale przekonywał, że dolar nie był już tak bardzo niedowartościowany, by zmieniać międzynarodową strukturę parytetów. Istniało zagrożenie,

\footnotetext{
${ }^{14}$ J. E. S p e r o, The Politics of International Economic Relations, New York 1999, s. 42-46.

${ }^{15}$ NARA, NPMS, NSC Files, Presidental Correspondence 1969-1974, Brandt do Nixona, 9 lutego 1973, box 753 .

${ }^{16}$ NARA, NPMP, NSC Files, HAK Office Files, Country Files-Europe, Nixon do Heatha, 3 marca 1973, box 53 .
} 
że zamieszanie na rynku walut spowoduje wprowadzenie przez niektóre rządy restrykcji handlowych. Ostatecznie podjęto decyzję o zorganizowaniu spotkania z przedstawicielami USA w Paryżu, by zapytać, czy chcieli bronić istniejących parytetów. Miało się ono odbyć w formule G10 plus EWG, co powodowało, że mogli w nim uczestniczyć ministrowie finansów wszystkich krajów „Dziewiątki” ${ }^{17}$.

W komunikacie prasowym z 9 marca 1973 r. stwierdzono, że ówczesny kryzys monetarny wynikał ze spekulacyjnego przepływu kapitału. Wobec tego wszystkie strony zgodziły się, że należy ustanowić nowy system kursów wymiany, a kolejne spotkanie miało się odbyć 16 marca ${ }^{18}$. W trakcie rozmów okazało się, że nie było możliwe uzgodnienie parytetów. Zdecydowano, że należy porzucić system sztywnych kursów walutowych i upłynnić je - ich wartość miał regulować rynek. Sekretarz skarbu George Shultz ogłosił, że Stany Zjednoczone nie były gotowe do podjęcia żadnej zasadniczej interwencji na rynkach walutowych, gdyż nie chciały podporządkowywać wewnętrznej polityki monetarnej celowi zażegnania światowego kryzysu walutowego. Oznaczało to, że Stany Zjednoczone nie zrobią nic by zwiększyć wartość USD oraz nie będą ograniczać jego odpływu za granicę ${ }^{19}$. Nie zamierzano też podwyższać stóp procentowych, by stymulować powrót do kraju eurodolarów. Głównym celem Amerykanów było doprowadzenie do sytuacji, w której dolar amerykański utrzymałby swą pozycję głównego międzynarodowego środka płatniczego. Shultz zażądał za to, by EWG przedstawiła jak najszybciej konkretne zobowiązania dotyczące redukcji ceł, szczególnie na artykuły rolnicze ${ }^{20}$.

12 marca 1973 r. RMWE zgodziła się wprowadzić plan płynnych kursów walut (strong currency float), który dotyczył sześciu państw: Belgii, Danii, Francji, RFN, Luksemburga, Holandii i nienależącej do Wspólnot Szwecji. Wielka Brytania, Irlandia i Włochy nie zdecydowały się na przyłączenie do wspólnej akcji. Sześć państw utworzyło nowy Fundusz Współpracy Walutowej (Monetary Cooperation Fund) i stosowały zasadę płynnych kursów w ograniczonym przedziale (wahania do 2,25\%). Była to decyzja przełomowa dla państw EWG. Jeszcze w 1971 r. Francja obawiała się, że wspólne upłynnienie walut uczyni z Europy strefę marki niemieckiej. Jednak konieczność utworzenia przeciwwagi dla poczynań Stanów Zjednoczonych oraz rewaluacja DM przekonała Paryż do przyłączenia się do Funduszu ${ }^{21}$.

17 NARA, NPMS, NSC Files, Country Files - Europe (Germany), ambasada w Bonn do Departamentu Stanu, 5 marca 1973, box 687.

${ }^{18}$ NARA, NPMS, NSC Files, VIP Visits, komunikat prasowy ze spotkania ministerialnego G10 + EWG, 9 marca 1973, box 953.

${ }^{19}$ Już w lutym 1973 r. Shultz ogłosił, że wszystkie te restrykcje będą zniesione do końca 1974 r. W praktyce zrobiono to w styczniu 1974 r. (E. R. G o o d m a n, The Fate of the Atlantic Community, New York 1975, s. 454).

${ }^{20}$ S. O. M o n y e, The International Business Blueprint, Oxford 1977, s. 125.

${ }^{21}$ S. H of f m a n n, Toward a Common European Foreign Policy?, [w:] The United States and Western Europe. Political, Economic and Strategic Perspectives, ed. W. F. Hanrieder, Cambridge, Mass. 1974, s. 93. 
Nixon był zaniepokojony wspólną europejską akcją. W tajnym memorandum do Kissingera pisał, że odkąd w Europie Zachodniej dominowały rządy lewicowe, nastawienie tych państw stawało się coraz bardziej antyamerykańskie. Prezydent obawiał się, że zintegrowana Europa stanie się niezależna od USA, co doprowadzi do atrofii sojuszu. Zalecał, żeby w tej sytuacji polityczne aspekty przeważały nad ekonomicznymi w dobie negocjacji monetarnych i handlowych. Przewidywał wprawdzie opór departamentów gospodarczych, lecz zawarcie kompromisu uważał za konieczne ${ }^{22}$.

Na forum spotkania ministerialnego G10 16 marca 1973 r. zgodzono się, że oficjalna interwencja na rynkach wymiany walut może być dobrym środkiem uniknięcia kolejnego kryzysu monetarnego - każdy rząd mógł ją zastosować z własnej inicjatywy. Przedstawiciele Stanów Zjednoczonych zapowiedzieli, że stopniowo zniosą kontrolę nad przepływem kapitału do końca 1974 r. Europejczycy nie byli zadowoleni z tej decyzji, gdyż oznaczało to kolejny wzrost ilości eurodolarów ${ }^{23}$. Jednak europejskie rynki wymiany, zamknięte 1 marca ze względu na kryzys, zostały otwarte 24 marca. Za formalny koniec obowiązywania systemu z Bretton Woods uważa się 19 marca 1973 r., kiedy to Stany Zjednoczone, Wielka Brytania, Japonia, Włochy, Kanada i Szwajcaria zrezygnowały z utrzymania stałych kursów swoich walut. Trwały wciąż prace nad ustaleniem zasad nowego systemu ${ }^{24}$.

Wydarzeniem dającym nadzieję na współpracę w tworzeniu nowego systemu monetarnego było spotkanie w kwietniu 1973 r. w bibliotece Białego Domu czterech ministrów finansów. Sekretarz skarbu, Shultz, zaprosił swoich odpowiedników z RFN (Helmuta Schmidta), Francji (Giscarda d'Estaign) i Wielkiej Brytanii (Anthony'ego Barbera) na nieformalne spotkanie. Politycy omawiali skutki załamania się sztywnych kursów wymiany i przedstawili swoje poglądy na temat kształtu nowego systemu. Tak zwana "Grupa Biblioteczna” (Library Group) postanowiła spotykać się regularnie ${ }^{25}$. Zaletą tych spotkań była możliwość swobodnej wymiany poglądów - ministrowie nie ustalali planu rozmów, nie byli też związani wytycznymi rządów. Pozwalało to na budowanie, tak istotnego w negocjacjach, wzajemnego zaufania.

${ }^{22}$ Foreign Relations of the United States (FRUS), 1969-1976, vol. 31: Foreign Economic Policy 1973-1976, Washington D.C. 2010, Nixon do Kissingera, 10 marca 1973, dok. 31, dostępne także przez: www.state.gov/r/pa/ho/frus/nixon.

${ }^{23}$ NARA, NPMS, NSC Files, VIP Visits, komunikat prasowy ze spotkania ministerialnego G10, 16 marca 1973, box 953.

${ }^{24}$ FRUS, 1969-1976, vol. 31, Sonnenfeldt do Kissingera, 13 marca 1973, dok. 32; na temat stanowiska amerykańskiego: ibidem, Shultz do Nixona, bez daty [maj 1973], dok. 39.

25 Podczas corocznego spotkania MFW we wrześniu 1973 r. w Nairobi, minister finansów Japonii - Kiichi Aichi - zaprosił uczestników waszyngtońskiego spotkania na rozmowy do japońskiej ambasady. Tym samym Japonia dołączyła do „Grupy Bibliotecznej”, znanej też po nazwą G5 (R. K. S c h a e f f e r, Understanding Globalization: the Social Consequences of Political, Economic, and Environmental Change, Lanham 1997, s. 59). 
W raporcie Departamentu Stanu dotyczącym relacji USA-RFN z kwietnia 1973 r. poruszono kwestię stanowiska RFN wobec reformy monetarnej. Ustalenie europejskich płynnych kursów było oceniane jako zwycięstwo Niemiec. Korygująca rewaluacja DM stanowiła niewielką cenę za zgodę na upłynnienie, gdyż w przeciwnym wypadku presja spekulacyjna na DM spowodowałaby bardzo negatywne skutki finansowe. RFN dążyła do utrzymania płynnych kursów, dopóki amerykański bilans płatniczy nie wykaże cech trwałej stabilności. Rząd zachodnioniemiecki sprzeciwiał się też udziałowi Wielkiej Brytanii w tym przedsięwzięciu, dopóki ten kraj nie ustabilizuje sytuacji gospodarczej. Brandt był również pod silną presją Francji, która dążyła do możliwie najszybszego powrotu do sztywnych kursów wymiany. RFN stała na stanowisku, że warunkami stabilnego systemu monetarnego były skuteczne środki kontroli międzynarodowej płynności finansowej (w tym celu należało uznać SDR-y za podstawową jednostkę rezerwową) i likwidacja przez Stany Zjednoczone deficytu bilansu płatniczego ${ }^{26}$.

W sprawie reformy monetarnej wciąż toczyły się negocjacje w ramach Komitetu Dwudziestu. Choć istniała zgoda co do najogólniejszych celów, wystąpiły zasadnicze różnice między stanowiskiem amerykańskim i francuskim. Francja postulowała wzmocnienie roli złota w systemie monetarnym, czemu sprzeciwiały się USA ze względu na ograniczone zasoby i niestabilną wartość tego kruszca na rynku. Argumentowano, że system nawet częściowo oparty na złocie zmniejszy znaczenie SDR-ów i przyniesie korzyści Francuzom, którzy byli największymi posiadaczami złota poza USA. Przedstawiciele francuscy stali na stanowisku, że niestabilność systemu wynikała głównie z jego oparcia na walutach rezerwowych, szczególnie na USD, gdyż Stany Zjednoczone prowadziły nieodpowiedzialną politykę monetarną. Postulowali zniesienie „uprzywilejowanej” roli dolara jako waluty rezerwowej, co pozwalało Stanom Zjednoczonym utrzymywać deficyt bilansu płatniczego. Amerykanie odrzucając ten zarzut argumentowali, że główną wadą systemu była niemożność podjęcia środków dostosowawczych w razie kryzysu. Ograniczenia dotyczyły głównie Stanów Zjednoczonych, właśnie ze względu na kluczową rolę dolara. Postulowali prawo do korekt kursów zarówno dla krajów z deficytem, jak i z nadwyżką BOP. Francja skupiała się na ustaleniu nowych mechanizmów monetarnych, tzn. warunków odbudowania wymienialności i technik stabilizowania nierównowagi płatniczej, natomiast Amerykanie chcieli zrewidować podstawy całego systemu gospodarki światowej, nie tylko struktury monetarnej, lecz także warunków handl ${ }^{27}$. Francuska strategia, która polegała na mocnym przywiązaniu do stałych kursów wymiany, była, zdaniem Amerykanów, błędna, gdyż w przeszłości uniemożliwiała równoważenie bilansów płatniczych, przyczyniając się do powracających kryzysów i niestabilności monetarnej.

\footnotetext{
${ }^{26}$ NARA, NPMS, NSC Files, VIP Visits, analiza Departamentu Stanu na temat relacji USA-RFN, 20 kwietnia 1973, box 916.

${ }^{27}$ NARA, NPMS, NSC Insitutional "H" Files, Senior Review Group Meetings, streszczenie raportu Departamentu Stanu na temat relacji amerykańsko-francuskich, 25 kwietnia 1973, box H-041.
} 
Od stycznia 1973 r. Komitet Przygotowawczy GATT pracował nad porozumieniem dotyczącym celów negocjacyjnych i procedur, które miały zostać zastosowane podczas wielostronnych rozmów handlowych we wrześniu lub w październiku. EWG, która była w trakcie renegocjacji ceł z krajami trzecimi, planowała przygotowanie wspólnego stanowiska do lipca $1973 \mathrm{r}$. Jean Monnet uważał, że EWG mogła być silnym partnerem w rozmowach handlowych i monetarnych tylko wtedy, kiedy zacznie mówić jednym głosem. Francuski polityk opowiadał się za powstaniem stałego europejsko-amerykańskiego ciała konsultacyjnego argumentując, że rozwiązywanie problemów gospodarczych potrwa kilka lat ${ }^{28}$.

Według NSC, wypracowanie wspólnej strategii mogło okazać się dla Europejczyków niezwykle trudne. Najważniejszą kwestią miały być sprawy rolnictwa. Oceniając perspektywy porozumienia, NSC zauważyła, że Francja była zdeterminowana, żeby utrzymać CAP w niezmiennym kształcie. Ostrzegano, że jeśli w związku z tym sukcesywnie będzie się zwiększać samowystarczalność EWG, przyniesie to wielkie straty Stanom Zjednoczonym, a także innym krajom eksportującym produkty rolnicze. Dlatego przyjęcie przez Europę stanowiska francuskiego mogło storpedować całość negocjacji handlowych. Stany Zjednoczone powinny domagać się koncesji na handel produktami rolnymi, szczególnie zbożem. Planowano również dalszą redukcję ceł. Według raportu GATT, średnie cła na produkty przemysłowe wynosiły dla EWG i Kanady 7\%, dla USA - 7,5\%, a dla Japonii - 9,8\%. EWG chciała ich obniżenia, natomiast Stany Zjednoczone proponowały jednolitą redukcję procentową ${ }^{29}$. Po raz kolejny najbardziej odmienna od planów amerykańskich była opinia Francji. Paryż stał na stanowisku, że wspólna taryfa zewnętrzna była bardzo ważnym czynnikiem cementującym EWG, a także środkiem ochrony dla niektórych francuskich przedsiębiorstw, w związku z tym chciano uniknąć znacznych redukcji. NSC oceniała, że mogły one dojść do skutku tylko w przypadku, gdy administracja amerykańska otrzyma uprawnienia od Kongresu, by wprowadzić w życie wszystkie wynegocjowane obniżki ${ }^{30}$.

Podczas spotkania z ambasadorem USA w Paryżu Johnem Irwinem w kwietniu 1973 r. minister spraw zagranicznych Francji, Michel Jobert, niepokoił się niektórymi aspektami proponowanej ustawy handlowej. Szczególnie kontrowersyjny był zapis, że prezydent może podjąć środki przeciwko krajowi, który dyskryminuje dostęp amerykańskich produktów na swój rynek czy dopuszcza do dokonywania korekt deficytu bilansu płatniczego poprzez czasowe ograniczenia importu. Irwin argumentował, że ponieważ w ustawie miały być zapisane szerokie uprawnienia

${ }^{28}$ C. L. S u l z b e rg e r, op. cit.

${ }^{29}$ S. D. C o h e n, The European Community and the General Agreement on Tariffs and Trade, Washington 1975, s. 23.

${ }^{30}$ NARA, NPMS, NSC Insitutional "H" Files, Study Memorandums (1969-1974), NSSM 166, 17 stycznia 1973, box H-195. 
negocjacyjne dla prezydenta, trzeba było również uwzględnić zabezpieczenia interesów Stanów Zjednoczonych ${ }^{31}$.

W analizie relacji amerykańsko-zachodnioniemieckich przygotowanej przez Departament Stanu stwierdzono, że RFN popiera liberalizację handlu i jej rola będzie kluczowa w spełnieniu głównych amerykańskich postulatów. Zauważono, że wszystko będzie zależało od układu sił w Europie w momencie rozpoczęcia rozmów. Za największy problem uznano utrzymywanie w ramach Wspólnej Polityki Rolnej wysokich cen, przy jednoczesnym braku kontroli produkcji, co zwiększało podaż i obniżało konsumpcję. Było to poważne zagrożenie dla amerykańskiego eksportu zarówno na rynku europejskim, jak i na pozostałych rynkach. W RFN narastała krytyka CAP, gdyż państwo to ponosiło największe koszty z nią związane. Jednak duże wpływy polityczne lobby rolniczego w koalicyjnym rządzie sprawiały, że oficjalnie RFN była zdecydowanym adwokatem utrzymania wysokich cen. Dyplomacji amerykańskiej udało się wprawdzie przekonać EWG do włączenia do planu wielostronnych negocjacji kwestii liberalizacji wymiany produktów rolniczych, jednak szanse zmiany polityki EWG były znikome. Poza tym Europa zawarła preferencyjne układy handlowe z krajami afrykańskimi ( $w$ ramach konwencji z Aruszy i Jaunde ${ }^{32}$ ), a w 1975 r. planowała je rozszerzyć na afrykańskie i karaibskie kraje brytyjskiego Commonwealthu. Kwestia była bardzo drażliwa: z jednej strony Europejczycy twierdzili, że działają w ramach pomocy rozwojowej, a z drugiej - w amerykańskim Kongresie pojawiały się opinie, że EWG tworzyła własny blok handlowy w opozycji do USA ${ }^{33}$.

W raporcie Amerykańskiej Agencji Informacyjnej zauważono, że opinia publiczna po obu stronach Atlantyku postrzegała stosunki USA-Europa jako coraz mniej przyjazne. Było to spowodowane mniejszym poczuciem zagrożenia ze strony ZSRR i dominacją kwestii handlowych i monetarnych. W raporcie Grupy Wysokiego Szczebla, powołanej przez OECD, obradującej pod przewodnictwem Jeana Reya ${ }^{34}$ stwierdzono, że te problemy powinno się rozpatrywać z perspektywy wzajemnych współzależności na innych polach, a podczas negocjacji brać pod uwagę również aspekt polityczny. Ostrzegano, że w przeciwnym wypadku groził upadek systemu liberalnej gospodarki i wzrost protekcjonizmu. Implikowało to również katastrofalne

${ }^{31}$ NARA, NPMS, NSC Files, Country Files - Europe (France), Irwin do Departamentu Stanu, 13 kwietnia 1973, box 679 .

32 Pierwsza konwencja z Jaunde między państwami członkowskimi EWG a 18 państwami afrykańskimi, weszła w życie 1 czerwca 1964 r. i obowiązywała do końca 1969 r. Druga - z 1 stycznia 1971 r. miała wygasnąć z końcem 1975 r. Obie strony obniżyły cła we wzajemnej wymianie. Konwencja z Aruszy to porozumienie między państwami EWG a Kenią, Ugandą i Tanzanią, które weszło w życie w $1969 \mathrm{r}$.

${ }^{33}$ NARA, NPMS, NSC Files, VIP Visits, analiza Departamentu Stanu na temat relacji USA-RFN, 20 kwietnia 1973, box 916.

${ }^{34}$ Jean Rey był belgijskim politykiem. W latach 1967-1970 pełnił funkcję przewodniczącego Komisji Wspólnot Europejskich. 
konsekwencje polityczne - obawiano się nawet powrotu do izolacjonizmu. W tym kontekście pozytywnie przyjęto oświadczenie Rogersa z 15 lutego 1973 r., który ogłosił, że nie istniały powiązania między wspólną obroną a kwestiami handlowymi i monetarnymi sugerując, że Amerykanie nie będą grozić podczas negocjacji wycofaniem sił z Europy.

Główną część raportu stanowiła ocena perspektyw osiągnięcia porozumienia w kwestiach monetarnych i handlowych. Stwierdzono, że doraźne środki niwelujące skutki kryzysu były niewystarczające - konieczna okazała się zmiana całego systemu, gdyż praktyka pokazała, że kryzysy monetarne powtarzały się w niewielkich odstępach czasu. Nie można też było myśleć w kategoriach krótkoterminowych interesów narodowych, gdyż mogło to doprowadzić do poważnych konfliktów. Niepokojono się rosnącą siłą lobby protekcjonistycznego w Stanach Zjednoczonych. Za dowód tego stanu rzeczy uznano zastrzeżenie w projekcje ustawy handlowej prawa obrony gospodarki amerykańskiej przed działaniami prowadzącymi do deficytu handlowego, z możliwością podwyższania ceł. Wzrost napięcia w stosunkach transatlantyckich mógł również spowodować opór wobec nowych amerykańskich inwestycji w Europie, a z drugiej strony zastrzeżenia amerykańskie wobec polityki EWG. Choć były one już wcześniej wysuwane, jednak istotną zmianą były żądania rekompensat za dyskryminację produktów z USA. Za pozytywny krok uznano to, że podczas negocjacji handlowych EWG zobowiązała się do wypracowania wspólnego stanowiska do 1 lipca 1973 r. Pilniejszą sprawą była jednak reforma monetarna, w sprawie której rozmowy toczyły się na forum G10 i Komitetu Dwudziestu. W tym przypadku było mniej prawdopodobne, że Europejczycy osiągną konsensus ${ }^{35}$.

W pierwszym rocznym raporcie CIEP z marca 1973 r. podkreślono, że ponieważ gospodarka amerykańska w coraz większym stopniu opierała się na usługach, tradycyjne sektory (przemysł i rolnictwo) zaczęły być coraz bardziej zależne od eksportu. Wzrosły też BIZ: z 32 mld USD w 1960 r. do 86 mld dol. w 1971 r. Dewaluacja dolara w 1971 i 1973 r. także zwiększyła inwestycje na terenie Stanów Zjednoczonych ze względu na spadek cen amerykańskich akcji ${ }^{36}$. Zauważono, że zaangażowanie w Wietnamie negatywnie wpłynęło na handel zagraniczny, a „szok Nixona” był ewidentnym znakiem zmniejszenia odpowiedzialności Stanów Zjednoczonych za światowy system gospodarczy ${ }^{37}$.

Zwrócono uwagę, że Europejczycy byli bardziej skłonni do stosowania praktyk nieuczciwej konkurencji. Jako przykład podano trudności przemysłu

${ }^{35}$ NARA, NPMS, NSC Files, Country Files - Europe (France), raport Reya dla OECD o politycznych perspektywach dla międzynarodowego handlu i relacji gospodarczych, 12 marca 1973, box 679.

${ }^{36}$ E. R. G o o d m a n, op. cit., s. 457.

${ }^{37} \mathrm{Z}$ niepokojem odnotowano też wzrost nastrojów protekcjonistycznych wśród liderów związków zawodowych - tylko $21 \%$ z nich opowiadało się za dalszym znoszeniem barier handlowych, co było sprzeczne z opinią przedsiębiorców, wśród których 81\% popierało zwiększenie swobody wymiany (International Economic Relations of the Western World, 1959-1971, ed. A. Shonfield, vol. 1: Politics and Trade, London 1976, s. 58-60). 
stalowego po obu stronach Atlantyku w latach 70. Rząd USA nie udzielił wsparcia rodzimym przedsiębiorcom, natomiast Europejczycy wprowadzili regionalną pomoc rządową dla obszarów dotkniętych zamykaniem fabryk, regulację importu, ograniczenia produkcji itp. Amerykanie postrzegali to jako nieuczciwe subsydia dla europejskiego eksportu i zaczęli myśleć o ochronie własnego przemysłu stalowego, co podsycało napięcie. Obawiano się, że taka rywalizacja mogła dotknąć również inne gałęzie produkcji, co uderzyłoby w interesy europejskie i amerykańskie. Zwrócono także uwagę na ryzyko pogorszenia się stosunków politycznych na tym tle ${ }^{38}$.

Po 1958 r., kiedy waluty europejskie stały się wymienialne, wiele amerykańskich banków przeniosło się za granicę. W $1960 \mathrm{r}$. aktywa filii zagranicznych stanowiły tylko 1,3\% całości ich aktywów, w 1973 r. wskaźnik ten wzrósł do 14,2\%. Banki chciały nadal zawierać korzystne umowy zagraniczne, ale wymagały, aby rząd je chronił przed niekorzystnym rozwojem wydarzeń w goszczącym je kraju ${ }^{39}$.

Ponieważ zdanie Paryża było bardzo istotne w kształtowaniu stanowiska całej EWG, Amerykanie priorytetowo traktowali kwestię prowadzenia wstępnych rozmów z francuskimi politykami. 23 kwietnia Grupa Robocza NSC przygotowała wytyczne dla polityki amerykańskiej wobec Francji. Rozważano ewentualne połączenie kwestii bezpieczeństwa i spraw ekonomicznych. Zauważono, że Francji zależy na rozwijaniu współpracy militarnej z USA, szczególnie na polu nuklearnym, proponowano więc, by uwarunkować ją spełnieniem amerykańskich postulatów na polu gospodarczym. Podkreślono konieczność dokładnego zdefiniowania amerykańskich postulatów - departamenty ekonomiczne powinny sprecyzować, jakich koncesji należy się domagać ${ }^{40}$.

Tymczasem w kwietniu 1973 r. Nixon podjął kolejną próbę zwiększenia uprawnień prezydenta w negocjowaniu porozumień handlowych. Zaproponował uchwalenie ustawy regulującej te kwestie (Trade Reform Act). „Potrzebujemy potwierdzenia od nowa naszych wspólnych celów, by negocjacjom ekonomicznym nadać kierunek polityczny"41 - stwierdził prezydent. Każdy partner, nie wyłączając Stanów Zjednoczonych, powinien zrezygnować z realizacji jakiegoś celu dla wspólnego dobra. Nixon wielokrotnie powtarzał, że rozbieżności ekonomiczne są destrukcyjne, bo tworzą napięcia polityczne, mogą prowadzić do osłabienia więzów bezpieczeństwa i niszczą wzajemne zaufanie - podstawę współpracy, na której

${ }^{38}$ Ibidem, s. 155.

${ }^{39}$ G. F. Trevert o n, Making the Alliance Work. The United States and Western Europe, Ithaca 1985, s. 131.

${ }^{40}$ NARA, NPMS, NSC Insitutional "H" Files, Senior Review Group Meetings, Sonnenfeldt do Kissingera, 23 kwietnia 1973, box H-041.

41 The Public Papers of the Presidents of the United States: Richard Nixon (PPP), vol. 5: 1973, Washington D.C. 1975, czwarty roczny raport dla Kongresu na temat polityki zagranicznej USA, 3 maja 1973, dok. 141, dostępne także przez: http://www.nixonfoundation.org. 
opiera się porządek wolnego świata ${ }^{42}$. Prezydent dostrzegł współzależność kompromisu w kwestiach gospodarczych i dalszej obecności silnego kontyngentu wojsk amerykańskich w Europie.

Według relacji Brenta Scowcrofta, doradcy prezydenta do spraw militarnych, w Europie odebrano to jako ostrzeżenie, że kraje europejskie stracą ochronę militarną USA, jeśli nie ugną się pod amerykańską presją. Taka opinia ukazała się we francuskim „Le Figaro”. Londyński „Times” uznał to przemówienie za „podstawowy tekst dla zrozumienia amerykańskiego sposobu myślenia”. „Frankfurter Allgemeine Zeitung" komentował, że był to rzadki przykład szczerości, gdyż Nixon wcześniej nigdy nie wyraził w tak dosadny sposób niezadowolenia ze stanu stosunków amerykańsko-europejskich ${ }^{43}$.

\subsection{Koncepcja instytucjonalizacji współpracy transatlantyckiej}

Stosunki transatlantyckie podczas rządów Richarda Nixona cechowała daleko posunięta nieufność. Coraz trudniej było obu stronom sformułować wspólną strategię w polityce zagranicznej. W stolicach europejskich odnoszono wrażenie, że paradoksalnie Stanom Zjednoczonym łatwiej było osiągać porozumienie z państwami z przeciwnego obozu - ZSRR czy ChRL - niż z tradycyjnymi sojusznikami.

W Waszyngtonie coraz częściej wysuwano propozycje instytucjonalizacji relacji transatlantyckich. Robert Hormats po podróży do stolic europejskich w grudniu 1972 r. sformułował wniosek, że Europa była w okresie poważnych zmian i niepewności co do swej przyszłości. Stwierdził, że poczynania państw europejskich w dziedzinie gospodarki zostały podporządkowane polityce wewnętrznej i zagranicznej. Działo się tak, ponieważ decyzje ekonomiczne były podejmowane na najwyższym szczeblu, więc czynnik polityczny zawsze brano pod uwagę. Zauważył, że obie strony powinny być gotowe do ustępstw - Amerykanie potwierdzając zaangażowanie w europejską obronę i zaprzestając gróźb wycofania wojsk, a Europejczycy zapewniając respektowanie amerykańskich interesów gospodarczych. Hormats radził, aby podobną umowę starać się zawrzeć z Japonią. Uważał, że Nixon powinien ogłosić program zacieśnienia sojuszu atlantyckiego wspólnie z Heathem. Propozycja miała wyrażać silne poparcie Stanów Zjednoczonych dla pogłębiania integracji europejskiej. Według Hormatsa, to wytrąciłoby argument z ręki tym państwom, które twierdziły, że Stany Zjednoczone dążyły do rozbicia europejskiej jedności ${ }^{44}$. Obie propozycje wydają się nieco naiwne - było wątpliwe, by brytyjski premier zaraz

\footnotetext{
${ }^{42}$ Ibidem.

${ }^{43}$ NARA, NPMS, NSC Files, Subject Files: Foreign Policy, Scowcroft do Nixona, 5 maja 1973, box 329

${ }^{44}$ NARA, NPMS, NSC Files, Subject Files: European Common Market, Hormats do Kissingera, 18 grudnia 1972, box 322 .
} 
po przystąpieniu swego kraju do Wspólnot odegrał rolę rzecznika amerykańskich interesów. Także werbalne poparcie integracji nie mogło stanowić przekonującego argumentu dla Europejczyków, gdyż formalnie USA przez cały okres powojenny prezentowały takie stanowisko.

Rozmowy z EWG jako całością były utrudnione ze względu na jej skomplikowaną strukturę i brak koordynacji polityki zagranicznej. Eksperci NSC uważali za mało prawdopodobne, że Wspólnota zgodzi się na utworzenie forum dyskusji z USA. Przeciwko temu opowiadali się szczególnie Francuzi, obawiając się ograniczenia europejskiej niezależności. Chociaż przedstawiciele Stanów Zjednoczonych prowadzili regularne, techniczne konsultacje z Komisją Europejską, utworzenie stałego mechanizmu postrzegano jako próbę usankcjonowania dominacji Amerykanów ${ }^{45}$.

Podczas rozmów sondażowych w kwestii sformalizowania współpracy transatlantyckiej ujawniła się nieufność sojuszników. Relacjonując Sonnenfeldtowi rozmowę z Pompidou, Brandt zauważył, że o ile RFN i Francja zgadzają się w wielu kwestiach dotyczących współpracy w Europie, Pompidou był zdecydowanie przeciwny instytucjonalizacji relacji Stany Zjednoczone - Europa Zachodnia. Brandt zresztą również był pod polityczną presją wewnętrznej opozycji ${ }^{46}$. Kissinger odbył rozmowę z Jacquesem Kosciuszko-Morizetem, francuskim ambasadorem w Waszyngtonie, 29 marca 1973 r. Tłumaczył, że USA pragnęły silnej Europy i nie zamierzały ograniczać samodzielności polityki zagranicznej żadnego kraju. Francuski ambasador przekazał, że Pompidou zaakceptował koncepcję wielostronnego spotkania na szczycie. Kissinger, chcąc podkreślić wagę relacji amerykańsko-francuskich zaproponował, żeby najpierw zorganizować bilateralne spotkanie Nixon-Pompidou ${ }^{47}$.

Nixon próbował zachęcać Heatha do odbudowy specjalnych relacji po wejściu Wielkiej Brytanii do Wspólnot. Na spotkaniu w Camp David w lutym 1973 r. zaproponował stworzenie amerykańsko-brytyjskiej grupy roboczej i zwołanie specjalnego szczytu liderów państw uprzemysłowionych. Heath jednak widział możliwość przyjęcia propozycji Nixona dopiero w momencie, gdy Europa Zachodnia zintegruje się politycznie i będzie miała możliwość przedstawienia jednolitego stanowiska. Uważał, że w rozmowach bilateralnych z USA żaden kraj europejski nie mógł być równorzędnym partnerem. Zresztą brytyjski premier już wcześniej wyrażał zdanie, że istnieje wystarczająco dużo instytucji współpracy transatlantyckiej: NATO, OECD, MFW, GATT i nie ma sensu tworzyć nowych ${ }^{48}$.

\footnotetext{
${ }^{45}$ NARA, NPMS, NSC Insitutional "H" Files, Study Memorandums (1969-1974), NSSM 166, 17 stycznia 1973, box H-195

${ }^{46}$ NARA, NPMS, NSC Files, Country Files - Europe (Germany), Sonnenfeldt do Kissingera, 30 stycznia 1973, box 688.

${ }^{47}$ H. K i s s in g e r, The Years of Upheaval, Boston 1982, s. 141-149.

${ }^{48}$ NARA, NPMP, WHCF, Subject Files, Countries (CO), Flanigan do Nixona, 28 stycznia 1973, box 31.
} 
Mimo dość chłodnego stosunku Europejczyków do koncepcji wzmocnienia sojuszu, administracja amerykańska zdecydowała się na wykonanie gestu świadczącego o wzroście pozycji EWG na liście priorytetów polityki zagranicznej USA. 23 kwietnia 1973 r. Henry Kissinger, przemawiając do wydawców z Associated Press, zaproponował uzgodnienie nowych zasad współpracy między USA a Europą - „nowej Karty Atlantyckiej”, ogłaszając rok 1973 „rokiem Europy”. W wystąpieniu skrytykował brak konsultacji w zmieniającej się sytuacji geopolitycznej. Stwierdził, że państwa Europy Zachodniej, które osiągnęły stabilność gospodarczą i polityczną, skupiły się na realizacji własnych interesów, krytykując Stany Zjednoczone za odmawianie im prawa do prowadzenia niezależnej polityki. Kissinger zwrócił uwagę, że również społeczeństwo amerykańskie, szczególnie po doświadczeniu wojny wietnamskiej, kwestionowało branie przez USA odpowiedzialności za losy świata bez wsparcia ze strony sojuszników. Zdaniem Kissingera, brak uzgodnienia celów w kluczowych dziedzinach mógł prowadzić do atrofii sojuszu, a nawet do klęski Zachodu w zimnowojennych zmaganiach. Wyartykułował również najważniejsze problemy we wzajemnych relacjach, za które uznał nadmierną rywalizację gospodarczą, brak ważnych decyzji we wspólnej polityce obronnej oraz niewystarczającą koordynację dyplomacji. Jego zdaniem głównym celem zacieśnienia stosunków powinno być ustalenie równowagi między interesami poszczególnych krajów a dążeniami wspólnoty atlantyckiej.

Kissinger zauważył konieczność wzięcia przez państwa europejskie większej odpowiedzialności za koszty obrony. Zadeklarował przy tym, że Stany Zjednoczone nie zamierzały wycofać sił militarnych z Europy, a jedynie zmniejszyć koszty ich obecności. Wyraził obawy związane z kresem niekwestionowanej przewagi militarnej Zachodu i niedopracowaniem strategii elastycznego reagowania. W tych kwestiach powinny rozpocząć się intensywne rozmowy na forum NATO. Zauważył niebezpieczeństwo dążeń do jednostronnych redukcji sił zbrojnych przez państwa europejskie, wynikające ze zmniejszenia napięcia w stosunkach Wschód-Zachód. Uważał, że nie można było do tego dopuścić, a wszelkie decyzje w dziedzinie obronności powinny być konsultowane z sojusznikami.

Kissinger był rozczarowany, że wspierana przez Waszyngton integracja europejska oddalała Stary Kontynent od Ameryki. Mimo że apelował o dalsze rozszerzenie EWG i pogłębianie integracji chciał, aby funkcjonowanie Wspólnot stało się częścią partnerstwa atlantyckiego. Krytykował protekcjonistyczną politykę rolną EWG, która eliminowała produkty amerykańskie z europejskiego rynku. Mówiąc o negocjacjach handlowych planowanych na 1973 r., zaproponował udział nie tylko ekspertów, lecz także polityków rozumiejących pozaekonomiczny wymiar relacji transatlantyckich. Tę wypowiedź poparł stwierdzeniem, że niekontrolowana rywalizacja gospodarcza mogła zniszczyć sojusz. Dał przez to wyraźnie do zrozumienia, że Europejczycy będą musieli w większym stopniu brać pod uwagę interes USA i poczynić ustępstwa, jeśli nie chcą sprowokować poważnych napięć politycznych. 
„Europejska autonomia nie jest ostatecznym celem”49 - powiedział. Wyraźnie akcentował wpływ stosunków gospodarczych na relacje transatlantyckie podkreślając, że „kwestie polityczne, militarne i ekonomiczne w relacjach atlantyckich są ze sobą sprzężone (linked) przez rzeczywiste wydarzenia; nie jest to związane z naszym wyborem, nie jest to nasza taktyka mająca na celu uzyskania korzyści na jednym z tych obszarów kosztem innego" ${ }^{\prime 50}$.

Koncepcja Kissingera nawiązywała do pomysłu Kennedy'ego utworzenia Wspólnoty Atlantyckiej. W jej skład wchodzić miały Stany Zjednoczone, Kanada, Europa Zachodnia i Japonia. Udział Tokio mógłby tonować napięte stosunki między Waszyngtonem i Brukselą ${ }^{51}$. „Nowa Karta Atlantycka” w założeniu miała koordynować politykę na dwóch najważniejszych obszarach: bezpieczeństwa i handlu. Europejczycy byli niechętni perspektywie łączenia tych dwóch kwestii. Mogło to doprowadzić do negocjowania ich jednocześnie. Wobec uzależnienia państw europejskich od amerykańskiej obrony, musieliby godzić się na niekorzystne układy handlowe. Uważali, że oznaczało to zmianę zasad sojuszu z USA ${ }^{52}$, jednak nie mogli zmienić faktu, że polityka gospodarcza stała się ważnym elementem polityki zagranicznej, ale i obronnej ${ }^{53}$.

Cele wystąpienia były długofalowe. Po pierwsze, miało ono zainicjować koordynację polityki zagranicznej Zachodu. Europa chciała występować w roli niezależnego aktora na arenie międzynarodowej. Idąc w ślady dyplomacji amerykańskiej, państwa Starego Kontynentu nawiązały stosunki z Chinami, a RFN w krótkim czasie stała się trzecim partnerem handlowym Państwa Środka ${ }^{54}$. Amerykanie nie chcieli, żeby polityka europejska wymknęła się im spod kontroli, a sojusznicy wychodzili z niezależnymi inicjatywami, szczególnie w kierunku Moskwy. Kissinger uważał, że konsultowanie wszelkich decyzji między USA, pozostałymi członkami NATO i Japonią przyczyni się do konsolidacji obozu zachodniego. Ważnym elementem przemówienia było kolejne wezwanie Europy do zwiększenia sił konwencjonalnych, umożliwiających adekwatną reakcję na ewentualną agresję ZSRR. Wydawało się mało prawdopodobne, że w odpowiedzi na konwencjonalny atak Stany Zjednoczone użyją broni nuklearnej ${ }^{55}$.

${ }^{49}$ H. A. K i s s i n g e r, przemówienie wygłoszone w Nowym Jorku, 23 kwietnia 1973, dostępne przez: http://www.ena.lu/address_given_henry_kissinger_new_york_23_april_1973-2-9561.pdf.

${ }^{50}$ Ibidem.

${ }^{51}$ Europejczycy podejrzewali, że miało to służyć skierowaniu większej części eksportu europejskiego do Japonii, zamiast do USA (S. H o f f m a n n, op. cit., s. 90).

${ }^{52}$ P. Y. H a m m o nd, Changing Bargaining Relations in the Atlantic Alliance, [w:] The United States and Western Europe..., s. 226.

${ }^{53}$ R. E. H u n t e r, Beyond Military Security in Europe, [w:] The United States and Western Europe..., s. 231.

${ }^{54}$ Congressional Record. Proceeding and Debates of the First Session of the $91^{\text {st }}$ Congress, vol. 115, part 21, posiedzenie Senatu z 1 października 1969, dostępne przez: http://www.archive. org/stream/congressionalrec115l-unit\#page/n1/mode/2up.

55 J. M. H a n h i m a ki, Flawed Architect: Henry Kissinger and American Foreign Policy, Oxford 2004, s. 275-277. 
Kissinger podkreślił, że jego kraj miał „globalne interesy i zobowiązania”, podczas gdy zainteresowania krajów europejskich określił jako „regionalne” ${ }^{\text {"5 }}$. Ten swoisty podział ról ewidentnie sprowadzał rolę krajów Starego Kontynentu do funkcji wykonawców amerykańskiej strategii. Kissinger powiedział, że Stany Zjednoczone nie chciały dopuścić, by państwa europejskie popadły w neutralizm. Jednak niechętnie widział Europę na arenie międzynarodowej prowadzącą wspólną politykę zagraniczną. Byłoby to korzystne, jeśli jej stanowisko pokrywałoby się z waszyngtońskim, ale niebezpieczne, jeśli byłoby odmienne w dobie negocjacji z ZSRR. Przemówienie Kissingera stanowiło odejście od polityki równorzędnego partnerstwa, promowanej na początku kadencji Nixona. Kissinger sugerował, żeby państwa europejskie zrezygnowały z prowadzenia samodzielnej polityki zagranicznej, ale zachęcał również do zintensyfikowania procesów integracyjnych.

W wymiarze ekonomicznym zajęcie się „regionalnymi interesami” mogło oznaczać dalsze zamykanie rynku EWG i EFTA na towary amerykańskie. Ta próba ścisłego określenia zasad działania sojuszu była spowodowana obawami, że wzmocnione o trzech kolejnych członków Wspólnoty będą rozluźniały więzy atlantyckie i staną się poważnym rywalem. Inicjatywa amerykańska została przedstawiona w szczególnie niefortunnym czasie i odebrana jako próba utrzymania hegemonii w Europie. Negatywnie odczytano również naciski w sprawie zwiększenia wydatków na cele militarne. Nie przyjmowano argumentu, że USA są zmuszone do redukowania kosztów zaangażowania na świecie z powodu rosnącego deficytu BOP ${ }^{57}$.

Opozycja wobec inicjatyw amerykańskich nie oznaczała bierności przywódców europejskich. Ministrowie spraw zagranicznych państw EWG zaproponowali podpisanie zamiast „nowej Karty Atlantyckiej” deklaracji zasad stosunków amerykańsko-europejskich, z uwzględnieniem równouprawnienia i poszanowania odrębności stron ${ }^{58}$. Jobert postrzegał propozycję amerykańską jako próbę zahamowania samodzielnej polityki Europy i osiągnięcie spektakularnego sukcesu w polityce międzynarodowej, by odwrócić uwagę opinii publicznej od afery Watergate ${ }^{59}$. Brytyjski premier Edward Heath był rozczarowany, że Amerykanie podjęli próbę narzucenia sojusznikom zasad współpracy, bez wcześniejszych konsultacji. Kissinger twierdził, że wręczył Kosciuszce-Morizetowi projekt wystąpienia dotyczącego „roku Europy”

${ }^{56}$ H. A. K i s s i n g e r, przemówienie wygłoszone w Nowym Jorku.

${ }^{57}$ G. W. N u t t e r, Kissinger's Grand Design, Washington 1975, s. 5.

${ }^{58}$ K. K a i s e r, Europe and America: a Critical Phase, „Foreign Affairs”, July 1974, s. 728. Według Roberta Dalleka, Nixon zlecił ogłoszenie tak ważnej propozycji w polityce zagranicznej Kissingerowi, gdyż sam nie był gotowy na przyjęcie krytycznych uwag z nią związanych. Wynikało z tego, że prezydent od początku wątpił w powodzenie projektu (R. D a ll e k, Nixon and Kissinger. Partners in Power, New York 2007, s. 474).

${ }^{59}$ M. J o b e r t, Mémoires d'avenir, Paris 1974, s. 231. Podobną opinię wyraził Dallek (R. D a ll e k, op. cit., s. 474). Na temat afery Watergate zob. np. D. T. C r i c h l o w, Lata Nixona, Forda i Cartera: 1968-1980, [w:] Historia Stanów Zjednoczonych Ameryki, red. A. Bartnicki, D. T. Critchlow, t. 5: 1945-1990, Warszawa 1995, s. 110-112. 
już 17 kwietnia. Przytaczając treść rozmów z przywódcami europejskimi udowadniał, że posunięcie amerykańskie było konsultowane z Londynem, Paryżem i Bonn ${ }^{60}$.

Przywódcy Francji, RFN i Wielkiej Brytanii podejmowali w tym czasie wysiłki w celu pogłębienia europejskiej integracji, byli więc w mniejszym stopniu zainteresowani ustalaniem sztywnych ram sojuszu atlantyckiego $0^{61}$. Reakcje państw europejskich były powściągliwe, jednak zapowiedziano podjęcie inicjatywy i opracowanie europejskiego projektu Deklaracji Atlantyckiej. Tylko Kosciuszko-Morizet obawiał się, że zbyt daleko idące postulaty mogą zaszkodzić w budowaniu atlantyckiej jedności ${ }^{62}$. W rozmowach $\mathrm{z}$ amerykańskimi dyplomatami Europejczycy dawali do zrozumienia, że będą dążyli do podkreślenia w niej odrębnej tożsamości Wspólnot w polityce zagranicznej i nie pozwolą, by ich aktywność na arenie międzynarodowej była podporządkowana amerykańskim interesom ${ }^{63}$.

Propozycja Kissingera była bardzo ogólnym zarysem planu odnowy sojuszu. Przewidywano, że będzie ona przedmiotem długiej dyskusji. Komentator dziennika „Washington Post” zauważył, że przedstawiciele Stanów Zjednoczonych i Europy musieli wyjaśnić między sobą przede wszystkim kwestie gospodarcze. Stwierdził, że zasady współdziałania w kwestii wspólnej obrony zostały ustalone w latach 40 . i 50., więc był to we wzajemnych relacjach problem drugorzędny. Najbardziej prawdopodobnym zarzewiem konfliktu były nieporozumienia monetarne i handlowe. W artykule cytowano Kissingera, który stwierdził, że „przywódcy poszczególnych krajów są obarczeni odpowiedzialnością zapewnienia, że przebieg negocjacji gospodarczych będzie służył dalekosiężnym celom politycznym" ${ }^{64}$. Jednak, zdaniem publicysty, Kissinger nie dał Europejczykom żadnych gwarancji, że Amerykanie byli gotowi do równorzędnej współpracy. Po negatywnych doświadczeniach związanych z „szokiem Nixona” mieli prawo się obawiać, że w celu ochrony amerykańskich interesów prezydent nie zawaha się podjąć unilateralnych kroków. Oceniano, że takie działania w stosunkach z sojusznikami miały destrukcyjne skutki, szczególnie na polu gospodarczym, gdzie zagrożone były interesy nie tylko poszczególnych rządów, ale prywatnych firm, klientów i inwestorów ${ }^{65}$.

Przebywający w Europie członek NSC, Denis Clift, w raporcie dla Kissingera oceniał reakcje w Europie jako pozytywne. Uważał, że wątpliwości wzbudzała tylko rola Japonii - obawiano się, że będzie w nowym układzie odgrywała rolę rzecznika interesów amerykańskich, głównie gospodarczych, jako przeciwwaga dla stanowiska europejskiego. Jednakże nawet Brytyjczycy - zdaniem Clifta najbardziej przychylni inicjatywie - byli przeciwnikami łączenia w negocjacjach wszystkich kwestii:

\footnotetext{
${ }^{60} \mathrm{H}$. K i s s in g e r, The Years of Upheaval..., s. 141-149.

${ }^{61}$ J. C a m p b e ll, Edward Heath. A Biography, London 1993, s. 345.

${ }^{62} \mathrm{H}$. K i s s in ger, The Years of Upheaval..., s. 154.

${ }^{63}$ M. J o b e r t, op. cit., s. 232.

${ }^{64}$ Dr. Kissinger and Europe, „Washington Post”, 25 kwietnia 1973.

${ }^{65}$ Ibidem.
} 
bezpieczeństwa, polityki i gospodarki. Największym problemem stało się użyte przez Kissingera sformułowanie o "globalnych” interesach Stanów Zjednoczonych i „regionalnych" Europy. Clift doradzał, by Kissinger w oficjalnych wypowiedziach tłumaczył, że była to jedynie próba opisu realnej sytuacji, a nie formułowania polityki zagranicznej aliantów ${ }^{66}$.

1 maja Kissinger przebywał w Londynie. Oprócz zrelacjonowania spotkania z przywódcą ZSRR Leonidem Breżniewem, jego celem było wysondowanie stosunku Brytyjczyków do projektu Deklaracji Atlantyckiej. Jego rozmówcy odnosili się tylko do procedury negocjacyjnej, unikając odpowiedzi na pytanie o jej treść. Heath zaproponował utworzenie specjalnej grupy złożonej z przedstawicieli czterech państw: USA, Francji, Wielkiej Brytanii i RFN, która miała być formalnie powołana na forum NATO lub odbywać nieoficjalne spotkania. Premier brytyjski zaproponował także spotkania ad hoc w celu podejmowania konkretnych tematów. Zaznaczył jednak, że ten scenariusz musiał być jeszcze zaakceptowany przez innych sojuszników. Kissinger był rozczarowany tym zastrzeżeniem - odniósł wrażenie, że Heath nie chciał robić nic, co nie byłoby po myśli Francuzów ${ }^{67}$.

2 maja 1973 r. do Waszyngtonu z wcześniej zapowiadaną wizytą przybył Brandt. Kissinger wspominał, że podczas rozmowy z niemieckim kanclerzem Nixon był „nieobecny duchem” - prezydent był wtedy przejęty skutkami afery Watergate. Brandt wyrażał się przychylnie o amerykańskiej inicjatywie wzmocnienia sojuszu, lecz nie przedstawił żadnych propozycji, jak ją wcielić w życie. Zaznaczył tylko, że porażka na jednym polu negocjacyjnym nie powinna wpłynąć na inne. „Jedną ręką dał, drugą zabrał" - skomentował Kissinger ten postulat. Celem propozycji amerykańskiej było osiąganie porozumienia we wszystkich kwestiach jednocześnie. Dlatego aprobatę niemieckiego kanclerza uznano za nieszczerą. Kissinger podkreślał rolę porozumienia na polu gospodarczym - do tego był potrzebny w deklaracji element polityczny. Podkreślił, że nie chodziło o wywieranie nacisków, ale stworzenie pola do osiągnięcia konsensusu. Stwierdził, że w ten sposób można uniknąć w przyszłości gróźb wycofania wojsk amerykańskich, które co jakiś czas pojawiały się w Kongresie. Tłumaczył, że porozumienie handlowe było konieczne, gdyż wpływowe grupy interesów w USA obawiały się protekcjonizmu EWG. Należało więc jak najszybciej doprowadzić do uchwalenia przez Kongres ustawy handlowej, dającej prezydentowi dużą elastyczność negocjacyjną. Kissinger stwierdził, że jej kształt będzie zależał od tego, czy Europejczycy wykażą zrozumienie dla amerykańskich problemów handlowych ${ }^{68}$.

Brandt zaproponował, żeby spotkanie na szczycie Nixona z przywódcami europejskimi odbyło się w ramach NATO. Jednak Kissinger oceniał, że nie było to box 329 .

${ }^{66}$ NARA, NPMS, NSC Files, Subject Files: Foreign Policy, Clift do Kissingera, 7 maja 1973,

${ }^{67} \mathrm{H}$. K i s s i n g e r, The Years of Upheaval..., s. 163.

${ }^{68}$ NARA, NPMS, NSC Files, VIP Visits, Kissinger do Nixona, 2 maja 1973, box 916. 
właściwe forum, gdyż nie wszyscy członkowie Sojuszu należeli do EWG, co odsunęłoby kwestie gospodarcze na dalszy plan. Kissinger przyznał po latach, że już wtedy należało zrezygnować z inicjatywy, wobec braku zainteresowania, a wręcz niechęci ze strony Europy. Brak konkretnych ustaleń po wizycie Brandta prasa niemiecka komentowała, że kanclerz nie zgodził się na amerykańską dominację ${ }^{69}$.

Minister spraw zagranicznych Francji - Jobert spotkał się z Kissingerem 17 maja ${ }^{70}$. Amerykański polityk we wspomnieniach wyrażał sięo nim bardzo pozytywnie: cenił jego intelekt, wspominał nawet o przyjaźni. Jednak trudno w to uwierzyć, gdyż właśnie Jobert wykazał najbardziej zdecydowany opór wobec Deklaracji Atlantyckiej. Podczas spotkania Kissinger powtarzał, że istniał realny związek między kwestiami obronnymi a gospodarczymi, grożąc perspektywą niekorzystnych dla Europejczyków postanowień Kongresu. Podkreślił, że z tego względu należało utrzymać polityczny wpływ na negocjatorów ustalających porozumienia gospodarcze. Przekonywał, że administracja była daleka od szantażowania sojuszników unilateralnymi krokami. Stwierdził, że jakby tak było, Amerykanie nie braliby pod uwagę aspektów politycznych i daliby wolną rękę departamentom gospodarczym i ich ekspertom.

Kissinger zapewnił, że Amerykanie nie chcieli osłabienia EWG, ale nie byli chętni do rozmów ze Wspólnotą jako jednością polityczną, preferując kontakty bilateralne. Uzasadniał, że spotkania nieformalne przynoszą zazwyczaj lepsze i szybsze efekty. Zapewniał, że nie chciał działać bez Francji lub przeciwko niej - jako dowód podał przychylny stosunek administracji Nixona do jej programu nuklearnego ${ }^{71}$. Jobert stwierdził, że po przemówieniu Kissingera spodziewał się, że Amerykanie będą chcieli wręczyć sojusznikom gotowy tekst deklaracji do podpisu. Za szczególnie aroganckie uznał stwierdzenie o „regionalnych interesach europejskich”. Kissinger przyznał, że niektóre fragmenty jego wystąpienia mogły być źle sformułowane. Przekonywał, że jego celem było pokazanie państwom europejskim, że mimo intensyfikacji kontaktów z ZSRR i Chinami, Stany Zjednoczone nie zaniedbują najlepszych sojuszników. Zaproponował ustalenie „deklaracji zasad” dalszego funkcjonowania sojuszu. Zgodnie z sugestiami brytyjskimi stwierdził, że powinny nad nią debatować wraz ze Stanami Zjednoczonymi największe mocarstwa europejskie:

${ }^{69}$ H. K i s s in g e r, The Years of Upheaval..., s. 156.

${ }^{70}$ Kissinger znał wcześniej Joberta - francuski polityk pomagał organizować jego spotkania z przedstawicielami Wietnamu Północnego.

${ }^{71}$ Amerykanie uzależniali współpracę od realizacji programów FRELOC - dotyczącego roszczeń wobec Francji związanych z kosztami przeniesienia wojsk amerykańskich do Brukseli w momencie wystąpienia tego kraju ze struktur wojskowych NATO w 1966 r., i LOC - dotyczącego udostępnienia linii komunikacyjnej przez terytorium Francji w przypadku konfliktu zbrojnego (NARA, NPMS, NSC Insitutional, "H" Files, Senior Review Group Meetings, Sonnenfeldt do Kissingera, 23 kwietnia 1973, box H041). Po latach milczenia Francuzi wreszcie zdecydowali się w 1973 r. spełnić amerykańskie żądania dotyczące FRELOC i zwrócić $40 \mathrm{mln}$ USD (Amerykanie żądali $378 \mathrm{mln}$ USD). (NARA, NPMS, NSC Insitutional "H" Files, Senior Review Group Meetings, streszczenie raportu Departamentu Stanu na temat relacji amerykańsko-francuskich, 25 kwietnia 1973, box H-041). 
Francja, Wielka Brytania i RFN, przewidując dopiero po uzgodnieniu podstawowych wytycznych dyskusję w szerszym gronie ${ }^{72}$.

Podstawowym problemem w podpisaniu Deklaracji Atlantyckiej były obawy Europejczyków przed dominacją USA i pozbawieniem Wspólnoty niezależności w polityce zagranicznej. Komitet wspierający integrację europejską (Action Committee for the United States of Europe ${ }^{73}$ ) oświadczył, że: „partnerstwo między Ameryką a zjednoczoną Europą musi być relacją dwóch osobnych, ale równie silnych całości". Podobną opinię wyraził Departament Stanu. Według Rogersa, zintegrowana politycznie Europa byłaby lepszym partnerem do negocjacji. Konsultacje na różnych polach mogły okazać się bardziej owocne, gdyż animozje powstające w wyniku różnicy sił między Stanami Zjednoczonymi a EWG zostałyby wyeliminowane. Już w 1966 r. George Ball stwierdził, że „dopóki będzie istniała wielka dysproporcja między USA a krajami europejskimi działającymi osobno, nie będzie możliwe sformułowanie jakiejkolwiek transatlantyckiej umowy o zacieśnieniu współpracy"74.

Obawy Europy były zbudowane na rzeczywistej dominacji USA w wielu dziedzinach: np. na forum NATO najczęściej były przyjmowane inicjatywy amerykańskie. Wspólna polityka zagraniczna mogła nie tylko zwiększyć siłę Europy na arenie międzynarodowej, ale również sprawić, że państwa europejskie zrezygnowałyby z partykularnych interesów narodowych i brały w większym stopniu pod uwagę sytuację globalną, co zbliży je do Stanów Zjednoczonych. Poza tym konsultowanie się z każdym państwem europejskim z osobna bardzo komplikowało proces podejmowania decyzji. Z drugiej strony, dawało to Waszyngtonowi możliwość nacisku na poszczególne rządy. Należało również rozważać scenariusz, że zjednoczona Europa niekoniecznie musi przyjąć cele tożsame z amerykańskimi.

Podobnie jak w kwestiach handlowych i monetarnych, najbardziej asertywni wobec inicjatywy amerykańskiej byli Francuzi. Jobert zwrócił się do Kissingera z propozycją, by Francja przejęła główną odpowiedzialność za kształt ewentualnego porozumienia i zażądał, by Stany Zjednoczone nie próbowały wywierać nacisku na inne rządy, by przyjęły ich wersję układu. Poprosił także o jak najszybsze dostarczenie amerykańskiego projektu deklaracji ${ }^{75}$. Według Kissingera, Amerykanie rzeczywiście zaniechali rozmów z państwami EWG w tej kwestii. Jobert z tego skorzystał i przekonał pozostałych członków Wspólnot do odrzucenia amerykańskiego pomysłu ${ }^{76}$.

${ }^{72}$ NARA, NPMP, NSC Files, HAK Office Files, Country Files - Europe, memorandum z rozmowy Kissingera i Irwina z Jobertem, 17 maja 1973, box 56.

${ }^{73}$ Action Committee for the United States of Europe został założony przez Jeana Monneta w 1955 r. po fiasku inicjatywy Europejskiej Wspólnoty Obronnej. Miał on na celu promowanie idei pogłębiania i poszerzania integracji. W skład Komitetu weszli członkowie partii politycznych i związków zawodowych, dlatego wywierał on istotny wpływ na politykę poszczególnych rządów.

${ }^{74}$ E. R. G o o d m a n, op. cit., s. 178.

${ }^{75}$ J. O. G o ld s b o r o u g h, France, the European Crisis and the Alliance, „Foreign Affairs”, April 1974, s. 539-543.

${ }^{76}$ H. K i s s i n g e r, The Years of Upheaval..., s. 164-167. Zob także: NARA, NPMP, NSC Files, HAK Office Files, Country Files - Europe, memorandum z rozmowy Kissingera z Pompidou, 18 maja 1973, box 56. 


\subsection{Spotkanie Nixon-Pompidou w Rejkiawiku}

Przed planowanym na koniec maja spotkaniem Nixona z Pompidou w Rejkiawiku, eksperci Departamentu Stanu radzili, żeby prezydent nie zawierał nawet nieformalnego porozumienia w kwestiach monetarnych tylko z Francją, gdyż mogłoby to wpłynąć niekorzystnie na relacje z innymi państwami. Twierdzili, że Francuzi chcieli wykorzystać negocjacje monetarne, by wzmocnić pozycję w Europie i w relacjach z USA. Departament Stanu ostrzegał, że Pompidou mógł użyć argumentu, że sojusz zachodni zostanie osłabiony, jeśli nie skończy się szybko „monetarna anarchia". Nixon miał odpowiedzieć, że sprawy monetarne i handlowe miały priorytetowe znaczenie, jednak Stany Zjednoczone nie zgodzą się na rozwiązania niezgodne $z$ ich interesem narodowym.

Przedstawiono także propozycje stanowiska amerykańskiego w sprawie negocjacji handlowych. Głównymi postulatami miały być żądania większego dostępu na rynki EWG dla produktów rolniczych i zatrzymanie podpisywania przez EWG preferencyjnych układów handlowych z krajami trzecimi. Doradzano, by prezydent nie negował wspólnej polityki rolnej, lecz jedynie naciskał na jej modyfikację, np. zmniejszenie taryf importowych. W tym celu Nixon miał podkreślać, że przyjęcie nowej ustawy handlowej przez Kongres zależało od postawy państw EWG przez kolejne tygodnie.

W raporcie stwierdzono, że priorytetem amerykańskim było przekonanie francuskiego prezydenta, żeby przemyślał propozycję Deklaracji Atlantyckiej. Nixon miał mu przekazać, że brak całościowego uregulowania wszystkich kwestii w stosunkach transatlantyckich, będzie powodowało dalsze nieporozumienia na linii Paryż-Waszyngton. Departament Stanu przewidywał, że Francuzi będą unikali wrażenia, że chcą z góry odrzucić amerykańską propozycję. Jednak będą przeciwni łączeniu spraw ekonomicznych i bezpieczeństwa przekonani, że stacjonowanie wojsk USA na Starym Kontynencie służy amerykańskiemu interesowi narodowemu. Wypowiedzi polityków francuskich na forum EWG sugerowały rozczarowanie brakiem propozycji realnego partnerstwa, szczególnie odnoszących się do większego udziału Europy w procesie podejmowania decyzji w NATO. Stwierdzono, że Francja chcąc utrzymania obecności militarnej USA w Europie, jednocześnie lansuje pogląd, że wpływy amerykańskie hamują jej integrację i niezależność w polityce światowej. W Paryżu obawiano się, że nowe narzędzie współpracy mogło służyć Amerykanom do wywierania większej presji na EWG, by była bardziej elastyczna w przyznawaniu koncesji gospodarczych korzystnych dla USA ${ }^{77}$.

18 maja 1973 r. Kissinger spotkał się z Pompidou. Podkreślił, że w toku rozpoczynających się we wrześniu negocjacji gospodarczych obie strony muszą wziąć

77 NARA, NPMS, NSC Insitutional "H" Files, Study Memorandums (1969-1974), raport Departamentu Stanu na temat najważniejszych kwestii w stosunkach amerykańsko-francuskich, 11 maja 1973, box H-195. 
pod uwagę cele polityczne, a nie tylko techniczne. Wyjawiał, że przed spotkaniem na Azorach doradcy prezydenta forsowali strategię, by faworyzować interesy Niemiec kosztem francuskich, doprowadzając do skłócenia w obozie europejskim. Kissinger twierdził, że nie dopuścił do takiego rozwiązania. Można to uznać za sugestię, że w przypadku nieugiętej postawy Francuzów, Amerykanie mogli tym razem próbować wygrywać na sprzeczności interesów miedzy członkami EWG. Pompidou, by zrównoważyć siłę tego argumentu poinformował, że minister spraw zagranicznych Japonii - Masayoshi Ōhira, zaproponował mu sojusz przeciwko polityce gospodarczej USA, lecz on się nie zgodził. Chciał przez to udowodnić, że Europa nie była bezsilna, a także zdolna odpowiedzieć na ewentualne wrogie posunięcia amerykańskie $^{78}$.

Spotkanie przywódców w Rejkiawiku odbyło się od 30 maja do 1 czerwca 1973 r. Głównym jego tematem były relacje gospodarcze. Amerykanie chcieli, by były one rozpatrywane w kontekście transatlantyckich stosunków politycznych, zgodnie z proponowaną miesiąc wcześniej przez Kissingera „nową Kartą Atlantycką”. Jednak Pompidou odnosił się do tego sceptycznie.

Oprócz prezydentów Stanów Zjednoczonych i Francji, w Rejkiawiku mieli spotkać się ministrowie spraw zagranicznych (Rogersa zastępował Kissinger, co doradca prezydenta z satysfakcją odnotował w swych wspomnieniach) i ministrowie odpowiedzialni za gospodarkę. Obaj przywódcy przybyli na spotkanie w nienajlepszej formie: Nixon był wyczerpany aferą Watergate, a Pompidou postępującą chorobą i atakami opozycji. 30 maja Kissinger spotkał się z Jobertem. Amerykański polityk wspominał, że szef francuskiej dyplomacji był wyraźnie negatywnie nastawiony do rozmów o Deklaracji Atlantyckiej. Zarzucał, że Amerykanie wyszli z inicjatywą po to, by zademonstrować jedność sojuszu przed rozmowami z Breżniewem, które miały się odbyć w czerwcu. Stwierdził, że byłoby to skuteczne narzędzie wzmocnienia siły nacisku na EWG w przyszłych negocjacjach handlowych. Jego zdaniem inicjatywa nie miała nic wspólnego w równorzędnym partnerstwem, a raczej mogła spowodować nieporozumienia w gronie członków Wspólnot. Jobert nie uwierzył zapewnieniom Kissingera, że Stany Zjednoczone nie przygotowały jeszcze projektu tej deklaracji i nie będą próbowały narzucić go Europie. Ironicznie stwierdził, że „dla Europejczyków każdy rok jest rokiem Europy”79. Po tej rozmowie Kissinger przewidział, że spotkanie liderów nie da żadnych rezultatów w kwestii zacieśnienia współpracy.

Pompidou wyraził opinię, że ściślejszy sojusz między USA a EWG był bardzo trudny, gdyż EWG stanowiła jedność gospodarczą, a nie polityczną i w obronie interesów ekonomicznych mogła działać wspólnie. Tym samym chciał skierować rozmowę na kwestie monetarne i handlowe, nie łącząc ich z interesami politycznymi

\footnotetext{
${ }^{78}$ NARA, NPMP, NSC Files, HAK Office Files, Country Files - Europe, memorandum z rozmowy Kissingera z Pompidou, 18 maja 1973, box 56.

${ }^{79}$ Cyt. za: H. K i s s in g e r, The Years of Upheaval..., s. 166.
} 
i obronnymi. Nixon wyszedł z propozycją nieformalnego spotkania przedstawicieli czterech mocarstw: Stanów Zjednoczonych, Francji, Wielkiej Brytanii i RFN w celu uzgodnienia treści całościowej deklaracji. Pompidou ją odrzucił, demonstrując solidarność ze wszystkimi członkami Wspólnot. Ostatecznie zgodził się jednak na odbycie rozmów bilateralnych reprezentantów poszczególnych państw europejskich z Amerykanami. Jednak ta propozycja nie zadawalała Nixona. Zauważył, że ustalenia z każdego spotkania będą musieli zaakceptować pozostali członkowie EWG, co niwelowało szanse na porozumienie. Rozmowy na ten temat utknęły więc w martwym punkcie ${ }^{80}$. W tej kwestii uwidoczniła się zmiana polityki Francji wobec USA: Paryż wyraźnie postawił na umacnianie swego stanowiska poprzez lansowanie jedności europejskiej.

Bez pozytywnych rezultatów zakończyły się też negocjacje na tematy gospodarcze $^{81}$. Kissinger zapowiadał, że propozycje francuskie ustalenia kursów walut według stałych parytetów będą brane pod uwagę, ale powinny być dostatecznie elastyczne, by umożliwić działania w razie kryzysu monetarnego ${ }^{82}$. Doradca prezydenta zdawał sobie sprawę, że sytuacja była niezręczna, gdyż podczas spotkania na Azorach w grudniu 1971 r. Nixon obiecał Pompidou, że nie będzie dalszych zmian kursu dolara, a do tamtej pory dokonano już dwóch dewaluacji. W związku z tym Amerykanie nie odrzucali wprost propozycji Pompidou, pragnąc odbudować wzajemne zaufanie ${ }^{83}$.

Francuski prezydent potwierdził za to poparcie dla utrzymania wojsk amerykańskich w Europie, co złagodziło nieco wrażenie rozbieżności interesów między Paryżem a Waszyngtonem ${ }^{84}$. Jednak w wywiadach prasowych wypowiadał się pesymistycznie na temat przyszłości stosunków amerykańsko-francuskich, szczególnie podkreślając negatywny wpływ kryzysu monetarnego. Uważał, że dewaluacja dolara najbardziej osłabiała jedność Zachodu - stawiała pod znakiem zapytania sukces przyszłych rozmów handlowych, a Kongres powołując się na deficyt bilansu płatniczego mógł naciskać na wycofanie wojsk z Europy. Pompidou obawiał się, że Stany Zjednoczone zawrą z ZSRR porozumienie o obustronnym powstrzymaniu się od użycia broni atomowej w konflikcie europejskim, co doprowadzi do „finlandyzacji" Europy Zachodniej. Zdaniem francuskiego prezydenta, do tego procesu mogły się także przyczynić naciski amerykańskie na sojuszników, by ponosili większe wydatki na obronę. Państwa europejskie mogły w takiej sytuacji wybrać prowadzenie własnej polityki wschodniej, co dodatkowo osłabiałoby NATO ${ }^{85}$.

${ }^{80}$ Ibidem, s. 179.

${ }^{81}$ S. B e r s t e i n, J.-P. R i o u x, The Pompidou Years 1969-1974, Cambridge 2000, s. 90.

${ }^{82}$ Nixon in Iceland: “Selling” a New Alliance to Europe, „Chicago Tribune”, 30 maja 1973.

${ }^{83}$ FRUS, 1969-1976, vol. 31, memorandum z rozmowy Nixona i Kissingera z Pompidou, 31 maja 1973, dok. 41.

${ }^{84}$ M. J o b e r t, op. cit., s. 233.

${ }^{85}$ NARA, NPMS, NSC Files, Country Files - Europe (France), Irwin do Kissingera, 9 lipca 1973, box 680 . 
1 czerwca 1973 r. Nixon zadeklarował, że użyje swoich wpływów, by nie dopuścić do redukcji sił amerykańskich w Europie. Zapewnił też, że w rozmowach rozbrojeniowych z ZSRR będzie brał pod uwagę interesy państw sojuszników. Pompidou sprzeciwiał się łączeniu kwestii ekonomicznych, politycznych i militarnych. Dlatego też stwierdził, że konferencja na szczycie państw członkowskich NATO i EWG mijałaby się z celem i nie była możliwa w najbliższej przyszłości ${ }^{86}$.

W rozmowie z Irwinem, sekretarz generalny francuskiego ministerstwa spraw zagranicznych Geoffroy De Courcel stwierdził, że Paryż był gotowy do bilateralnego dialogu z USA, dlatego sprzeciwiał się podpisaniu deklaracji i jakiejkolwiek formie Wspólnoty Atlantyckiej. Irwin był zaskoczony - przypomniał, że w Rejkiawiku przywódcy zgodzili się na rozpatrzenie tego pomysłu. Jednak De Courcel utrzymywał, że szczyt przywódców EWG i Stanów Zjednoczonych byłby możliwy tylko po pomyślnym rozwiązaniu sporów monetarnych i handlowych ${ }^{87}$. Strona francuska, obawiając się hegemonicznej roli USA, zdecydowała się podkreślać pierwszoplanową rolę czynnika gospodarczego w relacjach transatlantyckich. Spory na tym polu były jednak skomplikowane, a perspektywa ich złagodzenia - odległa.

Po spotkaniu w Rejkiawiku Pompidou napisał list do Nixona. Zgodnie z umową, przekazał w nim poufne uwagi na temat dyskutowanych kwestii ekonomicznych. Zauważył, że kryzys monetarny był spowodowany brakiem zaufania. W związku z tym należało podjąć zdecydowane kroki w kierunku zmiany systemu. Przede wszystkim, każdy kraj powinien podjąć zdecydowaną politykę antyinflacyjną. Parytety, jakie uzgodnili ministrowie finansów na konferencji w Paryżu w marcu 1973 r., powinny być jak najszybciej wprowadzane i utrzymane odpowiednimi środkami. Konieczne było także ograniczenie wycofywania inwestycji krótkoterminowych poprzez efektywną kontrolę ich przepływu. Pompidou zaproponował również zawarcie porozumienia w najbardziej, jego zdaniem, konfliktogennej kwestii: handlu produktami rolnymi. Miało ono zawierać następujące elementy: ustalenie cen poszczególnych produktów zgodnych z aktualną sytuacją rynkową, koordynację polityki eksportowej, regulację produkcji poszczególnych dóbr oraz wzrost pomocy żywnościowej dla krajów rozwijających się $e^{88}$.

\subsection{Kwestia redukcji sił amerykańskich w Europie}

W marcu 1973 r. NSC opracowała raport na temat konsekwencji redukcji sił amerykańskich w Europie. Pierwsza cześć dotyczyła skutków politycznych (osłabienie NATO, wzmocnienie Układu Warszawskiego, który miał przewagę w siłach

${ }^{86}$ R. Yo u n g, Nixon Vows no Troop Reduction in Europe, „Chicago Tribune”, 1 czerwca 1973.

${ }^{87}$ NARA, NPMP, NSC Files, HAK Office Files, Country Files - Europe, memorandum z rozmowy Irwina z De Courcelem, 2 czerwca 1973, box 56.

${ }^{88}$ NARA, NPMS, NSC Files, Country Files - Europe (France), Pompidou do Nixona, 25 czerwca 1973, box 679 . 
konwencjonalnych oraz spadek zaufania w relacjach transatlantyckich). Dużą część raportu zajęła analiza konsekwencji gospodarczych. Zwrócono uwagę, że sojusznicy ponosili coraz więcej kosztów wspólnej obrony, np. siły RFN wzrosły z 270 tys. w 1960 r. do 470 tys. w 1973 r. W tym czasie 90\% sił lądowych NATO, $80 \%$ morskich i $75 \%$ powietrznych nie pochodziło z USA. Siły wojsk sojuszników utrzymywane w czasie pokoju wynosiły ponad $3 \mathrm{mln}$ ludzi, a amerykańskich 2,5 mln, z których 300 tys. stacjonowało w Europie. Alianci wydali na obronę 25 mld USD w roku fiskalnym 1972, a w 1973 r. zobowiązali się przeznaczyć 3 mld USD tylko na nowe wyposażenie. Tyle samo kosztowało utrzymanie roczne amerykańskich sił w Europie, co stanowiło mniej niż 5\% amerykańskich wydatków zagranicznych. Poza tym nowa umowa offsetowa z RFN na lata 1972-1973 przynosiła dochód 2 mld USD dla amerykańskiego budżetu. W przypadku wycofania wojsk, RFN w przyszłości nie zgodziłaby się na równie korzystne warunki, przez co ucierpiałby bilans płatniczy.

NSC przekonywała, że niewielkie redukcje przyniosą małe oszczędności, a wycofanie znacznych sił było politycznie niemożliwe. Zwracano uwagę, że na utrzymanie w USA powracających z Europy wojsk należałoby przeznaczyć dodatkowe środki. Redukcje nie wpłynęłyby więc zasadniczo na poprawę bilansu płatniczego. Przypomniano, że w Europie działało ok. 500 amerykańskich firm. Przywódcy europejscy zapowiadali, że korzystne warunki działania, jakimi cieszą się na Starym Kontynencie mogły ulec pogorszeniu w momencie wycofania amerykańskich wojsk. Kolejny argumentem była spodziewana odmowa współpracy Europejczyków w kwestiach monetarnych ${ }^{89}$. Głosy wzywające do zaniechania pomysłu wycofania wojsk z Europy pojawiały się także w prasie. Oświadczenie wystosowały nawet amerykańskie związki zawodowe AFL-CIO ${ }^{90}$.

Pojawiła się również kwestia nowej umowy offsetowej z RFN, gdyż poprzednia wygasała 30 czerwca. Departament Skarbu domagał się powiększenia ogólnej kwoty rekompensat, a Departament Stanu optował za jej przedłużeniem na starych zasadach. Zaznaczono, że negocjatorzy powinni jednak podkreślać, że problem deficytu bilansu płatniczego miał bardzo duże znaczenie polityczne i społeczne w USA oraz że dewaluacja dolara zwiększała koszty stacjonowania ${ }^{91}$. Nixon przychylał się do tej opcji, jednak obawiał się reakcji Kongresu ${ }^{92}$.

3 maja 1973 r. zostało wydane memorandum decyzyjne numer 214 dotyczące niemieckiego offsetu, ujemnego amerykańskiego bilansu płatniczego i dzielenia kosztów obrony w NATO. Zauważono konieczność stworzenia stałego mechanizmu,

${ }^{89}$ NARA, NPMP, WHCF, IT International Organization, NATO, NSC do Sonnenfeldta, 7 marca 1973, box 3.

${ }^{90}$ Ibidem, Oświadczenie AFL-CIO przeciw wycofywaniu ameryklańskich wojsk z Europy, 20 lutego 1973.

${ }^{91}$ NARA, NPMS, NSC, Insitutional "H" Files, Study Memorandums (1969-1974), NSSM 170, Eliot do Kissingera, 22 lutego 1973, box H-129.

${ }_{92}$ Ibidem, raport NSSM 170, 2 kwietnia 1973. 
który umożliwiłby podjęcie nowego wysiłku w celu rekompensowania stacjonowania wojsk amerykańskich w Europie. Celem powinno być stworzenie funduszu płatniczego lub wielonarodowego mechanizmu regulującego te kwestie. Wzywano, by wszyscy sojusznicy jak najszybciej wydali oświadczenie na temat zasad dzielenia kosztów obrony, a do jesieni Europejczycy mieli przedstawić konkretne propozycje. W tym samym czasie powinny być podjęte negocjacje offsetowe z RFN. Umowa miała zawierać bezpośrednie pokrywanie przez RFN niektórych kosztów stacjonowania albo większe wydatki na rzecz $\mathrm{NATO}^{93}$.

Koszty wynikające ze stacjonowania wojsk amerykańskich w Europie oceniano w roku fiskalnym 1974 na 440 mln USD, w tym 310 mln dla RFN. W lipcu, w dobie rosnącej inflacji, administracja amerykańska wznowiła naciski na państwa europejskie, by w większym zakresie rekompensowały koszty stacjonowania wojsk na Starym Kontynencie. W tym samym czasie ponownie uaktywnił się Mansfield, próbując wprowadzić pod obrady Kongresu kwestię redukcji sił ${ }^{94}$. Postulował wycofanie 250 tys. amerykańskich żołnierzy z baz na całym świecie ( $w$ tym czasie było ich 483 tys. w bazach lądowych). Amerykanie zaproponowali podpisanie konkretnej umowy, by nie dopuścić do debaty w Kongresie - jej inicjatywa miała wyjść od Europejczyków. Waszyngton sugerował zwiększenie wydatków na obronę, zakup większej liczby sprzętu militarnego w USA lub nabycie obligacji skarbowych przy zrzeczeniu się odsetek. Jednak administracja amerykańska zdawała sobie sprawę, że europejskim rządom byłoby bardzo trudno przekonać opinię publiczną do takich rozwiązań ${ }^{95}$. Pozostałe kraje NAT0 zgadzały się rozważyć tę kwestię. Wielka Brytania postulowała zwiększenie sił europejskich, a RFN był skłonna dać rekompensatę USA i polegać na ich obronie ${ }^{96}$.

\subsection{Handel strategiczny}

Stany Zjednoczone w dobie odprężenia podjęły kroki, by poprawić relacje handlowe z ZSRR i ChRL. Korzystali z tego również Europejczycy, chcąc wyłączyć z listy niektóre towary objęte zakazem eksportu do państw komunistycznych. W wielu przypadkach Amerykanie odpowiadali negatywnie, co wywoływało napięcia, szczególnie z Francją. Kraj ten planował zintensyfikować handel z Chinami, które miały duże zapotrzebowanie na nowoczesną technologię. Jednak Francuzi

${ }^{93}$ NARA, NPMS, NSC Insitutional "H" Files, National Security Decision Memorandums (19691974), NSDM 214, 3 maja 1973, box H-220.

${ }_{94}$ G. F. T r e ver t o n, Making the Alliance..., s. 123. box 688.

${ }^{95}$ NARA, NPMS, NSC Files, Country Files - Europe (Germany), Casey do Kissingera, 9 lipca 1973,

${ }^{96}$ G. F. Tr e v e r t o n, The Dollar Drain and American Forces in Germany. Managing the Political Economics of Alliance, Athens 1978, s. 44. 
nie mogli uzyskać od Pekinu oświadczenia o jej pokojowym zastosowaniu (chodziło np. o systemy nawigacyjne). Amerykanie nie chcieli się zgodzić na sprzedaż tej technologii, a Francuzi grozili odwetem w postaci blokady amerykańskich inwestycji ${ }^{97}$. Francuski zaawansowany przemysł zbrojeniowy był bardzo zależny od eksportu. Francja zajmowała trzecie miejsce jako eksporter broni (po USA i ZSRR). Dlatego nie zgadzała się z narzucaną przez USA kontrolą strategicznego eksportu militariów, technologii i reeksport komponentów produkowanych przez firmy amerykańskie ${ }^{98}$.

W listopadzie 1972 r. rozpoczęły się rozmowy przygotowawcze do KBWE. Amerykanie, początkowo traktujący je jako drugorzędną kwestię, stopniowo angażowali się coraz bardziej. Kissinger chciał skłonić państwa europejskie do przyjęcia bardziej kompromisowych rozwiązań, szczególnie w kwestii klauzuli dotyczącej możliwości pokojowej zmiany granic i praw człowieka. Za mniej ważną uznawali również sprawę swobody inwestowania i wymiany kulturalnej ${ }^{99}$. Było to m.in. spowodowane obawą przed dalszym zbliżeniem gospodarczym Wschodniej i Zachodniej Europy.

Europejczycy, mimo obaw Amerykanów, nie zamierzali zrezygnować z intratnej wymiany. W rozmowie z ambasadorem amerykańskim w Bonn w maju $1973 \mathrm{r}$. Brandt przyznał, że Breżniew był chętny do współpracy gospodarczej z Zachodem. Kanclerz zauważył, że radziecki przywódca w oczywisty sposób chciał skłócić RFN z USA na tle niechęci Waszyngtonu do poszerzania oferty handlowej. Co więcej, radziecki przywódca groził, że jeśli RFN będzie opóźniała podpisywanie nowych umów, korzystniejsze warunki współpracy otrzyma Japonia ${ }^{100}$.

W przeciwieństwie do Stanów Zjednoczonych, Europa Zachodnia miała bardzo dynamiczne stosunki handlowe z blokiem wschodnim (zob. rozdział IV i V). Dominowała nie tylko w wartości wymiany, ale także biorąc pod uwagę udział handlu jako procent wymiany poszczególnych krajów Europy Wschodniej (tabela 6.3). Wymiana z krajami EWG stanowiła 15\% handlu ZSRR ${ }^{101}$.

W USA trwała debata nad możliwościami ekspansji na rynki wschodnie. Kraje Europy Zachodniej starały się więc uczynić swą ofertę bardziej atrakcyjną, np. wysunęły propozycję stworzenia europejskiego funduszu walutowego na wzór MFW, obejmującego kraje Starego Kontynentu po obu stronach „żelaznej kurtyny”, by

${ }^{97}$ NARA, NPMS, NSC Insitutional "H" Files, Study Memorandums (1969-1974), NSSM 166, 17 stycznia 1973, box H-195.

${ }^{98}$ Ibidem.

${ }^{99}$ Więcej na temat stanowiska USA wobec KBWE: J. M. Ha n h i m a ki, "They Can Write it in Swahili": Kissinger, The Soviets, and the Helsinki Accords, 1973-1975, „Journal of Transatlantic Studies" 2003, No. 1.

${ }^{100}$ NARA, NPMS, NSC Files, Country Files - Europe (Germany), ambasada w Bonn do sekretarza stanu, 22 maja 1973, box 687.

${ }^{101}$ D. E v a n s, The Politics of Trade. The Evolution of the Superbloc, London 1974, s. 41. 
zwalczać konkurencję finansową USA. Przez zgromadzenie funduszy chciano utrzymać wysoki poziom handlu wewnątrzeuropejskiego. Projekt ten nie został jednak zrealizowany.

Tabela 6.3. Udział procentowy wymiany z Europą Zachodnią i ze Stanami Zjednoczonymi w rynkach krajów bloku wschodniego

\begin{tabular}{|l|c|c|c|c|c|c|c|}
\hline & Bułgaria & $\begin{array}{c}\text { Czecho- } \\
\text { słowacja }\end{array}$ & NRD & Węgry & Polska & Rumunia & $\begin{array}{c}\text { Jugo- } \\
\text { sławia }\end{array}$ \\
\hline $\begin{array}{l}\text { Europa } \\
\text { Zachodnia }\end{array}$ & 12 & 21 & 26,5 & 27,7 & 23,7 & 36,2 & 60,5 \\
\hline USA & 0,1 & 0,9 & 0,5 & 0,9 & 1,8 & 2,5 & 5,4 \\
\hline
\end{tabular}

Źródło: NARA, NPMS, NSC Insitutional, "H” Files, Senior Review Group Meetings, raport Grupy ds. Polityki Gospodarczej wobec Europy Wschodniej, 1 lutego 1973, box H-041.

W rozmowie z Shultzem Hans Friderichs, minister gospodarki RFN stwierdził, że należy unikać rywalizacji, kto na lepszych warunkach udzieli kredytów państwom bloku wschodniego. Było to niebezpieczne dla relacji amerykańsko-europejskich, a także umacniało blok komunistyczny ${ }^{102}$. W kontaktach gospodarczych ze Wschodem ważna była rola prywatnych biznesmenów, którzy naciskali, aby rządy udzielały kredytów ich nowym partnerom handlowym. Zarówno decydenci w Waszyngtonie, jak i w stolicach europejskich, zauważali konieczność sprawowania kontroli nad tymi kontaktami ${ }^{103}$.

\subsection{Spór o kształt Deklaracji Atlantyckiej}

Po spotkaniu w Rejkiawiku, Amerykanie rozpoczęli bilateralne negocjacje z Francuzami na temat Deklaracji Atlantyckiej. Zakładano, że jeżeli uda się wypracować kompromisowy projekt, jesienią Nixon przyjedzie do Europy, by go podpisać. Pierwotnie Stany Zjednoczone dążyły do dokładnego określenia zasad współpracy na wszystkich polach i przedstawienie propozycji Francuzom, Niemcom i Brytyjczykom. Francja jednak stała na stanowisku, że sprawy ekonomiczne - będące w kompetencjach EWG, i militarne - którymi powinno się zajmować NATO nie mogły znaleźć się w tym samym dokumencie. Zaproponowano więc stworzenie dwóch oddzielnych deklaracji: jedną opracowaną przez EWG, drugą - przez NATO. 5 czerwca na spotkaniu RMWE, Jobert sprzeciwił się pomysłowi spotkania przywódców państw europejskich z Nixonem.

${ }^{102}$ NARA, NPMS, NSC Files, Country Files - Europe (Germany), memorandum z rozmowy Shultza z Friderichsem, 5 października 1973.

${ }^{103}$ Ibidem, memorandum z rozmowy Mennego z Rushem, 10 października 1973. 
Kissinger był zaniepokojony, że żaden z uczestników spotkania nie był chętny do przedstawienia mu szczegółów dyskusji na temat propozycji amerykańskiej. 8 czerwca spotkał się w Paryżu z Jobertem. Francuski minister zaczął rozmowę od oskarżeń Amerykanów o nielojalność. Twierdził, że na prośbę Kissingera, ambasador francuski w Waszyngtonie nie informował partnerów z NATO o treści rozmów w Rejkiawiku. Tymczasem amerykańska ambasador w Luksemburgu - Ruth Farkas powiedziała publicznie, że w sprawie przyszłej Deklaracji Atlantyckiej rozmowy bilateralne odbędą się między czterema mocarstwami. Jobert stwierdził, że pogłębiło to kontrowersje w kwestii podpisania Deklaracji wewnątrz Wspólnot. Kissinger zrzucił winę za przeciek informacji na znienawidzony przez siebie Departament Stanu ${ }^{104}$. Francuski minister przypomniał, że w Rejkiawiku Pompidou zgodził się na wysłanie zastępców ministrów spraw zagranicznych na wielostronne spotkanie. Miano utworzyć kilka forów do dyskusji. Kissinger przypomniał, że Stany Zjednoczone chciały konsultować również kwestie strategiczne, żeby zyskać w negocjacjach z ZSRR argument, że pewne propozycje były konsultowane z sojusznikami. Dałoby to Amerykanom silniejszą pozycję przetargową. Chciał tym samym zatrzeć negatywne wrażenie w Europie, wywołane jego wypowiedzią o „regionalnych" interesach Europy i zapewnić o chęci stworzenia prawdziwego partnerstwa.

Kissinger przyznał, że głównym powodem niezgody w relacjach transatlantyckich były kwestie gospodarcze. Stwierdził, że nadanie im przez Nixona wymiaru politycznego sprawiło, że Stany Zjednoczone były gotowe do ustępstw. Ocenił, że tylko dzięki takiemu podejściu spory te nie zdominowały transatlantyckiego dialogu i nie niszczyły sojuszu. Jobert jednak był nieufny wobec koncepcji „roku Europy”. Stwierdził wprost, że została ogłoszona, aby podzielić EWG i umocnić amerykańskie wpływy - głównie w celu wymuszenia koncesji gospodarczych ${ }^{105}$. Nieprzyjazny ton rozmowy potwierdził przekonanie Kissingera, że Francja zrobi wszystko, by nie dopuścić do zgody Europejczyków na podpisanie deklaracji współpracy.

Amerykanie pracowali nad jej własną wersją. Nie chcieli jej przedwcześnie ujawniać, gdyż mogło to spowodować zarzuty, że chcieli narzucić gotową koncepcję partnerom. Rozważano różne warianty porozumienia. W pierwszym deklaracja miała określać jak najbardziej ogólne zasady relacji między Europą Zachodnią a USA. Spodziewano się, że taka forma będzie łatwiejsza do zaakceptowania dla Europejczyków, gdyż najważniejsze cele będą zapisane zgodnie z założeniami ich polityk narodowych. Z drugiej strony, dokument składałby się z mało konkretnych

${ }^{104}$ Kissinger twierdził, że urzędnicy Departamentu Stanu nie potrafią zachować dyskrecji, a jeśli on nie przekazuje im ustaleń dotyczących polityki zagranicznej, skarżą się, że są niedoinformowani. Wynikało to z konfliktu między Kissingerem a Departamentem Stanu, a szczególnie z jego szefem - Rogersem. Kissinger nie chciał, by Departament ingerował w prowadzoną przez niego politykę zagraniczną.

${ }^{105}$ NARA, NPMP, NSC Files, HAK Office Files, Country Files - Europe, memorandum z rozmowy Kissingera z Jobertem, 8 czerwca 1973, box 56. 
sloganów. Drugi wariant przewidywał sformułowanie bardziej szczegółowych wytycznych dotyczących współpracy transatlantyckiej, ale zdawano sobie sprawę, że w takim przypadku trudno będzie wypracować kompromis. Problematyczne było również przyłączenie do projektu Japonii, ze względu na sprzeciw Europejczyków wobec takiego rozwiązania ${ }^{106}$.

Kissinger twierdził, że Jobert naciskał na spotkania bilateralne i domagał się przedstawienia mu amerykańskiego projektu. Ostatecznie uzyskał zgodę, a w zamian zapowiedział przekazanie jak najszybciej gotowej propozycji francuskiej. Poza tym Kissinger zobowiązał się, że do momentu przedstawienia projektu Francuzom, nie będzie się w sprawie Karty Atlantyckiej porozumiewał z innymi przywódca$\mathrm{mi}^{107}$. Kissinger powiedział o umowie tylko sekretarzowi generalnemu NATO Holendrowi Josephowi Lunsowi, który był postrzegany jako polityk proamerykański. Ostrzegł on Kissingera, że mniejsze państwa europejskie będą niezadowolone z rozmów francusko-amerykańskich bez ich wiedzy. Tym bardziej, że sprawa była właściwie tajemnicą poliszynela. 27 czerwca podczas wizyty w Waszyngtonie minister spraw zagranicznych Belgii, Etienne Davignon, informował, że bilateralne rozmowy z Francją blokują możliwość innym państwom „Dziewiątki” wymuszanie na niej ustępstw ${ }^{108}$.

Jednak Amerykanie przygotowali dwie wersje projektu: dłuższą autorstwa Departamentu Stanu i bardziej zwięzłą opracowaną przez NSC. 29 i 30 czerwca Kissinger spotkał się z Jobertem w San Clemente w Kalifornii. Francuski minister nie przywiózł obiecanego francuskiego planu Deklaracji Atlantyckiej. Stwierdził, iż przybył po to, by Nixon zrelacjonował mu swoje spotkanie z Breżniewem. Kissinger wręczył mu obie wersje projektu amerykańskiego.

Do San Clemente przyjechał też 12 lipca minister spraw zagranicznych RFN Walter Scheel, który przywiózł bardzo ogólny zarys projektu deklaracji. Przekonywał, że trudno będzie negocjować sprawy gospodarcze na forum NATO i zaproponował stworzenie dwóch deklaracji. Potwierdzało to niechęć większości państw europejskich do łączenia kwestii obronnych z gospodarczymi. Kissinger przekazał wtedy Scheelowi dwa projekty amerykańskie, wysłał je też 8 lipca do Londynu. Namawiał ponadto niemieckiego polityka, by przekonywał Francuzów do zmiany stanowiska ${ }^{109}$.

Projekty amerykańskie zostały udostępnione przywódcom Wielkiej Brytanii i RFN ponad tydzień później niż poznali je Francuzi. Jednak Jobert pokazał je

${ }^{106}$ NARA, NPMS, NSC Insitutional “H” Files, Senior Review Group Meetings, NSSM 183, zasady deklaracji o Karcie Atlantyckiej, box $\mathrm{H}-041$.

${ }^{107}$ H. K i s s in g e r, The Years of Upheaval..., s. 183. Wątku tego nie ma jednak w memorandum w Archiwum Narodowym w Waszyngtonie (NARA, NPMP, NSC Files, HAK Office Files, Country Files Europe, memorandum z rozmowy Kissingera z Jobertem, 8 czerwca 1973, box 56).

${ }^{108}$ H. K i s s in g e r, The Years of Upheaval..., s. 183.

${ }^{109}$ NARA, NPMS, NSC Files, Country Files - Europe (Germany), Kissinger do Nixona, 12 lipca 1973, box 687. 
wcześniej Brytyjczykom udając zdziwienie, że jeszcze do nich nie dotarły. Wzbudził tym samym nieufność co do intencji Waszyngtonu. 16 lipca Kissinger otrzymał list od Joberta odrzucający oba projekty, bez alternatywnej propozycji ${ }^{110}$. Heath napisał do Nixona, że „Dziewiątka” dążyła do wspólnej polityki wobec Stanów Zjednoczonych i żaden kraj nie będzie utrzymywał bliższych kontaktów z Waszyngtonem niż pozostali członkowie ${ }^{111}$. Można to uznać za wypowiedzenie „specjalnych stosunków” łączących oba kraje. Kissinger skarżył się brytyjskiemu szefowi dyplomacji Alecowi Douglas-Home'owi, że rezygnacja z kontaktów bilateralnych, spowoduje negatywne zmiany w relacjach transatlantyckich. Stwierdził z goryczą, że łatwiej było zorganizować rozmowy z przedstawicielami ZSRR niż Europy.

Wydawało się, że ze względu na zdecydowany opór Francji, los deklaracji był przesądzony. Na szczycie EWG w Kopenhadze 23 lipca zapadła decyzja o wstrzymaniu rozmów ze Stanami Zjednoczonymi, dopóki „Dziewiątka” nie wypracuje wspólnego stanowiska. Podczas spotkania Jobert twierdził wręcz, że najpierw należy się zająć relacjami wewnątrzeuropejskimi, a dopiero potem stosunkami z USA. Proponował wstrzymać się z odpowiedzią na amerykańską propozycję. Jednak przedstawiciele pozostałych państw nie zgodzili się na tak daleko idące jej zlekceważenie. Zdecydowano, że wysocy urzędnicy z ich ministerstw opracują projekt zasad deklaracji atlantyckiej na spotkanie ministerialne we wrześniu 1973 r. Jednak formalne negocjacje w tej sprawie państwa EWG chciały zacząć dopiero w czasie zapowiadanej na jesień wizyty Nixona na Starym Kontynencie. Europejczycy byli skłonni za to przyjąć deklarację o zacieśnieniu współpracy w ramach NATO ${ }^{112}$.

Takie rozwiązanie nie było jednak satysfakcjonujące dla Amerykanów. Nixon w listach do przywódców europejskich napisał, że ich decyzja pokazuje, iż EWG traktowała Stany Zjednoczone jak wspólnego wroga, a jego wizyta w Europie będzie uzależniona od ostatecznej treści dokumentu. Amerykanie byli zirytowani długim brakiem odpowiedzi na ich propozycję. Jej celem był przecież również efekt propagandowy: demonstracja jedności Zachodu. Został on całkowicie zniszczony przez brak konkretnych działań, choć oficjalnie prasa zamieszczała przychylne wypowiedzi europejskich polityków. Przywódcy europejscy nie chcieli się angażować w podpisywanie deklaracji z Nixonem skompromitowanym aferą Watergate.

Ważniejszym powodem chłodnego odbioru amerykańskiej inicjatywy był fakt, że w 1973 r. starano się pogłębiać integrację, a nie odbudowywać i zacieśniać więzy transatlantyckie ${ }^{113}$. Z wypowiedzi polityków europejskich można jednak wywnioskować, że największe obawy były związane z intencjami amerykańskim zawartymi

${ }^{110}$ H. K i s s in g e r, The Years of Upheaval..., s. 187.

${ }^{111}$ J. C a m p b e ll, op. cit., s. 345.

112 NARA, NPMS, NSC Files, Subject Files: European Common Market, Rogers do Kissingera, 27 lipca 1973, box 322 .

113 J. C a m p b e ll, op. cit., s. 346. 
w przemówieniu Kissingera. Deklaracja, łącząc kwestie gospodarcze z politycznymi i obronnymi mogła stanowić narzędzie nacisku na Europę właśnie na polu ekonomicznym. To właśnie w tych sprawach było najwięcej sporów, w tym też tkwiła siła EWG, by przeciwstawiać się koncepcjom amerykańskim w kwestiach, w których ich interesy były zbieżne.

Można było zauważyć wyraźną zmianę europejskiej taktyki. Politycy ze Starego Kontynentu przestali się konsultować z Amerykanami w sposób nieformalny. Odmawiali spotkań twierdząc, że przedłożą wspólną decyzję na piśmie. Chcieli uniknąć bezpośrednich nacisków i wykazać swoją jedność. Kissinger przewidywał, że przedstawiciel Wspólnot (duński minister spraw zagranicznych - Knud Andersen) po przekazaniu gotowego planu, nie będzie miał żadnych pełnomocnictw do negocjowania w nim zmian. Heath w liście do Nixona zaznaczył, że w przypadku jakichkolwiek bilateralnych rozmów przedstawiciela kraju EWG z Amerykanami, pozostali członkowie będą powiadomieni o ich treści. Kissinger winą za ten stan rzeczy obarczał Joberta, który zniszczył zaufanie wobec USA wśród członków EWG. Nixon bardzo chłodno odpowiedział na oświadczenie Heatha. Zapowiedział odwołanie wizyty w Europie oraz zadeklarował, że nie podpisze niczego, na co nie wyrażą zgody inni przywódcy oraz wyraził zdziwienie sceptyczną postawą Europy wobec najbliższego sojusznika ${ }^{114}$. Mimo deklaracji o braku konsultacji członków EWG z Amerykanami, korespondencja między Brandtem a Nixonem była bardzo ożywiona. Kanclerz obszernie relacjonował wypowiedzi Pompidou i Heatha. Można wobec tego uznać, że w Waszyngtonie śledzono na bieżąco europejski proces decyzyjny.

W rozmowie z Kissingerem przeprowadzonej 27 lipca 1973 r., sekretarz generalny OECD Emile van Lennep poprosił go o opinię na temat związków między współpracą gospodarczą, polityczną i obronną w stosunkach transatlantyckich w amerykańskim projekcie deklaracji. Zauważył, że na forum OECD Amerykanie coraz częściej podkreślali konieczność spojrzenia na problemy gospodarcze pod kątem politycznym. Kissinger odpowiedział, że administracja amerykańska była zirytowana podejściem Europejczyków do ich inicjatywy. Stwierdził, że propozycja ta była korzystna dla Starego Kontynentu. Opaczne zrozumienie amerykańskich intencji doprowadziło paradoksalnie do wzrostu napięć. Kissinger przewidywał, że jeśli obie strony nie podejmą wspólnych działań, spowodują katastrofę w sojuszu. Podkreślił, że prezydent i on osobiście byli zwolennikami partnerstwa atlantyckiego, co było już rzadkością wśród elit politycznych w Stanach Zjednoczonych. Wątpił, czy tak pozytywne podejście do sojuszu przetrwa prezydenturę Nixona. Stwierdził, że Stany Zjednoczone mogłyby podjąć konfrontację gospodarczą z Europą i wyjść z niej zwycięsko. Kissinger stwierdził, że stałoby się tak, gdyby prezydent powierzył prowadzenie negocjacji handlowych Flaniginowi i Shulzowi - zwolennikom obrony amerykańskich interesów gospodarczych za wszelką cenę. Udowadniał, że

${ }^{114}$ H. K i s s in g e r, The Years of Upheaval..., s. 190. 
gdyby administracja dążyła do wycofania sił z Europy, wystarczyłoby zaniechać nacisków na Kongres. Wobec panujących w Stanach Zjednoczonych nastrojów irytacji uprzywilejowaną pozycją Europy Zachodniej, administracja amerykańska potrzebowała symbolicznego sukcesu, by utrzymać przychylną politykę wobec Starego Kontynentu - byłoby to podpisanie Deklaracji Atlantyckiej. Natomiast państwa europejskie nie odpowiadały wprost na tę propozycję, co pogłębiało naciski na politykę konfrontacyjną. Co więcej, w prasie pojawiały się oskarżenia wysokich urzędników europejskich o dążenie Stanów Zjednoczonych do hegemonii, co zdaniem Kissingera stanowiło doskonałą pożywkę dla amerykańskich izolacjonistów i zwolenników protekcjonizmu ${ }^{115}$.

Van Lennep przyznał rację Kissingerowi, lecz stwierdził, że najważniejszy był realny dialog, a nie tworzenie nowych instytucji. Zaznaczył, że przybył do Waszyngtonu prywatnie, a nie jako szef OECD. Podkreślił, że poszczególne grupy interesów i instytucje zawsze chcą osiągnąć partykularne korzyści, co niekoniecznie było zbieżne $\mathrm{z}$ dążeniami państw. Chodziło mu o naciski wewnętrzne na rządy, które były priorytetowe dla utrzymania się przy władzy. Ostrzegł, że jeśli eksperci od spraw monetarnych w przygotowywaniu reformy światowego systemu będą działać bez politycznej kontroli, rozbieżności na tym polu spowodują konflikty w relacjach transatlantyckich. Przypomniał, że kryzys monetarny 1971 r. doprowadził nie tylko do konfrontacji politycznej, ale miał też bardzo złe skutki gospodarcze dla poszczególnych państw. Za priorytet uznał potrzebę intensywnych rozmów między USA a EWG, nie w sprawie abstrakcyjnych deklaracji partnerstwa, lecz na temat ustalenia stanowisk stron, żeby nie było zbyt wielkich rozbieżności podczas negocjacji monetarnych i handlowych. Byłoby to niezgodne ze wspólnym interesem: stabilnością gospodarki światowej ${ }^{116}$.

Jednak ani Amerykanie, ani Europejczycy nie porzucili prac nad przyszłą Deklaracją Atlantycką. Ze strony państw EWG były to działania mające na celu zmianę jej kształtu w stosunku do propozycji Waszyngtonu. Wielka Brytania na początku sierpnia 1973 r. przedstawiała projekt deklaracji na forum NATO. Według określenia Kissingera, był on „wyjątkowo uprzejmy i gładki” - czyli mało konkretny. Jako strona umowy nie została w nim wymieniona EWG, a jej treść miała być dyskutowana na spotkaniu Rady NATO w grudniu $1973 \mathrm{r}^{117}$ Amerykanie odebrali tę inicjatywę jako próbę pominięcia w deklaracji ważnych obszarów stosunków transatlantyckich i „rozwodnienia” jej wymowy.

Latem EWG zaproponowała dwa osobne teksty deklaracji umacniające sojusz atlantycki. Pierwsza miała dotyczyć relacji politycznych i gospodarczych między EWG a USA, a druga - wspólnego bezpieczeństwa w ramach NATO. Inicjatorką tej

${ }^{115}$ NARA, NPMP, NSC Files, HAK Office Files, Country Files - Europe, memorandum z rozmowy Kissingera z van Lennepem, 27 lipca 1973, box 56.

${ }^{116}$ Ibidem.

${ }^{117}$ H. K i s s in g e r, The Years of Upheaval..., s. 192. 
propozycji była Francja. Amerykanie zaakceptowali wstępnie taki podział. Ze względów prestiżowych nie chcieli, by ich propozycja Deklaracji Atlantyckiej upadła ${ }^{118}$.

Z biegiem czasu w Waszyngtonie zaczęto rozważać wykorzystanie nacisków o charakterze gospodarczym, by skłonić Europejczyków do współpracy nad projektem Deklaracji. W sierpniu 1973 r. Kissinger miał się spotkać z ministrem finansów Francji Giscard d'Estaignem. Sonnenfeldt poradził mu, by forsował nadanie politycznego kontekstu negocjacjom gospodarczym. Było to wyraźne przesunięcie priorytetów w koncepcji amerykańskiej. Kissinger miał tłumaczyć, że w takim sensie Stany Zjednoczone chciały współpracy Europy w sprawach globalnych i zaprzeczać dążeniu Waszyngtonu do omawiania wszystkich problemów na tym samym forum czy wymienianie zaangażowania w obronę sojuszników na koncesje gospodarcze. Kissinger miał też podkreślić, że jednym z celów USA było poparcie wiodącej roli Francji w Europie. Natomiast przed planowaną rozmową Kissingera z ministrem finansów RFN Helmutem Schmidtem Sonnenfeldt sugerował, by przekazać mu, że odrzucenie przez Europejczyków amerykańskiej propozycji spowoduje to, czego Stary Kontynent się najbardziej się obawiał: usztywnienie stanowiska USA wobec kwestii monetarnych i gospodarczych oraz wzrost presji na wycofanie wojsk ${ }^{119}$. Także Irwin radził, żeby podczas ewentualnej wizyty w Europie Nixon skupił się przede wszystkim na kwestiach ekonomicznych ${ }^{120}$.

Podczas rozmowy z Sonnenfeldtem, ambasador RFN w Stanach Zjednoczonych Berndt von Staden sugerował, że Deklaracja Atlantycka powinna zawierać jak najbardziej ogólne zasady współpracy. Ambasador był członkiem Komitetu Davignona formułującego zasady polityczne Wspólnot. Stwierdził, że konflikt podczas wspólnych prac nad tekstem projektu był nieunikniony. Jego zdaniem, dla osiągnięcia kompromisu o wiele skuteczniejsze byłyby bilateralne rozmowy z USA. Przekonywał, że projekt wypracowany przez EWG będzie z pewnością podkreślał europejską tożsamość. Sonnenfeldt obawiał się jednak, że będzie ona stała w opozycji do polityki Stanów Zjednoczonych. Według niego powinna być tworzona w szerszym kontekście solidarności atlantyckiej. Von Staden, zgadzając się z tą konkluzją, uświadomił Sonnenfeldtowi nikłe prawdopodobieństwo takiego scenariusza ze względu na niechętną postawę Francuzów ${ }^{121}$.

Na spotkaniu RMWE w Kopenhadze 10 września 1973 r. przyjęto w końcu wspólny projekt Deklaracji Atlantyckiej. Została ona dostarczona do Waszyngtonu 19 września wraz z propozycją, by Kissinger spotkał się z reprezentantem Wspólnot

${ }^{118}$ NARA, NPMP, NSC Files, HAK Office Files, Country Files - Europe, Kissinger do Nixona, 21 czerwca 1974, box 54 .

${ }^{119}$ NARA, NPMP, NSC Files, HAK Office Files, Country Files - Europe, Sonenfeldt do Kissingera, 30 lipca 1973, box 56.

${ }^{120}$ NARA, NPMS, NSC Files, Country Files - Europe (France), Irwin do Kissingera, 7 września 1973, box 680 .

${ }^{121}$ NARA, NPMS, NSC Files, Country Files - Europe (Germany), Sonnenfeldt do Kissingera, 2 sierpnia 1973, box 687. 
- duńskim ministrem spraw zagranicznych w Nowym Jorku, w celu przekazania amerykańskich uwag. Tekst odzwierciedlał francuską koncepcję stosunków transatlantyckich. Założono równość państw na wszystkich obszarach współpracy. Podkreślono odmienne tożsamości EWG i USA, zaznaczono dobitnie, że Wspólnoty były „odrębnym podmiotem” w stosunkach międzynarodowych. Kluczowe słowa pojawiające się w projekcie amerykańskim, opisujące wzajemne relacje: „partnerstwo" i „współzależność” - zostały zastąpione określeniami „dialog” i „niezależnośćn ${ }^{\prime 22}$. Był to dowód odrzucenia przez Europejczyków bezwarunkowego przywództwa USA w sojuszu.

Zdaniem Kissingera, przedstawiony przez Europejczyków dokument był pozbawiony treści, a amerykańskie intencje nie zostały w nim uwzględnione. Nazwał rozmowy z Europejczykami o Deklaracji „dialogiem głuchych”. Kissinger ocenił przedstawiony projekt jako „starą wizję”, a nie „nowy impuls” w stosunkach transatlantyckich. Był rozgoryczony, że Europejczykom nie zależało na wizycie Nixona. 25 września przedstawiciel Wspólnot Andersen spotkał się z Kissingerem, który trzy dni wcześniej został mianowany sekretarzem stanu ${ }^{123}$. Choć Andersen był zwolennikiem wzmocnienia sojuszu, nie miał uprawnień do negocjacji. Kissinger zaznaczył, że taka procedura rozmów nie mogła być stosowana w przyszłości, gdyż przedłużała cały proces, a wręcz go uniemożliwiała. Skrytykował również europejski projekt, jako pełen obaw o torpedowaniu przez Stany Zjednoczone jedności europejskiej, nie zawierający za to ani słowa o partnerstwie atlantyckim. Dla Kissingera kluczowa była odpowiedź na pytanie, czy członkowie EWG uznawali, że zjednoczona Europa nie była ostatecznym celem, ale ważnym komponentem wzmacniania Zachodu. Podczas rozmowy Kissinger nie szczędził gorzkich uwag Andersenowi, jej ton był zdecydowanie nieprzyjazny ${ }^{124}$.

0 wiele bardziej realna była perspektywa podpisania deklaracji zacieśnienia współpracy w NATO. 26 września przedłożono plan Deklaracji Sojuszu Atlantyckiego (Declaration for the Atlantic Alliance), który według Kissingera był „W takim stopniu rozważny, jak deklaracja Wspólnot była wstrzemięźliwa”125. Jego autorem był ambasador francuski przy NATO François de Rose. Podkreślono w nim konieczność wzmocnienia wspólnej obrony, zmian dostosowujących sojusz do dynamicznej sytuacji międzynarodowej i powiązania sił konwencjonalnych z nuklearnymi. Kissinger zaakceptował projekt. Oceniał, że zawierał bardzo dobre zestawienie celów Sojuszu. Jednakże rozczarowywał go brak wymiaru politycznego, a odniesienie do skoordynowania polityki wobec bloku wschodniego było niejasne.

${ }^{122}$ R. L. P f a l t z g r a f f, The Atlantic Community - A Conceptual History, [w:] Atlantic Community in Crisis. A Redefinition of the Transatlantic Relationship, eds. W. F. Hahn, R. L. Pfaltzgraff, New York 1979, s. 22.

${ }^{123}$ Kissinger zastąpił na tym stanowisku Williama Rogersa 22 września 1973 r. Równocześnie pełnił wciąż funkcję doradcy prezydenta do spraw bezpieczeństwa narodowego.

${ }^{124}$ H. K i s s in g e r, The Years of Upheaval..., s. 703.

125 Ibidem, s. 704. 
Jednak Amerykanie, wobec planów Kongresu zmniejszenia kosztów stacjonowania wojsk w Europie przez ich redukcję, zdecydowali się lansować francuską propozycję i uwypuklać jej pozytywne aspekty ${ }^{126}$.

1 października 1973 r. Nixon spotkał się z przewodniczącym Komisji Europejskiej Françoisem Xavierem Ortolim. Ortoli podkreślił rolę relacji gospodarczych zaznaczając, że Komisja Europejska została powołana do koordynacji wewnętrznych i zewnętrznych relacji ekonomicznych EWG, choć przyznał, że nie można przy tej okazji pomijać czynnika politycznego. Nixon zapewnił, że popiera niezmiennie integrację europejską, lecz należało unikać niepotrzebnych sporów. Jeśli Amerykanie uznają, że EWG działa przeciwko interesom ich kraju, nastąpi odrodzenie tendencji izolacjonistycznych, co będzie skutkować protekcjonizmem i naciskami na wycofanie wojsk z Europy. Prezydent stwierdził, że konkurencja na rynku światowym jest zjawiskiem normalnym, ale zamiana jej w konfrontację mogła doprowadzić do fatalnych skutków. Ortoli zapewnił o dążeniu do poprawy stosunków. Zauważył jednak, że po „szoku Nixona”, Europa przekonała się, że powinna głośno wypowiadać się na temat swoich celów. Przyznał, że tekst Deklaracji był trudny do ustalenia, jednakże najważniejszą kwestią było poprawienie klimatu we wzajemnych relacjach. Tłumaczył, że choć był to moment kształtowania się europejskiej tożsamości, w żadnym razie jej podstawą nie był antyamerykanizm, gdyż Wspólnoty łączyła ze Stanami Zjednoczonymi ideologia i wiele wspólnych celów ${ }^{127}$.

\subsection{Droga do rundy tokijskiej GATT}

10 kwietnia 1973 r. Nixon wysłał do Kongresu kolejny projekt ustawy handlowej.Zadeklarował, że jej głównym celem była możliwość rozwiązania konfliktów gospodarczych, które zagrażały stosunkom z sojusznikami. Prezydent chciał uzyskać możliwość sprawnego podejmowania decyzji w polityce handlowej, ze względu na szybko rosnącą wartość wymiany z najważniejszymi partnerami handlowymi (tabela 6.4). Zaproponował przyznanie prezydentowi nieograniczonego upoważnienia do obniżania, podwyższania lub całkowitej eliminacji ceł i barier pozataryfowych, w zależności od koncesji przyznanych przez partnerów handlowych. Kongres nie miałby możliwości wetowania podjętej przez prezydenta decyzji. Szef administracji mógłby przyznawać klauzulę najwyższego uprzywilejowania państwom bloku wschodniego, nakładać restrykcje na kraj stosujący nieuczciwe praktyki handlowe oraz wprowadzać nadzwyczajne środki (np. kontyngenty) w momencie pojawienia się poważnego deficytu $\mathrm{w}$ amerykańskim bilansie płatniczym. Ważnym elementem projektu ustawy była propozycja zniesienia ceł na produkty przemysłowe

${ }^{126}$ Ibidem, s. 706.

${ }^{127}$ NARA, NPMS, NSC Files, Subject Files: European Common Market, memorandum z rozmowy Nixona i Kissingera z Ortolim, 1 października 1973, box 322. 
oraz szybsze procedury pomocy gałęziom przemysłu amerykańskiego zagrożonym wzrostem importu ${ }^{128}$.

Tabela 6.4. Wartość handlu USA z wybranymi państwami w latach 1970-1974 (w mln USD)

\begin{tabular}{|l|r|r|r|r|r|r|r|r|r|r|}
\hline \multirow{2}{*}{ Kraj } & \multicolumn{2}{|c|}{1970} & \multicolumn{2}{c|}{1971} & \multicolumn{2}{c|}{1972} & \multicolumn{2}{c|}{1973} & \multicolumn{2}{c|}{1974} \\
\cline { 2 - 12 } & \multicolumn{1}{|c|}{ E } & \multicolumn{1}{c|}{ I } & \multicolumn{1}{c|}{ E } & \multicolumn{1}{c|}{ I } & \multicolumn{1}{c|}{ E } & \multicolumn{1}{c|}{ I } & \multicolumn{1}{c|}{ E } & \multicolumn{1}{c|}{ I } & \multicolumn{1}{c|}{ E } & \multicolumn{1}{|c|}{ I } \\
\hline Beluks & 119 & 696 & 107 & 843 & 1138 & 968 & 1622 & 1260 & 2285 & 1681 \\
\hline Dania & 227 & 284 & 252 & 285 & 257 & 366 & 403 & 458 & 360 & 477 \\
\hline Francja & 1483 & 942 & 1373 & 1087 & 1608 & 1368 & 2263 & 1715 & 2941 & 2305 \\
\hline RFN & 2740 & 3126 & 2831 & 3650 & 2807 & 4250 & 3755 & 5318 & 4987 & 6427 \\
\hline Irlandia & 111 & 134 & 138 & 124 & 125 & 151 & 158 & 202 & 193 & 247 \\
\hline Włochy & 1353 & 1316 & 1313 & 1405 & 1434 & 1756 & 2118 & 1988 & 2752 & 2592 \\
\hline Japonia & 4651 & 5875 & 4054 & 7258 & 4980 & 9067 & 8311 & 9644 & 10679 & 12455 \\
\hline Holandia & 165 & 527 & 178 & 534 & 1870 & 639 & 2860 & 922 & 3979 & 1453 \\
\hline Wlk. Br. & 2536 & 2193 & 2369 & 2498 & 2658 & 2987 & 3563 & 3642 & 4574 & 4021 \\
\hline Kanada & 9079 & 11091 & 10365 & 12691 & 12415 & 14907 & 15072 & 17442 & 19932 & 22282 \\
\hline
\end{tabular}

E - eksport, I - import

Źródło: Yearbook of International Trade Statistics, 1970-1971, New York 1973, s. 796; Yearbook of International Trade Statistics, 1972-1973, New York 1974, s. 877; Yearbook of International Trade Statistics, 1974, New York 1975, s. 957.

Postulaty przedstawione przez Nixona zostały przyjęte z nadzieją w Europie. Wzbudziły natomiast wiele kontrowersji w Stanach Zjednoczonych. Związki zawodowe twierdziły, że ustawa w takim kształcie nie rozwiąże problemów gospodarczych w USA, gdyż brak w niej było skutecznego mechanizmu obrony przed zalewem rynku przez tanie towary z importu. Ich zdecydowany lobbing wzmógł nastroje protekcjonistyczne w Kongresie. Wielu jego członków twierdziło, że prezydent nie mógł otrzymać tak rozległych prerogatyw w regulacji handlu zagranicznego. Przedstawiciele administracji, nawet departamentów gospodarczych, przekonywali, że brak skutecznej ustawy handlowej spowoduje „wojny handlowe”, co doprowadzi do spadku zarówno importu jak i eksportu. Rogers twierdził, że jej przyjęcie było warunkiem koniecznym owocnych rozmów podczas tokijskiej rundy GATT, co z kolei było kluczowe dla utrzymania jedności politycznej Zachodu ${ }^{129}$.

Tymczasem Nixon, zaniepokojony rosnącą inflacją, zamierzał jej przeciwdziałać postulując nadanie mu prerogatyw umożliwiających kontrolę i ograniczenie

${ }^{128}$ E. S. K a p l a n, American Trade Policy 1923-1995, Westport 1996, s. 89.

${ }^{129}$ Ibidem, s. 90. 
eksportu artykułów rolnych. Ich ceny wzrosły w skali roku aż o 62\%130. 13 czerwca 1973 r. prezydent ogłosił zamrożenie cen tych produktów na 60 dni. Zapowiedział również konieczność stworzenia nowego systemu kontroli eksportu produktów rolniczych, by zwiększyć ich podaż i doprowadzić do obniżenia cen. Poprosił Kongres, by dał mu do tego upoważnienie. Nixon zauważył, że choć wzrost eksportu był korzystny dla amerykańskiej gospodarki w długim okresie, to w momencie gwałtownie rosnących cen należy go ograniczyć ${ }^{131}$.

Działania Nixona były negatywnie odebrane za granicą. W Europie zauważono, że szkodzą one gospodarkom krajów Starego Kontynentu, gdyż doprowadzają do dalszej dewaluacji dolara, co osłabia konkurencyjność europejskiego eksportu i wartość rezerw walutowych. Wypowiadający się w tej sprawie dla „The Wall Street Journal" londyński bankier zauważył, że działania Nixona udowodniły, że walka $\mathrm{z}$ deficytem bilansu płatniczego miała niski priorytet $\mathrm{w}$ amerykańskiej polityce gospodarczej. Eksperci twierdzili, że może to negatywnie wpłynąć na negocjacje podczas nadchodzącej rundy tokijskiej ${ }^{132}$. Niepokojący był również spadek zaufania do dolara. Publicysta tygodnika „Time” stwierdził, że wpływały na to nie tylko problemy amerykańskiej gospodarki, ale również przekonanie, że administracja osłabiona aferą Watergate nie będzie w stanie podjąć zdecydowanych kroków w celu umocnienia waluty ${ }^{133}$.

Charles Cooper z NSC informował Kissingera, że ogłoszenie programu antyinflacyjnego miało bardzo duży wpływ na politykę zagraniczną. Stwierdził, że Stany Zjednoczone powinny jak najszybciej rozpocząć skoordynowany program międzynarodowych konsultacji, by wytłumaczyć partnerom uwarunkowania wewnętrzne, a także przekonać, że podejmowane środki były tymczasowe. Podkreślił, że wszystkie departamenty, szczególnie Stanu i Rolnictwa, musiały przyjąć tę samą strategię informacyjną. Postulował utworzenie w tym celu specjalnej grupy w ramach NSC $^{134}$. Kissinger przedstawił ten problem Nixonowi. Stwierdził, że państwa europejskie i Japonia zinterpretowały najnowsze ustawodawstwo amerykańskie jako brak gotowości do zaakceptowania politycznych konsekwencji liberalnego światowego systemu gospodarczego, co mogło utrudnić zawieranie umów, szczególnie

${ }^{130}$ PPP, Richard Nixon, vol. 5, oświadczenie dotyczące wprowadzania środków kontroli cen, 13 czerwca 1973, dok. 174.

${ }^{131}$ Ibidem. Zob. także: J. P. G a n n o n, Nixon Freezes Prices for up to 60 Days While New, Tighter Controls are Devised, „The Wall Street Journal”, 14 czerwca 1973.

${ }^{132}$ Nixon Action Viewed Skeptically Abroad; Dollar Declines Sharply and Gold Spurts, „The Wall Street Journal", 15 czerwca 1973.

${ }^{133} \mathrm{Na}$ dowód spadku zaufania do dolara w powszechnej świadomości Europejczyków przytoczono przypadek amerykańskiego turysty, który w Paryżu nie mógł kupić za swą narodową walutę nawet pudełka czekoladek - sprzedawca polecił mu wymienić dolary na franki (Policy: Nixon's Other Crisis: The Shrinking Dollar, „Time”, 18 czerwca 1973).

${ }^{134}$ NARA, NPMS, NSC Files, Subject Files: Foreign Policy, Cooper do Kissingera, 13 czerwca 1973, box 329 . 
dotyczących handlu produktami rolnymi ${ }^{135}$. Nixon zaakceptował pomysł Coopera. Specjalny Komitet ds. Kontaktów z Partnerami Handlowymi, składający się z sekretarzy stanu, skarbu, rolnictwa, przewodniczącego Rady Doradców Ekonomicznych oraz szefa CIA, działał pod przewodnictwem Kissingera. Jednak trend ochrony rynku wewnętrznego został utrzymany. 6 lipca 1973 r. Amerykanie rozszerzyli kontrolę eksportu na kolejne 41 produktów żywnościowych, co zostało negatywnie przyjęte w Europie ${ }^{136}$.

Administracja, chcąc stworzyć dobrą atmosferę przed wielostronnymi rozmowami handlowymi, starała się blokować najbardziej ograniczające wymianę międzynarodową inicjatywy Kongresu. W sierpniu 1973 r. prezydent podpisał ustawę o ochronie rolnictwa i konsumentów (Agriculture and Consumer Protection Act). Prezydent określił ją jako kompromis między stanowiskiem Kongresu a administracji. Stwierdził, że ustawa przyczyni się do zwiększenia produktywności, ustalała bowiem nowy system gwarancji cen w tym sektorze, co miało zniwelować skutki inflacji i zachęcić farmerów do dostarczania większej liczby produktów na rynek krajowy i zagraniczny. „Nowa ustawa będzie korzystna dla konsumentów, amerykańskiej gospodarki i naszego bilansu handlowego" 137 - zapewniał prezydent.

Nixon sprzeciwiał się za to przyjęciu przez kongres ustawy Hartke-Burke, która miała ograniczyć zagraniczne operacje firm amerykańskich. Pozostawał też sceptyczny wobec projektu „GATT dla Inwestycji”, mającym koordynować kontrolę państw OECD nad przepływem kapitału ${ }^{138}$. W 1973 r. szacowano, że od 75 do 80 mld USD amerykańskiego kapitału było zainwestowane za granicą. W $1971 \mathrm{r}$. firmy amerykańskie miały 28 mld USD zainwestowane w Europie, a europejskie 10 mld USD w USA. W 1972 r. dochód dla amerykańskiego budżetu z tych inwestycji wyniósł 2 mld USD, a europejski - 400 mln USD ${ }^{139}$.

Wielostronne negocjacje handlowe miały się rozpocząć jesienią $1973 \mathrm{r}$. Europejczycy zapowiadali jednak, ze nie przystąpią do nich dopóki amerykańscy przedstawiciele nie dostaną od Kongresu uprawnień, by porozumienia można było wprowadzić w życie. Przypominali przypadek, gdy po wynegocjowaniu w $1967 \mathrm{r}$. zniesienia American Selling Price, Kongres odmówił realizacji tego postanowienia. Chcieli też poznać szczegółowo amerykańskie stanowisko przed ustaleniem wspólnych wytycznych dla negocjatorów. Europejczycy opowiadali się za stopniową eliminacją ceł. Twierdzili, że był to najlepszy sposób rekompensaty za rozszerzenie

${ }^{135}$ Ibidem, Kissinger do Nixona, 13 czerwca 1973.

${ }^{136}$ G. F. Tr e v e r t o n, Making the Alliance..., s. 123.

137 PPP, Richard Nixon, vol. 5, oświadczenie o podpisaniu ustawy o ochronie rolnictwa i konsumentów, 10 sierpnia 1973, dok. 231.

${ }^{138}$ R. F. J a n s s e n, Multinationals Face Disorderly Struggle Over Foreign Controls, Conference Finds, „The Wall Street Journal”, 8 stycznia 1973. Zob. także W. D i e b o l d, Jr., U.S. Trade Policy: the New Political Dimension, „Foreign Affairs”, April 1974, s. 476-479.

${ }^{139}$ C. J. E l i a, Europeans, Japanese Find the Time is Ripe to Acquire US Firms, „Wall Street Journal”, 22 kwietnia 1973. 
EWG i zawarte przez Wspólnotę preferencyjne układy handlowe. Amerykanie zgadzali się z koniecznością wspierania krajów rozwijających się, jednakże uważali, że lepszym rozwiązaniem byłaby pomoc materialna i techniczna. W przypadku zaś obniżenia ceł, podobne ulgi powinny zostać zastosowane dla wszystkich partnerów handlowych. W przeciwnym wypadku była łamana podstawowa zasada GATT: stosowanie klauzuli najwyższego uprzywilejowania dla wszystkich sygnatariuszy układu $^{140}$.

Głównym problemem transatlantyckich relacji handlowych była jednak europejska wspólna polityka rolna, ustanawiająca wysokie ceny bez kontroli produkcji. Amerykanie widzieli szansę jej zmiany ze względu na niechętny stosunek do CAP Wielkiej Brytanii, gdyż wysokie ceny produktów rolnych powodowały wzrost inflacji i nierównowagę bilansu płatniczego. Jednak zdawali sobie sprawę, że perspektywy istotnych modyfikacji były niepewne - Europejczycy długo nie chcieli się zgodzić, by problem handlu artykułami rolnymi był w ogóle poruszany w Tokio. Było pewne, że dla osiągnięcia jakiegokolwiek porozumienia konieczne były także ustępstwa ze strony Stanów Zjednoczonych, np. zniesienie kontyngentów na produkty mleczne. Amerykanie przewidywali, że zniesienie ceł może dotknąć niektóre rodzime przedsiębiorstwa, wobec czego zaproponowali ustalenie tzw. międzynarodowego systemu zabezpieczeń. Miał on regulować zasady pomocy państwa dla zagrożonych sektorów, które byłyby stosowane we wszystkich krajach-sygnatariuszach GATT. Europejczycy byli przeciwni temu pomysłowi ${ }^{141}$.

Krytyczne stanowisko wobec działań rządu amerykańskiego na polu gospodarczym wyrażali również europejscy przedsiębiorcy. Alexander Menne, szef firmy chemicznej Farbwerke Hoechst podczas rozmowy w Departamencie Stanu stwierdził, że jeżeli w ustawie handlowej znajdzie się zapis o prawie prezydenta do stosowania środków protekcjonistycznych, trudno będzie powstrzymać kraje europejskie przed odwetem ${ }^{142}$. Ustawa handlowa była gotowa w kwietniu 1973 r., lecz dyskusja nad nią w Kongresie toczyła się bardzo opornie, w związku z czym Amerykanie nie mogli zaproponować żadnych ustępstw partnerom handlowym, jeszcze przed rozpoczęciem rozmów w Tokio ${ }^{143}$.

Ważnym czynnikiem wpływającym na przyszłe negocjacje handlowe była reforma systemu monetarnego. W lipcu 1973 r. ambasador amerykański w RFN Martin Hillenbrand rozmawiał ze Schmidtem, który podkreślał problem utraty zaufania do dolara ze względu na obawy przed jego kolejną dewaluacją. Zapowiedział, że jego rząd nie zgodzi się na rewaluację DM, a raczej w razie konieczności opuści

${ }^{140}$ NARA, NPMP, WHCF, Subject Files, Countries (CO), Flanigan do Nixona, 28 stycznia 1973, box 31 .

${ }^{141}$ Ibidem.

${ }^{142}$ NARA, NPMS, NSC Files, Country Files - Europe (Germany), memorandum z rozmowy Mennego z Rushem, 10 października 1973, box 688.

${ }^{143}$ NARA, NPMP, NSC Files, HAK Office Files, Country Files - Europe, Cooper i Hormats do Kissingera, 30 lipca 1973, box 56. 
europejskiego „węża walutowego" i pozwoli na jej płynny kurs ${ }^{144}$. Natomiast Karl Poehl z ministerstwa finansów RFN zapowiedział, że na najbliższym spotkaniu Komitetu Dwudziestu w Nairobi RFN i Francja wystąpią ze wspólnym apelem do USA, by zwiększyły wysiłki w celu umocnienia dolara. Poehl był temu przeciwny uważał, że spowoduje to tylko niepotrzebne zadrażnienia. Podkreślał jednak negatywne skutki polityczne chaosu gospodarczego. Zauważył, że w Europie panowało powszechne przekonanie, że winę za to ponosiły Stany Zjednoczone, które nie starały się reformować własnej gospodarki ${ }^{145}$.

W sierpniu 1973 r. Kissinger spotkał się z ministrem finansów Francji Giscard d’Estaignem, który był zaniepokojony słabością światowego systemu monetarnego. Twierdził, że Amerykanie nie zdają sobie sprawy z negatywnych skutków, jakie spowodowała dewaluacja USD do poziomu $10 \%$ poniżej parytetu ustalonego 12 lutego 1973 r. Wskazywał, że obniżyła się konkurencyjność handlowa Europy, co nieuchronnie miało doprowadzić do wzrostu bezrobocia ${ }^{146}$.

$\mathrm{Z}$ francuskim ministrem rozmawiał również ambasador amerykański w Paryżu Irwin. Giscard zażądał, żeby USA zobowiązały się do rewaluacji dolara. Uważał, że różnice między Stanami Zjednoczonymi a Europą na tym polu miały poważne reperkusje w innych dziedzinach, szczególnie w kwestiach obrony i bezpieczeństwa oraz polityki EWG wobec USA. Konsensus w sprawie kształtu reformy monetarnej, był więc konieczny dla trwałości zachodniego sojuszu ${ }^{147}$.

Również doradca Pompidou Édouard Balladur w rozmowie z Irwinem stwierdził, że działania Stanów Zjednoczonych powodują problemy polityczne dla rządów europejskich. Oświadczył, że przedstawiciel Francji będzie obecny podczas negocjacji handlowych w Tokio, nawet gdy nie uda się wcześniej osiągnąć konsensusu w kwestiach monetarnych. Zadeklarował, że stanowisko Europy w tej kwestii było jednolite: wszystkie kraje były przekonane o współzależności efektywnej umowy handlowej i reformy walutowej. Balladur stwierdził, że różnica stanowisk polegała na tym, że Stany Zjednoczone chciały rozmawiać o reformie monetarnej w zależności od rozwoju negocjacji handlowych, natomiast Francuzi podczas negocjacji handlowych chcieli brać pod uwagę aktualną sytuację sytemu monetarnego ${ }^{148}$.

Kwestii monetarnych dotyczył także raport Charlesa Coopera i Roberta Hormatsa z NSC przedłożony Kissingerowi 30 lipca 1973 r. Przedstawiono w nim wpływ międzynarodowej sytuacji gospodarczej na politykę zagraniczną. Autorzy stwierdzili, że kryzys monetarny - czwarty od 1971 r. - miał negatywne konsekwencje dla relacji międzynarodowych. Spadek wartości dolara zmniejszał zaufanie

${ }^{144}$ NARA, NPMS, NSC Files, Country Files - Europe (Germany), Hillenbrand do Departamentu Stanu, 5 lipca 1973, box 687.

${ }^{145}$ Ibidem, Hillenbrand do Departamentu Stanu, 10 lipca 1973.

${ }^{146}$ NARA, NPMP, NSC Files, HAK Office Files, Country Files - Europe, Sonnenfeldt do Kissingera, 30 lipca 1973, box 56.

${ }^{147}$ Ibidem, Irwin do Departamentu Stanu, 27 lipca 1973.

${ }^{148}$ Ibidem, memorandum z rozmowy Irwina z Balladurem, 28 lipca 1973. 
do Stanów Zjednoczonych, co z kolei stawiało powodzenie przyszłych negocjacji monetarnych i handlowych pod znakiem zapytania. Powodował również oskarżenia ze strony Europejczyków, że brak stabilizacji w USA utrudnia walkę z inflacją. Waluty europejskie od lutego 1973 r. uległy rewaluacji średnio o 14\% w stosunku do USD, co było dowodem, że Stany Zjednoczone wciąż miały problem z deficytem bilansu płatniczego. Korporacje, inwestorzy, banki i rządy poszczególnych krajów przenosiły fundusze do krajów o silniejszej walucie. Słaby dolar pogarszał ponadto bilans handlowy w państwach europejskich ${ }^{149}$. Te czynniki prowadziły do ochłodzenia stosunków, co przekładało się m.in. na niechętną postawę Europejczyków wobec podpisania Deklaracji Atlantyckiej.

Podczas wspomnianego spotkania Ortoliego z Nixonem i Kissingerem, przewodniczący Komisji Europejskiej zauważył, że Europejczycy inaczej rozumieli powiązanie kwestii politycznych i gospodarczych. Stwierdził, że Amerykanie chcieli rozwiązywać problemy monetarne przez działania na polu handlowym, a handlowe - na polu militarnym. Takie pojmowanie sprawy uważał za nielogiczne. Nixon wyjaśnił jednak, że dostrzegali raczej, że skutki nieporozumień w jednej z tych dziedzin negatywnie oddziaływały na inne pola współpracy. Przypomniał, że na dorocznej konferencji MFW, która odbyła się we wrześniu w Nairobi zgodzono się, że w 1974 r. zostanie osiągnięte porozumienie w sprawie nowego sytemu monetarnego i starał się, by Amerykanie byli gotowi wypełnić to zobowiązanie.

Ortoli odpowiedział, że dążenie do rozwiązania kryzysu monetarnego było bardzo pozytywne, gdyż kwestia ta „wisiała nad naszymi relacjami jak chmura atomowa"150. Zauważył jednak, że kwestie handlowe miały jeszcze większe znaczenie polityczne. Uważał porozumienie w sprawie redukcji ceł za możliwe do osiągnięcia, lecz ważniejsze wydawało mu się podpisanie przez wszystkie kraje GATT deklaracji o dążeniu do liberalizacji polityki handlowej. Stwierdził, ze najtrudniejszym problemem było rolnictwo tym bardziej, że zmiany w CAP były raczej niemożliwe do przeprowadzenia. Nixon zauważył, że również miał trudności w związku z relacjami transatlantyckimi. Stwierdził, że zaangażowanie w obronę NATO stawało się coraz mniej popularne w USA. Był także krytykowany za mało zdecydowane działania wobec Europy w kwestiach handlowych. Uważał, że łatwiej można osiągnąć konsensus w sprawie reformy monetarnej, bo była ona mało zrozumiała dla szerszego grona obywateli i kongresmanów. Oświadczył, że propozycja Deklaracji Atlantyckiej została przedstawiona właśnie w celu rozwiązania wszystkich problemów. Przewidywał, że jeżeli sojusz nie zostanie umocniony, ZSRR zdobędzie wpływy we wszystkich krajach Zachodu. Na takie dictum Ortoli zapewnił, że zrobi wszystko, by nie dopuścić do konfrontacji151.

${ }^{149}$ Ibidem, Cooper i Hormats do Kissingera, 30 lipca 1973.

${ }^{150}$ NARA, NPMS, NSC Files, Subject Files: European Common Market, memorandum z rozmowy Nixona i Kissingera z Ortolim, 1 października 1973, box 322.

${ }^{151}$ Ibidem. 


\subsection{Podsumowanie}

Rok 1972 r. można nazwać w amerykańskiej polityce zagranicznej „rokiem ZSRR i ChRL" ze względu na doniosłe wydarzenia w stosunkach bilateralnych z tymi państwami. Rok 1973 miał przynieść sukces w relacjach z Europą Zachodnią. Próba zacieśnienia więzi zakończyła się jednak niepowodzeniem. W „roku Europy” przywódcy państw-liderów Starego Kontynentu: Heath, Brandt i Pompidou, skupiali się raczej na pogłębieniu integracji europejskiej, co odsuwało relacje z Waszyngtonem na dalszy plan.

Nieporozumienia w relacjach transatlantyckich były podsycane przez spory gospodarcze. Kolejna dewaluacja USD w styczniu 1973 r. negatywnie wpłynęła na perspektywę liberalizacji handlu podczas przygotowanej na jesień rundy negocjacyjnej GATT. Ustalenie nowych zasad było z perspektywy Europejczyków niemożliwe bez porozumienia gwarantującego stabilność systemu monetarnego. Poza tym, w Stanach Zjednoczonych wciąż nie było konsensusu w Kongresie w sprawie nowej ustawy handlowej, określającej uprawnienia prezydenta w tej kwestii. Wymiana transatlantycka systematycznie rosła, przynosząc obopólne korzyści. Blokowanie porozumienia w tej kwestii mogło zahamować ten pozytywny trend.

Należy podkreślić, że stanowiska rządzących po obu stronach Atlantyku były determinowane polityką wewnętrzną. Ujawniające się tendencje protekcjonistyczne były rezultatem ścierania się interesów różnych grup społecznych, mających odmienne oczekiwania i próbujących nakłonić władze do stosowania określonej polityki. Na przykład w Stanach Zjednoczonych rolnicy dążyli do zapewnienia ochrony swojej produkcji przed zagraniczną konkurencją, a przedsiębiorcy produkujący na eksport naciskali na przestrzeganie zasad wolnego handlu i dalszą jego liberalizację. Administracja amerykańska musiała działać tak, by obie strony nie czuły się pokrzywdzone - stąd wrażenie niespójności zagranicznej polityki gospodarczej za kadencji Nixona. Poza tym autorytet administracji został poważnie nadszarpnięty przez aferę Watergate, co powodowało niemożność zdecydowanych reakcji na działania grup interesów, co z kolei prowadziło do konfliktów na tle gospodarczym z partnerami, szczególnie z Europy.

W miarę umacniania się zachodu Starego Kontynentu jako poważnego gracza na arenie międzynarodowej, nieporozumienia przenosiły się na grunt polityczny. Sprzeciw wobec polityki monetarnej i handlowej USA powodował konsolidację EWG dążącej do wypracowania na tych obszarach wspólnego stanowiska. Po ogłoszonej 23 kwietnia przez Kissingera propozycji zacieśnienia sojuszu na wszystkich obszarach współpracy, dążenie do „mówienia jednym głosem” przeniosło się na relacje polityczne z Waszyngtonem i podkreślanie odrębnej europejskiej tożsamości na arenie międzynarodowej. W lansowaniu takiego podejścia przodowała Francja, która zdołała przekonać większość państw EWG o konieczności przyjęcia wspólnego stanowiska. Wymusiło to na dyplomacji amerykańskiej zwrócenie baczniejszej 
uwagi na stosunki z Paryżem, co było powodem zorganizowania spotkania Nixona z Pompidou w Rejkiawiku na początku czerwca.

Propozycja Kissingera, który do kwietnia 1973 r. zdecydowanie sprzeciwiał się łączeniu różnych aspektów relacji transatlantyckich, świadczyła o zmianie amerykańskiej taktyki. Do tamtej pory praktyką było, że problemy te były rozstrzygane przez osobne grupy ekspertów. Ustawiało to hierarchię celów w sojuszu atlantyckim - najważniejszą kwestią było niewątpliwie bezpieczeństwo, traktowane jako element tzw. high politics. Relacje, powiązania, konflikty i wspólne interesy w ramach gospodarki światowej miały wobec tego znaczenie drugorzędne, były klasyfikowane jako low politics. Rozpatrywanie ich abstrahując od innych kwestii spajających sojusz, odsuwało prawdopodobieństwo poważnych rozbieżności transatlantyckich. Jednak w latach 70 . kwestie gospodarcze znalazły się w strefie high politics ze względu na sytuację wewnętrzną w krajach Zachodu. Coraz częściej zauważano, że decyzje podejmowane na obszarze zagranicznych relacji ekonomicznych wpływają na sytuację gospodarczą w kraju, więc na poparcie rządzących ${ }^{152}$.

Każdy rok w amerykańskiej polityce po II wojnie światowej mógłby być nazwany rokiem Europy, gdyż związki transatlantyckie były niezwykle silne. Przemówienie Kissingera można uznać za symboliczny przełom w tych stosunkach. Po raz pierwszy ze strony amerykańskiej w tak dobitny sposób wyartykułowano obawy przed niezależną Europą. Dlatego w amerykańskim planie ułożenia stosunków, wyraźnie można dostrzec próbę zmniejszenia oddziaływań gospodarczych sojuszników. Pierwszym krokiem miało być przyznanie amerykańskim towarom lepszego dostępu na rynek EWG i rekompensaty za jej rozszerzenie o Wielką Brytanię, Danię i Irlandię.

Retoryka użyta przez Kissingera pokazuje, jak współpraca została zastąpiona przez rywalizację: „wiemy, że zjednoczona Europa będzie bardziej niezależnym partnerem. Ale założyliśmy, pewnie zbyt bezkrytycznie, że nasz wspólny interes będzie zabezpieczony długą tradycją współpracy. Spodziewaliśmy się, że po integracji ekonomicznej nastąpi polityczna jedność i wtedy Europa współpracująca z nami pomoże nieść wiele ciężarów polityki światowej. Jednak silna gospodarczo Europa zmieniała się w silnego rywala ${ }^{153}$. Fiasko Deklaracji Atlantyckiej na warunkach Stanów Zjednoczonych było niezwykle wymowne. Waszyngtonowi nie udało się narzucić koordynacji polityki zagranicznej i gospodarczej. Zwyciężyła opcja europejska negocjowania tych kwestii na osobnych forach, raczej ad hoc, niż w ramach stałego mechanizmu konsultacyjnego. Gotowość do podpisania deklaracji współpracy w ramach NATO dowodzi, że mimo wciąż pojawiających się sporów na tle dzielenia kosztów obrony, bezpieczeństwo stanowiło najmniej konfliktogenny element relacji transatlantyckich.

${ }^{152}$ G. F. Tr e v e r t o n, Making the Alliance..., s. 123.

${ }^{153}$ H. A. K i s s i n g e r, przemówienie wygłoszone w Nowym Jorku... 
ROZDZIAŁ VII

\section{KRYZYS ENERGETYCZNY I DESTABILIZACJA JEDNOŚCI SOJUSZU (PAŹDZIERNIK 1973 - SIERPIEŃ 1974)}

\subsection{Ocena stanu sojuszu atlantyckiego przez Komitet Dziewięciu}

Podczas posiedzenia Zgromadzenia Północnoatlantyckiego (North Atlantic Assembly) w Ottawie we wrześniu 1971 r. utworzono Komitet Dziewięciu․ Miał on za zadanie zbadać kierunki rozwoju NATO oraz wskazać na możliwości porozumienia w celu poprawy bezpieczeństwa, relacji gospodarczych, politycznych i międzyparlamentarnych między Ameryka Północną a Europą Zachodnią. Sformułowanie takiego zadania wskazuje, że po obu stronach Atlantyku wzrosła świadomość ścisłego powiązania tych wszystkich kwestii. Co więcej, aspekty gospodarcze zajmowały największą część raportu.

Dokument ogłoszono podczas spotkania Zgromadzenia Północnoatlantyckiego w Ankarze 27 października 1973 r. Pierwszy punkt dotyczył bezpieczeństwa. Komitet stwierdził, że mimo poważnych zagrożeń, istnienie NATO przyczyniło się do utrzymania pokoju w latach powojennych. Wymieniono nowe czynniki wpływające na bezpieczeństwo globalne: względną równowagę nuklearną i sił konwencjonalnych między USA a ZSRR, odprężenie i związane z nim większe możliwości negocjacyjne oraz napięcia w stosunkach sowiecko-chińskich. Za kluczowe zjawiska uznano również wzrost gospodarczy Europy Zachodniej i rozszerzenie EWG, które uznano za podstawowy czynnik zmian w stosunkach transatlantyckich. Prowadziło to do napięć w relacjach handlowych i polityce monetarnej. Komitet wykazywał, że prosperity europejska była $\mathrm{w}$ dużej mierze wynikiem istnienia sojuszu atlantyckiego, którego struktury militarne chroniły ją przed zewnętrzną presją polityczną i agresją. Jednak również Stany Zjednoczone i Kanada korzystały z rozwoju Europy.

W raporcie zauważono też polepszenie stosunków z krajami Układu Warszawskiego. Zaznaczono, że negocjacje ze Wschodem wymagały większej koordynacji

\footnotetext{
${ }^{1}$ W skład Komitetu wchodzili:zeStanówZjednoczonych senator Jacob Javits-członeksenackiego komitetu spraw zagranicznych i Wayne Hays, członek Izby Reprezentantów i wiceprzewodniczący Zgromadzenia Północnoatlantyckiego, Manilio Brosio - ustępujący sekretarz generalny NATO, Michael Habib-Delonde z francuskiego MSZ, Walter Hallstein z RFN (były szef Komisji EWG), Lord Herlech z Wielkiej Brytanii, Lester Pearson - były premier Kanady, laureat pokojowej Nagrody Nobla (zmarł w 1972 r. i zastąpił go Halfdan Hegtun - parlamentarzysta z Norwegii) i Max van der Stoel parlamentarzysta z Holandii.
} 
między krajami europejskimi a USA, konsultacji i informacji o wszystkich podjętych krokach. Za priorytet uznano utrzymanie przez NATO równowagi militarnej ze Wschodem i jednoczesne promowanie odprężenia. Do osiągnięcia tego celu potrzebne było silne przywództwo, zgoda w sprawie metod działania wśród liderów sojuszu oraz zapewnienie poparcia opinii publicznej dla takiej polityki. Apelowano, by nie ulegać złudzeniom związanym ze stopniową zmianą systemu w ZSRR i wobec tego supermocarstwa nie czynić zbyt daleko idących ustępstw. Podkreślono, że détente nie podważało dalszego istnienia NATO. Poza tym strona amerykańska zadeklarowała, że podpisanie z ZSRR porozumienia o zapobieganiu wojnie nuklearnej w czerwcu $1973 \mathrm{r}^{2}$ nie zmniejszało ich odpowiedzialności za obronę nuklearną Europy Zachodniej, gdyż nie można było polegać jedynie na siłach konwencjonalnych. Jednakże obecność wojsk amerykańskich w Europie nadal było konieczna. Zauważono, że wciąż wiele do życzenia pozostawiało zaangażowanie krajów europejskich we wspólną obronę. Przyznano, że ich udział w dzieleniu kosztów stopniowo wzrastał, ale wciąż Stany Zjednoczone ponosiły ich największą część, co wpływało negatywnie na ich bilans płatniczy. Stwierdzono, że Europejczycy będą mogli mieć większy wpływ na decyzje organizacji, gdy zwiększą możliwości obronne i przejmą od USA niektóre obszary odpowiedzialności. Wezwano też do pogłębienia współpracy w dziedzinie badań nad energią nuklearną między Francją, Wielką Brytanią a USA.

Jednak za najpoważniejsze zagrożenie dla Sojuszu uznano konflikty gospodarcze. „Jeśli przywódcy państw nie podejmą żadnych kroków, napięcia spowodowane nieporozumieniami w dziedzinie handlu, inwestycji i układów monetarnych w połączeniu z innymi politycznymi i militarnymi kwestiami, mogą doprowadzić do osłabienia sojuszu i spadku poparcia dla niego przez opinię publiczną"3. Zrównując problemy gospodarcze z kwestiami politycznymi i militarnymi, Komitet chciał podkreślić wysoki stopień gospodarczej współzależności miedzy członkami Sojuszu. Przypominano, że minął czas, gdy każdy kraj mógł działać samodzielnie na polu gospodarczym, ale „instytucje i nawyki myślowe nie nadążają za tym faktem”.

Za najważniejsze zadanie uznano reformę światowego systemu monetarnego. Zgodzono się, że należy zapewnić taką płynność kursów wymiany, by dostosować i zapobiegać powstawaniu zbyt dużych deficytów i nadwyżek bilansu płatniczego, co powodowało kryzysy walutowe. Nowy system powinien opierać się na bardziej stabilnych parytetach, na podstawie uzgodnionej jednostki rozliczeniowej. Miał dopuszczać w wyjątkowych sytuacjach dostosowania kursów, ale takie, które nie powodowałyby inflacji i konsolidacji dużych ilości dolarów amerykańskich jako

${ }^{2}$ Podczas wizyty Breżniewa w Waszyngtonie 25 czerwca 1973 r. została podpisana umowa o zapobieganiu konfliktowi nuklearnemu oraz 10 układów o współpracy kulturalnej i naukowej.

${ }^{3}$ Raport Komitetu Dziewięciu ogłoszony na forum Zgromadzenia Północnoatlantyckiego w Ankarze 27 października 1973, [w:] The New Europe and the United States. Partners or Rivals, ed. G. Mally, Lexington 1974, s. 395.

${ }^{4}$ Ibidem, s. 396. 
rezerw w zagranicznych bankach centralnych. W przyszłości podstawową jednostką rezerwową miały stać się SDR-y.

Wspomniano też o toczących się negocjacjach handlowych w ramach GATT. Podkreślono konieczność walki z protekcjonizmem, apelując do wszystkich rządów o jak najszybsze znoszenie ograniczeń. Szczególną uwagę zwrócono na problem handlu towarami rolniczymi. Ponieważ ten sektor miał dla każdego kraju duże znaczenie społeczne i polityczne, rządy podtrzymywały wysokie ceny. To hamowało możliwości specjalizacji poszczególnych krajów w produkcji określonych towarów, gwarancji realnych dochodów dla rolników i niższych cen żywności dla konsumentów.

W dokumencie dostrzeżono potrzebę osiągnięcia porozumienia w sprawie polityki inwestycyjnej. Proponowano przedyskutować rolę zagranicznych inwestycji i rozwoju korporacji wielonarodowych na forum OECD, by skoordynować procedury działań rządów. Zauważono pozytywne efekty rozprzestrzeniania kapitału, technologii, umiejętności organizacyjnych przez MNCs. Jednakże zarówno kraje, z których pochodziły inwestycje jak i je przyjmujące, obawiały się negatywnych konsekwencji dla własnych gospodarek. Inwestycje wszystkich krajów uprzemysłowionych rosły, a system gospodarki światowej nie wypracował uzgodnionych reguł na tym obszarze. Napięcia na tym tle negatywnie wpływały na stosunki międzynarodowe.

W części zatytułowanej „współpraca polityczna” zauważono konieczność częstszych konsultacji, szczególnie ze względu na deklarację utworzenia do 1980 r. Unii Europejskiej ze wspólną polityką zagraniczną. Komitet zauważył, że w relacjach transatlantyckich powstało wiele poważnych rozbieżności, co mogło wymagać organizowania regularnie spotkań na szczycie, aby podnieść rangę współpracy i przekonać opinię publiczną, że utrzymanie ścisłych więzów, nawet kosztem pewnych ustępstw, było konieczne. By to osiągnąć, wszystkie strony powinny uznać nadrzędność współpracy politycznej i obronnej nad partykularnymi interesami gospodarczymi. Ostrzegano, że jeśli zabraknie tego czynnika, relacje transatlantyckie ulegną osłabieniu, a instytucje polityczne i gospodarcze staną się anachroniczne i nie będą mogły nic zdziałaćs.

Najbardziej „proroczym” fragmentem raportu okazały się przewidywania dotyczące nieporozumień na tle dostaw energii ${ }^{6}$. Problem ten uznano za wspólny dla USA, Europy Zachodniej i Japonii. Przyznano, że przez najbliższe lata świat będzie uzależniony od ropy, gdyż stosowanie nowych źródeł energii było kosztowne. Światowe zapotrzebowanie na ropę dramatycznie rosło: Zachód konsumował $35 \mathrm{mln}$ baryłek dziennie. Przewidywano, że do 1980 r. zużycie wzrośnie do 55 mln baryłek. Także Stany Zjednoczone importowały coraz większe ilości tego surowca i odczuwały jego braki, nie mogłyby więc wesprzeć Europy w razie sytuacji wyjątkowej. Główne

\footnotetext{
${ }^{5}$ Ibidem, s. 397-409.

${ }^{6}$ Raport został ogłoszony, kiedy kryzys bliskowschodni i energetyczny był w krytycznej fazie (patrz podrozdział 7.3).
} 
zasoby ropy znajdowały się w Zatoce Perskiej - regionie politycznie niestabilnym, w którym oprócz tego niektóre państwa były podatne na wpływy ZSRR. Zachód musiał wobec tego przyjąć wspólną strategię․

W każdym poruszanym w raporcie aspekcie, Komitet podkreślał kluczową rolę czynnika gospodarczego. To nieporozumienia na tym tle były największym zagrożeniem nie tylko dla relacji transatlantyckich, ale także spójności działań na arenie międzynarodowej w dobie zimnej wojny. Wiele tez było ewidentnie zapisanych pod wpływem przedstawicieli Stanów Zjednoczonych, co wynikało z hegemonii tego państwa w NATO. Często były to postulaty zmiany stanowiska przez państwa europejskie.

\subsection{Problem surowców energetycznych}

Europejskie i amerykańskie podejście do kwestii regularnego zaopatrzenia w surowce energetyczne było odmienne. Państwa europejskie, w dużym stopniu uzależnione od dostaw ropy z krajów arabskich, były coraz bardziej zaniepokojone amerykańską konkurencją w ich pozyskiwaniu. W Waszyngtonie przewidywano, że w związku z tym będą próbowały zawierać osobne układy z poszczególnymi krajami regionu, co mogło mieć oprócz gospodarczych, poważne konsekwencje polityczne ${ }^{8}$. Obawiano się wypierania amerykańskich wpływów i zwiększonej spolegliwości EWG wobec arabskich żądań, szczególnie w konflikcie z Izraelem.

W Stanach Zjednoczonych, posiadających także własne zasoby ropy, jej producenci do 1973 r. mieli dużą swobodę w kształtowaniu cen. Program Importu Ropy (Oil Import Program) obowiązujący w latach 1959-1971, chronił ich dodatkowo przed konkurencją z krajów Bliskiego Wschodu. To sprawiło, że ceny tego surowca w USA były ok. 30\% wyższe niż na rynku światowym. Jednak na początku lat 70. XX w., w Kongresie zaczęto się domagać zmiany tej sytuacji, co stanowiło przeciwwagę dla interesów producentów. Po wprowadzonej w sierpniu 1971 r. przez Nixona kontroli cen i płac, po raz pierwszy od zakończenia II wojny światowej, na początku $1973 \mathrm{r}$. światowe ceny ropy były wyższe niż te obowiązujące w USA. Wpłynęło na to zmniejszenie wydobycia, a także dewaluację dolara ${ }^{9}$.

W 1973 r. 60\% francuskiego importu ropy pochodziło z krajów arabskich. Tam też ulokowane było 70\% zasobów kontrolowanych przez francuskie firmy. Według raportu Departamentu Stanu, takie uzależnienie wpływało na stosunek Francji do

\footnotetext{
${ }^{7}$ Raport Komitetu Dziewięciu..., s. 409.

${ }^{8}$ National Archives and Record Administration, College Park, MD (NARA), Nixon Presidential Materials Staff (NPMS), NSC (National Security Council) Files, Subject Files: European Common Market, Hormats do Kissingera, 18 grudnia 1972, box 322.

${ }^{9}$ G. J. I k e n b e r r y, Market Solutions for State Problems: the International and Domestic Politics of American Oil, „International Organization”, Winter 1988, s. 155.
} 
konfliktu izraelsko-arabskiego. Dyplomaci francuscy sugerowali nawet, że Stany Zjednoczone powinny wywrzeć presję na Izrael, by ten wycofał się z terytoriów arabskich, obarczając ten kraj winą za przedłużający się konflikt ${ }^{10}$. Podobny zwrot polityczny obserwowano w przypadku RFN. W czerwcu 1973 r. Brandt zapowiedział prowadzenie „bardziej bezstronnej” polityki bliskowschodniej, skłaniając się do zacieśnienia współpracy z państwami arabskimi. Oświadczył wprawdzie, że nie oznaczało to zmiany dobrych stosunków z Izraelem, jednak w Waszyngtonie obawiano się, że Europejczycy będą prowadzili politykę nieskoordynowaną z amerykańskąą .

Stany Zjednoczone dążyły wobec tego do zinstytucjonalizowania współdziałania krajów konsumenckich na forum OECD, w celu zapewnieniu sobie stałych dostaw ropy. Utworzono Komitet do Spraw Ropy (OECD Oil Committee), w ramach którego działała Grupa Wysokiego Szczebla (High Level Group). Była ona głównym forum dyskusji na temat problemów energetycznych.

Wysiłki amerykańskie blokowała Francja, obawiając się zantagonizowania krajów Organizacji Krajów Eksportujących Ropę Naftową (Organization of the Petroleum Exporting Countries - OPEC), które mogłyby poczuć się zaniepokojone ewentualnymi naciskami ze strony konsumentów. Przedstawiciele Paryża twierdzili, że na początku musi zostać uzgodniona wspólna polityka energetyczna EWG. Od 1971 r., kiedy Francja doświadczyła braku ropy naftowej, kraj ten gromadził jej rezerwy i zachęcał członków EWG do dywersyfikacji dostaw i badań nad alternatywnymi źródłami energii, by zmniejszyć zależność Europy od amerykańskich koncernów i polityki USA na Bliskim Wschodzie. Deklarowano jedynie chęć współpracy w gromadzeniu zapasów i dzielenia się zasobami ropy. Podobne stanowisko przyjęły pozostałe kraje Europy Zachodniej ${ }^{12}$.

Od szczytu EWG w Paryżu w październiku 1972 r., starano się wypracować zasady wspólnej polityki energetycznej. Jednak propozycja Komisji stopniowej unifikacji regulacji importowych ropy naftowej i podatków na produkty pochodne nie została zaakceptowana. Europa nie sformułowała długofalowej strategii, która brałaby pod uwagę możliwość ryzyka popadnięcia w zależność od dostawców ropy.

${ }^{10}$ NARA, NPMS, NSC Institutional "H" Files, National Security Staff Memorandums, NSSM 166, raport Departamentu Stanu na temat stosunków amerykańsko-francuskich, box H-195. 5 czerwca 1967 r. lotnictwo izraelskie, uprzedzając działania państw z nim sąsiadujących, zdecydowało się rozpocząć atak, szybko pokonując siły powietrzne Egiptu, Jordanii, Syrii i Iraku. Izrael opanował w ciągu sześciu dni (stąd nazwa wojny - „Sześciodniowa”) Półwysep Synaj, Zachodni Brzeg Jordanu i Wzgórza Golan. Zyskał tym samym ważne strategicznie obszary, które zdaniem władz izraelskich, były niezbędne dla skutecznej obrony państwa. Od tego momentu na Bliskim Wschodzie utrzymywało się napięcie, grożące w każdej chwili wybuchem wojny (P. M a te r a, R. M a t e r a, Stany Zjednoczone i Europa. Stosunki polityczne i gospodarcze 1776-2004, Warszawa 2007, s. 241).

11 J. M. G o s h k o, Brandt Promises „Special” Ties for Israel in the Middle East Policy, „Washington Post", 9 czerwca 1973.

12 NARA, NPMS, NSC Files, VIP Visits, analiza stosunków z RFN przygotowana przez Departament Stanu, 20 kwietnia 1973, box 916. 
Poszczególne kraje wolały ścieżkę osobnych rozmów z producentami, zawierając bilateralne umowy z członkami OPEC ${ }^{13}$. Zdawano sobie sprawę, że zmiana dostawców energii była procesem trudnym i długofalowym.

Również Amerykanie dążyli do zawierania układów bilateralnych z eksporterami ropy. Minister gospodarki RFN Hans Friderichs, podczas rozmowy z sekretarzem skarbu Georgem Shultzem i Kissingerem, niepokoił się planowanym przez USA bilateralnym porozumieniem z Arabią Saudyjską. Twierdził, że w Europie panowało przekonanie, że Stany Zjednoczone dbały tylko o własne interesy, próbując jednocześnie blokować sojuszników w zawieraniu układów z państwami arabskimi. Kissinger argumentował, że układ z Arabią Saudyjską będzie korzystny dla całego Zachodu, o ile uda się skoordynować politykę energetyczną. Friderichs sceptycznie odniósł się do tych zapewnień informując, że RFN była w trakcie negocjacji z Iranem na temat bilateralnego układu w sprawie dostaw ropy i gazu ${ }^{14}$.

\subsection{Konsekwencje polityczne wojny Jom Kippur i embarga OPEC}

Jesienią 1973 r. kolejny konflikt arabsko-izraelski wystawił na próbę Sojusz Północnoatlantycki. 6 października, w dzień żydowskiego święta religijnego Jom Kippur, siły zbrojne Egiptu i Syrii niespodziewanie zaatakowały Izrael. Wsparcia udzieliły im inne państwa arabskie: Algieria, Arabia Saudyjska, Irak, Jordania, Kuwejt, Maroko, Sudan i Tunezja. Wojska koalicji państw arabskich w ciągu pierwszych dni konfliktu zajęły tereny opanowane przez Izrael w wojnie sześciodniowej w 1967 r. Waszyngton pospieszył z pomocą Izraelowi, organizując od 13 października most powietrzny i dostarczając mu uzbrojenia. Związek Radziecki zaczął wtedy przysyłać broń Syriii ${ }^{15}$.

Stany Zjednoczone liczyły na wsparcie państw zachodnioeuropejskich dla swej polityki bliskowschodniej. Nie dopuszczały jednak ich przywódców do opracowania strategii i współdecydowania. Przykładem takiej polityki może być wykorzystanie niemieckich baz do zaopatrywania Izraela w środki militarne bez powiadomienia o tym władz RFN. 23 października kanclerz RFN Willy Brandt złożył protest przeciw takim działaniom. Starał się jednak załagodzić spór zapewniając, że nie dążył do pogorszenia stosunków z USA. W prasie komentowano, że było to spowodowane trwającymi rozmowami na temat offsetu ${ }^{16}$. Przeciwko strategii

${ }^{13}$ Po znacjonalizowaniu ich udziałów w spółkach naftowych w Algierii, przedsiębiorstwa francuskie zaczęły zawierać kontrakty z innymi państwami posiadającymi zasoby ropy. Compagnie Française des Pétroles zawarła długoterminowy kontrakt na dostawy z Irakiem w 1973 r. Włoska spółka ENI miała umowę typu joint venture z Libią, RFN negocjowała z Iranem (G. d e C a r m o y, The Energy Crisis, [w:] The New Europe and the United States..., s. 218).

${ }^{14}$ NARA, NPMS, NSC Files, Country Files - Europe (Germany), memorandum z rozmowy Shultza z Friderichsem, 5 października 1973, box 688.

${ }^{15}$ P. M a te r a, R. M a te r a, op. cit., s. 260.

${ }^{16}$ D. M o r g a n, Brandt: Bonn Loyal to Alliance, „Washington Post”, 31 października 1973. Na temat negocjacji offsetowych: patrz podrozdział 7.6. 
amerykańskiej wystąpiły Francja i Wielka Brytania, nie popierając na forum ONZ amerykańskiej rezolucji o zawieszeniu broni, zobowiązującej obie strony do powrotu do status quo.

Tymczasem Nixon, obawiając się bezpośredniej interwencji ZSRR, 25 października ogłosił stan pogotowia dla sił zbrojnych USA. W Europie niepokojono się tak ostrą reakcją. Obawiano się, że Nixon, chcąc odwrócić uwagę opinii publicznej od skandalu Watergate, zdecyduje się na zbrojną interwencję na Bliskim Wschodzie ${ }^{17}$. Oburzenie w Europie wzbudził brak konsultacji przed podjęciem tak ważnej decyzji. Przywódcy zachodnioeuropejscy twierdzili, że zagrażało to pokojowi światowemu, a tym samym bezpieczeństwu ich krajów. Chcąc sprzeciwić się polityce USA, wszystkie państwa NATO, z wyjątkiem Portugalii i Holandii, odmówiły udostępnienia Amerykanom swoich lotnisk do międzylądowań, przelotów nad swym terytorium oraz pomocy przy transportowaniu ich oddziałów na Bliski Wschód. Nawet Brytyjczycy nałożyli embargo na dostawy broni w rejon konfliktu. Turcja i Grecja odmówiły udostępnienia baz NATO ${ }^{18}$.

Motywem działań państw europejskich była, oprócz urażonej ambicji, niechęć do drażnienia głównych dostawców ropy naftowej. Mimo odcięcia się od polityki amerykańskiej, państwa europejskie nie uniknęły skutków rewanżu za popieranie Izraela. 17 października 1973 r., arabscy członkowie OPEC, zdecydowali się na ograniczenie produkcji. Nałożono również całkowite embargo na dostawy tego surowca do USA i Holandii ${ }^{19}$. W ciągu kilku miesięcy cena ropy wzrosła niemal czterokrotnie $^{20}$. Decyzja ta dotknęła początkowo głównie Europę, która importowała z krajów arabskich średnio 80\% ropy naftowej, zaś Stany Zjednoczone tylko $12 \%{ }^{21}$.

Rządy państw europejskich były przekonane, iż wzrost cen ropy był na rękę Amerykanom, którzy liczyli na pozbawienie ich rezerw dolarowych i osłabienie pozycji jako rywali gospodarczych. Jako dowód na takie intencje Amerykanów przytaczano fakt, że podwyżki cen ropy wprowadził również szach Iranu, najbliższy sojusznik i wykonawca polityki Stanów Zjednoczonych na Bliskim Wschodzie. Według tej teorii Amerykanie liczyli, że szach za uzyskane ze sprzedaży ropy dolary zakupi

${ }^{17}$ Istotnie kryzys bliskowschodni był wykorzystywany w polityce wewnętrznej Stanów Zjednoczonych. Próbowano przekonać kongresmanów, by nie wszczynali procedury impeachmentu, gdyż osłabi to pozycję prezydenta, który odgrywał główną rolę w zażegnywaniu konfliktu izraelskoarabskiego. W rzeczywistości jednak tę sprawę monitorował Kissinger (R. Dallek, Nixon and Kissinger. Partners in Power, New York 2007, s. 529).

${ }^{18} \mathrm{H}$. K i s s in g e r, The Years of Upheaval, Boston 1982, s. 709. W rozmowie z dziennikarzami Heath wprost obwinił USA za wybuch konfliktu bliskowschodniego (J. C a m p b e l, Edward Heath. A Biography, London 1993, s. 350).

${ }^{19}$ Embargo dla Stanów Zjednoczonych zostało zniesione w marcu, a dla Holandii w lipcu $1974 \mathrm{r}$.

${ }^{20} \mathrm{~W}$ okresie dwóch miesięcy cena ropy na giełdach wzrosła z 5 do 17 USD za baryłkę (oficjalna cena OPEC z 3,6 do 11,6 USD), a do grudnia 1973 r. wydobycie zmniejszyło się z 21 mln baryłek dziennie do 16 mln (J. S k o d l a r s k i, R. M a t e r a, Gospodarka światowa. Geneza i rozwój, Warszawa 2005, s. 273).

${ }^{21}$ P. M a te r a, R. M a te r a, op. cit., s. 261. 
w Stanach Zjednoczonych sprzęt wojskowy²2. Między innymi z tych powodów przywódcy Europy Zachodniej nie zgodzili się na amerykańską propozycję, by stworzyć „wspólny front konsumentów” i wywrzeć presję na kraje arabskie w celu odwołania ich decyzji. Kissinger dowodził, że kraje arabskie chciały skłócić ze sobą państwa zachodnie.

Postawa Europejczyków była oceniona przez Departament Stanu jako dowód braku solidarności i niepotrzebna demonstracja różnic interesów. Zaskoczeniem była postawa Wielkiej Brytanii ${ }^{23}$. Tłumaczono to poczuciem zaniedbania Europy przez dyplomację amerykańską i nieliczenia się ze zdaniem sojuszników. Specjalista ds. europejskich w NSC Helmut Sonnenfeldt wskazywał, że głównym tego powodem było zaniepokojenie kontaktami Stanów Zjednoczonych z ZSRR. Niekonsultowana amerykańska akcja na Bliskim Wschodzie umocniła te nastroje. Choć politykę europejską Sonnenfeldt uważał za bardzo krótkowzroczną, odradzał jednak zaostrzanie sporu $^{24}$.

Jednak erupcja rozbieżności była nieunikniona. Europejczycy zarzucali Amerykanom jednostronne popieranie Izraela i wystawianie na niebezpieczeństwo interesów europejskich. Kissinger negował te zarzuty utrzymując, że to Arabowie byli bardziej radykalni, a poza tym podburzani i zbrojeni przez ZSRR. Twierdził, że odmowa wsparcia akcji pomocy dla Izraela była sprzeniewierzeniem się Traktatowi Waszyngtońskiemu. Europejczycy odpierali ten zarzut dowodząc, że działania miały miejsce poza obszarem obrony NATO ${ }^{25}$. W liście do kanclerza RFN z 30 października Nixon wskazał na silne zaangażowanie się ZSRR w tym regionie stwierdzając, że kraje NATO nie mogły być bierne, gdy w grę wchodziły poważne napięcia między supermocarstwami. Ostrzegł, że dystansowanie się od polityki USA mogło przynieść złe skutki dla stabilności sojuszu atlantyckiego, a także - wbrew pozorom - nie ochroni na dłuższą metę europejskich interesów gospodarczych ${ }^{26}$. Podobne noty zostały skierowane do przywódców pozostałych państw europejskich, które odmówiły Amerykanom wsparcia ${ }^{27}$.

Prezydent Francji Georges Pompidou niepokoił się, że państwa europejskie zostały wyłączone z udziału w bliskowschodnich rozmowach pokojowych (miały

${ }^{22}$ R. J. B a r n e t, The Alliance. America, Europe, Japan. Makers of the Postwar World, New York 1983, s. 328.

${ }^{23}$ Na spotkaniu w gronie wyższych urzędników Departamentu Stanu i NSC, rozczarowany Kissinger powiedział, że do tamtej pory traktowano Wielką Brytanię jako pomost z relacjach z Europą, a nie jak obcy rząd (NARA, NPMS, NSC Files, Presidental/HAK Memcons, spotkanie dotyczące relacji amerykańsko-europejskich w Departamencie Stanu, 28 listopada 1973, box 1027).

${ }^{24}$ NARA, NPMS, NSC Files, Subject Files: European Common Market, Hormats do Kissingera, 18 grudnia 1972, box 322 .

${ }^{25} \mathrm{H}$. K i s s i n g e r, op. cit., s. 708.

${ }^{26}$ M. W o $\mathrm{l} f \mathrm{f}$ s o h n, West-Germany's Foreign Policy in the Era of Brandt and Schmidt, 1969-1982. An Introduction, New York 1986, s. 32.

${ }^{27}$ Ibidem, s. 32. Por. H. K i s s in g e r, op. cit., s. 714. 
one odbyć się w grudniu 1973 r. w Genewie). Stwierdził, że miały one żywotne interesy w rejonie konfliktu. Zaproponował ustalenie regularnych spotkań głów państw w celu koordynacji polityki zagranicznej. Dzięki temu w sytuacji kryzysowej Wspólnoty Europejskie miały przedstawiać jednolite stanowisko. Ta propozycja miała zapobiec próbom dyplomacji waszyngtońskiej rozbicia spójnego stanowiska europejskiego i izolacji Francji. Pompidou przedstawił też postulaty współpracy gospodarczej: w utrzymaniu stabilności walut, walce z inflacją i przeciwdziałaniu transakcjom spekulacyjnym ${ }^{28}$.

Wydawało się, że propozycja francuska miała małe szanse na realizację. Pozostałe państwa europejskie uznawały, że antagonizowanie USA nie leżało w ich interesie. 5 listopada 1973 r. Schmidt napisał do Kissingera, że w obliczu kryzysu energetycznego należało zorganizować lepszy przepływ informacji między rządami, ekspertami i przedsiębiorcami, by ustalić spójną politykę wobec krajów OPEC ${ }^{29}$. Jednak Francja potrafiła przeforsować swoje postulaty. 6 listopada EWG, bez konsultacji z Amerykanami, wydała wspólną deklarację na temat Bliskiego Wschodu. Znalazło się w niej poparcie dla apelu ONZ, by Izrael wycofał się z okupowanych terytoriów i nastąpił powrót do granic z 1967 r. Stwierdzono także, że przyszłe porozumienie pokojowe musi brać pod uwagę prawa palestyńskich uchodźców. Taką postawę Europejczyków jednoznacznie postrzegano w Waszyngtonie jako próbę uspokojenia państw arabskich i zapewnienia nieprzerwanych dostaw ropy, szczególnie przed zbliżającą się zimą. Rezolucję uważana za zwycięstwo polityczne Francji, która od 1967 r. starała się zwiększyć wpływy na Bliskim Wschodzie popierając państwa arabskie. Zwrócono też uwagę na postawę Brytyjczyków, którzy poparli dokument nalegając, by wszystkie państwa EWG zajęły jednolite stanowisko w tej sprawie, gdyż tylko tak mogły mieć jakikolwiek wpływ na działania supermocarstw w tym regionie ${ }^{30}$.

Amerykanie uznawali deklarację za próbę osłabienia pozycji negocjacyjnej USA. W dniach 8-14 listopada Kissinger składał wizyty w stolicach Maroka, Tunezji, Egiptu, Jordanii, Arabii Saudyjskiej, Iranu i Pakistanu. Przekonywał przywódców tych krajów, że jedynie prowadząc rozmowy z Amerykanami mogli uzyskać korzystny dla siebie pokój. Wskazywał jednocześnie na niewielkie wpływy polityczne Wspólnot Europejskich, szczególnie, jeśli chodzi o możliwość wywierania nacisków na Izrael. Warunkiem zaangażowania USA było zniesienie embarga na dostawy ropy.

${ }^{28}$ NARA, Nixon Presidential Materials Project (NPMP), NSC Files, HAK Office Files, HAK Trip Files, Europe and Middle East, oświadczenie Pompidou przed Radą Ministrów, 31 października 1973, box 56 .

${ }^{29}$ NARA, NPMS, NSC Files, Country Files - Europe (Germany), Schmidt do Kissingera, 5 listopada 1973, box 688.

${ }^{30}$ J. M. G o s h k o, Common Market Issues Mideast Statement to Mollify Arabs, „Washington Post”, 7 listopada 1973. Deklaracja nie była jednak zaskoczeniem dla Amerykanów. 0 decyzji jej ogłoszenia dowiedzieli się od polityków niemieckich (NARA, NPMS, NSC Files, Country Files - Europe (Germany), box 688). 
Najbardziej obiecujące efekty Kissinger uzyskał w rozmowie z prezydentem Egiptu Anwarem Sadatem. Zapowiedział on przywrócenie stosunków dyplomatycznych zerwanych w 1967 r. i wspólne działania na rzecz pokoju na Bliskim Wschodzie. Decydenci Arabii Saudyjskiej obiecali rychłe zniesienie embarga, zaraz po ogłoszeniu przez Stany Zjednoczone planów bliskowschodniej konferencji pokojowej, która miała się odbyć w dniach 21-23 grudnia 1973 r. w Genewie ${ }^{31}$.

Niezależne stanowisko Europy irytowało Amerykanów. Na wspomniany list Schmidta z propozycją polepszenia przepływu informacji w dobie kryzysu energetycznego, Kissinger odpowiedział dopiero 23 listopada. Wątpił w skuteczność takiej inicjatywy ${ }^{32}$. Natomiast $w$ rozmowie z Kosciuszko-Morizetem 5 grudnia, Kissinger stwierdził, że Francja sama wykluczyła się z bliskowschodnich rozmów pokojowych, jawnie wspierając stanowisko państw arabskich. Zarzucał jej „buntowanie” członków EWG przeciw USA - był przekonany, że pod jej wpływem wspólna deklaracja na temat Bliskiego Wschodu nie była wcześniej konsultowana z Waszyngtonem. Stwierdził, że atmosfera nie sprzyjała podpisywaniu żadnych deklaracji partnerstwa $^{33}$.

Choć polityka Francji irytowała Amerykanów, dalsze antagonizowanie tego kraju nie leżało w interesie Stanów Zjednoczonych. Ambasador w Paryżu John N. Irwin doradzał, aby Waszyngton zaczął traktować Francuzów jak prawdziwych partnerów. Alarmował, że pogorszenie stosunków amerykańsko-europejskich było niezaprzeczalnym faktem ${ }^{34}$. Również opozycja krytykowała politykę atlantycką urzędującej administracji. Zbigniew Brzeziński za największy błąd Nixona w trakcie kryzysu bliskowschodniego uznał brak konsultacji $\mathrm{z}$ aliantami przed postawieniem w stan gotowości sił amerykańskich. Twierdził, że było to niedopuszczalne ze względu na żywotny charakter interesów europejskich w tym regionie. Ocenił, że nadwerężyło to poważnie stosunki transatlantyckie, co było na rękę Moskwie. Europejczycy, niezadowoleni z marginalnej roli w polityce światowej, jaką przydzielił im Kissinger w przemówieniu z 23 kwietnia, chcieli zademonstrować zaangażowanie w rozwiązywanie konfliktu ${ }^{35}$.

W dniach 8-22 grudnia 1973 r. Kissinger odbył wizytę w krajach Bliskiego Wschodu i Europy Zachodniej. Na spotkaniu w gronie ministrów spraw zagranicznych państw NATO 11 grudnia tłumaczył, że ostra reakcja Stanów Zjednoczonych

${ }^{31}$ R. D a 1 l e k, op. cit., s. 538. Na temat wojny Jom Kippur zobacz także: H. K i s s i n g e r, Kryzys. Anatomia dwóch kryzysów: Wojna Jom Kippur (1973) i wycofanie się USA z Wietnamu (1975). Kulisy dyplomacji, Wrocław 2005, s. 17-328.

32 NARA, NPMS, NSC Files, Country Files - Europe (Germany), Kissinger do Schmidta, 23 listopada 1973, box 688 .

${ }^{33}$ NARA, NPMP, NSC Files, HAK Office Files, HAK Trip Files, Europe and Middle East, relacja Kosciuszko-Morizeta z rozmowy z Kissingerem, 5 grudnia 1973, box 56.

${ }^{34}$ NARA, NPMS, NSC Files, Country Files - Europe (France), Irwin do Kissingera, 17 grudnia 1973, box 677.

${ }^{35}$ Z. B r z e z i ń s k i, The Mideast: Who Won?, „Washington Post”, 21 listopada 1973. 
w czasie wojny Jom Kippur była konieczna wobec realnego zagrożenia interwencją ZSRR. Stwierdził, że europejskie próby pozyskania przychylności krajów arabskich, podejmowane bez konsultacji ze Stanami Zjednoczonymi, oddalają perspektywy porozumienia na Bliskim Wschodzie. Przekonywał, że pokój w tym regionie zapewni w przyszłości regularne dostawy surowców energetycznych. Ostrzegł w ostrym tonie przed próbami wykorzystania przez państwa europejskie ówczesnych napięć do osłabienia wpływów amerykańskich ${ }^{36}$. Był rozczarowany brakiem chęci sojuszników do zacieśnienia sojuszu atlantyckiego. Uważał, że Europa powinna jednoznacznie określić, czy będzie partnerem, czy też rywalem Stanów Zjednoczonych. Wskazał, że w celu umocnienia związków należałoby podjąć trzy podstawowe kroki: zakończyć prace nad Deklaracją Atlantycką, wcielić w życie jej postanowienia - przede wszystkim dotyczące procedur częstszych konsultacji politycznych oraz stworzyć spójny program działania w razie braków w dostawach ropy umożliwiający współpracę między jej importerami i eksporterami. Zaproponował regularne spotkania przedstawicieli ministrów spraw zagranicznych w celu koordynowania polityki prowadzonej poza obszarem NATO ${ }^{37}$.

Kissinger pozytywnie oceniał efekty swojej misji. Twierdził, że mimo napiętej atmosfery na początku obrad, udało mu się uspokoić nastroje i przygotować grunt do współpracy ${ }^{38}$. Jedynym uczestnikiem spotkania podważającym amerykańskie postulaty był Michel Jobert, wygłaszający m.in. tezy o istnieniu kondominium między USA a ZSRR, które podzieliły się tajnie strefami wpływów na świecie. Jednak w relacji dla Nixona Kissinger wspominał, że szef francuskiej dyplomacji stopniowo łagodził stanowisko. Sekretarz stanu oceniał, że był to efekt coraz większej izolacji tego polityka przez przywódców „Dziewiątki”, którzy nie chcieli otwartej konfrontacji z USA.

Podczas spotkania z Kissingerem ministrowie spraw zagranicznych EWG zadeklarowali, że będą konsultować się ze stroną amerykańską przed podjęciem jakichkolwiek decyzji w sprawie Bliskiego Wschodu. Wyrazili też wolę zintensyfikowania prac nad Deklaracją Atlantycką ${ }^{39}$, choć Walter J. Stoessel (podsekretarz stanu do spraw europejskich i kanadyjskich) twierdził, że rozmowy na ten temat były trudne i pozostało wiele rozbieżności ${ }^{40}$.

Podczas pobytu w Londynie 12 grudnia Kissinger ostrzegł Heatha przed prowadzeniem przez Europę konkurencyjnej polityki wobec państw arabskich. Uzyskał jednak zapewnienie o solidarności, choć Heath nie ukrywał zaniepokojenia

${ }^{36}$ M. B e r g e r, Kissinger in Clash at NATO, „Washington Post”, 11 grudnia 1973.

${ }^{37}$ NARA, NPMP, NSC Files, HAK Office Files, HAK Trip Files, Europe and Middle East, Scowcroft do Nixona, 12 grudnia 1973, box 43.

${ }^{38} \mathrm{H}$. K i s s in g e r, The Years of Upheaval..., s. 722.

${ }^{39}$ NARA, NPMP, NSC Files, HAK Office Files, HAK Trip Files, Europe and Middle East, Kissinger do Scowcrofta, 11 grudnia 1973, box 44.

${ }^{40}$ NARA, NPMS, NSC Files, Country Files - Europe (France), Stoessel do Kissingera, 20 grudnia 1973, box 677. 
przedłużającym się kryzysem energetycznym i jego wpływem na sytuację w Wielkiej Brytanii. Zauważył, że powodem postawy Europejczyków był brak konsultacji na forum NATO w sprawie polityki bliskowschodniej. Przypomniał, że takie zaniechanie było przyczyną nieporozumień między sojusznikami w czasie kryzysu sueskiego w 1956 r. Heath stwierdził, że działania amerykańskie stały w sprzeczności z deklarowaną współpracą w ramach „roku Europy” i były dowodem na próbę marginalizacji sojuszników na arenie międzynarodowej ${ }^{41}$.

Najbardziej spektakularnym punktem wizyty Kissingera była mowa wygłoszona 12 grudnia na spotkaniu z członkami stowarzyszenia Pilgrims of Great Britain ${ }^{42}$ (tzw. Pilgrim Speech). Sekretarz stanu tłumaczył, że Deklaracja Atlantycka miała być odpowiedzią na spadek poparcia dla integracji europejskiej w społeczeństwie amerykańskim, spowodowanym narastającą rywalizacją na polu gospodarczym. Za niepokojące uznał wysiłki Kongresu w celu wycofania części wojsk amerykańskich z Europy i uchwalanie ustaw ograniczających wolny handel. Zapewniając, że administracja Nixona starała się blokować takie inicjatywy stwierdził, że jedność europejska nie mogła być budowana kosztem Stanów Zjednoczonych i sojuszu atlantyckiego. Zarzucił Europejczykom, że choć chcą mówić jednym głosem, nie byli w stanie wysłać do Waszyngtonu przedstawiciela posiadającego uprawnienia negocjacyjne ${ }^{43}$.

Najważniejszym punktem przemówienia był postulat utworzenia Grupy do spraw Energii (Energy Action Group - EAG) - w celu współpracy między producentami i konsumentami w niwelowaniu skutków „szoku naftowego”. Zaproponował, żeby zanim do Grupy zostaną zaproszeni producenci, doszło do spotkania krajów uprzemysłowionych $\mathrm{w}$ celu opracowania w ciągu trzech miesięcy programu działania zachęcającego kraje OPEC do zniesienia embarga i zwiększenia produkcji. Zauważył, że współpraca mogłaby objąć też inne obszary: dzielenie się zasobami w razie kryzysu i ich racjonalne wykorzystywanie, a także pozyskiwanie surowców strategicznych ważnych dla bezpieczeństwa Zachodu, np. uranu. Przekonywał, że żadne państwo osobno nie rozwiąże problemów energetycznych - konieczna była skoordynowana akcja ${ }^{44}$.

Reakcja Europejczyków na przemówienie Kissingera była ambiwalentna. Przywódcy akceptowali współpracę w USA w pozyskiwaniu nowych źródeł energii i dzielenia się zasobami w sytuacjach kryzysowych. Niechętnie patrzyli jednak na perspektywę stworzenia formalnego „frontu konsumentów”, jak postrzegano

${ }^{41}$ B. D. N o s s i t e r, Professor Kissinger's Lectures Annoy British, „Washington Post”, 30 listopada 1973.

42 Pilgrims of Great Britain to brytyjsko-amerykańskie stowarzyszenie założone w 1902 r. Jego celem jest promocja bliskich relacji między Stanami Zjednoczonymi a Wielką Brytanią.

${ }^{43}$ Kissinger miał na myśli rozmowy w Waszyngtonie we wrześniu 1973 r. z ministrem spraw zagranicznych Danii Andersenem.

${ }^{44} \mathrm{H}$. K i s s in g e r, US-European Relations (Address to the Pilgrims of Great Britain), [w:] The New Europe and the United States..., s. 40-45. 
EAG, bojąc się, że sprowokuje to państwa arabskie do nałożenia embarga na wszystkich członków grupy ${ }^{45}$. Kissinger starał się ich przekonać, że bezpieczeństwo energetyczne i pokój na Bliskim Wschodzie mogli uzyskać tylko za pośrednictwem Amerykanów $^{46}$. Poza tym stwierdził, że jeśli Europejczycy nie zgodzą się na działania wielostronne, Stany Zjednoczone zaczną zawierać umowy bilateralne z producentami. Był przekonany, że w takiej konkurencji państwa europejskie nie miały szans $^{47}$.

14 grudnia 1973 r. w Kopenhadze na szczycie państw EWG pojawili się ministrowie czterech państw arabskich (Algierii, Tunezji, Sudanu i Zjednoczonych Emiratów Arabskich) ${ }^{48}$. Ujawnił się wtedy brak solidarności państw europejskich i ich polityczna słabość, nie udało się bowiem przeforsować - jak postulowała RFN - jednolitego wsparcia Holandii w jej wysiłkach w celu zniesienia embarga. Sprzeciwiły się temu Francja i Wielka Brytania sądząc, że podjęcie takiej decyzji utrudniłoby negocjacje z państwami arabskimi. W oświadczeniu końcowym uniknięto stwierdzenia, że kraje EWG będą wspierały Holandię własnymi zasobami ${ }^{49}$. Na taką postawę miała wpływ obecność przedstawicieli państw, które nałożyły embargo. Perspektywa przyjęcia przez EWG wspólnej polityki energetycznej została oddalona. Osłabiało to też siłę argumentu wysuwanego wobec Stanów Zjednoczonych, że solidarne działania Europy służą interesom wszystkich członków EWG. W Waszyngtonie twierdzono nawet, że Europa była bardziej zagrożona uzależnieniem ze strony producentów ropy naftowej niż ze strony ZSRR. 0 trwałości transatlantyckich rozbieżności świadczył też brak odniesienia się do Pilgrim Speach w oficjalnym komunikacie końcowym kopenhaskiego szczytu ${ }^{50}$.

20 grudnia Kissinger przekonywał Pompidou i Joberta, że Stany Zjednoczone pragnęły silnej Europy, a on sam nie dążył do skłócenia „Dziewiątki”. Sekretarz stanu podkreślał, że USA chciałyby większego zaangażowania Europy w negocjacje z państwami arabskimi w celu zakończenia kryzysu energetycznego. Zapewniał Pompidou, że Francja odgrywała szczególną rolę w polityce zagranicznej USA, gdyż jako jedyny kraj sojuszniczy chciała wziąć współodpowiedzialność za losy świata. Był jednak niechętny postulowanej przez EWG odrębnej polityce. Twierdził, że dopóki będą trwały spory wewnątrz sojuszu, producenci ropy nie zgodzą się na korzystne rozwiązania dla całego Zachodu. Wspomniał, że podczas negocjacji z krajami arabskimi warunków zwiększenia wydobycia ropy otrzymał odpowiedź, że

${ }^{45} \mathrm{H}$. K i s s in g e r, The Years of Upheaval..., s. 897.

${ }^{46}$ NARA, NPMS, NSC Files, Presidental/HAK Memcons, memorandum z rozmowy Kissingera z prezydentem Algierii Houari Boumedienne, 13 grudnia 1973, box 1027.

${ }^{47} \mathrm{H}$. K i s s in ger, The Years of Upheaval..., s. 905.

${ }^{48}$ Arab Visit Upstages Summit, „Washington Post”, 14 grudnia 1973.

${ }^{49}$ J. M. G o s h ko, J. Randal, EEC Leaders Make Show of Unity on Oil, „Washington Post”, 15 grudnia 1973.

${ }^{50}$ R. L. Pf altzgraff, Energy Issues and Alliance Relationship. The United States, Western Europe and Japan, Cambridge, Mass. 1980, s. 22. 
dostali już lepszą ofertę z Londynu. Uznał taką konkurencję za szkodliwą dla interesów wszystkich państw OECD. Kissinger udowadniał również, że działając niespójnie, Zachód wzmacnia niedemokratyczne arabskie reżimy ${ }^{51}$.

Pompidou przedstawił odmienny punkt widzenia: stwierdził, że „front konsumentów" oddali perspektywę porozumienia. Producenci nie zgodzą się, by narzucano im warunki, gdyż czuli przewagę ze względu na duże straty gospodarcze, jakie ponosił Zachód. Prezydent stwierdził, że Francji, jak i większości państw europejskich, nie stać na długie czekanie na zmianę stanowiska państw arabskich. Kissinger odpowiedział, że zdaje sobie sprawę, że przedłużający się kryzys energetyczny mógł doprowadzić do upadku europejskich rządów. Zwrócił jednak uwagę, że Stany Zjednoczone dysponowały o wiele większymi środkami nacisku politycznego niż kraje EWG. W zaufaniu zdradził, że kluczowy eksporter - Arabia Saudyjska, skłania się coraz bardziej do zniesienia embarga ${ }^{52}$. Dlatego tylko działania dyplomacji amerykańskiej mogły doprowadzić do ożywienia procesu pokojowego, niedopuszczenia do objęcia władzy w Arabii Saudyjskiej przez radykałów czy zapewnienie przetrwania Izraela. Stwierdził, że były to warunki konieczne do utrzymania względnie stabilnej sytuacji na Bliskim Wschodzie, co z kolei zapewniałoby niezakłócone dostawy surowców energetycznych. Te argumenty nie zmieniły stanowiska Pompidou, który zapewnił jednak, że Francja, mimo żądań niektórych krajów arabskich, nie będzie wywierała nacisków politycznych na Izrael ${ }^{53}$.

Amerykanie nie mogli się pogodzić, że bezpieczeństwo, polityka zagraniczna i rozwój gospodarczy najbogatszych państw świata, miały być uzależnione od „małych, półfeudalnych i militarnie słabych państewek”54. 9 stycznia 1974 r. Nixon zaprosił ministrów spraw zagranicznych najbardziej uprzemysłowionych krajów odbiorców ropy naftowej: Kanady, RFN, Francji, Włoch, Japonii, Holandii, Norwegii i Wielkiej Brytanii, na konferencję do Waszyngtonu. Nawiązując do Pilgrim Speech Kissingera, prezydent USA wezwał do wypracowania wspólnego stanowiska w relacjach z eksporterami ropy naftowej ${ }^{55}$.

Francja wciąż promowała politykę bilateralnych umów z krajami arabskimi. Chciała również wykreować się na lidera w EWG, wykorzystując opozycję wobec polityki USA. Sceptycyzm Francuzów wobec utworzenia EAG Kissinger tłumaczył

51 NARA, NPMP, NSC Files, HAK Office Files, HAK Trip Files, Europe and Middle East, memorandum rozmowy Kissingera z Pompidou, 20 grudnia 1973, box 56.

${ }^{52}$ Stany Zjednoczone negocjowały umowę o dostawach broni w zamian za korzystne warunki zakupu ropy naftowej (J. E. H a r t s h o r n, Too Much Independence in Atlantic Oil Bargaining?, [w:] Transatlantic Crisis. Europe and America in the 1970s., ed. J. Godson, London 1974, s. 46.

${ }^{53}$ NARA, NPMP, NSC Files, HAK Office Files, HAK Trip Files, Europe and Middle East, memorandum rozmowy Kissingera z Pompidou, 20 grudnia 1973, box 56.

${ }^{54}$ Cyt. za: R. J. B a r n e t, op. cit., s. 329.

${ }^{55}$ NARA, NPMP, NSC Files, HAK Office Files, HAK Trip Files, Europe and Middle East, Nixon do ministrów spraw zagranicznych głównych uprzemysłowionych krajów konsumenckich, 15 stycznia 1974, box 50 . 
obawami o utratę przywództwa w EWG ${ }^{56}$. Na spotkaniu dyrektorów politycznych EWG w Bonn 11 stycznia, przedstawiciele Francji zaproponowali rozpoczęcie dialogu europejsko-arabskiego na poziomie spotkań ekspertów, a docelowo przez zorganizowanie konferencji ministrów spraw zagranicznych. Po raz kolejny Europejczycy planowali niezależną inicjatywę podczas pobytu Kissingera na Bliskim Wschodzie (prowadził wtedy negocjacje z przywódcami Egiptu, Syrii, Izraela i Arabii Saudyjskiej) ${ }^{57}$.

W liście do Kissingera Jobert dziwił się, że na konferencję do Waszyngtonu zostali zaproszeni ministrowie spraw zagranicznych. Uważał, że choć problem kryzysu energetycznego mógł stać się polityczny, jednak lepiej by było, gdyby dyskutowali o nim ministrowie odpowiedzialni za kwestie gospodarcze i to na forum OECD. Poinformował, że propozycja amerykańska była przyjęta z mieszanymi uczuciami przez Belgię, Luksemburg, Danię i Irlandię, które nie zostały zaproszone na obrady. Jobert zaproponował, żeby jeszcze raz przedyskutować warunki rozmów, sugerując zwołanie konferencji do spraw energii na forum $\mathrm{ONZ}^{58}$. Stwierdzenia francuskiego premiera potwierdzały tezę Kissingera, że Francja nie chciała dopuścić do przejęcia przez Amerykanów przywództwa nad rozwiązywaniem kwestii energetycznej i podporządkowania własnym celom polityki europejskiej. Pragnął skierować rozmowy na tory ściśle gospodarcze, pozostawiając debatę nad innymi kwestiami krajom europejskim, na które Francja mogła wywierać wpływ.

Kissinger nie zgodził się z propozycjami Joberta. W odpowiedzi na jego list przekonywał, że kwestię współpracy energetycznej należało załatwić w węższym gronie, gdyż nie była ona czysto ekonomiczna, dotyczyła spraw wielkiej polityki, które mogą zrozumieć tylko wielkie mocarstwa. Podzielił się też refleksją, że podczas rozmów sondażowych odniósł wrażenie, że państwa arabskie nie były zaniepokojone zwołaniem takiej konferencji. Zapewnił, że po wstępnych rozmowach można będzie zorganizować obrady także z udziałem producentów ${ }^{59}$.

Pozostałe zaproszone państwa przyjęły bez większych zastrzeżeń amerykańską propozycję. Tylko Heath zaznaczył, że należałoby unikać poruszania spraw politycznych, skupiając się na technicznym aspekcie współpracy, by nie dopuścić do zantagonizowania uczestników ${ }^{60}$. Miał oczywiście na myśli stronę francuską, która była niechętna składaniu politycznych deklaracji, np. powstrzymania się od pogłębiania współpracy z krajami arabskimi. Zwrócił jednak uwagę, że EWG odłożyła wszystkie

${ }^{56}$ Ibidem, Kissinger do Nixona, 16 stycznia 1974.

${ }^{57}$ R. D a ll e k, op. cit., s. 551-553.

${ }^{58}$ NARA, NPMP, NSC Files, HAK Office Files, HAK Trip Files, Europe and Middle East, Jobert do Kissingera, 16 stycznia 1974, box 50.

${ }^{59}$ NARA, NPMS, NSC Files, Country Files - Europe (France), Kissinger do Joberta, 31 stycznia 1974, box 678.

${ }^{60}$ NARA, NPMP, NSC Files, HAK Office Files, HAK Trip Files, Europe and Middle East, Heath do Nixona, 19 stycznia 1974, box 50 . 
formalne spotkania z przedstawicielami państw-producentów, by stworzyć lepszą atmosferę przed konferencją waszyngtońską. Pompidou, nie chcąc dopuścić by jego kraj został zmarginalizowany, zgodził się wysłać do stolicy USA Joberta. Jednak w liście do Nixona zaznaczył, że czyni to z czystej kurtuazji oraz żeby umożliwić Europie zajęcie jednolitego stanowiska ${ }^{61}$. Rząd francuski oświadczył, że sprzeciwia się powołaniu na tej konferencji organu koordynującego kwestie polityczne i gospodarcze związane z zapewnieniem dostaw energii. Była to zapowiedź zniweczenia wysiłków amerykańskich. By okazać niezależność Francji, przed wyjazdem do Waszyngtonu Jobert złożył wizytę w Iraku² ${ }^{62}$

Kolejną demonstracją europejskiej niezależności było przyjęcie 7 lutego na spotkaniu RMWE inicjatywy dialogu z państwami arabskimi. Amerykanie nie zostali oficjalnie poinformowani o tym fakcie, znali sprawę tylko z przecieków ${ }^{63}$. W rozmowie z doradcami 9 lutego 1974 r. Nixon polecił Williamowi Simonowi - szefowi Federalnego Biura Energii (Federal Energy Office), by w rozmowie ze swymi europejskimi odpowiednikami dał do zrozumienia, że działania EWG w celu nawiązania bez konsultacji z USA stosunków z krajami arabskimi, mogły doprowadzić do stopniowego wycofywania się Stanów Zjednoczonych z obrony Starego Kontynentu. Prezydent proponował poinformowanie Europejczyków, że Kongres zniecierpliwiony narastającą rywalizacją na polu gospodarczym, mógł przegłosować ustawy o znacznej redukcji wojsk amerykańskich. Jednak Kissinger odradzał taką taktykę twierdząc, że wycofywanie wojsk amerykańskich spowodowałoby jedynie utratę wpływów w Europie Zachodniej, jej neutralizację, a także konieczność rozbudowy przez USA sił nuklearnych. Doradzał dalsze negocjacje, choć - jak stwierdził - wszyscy ministrowie spraw zagranicznych EWG byli „idiotami”, oprócz MSZ Wielkiej Brytanii, Aleca Douglasa-Home' ${ }^{64}$.

Kissinger proponował osobne rozmowy z każdą delegacją, by wykorzystać rozbieżności między poszczególnymi krajami. Podkreślił też, że należy postawić bardziej zdecydowane warunki współpracy delegacjom ze Starego Kontynentu niż japońskiej, ale nie używać argumentu o wycofaniu sił, gdyż Europejczycy dobrze wiedzieli, że nie leżało to $w$ interesie Waszyngtonu. Proponował podnosić kwestie związane ze współpracą gospodarczą, szczególnie dotyczące rozmów handlowych i reformy systemu monetarnego. Kissinger wyraził opinię, że ostry ton był konieczny, gdyż Europa przygotowywała jednolite stanowisko na bazie antyamerykanizmu. Nixon zgodził się, że Europejczycy starają się zmniejszyć wpływy - szczególnie ekonomiczne - USA na świecie. Polecił jednak skupić się na obszarach kluczowych dla

\footnotetext{
${ }^{61}$ NARA, NPMS, NSC Files, Presidental Correspondence 1969-1974, Clift do Kissingera, 8 lutego 1974, box 752 .

${ }^{62}$ M. J o b e r t, Mémoires d'avenir, Paris 1974, s. 285-286.

${ }^{63} \mathrm{H}$. K i s s i n g e r, The Years of Upheaval..., s. 899.

${ }^{64}$ NARA, NPMS, NSC Files, Presidental/HAK Memcons, memorandum ze spotkania Nixona, Kissingera, Shultza, Simona i Scowcrofta w Białym Domu, 9 lutego 1974, box 1027.
} 
amerykańskiej polityki i wciąż rozmawiać z przywódcami EWG tak, by nie dopuścić do utraty przywództwa w zakończeniu kryzysu energetycznego i konfliktu bliskowschodniego ${ }^{65}$.

Przed rozpoczęciem konferencji, Kissinger odbył szereg dwustronnych spotkań z ministrami spraw zagranicznych poszczególnych krajów. Celem ich było wywarcie nacisku i wysondowanie stopnia solidarności europejskiej w sprawie dialogu z państwami arabskimi. W rozmowie z Walterem Scheelem, szefem dyplomacji RFN, pełniącym jednocześnie funkcję przewodniczącego RMWE stwierdził, że Stany Zjednoczone nie będą tuszować ewentualnego fiaska konferencji: miała ona zakończyć się albo podpisaniem umowy albo ogłoszeniem braku porozumienia między aliantami. W tym ostatnim przypadku Kissinger groził wyciągnięciem przez USA politycznych konsekwencji.

Z wypowiedzi Scheela wywnioskował, że decyzja o niezależnych staraniach EWG rozwiązania kryzysu energetycznego była głównie forsowana przez Francję, a pozostałe kraje nie były przekonane do takiego rozwiązania. Minister spraw zagranicznych RFN stwierdził, że jeśli inicjatywa Paryża nie zostałaby przyjęta, Francja poczułaby się urażona, co mogłoby nawet doprowadzić do jej wystąpienia ze Wspólnot. Był także pewny, że na konferencji Jobert nie podpisze się pod żadną propozycją utworzenia nowego organu współpracy energetycznej. Zaproponował Kissingerowi, żeby komunikat o wynikach konferencji został wstrzymany przez kilka dni i ogłoszony dopiero po planowanym spotkaniu RMWE. Powstałoby wtedy wrażenie, że Europejczycy mieli decydujący wpływ na treść porozumienia, co pozwoliłoby Francji przystąpić do układu w sposób „honorowy” i uniknąć wrażenia poddania się amerykańskim naciskom. Kissinger był gotów zgodzić się na takie rozwiązanie tylko w przypadku gwarancji, że proponowane przez Stany Zjednoczone cele nie uległyby zmianie. Tego Scheel nie mógł obiecaćc6.

Kissinger był pewien poparcia RFN, Japonii i Wielkiej Brytanii. Jednak przewidywał sprzeciw Francji. Jobert przybył do Waszyngtonu prosto ze swej bliskowschodniej podróży. Francuski minister spraw zagranicznych miał powiedzieć wprost, że największy jego sprzeciw budzi amerykańskie przywództwo w rozwiązywaniu kryzysu energetycznego. Kissinger zaproponował, że po przyjęciu wspólnego stanowiska w Waszyngtonie, rozmowy zostaną przeniesione na forum OECD, które miało siedzibę w Paryżu. Jobert nalegał, by tam ustalić szczegóły planu, a nie na konferencji w stolicy USA. Kissinger obawiał się, że wtedy amerykańskie postulaty zostaną odrzucone - tym bardziej, że poparcie dla nich większości państw uprzemysłowionych było oparte na kruchych podstawach. Dlatego odrzucił sugestie Joberta ${ }^{67}$.

\footnotetext{
${ }^{65}$ Ibidem.

${ }^{66} \mathrm{H}$. K i s s i n g e r, The Years of Upheaval..., s. 907-908.

${ }^{67}$ Ibidem, s. 910-911.
} 


\subsection{Konferencja waszyngtońska}

Konferencja w Waszyngtonie trwała od 11 do 13 lutego 1973 r. Wzięli w niej udział szefowie dyplomacji i ministrowie odpowiedzialni za kwestie gospodarcze (głównie ministrowie finansów) ze Stanów Zjednoczonych, Kanady, Norwegii i państw EWG. Wspólnoty Europejskie były reprezentowane przez przewodniczącego RMWE Waltera Scheela i szefa Komisji Europejskiej Françoisa Xaviera Ortoliego. W spotkaniu wziął także udział Emile van Lennep - sekretarz generalny OECD.

W pierwszym dniu obrad Kissinger zaproponował realizację siedmiopunktowego planu współpracy energetycznej. Przewidywał on koordynację działań mających na celu oszczędzanie zasobów, spadek zużycia energii, poszukiwanie jej alternatywnych źródeł, przeznaczanie większych środków na badania i rozwój oraz utworzenie mechanizmu dzielenia się rezerwami w sytuacjach kryzysowych. Dostrzeżono konieczność ustalenia zasad konsultacji państw konsumenckich z producentami. W projekcie amerykańskim znalazły się punkty mówiące o współpracy w celu reformy światowego systemu monetarnego. Do czasu jej wprowadzenia w życie, najbardziej uprzemysłowione kraje świata miały powstrzymać się m.in. od deprecjacji walut, restrykcji importowych i płatniczych oraz prowadzić wewnętrzną politykę gospodarczą tak, by nie odbywało się to kosztem innych krajów. Kissinger zaapelował też o koordynację pomocy krajom Trzeciego Świata w walce ze skutkami kryzysu energetycznego. Zapewnił, że proponując utworzenie nowego forum dyskusji, Stany Zjednoczone chciały działać we wspólnym interesie Zachodu, ale niektóre kwestie nie były możliwe do rozstrzygnięcia w szerokim gronie, np. na forum ONZ. Zapowiedział, że na następne konferencje powinni zostać zaproszeni przedstawiciele krajów Trzeciego Świata, a w końcu także eksporterzy ropy. Ci ostatni mieli brać udział w rozmowach dopiero wtedy, gdy konsumenci realizując wspólny plan działania będą na tyle niezależni, by nie ulegali szantażowi i nie musieli godzić się na wszystkie ich warunki ${ }^{68}$. Przypominając skutki braku międzynarodowej współpracy podczas wielkiego kryzysu gospodarczego w latach 30. XX w., wezwał do przyjęcia amerykańskich propozycji. Przewidywał, że w przypadku braku kooperacji, świat Zachodu będzie zmierzał w kierunku niezdrowej konkurencji i wrogości, co przyniesie szkody gospodarcze i polityczne wszystkim państwom ${ }^{69}$.

Propozycję Kissingera skłonni byli poprzeć minister finansów RFN Helmut Schmidt, Douglas-Home oraz przemawiający w imieniu EWG Scheel. Zdecydowany sprzeciw zgłosił Jobert, który oskarżył Scheela, że godząc się na amerykański plan nie wypełnia postanowień EWG, co automatycznie pozbawia go prawa przemawiania w jej imieniu. Przedstawił się jako wyraziciel woli Wspólnoty, gdyż, jak

\footnotetext{
${ }^{68} \mathrm{H}$. K i s s i n g e r, Opening Remarks on Washington Energy Conference, [w:] The New Europe and the United States..., s. 50-54.

${ }^{69} \mathrm{H}$. K i s s in g e r, The Years of Upheaval..., s. 912.
} 
stwierdził, jego koledzy nie mieli politycznej odwagi bronić jej interesów. Zarzucił Amerykanom, że ich jedynym celem było ustanowienie dominacji i zablokowanie Europejczykom możliwości bilateralnych porozumień z producentami. Nie udało mu się jednak przekonać uczestników konferencji ${ }^{70}$.

RFN zgłosiła inicjatywę, by państwa dokonały wspólnej analizy polityki cenowej, dochodów i opodatkowania wielonarodowych korporacji naftowych. Rządy były zaniepokojone sytuacją, że miały bardzo małą kontrolę nad tymi przedsiębiorstwami, które nie zważając na kryzys, nie chciały dopuścić do obniżenia zysków i podwyższały ceny. Niemcy zauważyli, że bez współpracy międzynarodowej żaden rząd nie będzie w stanie wpłynąć na korporacje, a tym samym w pełni kontrolować polityki gospodarczej ${ }^{71}$. W czasie kryzysu energetycznego rządy przekonały się, do jakiego stopnia były uzależnione w tej dziedzinie od wielkich przedsiębiorstw. Chodziło o to, by firmy nie mogły zawierać niezależnych układów z producentami. Problem ten dotyczył szczególnie państw europejskich - niektóre kraje eksportujące ropę wolały zawierać umowy na jej dostawę z wielonarodowymi korporacjami niż z rządami. Natomiast kontrakty z rządem USA, światowego mocarstwa, były dla nich bardziej atrakcyjne. Jednak nie można było stwierdzić, że administracja amerykańska dzierżyła kontrolę nad ulokowanymi w Stanach Zjednoczonych przedsiębiorstwami. Jeszcze przed kryzysem energetycznym, latem 1973 r., gdy na wielu stacjach benzynowych w USA ustawiały się kolejki spowodowane brakiem towa$\mathrm{ru}^{72}$. w Senacie dyskutowano, czy nie była to celowa gra przedsiębiorstw w celu podwyższenia cen ${ }^{73}$.

Jednak sytuacja ta była spowodowana raczej polityką rządu USA. W Stanach Zjednoczonych ceny ropy były wciąż regulowane przez rząd, co chroniło konsumentów przed ich gwałtownym wzrostem. Jednakże stosunkowo niskie ceny nie pobudzały wewnętrznej produkcji, a ograniczony import przyczyniał się do braku ropy na rynku. Rząd stanął przed trudnym zadaniem pogodzenia interesów konsumentów reprezentowanych w Kongresie i firm producenckich, które naciskały na uwolnienie cen ropy ${ }^{74}$.

${ }^{70}$ Ibidem, s. 913.

${ }^{71}$ R. G il p i n, U.S. Power and Multinational Corporation. The Political Economy of Foreign Direct Investments, New York 1975, s. 242.

${ }^{72}$ E. C o w a n s, The Gasoline Shortage: Real or Contrived?, „New York Times”, 8 czerwca 1973. Podobne podejrzenia pojawiły się w prasie w grudniu 1973 r. (D. E. Kn e e lan d s, Energy: Many Skeptical on Reasons of Crisis, „New York Times”, 23 grudnia 1973).

${ }^{73}$ Congressional Record. Proceeding and Debates of the First Session of the $93^{\text {rd }}$ Congress, vol. 119, part 33, posiedzenie Senatu z 19 grudnia 1973, dostępne przez: http:/www.archive.org/stream/ congressionalrec119qunit/-congressionalrec119qunit_djvu.txt.

${ }^{74}$ Ceny ropy w USA przestały być regulowane w 1979 r. Administracja Cartera przedstawiła konieczność takiego rozwiązania, stanowiącego ważny element polityki zagranicznej. Na spotkaniu G7 w 1979 r. Amerykanie zobowiązali się do takiego kroku w zamian za zgodę RFN i Japonii na zwiększenie podaży pieniądza na swoich rynkach (G. J. I k e n b e r r y, op. cit., s. 153). 
Ostatecznie zapis zaproponowany przez RFN został przyjęty przez uczestników konferencji waszyngtońskiej ${ }^{75}$. Gilpin posłużył się przykładem tego porozumienia, podważając model „zagrożonej suwerenności” (sovereignity-at-bay). Rządy dążyły do utrzymania kluczowej roli w gospodarce i były gotowe powstrzymywać korporacje przed działaniami, w wyniku których mógłby być zagrożony żywotny interes państwa, jakim były nieprzerwane dostawy surowców ${ }^{76}$.

Podczas kolacji kończącej pierwszy dzień obrad, Nixon wygłosił toast w formie szantażu, zwracając się zwłaszcza do Francji, będącej „prowodyrem” rozbijania sojuszu. Prezydent stwierdził, że wobec europejskiej odmowy podjęcia wspólnych działań, nie można było wykluczyć w najbliższym czasie całkowitego wycofania wojsk amerykańskich z Europy. Nixon zwrócił uwagę, że izolacjonizm w Stanach Zjednoczonych był dobrze ugruntowany, a postawa państw europejskich dostarczała argumentów jego zwolennikom. Przypomniał, że współpraca transatlantycka nie układała się pomyślnie nie tylko w dziedzinie energetyki. Europejczycy torpedowali propozycje amerykańskie na polu ułatwień dla wolnego handlu czy reformy światowego systemu monetarnego. Powtórzył tezę Kissingera o konieczności współpracy transatlantyckiej w sprawach bezpieczeństwa, polityki zagranicznej i gospodarczej. Mimo że zapewniał o przywiązaniu do sojuszu, a Kissinger tłumaczył jego ostrą wypowiedź zmęczeniem psychicznym spowodowanym aferą Watergate, prezydent ewidentnie chciał skłonić Europejczyków do podjęcia współpracy na amerykańskich warunkach ${ }^{77}$.

Można jednak przypuszczać - sugerował to zresztą Kissinger na spotkaniu z Nixonem przed konferencją - że przedstawiciele państw Starego Kontynentu nie wierzyli w możliwość wycofania się wojsk amerykańskich. Do współpracy mogła ich bardziej zachęcić zapowiedź dzielenia zasobów energii oraz wysoka cena polityczna i niepewność bilateralnych kontaktów z państwami arabskimi. Poszczególne kraje europejskie miały małą możliwość wywierania nacisków na producentów, a przypadek braku solidarności wobec Holandii i niemożność wypracowania wspólnej polityki energetycznej $w$ ramach EWG, czyniła odrzucenie amerykańskiego „koła ratunkowego" zbyt ryzykownym. Niewątpliwie nie chciano też doprowadzić do poważniejszego konfliktu z USA, gdyż sojuszników łączyły poza obroną liczne wspólne polityczne i gospodarcze interesy.

Podczas obrad plenarnych 12 lutego przedstawiciele państw EWG często opuszczali salę w celu konsultacji. Jednak już około południa Douglas-Home powiadomił Kissingera, że ośmiu reprezentantów zgodziło się, mimo sprzeciwu Francji, na powstanie EAG. Szef dyplomacji brytyjskiej zażądał w zamian gwarancji, że Stany

\footnotetext{
${ }^{75}$ W. J. L e vy, An Atlantic-Japanese Energy Policy, [w:] The New Europe and the United States..., s. 236-237.

${ }^{76}$ R. G il p in, Three Models of the Future, [w:] Key Concepts in International Political Economy, ed. D. A. Baldwin, vol. 1, Vermont 1993, s. 45.

${ }^{77}$ H. K i s s in g e r, The Years of Upheaval..., s. 915-916.
} 
Zjednoczone nie będą szukały po powstaniu tego ciała osobnego porozumienia z Paryżem, na co Kissinger wyraził zgodę ${ }^{78}$. Jobert, zdając sobie sprawę z politycznej izolacji, poprosił Kissingera o spotkanie, na którym zaproponował, że poprze amerykańskie postulaty oprócz punktu o utworzeniu EAG. Przekonywał, że sukces konferencji zostanie uratowany, a grupa współpracy energetycznej powstanie na zwołanej jak najszybciej konferencji $\mathrm{OECD}^{79}$. W ten sposób Jobert chciał wystawić Kissingera na próbę, by przekonać się, czy Amerykanom chodziło istotnie o zażegnanie kryzysu najlepszymi możliwymi sposobami czy dokonanie tego na własnych warunkach, niezależnie od interesów sojuszników.

Kissinger jednak uznał, że odkładanie najważniejszej z punktu widzenia USA decyzji nie zapewni konferencji sukcesu. We wspomnieniach tłumaczył, że gdyby uległ sugestiom francuskim, nigdy nie udałoby się już przekonać pozostałych krajów do tak daleko idącego poparcia amerykańskiego programu. Przewidywał, że na forum OECD, w toku przeciągających się dyskusji, państwa gotowe do zdecydowanych działań na konferencji w Waszyngtonie mogłyby zmienić zdanie. Sekretarz stanu odpowiedział więc Jobertowi, że konferencja OECD mogłaby odegrać jedynie rolę forum do ratyfikacji postanowień waszyngtońskich. Uznał, że konieczne było podpisanie przez Francję wstępnej zgody na powstanie tymczasowego mechanizmu konsultacji w sprawach związanych z kryzysem energetycznym. Jobert obiecał skonsultować tę propozycję z Pompidou, a Kissinger zgodnie z umową poinformował Douglasa-Home’a o treści rozmowy i ponownie obiecał, że nie zaangażuje się w żadną osobną umowę z Francją. Jeszcze tego samego dnia wieczorem Jobert otrzymał odpowiedź z Paryża: Pompidou polecił mu nie zgadzać się na kompromis zaproponowany przez Kissingera ${ }^{80}$.

Wszystkie postulaty zgłoszone przez Kissingera w pierwszym dniu obrad znalazły się w tekście deklaracji ogłoszonej 13 lutego 1974 r. Najważniejszym rezultatem było utworzenie Grupy Koordynacyjnej ds. Energii (Energy Coordinating Group - ECG ${ }^{81}$. Powstaniu tego ciała sprzeciwili się przedstawiciele Francji utrzymując, że konsultacje powinny się odbywać w ramach istniejących instytucji. Nie zaakceptowali większości postanowień zawartych w komunikacie waszyngtońskim. Nie zanegowali jedynie współpracy w reformowaniu światowego systemu monetarnego, nie akceptując jednak zaproponowanych środków prowadzących do tego celu. Nie

${ }^{78}$ Douglas-Home obawiał się tego w związku ze zgodą Kissingera w czerwcu 1973 r. na prowadzenie bilateralnych rozmów z Francją w sprawie Deklaracji Atlantyckiej, bez konsultacji z pozostałymi członkami Wspólnot.

${ }^{79} \mathrm{H}$. K i s s in g e r, The Years of Upheaval..., s. 917.

${ }^{80}$ Ibidem, s. 918-920. Oceniając nieprzejednaną postawę Pompidou, należy wziąć pod uwagę jego ciężką chorobę, która zakończyła się śmiercią 2 kwietnia 1974 r. Był zdeterminowany, by utrzymać-zgodnie z założeniami polityki gaullistowskiej, której był zwolennikiem - silną i niezależną rolę Francji na arenie międzynarodowej.

${ }^{81}$ Grupa działała od listopada 1974 r. przy OECD jako Międzynarodowa Agencja Energetyczna (International Energy Agency). 
sprzeciwili się także zapisom o konieczności powstania narodowych programów pozyskiwania źródeł energii, ochrony środowiska, zwiększenia pomocy dla krajów rozwijających się, przyjrzeniu się działalności wielonarodowych korporacji oraz rozwijaniu wielostronnych relacji z producentami ropy naftowej ${ }^{82}$.

Jobert twierdził, że ECG miała dla Amerykanów cel wyłącznie polityczny - odzyskanie przywództwa i uniemożliwienie Europie prowadzenia samodzielnej polityki wobec państw arabskich ${ }^{83}$. Chociaż większość krajów zaakceptowała przywództwo Stanów Zjednoczonych przystępując do Grupy, wrażenie rozłamu atlantyckiego pozostało. W prasie amerykańskiej pisano o braku jednolitej strategii liderów ${ }^{84}$.

Irwin zauważał, że z powodu sprzecznych opinii w EWG na temat konferencji waszyngtońskiej, problem współpracy energetycznej stał się w kwestią polityczną. Spotkanie mogło wywrzeć negatywny wpływ na relacje transatlantyckie, bezpieczeństwo i stosunki z krajami Bliskiego Wschodu ${ }^{85}$. Ambasador informował o wielkim rozgoryczeniu Joberta, który na spotkaniu Komitetu Spraw Zagranicznych w Zgromadzeniu Narodowym relacjonował ton rozmów z Kissingerem jako obraźliwy. Twierdził, że sekretarz stanu uciekał się do szantażu w stosunku do RFN - zapowiadając wycofanie wojsk w przypadku braku poparcia dla ECG. Wielkiej Brytanii miał zagrozić zaprzestaniem pomocy w utrzymaniu kursu funta szterlinga, a Francji atakiem na polu monetarnym ${ }^{86}$. Wprawdzie w rozmowie z Brandtem i Scheelem w Bonn Kissinger zaprzeczał tym sugestiom, ale wersja Joberta wydaje się być bardzo prawdopodobna, biorąc pod uwagę sugestie sekretarza stanu wygłoszone przed konferencją waszyngtońską na naradzie u prezydenta 9 lutego. Jobert był rozczarowany postawą europejskich partnerów. Stwierdził, że „zastraszeni” przez Kissingera nie byli zdolni wypracować jednolitego stanowiska i przeciwstawić się dominacji USA ${ }^{87}$.

Irwin oceniał, że Francja była zdecydowana utrzymać sprzeciw wobec koordynacji działań antykryzysowych pod egidą amerykańską i starać się przekonać pozostałą ósemkę państw do prowadzenia odrębnej polityki w tej kwestii ${ }^{88}$. Nixon - wbrew radom Kissingera - zdecydował się wtedy publicznie ostrzec państwa

82 Tekst komunikatu z obrad konferencji waszyngtońskiej, 13 stycznia 1974, [w:] Atlantic Community in Crisis. A Redefinition of the Transatlantic Relationship, eds. W. F. Hahn, R. L. Pfaltzgraff, New York 1979, s. 451-454.

${ }^{83}$ M. J o b e r t, op. cit., s. 286.

${ }^{84}$ J. A s l o p, The Decline West, „Washington Post”, 15 lutego 1974; zob. także: An Atlantic Energy Program, „Washington Post”, 14 lutego 1974.

${ }^{85}$ NARA, NPMS, NSC Files, Country Files - Europe (France), Irwin do Kissingera, 21 lutego 1974, box 678 .

${ }^{86}$ Po zamrożeniu cen na 60 dni przez rząd amerykański w czerwcu 1973 r. (por. podrozdział 6.8) nastąpiła kolejna dewaluacja dolara w stosunku do walut europejskich (A. W. D e P o r t e, Europe Between the Superpowers. The Enduring Ballance, New Haven 1979, s. 407).

${ }^{87}$ M. J o b e r t, op. cit., s. 287.

${ }^{88}$ NARA, NPMS, NSC Files, Country Files - Europe (France), Irwin do Kissingera, 22 lutego 1974, box 679 . 
europejskie przed narastaniem nastrojów izolacjonistycznych w Kongresie, co mogło doprowadzić do wycofania wojsk amerykańskich ze Starego Kontynentu. „Bezpieczeństwo i uwarunkowania gospodarcze są nieuchronnie połączone. Kwestie energetyczne nie mogą być oddzielone również od tych zależności" ${ }^{\prime \prime 9}$ - przypomniał Nixon sojusznikom w przemówieniu wygłoszonym 12 lutego.

Mimo nawiązania współpracy z Amerykanami na konferencji waszyngtońskiej, Europejczycy nie zrezygnowali z samodzielnych inicjatyw na Bliskim Wschodzie. 5 marca 1974 r. ministrowie spraw zagranicznych EWG ogłosili decyzję o uruchomieniu wielostronnych spotkań ze swoimi odpowiednikami z krajów arabskich. Zapowiedziano, że kwestie energetyczne i pokoju w regionie nie będą poruszane, a szefowie dyplomacji zajmą się ustaleniem warunków pomocy rozwojowej. Amerykanie przyjęli tę inicjatywę z nieufnością. Mieli żal do Europejczyków, że przed jej ogłoszeniem nie przeprowadzono z nimi konsultacji. Szczególnie zaskoczony był Kissinger, który zatrzymał się w Bonn 3 marca w drodze na Bliski Wschód. Rozmawiał wtedy z Scheelem, który odcinał się zdecydowanie od konfrontacyjnej wobec USA polityki Francji. Wspomniał wprawdzie, że ministrowie spraw zagranicznych będą rozmawiać o stosunkach z państwami arabskimi, ale zapowiedział, że proponowana współpraca ograniczy się do dziedzin zdrowia i współpracy naukowej. Kissinger ostrzegł, że gdyby szefowie dyplomacji państw europejskich spotkali się z reprezentantami państw arabskich, spowodowałoby to umocnienie się radykalnych rządów na Bliskim i Środkowym Wschodzie ${ }^{90}$.

4 marca Kissinger przybył do Brukseli na spotkanie z ambasadorami przy NATO. Tłumaczył tam strategię podczas nadchodzącej wizyty na Bliskim Wschodzie. Po spotkaniu odbyła się konferencja prasowa, na której sekretarz stanu i sekretarz generalny NATO Joseph Luns bardzo dobrze ocenili stan relacji atlantyckich. Przyjazną atmosferę zniszczyło pytanie dziennikarza, czy Kissinger wie o postanowieniach RMWE dotyczących daleko idącej współpracy z państwami arabskimi. Kissinger w rozmowie z Scheelem wyraził niezadowolenie, że dowiedział się o tak ważnych decyzjach na konferencji prasowej. Stwierdził, że postawa Europejczyków utrudni jego rozmowy na Bliskim Wschodzie. Zapowiedział, że Stany Zjednoczone nie będą konsultowały się z EWG przed podjęciem decyzji istotnych dla własnego interesu narodowego. Poprosił też Scheela, by publicznie nie mówił o planowanej wizycie Nixona w Europie (prezydent miał przyjechać jesienią, by podpisać Deklarację Atlantycką), gdyż decyzja ta będzie musiała być rozważona w świetle zmian w relacjach amerykańsko-europejskich.

Departament Stanu zdecydował o odwołaniu z tego powodu kolejnego spotkania między przedstawicielami EWG i USA w sprawie Deklaracji Atlantyckiej, które miało się odbyć 13 marca w Bonn. Rozważano również odwołanie spotkania ECG. Irwin odradzał takie rozwiązanie. Stwierdził, że potwierdziłoby to przekonanie Francji,

\footnotetext{
${ }^{89}$ M. B e rg e r, Nixon Links Security and Fuel, „Washington Post”, 12 lutego 1974.

${ }^{90} \mathrm{H}$. K i s s in g e r, The Years of Upheaval..., s. 927-928.
} 
że powołanie Grupy miało na celu zahamowanie rozwoju niezależnych stosunków Europy z państwami arabskimi ${ }^{91}$. Spowodowałoby to również nadwerężenie zaufania pozostałej ósemki państw, które godząc się na udział w jej pracach, zaryzykowały pogorszenie się stosunków z Francją, a tym samym konflikt wewnętrzny w EWG $\mathrm{G}^{92}$.

Na spotkaniu z Étiennem Davignonem (ministrem spraw zagranicznych Belgii) podsekretarz stanu William H. Donaldson poinformował o zawieszeniu konsultacji w sprawie Deklaracji Atlantyckiej. Davignon przypomniał o zaangażowaniu się ośmiu państw europejskich w dialog energetyczny z USA, mimo sprzeciwów Francji. Zauważył, że Stany Zjednoczone były wcześniej poinformowane o zakresie przyszłych rozmów EWG z państwami arabskimi. Zapewnił, że nie będzie zawarte żadne porozumienie polityczne, a ewentualna umowa będzie dotyczyła współpracy kulturalnej, naukowej i gospodarczej. Zaprzeczył, że był to krok wymierzony przeciwko Stanom Zjednoczonym. Zapewnił, że Waszyngton będzie szczegółowo informowany o przebiegu rozmów, a dialog dotyczący dostaw ropy będzie, na życzenie państw arabskich, prowadzony bilateralnie z każdym państwem EWG z osobna. Donaldson stwierdził, że w takim przypadku istnienie ECG nie miało sensu, lecz Davignon zapewnił go, że państwom europejskim zależało na utrzymaniu tej grupy. Mówił, że osobny dialog z państwami arabskimi miał na celu pokazanie obywatelom, że EWG nie była bezsilna w polityce zagranicznej i współpracując może zniwelować negatywne skutki kryzysu ${ }^{93}$.

6 marca Nixon w liście do Brandta stwierdził, że porozumienie o współpracy $\mathrm{z}$ eksporterami było dowodem na brak konsultacji w stosunkach transatlantyckich. Prezydent uznał, że Europejczycy potraktowali Stany Zjednoczone jak wroga, dlatego odwołał spotkanie na temat Deklaracji Atlantyckiej planowane na kolejny tydzień. Podkreślił, że USA nie miały nic przeciwko współpracy Europy z państwami arabskimi. Za niedopuszczalny uznał moment porozumienia - EWG wykonywała przyjazne gesty, podczas gdy Stany Zjednoczone wywierały naciski, by doprowadzić do pokojowego zakończenia konfliktu bliskowschodniego. Obawiał się, że chcąc zapewnić sobie dostawy ropy, Europejczycy ulegną państwom ją eksportującym w sprawach politycznych, co postawi ich w opozycji wobec dyplomacji USA ${ }^{94}$.

Jednak obawy amerykańskie wobec poważnej konkurencji EWG na Bliskim Wschodzie okazały się być nieuzasadnione. Europa była w tej kwestii podzielona.

${ }^{91}$ Takie stwierdzenia pojawiły się we francuskiej prasie. W „Le Figaro” sugerowano, że spotkanie zostało celowo zorganizowane przez Amerykanów przed obradami RMWE EWG, zaplanowanymi na 4 marca 1974 r., by zapobiec podjęciu przez Europejczyków decyzji o prowadzeniu niezależnej polityki wobec państw arabskich (NARA, NPMS, NSC Files, Country Files - Europe (France), Irwin do Kissingera, 22 lutego 1974, box 678).

92 Ibidem, Stone do Kissingera, 5 marca 1974.

${ }^{93}$ NARA, NPMS, NSC Files, Country Files - Europe (France), Donaldson do Kissingera, 6 marca 1974 , box 679.

${ }^{94}$ NARA, NPMS, NSC Files, Presidental Correspondence 1969-1974, Nixon do Brandta, 6 marca 1974, box 753 . 
Francję, która zdecydowanie dążyła, by EWG prowadziła możliwie najbardziej niezależną politykę energetyczną i zagraniczną, poparła Wielka Brytania. Natomiast politycy RFN byli rozdarci - nie chcieli wyłamywać się ze wspólnych działań europejskich, ale pragnęli również uniknąć konfrontacji z USA ${ }^{95}$. Te wahania wewnątrz Wspólnoty sprawiły, że ostatecznie każde państwo negocjowało bilateralne układy z państwami arabskimi, np. Francja zawarła w 1974 r. szereg umów o dostawach ropy, sprzedając w zamian samoloty i broń. Podobne umowy podpisała RFN ${ }^{96}$. Identyczną taktykę przyjęły Stany Zjednoczone, które miały większy potencjał, jeśli chodzi o tego typu wymianę ${ }^{97}$.

Jednocześnie kontynuowano współpracę energetyczną w ramach ECG. Na piątym spotkaniu tej grupy 17 i 18 czerwca w Brukseli, Stany Zjednoczone zaproponowały stworzenie Wspólnego Programu Kryzysowego (Integrated Emergency Program - IEP) przewidującego skoordynowane działania w przypadku wystąpienia kryzysów w przyszłości ${ }^{98}$. Miało to nie tylko zniwelować negatywne skutki gospodarcze, ale i polityczne. Jednym z celów było wciągnięcie do ECG Francji, która była zainteresowana współpracą kryzysową w ramach IEP. Program był jednak sformułowany całościowo - korzystanie z zasobów energii innych państw w czasie kryzysu wymuszało podjęcie współpracy w innych dziedzinach, które ustalono na konferencji waszyngtońskiej. Amerykanie liczyli, że poprzez ten program Francja zaniecha oporu i zaangażuje się w prace ECG. Sami nie składali takiej propozycji Paryżowi - pośrednikiem w zachęcaniu Francji do udziału byli dyplomaci RFN ${ }^{99}$.

Po odejściu Joberta ze stanowiska ministra spraw zagranicznych w maju 1974 r., Kissinger widział więcej szans na pozyskanie Francji. W rozmowie z nowym szefem dyplomacji francuskiej Jeanem Sauvagnarguesem, namawiał go do współpracy. Twierdził, że tylko wspólne działania państw konsumenckich mogły zmusić producentów do zwiększenia wydobycia, co mogło obniżyć ceny ropy. Określił zachowanie się państw europejskich w październiku 1973 r. „reakcją królika zahipnotyzowanego przez węża"100. Jednak Sauvagnargues twierdził, że Europy nie stać na zantagonizowanie państw arabskich.

W wyniku rozmów na forum ECG, 15 listopada $1974 \mathrm{r}$. w ramach OECD utworzono Międzynarodową Agencję Energetyczną (International Energy Agency - IEA).

${ }^{95}$ K. K a i s e r, Europe and America: a Critical Phase, „Foreign Affairs”, July 1974, s. 732. Por. C. R. W h i t n e y, Bonn Sees Itself in the Middle, Forced to Choose between Paris and Washington, „New York Times", 8 marca 1974.

${ }^{96}$ M. W o l f f s o h n, op. cit., s. 28.

${ }^{97}$ J. K r a s u s k i, Historia polityczna Europy Zachodniej 1945-2002, Poznań 2003, s. 277.

${ }^{98}$ A. S h o n f i e l d, International Economic Relations: The Western System in the 1960s and 1970s, Beverly Hills-London 1976, s. 49.

${ }_{99}$ NARA, NPMS, NSC Files, Country Files - Europe (Germany), Springsteen do Scowcrofta, 22 lipca 1974, box 687.

${ }^{100}$ NARA, NPMS, NSC Files, Presidental/HAK Memcons, memorandum z rozmowy Kissingera z Sauvagnarguesem, 4 lipca 1974, box 1029. 
Było to spełnienie postulatu francuskiego przeniesienia dialogu na forum OECD, jednakże Paryż nie zdecydował się na przyłączenie się do Agencji. Jej członkamizałożycielami było 17 państw: Austria, Belgia, Dania, Hiszpania, Holandia, Irlandia, Japonia, Kanada, Luksemburg, Norwegia (na podstawie osobnej umowy), RFN, Stany Zjednoczone, Szwajcaria, Szwecja, Turcja, Wielka Brytania i Włochy ${ }^{101}$.

\subsection{Wpływ kryzysu energetycznego na Deklarację Atlantycką}

Bezpośrednio przed wybuchem wojny Jom Kippur, w negocjacjach na temat Deklaracji Atlantyckiej, Amerykanie kładli największy nacisk na konieczność ustalenia mechanizmu konsultacji politycznych. Z niepokojem patrzyli na próby stworzenia wspólnej polityki zagranicznej państw EWG. Obawiali się, że Europejczycy mogli utrudniać zadanie dyplomacji amerykańskiej, dążąc do forsowania własnych rozwiązań w relacjach z blokiem wschodnim czy w polityce bliskowschodniej ${ }^{102}$.

Przyszłość Deklaracji Atlantyckiej stanęła pod jeszcze większym znakiem zapytania w dobie kryzysu energetycznego. Znów na pierwszy plan wysunął się czynnik gospodarczy. W raporcie dla Kissingera z 26 października 1973 r. Sonnenfeldt przedstawił kwestie pod dyskusję na planowane na 14 listopada spotkanie dyrektorów politycznych EWG z przedstawicielami USA. Przewidywał, że Europejczycy przedstawią wcześniej propozycje zmian w Deklaracji. Zdawał sobie sprawę, że poprawki, które można od nich uzyskać będą miały charakter „kosmetyczny”. Zakładał, że zgodnie z sugestią Amerykanów, nowy tekst będzie miał charakter bardziej ogólny, gdyż priorytetowo zostanie potraktowane porozumienie w ramach NATO. Stwierdził, że niemożliwa była zgoda Europejczyków na rozpatrywanie łącznie kwestii politycznych, obronnych i gospodarczych oraz utworzenie dodatkowego forum konsultacyjnego. Można było jedynie przeforsować zapis o intensyfikacji kontaktów w ramach istniejących instytucji. Sonnenfeldt uważał, że nie należało dopuścić do eskalacji kryzysu w stosunkach transatlantyckich, próbując narzucić amerykańską wersję porozumienia. Radził utrzymywać dialog w tej sprawie i nie wykluczać jesiennej podróży Nixona do Europy ${ }^{103}$.

Największe zainteresowanie dokumentem wykazywała RFN, która od stycznia 1974 r. miała objąć przewodnictwo w EWG. Niemieckie ministerstwo spraw zagranicznych popierało stanowisko Amerykanów, że tekst trzeba skrócić i zrobić z niego ogólną deklarację polityczną, by uniknąć dyskutowania kontrowersyjnych

${ }^{101}$ R. L. Pfaltzgraff, op. cit., s. 22. Obecnie IEA ma 28 państw członkowskich. Francja przystąpiła do niej w $1992 \mathrm{r}$.

102 D. M ö c k l i, European Foreign Policy during the Cold War: Heath, Brandt, Pompidou and the Dream of Political Unity, London 2008, s. 183.

${ }^{103}$ NARA, NPMS, NSC Files, Subject Files: European Common Market, Sonnenfeldt do Kissingera, 26 października 1973, box 322. 
szczegółów. Politycy niemieccy informowali, że niechętną postawę Francji zaczęła podzielać Wielka Brytania, rozczarowana brakiem zaproszenia na rozmowy w Genewie w sprawie konfliktu izraelsko-arabskiego. Brytyjczycy byli sceptycznie nastawieni do możliwości prawdziwego partnerstwa w relacjach transatlantyckich. Dodatkowym czynnikiem hamującym była trudna sytuacja polityczna rządów podczas kryzysu energetycznego ${ }^{104}$.

Na wniosek Francji, kraje EWG zawiesiły prace nad tekstem Deklaracji. Dopiero na spotkaniu RMWE w Kopenhadze 20 listopada 1973 r., upoważniono przedstawiciela Danii do reprezentowania całej Wspólnoty w negocjacjach ${ }^{105}$. W komunikacie po zakończeniu szczytu ogłoszono powstanie Deklaracji Europejskiej Tożsamości (Declaration on European Identity). Zawarto w niej katalog elementów łączących państwa członkowskie, takich jak wspólne dziedzictwo kulturowe, interesy, zobowiązania i dążenie do pogłębiania integracji. Szczególnie dużo uwagi poświęcono polityce zagranicznej. Stwierdzono, że każdy kraj mógł być w tej dziedzinie niezależny, lecz w dobie rywalizacji supermocarstw było to znacznie utrudnione. Wzywano do zjednoczenia politycznego Europy, by EWG mogła odgrywać właściwą rolę na arenie międzynarodowej. W związku z tym zadeklarowano dążenie do jednolitego stanowiska, ustalanego na spotkaniach ministrów spraw zagranicznych. Wyrażono wolę współpracy w wychodzeniu z kryzysu energetycznego zarówno w ramach EWG, jak i w OECD. Nie odrzucono współpracy ze Stanami Zjednoczonymi, lecz wspomniano o niej tylko w kontekście obrony nuklearnej i utrzymania obecności wojsk amerykańskich w Europie ${ }^{106}$. Zadecydowano także o wysłaniu oficjalnych listów z propozycją współpracy do rządów państw arabskich ${ }^{107}$.

Deklaracja Europejskiej Tożsamości była demonstracją niezależności, co było kolejnym dowodem na obawy przed sformalizowaniem współpracy transatlantyckiej w kwestiach innych niż bezpieczeństwo. Kwestia ta została poruszona podczas rozmowy Kissingera z Jobertem 19 grudnia w Paryżu. Kissinger skrytykował przedstawiony przez Europejczyków projekt Deklaracji, zachęcając do pracy nad nowym. Jobert stwierdził, że w przygotowanie poprzedniego tekstu włożono wiele wysiłku, by osiągnąć jednolite stanowisko. Jeśli Amerykanie zaproponowaliby zmiany, cały proces zacząłby się od nowa, powodując rozbieżności wewnątrz Wspólnot. Podejrzewał, że doprowadzenie do takiej sytuacji było celem amerykańskiej polityki. Jako przykład podał naciski wywierane przez Amerykanów na Luksemburg, by nie poddawał się decyzjom najsilniejszych państw EWG. Kissinger, wyraźnie zirytowany, zdementował tę

${ }^{104}$ NARA, NPMS, NSC Files, Country Files - Europe (Germany), Hillenbrand do Departamentu Stanu, 17 grudnia 1973, box 688.

${ }^{105}$ R. L. P f a l t z g r a ff, The Atlantic Community - A Conceptual History, [w:] Atlantic Community in Crisis..., s. 21.

${ }^{106}$ Communique of European Community "Summit" Meeting, [w:] The New Europe and the United States..., s. 377-382.

${ }^{107}$ NARA, NPMS, NSC Files, Country Files - Europe (Germany), Hillebrand do Departamentu Stanu, 27 listopada 1973, box 687. 
informację, dodając, że jakby Amerykanie chcieli podzielić EWG, zwróciliby się raczej do Wielkiej Brytanii bądź RFN. Powiedział wprost, że kraje europejskie mają słabe rządy i takiż liderów, więc rozbicie ich jedności nie byłoby trudne, gdyby rzeczywiście leżało to w interesie Stanów Zjednoczonych ${ }^{108}$. Ton tej rozmowy wskazywał, że nie tylko Deklaracja Atlantycka była martwym projektem, ale również w innych sprawach - szczególnie współpracy w rozwiązywaniu kryzysu energetycznego - porozumienie amerykańsko-francuskie było mało prawdopodobne. Kissinger nawet nie zabiegał o pozyskanie przychylności Francji. W tym przypadku ważnym czynnikiem była osobista i wzajemna niechęć Kissingera i Joberta.

Podczas spotkania z Kissingerem politycy niemieccy tłumaczyli wrogą postawę Francji odsunięciem jej od udziału w negocjacjach bliskowschodnich. Scheel zapewnił, że polityka europejska nie była polityką francuską - inne kraje miały również wpływ na kształtowanie strategii i nie chciały dopuścić do poważnego konfliktu ze Stanami Zjednoczonymi. Kissinger odpowiedział na to dość sarkastycznie: „niektórzy Europejczycy przychodzą do nas i oświadczają nam, że są za ścisłym sojuszem atlantyckim, gdyż robią tylko 30\% tego, co chciałaby Francja. Dotyczy to jednak tylko działań niekorzystnych dla USA, a nie ogólnego kierunku polityki europejskiej"109. Powiedział też, co Niemcy przyjęli z niedowierzaniem, że Francja namawiała kraje arabskie, by wstrzymywały się ze znoszeniem embarga wobec USA ${ }^{110}$.

Decyzja o intensyfikacji współpracy z państwami arabskimi z 5 marca 1974 r. spowodowała odwołanie spotkań w sprawie Deklaracji Atlantyckiej. Fakt ten wpłynął na przełożenie planowanej wizyty Nixona na Starym Kontynencie. 5 marca 1974 r., w czasie rozmów „Dziewiątki” z przedstawicielami państw arabskich, przekazano Amerykanom projekt, który nie został zaakceptowany, gdyż partnerstwo transatlantyckie było, ich zdaniem, potraktowane jako drugorzędny aspekt polityki europejskiej. Poza tym, określenie procedur konsultacyjnych, na czym najbardziej zależało Stanom Zjednoczonym, było ich zdaniem bardzo nieprecyzyjne. Deklaracja EWG-USA została zarzucona ${ }^{111}$.

15 marca Nixon stwierdził, że Europejczycy nie mogli liczyć na współpracę z USA na polu bezpieczeństwa i jednocześnie dążyć do konfrontacji gospodarczej i politycznej. Zapowiedział, że dopóki Europejczycy nie zechcą uregulować wszystkich kontrowersji, nie było możliwe spotkanie na szczeblu głów państw ${ }^{112}$. Kissinger oceniał, że antyamerykańska postawa Francji pogrzebała ideę „roku Europy”113.

${ }^{108}$ NARA, NPMP, NSC Files, HAK Office Files, Country Files - Europe, memorandum z rozmowy Kissingera z Jobertem, 19 grudnia 1973, box 56.

${ }^{109}$ NARA, NPMS, NSC Files, Presidental/HAK Memcons, memorandum ze spotkania Kissingera,

Brandta i Scheela w Bonn, 24 marca 1974, box 1027.

${ }^{110}$ Ibidem.

${ }^{111}$ NARA, NPMP, NSC Files, HAK Office Files, Counrty Files - Europe, Kissinger do Nixona,

21 czerwca 1974, box 54 .

${ }^{112}$ H. K i s s in g e r, The Years of Upheaval..., s. 931-932.

${ }^{113}$ Ibidem, s. 729. 
18 marca Amerykanie zdołali wynegocjować bezwarunkowe zniesienie przez kraje arabskie embarga, a dzień później Arabia Saudyjska ogłosiła zwiększenie produkcji o milion baryłek dziennie. Tym samym została potwierdzona skuteczność amerykańskiej dyplomacji i podważony sens konkurencyjnej polityki EWG. Europa zaczęła wykonywać w kierunku Stanów Zjednoczonych gesty pojednania. 25 kwietnia podpisana została - negocjowana od września 1973 r. - umowa offsetowa z RFN ${ }^{114}$.Zgłoszona została także propozycja niemiecka konsultacji z Waszyngtonem na temat Deklaracji Atlantyckiej po uzgodnieniu decyzji przez dyrektorów politycznych EWG, ale przed przedłożeniem konkretów na forum RMWE ${ }^{115}$. Każdy kraj członkowski mógł zaproponować takie konsultacje, ale miały być one prowadzone przez kraj dzierżący przewodnictwo we Wspólnotach tylko wtedy, jeśli wszyscy członkowie wyrażą na to zgodę $e^{116}$.

W memorandum dla prezydenta z 11 czerwca 1974 r., Kissinger zwrócił jednak uwagę na poprawę relacji USA-Europa od wiosny tego roku. Podkreślał, że w wielu państwach Europy Zachodniej rządy miały bardzo kruchą większość parlamentarną. Zmagały się także z poważnym deficytem bilansu płatniczego, inflacją, bezrobociem oraz niedoborami surowców energetycznych. Obawiały się rosnącej siły konwencjonalnej ZSRR. Nie byli pewni, czy Stany Zjednoczone wezmą pod uwagę interesy sojuszników w relacjach ze wschodnim mocarstwem. Kissinger odnotował następujące pozytywne aspekty: perspektywę podpisania deklaracji współpracy na forum NATO, progres w rozwiązywaniu kontrowersji między USA a EWG w sprawie wstępnych konsultacji oraz porozumienie w kwestii rekompensat za rozszerzenie EWG. Zauważył, że problemy gospodarcze w Europie spowodowane przez kryzys naftowy, spowolniły wysiłki EWG w pogłębianiu integracji i emancypacji politycznej. Większość przywódców zaakceptowała konieczność bliższej współpracy z USA, gdyż nie byli pewni, czy Wspólnoty mogły odegrać samodzielnie rolę w światowej polityce. Potrzebowali również współpracy w kwestii reformy światowego systemu monetarnego, jego niestabilność pogarszała bowiem sytuację ekonomiczną.

Według Kissingera, wizyta Nixona na Bliskim Wschodzie, którą rozpoczął 10 czerwca, przekonała partnerów do konstruktywnego zaangażowania się USA w proces pokojowy. Wobec tego Kissinger bardzo pozytywnie oceniał perspektywy wizyty Nixona w Brukseli, którą zaplanowano na 25-27 czerwca 1974 r. z okazji 25 rocznicy powstania $\mathrm{NATO}^{117}$. Radził, by prezydent zapewnił partnerów o chęci USA odegrania przywódczej roli we wszystkich ważnych dla sojuszu kwestiach, zarówno gospodarczych jak i politycznych. Miał też podkreślić znaczenie obustronnych konsultacji, szczególnie w sprawach bliskowschodnich i relacji z ZSRR.

${ }^{114}$ Germany, U.S. Sign Troop Pact, „Washington Post”, 26 kwietnia 1974. Więcej na ten temat: w podrozdziale 7.6.

${ }^{115}$ H. K i s s in ge r, The Years of Upheaval..., s. 933.

${ }^{116}$ E. R. G o o d m a n, The Fate of the Atlantic Community, New York 1975, s. 177.

${ }^{117}$ Uroczystości zostały przełożone na czerwiec w związku ze śmiercią prezydenta Pompidou 2 kwietnia 1974 r., dwa dni przed rocznicą. 
Ważnym aspektem rozmów miało być przekonanie sojuszników, by zwiększali wydatki na obronę. Kissinger informował Nixona, że wielu przywódców europejskich wyraziło chęć przeprowadzenia z nim rozmowy, co powinno być przez prezydenta wykorzystane ${ }^{118}$.

Kissinger celowo przedstawiał Nixonowi optymistyczny obraz stosunków transatlantyckich, by skłonić go do większego zaangażowania się w sprawy sojuszu. Nixon był w tym okresie zajęty rozwojem afery Watergate, co obniżało jego zainteresowanie relacjami międzynarodowymi. Perspektywy poprawy stosunków transatlantyckich zostały bardziej obiektywnie przedstawione w szczegółowym raporcie Departamentu Stanu.

Nowy prezydent Francji Valèry Giscard d'Estaign miał być nieobecny na szczycie Rady Północnoatlantyckiej, usprawiedliwiając się zapowiedzianą wcześniej wizytą szacha Iranu w Paryżu ${ }^{119}$. Do Brukseli miał za to przyjechać nowy premier Jaques Chirac, który deklarował swą fascynację USA. Departament Stanu zauważał oznaki większej przychylności Francuzów nie tylko do planowanej deklaracji NATO, ale też do ustanowienia mechanizmu konsultacyjnego USA-EWG, szczególnie w kwestii sytuacji na Bliskim Wschodzie i dostaw ropy. Zakładano, że Giscard d'Estaign będzie rozważał udział Francji w ECG i nie będzie kontynuował polityki Joberta bilateralnych stosunków z państwami OPEC. Sprawdzianem dla tych prognoz miała być polityka Francji po przejęciu przewodnictwa w RMWE od 1 lipca 1974 r. Departament Stanu proponował, żeby Nixon podczas spotkania w Brukseli rozmawiał z Chirakiem na tematy: współpracy NATO na obszarach out of area, zaangażowania Francji w tworzenie tekstu Deklaracji NAT0 oraz związków spraw ekonomicznych, politycznych i bezpieczeństwa. Sugerowano, by poinformować Chiraka o planach amerykańskich wobec Bliskiego Wschodu i zaproponować konsultacje i współdziałanie w tej sprawie.

W tym samym raporcie analizowano perspektywy relacji z RFN. Od maja 1974 r. kanclerzem został Helmut Schmidt z SPD. Deklarował on chęć regularnych konsultacji z USA. Pozytywnie odebrano w Waszyngtonie jego większą powściągliwość w relacjach z blokiem wschodnim. Zauważono, że Amerykanie potrzebowali potencjału gospodarczego RFN. Kryzys energetyczny spowodował, że kraje OECD zanotowały w 1974 r. łączny deficyt bilansu płatniczego ok. 40 mld USD. Nastąpiło przesunięcie kapitału do krajów eksportujących ropę. Tymczasem BOP RFN pozostawał dodatni. Zapewniało to rekompensowanie kosztów stacjonowania sił USA w Europie i wsparcie dla wartości dolara. Silna pozycja RFN na Starym Kontynencie miała zapewniać poprawę relacji transatlantyckich. W zamian Stany Zjednoczone mogły zadeklarować niezmienne zaangażowanie w obronę tego państwa i branie pod uwagę jego interesów w negocjacjach z ZSRR.

${ }^{118}$ NARA, NPMS, NSC Files, VIP Visits, Kissinger do Nixona, 11 czerwca 1974, box 950.

${ }^{119}$ Pojawiły się jednak komentarze, że prezydent nie chciał się narażać gaullistom z koalicji rządzącej Francją, którzy byli niechętni zacieśnianiu współpracy ze Stanami Zjednoczonymi. 
W Wielkiej Brytanii po wyborach 28 lutego 1974 r. wygranych przez Partię Pracy, rząd utworzył Harold Wilson. W kwietniu rozpoczął on starania o renegocjację warunków członkostwa Wielkiej Brytanii w EWG, co osłabiło jedność Wspólnoty, i podjął próby ponownego zbliżenia z USA. Minister spraw zagranicznych James Callaghan zapewniał Amerykanów, że będzie przekonywał partnerów europejskich, by przenieśli w czasie planowane spotkanie z przedstawicielami dwudziestu krajów arabskich, by nie osłabiać pozycji negocjacyjnej Stanów Zjednoczonych przed planowanymi rozmowami Kissingera na Bliskim Wschodzie ${ }^{120}$. Departament Stanu oceniał jednak pozycję rządu brytyjskiego jako słabą: nie miał on większości parlamentarnej, a do tego musiał się zmagać z eskalacją konfliktu w Irlandii Północnej. W związku z tym, mimo chęci intensyfikacji konsultacji i współpracy z USA, musiał obiecać ograniczenie wydatków na obronę ${ }^{121}$.

Na większą przychylność rządów europejskich wobec Stanów Zjednoczonych miał niewątpliwie wpływ pewien zastój w procesie integracji. W dobie kryzysu solidarność państw EWG została wystawiona na trudną próbę. W styczniu 1974 r. Francja wycofała się z „węża walutowego” regulującego kurs walut państw EWG ${ }^{122}$. Płynne kursy obowiązywały już w pięciu państwach Wspólnoty: Wielkiej Brytanii, Irlandii, Danii, Włoszech i Francji, co podważało sens mechanizmu regulacji kursów. Kryzys zniweczył też próby budowania wspólnego rynku energetycznego. Wszystkie kraje EWG, oprócz RFN, bardzo mocno odczuły skutki kryzysu. Natomiast sytuacja w Stanach Zjednoczonych, mniej zależnych od eksportu ropy, na początku 1974 r. uległa nieznacznej poprawie, np. zmniejszył się deficyt bilansu płatniczego. Sukcesy Kissingera w negocjacjach bliskowschodnich dodatkowo przekonały Europejczyków, że współpraca z sojusznikiem zza Oceanu była konieczna ${ }^{123}$.

Należy też zauważyć, że nowi przywódcy państw europejskich: Schmidt i Giscard d'Estaign, pełnili w przeszłości funkcje ministrów finansów. Obaj uczestniczyli w spotkaniach ministrów finansów Stanów Zjednoczonych, Wielkiej Brytanii, RFN, Francji i Japonii (tzw. Library Group). Zdawali sobie sprawę, że jedynie współpracując z USA można było pokonać kryzys gospodarczy. W maju 1974 r. kanclerz RFN oświadczył w Bundestagu, że polityczne zjednoczenie Europy powinno być poprzedzone umocnieniem sojuszu z USA ${ }^{124}$, dlatego perspektywa podpisania deklaracji umacniającej relacje transatlantyckie stała się bardziej realna.

19 czerwca 1974 r., na spotkaniu NATO w Ottawie uzgodniono tekst Deklaracji o Relacjach Atlantyckich. Znalazł się w niej m.in. zapis, że harmonijne stosunki

${ }^{120}$ A Good Atlantic Day, „Washington Post”, 23 marca 1974.

${ }^{121}$ NARA, NPMP, NSC Files, HAK Office Files, Counrty Files - Europe, raport Departamentu Stanu, 2 czerwca 1974, box 53.

122 Było to wielkie zaskoczenie dla rządu RFN, który proponował pomoc finansową na utrzymanie kursu franka.

${ }^{123}$ D. M ö c k li, op. cit., s. 15.

${ }^{124}$ Ibidem, s. 313. 
polityczne i gospodarcze były konieczne do utrzymania współpracy na rzecz bezpieczeństwa. Stany Zjednoczone próbowały się w ten sposób zabezpieczyć przed zbytnią emancypacją Europy. Uzgodniony dokument miał załagodzić spór, który pojawił się w sojuszu atlantyckim w „roku Europy”. Był swoistym kompromisem - zrezygnowano z odrębnej Deklaracji Atlantyckiej, przenosząc jej najmniej kontrowersyjne zapisy do szerszej deklaracji w ramach sojuszu obronnego.

Tekst deklaracji NATO odnosił się siłą rzeczy do kwestii obronnych. Sygnatariusze zgodzili się, że oprócz wspólnych działań, żaden kraj nie powinien zaniedbywać własnego bezpieczeństwa i przeznaczać na ten cel adekwatne środki. Potwierdzono, że Stany Zjednoczone były gotowe bronić Europy przy pomocy sił nuklearnych, uznano stacjonowanie wojsk amerykańskich na zachodzie Starego Kontynentu za niezbędne. Kraje europejskie zobowiązały się utrzymywać siły zdolne odstraszać ewentualny atak, a Stany Zjednoczone potwierdziły, że nie doprowadzą do sytuacji, która by narażała ich sojuszników na zewnętrzną presję polityczną bądź militarną. Oświadczyły również, że w układach z ZSRR nie zobowiążą się do niczego, co by zagrażało bezpieczeństwu członków sojuszu.

Największą wymowę polityczną miał punkt jedenasty, dotyczący utrzymywania stałych konsultacji stwarzających warunki konieczne do obrony i odprężenia w stosunkach ze Wschodem. Strony zobowiązały się do pełnego informowania się o wszystkich posunięciach na arenie międzynarodowej, zdając sobie sprawę, że na interesy Sojuszu mogły mieć wpływ wydarzenia we wszystkich częściach świata. Była to wyraźna aluzja do negocjacji Europy z państwami arabskimi. W tym samym punkcie zapewniono, że sojusz obronny musiał być oparty na harmonijnych relacjach politycznych i ekonomicznych. Zapowiedziano działania na rzecz eliminacji źródeł konfliktów gospodarczych ${ }^{125}$. Odniesienie do związku między kwestiami obronnymi a gospodarczymi było poniżej amerykańskich oczekiwań. Deklarację podpisano na szczycie NATO w Brukseli 26 czerwca $1974 \mathrm{r}$.

Deklarację NATO była zbiorem ogólnych zasad w wymiarze szerszym niż obronny i próbą zatarcia fiaska Deklaracji Atlantyckiej. Wprawdzie w dokumencie mówiono o ważnej roli czynnika gospodarczego, jednak było to tylko stwierdzenie faktu, bez konkretnych wskazówek. Największą słabością dokumentu, biorąc pod uwagę pierwotne cele amerykańskie, był brak ustanowienia mechanizmu regularnych konsultacji, nie mówiąc już o ich instytucjonalizacji. Jednak oficjalnie Europejczycy i Amerykanie przedstawiali porozumienie jako sukces. Przyjęcie deklaracji w Ottawie przez ministrów spraw zagranicznych było transmitowane przez telewizję. Miało to na celu przekonanie opinii publicznej, że nieporozumienia między sojusznikami zostały rozwiązane ${ }^{126}$. Deklaracja nie miała kilka pozytywnych aspektów. Europejczycy zaakceptowali konieczność bardziej sprawiedliwego dzielenia

\footnotetext{
${ }^{125}$ NARA, NPMP, NSC Files, HAK Office Files, Counrty Files - Europe, tekst Deklaracji o Relacjach Atlantyckich, box 54 .

${ }^{126}$ D. M ö c k l i, op. cit., s. 136.
} 
kosztów obrony. Podpisali się pod stwierdzeniem, że postęp integracji europejskiej powinien mieć „pozytywny wpływ na udział we wspólnej obronie Sojuszu” 127 . Z drugiej strony, Stany Zjednoczone przyznały, że Europejczycy mieli w niej znaczący udział, zapewniając 75\% sił konwencjonalnych na Starym Kontynencie, a siły nuklearne Wielkiej Brytanii i Francji były istotne dla zapobiegania atakowi ze strony ZSRR. Jednak nie udało się rozwiązać najważniejszych sporów politycznych i gospodarczych. Okazało się, że konsensus był możliwy tylko w kwestiach wspólnego bezpieczeństwa.

\subsection{Kwestia stacjonowania wojsk amerykańskich w Europie}

W połowie września $1973 \mathrm{r}$. Amerykanie rozpoczęli negocjacje z RFN na temat offsetu. Zażądali, by wyniósł on 3,3 mld USD na 2 lata. RFN nie zamierzała tym razem tak łatwo ulec i zadeklarowała, że mogła podpisać umowę na połowę tej sumy. Odmówiła również przyznania bezpośredniego wsparcia dla amerykańskiego budżetu $^{128}$.

Tabela 7.1. Siły amerykańskie w Europie w latach 1950-1974 (w tys. osób)

\begin{tabular}{|l|c|c|c|c|c|c|c|c|c|c|c|}
\hline & $\mathbf{1 9 5 0}$ & $\mathbf{1 9 5 3}$ & $\mathbf{1 9 6 0}$ & $\mathbf{1 9 6 5}$ & $\mathbf{1 9 6 8}$ & $\mathbf{1 9 6 9}$ & $\mathbf{1 9 7 0}$ & $\mathbf{1 9 7 1}$ & $\mathbf{1 9 7 2}$ & $\mathbf{1 9 7 3}$ & $\mathbf{1 9 7 4}$ \\
\hline $\begin{array}{l}\text { Europa Zachodnia } \\
\text { (w tym RFN) }\end{array}$ & 122 & 407 & 365 & 353 & 320 & 320 & 300 & 300 & 307 & 313 & 319 \\
\hline RFN & 98 & 254 & 237 & 262 & 210 & 210 & 213 & 213 & 221 & 228 & 228 \\
\hline
\end{tabular}

Źródło: G. F. Tre vert o n, The Dollar Drain and American Forces in Germany. Managing the Political Economics of Alliance, Athens 1978, s. 4.

Z danych zawartych w tabeli 7.1 wynika, że większość sił amerykańskich stacjonowało w RFN (w latach rządów Nixona średnio blisko 75\%). Koszty stacjonowania wojsk dla amerykańskiego budżetu wynosiły ok. 6 mld USD dla RFN, a dla reszty Europy 1,7 mld. Niektórzy autorzy uwzględniają także koszty utrzymywanie wojsk na terenie USA, które były przypisane do obrony w ramach NATO. Minimalny szacunek kosztów obrony Europy wynosił 17 mld USD, maksymalny $-28,4$ mld $^{129}$.

Negocjacje z RFN zostały przerwane w momencie wybuchu nieporozumień transatlantyckich w czasie wojny Jom Kippur. W październiku 1973 r. podsekretarz

\footnotetext{
${ }^{127}$ NARA, NPMP, NSC Files, HAK Office Files, Counrty Files - Europe, tekst Deklaracji o Relacjach Atlantyckich, box 54 .

${ }^{128}$ G. F. Tr e v e r t o n, The Dollar Drain and American Forces in Germany. Managing the Political Economics of Alliance, Athens 1978, s. 47.

${ }^{129}$ Ibidem, s. 5.
} 
stanu do spraw gospodarczych William Casey spotkał się z urzędnikami z niemieckiego Ministerstwa Spraw Zagranicznych, Obrony i Finansów. Casey poinformował, że Kongres wkrótce będzie debatował o warunkach utrzymania niezmiennego kontyngentu wojsk amerykańskich w Europie. W związku z tym apelował o jak najszybszy kompromis. Zauważył, że różnice w proponowanych warunkach umowy strony niemieckiej i amerykańskiej były wciąż bardzo duże. Zaznaczył, że amerykańska opinia publiczna była świadoma, że Stany Zjednoczone przeznaczały 8\% swego PKB na obronę, a RFN tylko $4 \%{ }^{130}$.

Rozmowy na temat umowy offsetowej zostały wznowione w listopadzie $1973 \mathrm{r}$. Na większą skłonność RFN do negocjacji miały wpływ działania Kongresu. 23 listopada 1973 r. przegłosował on poprawkę do ustawy o dostawach militarnych (Military Procurement Bill) zgłoszoną przez senatorów Partii Demokratycznej: Henry'ego Jacksona i Sama Nunna. Mówiła ona, że procent redukcji wojsk Stanów Zjednoczonych w Europie będzie zależał od wywiązania się sojuszników ze zobowiązania pokrycia deficytu wynikającego ze stacjonowania tych oddziałów ${ }^{131}$.

Administracji zależało, by Kongres uznał, że Europa spełnia te warunki. Ustawa zobowiązywała administrację do przygotowania raportu o postępach w tej kwestii. Nixon polecił Kissingerowi, żeby zawrzeć w nim toczące się negocjacje z RFN na temat offsetu na lata 1974-1975, utworzenie z inicjatywy amerykańskiej grupy roboczej w NATO zajmującej się dzieleniem kosztów obrony oraz zaprezentowanie Radzie NATO programu dotyczącego dostaw militarnych i budżetowego wsparcia dla inicjatyw NATO. Nixon informował, że liderzy obu izb Kongresu zgodzili się, że proponowanie $\mathrm{w}$ tym czasie rezolucji o wycofaniu wojsk z Europy byłoby niepożądane. Trwały też prace nad propozycją dla Europejczyków na temat sposobów rekompensowania strat dla amerykańskiego bilansu płatniczego związanych ze stacjonowaniem wojsk na Starym Kontynencie. Koszty te obliczono na 2,1 mld USD w $1974 \mathrm{r}^{132}$

Na początku stycznia 1974 r. Sonnenfeldt oceniał, że niemieccy negocjatorzy traktowali ten problem lekceważąco. Zauważył, że czas pracował na niekorzyść USA, gdyż wzrastała wartość USD w stosunku do DM. Relacjonował, że do tamtej pory RFN oferowała 1,4 mld USD w tak zwanym „twardym” offsecie (tzn. bez pożyczek). Zauważył, że było to tylko 40\% amerykańskich wydatków, pozostałe spodziewano się odzyskać w niskooprocentowanych pożyczkach. Niemcy jednak wstrzymali negocjacje twierdząc, że najpierw musieli uzyskać potwierdzenie, czy ich propozycje spełnią warunki postawione w poprawce Jacksona-Nunna. Sonnenfeldt dostrzegł

${ }^{130}$ NARA, NPMS, NSC Files, Country Files - Europe (Germany), memorandum z rozmowy o offsecie w Bonn, 5 października 1973, box 688.

${ }^{131}$ G. Lunde stad, The United States and Western Europe since 1945. From "Empire" by Integration to Transatlantic Drift, Oxford 2003, s. 195. Por. M. G e tl e r, J. M. G o s h k o, NATO: A General Accord, „Washington Post”, 8 grudnia 1973.

${ }^{132}$ NARA, NPMP, White House Central Files (WHCF), IT International Organization, NATO, Nixon do Kissingera, 18 lutego 1974, box 3. 
konieczność uzgodnienia jednolitego stanowiska amerykańskiego. Departament Skarbu nalegał, by nie zgadzać się na żadne ustępstwa, co mogło spowodować zniweczenie głównego politycznego celu Stanów Zjednoczonych - utrzymania wojsk amerykańskich w Europie ${ }^{133}$.

Nixon zdecydował się wtedy na zastosowanie nacisku politycznego. W styczniu 1974 r. poinformował Brandta, że Kongres, na podstawie poprawki NunnaJacksona, dał mu czas na podpisanie umowy offsetowej do lutego $1974 \mathrm{r}^{134}$ Podpisano ją dopiero 25 kwietnia 1974 r. na dwa lata - całość offsetu określono tym razem na 2,2 mld USD, a więc kwota nieznacznie wzrosła w stosunku do poprzedniej. Większość środków miało zostać przeznaczonych na zakupy sprzętu militarnego. Uzgodniono współpracę technologiczną; RFN miała także zakupić obligacje amerykańskiego skarbu i sfinansować remont kwater wojsk amerykańskich na swoim terytorium. Ta ostatnia kwestia była szczególnie drażliwa politycznie, gdyż renowacja baraków była finansowana bezpośrednio z budżetu państwa $^{135}$.

Porozumienia amerykańsko-niemieckie było kompromisowe w stosunku do pierwotnych propozycji. Zadecydowały o tym względy polityczne. Amerykanie zdawali sobie sprawę, że wypełnianie offsetu przez RFN zależało od decyzji rządu, stanu budżetu i woli politycznej. Przede wszystkim obie strony uznawały konieczność współpracy w relacjach z blokiem wschodnim. Poza tym, poprawka JacksonaNunna mobilizowała rządy obu państw, które nie chciały dopuścić do wycofania wojsk z Europy.

Przy okazji negocjacji offsetowych można było zauważyć ich duże powiązanie z polityką wewnętrzną rządów. Administracja amerykańska znajdowała się pod presją Kongresu ${ }^{136}$ i departamentów gospodarczych, a niemiecka musiała się zmagać z naciskami opozycji, by nie godzić się na zbyt duże ustępstwa w stosunku do USA. Coraz wyraźniejsze było też powiązanie kwestii politycznych i obronnych z gospodarczymi. Amerykanie uważali, że był to argument za negocjowaniem problemów z różnych dziedzin jednocześnie ${ }^{137}$. Ostatecznie jednak strona amerykańska uznała, że spełniono warunki postawione w poprawce Jacksona-Nunna. Z tabeli 7.2 wynika, że RFN rzeczywiście pokrywała poprzez offset wydatki w bilansie płatniczym USA na stacjonowanie wojsk amerykańskich na swoim terytorium.

${ }^{133}$ NARA, NPMS, NSC Insitutional "H" Files, National Security Decision Memorandums (19691974), NSDM 214, Sonnenfeldt do Kissingera, 5 stycznia 1974, box H-220.

${ }^{134}$ G. F. Treverton, op. cit., s. 48. Zob także: NARA, NPMS, NSC Files, Presidental Correspondence 1969-1974, Nixon do Brandta, 18 stycznia 1974, box 753.

${ }^{135}$ Germany and U.S. Sign Troop Pact, „Washington Post”, 26 kwietnia 1974; por. J. C h a c e, The Concert of Europe, „Foreign Affairs”, October 1973, s. 52.

${ }^{136}$ Congressional Record. Proceeding and Debates of the Second Session of the $93^{\text {rd }}$ Congress, vol. 120, part 8, posiedzenie Senatu z 4 kwietnia 1974, dostępne przez: http://www.archive.org/ details/congressionalrec120dunit.

${ }^{137}$ G. F. Trevert o n, op. cit., s. 202. 
Tabela 7.2. Wydatki USA na cele militarne w Europie Zachodniej i ich pokrycie zgodnie z umowami offsetowymi z RFN w latach 1968-1974 (w mln USD)

\begin{tabular}{|c|c|c|c|}
\hline & \multicolumn{2}{|c|}{ Wydatki w bilansie płatniczym } & Pokrycie wydatków przez umowy \\
\cline { 2 - 3 } & Europa Zachodnia (wraz z RFN) & RFN & 725 \\
\hline 1968 & 1600 & 889 & 725 \\
\hline 1969 & 1600 & 910 & 1520 (na 3 lata) \\
\hline 1970 & 1700 & 1030 & \\
\hline 1971 & 1900 & 1176 & \\
\hline 1972 & 2300 & 1388 & \\
\hline 1973 & b.d. & b.d. & 2034 (na 2 lata) \\
\hline 1974 & b.d. & b.d. & \\
\hline
\end{tabular}

Źródło: G. F. Treve rt o n, The Dollar Drain and American Forces in Germany. Managing the Political Economics of Alliance, Athens 1978, s. 12.

\subsection{Negocjacje handlowe}

Kryzys energetyczny znacznie pogorszył sytuację gospodarczą we wszystkich krajach $\mathrm{OECD}^{138}$. W państwach uprzemysłowionych, zależnych od importu ropy, utrzymywała się wysoka inflacja, której źródeł rządy nie mogły kontrolować, gdyż znajdowały się poza granicami państw narodowych. Presję inflacyjną zwiększyła dewaluacja dolara - waluty rezerwowej większości państw.

Tabela 7.3. Inflacja $w$ wybranych krajach w latach 1972-1974 (w \%)

\begin{tabular}{|l|c|c|c|}
\hline & $\mathbf{1 9 7 2}$ & $\mathbf{1 9 7 3}$ & $\mathbf{1 9 7 4}$ \\
\hline USA & 3,3 & 6,2 & 11,0 \\
\hline Kanada & 4,8 & 7,6 & 10,9 \\
\hline Japonia & 4,5 & 11,7 & 24,5 \\
\hline Francja & 5,9 & 7,3 & 13,7 \\
\hline RFN & 5,5 & 6,9 & 7,0 \\
\hline Włochy & 5,7 & 10,8 & 19,4 \\
\hline Wielka Brytania & 7,1 & 9,2 & 16,0 \\
\hline
\end{tabular}

Źródło: B. Griffith s, Monetary Policies in the Atlantic Community, [w:] Atlantic Community in Crisis. A Redefinition of the Transatlantic Relationship, eds. W. F. Hahn, R. L. Pfaltzgraff, Jr., New York 1979, s. 291.

${ }^{138}$ W. J. Le vy, World Oil Cooperation or International Chaos, „Foreign Affairs”, July 1974, s. 691,712 . 
Kraje OPEC inwestowały środki ze sprzedaży ropy na Zachodzie, szczególnie w Europie, tam też dokonywały zakupów. Doprowadziło to do powstania tzw. rynku petrodolarów ${ }^{139}$. Potrzeba uzyskania środków na zakup surowców energetycznych spowodowała konieczność zwiększania eksportu. Niepokojącym efektem, mającym wpływ na sytuację polityczną na świecie, był rosnący eksport broni do krajów Trzeciego Świata przez państwa uprzemysłowione. W USA narastały tendencje protekcjonistyczne, co źle wróżyło dalszej liberalizacji handlu. Dodatkowo walka o rynki zbytu miała negatywny wpływ na transatlantyckie relacje polityczne ${ }^{140}$.

Projekt Rundy GATT został przedstawiony w tzw. „deklaracji tokijskiej” z września 1973 r., którą przyjęło stu ministrów odpowiedzialnych za handel w poszczególnych państwach członkowskich, co pozwoliło rozpocząć negocjacje ${ }^{141}$. Sygnatariusze zobowiązali się dążyć do liberalizacji handlu i zapewnienia jego korzystnych warunków dla krajów rozwijających się. Jednak konflikt interesów między EWG a USA utrudniał osiągnięcie tych celów. Rozmawiano nie tylko o cłach, ale też o barierach pozataryfowych i warunkach handlu produktami rolniczymi ${ }^{142}$. Nieporozumienia między członkami GATT na tle kryzysu energetycznego negatywnie wpływały na rozmowy, także o kwestiach monetarnych. Komitet Dwudziestu już w styczniu 1974 r. ogłosił, że nie był w stanie stworzyć dobrego planu reformy międzynarodowego systemu walutowego, ze względu na zbyt dużą niepewność i niestabilność w gospodarce światowej ${ }^{143}$. Europejczycy także nie mogli się porozumieć co do warunków powstania unii monetarnej.

Tymczasem Kongres wciąż nie przegłosował ustawy handlowej.Uniemożliwiała to zgłoszona tzw. poprawka Jacksona-Vanika, przewidująca, że kraje wstrzymujące emigrację swych obywateli nie otrzymają klauzuli najwyższego uprzywilejowania. Wykluczało to możliwość przyznania KNU dla ZSRR ${ }^{144}$. Sprawa ta była przedmiotem burzliwych dyskusji. Mimo że tokijska runda GATT była w toku, wciąż nie było wiadomo, jakie porozumienie mogą negocjować przedstawiciele USA. 28 listopada Kissinger, Shultz i Flanigan napisali list do Nixona. Skarżyli się, że senator Henry Jackson nie chciał współpracować w ustaleniu kompromisowego rozwiązania.

${ }^{139}$ A. W. D e P o r te, Europe Between the Superpowers. The Enduring Ballance, New Haven 1979, s. 208-209.

${ }^{140}$ R. L. P f a l t z g r a f f, op. cit., s. 3-4.

${ }^{141}$ S. D. Co h e n, The European Community and the General Agreement on Tariffs and Trade, Washington 1975, s. 11.

${ }^{142}$ D. E v a n s, The Politics of Trade. The Evolution of the Superbloc, London 1974, s. 5.

${ }^{143}$ J. E. S p e r o, The Politics of International Economic Relations, New York 1999, s. 42-46, 92.

${ }^{144}$ Była to poprawka do paragrafu V ustawy mówiącego, że prezydent mógł przyznać KNU krajom komunistycznym (NARA, NPMS, NSC Files, Subject Files: Trade General, Kissinger, Shultz, Flanigan do Nixona, 28 listopada 1973, box 403). Inicjatywa Demokratów, członka Izby Reprezentantów Charlesa Vanika i senatora Henry'ego Jacksona, miała związek z ograniczaniem przez ZSRR emigracji swoich obywateli; szczególnie dotyczyło to osób pochodzenia żydowskiego starających się o wyjazd do Izraela. 
Stwierdzali, że odkładanie przyjęcia ustawy handlowej było niekorzystne dla amerykańskiej polityki zagranicznej. Ostrzegali, że bez mandatu Kongresu obróci się wniwecz cała struktura związków politycznych i obronnych z Europą, z czego skorzysta ZSRR. Izba Reprezentantów przyjęła ustawę handlową 11 grudnia 1973 r., lecz musiała być ona jeszcze zaakceptowana przez Senat, co przedłużało proces jej wejścia w życie ${ }^{145}$.

Ważnym elementem negocjacji handlowych były rozmowy między USA a EWG $\mathrm{w}$ sprawie rekompensat dla gospodarki amerykańskiej w wyniku przyjęcia przez Wspólnotę nowych członków. Ze strony amerykańskiej prowadził je specjalny przedstawiciel ds. negocjacji handlowych William Eberle. Po raz pierwszy brał w nich udział reprezentant Komisji Europejskiej - Christopher Soames (odpowiedzialny za sprawy zagraniczne Wspólnot), a nie przedstawiciele poszczególnych państw EWG ${ }^{146}$. Zdecydowanie przeciwna przyznaniu rekompensat Amerykanom była tradycyjnie Francja, z kolei minister gospodarki RFN Friderichs przekonywał Paryż do zmiany zdania ${ }^{147}$.

Rozmowy na tematy handlowe trwały od marca 1973 r., a jeszcze rok później Eberle twierdził, że EWG nie była gotowa do żadnych ustępstw, zwłaszcza w sprawie najbardziej kontrowersyjnych produktów, takich jak cytrusy czy tytoń, co mogło doprowadzić do impasu w negocjacjach. Propozycje strony europejskiej wydawały się Amerykanom niewystarczające. Soames przypomniał, że USA i EWG były na skraju „wojny handlowej”. Eberle powtarzał, że bez zmniejszenia ceł na wymienione produkty nie uda się przeforsować w USA ustawy handlowej. W memorandum przekazanym do Waszyngtonu wyraził opinię, że kontynuowanie twardych negocjacji z Europejczykami pozwoli zrealizować większość amerykańskich postulatów ${ }^{148}$.

Pod koniec kwietnia 1974 r. EWG przedstawiła nową ofertę warunków negocjacji handlowych. Były one bardziej korzystne dla Amerykanów, ale zgłosili oni nowe żądania, o których EWG nie chciała już dyskutować. Stany Zjednoczone zagroziły wtedy „wojną handlową”. Eberle ostrzegł, że administracja poprosi Kongres o podwyżki taryf celnych na francuski koniak i irlandzką whisky. Europejczycy byli zaskoczeni - długo pracowali nad osiągnięciem kompromisu, by spełnić amerykańskie żądania. Zgoda na dalsze ustępstwa wszystkich krajów członkowskich byłaby niezwykle trudna do wypracowania. Proponowali, by ugodę z EWG administracja przedstawiła Kongresowi jako taktyczne zwycięstwo, dowód na uwzględnienie przez Wspólnotę amerykańskich interesów gospodarczych. Uważali, że proponowane ustępstwa powinny przyspieszyć uchwalenie ustawy handlowej.

\footnotetext{
${ }^{145}$ G. S h u l tz, K. W. D a m, Economic Policy Beyond the Headlines, Chicago 1998, s. 135.

${ }^{146}$ S. D. C o h e n, op. cit., s. 9.

${ }^{147}$ NARA, NPMS, NSC Files, Country Files - Europe (Germany), memorandum z rozmowy Shultza z Friderichsem, 5 października 1973, box 688.

${ }^{148}$ NARA, NPMS, NSC Files, Subject Files: Trade General, Eberle do Kissingera, Rusha, Shultza, Flanigana, 29 marca 1974, box 403.
} 
Do kwietnia 1974 r. Waszyngton odrzucił już dwie europejskie oferty porozumienia. W prasie przewidywano, że jeśli dojdzie do tego po raz kolejny, będzie to miało bardzo negatywny wpływ na relacje polityczne. Zwrócono jednak uwagę, że administracja Nixona mogła doprowadzić do „wojny handlowej” z powodu problemów wewnętrznych, by wykazać swoją stanowczość ${ }^{149}$. Jednak groźby Eberle'ego okazały się tylko bluffem - Waszyngton zrezygnował ze stawiania twardych warunków ${ }^{150}$. Nawet urzędnicy Departamentu Skarbu, zwykle optujący za zdecydowaną obroną amerykańskich interesów, zauważali konieczność kompromisu. W memorandum dla sekretarza skarbu George'a Shultza jego zastępca William Simon zauważył, że stawiając zbyt wygórowane żądania Stany Zjednoczone ryzykują poważny konflikt z Europą. „Minął czas, jeśli kiedykolwiek tak było, że kwestie handlowe można było omawiać osobno na forum gospodarczym, nie biorąc pod uwagę problemów politycznych i militarnych"151 - pisał Simon.

Kwestia rekompensat została rozwiązana pod koniec maja. EWG wyraziła zgodę na redukcję ceł importowych o wartości ok. 1 miliarda USD w ciągu roku. Dotyczyło to także produktów rolnych, na których najbardziej zależało Amerykanom: tytoniu i owoców cytrusowych. Nie spełniono jednak wszystkich postulatów, np. nie obniżono ceł na eksportowane do Europy zboża. Jednak strona amerykańska zgodziła się przełożyć te kwestie na czas rozmów w ramach GATT. Wzbudzało to nadzieje na przyjęcie przez Senat ustawy handlowej i ocieplenie stosunków politycznych ${ }^{152}$. Warto zauważyć, że choć administracja amerykańska używała argumentu odrzucenia ustawy przez Senat $w$ razie braku porozumienia z Europą w sprawie rekompensat, również Waszyngtonowi zależało na przyjęciu jej ostatecznej wersji. Ważnym powodem była chęć poprawy relacji transatlantyckich, a także zapobieżenie tworzeniu się bloków handlowych. Poza tym Nixon podczas rozmów w 1972 r. obiecał ZSRR podpisanie umowy handlowej ożywiającej wymianę ze wschodnim mocarstwem $^{153}$.

Tymczasem pod koniec drugiej kadencji Nixona, w społeczeństwie amerykańskim można było zauważyć zniechęcenie do polityki odprężenia. ZSRR prowadził aktywną politykę w krajach rozwijających się i oceniano, że zdobywał tam przewagę nad blokiem zachodnim. Stąd w projekcie ustawy handlowej pojawił się zapis o konieczności swobodniejszego dostępu na rynek amerykański produktów z państw tzw. Trzeciego Świata, by wspierać ich rozwój. Przejawem tych obaw była również

${ }^{149}$ D. R a m s e y, EEC Ready to Call U.S. Bluff on Its Threats of Trade War, „Washington Post”, 30 kwietnia 1974.

${ }^{150}$ D. R a m s e y, U.S. Seeking Accord on European Trading, „Washington Post”, 4 maja 1974.

${ }^{151}$ Foreign Relations of the United States (FRUS), 1969-1976, vol. 31: Foreign Economic Policy 1973-1976, Washington D.C. 2010, Simon do Shultza, 25 stycznia 1973, dok.156, dostępne także przez: www.state.gov/r/pa/ho/frus/nixon.

${ }^{152}$ W. C l a i r b o r n e, Europeans Cut Duty on U.S. Exports, „Washington Post”, 1 czerwca 1974.

${ }^{153}$ G. S h u l t z, K. W. D a m, op. cit., s. 136. 
poprawka Jacksona-Vanika ${ }^{154}$. Kontakty handlowe z blokiem wschodnim sprawiły, że Europa była coraz bardziej zainteresowana poprawą stosunków politycznych. Choć zarówno w przypadku Stanów Zjednoczonych jak i Europy Zachodniej handel ten stanowił niewielki procent całości wymiany, lecz jej wartość różniła się zasadniczo. Państwa EWG podpisywały z blokiem wschodnim długoterminowe kontrakty. Jednak to USA miały w tym przypadku dodatni bilans handlowy, a Europa deficyt, ze względu na import dużej ilości surowców energetycznych, szczególnie po kryzysie paliwowym z $1973 \mathrm{r}^{155}$

Ustawa handlowa została przyjęta przez Kongres dopiero 20 grudnia 1974 r., czyli za kadencji następcy Nixona - Geralda Forda. Dała ona prezydentowi pełnomocnictwa negocjowania porozumień handlowych z innymi państwami. Miał on też prawo zarządzenia środków ochrony amerykańskich przedsiębiorstw przed skutkami nadmiernego napływu do USA produktów wytwarzanych przez te firmy. Podjęcie takich działań było możliwe również wtedy, gdy wzrost napływu danego towaru nie był skutkiem nieuczciwych praktyk handlowych. Ustawa wzmacniała kontrolę Kongresu nad negocjacjami handlowymi z zagranicznymi partnerami. Rozszerzała możliwości rozmów na nowy obszar pozataryfowych barier w handlu - zmiany w tej dziedzinie miały być przyjmowane przez Kongres w ciągu 60 dni, co przyspieszało proces ich znoszenia lub decyzję o utrzymaniu ${ }^{156}$. Nowa ustawa została oceniona przez wielu ekspertów jako bardziej protekcjonistyczna niż poprzednia - z $1962 \mathrm{r}^{157}$

\subsection{Podsumowanie}

Na podjęcie przez Europę Zachodnią próby realizacji niezależnej od Waszyngtonu polityki, miała wpływ determinacja rządów zagrożonych przez niezadowolenie społeczne w dobie pogłębiającego się kryzysu. Próba ta jednak nie powiodła się - Europa wciąż potrzebowała wsparcia USA, nie była też gotowa do ujednolicenia polityki zagranicznej, co było jedyną szansą na uzyskanie silnej pozycji na arenie międzynarodowej.

Kryzys energetyczny - jak stwierdził Nixon - miał charakter nie tylko gospodarczy, ale i polityczny. Spowodował niezadowolenie opinii publicznej w poszczególnych krajach, ale także obnażył rozbieżności państw bloku zachodniego ${ }^{158}$. Oprócz

154 Ibidem, s. 140.

${ }^{155}$ Economic Relations with the USSR. Issues for the Western Alliance, ed. A. S. Becker, Lexington 1983, s. 4.

${ }^{156}$ G. F. Tr e ve r t o n, Making the Alliance Work. The United States and Western Europe, Ithaca 1985, s. 132.

${ }^{157}$ History of the U.S. Economy since World War II, eds. H. G. Vatter, J. F. Walker, M. E. Shape, New York 1996, s. 438.

${ }^{158}$ R. N i x o n, A Real War, New York 1980, s. 82. 
czynnika gospodarczego - dążenia państw europejskich do zabezpieczenia sobie dostaw ropy - do zaostrzenia transatlantyckiego sporu przyczyniła się z pewnością afera Watergate, która zachwiała pozycją Nixona w Stanach Zjednoczonych. Sytuację tę próbowali wykorzystać politycy francuscy, którzy zdołali przekonać partnerów z EWG, że nie było sensu zawierać porozumień zacieśniających sojusz ze skompromitowaną administracją. Należy też brać pod uwagę, że relacje z Europą Zachodnią były w istocie drugorzędne podczas rządów Nixona. Priorytetem dla Amerykanów było zakończenie zaangażowania w Wietnamie, jednocześnie pracowano nad porozumieniami z ZSRR i nawiązaniem stosunków z ChRL. Długotrwałość konfliktu w Wietnamie i wycofanie się Amerykanów z pomocy Wietnamowi Południowemu ukazały, że mocarstwo to nie było w stanie osiągnąć geopolitycznych celów. Mimo wielkich nakładów na obronę, Amerykanie zostali zmuszeni do opuszczenia Indochin, co skazywało walczących przeciwko komunistom na nieuchronną klęskę. Budziło to zaniepokojenie w Europie i zmuszało do zadania pytania, czy sytuacja z Wietnamu mogła się powtórzyć przy bezpośrednim zagrożeniu bezpieczeństwa Starego Kontynentu. Zaufanie Europejczyków do Stanów Zjednoczonych jako państwa mogącego zapewnić im obronę i prowadzącego wojnę ideologiczną z ZSRR w imię wartości demokratycznych znacznie spadło ${ }^{159}$.

Kissinger przekonywał przywódców europejskich o szczególnej wadze, jaką przywiązywał Nixon do poprawnych relacji z Europą. Ostrzegał, że taki pogląd może nie przetrwać podczas sprawowania władzy przez następną administrację. Przyczyną tego miały być narastające spory gospodarcze ${ }^{160}$. Wśród nich należy wymienić żądanie przez Waszyngton rekompensaty za rozszerzenie EWG, spory handlowe, odmienne koncepcje reformy światowego systemu walutowego czy kwestię dzielenia kosztów obrony. Napięcie zwiększyło się dodatkowo po pogorszeniu się sytuacji ekonomicznej w krajach uprzemysłowionych po „szoku naftowym”. Te spory, w połączeniu z dążeniem do większej emancypacji politycznej państw Europy Zachodniej, zmieniały charakter sojuszu. Wprawdzie politycy amerykańscy byli tego świadomi - stąd oficjalne deklaracje o konieczności partnerstwa - lecz nie potrafili stworzyć formuły satysfakcjonującej ambicje Europy.

Winą za napięcia wśród sojuszników nie można obarczać jednak tylko strony amerykańskiej. Europejczycy, przyzwyczajeni do powojennej pomocy Waszyngtonu, przyjmowali konieczność ustępstw amerykańskich w kwestiach gospodarczych z powodów politycznych za pewnik. Zmiana strategii wobec Europy, która, jak wielokrotnie podkreślał Nixon, nie potrzebowała już pomocy ekonomicznej, była nowością dla krajów Starego Kontynentu. Zaczęły one prowadzić coraz bardziej samodzielną politykę zagraniczną. W przypadku obszaru Bliskiego Wschodu była ona sprzeczna ze strategią USA. Ujawniony po raz kolejny podczas kryzysu

${ }^{159} 30$ kwietnia 1975 r. Sajgon został zdobyty przez siły komunistyczne.

${ }^{160}$ NARA, NPMP, NSC Files, HAK Office Files, Country Files - Europe, memorandum z rozmowy Kissingera z Emilem van Lennepem, 27 lipca 1973, box 56. 
energetycznego przemożny wpływ kwestii gospodarczych na obszar polityczny i obronny, miał tym razem wyjątkowy charakter. Napięcia zostały wywołane przez państwa trzecie: producentów ropy naftowej, którzy użyli tego surowca jako narzędzia politycznego nacisku. Po wydarzeniach z lat 1973-1974 coraz częściej zaczęto mówić o „ekonomizacji” europejskiej polityki zagranicznej ${ }^{161}$. Daniel Möckli trafnie stwierdził, że jeśli rok 1973 był nazwany w amerykańskiej polityce zagranicznej „rokiem Europy”, to rok 1974 mógłby być nazwany „rokiem gospodarki”, gdyż wtedy kwestie gospodarcze zdominowały stosunki transatlantyckie ${ }^{162}$. Okazało się wtedy, że Stany Zjednoczone miały ograniczone możliwości wpływu na decyzje EWG, która pod przewodnictwem Francji, wykazała początkowo odporność na naciski Waszyngtonu. Jednak w realiach zimnowojennych, a przede wszystkim w warunkach uzależnienia Europy Zachodniej od amerykańskiej obrony, spór ten był stopniowo łagodzony. Poza tym państwa zachodu Starego Kontynentu przekonały się o trudnościach, a wręcz niemożności, przyjęcia wspólnego stanowiska w kluczowych sprawach polityki zagranicznej.

Kryzys spowodował także zmiany w światowym systemie finansowym. Europa Zachodnia wydawała dużo środków na zakup ropy na Bliskim Wschodzie. Państwa eksportujące ten surowiec udzielały z kolei pożyczek zagranicznych i nabywały więcej towarów na rynkach zachodnich, co generowało tam wzrost ilości tzw. petrodolarów (więcej ich znalazło się na rynkach Europy Zachodniej niż Stanów Zjednoczonych) ${ }^{163}$.

W dobie eskalacji tych nieporozumień, projekt Deklaracji Atlantyckiej został odłożony. Mimo zapewnień Kissingera o chęci zbudowania równorzędnego partnerstwa, Europejczycy obawiali się, że jakikolwiek stały mechanizm konsultacyjny stanie się narzędziem wywierania nacisków przez silniejszego partnera. Szczególnie dotyczyło to kwestii ekonomicznych, o które wybuchały najbardziej zaciekłe spory. Dlatego torpedując propozycję amerykańską używali argumentu odrębnej tożsamości. Kissinger podsumował to ironicznie: „niektórzy Europejczycy myślą, że ich tożsamość powinna być mierzona przez dystans do USA"164.

Amerykanie podtrzymywali niemal do końca rządów Nixona inicjatywę Deklaracji Atlantyckiej. Oprócz powodów prestiżowych, powodem prowadzenia rozmów z Europejczykami na ten temat były kwestie gospodarcze. Kryzys naftowy, zwrot EWG w kierunku odrębnych porozumień z państwami arabskimi, zbliżające się negocjacje monetarne i handlowe dawały Stanom Zjednoczonym wystarczającą motywację, by ponawiać próby porozumienia. Poza tym w 1973 r. miało

161 Europejscy przywódcy uznali, że Stany Zjednoczone lekceważą interesy ich krajów, a powodem napięć na Bliskim Wschodzie było okupowanie przez Izrael terytoriów palestyńskich i nierespektowanie przez ten kraj rezolucji 242 ONZ (M. Wolff s o h n, op. cit., s. 27. Zob. także: J. C a m p be ll, op. cit., s. 348).

${ }^{162}$ D. Mö c k l i, op. cit., s. 250.

${ }^{163}$ R. G i l p i n, U.S. Power and Multinational Corporation..., s. 409.

${ }^{164}$ Cyt. za: E. R. G o o d m a n, op. cit., s. 176. 
miejsce rozszerzenie Wspólnot, co dodatkowo zwiększało ich potencjał. Kissinger jako główny powód podał konieczność przedefiniowania strategii NAT0, która była oparta na amerykańskiej przewadze nuklearnej. Jednak śledząc sposób, w jaki Stany Zjednoczone wykorzystywały kwestię dzielenia kosztów obrony, należy stwierdzić, że był to argument ważny, ale nie najważniejszy. Kissinger wspominał również w tym kontekście napięcia gospodarcze twierdząc, że były one tak destrukcyjne, gdyż w przeciwieństwie do NAT0, nie było żadnego mechanizmu koordynującego ${ }^{165}$. Jednakże istniały przecież takie organizacje jak GATT, OECD, MFW, w których ważny głos miały Stany Zjednoczone. Wyodrębnienie kolejnego forum, z mniejszą liczbą uczestników, umożliwiłoby Stanom Zjednoczonym koordynację działań ekonomicznych Zachodu zgodnie ze swoim interesem narodowym.

Europa uczyniła kwestią priorytetową umacnianie integracji. Poza tym w dobie kryzysu energetycznego rządy były poddane wewnętrznej presji. Podobna sytuacja była w Stanach Zjednoczonych, które dodatkowo były poruszone aferą Watergate. Takie warunki nie sprzyjały wzmocnieniu współpracy i osiąganiu kompromisu.

${ }^{165}$ H. K i s s i n g e r, The Years of Upheaval..., s. 134-135. 



\section{WNIOSKI I UWAGI KOŃCOWE}

Kształtowanie się stosunków transatlantyckich w czasie rządów Nixona potwierdza główną tezę pracy o dominującym znaczeniu kwestii gospodarczych w polityce zagranicznej USA. W stosunkach z Europą Zachodnią tradycyjne zagadnienia: obrona i dyplomacja, zostały przyćmione przez nieporozumienia na tym polu, które zdawały się charakteryzować wzajemne relacje. W polityce USA wobec europejskich sojuszników pojawiły się nowe elementy: dążenie do ściślejszego zinstytucjonalizowania współpracy transatlantyckiej, spadek poparcia dla integracji europejskiej (w tym domaganie się rekompensat strat związanych z przyjęciem nowych członków do Wspólnot), próby ograniczania ekspansji gospodarczej EWG, nacisk na bardziej sprawiedliwe dzielenie kosztów obrony, stosowanie nacisków politycznych w celu uzyskania koncesji gospodarczych, unilateralne działania szkodzące interesom partnerów gospodarczych.

Można stwierdzić, że inicjatywy z pozoru czysto polityczne, takie jak np. projekt Deklaracji Atlantyckiej, miały podłoże ekonomiczne. Dążenie do ściślejszego zinstytucjonalizowania relacji wynikało z faktu, że sojusz ulegał rozluźnieniu przede wszystkim na tle nieporozumień gospodarczych. Kissinger zgłosił tę propozycję w kwietniu 1973 r. w czasie intensywnych prac nad reformą systemu monetarnego. Poza tym na jesień tego roku planowano rozpoczęcie tokijskiej rundy negocjacyjnej GATT. W obu tych kwestiach Stany Zjednoczone potrzebowały wsparcia państw europejskich. Także w tym roku EWG została wzmocniona o trzech nowych członków. Chociaż Amerykanie nie mogli wiosną przewidzieć kryzysu energetycznego, jednak byli także zaniepokojeni próbami Europejczyków nawiązania bliższych stosunków z państwami arabskimi - producentami ropy naftowej. Fiasko Deklaracji Atlantyckiej pokazuje, że Europejczycy unikali podejmowania zobowiązań w dziedzinie, w której mogli konkurować ze swoim sojusznikiem.

Konflikty na tle samodzielnej polityki zagranicznej Europy Zachodniej były uwarunkowane również rywalizacją gospodarczą. Tak było w przypadku polityki bliskowschodniej, kiedy EWG starała się wypracować dobre stosunki z państwami arabskimi. Próby te zostały podjęte bez konsultacji z Amerykanami, a ich głównym celem było zapewnienie dostaw ropy. Żeby to osiągnąć, Europejczycy odcięli się od polityki bliskowschodniej Waszyngtonu, wspierającego Izrael w wojnie Jom Kippur. Drugim przykładem była polityka wobec bloku wschodniego. Państwom zachodu Starego Kontynentu nie chodziło wyłącznie o ocieplenie stosunków w celu poprawy własnego bezpieczeństwa. Nastąpił zdecydowany wzrost wymiany między Zachodnią a Wschodnią Europą. Stany Zjednoczone ograniczały handel ze 
Wschodem, pozostając $w$ tej dziedzinie wyraźnie w tyle. Niepokoiły się przy tym, że zbliżenie gospodarcze z państwami socjalistycznymi spowoduje erozję sojuszu atlantyckiego.

W obu przypadkach rywalizacja gospodarcza wpłynęła negatywnie na relacje polityczne między sojusznikami. Miało to również miejsce, gdy Stany Zjednoczone podejmowały unilateralne działania, szkodzące interesom ich partnerów. Po zawieszeniu wymienialności dolara na złoto Europejczycy z dużą podejrzliwością podchodzili do amerykańskich propozycji budowy równorzędnego partnerstwa.

Jednym z powodów wzrostu znaczenia kwestii gospodarczych w stosunkach transatlantyckich było zmniejszenie $\mathrm{w}$ dobie détente prawdopodobieństwa użycia siły militarnej przez obie strony zimnowojennego konfliktu. Dlatego nie dominowały już zagadnienia takie jak podejmowanie decyzji w sojuszu czy wyposażenie państw europejskich w broń nuklearną, ustępując miejsca sporowi o dzielenie kosztów obrony. W państwach Europy Zachodniej zmniejszyło się poczucie zagrożenia ewentualnym atakiem. Był to niewątpliwie powód większej asertywności wobec Waszyngtonu, choć nadal nie zamierzano rezygnować z gwarancji obronnych Stanów Zjednoczonych. W związku z tym, Amerykanie używali groźby wycofania części wojsk ze Starego Kontynentu, starając się łączyć tę kwestię z negocjacjami monetarnymi i handlowymi. Domagali się również zwiększenia przez Europejczyków wydatków na obronę, a od RFN rekompensaty kosztów utrzymywania kontyngentu na jej terenie. Siła militarna była dla nich ważnym narzędziem polityki zagranicznej.

Państwa europejskie, rezygnując z podnoszenia możliwości obronnych, preferowały używanie narzędzi ekonomicznych, broniąc się przed naciskami USA. Zdawały sobie sprawę, że były najważniejszymi partnerami gospodarczymi Stanów Zjednoczonych i bez ich udziału wszelkie reformy zachodniego systemu były niemożliwe, tym bardziej, że wycofanie wojsk amerykańskich z Europy nie leżało w interesie USA. Oznaczało to nie tylko zmniejszenie wpływów politycznych w Europie (w które już sporo zainwestowano), lecz także osłabienie pozycji w dobie negocjacji z ZSRR. Kissinger, choć w rozmowach z Europejczykami wskazywał na możliwość takiej decyzji w Kongresie, w ścisłym gronie wyrażał opinię, że sojusznicy nie biorą tych gróźb poważnie. Mimo to przyjęcie przez Kongres poprawki Jacksona-Nunna o rekompensowaniu strat dla amerykańskiego bilansu płatniczego skłoniło RFN do podpisania w kwietniu 1974 r. długo negocjowanej umowy offsetowej. Natomiast amerykańskie próby wymuszenia w ten sposób współpracy Europejczyków w kwestiach monetarnych i handlowych, kończyły się niepowodzeniem. Paradoksalnie, zbyt daleko idące naciski Kongresu w kwestii redukcji wojsk w Europie uniemożliwiały Waszyngtonowi skuteczne wykorzystanie tego argumentu w kontaktach z sojusznikami.

W pracy starałam się wykazać, że siła gospodarcza EWG zapewniała Europejczykom lepszą pozycję negocjacyjną wobec Amerykanów, ale tylko w kwestiach ekonomicznych. Brak jednolitej polityki zagranicznej, różnice interesów 
między poszczególnymi państwami, a nade wszystko poleganie na USA w sprawach obronnych sprawiało, że próby prowadzenia niezależnej dyplomacji w ważnych sprawach międzynarodowych kończyły się niepowodzeniem. Najbardziej dobitnym przykładem była sytuacja w dobie kryzysu energetycznego, kiedy Wspólnota początkowo próbowała samodzielnie ułożyć relacje z państwami arabskimi. Ostatecznie przyłączyła się do „frontu konsumentów” zorganizowanego przez Waszyngton, gdyż nie posiadała porównywalnych z Amerykanami narzędzi oddziaływania na sytuację na Bliskim Wschodzie.

Natomiast bez nacisków politycznych Stany Zjednoczone nie były w stanie zapewnić sobie żadnych koncesji. Mogły oczywiście zastosować sankcje, lecz takie rozwiązanie było politycznie niebezpieczne. Poza tym w dobie recesji, na początku lat 70., obie strony decydowały się na wprowadzanie środków protekcjonistycznych. Jednak wszystkie rządy państw zachodnich starały się, by odstępstwa od zasad światowego systemu gospodarczego nie były zbyt radykalne. W przypadku relacji transatlantyckich siła gospodarcza nie była więc najskuteczniejszym narzędziem polityki zagranicznej. Z pewnością jej używanie sprawdza się lepiej w sytuacji, gdy jedna ze stron ma znaczną przewagę na tym polu.

Kwestie polityczne i militarne nie stały się mniej ważne przez ekonomiczne uwarunkowania stosunków międzynarodowych, ale polityka zagraniczna państw uległa zasadniczym przekształceniom. Zgodnie z koncepcją złożonej współzależności, relacje między państwami opierały się na sprzężonych ze sobą interesach gospodarczych, politycznych i obronnych. Większa rola czynnika gospodarczego w polityce zagranicznej spowodowała zmianę relacji Stanów Zjednoczonych z mocarstwami europejskimi. W latach 50. i 60. można było mówić o „wyjątkowych relacjach” (special relationship) z Wielką Brytanią. Po objęciu władzy przez rząd Edwarda Heatha, w dobie starań o członkostwo we Wspólnotach Europejskich, stosunki te uległy wyraźnemu ochłodzeniu. Nie tylko Brytyjczycy starali się udowodnić, że nie będą amerykańskim „koniem trojańskim”, ale także Amerykanie mieli dużo obaw związanych z rozszerzeniem EWG.

Najczęściej rolę głównego oponenta USA odgrywała Francja. Zdarzało się, tak jak w przypadku projektu Deklaracji Atlantyckiej czy nawiązania relacji z państwami arabskimi, że udało jej się przekonać do swoich koncepcji pozostałe państwa EWG. Także w sprawach gospodarczych jej przedstawiciele prezentowali stanowisko odmienne od amerykańskiego. Sprawiło to, że Amerykanie zaangażowali się bardziej w dyplomację wobec tego kraju. W memorandum Rady Bezpieczeństwa Narodowego (NSSM 166) stwierdzono, że polityka francuska miała podłoże nacjonalistyczne, z ambicją przyjęcia roli lidera we Wspólnotach Europejskich. Dlatego Kissinger - zwolennik koncepcji realizmu w stosunkach międzynarodowych - starał się dowartościować polityków znad Sekwany, nawiązując z nimi „wyjątkowe relacje". W dobie uzgadniania zasad nowego systemu monetarnego, na początku konsultowano się z prezydentem Francji Georgesem Pompidou. Z nim też spotkał się 
osobno Nixon niedługo po ogłoszeniu propozycji podpisania Deklaracji Atlantyckiej. Podczas tych spotkań Kissinger nie wahał się nazywać Francji „liderem politycznym Europy". Jednak nie skłaniało to Paryża do zmiany polityki wobec USA.

Zarówno z wypowiedzi polityków, jak i z działań dyplomacji wynika jednak, że najważniejszym partnerem w oczach Amerykanów była RFN. Amerykanie pragnęli zachować kontrolę nad polityką wschodnią kanclerza Willy'ego Brandta. Lecz najistotniejszy wydaje się fakt, że RFN była najbardziej prężnie rozwijającą się gospodarką w EWG. Zgodnie z przedstawioną w pracy tezą o dominacji czynnika gospodarczego $w$ relacjach transatlantyckich, Waszyngton zabiegał przede wszystkim o współpracę Europy w kwestiach handlu i reformy systemu monetarnego. W takim przypadku rola RFN jako wiodącej siły gospodarczej, jednocześnie podatnej na naciski polityczne ze względu na uzależnienie od amerykańskiej obrony, była kluczowa. Chociaż trzeba zaznaczyć, że dzięki potencjałowi gospodarczemu i oparciu w strukturach europejskich RFN umocniła pozycję negocjacyjną względem potężnego sojusznika zza oceanu.

Konflikty w stosunkach transatlantyckich były nieuniknione ze względu na odmienne wewnętrzne cele rozwojowe. Bardzo ścisła współzależność obu stron sprawiała, że różnice te często się ujawniały, generując spory. Jakie były jednak powody ich długotrwałości? Obie strony ponosiły winę za trudności w osiągnięciu konsensusu. Europejczycy pragnęli utrzymać amerykańską odpowiedzialność za swoje bezpieczeństwo, a jednocześnie prowadzić niezależną politykę zagraniczną, czasami sprzeczną z koncepcją Stanów Zjednoczonych. Natomiast Amerykanie, mimo oficjalnych deklaracji o dążeniu do zbudowania równorzędnego partnerstwa, pragnęli ograniczyć rolę sojuszników do spraw regionalnych. Należy wziąć pod uwagę, że w czasach prezydentury Nixona priorytetem dla USA były relacje z ZSRR i ChRL, a nie z Europą. Waszyngtonowi zależało, żeby sojusznicy nie przeszkadzali $\mathrm{w}$ ich kształtowaniu, np. poprzez podpisywanie umów gospodarczych, co mogło osłabić ich pozycję negocjacyjną. Powodowało to frustrację Europejczyków i dążenie do emancypacji, co wprowadzało nieufność w relacje transatlantyckie. Ważnym czynnikiem utrudniającym porozumienie była afera Watergate i upadek autorytetu administracji Nixona.

Podobny wniosek można wysnuć, przyglądając się stosunkom gospodarczym. Państwa europejskie, przekonane o bezwarunkowym poparciu Stanów Zjednoczonych dla ich integracji, stosowały praktyki niekorzystne dla gospodarki tego państwa, np. zawierały preferencyjne układy handlowe z państwami trzecimi. Mimo odzyskania siły gospodarczej, nie były gotowe wraz ze Stanami Zjednoczonymi ponieść kosztów reform gospodarki światowej w dobie kryzysu monetarnego i energetycznego. Natomiast Amerykanie nie byli skłonni do kompromisu, dążąc do zmian systemu według zasad zgodnych z ich interesem narodowym. Połączenie tych uwarunkowań politycznych i gospodarczych sprawiło, że relacje transatlantyckie stały się najbardziej napięte od zakończenia II wojny światowej. 
Rozbieżności między sojusznikami, powstające głównie na tle gospodarczym, negatywnie wpływały na pozycję mocarstwową USA, integrację europejską, a także na spoistość Zachodu. Starające się przezwyciężyć wewnętrzne trudności gospodarcze Stany Zjednoczone napotkały opór sojuszników. Europejczycy nie tylko mieli inną koncepcję reform światowego systemu handlowego i monetarnego, ale także stali się rywalami USA na rynkach światowych, co osłabiało konkurencyjność amerykańskiej gospodarki. Waszyngton, planujący prowadzić negocjacje z ZSRR z pozycji siły, niechętnie patrzył na wzrastające kontakty handlowe Europy Zachodniej z blokiem wschodnim. Najbardziej niepokojący wydawał się eksport technologii, wzmacniający zimnowojennego przeciwnika. Podobna sytuacja miała miejsce na Bliskim Wschodzie, gdy próby odrębnych układów członków EWG z producentami ropy utrudniały USA nadzorowanie procesu pokojowego w tym regionie i negocjacji w sprawie znoszenia embarga.

Nieporozumienia z Amerykanami i niezgoda na narzucanie przez nich rozwiązań na wszystkich polach, mobilizowała Europejczyków do podejmowania wysiłków na rzecz pogłębiania integracji. Były to działania na polu ekonomicznym, ale także dążenia do ujednolicenia polityki zagranicznej. Próby te nie zawsze były udane. Koordynacja polityki zagranicznej EWG, postulowana w raporcie Davignona z października 1970 r., okazała się najtrudniejsza. Obawy przed dominacją amerykańską w czasie prac nad Deklaracją Atlantycką zmusiły Europejczyków do przyjęcia wspólnego stanowiska. Jednak skończyło się to tylko podkreśleniem odmiennej od amerykańskiej tożsamości w projekcie Deklaracji. Większość państw, oprócz Francji, mimo wcześniejszego oporu, przyłączyła się do amerykańskiej inicjatywy powołania Grupy Koordynacyjnej ds. Energii. Kraje europejskie wolały polegać na sprawdzonym, silnym sojuszniku. Przyznały tym samym rację Kissingerowi twierdzącemu, że Europa powinna zająć się raczej sprawami regionalnymi niż polityką na skalę globalną. Można również stwierdzić, że niepowodzenia w ustalaniu jednolitego stanowiska wobec Stanów Zjednoczonych zahamowały proces kształtowania wspólnej polityki zagranicznej. Pośrednio różnice zdań z sojusznikiem opóźniały również integrację ekonomiczną, np. proces tworzenia unii monetarnej. Brak porozumienia $\mathrm{w}$ sprawie reformy światowego systemu uniemożliwiał umocowanie europejskiego projektu w ramach gospodarki światowej.

Rosnąca rywalizacja ekonomiczna godziła w spoistość bloku zachodniego na wszystkich polach, co było niebezpieczne w dobie zimnej wojny. Konflikty gospodarcze, pogarszające relacje polityczne, utrudniały zajęcie wspólnego stanowiska wobec ZSRR. Próby USA wymuszania koncesji gospodarczych podsycały wzajemną nieufność. Dlatego coraz częściej w Stanach Zjednoczonych niepokojono się możliwością „finlandyzacji” Europy Zachodniej.

Analiza procesu podejmowania decyzji pozwala stwierdzić, że rola państwa w gospodarce światowej w latach 70. XX w. wciąż była kluczowa. To oddelegowani przez rządy urzędnicy prowadzili negocjacje o zasadach jej funkcjonowania. 
Wynikało to z faktu, że ich regulacja była uzależniona od polityki władz państwowych, szczególnie ich możliwości interwencji w poszczególne sektory. Należało zachować równowagę między koniecznością utrzymania dobrych relacji z sojusznika$\mathrm{mi}$ a dbaniem o interes gospodarczy własnych obywateli. Dlatego w tym okresie nie można mówić o zaniku ani marginalizacji roli państwa narodowego w gospodarce. Należy natomiast zwrócić uwagę na przemożny wpływ kryzysów światowego systemu ekonomicznego na polityczne stosunki międzynarodowe i politykę wewnętrzną państw. Rządy musiały reagować na wszelkie zmiany, próbując zorganizować międzynarodową współpracę, jednocześnie chroniąc własną gospodarkę.

Sytuacja w Stanach Zjednoczonych była specyficzna, gdyż główni kreatorzy polityki zagranicznej - Nixon i Kissinger - starali się sprawować jak największą kontrolę nad wszystkimi jej dziedzinami. Takie neomerkantylistyczne podejście było atrakcyjne dla rządów stojących w obliczu rosnących oczekiwań społeczeństw, zwłaszcza w dobie recesji. Jest rzeczą naturalną, że rządy demokratyczne chronią przede wszystkim interesy swoich obywateli - jest to wręcz ich obowiązek, z którego są rozliczane podczas wyborów.

Neomerkantylizm nie występował jednak w czystej postaci. Nurt ten abstrahuje bowiem od współzależności gospodarki światowej i polityki międzynarodowej. Analiza sytuacji w czasie rządów Nixona nie przyniosła potwierdzenia tezy, że współzależność państw powoduje brak konfliktów między nimi. Można zgodzić się, że - jak głosili zwolennicy perspektywy liberalnej - działania państwa generowały większość nieporozumień. To rządy wprowadzały środki protekcjonistyczne, narzucały regulacje, ograniczały inwestycje czy manipulowały kursami walut. Nie sposób jednak stwierdzić, jak funkcjonowałaby gospodarka światowa bez interwencji władz państwowych i regulującego ją systemu, jest to bowiem sytuacja hipotetyczna: państwa narodowe były wciąż głównymi aktorami na arenie międzynarodowej.

Możliwości wpływu państwa na gospodarkę ujawniają się w szczególny sposób w czasie kryzysu, gdy wzrasta społeczne przyzwolenie dla interwencjonizmu. W momencie zakłóceń działania systemu gospodarczego politycy próbują dokonać jego korekt. Powoduje to nieuchronne zmiany w polityce zagranicznej państw, szczególnie hegemonicznego mocarstwa. Najlepszym przykładem jest reorientacja stanowiska Stanów Zjednoczonych w kwestii umacniania się integracji europejskiej. Jej wspieranie było fundamentem polityki amerykańskiej wobec Europy Zachodniej od zakończenia II wojny światowej. Podczas recesji w pierwszej połowie lat 70. Stany Zjednoczone widziały w EWG poważnego rywala. Dlatego żądano rekompensat po rozszerzeniu tej organizacji, choć jeszcze w latach 60. amerykańscy prezydenci bezwarunkowo popierali przystąpienie do niej nowych członków.

Rosnące współzależności gospodarcze zmusiły rządy, by dostosowały do nich swoje działania. Skomplikowany system powiązań łączący Europę Zachodnią i Stany Zjednoczone Goodman nazwał "gospodarką mieszaną”, składającą się z prywatnych przedsiębiorstw i państw mogących interweniować w zasady jej funkcjonowania. 
Kraje ją tworzące miały intensywne kontakty handlowe i inwestycyjne, podobne problemy gospodarcze, należały do tych samych organizacji, co prowadziło do swoistej integracji gospodarki atlantyckiej ${ }^{1}$.

Gospodarki narodowe były elementami światowego systemu i w tym sensie rzeczywiście państwa utraciły część suwerenności, gdyż musiały przestrzegać określonych zasad. Niekiedy decydowały się na ich łamanie, chroniąc partykularne interesy narodowe, co powodowało konflikty. Jednak istnienie tych ograniczeń miało więcej efektów pozytywnych. Organizacje, takie jak GATT, stanowiły ważne forum negocjacyjne. Eskalacja konfliktów gospodarczych groziła upadkiem całego systemu, co spowodowałoby negatywne skutki dla wszystkich jego uczestników. „Upolitycznienie” relacji gospodarczych często prowadziło do łagodzenia sporów. Za kadencji Nixona powiązania polityczne i obronne sojuszników skłaniały ich do podejmowania negocjacji, nie pozwalały na przekształcenie się nieporozumień w długotrwałe „wojny handlowe”. Zasadę współzależności dobrze oddają słowa Kissingera: „wszyscy jesteśmy zaangażowani we wspólne przedsięwzięcie. Żaden naród ani grupa państw nie może wygrać, stawiając zbyt wygórowane żądania”2.

Analiza procesu podejmowania decyzji przez administrację Nixona przyniosła potwierdzenie tezy koncepcji pluralistycznej, że polityka zagraniczna jest próbą kompromisu między żądaniami różnych grup interesów. Mogły one wywierać naciski na rządy, które starały się brać pod uwagę postulaty najsilniejszych lobby reprezentowanych w Kongresie. Potwierdza to tezę, że system polityczny kształtuje działania gospodarcze rządu. Konieczność brania pod uwagę opinii obywateli, która istnieje w państwach demokratycznych, wpływała na amerykańską politykę zagraniczną, generowała napięcia i spory gospodarcze. Przykładem mogą być próby blokowania podpisywania przez EWG preferencyjnych układów handlowych z krajami trzecimi. Było to jednak sprzeczne z interesami wielonarodowych korporacji inwestujących w Europie, obawiających się utrudnień w działalności. Starały się wywierać presję na rządy, by dostosowywały zasady handlu i inwestycji do ich oczekiwań. Do 1969 r. wielonarodowe korporacje, których właścicielami byli Amerykanie, produkowały za granicą towary o wartości pięciokrotnie przewyższającej wartość eksportu USA. Podstawowa aktywność USA w międzynarodowych transakcjach gospodarczych dokonywała się przez te przedsiębiorstwa, a nie przez handel zagraniczny. Dochód netto USA z ich działalności był również większy niż z handlu zagranicznego $^{3}$. Dlatego ich wpływ na politykę gospodarczą stopniowo wzrastał.

Rządy zaczęły obawiać się aktywności przedsiębiorstw wielonarodowych. Dowodem na to może być przyjęcie na konferencji energetycznej w Waszyngtonie

${ }^{1}$ E. R. G o o d m a n, The Impact of the Multinational Enterprise upon Atlantic Community, [w:] The New Europe and the United States. Partners or Rivals, ed. G. Mally, Lexington 1974, s. 134-135.

${ }^{2}$ Cyt. za: C. F. B e r g s t e n, R. Ke o h a n e, J. N y e, International Economics and International Politics: a Framework for Analysis, „International Organization”, Winter 1975, s. 21.

${ }^{3}$ E. R. G o o d m a n, op. cit., s. 247. 
w lutym 1974 r. postulatu wspólnych działań w celu kontroli korporacji naftowych. Przedstawiciele rządów państw uprzemysłowionych obawiali się, że bez skoordynowanej, międzynarodowej akcji stracą możliwość kontroli nad własną polityką gospodarczą. Drugim przykładem może być dążenie do ograniczenia inwestycji zagranicznych. Decydenci europejscy odpowiadali na obawy społeczeństw przed zdominowaniem rodzimych przedsiębiorstw przez amerykańskie firmy, a w Stanach Zjednoczonych zauważano zbyt duży odpływ kapitału do Europy, co mogło pogłębić deficyt bilansu płatniczego.

Bergsten twierdził, że napięcie w stosunkach transatlantyckich trwało tak długo, gdyż Europejczycy nie mogli ustanowić jedności politycznej. Nie tylko osłabiało to ich pozycję, ale często uniemożliwiało konsensus. Taka sytuacja utrudniała zadanie również dyplomacji amerykańskiej. Gdy prowadzono rozmowy bilateralne z poszczególnymi państwami, pojawiały się oskarżenia o próby rozbicia jedności europejskiej, gdy zaś powstrzymywano się od konsultacji - Stany Zjednoczone były oskarżane o unilateralizm4. Takie uzasadnienie jednostronnych działań USA jest bardzo przewrotne - wielokrotnie udawało się przecież organizować negocjacje z przedstawicielami państw europejskich na różnych forach. Można także stwierdzić, że Amerykanie woleli prowadzić negocjacje bilateralne niż konfrontować się ze wspólnym stanowiskiem Wspólnot. Dlatego wątpliwe jest, czy Kissinger naprawdę chciał znać „telefon do Europy”.

Jednak państwa europejskie potrafiły „mówić jednym głosem”, gdy w grę wchodziły wspólne interesy gospodarcze. Przykładem było wspólne stanowisko po „szoku Nixona", kiedy Europejczycy oparli się presji Amerykanów, stawiających wygórowane żądania w zamian za stabilizację kursu USD i zniesienie podatku importowego. Skutecznie także bronili wspólnej polityki rolnej i wbrew protestom Waszyngtonu zawierali preferencyjne układy handlowe z krajami trzecimi. Wszelkie próby kwestionowania ustalonych przez EWG zasad współpracy zadrażniały stosunki transatlantyckie. Dlatego Amerykanie rzadko domagali się ich zmian. Wyjątkiem było przeforsowanie rekompensat za negatywne skutki rozszerzenia EWG dla eksportu USA.

Złożoność problemu sprawia, że nie można kwestii wpływu gospodarki na politykę zagraniczną Stanów Zjednoczonych wtłoczyć w sztywne ramy jednej teorii. Podejmowane w tej materii decyzje nie mogą być oderwane od kontekstu historycznego i ich ideologicznej natury. Analizując politykę administracji Nixona wobec Europy Zachodniej, można znaleźć potwierdzenie teorii związanych zarówno z nurtem realistycznym, jak i liberalnym.

Gospodarczą politykę zagraniczną państwa tworzą współzależne czynniki polityczne i ekonomiczne. Jest zdeterminowana sytuacją wewnętrzną państw. Jednak partykularne interesy narodowe muszą być w pewnych sytuacjach ograniczone,

${ }^{4}$ C. F. B e r g s t e n, Toward a New International Economic Order: Selected Papers of C. F. Bergsten, 1972-1974, Lexington 1975, s. 313. 
by można było wypełnić zobowiązania wobec innych członków systemu. W latach 50. i 60. XX w. polityki gospodarcze USA, EWG i Japonii były komplementarne. Konflikty gospodarcze były wygaszane ze względu na konieczność politycznej jedności w konfrontacji zimnowojennej. Cieszące się bezprecedensową prosperity Stany Zjednoczone, akceptowały wprowadzane przez sojuszników ograniczenia w handlu. Firmy amerykańskie miały bardzo duże możliwości inwestycyjne i kontrolowały dużą część rynku światowego. Nie był też zagrożony ich dostęp do surowców.

W latach 70. Stany Zjednoczone zaczęły dokładniej liczyć koszty polityki zagranicznej. Niepokojono się deficytem w bilansie płatniczym i handlu zagranicznym. Europejczycy chcieli natomiast zakończenia hegemonii dolara na światowych rynkach finansowych, przede wszystkim jako waluty rezerwowej. Wciąż jednak trwała zimna wojna, więc zarówno Stany Zjednoczone, jak i kraje Europy Zachodniej musiały brać pod uwagę, oprócz powiązań gospodarczych, również uwarunkowania polityczne.

$\mathrm{Na}$ początku lat 70 . można zaobserwować objawy zmierzchu hegemonii Stanów Zjednoczonych. Zaczęły przeżywać trudności gospodarcze, dlatego chciały scedować część odpowiedzialności za utrzymywanie systemu na sojuszników. Europejczycy nie byli jednak skłonni ponosić większych wydatków na obronę ani rezygnować z przywilejów, jakie dawała im integracja. Zauważali za to nadmierną dominację Stanów Zjednoczonych w sferze politycznej, byli zaniepokojeni skalą inwestycji w europejską gospodarkę oraz kwestionowali przywileje USA związane z pozycją USD. Poza tym amerykańskie trudności gospodarcze wpływały na pogorszenie się koniunktury w krajach Europy Zachodniej. Ich rządy, korzystając z osłabienia pozycji USA, decydowały się na odstępstwa od ustalonych zasad. Musiały się liczyć z wymaganiami obywateli, którzy oczekiwali poprawy sytuacji, nawet kosztem naruszania interesów innych państw. Z kolei Stany Zjednoczone były bardziej skłonne do podejmowania kroków chroniących własne interesy. Jako twórcy zasad funkcjonowania relacji międzynarodowych świata zachodniego, Amerykanie powinni również strzec ich przestrzegania, jednak sami je łamali. To jeden z dowodów na zmierzch ich hegemonii. Co więcej, w czasie wojny w Wietnamie autorytet Stanów Zjednoczonych jako lidera państw demokratycznych uległ osłabieniu. Zarówno Europejczycy jak i Amerykanie, protestowali przeciw metodom działania waszyngtońskiej administracji. Sojusznicy zauważyli, że polityka hegemona nie zawsze służy ich interesom.

Jednocześnie obywatele USA doszli do wniosku, że koszty przywództwa były dla nich zbyt duże i szkodziły ich gospodarce. Zaczęli domagać się od rządzących, by zwiększyli wymagania wobec Europejczyków. W Stanach Zjednoczonych nie widziano powodu, by pozwalać na zachowanie przywilejów krajom, które odzyskały siłę gospodarczą, a nie były skłonne wspierać USA w Wietnamie czy na Bliskim Wschodzie, ani przyznać im koncesji gospodarczych. Wynikał stąd wniosek, że pozostali uczestnicy systemu korzystali z niego bardziej niż sam hegemon. Zgodnie z teorią hegemonicznej 
stabilności, osłabienie pozycji Stanów Zjednoczonych sprawiło, że także stworzony przez nie międzynarodowy system gospodarczy uległ zachwianiu.

Nieporozumienia transatlantyckie przekładały się na opóźnianie reform międzynarodowych instytucji gospodarczych. Według Bergstena, najtrudniejszą kwestią było znalezienie równowagi między koniecznością przyjęcia rozwiązań korzystnych dla wszystkich uczestników a zachowaniem przez państwo możliwości podejmowania autonomicznych decyzji. Dodatkową komplikacją były rosnące współzależności między sferą gospodarczą, polityczną i obronną. W praktyce nie można było szukać rozwiązania żadnego problemu gospodarczego abstrahując od konsekwencji politycznych. Po II wojnie światowej Stany Zjednoczone pełniły funkcję lidera reform, narzucając pozostałym uczestnikom systemu własne rozwiązania, ale także poświęcając czasem swe interesy dla wspólnego dobra. W latach 70. inne kraje były na tyle silne gospodarczo, by odmówić podporządkowania się amerykańskim koncepcjom ${ }^{5}$.

Stany Zjednoczone wywierały naciski na sojuszników, by podejmowali korzystne dla nich decyzje, wciąż dominowały bezdyskusyjnie w gospodarce światowej i pozostawały liderem politycznym Zachodu. Tylko to państwo było zdolne ponosić gros kosztów, choć było oczywiste, że system wymagał reformy. Żeby utrzymać dobrobyt i bezpieczeństwo, potrzebna była hegemonia amerykańska, dla której nie było w tym czasie sensownej alternatywy. Dopóki dwaj najpoważniejsi rywale: państwa Europy Zachodniej i Japonia byli zależni od obrony Stanów Zjednoczonych, było mało prawdopodobne, że zdecydują się na poważny konflikt z USA na jakimkolwiek polu. Państwa Europy Zachodniej zdawały sobie z tego sprawę, dlatego dążyły do porozumienia, godząc się na przykład na niewielkie zwiększenie wydatków na obronę, rekompensaty za rozszerzenie EWG czy umowę w sprawie płynnych kursów walut.

Mimo trudności w osiągnięciu konsensusu, państwa były skłonne do współpracy w zakresie reform instytucji, które były konieczne dla zachowania ich bezpieczeństwa gospodarczego $0^{6}$. Jednak jej warunki musiały ulec zmianie. W drugiej połowie lat 70., pojawiła się koncepcja pluralistycznego przywództwa (pluralist leadership), polegająca na wspólnych decyzjach dotyczących gospodarki światowej i koordynacji polityk między Stanami Zjednoczonymi a ich największymi partnerami gospodarczymi. Długotrwałość kryzysu groziła problemami dla wszystkich gospodarek Zachodu, powrotem protekcjonizmu i w rezultacie osłabieniem sojuszu. Odpowiedzią na te zagrożenia było m.in. powstanie, już za kadencji następcy Nixona, Geralda Forda, forum G7 - nowej instytucji gospodarki światowej. Warto podkreślić, że państwami inicjującymi powstanie tego forum były Francja i RFN. Pierwsze spotkanie przywódców najbogatszych państw uprzemysłowionych miało

\footnotetext{
${ }^{5}$ C. F. B e r g s t e n, Interdependence and the Reform of International Institutions, „International Organization", Spring 1976, s. 363-366.

${ }^{6}$ L. B. Kra u se, J. N y e, Reflections on the Economics and Politics of International Economic Organizations, „International Organization”, Winter 1975, s. 333.
} 
miejsce między 15 a 17 listopada 1975 r. na zamku w Rambouillet. Wzięli w nim udział przedstawiciele sześciu państw: Francji, RFN, Wielkiej Brytanii, Japonii, Stanów Zjednoczonych i Włoch. Od 1976 r. można mówić o skompletowaniu G7, gdyż w szczycie w San Juan wziął udział również premier Kanady?

Analiza procesu podejmowania decyzji wskazuje, że w polityce amerykańskiej ścierały się dwie koncepcje: prymatu spraw gospodarczych lub politycznych. Pierwsza z nich była reprezentowana przez przedstawicieli Departamentów Skarbu, Handlu i Rolnictwa oraz Biura Zarządzania i Budżetu. Ich dążenia do stosowania nacisków politycznych tonował przede wszystkim Departament Stanu i Rada Bezpieczeństwa Narodowego. Członkowie Kongresu ulegali presji swych wyborców - grup interesów, łączyli więc często zagraniczną politykę gospodarczą z partykularnymi interesami wewnętrznymi. Administracja natomiast częściej podporządkowywała decyzje w tych kwestiach długofalowym celom polityki zagranicznej. Decydenci mieli świadomość współzależności tych dwóch obszarów, lecz inną koncepcję priorytetów w stosunkach transatlantyckich. Sprzeczność stanowisk skłoniła Nixona do powołania w styczniu 1971 r. Rady ds. Międzynarodowych Stosunków Gospodarczych (Council on International Economic Affairs - CIEP). W jej skład weszli szefowie departamentów politycznych i gospodarczych, którzy mieli współpracować w podejmowaniu najważniejszych decyzji. Potwierdza to założenia teorii polityki biurokratycznej głoszącej, że polityka zagraniczna jest efektem kompromisu między różnymi ośrodkami władzy.

\section{Schemat 1. System podejmowania decyzji w polityce zagranicznej za kadencji Nixona}

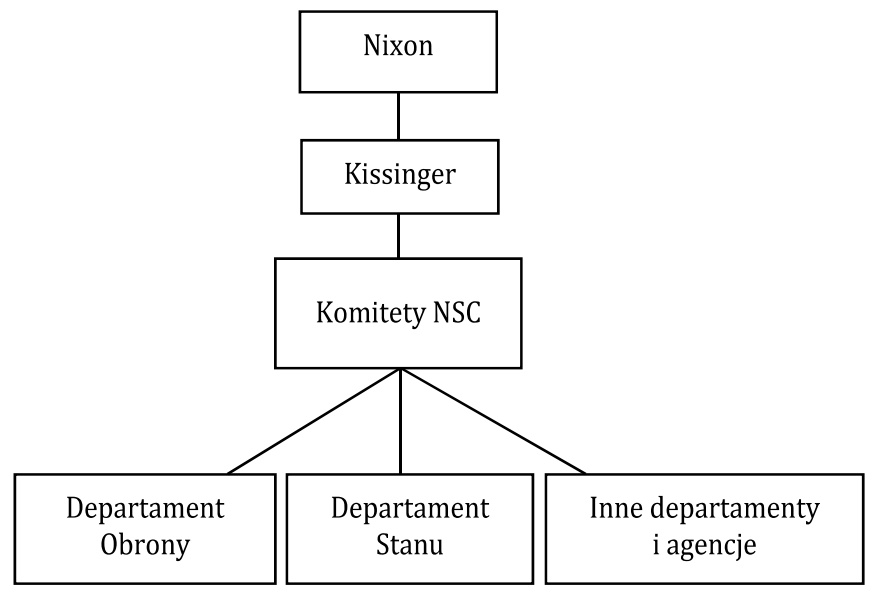

Źródło: J. R o s a t i, The Politics of US Foreign Policy, Fort Worth 1993, s. 43.

${ }^{7}$ Więcej na temat genezy G7 zob. R. M a te ra, G8 jako instytucja gospodarki światowej, Łódź 2009, s. 42-59. 
Na podstawie schematu 1. zaproponowanego przez Jerela Rosatiego można wnioskować, że to Kissinger był najważniejszym doradcą Nixona, a jego opinia ważyła najbardziej na decyzjach podejmowanych przez prezydenta. Gdyby teza ta była prawdziwa, Nixon kierowałby się przede wszystkim względami politycznymi, czego zwolennikiem był doradca ds. bezpieczeństwa narodowego przekonany, jako zwolennik realizmu, o dominacji tych kwestii nad interesem ekonomicznym. Tymczasem za kadencji Nixona interes gospodarczy Stanów Zjednoczonych był traktowany priorytetowo w relacjach z sojusznikami. Nie oznaczało to, że prezydent nie dbał o więzy polityczne i obronne łączące Amerykanów z krajami Europy Zachodniej było to niemożliwe $\mathrm{w}$ dobie zimnowojennego systemu blokowego. Jednak Nixon, sam dobrze zorientowany w zawiłościach polityki zagranicznej i pragnący utrzymać nad nią kontrolę, nie zawsze słuchał rad Kissingera. Często brał pod uwagę opinię szefów departamentów zajmujących się sprawami gospodarczymi. Dlatego schemat zaproponowany przez Rosatiego można zmodyfikować. Schemat 2. obrazuje rosnącą rolę departamentów gospodarczych w kształtowaniu relacji z sojusznikami.

Schemat 2. System podejmowania decyzji w polityce USA wobec Europy Zachodniej za kadencji Nixona

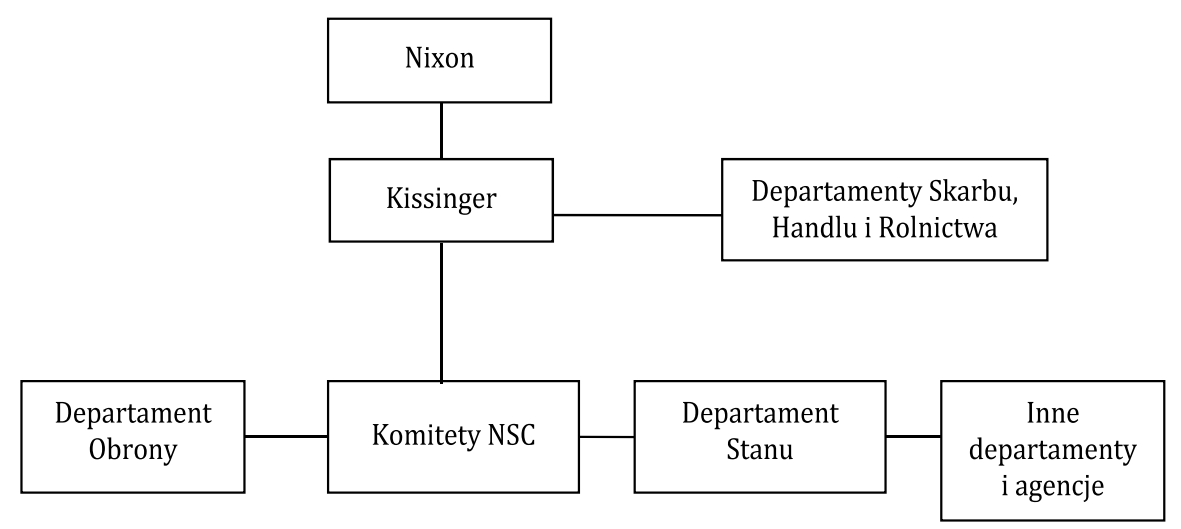

Źródło: opracowanie własne.

Według Bergstena, ważną rolę odgrywali również urzędnicy zajmujący się sprawami monetarnymi i handlowymi. Mimo zmian rządów, zazwyczaj utrzymywali funkcje, zachowując osobiste kontakty. Bergsten twierdził, że przed rozpoczęciem rozmów negocjatorów nie było pewne, czy przeważą argumenty polityczne czy gospodarcze. Według niego ustalając warunki umów gospodarczych powinno się unikać ich upolityczniania (politisation) ${ }^{8}$. Odmiennego zdania był Kissinger, który wielokrotnie podkreślał, że gdyby porozumienia negocjowali urzędnicy od spraw

\footnotetext{
${ }^{8}$ C. F. B e r g s t e n, Toward a New International Economic Order..., s. 319-320.
} 
gospodarczych, którzy nie brali pod uwagę konieczności dbania o spójność sojuszu, układy byłyby zawierane według planów amerykańskich lub dochodziłoby do poważnych konfliktów.

Jednak to prezydent podejmował ostateczną decyzję. Przykładem przyjęcia opinii departamentów gospodarczych jest niewątpliwie „szok Nixona”, kiedy to decyzja kluczowa także dla państw europejskich została podjęta bez wcześniejszych konsultacji. Natomiast ewidentnym dowodem liczenia się z dalekosiężnymi skutkami politycznymi, były zdecydowane działania prezydenta $\mathrm{w}$ celu przekonania Kongresu o szkodliwości przejęcia poprawki Mansfielda o wycofaniu części wojsk amerykańskich z Europy9.

Georges Pompidou stwierdził, po spotkaniu z Nixonem na Azorach w grudniu 1971 r., że związki transatlantyckie były tak silne, że budowanie jedności europejskiej w opozycji do Stanów Zjednoczonych byłoby absurdem. Jednak przyznał, że równie absurdalne byłoby stwierdzenie, że Europa nie posiada „odrębnej w stosunku do USA osobowości"10. Wydaje się to dobrym podsumowaniem charakteru stosunków transatlantyckich także w XXI w. Sytuacja geopolityczna uległa wprawdzie radykalnej zmianie od lat 70. XX w., jednak wciąż Stany Zjednoczone pozostają supermocarstwem, podczas gdy Europa skupia się głównie na problemach własnej integracji i liczy na amerykańską obronę. Rozbieżności wciąż istnieją, lecz są na bieżąco rozwiązywane dzięki ścisłym powiązaniom ekonomicznym, a także politycznym. Powstało wiele nowych forów dyskusji, instytucji i dokumentów regulujących te relacje. Ewidentna jest również współzależność kształtujących je kwestii ekonomicznych i politycznych.

\footnotetext{
${ }^{9}$ Mimo to należy pamiętać, że Mansfield uzasadniał złożony przez siebie projekt argumentem gospodarczym - deficytem bilansu płatniczego.

${ }^{10}$ Cyt. w: The Public Papers of the Presidents of the United States: Richard Nixon, vol. 5: 1973, Washington D.C. 1975, czwarty roczny raport dla Kongresu na temat polityki zagranicznej USA, 3 maja 1973, dok. 141, dostępne także przez: http://www.nixonfoundation.org.
} 



\section{BIBLIOGRAFIA}

\section{I. Źródła archiwalne}

National Archives and Record Administration, College Park, MD (NARA)

1. Nixon Presidential Materials Staff (NPMS)

A. National Security Council (NSC) Instiutional "H" Files

- National Security Council Meetings

- National Security Decision Memorandums (1969-1974)

- Senior Review Group Meetings

- Study Memorandums (1969-1974)

B. National Security Council (NSC) Files

- Country Files - Europe (France)

- Country Files - Europe (Germany)

- President's Trips

- Presidental Correspondence 1969-1974

- Presidental/HAK Memcons

- Subject Files

- Subject Files: European Common Market

- Subject Files: Foreign Policy

- Subject Files: Trade General

- Subject Files: Year of Europe

- VIP Visits

2. Nixon Presidential Materials Project (NPMP)

A. White House Central Files (WHCF)

- IT International Organization, Economic Community-Common Market (EEC)

- IT International Organization, NATO

- Subject Files, Business-Economics

- Subject Files, Countries (CO)

- Subject Files, Foreign Affairs (FO)

B. NSC Files, HAK Office Files

- Country Files - Europe

- European Unity

- HAK Administrative and Staff Files

- HAK Trip Files

\section{II. Źródła opublikowane}

Atlantic Community in Crisis. A Redefinition of the Transatlantic Relationship, eds. W. F. Hahn,

R. L. Pfaltzgraff, Jr, Pergamon Press, New York 1979 
Congressional Record. Proceeding and Debates of the First Session of the $91^{\text {st }}$ Congress, vol. 115, part 21, dostępne przez: http://www.archive.org/stream/congressio-nalrec115lunit\#page/ $\mathrm{n} 1 /$ mode/2up

Congressional Record. Proceeding and Debates of the Second Session of the $91^{\text {st }}$ Congress, vol. 116, part 26, dostępne przez: http://www.archive.org/details/congressionalrec116munit

Congressional Record. Proceeding and Debates of the First Session of the $92^{\text {nd }}$ Congress, vol. 117, part 17, dostępne przez: http://www.archive.org/stream/ congressionalrec117junit\#page/n0/mode/2up

Congressional Record. Proceeding and Debates of the Second Session of the $92^{\text {nd }}$ Congress, vol. 118, part 6, dostępne przez: http://www.archive.org/stream/congressionalrec118eunit\#-page/n169/mode/1up

Congressional Record. Proceeding and Debates of the First Session of the $93^{\text {rd }}$ Congress, vol. 119, part 33, dostępne przez: http://www.archive.org/stream/congressionalrec119qunit/congressionalrec119qunit_djvu.txt

Congressional Record. Proceeding and Debates of the Second Session of the $93^{\text {rd }}$ Congress, vol. 120, part 8, dostępne przez: http://www.archive.org/details/congressionalrec-120dunit

Documents on European Union, ed. A. G. Harryvan, J. Van der Harst, Palgrave Macmillan, Houndmills 1997

Foreign Relations of the United States (FRUS), 1961-1963, vol. 13: Western Europe and Canada, Government Printing Office, Washington D.C. 1994

Foreign Relations of the United States (FRUS) 1969-1976

- vol. 1: Foundations of Foreign Policy, Government Printing Office, Washington D.C. 2003;

- vol. 2: Organization and Management of U.S. Foreign Policy, 1969-1972, Government Printing Office, Washington D.C. 2007;

- vol. 3: Foreign Economic Policy, 1969-1972; International Monetary Policy, 19691972, Government Printing Office, Washington D.C. 2002;

- vol. 4: Foreign Assistance, International Development, Trade Policies, 1969-1972, Government Printing Office, Washington D.C. 2003;

- vol. 31: Foreign Economic Policy 1973-1976, Government Printing Office, Washington

D.C. 2010

Great Issues in American History. From Reconstruction to the Present Day, 1864-1969, ed.

R. Hofstadter, Random, New York 1969

Krew, znój, łzy i pot. Sławne mowy Winstona Churchilla, red. D. Cannadine, Zysk i S-ka, Poznań 2001

Makings of America: the U.S. and the World, vol. 2: Since 1865, ed. J. Miller, Diane Publishing Company, Darby 1993

The New Europe and the United States. Partners or Rivals, ed. G. Mally, Lexington Books, Lexington 1974

The Public Papers of the Presidents of the United States: John F. Kennedy, vol. 3: 1962, Government Printing Office, Washington D.C. 1963

The Public Papers of the Presidents of the United States: Richard Nixon

- vol. 1: 1969, Government Printing Office, Washington D.C. 1969

- vol. 2: 1970, Government Printing Office, Washington D.C. 1971

- vol. 3: 1971, Government Printing Office, Washington D.C. 1972

- vol. 4: 1972, Government Printing Office, Washington D.C. 1974

- vol. 5: 1973, Government Printing Office, Washington D.C. 1975

- vol. 6: 1974: Government Printing Office, Washington D.C. 1978 


\section{Materiały statystyczne}

Foreign Investments in the United States. Department of Commerce and Department of Treasury

Estimates, ed. M. Wilkins, Arno Press, New York 1977

Historical Statistics of the United States, vol. 1: Governance and International Relations,

Cambridge University Press, New York 2006

Monthly Bulletin of Statistics, October 1969-1974, United Nations, New York 1969-1974

US Direct Investment Abroad, 1966. Final Data, U.S. Department of Commerce, U.S. Government

Printing Office, Washington 1967

Yearbook of International Trade Statistics, 1969-1974, United Nations, New York 1971-1975

\section{Wspomnienia i prace polityków}

B a 11 G. W., Diplomacy for the Crowded World. An American Foreign Policy, Little, Brown \& Company, Boston 1976

B a 11 G. W., The Past Has Another Pattern. Memoirs, Norton \& Company, New York 1982

B e rgsten C. F., Toward a New International Economic Order: Selected Papers of C. Fred Bergsten, 1972-1974, Lexington Books, Lexington 1975

B e r g s t e n C. F., The New Economics and US Foreign Policy, Brooking Institution, Washington 1972

B e r g s t e n C. F., U.S. Trade Policy: Revolutions of a Decade, [w:] Foreign Affairs in the Seventies.

A Symposium of Young Professionals in Foreign Affairs: 1971, ed. C. F. Bergsten, The Fletcher

School of Law and Diplomacy, Medford 1971

B e rgste n C. F., International Monetary Reform and U.S. Balance of Payments, [w:] U.S. Foreign Economic Policy for the 1970s: A New Approach to New Realities. A Policy Report by A National Planning Association Advisory Committee, National Planning Association, Washington 1971

Fr i e d m a n M., F r i e d m a n R. D., Two Lucky People. Memoirs, University of Chicago Press, Chicago 1998

J o b e r t M., Mémoires d'avenir, Grasset, Paris 1974

K i s s i n g e r H., Central Issues of American Foreign Policy, [w:] American Foreign Policy: Three Essays, W.W. Norton \& Company, New York 1969

K i s s i n ge r H., Dyplomacja, Philip Wilson, Warszawa 2002

K i s s in g e r H., Kryzys. Anatomia dwóch kryzysów: Wojna Jom Kippur (1973) i wycofanie się USA z Wietnamu (1975). Kulisy dyplomacji, Wydawnictwo Dolnośląskie, Wrocław 2005

K is sing e r H., The Troubled Partnership: A Re-appraisal of the Atlantic Alliance, Anchor Books, New York 1966

K is s in ge r H., The Years of Upheaval, Little, Brown \& Company, Boston 1982

K i s s in g e r H., White House Years, Little, Brown \& Company, Boston 1979

N i x o n R., A Real War, Warner Books, New York 1980

N i x o n R., The Memoirs of Richard Nixon, Grosset and Dunlap, New York 1978

R a o u l - D u v a l M., Foreign Policy and the Bureaucracy, [w:] Portraits of American Presidents, vol. 6: The Nixon Presidency, ed. K. W. Thompson, Miller Center, University of Virginia, Lanham 1987

R u s h K., An Ambassador's Perspective, [w:] Portraits of American Presidents, vol. 6: The Nixon Presidency, ed. K. W. Thompson, Miller Center, University of Virginia, Lanham 1987

S h u lt z G., D a m K. W., Economic Policy Beyond the Headlines, University of Chicago Press, Chicago 1998 


\section{Opracowania}

A l d c r o f t D. H., The European Economy 1914-1990, Routledge, London 1993

B a k e r Fox A., Domestic Pressures in North America to Withdraw Forces from Europe, [w:] European Security and the Atlantic System, eds. W. T. R. Fox, W. R. Schilling, Columbia University Press, New York 1973

B a l a a m D. N., V e s e th M., Introduction to International Political Economy, Pearson Prentice Hall, New Jersey 2005

B a l d w in D. A., Economic Statecraft, Princeton University Press, Princeton 1985

B a l d w i n D. A., Neorealism and Neoliberalism: The Contemporary Debate, Columbia University Press, New York 1993

B a l d w i n D. A, K a y R. E., International Trade and International Relations, [w:] World Politics and International Economics, eds. C. F. Bergsten, L. B. Krause, Brookings Institution, Washington 1975

B a r a n P., The Political Economy of Growth, Monthly Review Press, New York 1957

$\mathrm{B}$ a r n e t R. J., The Alliance. America, Europe, Japan. Makers of the Postwar World, Simon and Schuster, New York 1983

B e h rman J. N., National Interests and the Multinational Enterprise. Tensions among the North Atlantic Countries, Prentice-Hall, Eaglewood Clifs 1970

B e 11 C., The Diplomacy of Detente. The Kissinger Era, St. Martin's Press, New York 1977

B e l o ff M., The United States and the Unity of Europe, Faber, London 1963

B ergste n C. F., Ko a h a n e R. O., Nye J. S., International Economics and International Politics. A Framework for Analysis, [w:] World Politics and International Economics, eds. C. F. Bergsten, L. B. Krause, Brookings Institution, Washington 1975

B e r s te in S., R i o u x J.-P., The Pompidou Years 1969-1974, Cambridge University Press, Cambridge 2000

Between Power and Plenty, ed. P. Katzenstein, University of Wisconsin Press, Madison 1978

B i ał e c ki K., D o r o s z A., J a n u s z ki e w i c z W., Słownik handlu zagranicznego, PWE, Warszawa 1986

B l o c k F. L., The Origins of International Economic Disorder, University of California Press, Berkeley 1977

Bógdał-Brzezińska A., Globalizacja polityki Stanów Zjednoczonych 1945-1949, Aspra-JR, Warszawa 2001

B r a d y L., The Politics of Negotiation: America's Dealings with Allies, Adversaries, and Friends, University of North Carolina Press, Chapel Hill 1991

B u n d y W., A Tangled Web. The Making of Foreign Policy in the Nixon Presidency, I. B. Tauris, London 1998

B urgess W. R., Huntley J. R., Europe and America. The Next Ten Years, Walker and Company, New York 1970

C a 11 e o D. P., American Foreign Policy and American European Studies: An Imperil Bias?, [w:] The United States and Western Europe. Political, Economic and Strategic Perspectives, ed. W. F. Hanrieder, Winthrop Publishers, Cambridge, Mass. 1974

C a ll e o D. P., The Atlantic Fantasy: The U.S., NATO, and Europe, The Johns Hopkins University Press, Baltimore 1970

C a ll e o D. P., The Imperious Economy, Harvard University Press, Cambridge, Mass. 1982

$\mathrm{C}$ a $1 \mathrm{l}$ e o D. P., NATO Costs and U.S. Economic Imbalances, [w:] Economic and Strategic Issues in U.S. Foreign Policy, ed. C. L. Holtfrerich, W. de Gruyter, New York 1989

C all e o D. P., Since 1961. American Power in a New World Economy, [w:] Economics and the World Power. An Assessment of American Diplomacy since 1789, eds. W. H. Becker, S. F. Wells, Jr, Columbia University Press, New York 1984 
C a m p b ell J., Edward Heath. A Biography, Jonathan Cape, London 1993

C ar m oy G. de, The Energy Crisis, [w:] The New Europe and the United States. Partners or Rivals, ed. G. Mally, Lexington Books, Lexington 1974

C h o d u b s k i A. J., Wstęp do badań politologicznych, Wydawnictwo Uniwersytetu Gdańskiego, Gdańsk 2006

C o h e n B., The Revolution in Atlantic Economic Relations. The Bargain Comes Unstuck, [w:] The United States and Western Europe. Political, Economic and Strategic Perspectives, ed. W. F. Hanrieder, Winthrop Publishers, Cambridge, Mass. 1974

$\mathrm{C}$ o he $\mathrm{n}$ S. D., The European Community and the General Agreement on Tariffs and Trade, European Commision Information Service, Washington 1975

C o h e n S. D., The Making of United States International Economic Policy. Principles, Problems, and Proposals for Reform, Praeger Publishers, Westport 2000

$\mathrm{C}$ o o p e r R., The Economics of Interdependence: Economic Policy in the Atlantic Community, McGraw Hill, New York 1968

C o x R., Production, Power, and World Order: Social Forces in the Making of History, Columbia University Press, New York 1987

C r i t c h l o w D. T., Lata Nixona, Forda i Cartera: 1968-1980, [w:] Historia Stanów Zjednoczonych Ameryki, red. A. Bartnicki, D. T. Critchlow, t. 5: 1945-1990, PWN, Warszawa 1995

C z a p u to w i c z J., Teorie stosunków międzynarodowych. Krytyka i systematyzacja, PWN, Warszawa 2008

C z i o m e r E., Zarys historii Niemiec powojennych 1945-1995, PWN, Warszawa 1997

D a 1 l e k R., Nixon and Kissinger. Partners in Power, HarperCollins Publishers, New York 2007

D e l P e r o M., Eccentric Realist: Henry Kissinger and the Shaping of American Foreign Policy, Cornell University Press, Ithaca 2009

D e P o r te A. W., Europe Between the Superpowers. The Enduring Balance, Yale University Press, New Haven 1979

Détente and Defense. A Reader, ed. R. J. Pranger, American Enterprise Institute for Public Policy Research, Washington 1976

D e V ri e s M., H o r s e f i el d J., The International Monetary Fund, 1966-1971: The System Under Stress, International Monetary Fund, Washington 1976

D i c k s o n P., Kissinger and the Meaning of History, Cambridge University Press, Cambridge 1978

D o b s o n A. P., Anglo-American Relations in the Twentieth Century. Of Friendship, Conflict and the Rise and Decline of Superpowers, Routledge, London 1995

D o b s o n A. P., M a r s h S., U.S. Foreign Policy since 1945, Routledge, London 2000

D o u g h e rty J. E., The Soviet Strategy of Finlandization of Western Europe - the External Process, [w:] Atlantic Community in Crisis. A Redefinition of the Transatlantic Relationship, eds. W. F. Hahn, R. L. Pfaltzgraff, Jr, Pergamon Press, New York 1979

D u ig n a n P., Gann L. H., The United States and the New Europe 1945-1993, Blackwell, Oxford 1994

D ü r A., Protection for Exporters: Power and Discrimination in Transatlantic Relations, 19302010, Cornell University Press, Ithaca 2010

Economic Relations with the USSR. Issues for the Western Alliance, ed. A. S. Becker, Lexington Books, Lexington 1983

Economics and the World Power. An Assessment of American Diplomacy since 1789, eds. W. H. Becker, S. F. Wells, Jr, Columbia University Press, New York 1984

Europe, America and the World Economy, ed. L. Tsoukalis, Basil Blackwell, New York 1986

E v a n s D., The Politics of Trade. The Evolution of the Superbloc, Macmillan, London 1974

Fre y B. S., The Public Choice View of International Political Economy, [w:] Key Concepts in International Political Economy, ed. D. A. Baldwin, vol. 1, Edward Elgar Publishing, Vermont 1993 
F u n i g i ell o P. J., American-Soviet Trade in the Cold War, The University of North Carolina Press, Chapel Hill 1988

G a d d i s J. L., Zimna wojna. Historia podzielonego świata, Znak, Kraków 2007

G a r r i s o n J. A., Games Advisors Play. Foreign Policy in the Nixon and Carter Administrations, Texas A \& M University Press, College Station 1999

G e i g e r T., Toward a World of Trade Blocks, [w:] U.S. Foreign Economic Policy for the 1970s: A New Approach to New Realities. A Policy Report by An National Planning Association Advisory Committee, National Planning Association, Washington 1971

G i a u q u e J. G., Grand Designs and Visions of Unity, University of North Carolina Press, Chapel Hill 2002

Gilp in R., Global Political Economy: Understanding the International Economic Order, Princeton University Press, Princeton 2001

Gilp in R., The Political Economy of International Relations, Princeton University Press, Princeton 1987

G i l p i n R., Three Models of the Future, [w:] Key Concepts in International Political Economy, ed.

D. A. Baldwin, vol. 1, Edward Elgar Publishing, Vermont 1993

G il p i n R., U.S. Power and the Multinational Corporation. The Political Economy of Foreign Direct Investment, Basic Books, New York 1975

G i o l it t i A., Politics and the Money System, [w:] Transatlantic Crisis. Europe and America in the 1970s, ed. J. Godson, Alcove Press, London 1974

G ł u c h o w s k i J., Międzynarodowe stosunki finansowe, PWE, Warszawa 1997

$\mathrm{G}$ o o d m a n E. R., The Fate of the Atlantic Community, Praeger Publishers, New York 1975

$\mathrm{G}$ o o d m a n E. R., The Impact of the Multinational Enterprise upon Atlantic Community, [w:] The New Europe and the United States. Partners or Rivals, ed. G. Mally, Lexington Books, Lexington 1974

G r i e c o J. M., Cooperation among Nations. Europe, America, and Non-Tariff Barriers to Trade, Cornell University Press, Ithaca 1990

Griffiths M., O'Callaghan T., International Relations. The Key Concepts, Routledge, London 2001

Gros s e r A., Les Occidentaux. Les pays d'Europe et les États-Unis depuis la guerre, Fayard, Paris 1978

G r y z J., Proces instytucjonalizacji stosunków transatlantyckich, SCHOLAR, Warszawa 2004

$\mathrm{H}$ a a s E. B., The Uniting Europe, Stanford University Press, Stanford 1958

Haliżak E., Międzynarodowe stosunki ekonomiczne, [w:] Stosunki międzynarodowe. Geneza, struktura, dynamika, red. E. Haliżak, R. Kuźniar, Wydawnictwo Uniwersytetu Warszawskiego, Warszawa 2006

$\mathrm{H}$ a l i ż a k E., Ujęcie roli państwa w ekonomii politycznej stosunków międzynarodowych, [w:] Państwo w teorii i praktyce stosunków międzynarodowych, red. M. Sułek, J. Symonides, Wydawnictwo Uniwersytetu Warszawskiego, Warszawa 2009

Hali żak E., Współzależność polityki i ekonomii w stosunkach międzynarodowych, [w:] Stosunki międzynarodowe w XXI wieku. Księga jubileuszowa z okazji 30-lecia Instytutu Stosunków Międzynarodowych Uniwersytetu Warszawskiego, red. E. Haliżak i in., SCHOLAR, Warszawa 2006

$\mathrm{H}$ a $\mathrm{m}$ m o n d P. Y., Changing Bargaining Relations in the Atlantic Alliance, [w:] The United States and Western Europe. Political, Economic and Strategic Perspectives, ed. W. F. Hanrieder, Winthrop Publishers, Cambridge, Mass. 1974

$\mathrm{H}$ a r p e r J. L., American Visions of Europe. Franklin D. Roosevelt, George F. Kennan and Dean G. Acheson, Cambridge University Press, Cambridge 1994

$\mathrm{H}$ a r t s h or n J. E., Too Much Independence in Atlantic Oil Bargaining, [w:] Transatlantic Crisis. Europe and America in the 1970s, ed. J. Godson, Alcove Press, London 1974 
H e r s h S. M., The Price of Power. Kissinger in the Nixon White House, Simon \& Schuster, New York 1984

H i r s c h m a n A., National Power and the Structure of Foreign Trade, University of California Press, Berkeley 1945

History of the U.S. Economy since World War II, eds. H. G. Vatter, J. F. Walker, M. E. Shape, New York 1996

H o ga n M., The Marshall Plan. America, Britain, and the Reconstruction of Western Europe, 1947-1952, Cambridge University Press, Cambridge 1989

H o l z m a n F. D., L e g v o l d R., The Economics and Politics of East-West Relations, [w:] World Politics and International Economics, ed. C. F. Bergsten, L. B. Krause, Brookings Institution, Washington 1975

$\mathrm{H}$ u $\mathrm{n}$ t e r R. E., Beyond Military Security in Europe, [w:] The United States and Western Europe, ed. W. Hanrieder, Cambridge University Press, Cambridge 1974

$\mathrm{H}$ u n te r R. E., U.S. Defense Commitments in Europe and Asia During the 1970s: Military and Political Factors in Economic Policy, [w:] U.S. Foreign Economic Policy for the 1970s: A New Approach to New Realities. A Policy Report by National Planning Association Advisory Committee, National Planning Association, Washington 1971

International Economic Relations of the Western World, 1959-1971, ed. A. Shonfield, vol. 1: Politics and Trade, Oxford University Press, London 1976

International Relations Theory, eds. P. Viotti, M. Kauppi, Macmillan, Pearson Education, New York 1997

J o n a s M., The US and Germany. A Diplomatic History, Cornell University Press, London 1985

Josling T., Agricultural Policies and World Trade, [w:] Europe, America and the World Economy, ed. L. Tsoukalis, Basil Blackwell, New York 1986

Ka pla n E. S., American Trade Policy 1923-1995, Greenwood Publishing Group, London 1996

K a p l a n L. S., NATO Divided, NATO United. The Evolution of an Alliance, Praeger Publishers, Westport 2004

$\mathrm{K}$ a $\mathrm{p} \mathrm{l}$ a $\mathrm{L}$ L. S., NATO and the United States. The Enduring Alliance, Twayne Publishers, New York 1994

Ke m p T., The Climax of Capitalism. The U.S. Economy in the Twentieth Century, Longman, New York 1990

Ke $\mathrm{n} n$ e d y P. M., The Rise and Fall of the Great Powers: Economic Change and Military Conflict from 1500 to 2000, Random House, London 1987

Ke o h a n e R., After Hegemony: Cooperation and Discord in International Political Economy, Princeton University Press, Princeton 1984

K e o h a n e R., N y e J., Power and Interdependence. World Politics in Transition, Little, Brown \& Company, Boston 1977

$\mathrm{Ke}$ o h a n e R., Va n D o o n 0 o m s, The Multinational Firm and International Regulations, [w:] World Politics and International Economics, ed. C. F. Bergsten, L. B. Krause, Brookings Institution, Washington 1975

Kind leberger Ch., Foreign Trade and National Economy, Yale University Press, New Haven 1962

K i n d l e b e r g e r Ch., Manias, Panics, and Crashes. A History of Financial Crisises, Basic Books, New York 1978

K i w e r s k a J., Gra o Europę. Bezpieczeństwo europejskie w polityce Stanów Zjednoczonych pod koniec XX wieku, Instytut Zachodni, Poznań 2000

Kn o r r K., Economic Factors in Future Arrangements for European Security, [w:] European Security and the Atlantic System, eds. W. T. R. Fox, W. R. Schilling, Columbia University Press, New York 1973 
K n o r r K., The Power of Nations. The Political Economy of International Relations, Basic Books, New York 1975

Kr a s n e r S., American Policy and Global Economic Stability, [w:] America in the Changing World Political Economy, eds. W. Avevy, D. Rapkin, Longman, New York 1982

$\mathrm{K} r$ a s $\mathrm{n}$ e r S., Defending the National Interest: Raw Materials, Investment and American Foreign Policy, Princeton University Press, Princeton 1978

Krasner S., Regimes and the Limits of Realism: Regimes as Autonomous Variables, [w:] International Regimes, ed. S. Krasner, Cornell University Press, Ithaca 1983

Kras u ski J., Historia polityczna Europy Zachodniej 1945-2002, Wydawnictwo Kurpisz, Poznań 2003

L a F e b e r W., America, Russia, and the Cold War 1945-1992, McGraw Hill, New York 1992

L a n d a u Z., Zwiqzzki gospodarki z polityką, [w:] Nauki ekonomiczno-społeczne i rozwój, red. K. Żukrowska, Szkoła Główna Handlowa w Warszawie - Oficyna Wydawnicza, Warszawa 2008

Lang W. J., U.S. Export Conrol Policy. Executive Autonomy versus Congressional Reform, Columbia University Press, New York 1989

Leading Issues in International Economic Policy, eds. C. F. Bergsten, W. G. Tyler, Lexington Books, Lexington 1973

L e e D., Endgame at the Kennedy Round: A Case Study of Multilateral Economic Diplomacy, [w:] Diplomacy, vol. 3, eds. C. Jönsson, R. Langhorne, Sage Library of International Relations, London 2005

L e vy W. J., An Atlantic-Japanese Energy Policy, [w:] The New Europe and the United States. Partners or Rivals, ed. G. Mally, Lexington Books, Lexington 1974

$\mathrm{L}$ i e b l e r G i b s o n M., Conflict and Consensus in American Trade Policy, Georgetown University Press, Washington 2000

L i v ing s t o n R. G., A Washington Look at Europe, [w:] The United States and Western Europe. Political, Economic and Strategic Perspectives, ed. W. F. Hanrieder, Winthrop Publishers, Cambridge, Mass. 1974

L u n d e s t a d G., "Empire" by Integration. The United States and European Integration, 19451997, Oxford University Press, New York 1998

L u n d e s t a d G., The United States and Western Europe since 1945. From "Empire" by Invitation to Transatlantic Drift, Oxford University Press, Oxford 2003

Ł u k a s z e w s ki J., Cel: Europa. Dziewięć esejów o budowniczych jedności europejskiej, Noir sur Blanc, Warszawa 2002

M a h a n E. R., Kennedy, de Gaulle, and Western Europe, Palgrave Macmillan, Gordonsville 2003

M ally G., Pan-European Relationship and the United States, [w:] The New Europe and the United States Partners or Rivals, ed. G. Mally, Lexington Books, Lexington 1974

M a ni a A., Bridge Building. Polityka USA wobec Europy Wschodniej w latach 1961-1968, Wydawnictwo Uniwersytetu Jagiellońskiego, Kraków 1996

M a n i a A., Détente i polityka Stanów Zjednoczonych wobec Europy Wschodniej styczeń 1969 styczeń 1981, Wydawnictwo Uniwersytetu Jagiellońskiego, Kraków 2003

M a n i a A., The National Security Council i amerykańska polityka wobec Europy ŚrodkowoWschodniej w latach 1945-1960, Wydawnictwo Uniwersytetu Jagiellońskiego, Kraków 1994

M a n s f i e l d E. D., Quantitative Approaches to the International Political Economy, [w:] Cases, Numbers, Models: International Relations Research Methods, eds. D. F. Sprinz, Y. Wolinsky, University of Michigan Press, Ann Arbor 2004

M a te ra P., Francja w polityce zagranicznej Stanów Zjednoczonych w latach 1929-1933, Wydawnictwo Adam Marszałek, Toruń 2003 
M a t e r a P., The Attitude of the United States towards the Membership of Great Britain in the European Economic Community, [w:] 4'E's: Economic Development, Environment, Energy and Ethics, in a Global Economy, eds. D. Frear, W. Taylor, Congress of Political Economists, International, USA 2007

$\mathrm{M}$ a t e r a P., The Impact of Economic Issues on American Policy toward Western Europe during Richard Nixon's Presidency, [w:] U.S. Foreign Policy. Theory, Mechanisms, Practice, ed. A. Mania, P. Laidler, Ł. Wordliczek, Wydawnictwo Uniwersytetu Jagiellońskiego, Kraków 2007

M a te r a P., Wpływ „szoku Nixona” na relacje transatlantyckie, [w:] Rosja, Unia Europejska, Stany Zjednoczone - współpraca czy konfrontacja?, Wydawnictwo Wyższej Szkoły Handlowej im. Króla Stefana Batorego, Piotrków Trybunalski 2009

M a t e r a P., M a t e r a R., Stany Zjednoczone i Europa. Stosunki polityczne i gospodarcze. 17762004, Książka i Wiedza, Warszawa 2007

M a t e r a R., G8 jako instytucja gospodarki światowej, Wydawnictwo Uniwersytetu Łódzkiego, Łódź 2009

M e i e r G. M., International Economics. The Theory of Policy, Oxford University Press, New York 1980

M i c h a ł e k K., Amerykańskie stulecie. Historia Stanów Zjednoczonych Ameryki 1900-2001, Mada, Warszawa 2004

Miln e r H., The Analysis of International Relations: International Political Economy and Formal Models of Political Economy, [w:] Cases, Numbers, Models: International Relations Research Methods, eds. D. F. Sprinz, Y. Wolinsky, University of Michigan Press, Ann Arbor 2004

M in t z A., The Method-of Analysis - A Problem in International Relations, [w:] New Directions for International Relations. Confronting the Method-of Analysis Problem, eds. A. Mintz, B. Russet, Lexington Books, Lanham 2005

M i t r a ny D., A Working Peace System, Quadrangle, Chicago 1943

M o n y e S. O., The International Business Blueprint, Willey-Blackwell, Oxford 1977

M or g e $\mathrm{nth}$ a u H. J., The United States and Europe in a Decade of Détente, [w:] The United States and Western Europe, ed. W. Hanrieder, Cambridge University Press, Cambridge, Mass. 1974

M o r r i s R., Uncertain Greatness: Henry Kissinger and American Foreign Policy, Harper \& Row, New York 1977

Morse E. L., European Monetary Union and American Foreign Economic Policy, [w:] The United States and Western Europe. Political, Economic and Strategic Perspectives, ed. W. F. Hanrieder, Winthrop Publishers, Cambridge, Mass. 1974

M ö c kl i D., European Foreign Policy during the Cold War: Heath, Brandt, Pompidou and the Dream of Political Unity, Tauris, London 2008

$\mathrm{N}$ a th a n J. A., 0 l i ve r J. K., United States Foreign Policy and World Order, Little, Brown \& Company, Boston 1985

$\mathrm{N}$ el s o n K. L., The Making of Détente. Soviet-American Relations in the Shadow of Vietnam, Johns Hopkins University Press, Baltimore 1995

The New Europe and the United States. Partners or Rivals, red. G. Mally, Lexington Books, Lexington 1974

N utter G. W., Kissinger's Grand Design, American Enterprise Institute for Public Policy Research, Washington 1975

N y e J., Bound to Lead: The Changing Nature of American Power, Basic Books, New York 1990

O dell J. S., Case Study Methods in International Political Economy, [w:] Cases, Numbers, Models: International Relations Research Methods, eds. D. F. Sprinz, Y. Wolinsky, University of Michigan Press, Ann Arbor 2004 
P a s t o r R. A., Congress and the Politics of U.S. Foreign Economic Policy (1929-1976), University of California Press, Berkeley 1980

P el k m a n s J., The Bickering Bigemony: GATT, [w:] Europe, America and the World Economy, ed. L. Tsoukalis, Basil Blackwell, New York 1986

P e r l o V., Unstable Economy: Booms and Recessions in the United States since 1945, Lawrence and Wishart, London 1973

P e tr a s J., Critical Perspectives on Imperialism and Social Class in the Third World, Monthly Review Press, New York 1978

P f a l t z g r a f f R. L., The Atlantic Community - A Conceptual History, [w:] Atlantic Community in Crisis. A Redefinition of the Transatlantic Relationship, eds. W. F. Hahn, R. L. Pfaltzgraff, Pergamon Press, New York 1979

$\mathrm{P} f \mathrm{a} l \mathrm{t} \mathrm{z} \mathrm{g} \mathrm{r}$ a f $\mathrm{f}$ R. L., Energy Issues and Alliance Relationship. The United States, Western Europe and Japan, Institute for Foreign Policy Analysis, Cambridge, Mass. 1980

Policy Aspects of Foreign Investment by US Multinational Corporations, [w:] The Multinational Corporation. Studies on US Foreign Investment, vol. 1, US Department of Commerce, Washington 1972

Portraits of American Presidents, vol. 6: The Nixon Presidency, ed. K. W. Thompson, Miller Center, University of Virginia, Lanham 1987

Pr e s t o n Ch., Enlargement \& Integration in the European Union, Routledge, London 1997

Rational Choice, ed. J. Elster, New York University Press, New York 1986

Rational Choice Theory: Advocacy and Critique, eds. J. Coleman, T. Fararo, Sage Publications, Newbury Park 1992

$\mathrm{R}$ a v e $\mathrm{n}$ a l E. C., Large-Scale Foreign Policy Change: The Nixon Doctrine as History and Portent, Institute of International Studies, University of California, Berkeley 1989

R i c h G., Emerging U.S. Trade Patterns with Western European Countries, [w:] U.S. Trade in the Sixties and Seventies. Continuity and Change, eds. K. Jameson, R. Skurski, Lexington Books, Lexington 1974

R o s a t i J., The Politics of US Foreign Policy, Harcourt Brace Jovanovich, Fort Worth 1993

Russett B., Four Methods and Five Revolutions, [w:] New Directions for International Relations. Confronting the Method-of Analysis Problem, eds. A. Mintz, B. Russet, Lexington Books, Lanham 2005

R u s z k o w s k i J., G ó r n i c z E., Ż u r e k M., Leksykon integracji europejskiej, PWN, Warszawa 1998

S a r M., Polityka Stanów Zjednoczonych wobec procesów integracyjnych Europy Zachodniej w latach 1947-1963, Wydawnictwo Uniwersytetu Warszawskiego, Warszawa 1981

S c a m m e ll W. M., The International Economy since 1945, St. Martin's Press, New York 1980

$\mathrm{S} \mathrm{ch}$ a e ff e r R. K., Understanding Globalization: the Social Consequences of Political, Economic, and Environmental Change, Rowman \& Littlefield Publishers, Lanham 1997

Schilling W. R., American Arms and a Changing Europe: Dilemmas of Deterrence and Disarmament, Columbia University Press, New York 1973

$\mathrm{S}$ e r v a $\mathrm{n}-\mathrm{S} \mathrm{c}$ h r e i b e r J.-J., American Challenge. The Impact of American Industry and Culture on Europe and the World, Hamish Hamilton, New York 1968

$\mathrm{S}$ h o $\mathrm{n}$ f i e l d A., International Economic Relations. The Western System in the 1960s and 1970s, Sage Publications, Beverlyhills-London 1976

S k o d la r s k i J., M a te r a R., Gospodarka światowa. Geneza i rozwój, PWN, Warszawa 2005

S k u r s k i R., Trade with the Soviet Union and Eastern Europe, [w:] U.S. Trade in the Sixties and Seventies. Continuity and Change, eds. K. Jameson, R. Skurski, Lexington Books, Lexington 1974

S l o a n S. R., NATO, the European Union, and the Atlantic Community: the Transatlantic Bargain Challenged, Rowman \& Littlefield, Lanham 2005 
S l o a n S. R., United States-German Relations: A Contemporary Perspective, [w:] United StatesGerman Relations. Past and Present, Library of Congress, Washington 1984

$\mathrm{S} \mathrm{mith}$ M., Western Europe and the United States. The Uncertain Alliance, Unwin Hyman, London 1984

S o d o r o M. J., US-Soviet Relations: Detente or Cold War, [w:] Economic Relations with the Soviet Union. American and West German Perspective, ed. A. E. Stent, Westview Press, Boulder 1989

S p e r o J. E., The Politics of International Economic Relations, St. Martin's Press, New York 1999

$\mathrm{S}$ t a $\mathrm{s} \mathrm{z} \mathrm{z}$ a k D. E., USA-UE. Wzajemne stosunki na tle zmian globalnych, Wydawnictwo Adam Marszałek, Toruń 1998

The State and American Foreign Economic Policy, eds. G. J. Ikeberry, D. A. Lake, M. Mastanduno, Cornell University Press, Ithaca 1988

S te a n s J., Gender and International Relations: Issues, Debates and Future Directions, Polity Press, Cambridge 2006

$\mathrm{S}$ t e $\mathrm{n} \mathrm{n}$ i s J. C., F u l b r i g h t J. W., The Role of Congress in Foreign Policy, American Enterprise Institute for Public Policy, Washington 1971

Stern P., Water's Edge. Domestic Politics and the Making of American Foreign Policy, Greenwood Press, Westport 1979

S tr a n g e S., Casino Capitalism, Blackwell Publishers, Oxford 1986

$\mathrm{S}$ tra n g e S., International Economics and International Relations. A Case of Mutual Neglect, [w:] Key Concepts in International Political Economy, ed. D A. Baldwin, vol.1, Redward Elgar Publishing, Vermont 1993

S t r a n g e S., Mad Money, Manchester University Press, Manchester 1998

S t r a n g e S., The Retreat of the State: The Diffusion of Power in the World Economy, Cambridge University Press, Cambridge 1996

$\mathrm{S}$ t $\mathrm{r}$ a $\mathrm{n}$ g e S., States and Markets. An Introduction to the International Political Economy, Basil Blackwell, New York 1988

Stre it C. K., Union Now. A Proposal for a Federal Union of the Democracies of the North Atlantic, Harper \& Brothers Publishers, New York 1939

$\mathrm{S}$ z u lc T., The Illusion of Peace. Foreign Policy in the Nixon Years, The Viking Press, New York 1978

Ś w i e r k o c k i J., Zarys międzynarodowych stosunków gospodarczych, PWE, Warszawa 2004

The Theoretical Evolution of International Political Economy: A Reader, eds. G. T. Crane, A. Amawi, Oxford University Press, Oxford 1997

Th yg e s e n N., Flexible Exchange Rates and the Monetary Policies, [w:] Europe, America and the World Economy, ed. L. Tsoukalis, Basil Blackwell, New York 1986

T in d all G. B., S h i D. E., Historia Stanów Zjednoczonych, Zysk i S-ka, Poznań 2002

To o z e R., Perspectives and Theory: A Consumer's Guide, [w:] Key Concepts in International Political Economy, ed. D .A. Baldwin, vol. 1, Edward Elgar Publishing, Vermont 1993

T r a c h t e n b e r g M., A Constructed Peace. The Making of the European Settlement 1945-1963, Princeton University Press, New Jersey 1999

Transnational Relations and the World Politics, eds. R. Keohane, J. Nye, Jr, Harvard University Press, Boston 1972

Tre ve r to n G. F., The Dollar Drain and American Forces in Germany. Managing the Political Economics of Alliance, Ohio University Press, Athens 1978

Tr e ver t o n G. F., Making the Alliance Work. The United States and Western Europe, Cornell University Press, Ithaca 1985

The United States and Western Europe. Political, Economic and Strategic Perspectives, ed. W. F. Hanrieder, Winthrop Publishers, Cambridge, Mass. 1974 
Vernon R., The Economic and Political Consequences of Multinational Enterprise: An Anthology, Harvard University Press, Boston 1972

V e r n o n R., Sovereignty-at-bay: the Multinational Spread of U.S. Enterprises, Basic Books, New York 1971

Walke r D. A., Some Underlying Problems for International Monetary Reform, [w:] The United States and Western Europe. Political, Economic and Strategic Perspectives, ed. W. F. Hanrieder, Winthrop Publishers, Cambridge, Mass.1974

W a $1 \mathrm{l}$ e r s t e i n I., The Modern World System: Capitalist Agriculture and the Origins of European World Economy in the Sixteenth Century, Academic Press, New York 1974

W a l t z K., Theory of International Politics, McGraw-Hill, New York 1979

W a n d y c z P. S., The United States and Poland, Harvard University Press, Boston 1980

W a r d S., Kennedy, Britain, and the European Community, [w:] John F. Kennedy and Europe, eds. D. Brinkley, R. T. Griffiths, Luisiana State University Press, Baton Rouge 1999

W e n d t A., Social Theory of International Relations, Cambrigde University Press, Cambridge 1999

W ill i a m s o n J., The Failure of World Monetary Reform 1971-1974, New York University Press, New York 1977

W in a n d P., Eisenhower, Kennedy, and the United States of Europe, Macmillan, Houndmills 1993

W in i d B. W., Rozszerzenie NATO w Kongresie Stanów Zjednoczonych 1993-1998, Ośrodek Studiów Amerykańskich Uniwersytetu Warszawskiego, Warszawa 1999

W o $\mathrm{l} f \mathrm{f} s$ o h n M., West-Germany's Foreign Policy in the Era of Brandt and Schmidt, 1969-1982. An Introduction, Verlag Peter Lang, New York 1986

Wo o d s N., Międzynarodowa ekonomia polityczna $w$ dobie globalizacji, [w:] Globalizacja polityki światowej. Wprowadzenie do stosunków międzynarodowych, red. J. Baylis, S. Smith, Wydawnictwo Uniwersytetu Jagiellońskiego, Kraków 2009

Współczesna gospodarka światowa, red. A. Kisiel-Łowczyc, Wydawnictwo Uniwersytetu Gdańskiego, Gdańsk 1999

Z i m m e rman n H., Money and Security: Troops, Monetary Policy and West Germany's Relations with the United States and Britain, 1950-1971, Cambridge University Press, Cambridge 2002

\section{Artykuły naukowe}

A c h e s o n D., The Eclipse of the State Department, „Foreign Affairs”, July 1971

Baldwin D., International Political Economy and International Monetary System, „International Organization”, Autumn 1980

B a 11 G. W., Slogans and Realities, „Foreign Affairs”, July 1969

B e r g s t e n C. F., Crisis in U.S. Trade Policy, „Foreign Affairs”, July 1971

$\mathrm{B}$ e r g s t e n C. F., Interdependence and the Reform of International Institutions, „International Organization", Spring 1976

B e r g s te n C. F., K e o h a n e R., N y e J., International Economics and International Politics: A Framework for Analysis, „International Organization”, Winter 1975

B o s s u t G., Europe and United States, 1944-2006: Two Destinies in an Uncertain World, Institute of European Studies (University of California, Berkeley), Year 2006, Paper 060530, dostępny przez: eScholarship Repository, University of California, http:// repositories.cdlib.org/ies/060530 
B o w i e R., Tensions within the Alliance, „Foreign Affairs”, July 1963

B r a n d t W., Germany's “Westpolitik”, „Foreign Affairs”, April 1972

B r u s h S. N., Implementation of Export Administration Act of 1969, dostępny przez: http:// hein online.org/HOL/LandingPage?collection=journals \&handle=hein.journals / conlr4\&div=11\&id=\&page $=$

B r z e z i ń s k i Z., America and Europe, „Foreign Affairs”, October 1970

B r z e z i ń s k i Z., U.S. Foreign Policy. The Search for Focus, „Foreign Affairs”, July 1973

B u c h a i i A., Partners and Allies, „Foreign Affairs”, July 1963

C a p o r a s o J. A., Dependence, Dependency, and Power in the Global System: a Structural and Behavioral Analysis, „International Organization”, Winter 1978

C h a c e J., The Concert of Europe, „Foreign Affairs”, October 1973

Chavagne ux C., Economics and Politics: Some Bad Reasons for a Divorce, „Review of International Political Economy", Winter 2001

C o h e n B., The Political Economy of International Trade, „International Organization”, Spring 1990

C r o s s m a n R. H. S., British Labor Looks at Europe, „Foreign Affairs”, July 1963

D i e b o l d W., Jr, U.S. Trade Policy: the New Political Dimension, „Foreign Affairs”, April 1974

Gałga ne k A., Koncepcje hegemonii w nauce o stosunkach międzynarodowych, „Przegląd Politologiczny" 2006, nr 1

G e l b e r L., A Marriage of Inconvenience, „Foreign Affairs”, January 1963

Gilp in R., The Politics of Transnational Economic Relations, „International Organization”, Summer 1971

G o l d s b o r o u g h J. O., France, the European Crisis and the Alliance, „Foreign Affairs”, April 1974

G o l d s t e i n J., Ideas, Institutions, and American Trade Policy, „International Organization”, Winter 1988

G o u r e v it c h P., The Second Image Reversed: the International Sources of Domestic Politics, „International Organization”, Autumn 1978

$\mathrm{H}$ e a th E., Realism in British Foreign Policy, „Foreign Affairs”, October 1969

H o g a n M. J., Blueprint for Recovery, „American Studies Journal”, Summer 1998

H a n h i m a k i J. M., "They Can Write it in Swahili”: Kissinger, The Soviets, and the Helsinki Accords, 1973-1975, ,Journal of Transatlantic Studies” 2003, No. 1

$\mathrm{H}$ o l z m a n F. D., L e g v o l d R., The Economics and Politics of East-WestRelations, „International Organization", Winter 1975

I ke n s o n D., Ending the "Chicken War”. The Case for Abolishing the 25 Percent Truck Tariff, dostępny przez: http://www.cato.org/pubs/tbp/tbp-017.pdf

I ke n b e r ry G. J., L a ke D. A., M a s t a n d u n o M., Introduction: Approaches to Explaining American Foreign Economic Policy, „International Organization”, Winter 1988

J a v i t s J. K., The Congressional Presence in Foreign Relations, „Foreign Affairs”, January 1970

K a i s e r K., Europe and America: a Critical Phase, „Foreign Affairs”, July 1974

$\mathrm{K}$ a $\mathrm{z} \mathrm{z}$ e $\mathrm{s}$ t e i n P., International Relations and Domestic Structure: Foreign Economic Policies of Advanced Industrial States, „International Organization”, Winter 1976

$\mathrm{K}$ a t z e n st e in P., Ke o h a n e R., Kr a s n e r S., International Organization and the Study of World Politics, „International Organization”, Autumn 1998

Ke o h a n e R., International Institutions: Two Approaches, „International Studies Quarterly” 1988, No. 32

Ke ohane R., Van Do orn Ooms, The Multinational Enterprise and World Political Economy, „International Organization”, Winter 1975

Ko n op acki S., Funkcjonalistyczna teoria integracji politycznej D. Mitrany'ego, „Studia Europejskie" 1998, nr 2 
Krasner S., US Commercial and Monetary Policy: Unravelling the Paradox of External Strength and Internal Weakness, „International Organization”, Autumn 1977

Krause L., Nye J., Reflections on the Economics and Politics of International Economic Organizations, „International Organization”, Winter 1975

La ke D., The State and American Trade Strategy in the Pre-hegemonic Era, „International Organization", Winter 1988

L e v y W. J., World Oil Cooperation or International Chaos, „Foreign Affairs”, July 1974

Malmgren H. B., Coming Trade Wars? (Neo-Mercantilism and Foreign Policy), „Foreign Policy", Winter 1970-1971

Mast a nd un o M., Trade as the Strategic Weapon: American and Alliance Export Control Policy in the Early Postwar Period, „International Organization”, Winter 1988

M a te r a P., M a t e r a R., Stosunki transatlantyckie w szczytowym okresie zimnej wojny (19451956), „Studia Polityczne” 2004, nr 15

M a t e r a P., M a te r a R., USA - promotor integracji europejskiej, „Międzynarodowy Przegląd Polityczny" 2006, nr 4

Moravcsik A., Taking Preferences Seriously: A Liberal Theory of International Politics, „International Organization”, Autumn 1997

N ivola S., Commercializing Foreign Policy? American Trade Policy, Then and Now, „The Brookings Review", Spring 1997

N y e J., Multinational Corporations in World Politics, „Foreign Affairs”, October 1974

P al a n R., Susan Strange 1923-1998: A Great International Relations Theorist, „Review of International Political Economy", Summer 1999

R a y D. M., Corporations and American Foreign Relations, „The Annals of the American Academy of Political and Social Science", September 1972

S c h a e t z e l R., The Necessery Partnership, „Foreign Affairs”, April 1966

Shonfield A., The Economic Factor in International Relations, „International Affairs”, November 1970

Str a n g e S., International Economics and International Relations: A Case of Mutual Neglect, „International Affairs”, April 1970

Té t r e a u lt M., The Declining Hegemony Thesis, „Journal of Politics”, February 1987

T $r$ i f f i n R., The Thrust of History in International Monetary Reform, „Foreign Affairs”, April 1969

Ve s e th M., International Political Economy, artykuł z UNESCO International Encyclopedia

Project, 2004, dostępny przez: http://www.pugetsound.edu/x12490.xml

\section{Prasa z lat 1969-1974}

„Chicago Tribune”

„New York Times”

„The Wall Street Journal”

„Washington Post”

\section{Strony internetowe}

The American Presidency Project: http://www.presidency.ucsb.edu Archive of European Integration: http:// aei.pitt.edu 
Atlantic Council of the United States: http://www.acus.org

CATO Institute: http://www.cato.org

Departament Stanu USA: http:// www.state.gov

European Navigator: http://www.ena.lu

Foreign Relations of the United States (FRUS), 1961-1963, vol. 13: Western Europe and Canada: http://history.state.gov/historicaldocuments/frus1961-63v13

Foreign Relations of the United States (FRUS) 1969-1976: www.state.gov/r/pa/ho/-frus/ nixon

Fundacja Nixona: http://www.nixonfoundation.org

HeinOnline's Law Journal Library: http://heinonline.org

Heritage Foundation: http://www.heritage.org

Inflation Data: http://inflationdata.com

Internat Archive: http://www.archive.org

The Public Papers of the Presidents of the United States: John F. Kennedy, vol. 3: 1962: http:// www.presidency.ucsb.edu

The Public Papers of the Presidents of the United States: Richard Nixon: http://www. nixonfoundation.org

University of California: http://repositories.cdlib.org

University of Puget Sound: http://www.pugetsound.edu

World Gold Council: http://www.gold.org

World Trade Organization: http://www.wto.org

Yale Law School: http://avalon.law.yale.edu 



\section{WYKAZ SKRÓTÓW}

AFL-CIO American Federation of Labor and Congress of Industrial Organization (Amerykańska Federacja Pracy i Kongres Organizacji Przemysłu)

ASP American Selling Price (regulacja narzucająca stałe ceny na wybrane produkty przemysłu chemicznego)

BIZ bezpośrednie inwestycje zagraniczne

BOP balance of payments (bilans płatniczy)

CAP Common Agriculture Policy (wspólna polityka rolna)

CCEP The Cabinet Committee on Economic Policy (Komitet Gabinetowy do spraw Polityki Gospodarczej)

CIEP Council on International Economic Affairs (Rada ds. Międzynarodowych Stosunków Gospodarczych)

COCOM Coordinating Committee for Multilateral Export Controls (Komitet Koordynacyjny Wielostronnej Kontroli Eksportu)

DISC Domestic International Sales Corporation (program subsydiów eksportowych dla amerykańskich firm)

DM Deutsche Mark (marka niemiecka) EAG Energy Action Group (Grupa ds. Energii)

EAG Energy Action Group (Grupa ds. Energii)

ECG Energy Coordinating Group (Grupa Koordynacyjna ds. Energii)

EFTA European Free Trade Association (Europejskie Stowarzyszenie Wolnego Handlu)

EPSM ekonomia polityczna stosunków międzynarodowych

EURATOM Europejska Wspólnota Energii Atomowej

EWG Europejska Wspólnota Gospodarcza

EWWiS Europejska Wspólnota Węgla i Stali

FED Federal Reserve System (System Rezerwy Federalnej)

FRUS Foreign Relations of the United States (Relacje Zagraniczne Stanów Zjednoczonych)

G10 Group of Ten (Grupa Dziesięciu)

GATT General Agreement on Tariffs and Trade (Układ Ogólny w sprawie Ceł i Handlu)

GCCs International Political Economy of Global Commodity Chains (międzynarodowa polityka gospodarcza globalnych powiązań)

HAK Henry Alfred Kissinger

ICBM Intercontinental Ballistic Missiles (międzykontynentalne pociski balistyczne)

IEA International Energy Agency (Międzynarodowa Agencja Energetyczna)

IEP Integrated Emergency Program (Zintegrowany Program Kryzysowy)

IPE International Political Economy (międzynarodowa ekonomia polityczna)

IRBM Intermediate-Range Ballistic Missile (pociski balistyczne średniego zasięgu)

IT0 International Trade Organisation (Międzynarodowa Organizacja Handlu)

KBWE Konferencja Bezpieczeństwa i Współpracy w Europie

KNU klauzula najwyższego uprzywilejowania

LDC Less Developed Countries (kraje mniej rozwinięte)

MCG Ministerial Consultative Group (Ministerialna Grupa Konsultacyjna)

MFW Międzynarodowy Fundusz Walutowy 
MNCs multinational corporations (korporacje wielonarodowe)

MWS Modern World System (teoria nowoczesnego systemu światowego)

NARA National Archives and Record Administration (Archiwa Narodowe Stanów Zjednoczonych)

NATO North Atlantic Treaty Organization (Organizacja Paktu Północnoatlantyckiego)

NPMP Nixon Presidential Materials Project (zbiór materiałów z okresu prezydentury Nixona)

NPMS Nixon Presidential Materials Staff (zbiór materiałów z okresu prezydentury Nixona)

NSC National Security Council (Rada Bezpieczeństwa Narodowego)

NSDM National Security Decision Memorada (memoranda decyzyjne dotyczące bezpieczeństwa narodowego)

NSSM National Security Study Memoranda (memoranda robocze Rady Bezpieczeństwa Narodowego)

OECD Organization of Economic Cooperation and Development (Organizacja Współpracy Gospodarczej i Rozwoju)

OEEC Organization for European Economic Cooperation (Organizacja Europejskiej Współpracy Gospodarczej)

ONZ Organizacja Narodów Zjednoczonych

OPEC Organization of Petroleum Exporting Countries (Organizacja Krajów Eksportujących Ropę Naftową)

PKB produkt krajowy brutto

PPP The Public Papers of the Presidents of the United States (publiczne wystapienia prezydentów Stanów Zjednoczonych)

PUH preferencyjny układ handlowy

REDCOSTE Reduction the Costs in Europe (redukcja kosztów [obrony] w Europie)

RMWE Rada Ministrów Wspólnot Europejskich

SACEUR Supreme Allied Commander, Europe (dowódca sił NATO w Europie)

SALT Strategic Arms Limitation Talks (rozmowy w sprawie ograniczenia zbrojeń strategicznych)

SDR Special Drawing Rights (specjalne prawa ciągnienia)

SLBM Submarine-Launched Ballistic Missiles (pociski rakietowe wystrzeliwane z okrętów podwodnych)

STR Special Trade Representative (specjalny przedstawiciel handlowy)

UNCTAD United Nations Conference on Trade and Development (Konferencja Narodów Zjednoczonych ds. Handlu i Rozwoju)

USD United States Dollar (dolar amerykański)

WHCF White House Central Files (Centralne Archiwa Białego Domu) 


\section{WYKAZ TABEL I WYKRESÓW}

Tabela 1.1. Charakterystyka głównych perspektyw MEP ......................................................... 29

Wykres 2.1. Roczne stopy wzrostu PKB per capita wybranych krajów kapitalistycznych .......... 67

Tabela 2.1. Wartość handlu USA z wybranymi krajami w latach 1965-1969 ........................... 87

Wykres 2.2. BIZ Stanów Zjednoczonych w 1966 r. ....................................................................... 92

Tabela 3. 1. Międzynarodowe transakcje Stanów Zjednoczonych ................................................ 112

Tabela 3.2. Wartość wymiany handlowej wewnątrz EWG i EWG-USA ....................................... 114

Tabela 4.1. Bilans skutków rozszerzenia EWG dla amerykańskiego eksportu produktów nierolniczych ...................................................................................................... 139

Tabela 4.2. Bilans płatniczy Stanów Zjednoczonych w latach 1960-1971 _................................ 161

Tabela 4.3. Wydatki na obronę i potencjał militarny wybranych państw oraz ugrupowań w $1970 \mathrm{r}$............................................................................................................... 165

Wykres 5.1. BIZ wybranych krajów jako procent światowych BIZ .............................................. 206

Tabela 5.1. BIZ Stanów Zjednoczonych na świecie i w Europie Zachodniej .............................. 207

Tabela 5.2. BIZ w USA ........................................................................................................ 207

Tabela 5.3. Bilans wartości inwestycji zagranicznych dla wybranych krajów ............................. 208

Tabela 5.4. Eurodolary, rezerwy dolarowe i bilans płatniczy USA .............................................. 209

Wykres 5.2. Handel Stanów Zjednoczonych z Europą Wschodnią (bez ZSRR) ............................ 222

Tabela 5.5. Handel Stanów Zjednoczonych z ZSRR w latach 1963-1972 …............................... 222

Tabela 6.1. Wartość importu i eksportu EWG, EFTA i USA w latach 1962-1973 ..................... 227

Tabela 6.2. Wymiana z USA jako procent całości wymiany państw członkowskich EWG .......... 228

Tabela 6.3. Udział procentowy wymiany z Europą Zachodnią i ze Stanami Zjednoczonymi w rynkach krajów bloku wschodniego ..................................................................... 254

Tabela 6.4. Wartość handlu USA z wybranymi państwami w latach 1970-1974 ........................ 263

Tabela 7.1. Siły amerykańskie w Europie w latach 1950-1974 ................................................ 303

Tabela 7.2. Wydatki USA na cele militarne w Europie Zachodniej i ich pokrycie zgodnie z umowami offsetowymi z RFN w latach 1968-1974 …................................................. 306

Tabela 7.3. Inflacja $w$ wybranych krajach $w$ latach 1972-1974 ….......................................... 306 



\section{THE IMPACT OF ECONOMIC ISSUES ON THE UNITED STATES POLICY TOWARD WESTERN EUROPE DURING THE PRESIDENCY OF RICHARD M. NIXON (1969-1974)}

(Summary)

The objective of this dissertation is to analyze the changes in transatlantic relations in the 1970s. Up to that moment Western European countries, largely thanks to the assistance from the United States, had already managed to rebuild their economic strength after the damages of the Second World War. The European Economic Community became the strong competitor on the world market and aimed at more independent role in the world politics. It led to the serious divergences between the allies, but the interdependence in many fields forced the negotiations and settlements by compromise. However, it became obvious that the economic factor had gained a decisive impact on the formation of transatlantic relations in the era of erosion of American unlimited domination in the world economy.

The first chapter is theoretical and presents the development of the International Political Economy (IPE) as the sub-discipline of the international relations. It includes the basic definitions, theories and the scope of the research of the IPE. The second part constitutes the introduction to the main topic of the book. The most important aspects of the transatlantic relations from the end of the WWII until 1969 are discussed here. The main focus is on the political-economic issues which are also in attendance in the following chapters. These are European integration, the concepts of Atlantic partnership, the problem of burden-sharing and mutual economic relations.

The third chapter refers to the actions of the American diplomacy towards Western Europe at the beginning of Richard Nixon's first term of office. They are described in the context of the major changes in US foreign policy: the détente with the Soviet Union, the attempts to establish the diplomatic relations with China and the plans of ending the American engagement in the war in Vietnam. The economic problems of the United States and the Western world appeared to be vital for development of transatlantic relations. In this chapter the trade affairs, the attitude of the US towards the enlargement of the EEC, burden-sharing in NATO and the costs of deployment of American troops in Europe are also explored.

The major concept of the forth chapter is the crisis of the global monetary system and the American response to it - so called "Nixon shock". The American President decided to suspend the convertibility of dollar into gold and to impose the surcharge to import. This decision had a very negative influence on the transatlantic relations since it was made without any consultations with the allies and it was harmful for the political and economic situation in the Western European countries. The issue of the impact of the economic relations with the communist bloc on the alliance is also considered in this part.

The fifth chapter starts with the issue of "Smithsonian agreement". It was the beginning of the negotiations aiming at the reform of the world monetary system. The divergences between the European countries and the US on that matter were increasing. The former postulated discussing the monetary matters together with the question of trade liberalization and the latter wanted to deal with those two problems separately. The offset agreement on the compensation of the costs of stationing of the US troops in West Germany was linked with the Ostpolitik conducted by the Chancellor Willy Brandt. Americans were anxious about the independence of the GFR in the relations with the Eastern bloc as well as about its reluctance to accept the conditions of the offset. 
The next chapter is devoted to the US initiative of signing Atlantic Declaration - the agreement on the terms of closer cooperation and consultations in different fields between the US and Western Europe. Also, the reasons of announcing 1973 as the "Year of Europe" in American foreign policy are presented at this point. The author tried to prove the thesis that the main objective of American administration was to force Europeans to cooperate in the economic field.

The last part of the dissertation deals with the political and economic consequences of the energy crisis in 1973 caused by the Yom Kippur war. The differences in the interests of the US and the European countries led to pursuing of the discrepant policies towards the sides of the conflict and to the serious tensions in the Atlantic alliance. An attempt of signing an agreement was undertaken during the conference in Washington in February 1974. It ended up with the creation of the Energy Coordinating Group. However the mutual distrust contributed to the fiasco of the Atlantic Declaration initiative. Although the NATO Declaration was signed in June 1974, it did not meet the original American expectations as its rules were too broad.

In the end of Nixon's presidency the transatlantic relations aggravated. In the era of the recession in the world economy and the monetary and energy crises, the perspective of disintegration of the Atlantic alliance was particularly distressing.

The main conclusions of the dissertation are:

- The economic factor prevailed in the US-Western European relations during the presidency of Richard Nixon.

- Reestablished economic strength of Western Europe caused its more independent policy in economic and political fields which led to growing transatlantic divergences.

- The strong interdependence does not eliminate the conflicts, but often leads to the escalation of the divergences, however the close political relations might increase the tendency to compromise in economic field.

- The structures of the nation states in the international economic relations were still crucial, but the emerging role of the multinational corporations could already be noticed.

- It is impossible to apply one theory to analyze the US foreign policy due to the complex national interests and the changing international environment.

- The consideration of the mutual interactions and dependencies of foreign and domestic policies is indispensable.

- The foreign economic policy consists of interrelated economic and political factors. It is hard to establish a line between them as they are interdependent. 


\section{OD REDAKCJI}

Paulina Matera po ukończeniu w 1998 r. studiów na Wydziale Filozoficzno-Historycznym Uniwersytetu Łódzkiego uzyskała tytuł magistra historii. W 2002 r. Rada Wydziału FilozoficznoHistorycznego nadała jej stopień doktora nauk humanistycznych w zakresie historii. Od $2003 \mathrm{r}$. jest zatrudniona w Katedrze Studiów Transatlantyckich i Mediów Masowych na Wydziale Studiów Międzynarodowych i Politologicznych Uniwersytetu Łódzkiego.

Zainteresowania badawcze dr Matery to polityka zagraniczna Stanów Zjednoczonych, relacje transatlantyckie i historia USA. Jest autorką monografii Francja w polityce zagranicznej Stanów Zjednoczonych w latach 1929-1933 (Wydawnictwo Adam Marszałek, Toruń 2003) oraz współautorką (z Rafałem Materą) pracy Stany Zjednoczone i Europa. Stosunki polityczne i gospodarcze. 17762004 (Książka i Wiedza, Warszawa 2007). Opublikowała także ponad 40 artykułów i recenzji prac naukowych, m.in. w „Sprawach Międzynarodowych”, „Stosunkach Międzynarodowych”, „Studiach Politycznych”, „Międzynarodowym Przeglądzie Politycznym”, „Studiach Prawno-Ekonomicznych”, „Politei”, „Wrocławskich Studiach Politologicznych” i „Przeglądzie Zachodnim”.

Autorka uczestniczyła w ponad 20 konferencjach naukowych - krajowych i międzynarodowych. Prowadziła także wykłady w ramach polskich i międzynarodowych konferencji organizacji studenckich i na Festiwalach Nauki. W 2007 r. otrzymała trzymiesięczne stypendium Fundacji Kościuszkowskiej na wyjazd do Stanów Zjednoczonych. Od listopada 2007 r. do stycznia 2008 r. prowadziła tam badania naukowe w Archiwach Narodowych i Bibliotece Kongresu. W maju 2009 r. przeprowadziła na Uniwersytecie w Gandawie cykl wykładów dotyczących relacji gospodarczych USA - Unia Europejska (w ramach programu Erasmus).

W toku pracy dydaktycznej dr Matera prowadziła wykłady i konwersatoria z międzynarodowych stosunków politycznych, relacji transatlantyckich, polityki zagranicznej Stanów Zjednoczonych, bezpieczeństwa międzynarodowego oraz seminarium magisterskie dotyczące polityki i historii Stanów Zjednoczonych (w języku polskim i angielskim). Była promotorką ponad 70 prac magisterskich. Otrzymała Nagrodę Rektora UŁ za działalność dydaktyczną i organizacyjną w 2008 r. 
